ПРИЧОРНОМОРСЬКИЙ НАУКОВО-ДОСЛІДНИЙ ІНСТИТУТ ЕКОНОМІКИ ТА ІННОВАЦІЙ

\title{
ІННОВАЦІЙНА ПЕДАГОГІКА
}

\author{
Науковий журнал
}

Випуск 24

TOM 2

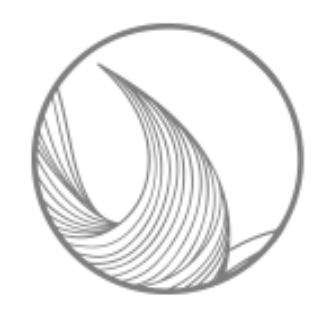


Головний редактор:

Терешкінас Артурас - доктор соціальних наук, профресор, профресор кафедри соціології Університету імені Вітовта Великого (Каунас, Литовська Республіка)

Члени редакційної колегії:

Байша Кіра Миколаївна - кандидат педагогічних наук, доцент, доцент кафредри іноземних мов Херсонського національного технічного університету

Благун Наталія Михайлівна - доктор педагогічних наук, профресор, профресор касредри педагогіки початкової освіти Прикарпатського національного університету імені Василя Стесраника

Богуш Людмила Андріївна - кандидат педагогічних наук, старший викладач кафедри менеджменту Міжнародного економіко-гуманітарного університету імені академіка Степана Дем'янчука

Бочелюк Віталій Йосипович - доктор педагогічних наук, профресор, завідувач кафредри Запорізького національного технічного університету

Кочарян Артур Борисович - кандидат педагогічних наук, доцент, радник Міністра освіти і науки України

Невмержицька Олена Василівна - доктор педагогічних наук, доцент, професор кафедри загальної педагогіки та дошкільної освіти Дрогобицького державного педагогічного університету імені Івана Франка

Пермінова Владислава Анатоліївна-кандидат педагогічних наук, доцент, доцент кафредри іноземних мов професійного спрямування Чернігівського національного технологічного університету

Пушкарьова Тамара Олексіївна - доктор педагогічних наук, професор, начальник відділу проектного управління ДНУ «Інститут модернізації змісту освіти» МОН України

Шапошникова Ірина Василівна - доктор соціологічних наук, професор, декан соціальнопсихологічного факультету Херсонського державного університету

Алісаускіене Мілда - доктор соціальних наук, професор, завідувач кафредри соціології Університету імені Вітовта Великого (Каунас, Литовська Республіка)

Гражієне Віталія - доктор педагогічних наук, завідувач відділу якості освіти Вільнюської академії мистецтв (Вільнюс, Литовська Республіка)

Конрад Яновський - PhD, ректор Економіко-гуманітарного університету у Варшаві (Варшава, Республіка Польща)

Електронна сторінка видання - www.innovpedagogy.od.ua

Рекомендовано до друку та поширення через мережу Internet Вченою радою Причорноморського науково-дослідного інституту

економіки та інновацій (протокол № 6 від 29.06.2020 року)

Журнал включено до Переліку наукових фрахових видань України (категорія «Б»)

у галузі педагогічних наук (011 - Освітні, педагогічні науки, 012 - Дошкільна освіта, 013 - Початкова освіта, 014 - Середня освіта, 015 - Профресійна освіта

(за спеціальностями), 016 - Спеціальна освіта) відповідно до Наказу МОН України від 14.05.2020 № 627 (додаток 2)

Журнал включено до міжнародної наукометричної бази Index Copernicus International (Республіка Польща)

Науковий журнал «Інноваційна педагогіка» зареєстровано

Міністерством юстиції України

(Свідоцтво про державну реєстрацію друкованого засобу масової інорормації серія КВ № 22897-12797Р від 02.08.2017 року)

Міжнародний цифровий ідентифрікатор журналу: https://doi.org/10.32843/2663-6085 
3MICT

\section{РОЗДІЛ 1. ЗАГАЛЬНА ПЕДАГОГІКА ТА ІСТОРІЯ ПЕДАГОГІКИ}

Матіюк Д.В.

РОЗВИТОК НАУКИ В НІМЕЦЬКОМОВНИХ КРАЇНАХ ЄВРОПИ НАПРИКІНЦІ ХХ - НА ПОЧАТКУ

ХХІ СТОЛІТТЯ ТА ПЕРСПЕКТИВНІ НАПРЯМИ ЕКСТРАПОЛЯЦІЇ В СИСТЕМУ ОСВІТИ УКРАЇНИ.......9

\section{Никифоров А.М.}

ВНЕСОК ЛЬВІВСЬКОЇ ХУДОЖНЬО-ПРОМИСЛОВОЇ ШКОЛИ У ПРОЦЕС ВПРОВАДЖЕННЯ НАВЧАННЯ ДЕКОРАТИВНОГО МИСТЕЦТВА В СИСТЕМУ ХУДОЖНЬОЇ ОСВІТИ УКРАЇНИ (ДРУГА ПОЛОВИНА ХІХ - ПОЧАТОК ХХ СТОЛІТТЯ).

Окольнича Т.В.

ОСОБЛИВОСТІ ВИХОВАННЯ ДИТИНИ ВІД НАРОДЖЕННЯ ДО 7 РОКІВ У СХІДНОСЛОВ'ЯНСЬКІЙ

ПЕДАГОГІЦІ (В ЕТНОГРАФІЧНИХ ДЖЕРЕЛАХ ХІХ - ПЕРШОЇ ЧВЕРТІ ХХ СТ.).

Пастирська І.я.

ДОСВІД ВНУТРІШНЬОЦИКЛОВОЇ ІНТЕГРАЦІї ДИСЦИПЛІН..

Подчасова К.В.

ФАКУЛЬТЕТИ ХІМІЇ УКРАЇНСЬКИХ ВИЩИХ НАВЧАЛЬНИХ ЗАКЛАДІВ

У ПЕРІОД ДРУГОї СВІТОВОї ВІЙНИ..

Тарасова B.A.

КОМПЕТЕНТНІСНИЙ ПІДХІД В ОСВІТІ ЯК УМОВА ПРОФЕСІЙНОГО РОЗВИТКУ ВЧИТЕЛІВ.

Філоненко О.В.

ВНЕСОК ВАСИЛЯ АНТОНОВИЧА ФЛОРОВСЬКОГО В РОЗВИТОК НАВЧАЛЬНОГО

ЗАКЛАДУ ПРАВОСЛАВНОЇ ЦЕРКВИ НА ЄЛИСАВЕТГРАДЩИНІ.

\section{РОЗДІЛ 2. ТЕОРІЯ ТА МЕТОДИКА НАВЧАННЯ (З ГАЛУЗЕЙ ЗНАНЬ)}

Кобринець О.С., Малець І.В.

ДО ПРОБЛЕМИ ВИВЧЕННЯ МІЖКУЛЬТУРНОЇ КОМУНІКАЦІЇ

У ПРОЦЕСІ НАВЧАННЯ ІНОЗЕМНОÏ МОВИ.

Kormiltsyna S.Yu., Hrechok L.M.

PECULIARITIES OF THE COMMUNICATIVE METHOD USE OF TEACHING FOREIGN

LANGUAGES AT NON-LINGUISTIC HIGHER EDUCATIONAL ESTABLISHMENTS.

Korsykova K.G.

PEDAGOGICAL CONDITIONS FOR FORMING METHODOLOGICAL COMPETENCE

OF EDUCATORS IN THE PROCESS OF PEDAGOGICAL PRACTICE.

Петрачков О.В., Білошицький В.В., Любчич Р.І., Коновалов Д.О., Василенко М.М.

УДОСКОНАЛЕННЯ МЕТОДИЧНОЇ ПІДГОТОВЛЕНОСТІ КУРСАНТІВ ВИЩИХ

ВІЙСЬКОВИХ НАВЧАЛЬНИХ ЗАКЛАДІВ У СИСТЕМІ ФІЗИЧНОЇ ПІДГОТОВКИ.

Степаненко О.К.

ЕФЕКТИВНІ ТЕХНОЛОГІЇ НАВЧАННЯ ЗАРУБІЖНОЇ ЛІТЕРАТУРИ.

Тютюма T.C.

ТИПОЛОГІЙНІ ВИЯВИ СИНТАКСИЧНОГО ЗВ'ЯЗКУ В СЛОВОСПОЛУЧЕННІ:

ЛІНГВІСТИЧНИЙ I ЛІНГВОДИДАКТИЧНИЙ АСПЕКТИ

цимбал Т.М.

ІГРОВІ ТЕХНОЛОГІЇ В МОВНІЙ ПІДГОТОВЦІ ІНОЗЕМНИХ СТУДЕНТІВ.

Shayner H.I., Havran M.I.

ROLE OF STUDENTS' INDIVIDUAL WORK

IN ACQUISITION OF A FOREIGN LANGUAGE.

Шемчук В.А., Петрачков О.В., Федоренко О.О., Муштатов Ю.В., Коновалов Д.О.

ПЕДАГОГІЧНА ТЕХНОЛОГІЯ ОРГАНІЗАЦІЇ ПРОФЕСІЙНОГО РОСТУ КОМАНДИРІВ

КУРСАНТСЬКИХ ПІДРОЗДІЛІВ ВИЩИХ ВІЙСЬКОВИХ НАВЧАЛЬНИХ ЗАКЛАДІВ

ЗБРОЙНИХ СИЛ УКРАЇНИ В СИСТЕМІ ФІЗИЧНОЇ ПІДГОТОВКИ. 


\section{РОЗДІЛ 3. ТЕОРІЯ І МЕТОДИКА ПРОФЕСІЙНОЇ ОСВІТИ}

Малик Г.Д.

МАСОВІ ВІДКРИТІ ОНЛАЙН-КУРСИ ЯК ІНСТРУМЕНТ ІНТЕРНАЦІОНАЛІЗАЦІЇ

ПРОФЕСІЙНОЇ ПІДГОТОВКИ МАЙБУТНЬОГО ПЕРЕКЛАДАЧА

Малишевська В.О.

МОТИВАЦІЙНО-ЦІННІСНІ ЗАСАДИ ФОРМУВАННЯ ГОТОВНОСТІ МАЙБУТНІХ ПЕДАГОГІВ ДОШКІЛЬНОЇ ОСВІТИ ДО ЗАСТОСУВАННЯ SТЕМ-ТЕХНОЛОГІЙ У ПРОФЕСІЙНІЙ ДІЯЛЬНОСТІ

\section{Мамиченко С.A.}

МЕТОДОЛОГІЧНІ ЗАСАДИ ФОРМУВАННЯ КУЛЬТУРИ КОНКУРЕНТНИХ ВІДНОСИН

У МАЙБУТНІХ ФАХІВЦІВ 3 БІЗНЕС-АДМІНІСТРУВАННЯ

Пономаренко О.В.

СУКУПНІСТЬ КРИТЕРІЇВ ТА ПОКАЗНИКІВ ГОТОВНОСТІ МАЙБУТНІХ МАГІСТРІВ ПСИХОЛОГІЇ ДО ПРОФЕСІЙНОЇ ДІЯЛЬНОСТІ В УМОВАХ НЕФОРМАЛЬНОЇ ОСВІТИ ЗА ІІЇ КОМПОНЕНТАМИ.

Ребуха Л.з., Главацька О.Л.

ПРОФЕСІЙНА ГОТОВНІСТЬ МАЙБУТНІХ ФАХІВЦІВ СОЦІОНОМІЧНИХ ПРОФЕСІЙ

ДО ВПРОВАДЖЕННЯ ІНКЛЮЗИВНОЇ ОСВІТИ: АКСІОЛОГІЧНІ ЗАСАДИ.

\section{Рябець І.В.}

ВИЗНАЧЕННЯ ТЕРМІНІВ «ФАХІВЕЦЬ ІЗ ЗВ'ЯЗКІВ ІЗ ГРОМАДСЬКІСТЮ»

ТА «МАЙБУТНІЙ ФАХІВЕЦЬ ІЗ ЗВ'ЯЗКІВ ІЗ ГРОМАДСЬКІСТЮ»

У ВІТЧИЗНЯНОМУ НАУКОВОМУ ПЕДАГОГІЧНОМУ ПРОСТОРІ.

\section{Скрипник H.I.}

СУЧАСНІ ПІДХОДИ ДО ФОРМУВАННЯ КОМУНАКАТИВНО-МОВЛЕННЄВОЇ КОМПЕТЕНТНОСТІ

СТУДЕНТІВ ГУМАНІТАРНО-ПЕДАГОГІЧНОГО КОЛЕДЖУ..

Соломаха А.В., Лобода О.В.

СУЧАСНІ ТЕНДЕНЦІЇ ІНШОМОВНОЇ ПІДГОТОВКИ

МАЙБУТНІХ УЧИТЕЛІВ ПОЧАТКОВОЇ ЛАНКИ ОСВІТИ УГОРЩИНИ.

Стародуб С.л.

ВИКОРИСТАННЯ АКТИВНИХ МЕТОДІВ І ФОРМ ВИКЛАДАННЯ

ПЕДАГОГІЧНИХ ДИСЦИПЛІН У ПІДГОТОВЦІ МАЙБУТНІХ УЧИТЕЛІВ.

Супрунчук ю.О.

НАУКОВІ ПІДХОДИ ДО ФОРМУВАННЯ МОВЛЕННЄВОЇ КОМПЕТЕНТНОСТІ КУРСАНТІВ

ВІЙСЬКОВИХ ЗАКЛАДІВ ВИЩОЇ ОСВІТИ У ПРОЦЕСІ САМОСТІЙНОЇ ПІДГОТОВКИ.

Tymoschuk N.M.

MULTIMEDIA IN TEACHING FOREIGN LANGUAGES.

Фіголь Н.А.

ПЕДАГОГІЧНА МАЙСТЕРНІСТЬ ЯК ФАКТОР ПРОЯВУ

ПРОФЕСІОНАЛІЗМУ ВИКЛАДАЧА ЗАКЛАДУ ВИЩОЇ ОСВІТИ.

Фодор К.Й.

МЕТОДОЛОГІЧНІ ОСНОВИ ФОРМУВАННЯ

СОЦІОКУЛЬТУРНОЇ КОМПЕТЕНТНОСТІ МАЙБУТНІХ БАКАЛАВРІВ

ІНОЗЕМНОЇ МОВИ НА ЗАСАДАХ МІЖДИСЦИПЛІНАРНОЇ ІНТЕГРАЦІї..

Хамська Н.Б., Киналь А.Ю.

ШЛЯХИ АКТИВІЗАЦІЇ САМОСТІЙНОЇ РОБОТИ У ФОРМУВАННІ

ІНФОРМАЦІЙНОÏ КОМПЕТЕНТНОСТІ МАЙБУТНІХ УЧИТЕЛІВ.

Човган 0.0 .

ПСИХОЛОГО-ПЕДАГОГІЧНІ ТА МЕТОДИЧНІ АСПЕКТИ ВИКОРИСТАННЯ ТРЕНІНГІВ

У ПРОФЕСІЙНІЙ ПІДГОТОВЦІ МАЙБУТНІХ СОЦІАЛЬНИХ ПРАЦІВНИКІВ.

Шаравара B.B.

СТРУКТУРА ПРОГНОСТИЧНОÏ КОМПЕТЕНТНОСТІ

МАЙБУТНІХ БАКАЛАВРІВ КОМП'ЮТЕРНИХ НАУК. 


\section{Шпортюк О.М.}

КОМПОНЕНТИ, КРИТЕРІЇ ТА РІВНІ ПРОФЕСІЙНОЇ ГОТОВНОСТІ МАЙБУТНІХ ОФІЦЕРІВ

ОРГАНУ ПРОБАЦІЇ ДО СОЦІАЛЬНО-ВИХОВНОЇ РОБОТИ 3 НЕПОВОЛІТНІМИ..

Штефан Л.В.

ІННОВАЦІЙНА КОМПЕТЕНТНІСТЬ СУЧАСНОГО ПЕДАГОГА.

Яременко-Гасюк О.О., Петровська О.Я.

ПЕРЕКЛАДАЦЬКИЙ АСПЕКТ У МОДЕРНІЗАЦІї ПІДГОТОВКИ МАЙБУТНІХ ПЕДАГОГІВ

НЕМОВНИХ СПЕЦІАЛЬНОСТЕЙ (НА МАТЕРІАЛІ ФРАНЦУЗЬСЬКОЇ МОВИ).

\section{РОЗДІЛ 4. ТЕОРІЯ І МЕТОДИКА ВИХОВАННЯ}

\section{Бабкіна М.I.}

ФІЛОСОФСЬКІ ПОГЛЯДИ ЩОДО ВИХОВАННЯ ГРОМАДЯНИНА

Красін С.A.

ТЕОРЕТИЧНЕ ОБҐРУНТУВАННЯ ПЕДАГОГІЧНИХ УМОВ ФОРМУВАННЯ ГОТОВНОСТІ ДО УСВІДОМЛЕНОГО БАТЬКІВСТВА СТУДЕНТІВ ЗАКЛАДІВ ВИЩОЇ ОСВІТИ

Охріменко 3.В.

ЗМІСТОВІ АСПЕКТИ ФОРМУВАННЯ ПРОФЕСІЙНО-ЦІННІСНИХ ОРІЄНТАЦІЙ

УЧНІВ ДО ТРУДОВОї ДІЯЛЬНОСТІ.

Хуртенко О.В., Білошицький В.В., Власко С.В., Партика С.С., Коновалов Д.О.

ПЕДАГОГІЧНІ УМОВИ ФОРМУВАННЯ ПСИХОЛОГІЧНОГО ПРОФІЛЮ

ЖІНОК-ЄДИНОБОРЦІВ ВИСОКОЇ КВАЛІФІКАЦІЇ.

Чаговець А.І., Пивоваренко М.С.

ІСТОРИЧНИЙ ОГЛЯД ПРОБЛЕМИ МОРАЛЬНО-ЕСТЕТИЧНОГО ВИХОВАННЯ

ДІТЕЙ ДОШКІЛЬНОГО ВІКУ ЗАСОБАМИ МУЗИЧНО-РИТМІЧНОЇ ГІМНАСТИКИ.

\section{РОЗДІЛ 5. ІНФОРМАЦІЙНО-КОМУНІКАЦІЙНІ ТЕХНОЛОГІЇ В ОСВІТІ}

Антонюк Д.С., Вакалюк Т.А., Дідківський В.В., Візгалов О.ю.

НЕОБХІДНІСТЬ РОЗРОБЛЕННЯ СИМУЛЯТОРА

УПРАВЛІННЯ ПЕРСОНАЛЬНИМИ ФІНАНСАМИ.

Бриндіков Ю.Л.

ОПТИМІЗАЦІЯ КОГНІЦІЇ У СТУДЕНТІВ

ЧЕРЕЗ ВІЗУАЛЬНИЙ СКЛАДНИК ЛЕКЦІЙНОГО ЗАНЯТТЯ

Гоу Кванденг

ПЕРСОНАЛІЗАЦІЯ НАВЧАННЯ СТУДЕНТІВ У ЦИФРОВОМУ

ОСВІТНЬОМУ СЕРЕДОВИЩІ УНІВЕРСИТЕТІВ КИТАЮ.

Грабовська Н.А., Цимбалюк Т.П.

ІНФОРМАЦІЙНІ ТЕХНОЛОГІЇ У ВИВЧЕННІ ІНОЗЕМНОЇ МОВИ.

Кайдалова Л.Г., Сабатовська-Фролкіна І.С., Фесенко В.Ю.

УПРОВАДЖЕННЯ ДИСТАНЦІЙНОЇ ФОРМИ ПІДВИЩЕННЯ КВАЛІФІКАЦІЇ

НАУКОВО-ПЕДАГОГІЧНИХ ПРАЦІВНИКІВ З ІННОВАЦІЙНИХ ТЕХНОЛОГІЙ ВИКЛАДАННЯ

Паламарчук Ю.Г., Пилипчак І.В., Пилипчак В.В., Василенко М.М.

ОСОБЛИВОСТІ ВИКОРИСТАННЯ СУЧАСНИХ ТЕХНІЧНИХ ЗАСОБІВ НАВЧАННЯ

СПОРТСМЕНАМИ ВИСОКОЇ КВАЛІФІКАЦІЇ В УМОВАХ САМОІЗОЛЯЦІЇ.

Протасова А.С.

ПІДГОТОВКА МАЙБУТНІХ ВИХОВАТЕЛІВ ДО ПРОЦЕСУ ФІЗИЧНОГО ВИХОВАННЯ

ДОШКІЛЬНИКІВ ЗАСОБАМИ ІНФОРМАЦІЙНО-КОМУНІКАЦІЙНИХ ТЕХНОЛОГІЙ.

Ходунова В.Л.

ДИСТАНЦІЙНЕ НАВЧАННЯ ПЕДАГОГІЧНИХ ПРАЦІВНИКІВ ЗАКЛАДІВ ДОШКІЛЬНОЇ ОСВІТИ. 


\section{CONTENTS}

\section{SECTION 1 . GENERAL PEDAGOGY AND HISTORY OF PEDAGOGY}

Matiiuk D.V.

THE DEVELOPMENT OF SCIENCE IN GERMAN-SPEAKING COUNTRIES OF EUROPE IN THE LATE $20^{\text {TH }}-$ EARLY $21^{\text {ST }}$ CENTURIES AND PERSPECTIVE DIRECTIONS OF EXTRAPOLATION TO THE EDUCATION SYSTEM OF UKRAINE.

Nykyforov A.M.

CONTRIBUTION OF LVIV ART-INDUSTRIAL SCHOOL IN THE PROCESS OF INTRODUCING DECORATIVE ARTS TEACHING IN THE SYSTEM OF ART EDUCATION OF UKRAINE

(SECOND HALF OF THE XIX - EARLY XX CENTURY).

Okolnycha T.V.

PECULIARITIES OF RAISING CHILD FROM BIRTH 7 YEARS

OF AGE IN EAST SLAVIC PEDAGOGY (IN THE ETHNOGRAPHICAL

SOURCES OF THE 19TH - FIRST QUARTER OF THE 20TH CENTURY),

Pastyrska I.Ya.

EXPERIENCE OF INTRA-CYCLE INTEGRATION OF DISCIPLINES.

Podchasova K.V.

FACULTIES OF CHEMISTRY OF UKRAINIAN HIGHER EDUCATIONAL

INSTITUTIONS DURING THE SECOND WORLD WAR.

Tarasova V.A.

COMPETENCE APPROACH IN EDUCATION AS A CONDITION

FOR TEACHERS' PROFESSIONAL DEVELOPMENT.

Filonenko O.V.

VASYL ANTONOVYCH FLOROVSKY'S CONTRIBUTION

TO THE DEVELOPMENT OF THE EDUCATIONAL INSTITUTION

OF THE ORTHODOX CHURCH IN YELISAVETHRAD REGION.

\section{SECTION 2. THEORY AND METHODS OF TEACHING (BY DISCIPLINES)}

Kobrynets O.S., Malets I.V.

TO THE PROBLEM OF STUDYING INTERCULTURAL COMMUNICATION

IN THE PROCESS OF LEARNING A FOREIGN LANGUAGE.

Kormiltsyna S.Yu., Hrechok L.M.

PECULIARITIES OF THE COMMUNICATIVE METHOD USE OF TEACHING FOREIGN

LANGUAGES AT NON - LINGUISTIC HIGHER EDUCATIONAL ESTABLISHMENTS.

Korsykova K.G.

PEDAGOGICAL CONDITIONS FOR FORMING METHODOLOGICAL COMPETENCE

OF EDUCATORS IN THE PROCESS OF PEDAGOGICAL PRACTICE.

Petrachkov O.V., Biloshytskyi V.V., Liubchych R.I., Konovalov D.O., Vasylenko M.M.

IMPROVEMENT OF METHODOLOGICAL PREPAREDNESS

OF CADETS OF HIGHER MILITARY EDUCATIONAL INSTITUTIONS

IN THE SYSTEM OF PHYSICAL TRAINING.

Stepanenko O.K.

EFFECTIVE TECHNOLOGIES OF TEACHING FOREIGN LITERATURE.

Tiutiuma T.S.

TYPOLOGICAL OCCURRENCES OF SYNTACTICAL CONNECTION

IN WORD COMBINATIONS: LINGUISTIC AND LINGUODIDACTIC ASPECTS.

Tsymbal T.M.

GAME TECHNOLOGIES IN THE LANGUAGE TRAINING OF FOREIGN STUDENTS.

Shayner H.I., Havran M.I.

ROLE OF STUDENTS' INDIVIDUAL WORK IN ACQUISITION OF A FOREIGN LANGUAGE. 
Shemchuk V.A., Petrachkov O.V., Fedorenko O.O., Mushtatov Yu.V., Konovalov D.O.

EDUCATIONAL TECHNOLOGY ORGANIZATION OF PROFESSIONAL DEVELOPMENT

OF COMMANDERS OF CADET DIVISIONS OF HIGHER MILITARY EDUCATIONAL ESTABLISHMENTS

OF ARMED FORCES OF UKRAINE IN THE SYSTEM OF PHYSICAL TRAINING.....

\section{SECTION 3. THEORY AND METHODOLOGY OF EDUCATIONAL MANAGEMENT}

Malyk H.D.

MASSIVE OPEN ONLINE COURSES AS A TOOL OF THE INTERNATIONALIZATION

OF PROFESSIONAL TRAINING OF WOULD-BE TRANSLATORS.

Malyshevska V.O.

MOTIVATIONAL-VALUE FOUNDATIONS OF THE FORMATION OF FUTURE PRESCHOOL EDUCATION

TEACHERS' READINESS TO USING STEM TECHNOLOGIES IN PROFESSIONAL ACTIVITY.

Mamychenko S.A.

METHODOLOGICAL PRINCIPLES OF FORMATION OF THE CULTURE OF COMPETITIVE

RELATIONS IN FUTURE PROFESSIONALS FROM BUSINESS ADMINISTRATION.

Ponomarenko O.V.

SET OF THE CRITERIA AND READINESS INDEXES

OF FUTURE PSYCHOLOGY MASTERS FOR PROFESSIONAL ACTIVITY

IN CONDITIONS OF INFORMAL EDUCATION BASED ON ITS COMPONENTS.

Rebukha L.Z., Hlavatska O.L.

PROFESSIONAL PREPAREDNESS OF FUTURE SPECIALISTS OF SOCIONOMIC PROFESSIONS

FOR THE INTRODUCTION OF INCLUSIVE EDUCATION: AXIOLOGICAL PRINCIPLES.

Riabets I.V.

THE DEFINITION "PUBLIC RELATIONS SPECIALIST" AND "FUTURE PUBLIC

RELATIONS SPECIALIST" IN THE DOMESTIC SCIENTIFIC PEDAGOGICAL SPACE.

Skrypnyk N.I.

MODERN APPROACHES TO THE FORMATION OF STUDENTS' COMMUNICATIVE-SPEECH

COMPETENCE OF THE HUMANITARIAN-PEDAGOGICAL COLLEGE.

Solomakha A.V., Loboda O.V.

CURRENT TRENDS IN FOREIGN LANGUAGE TRAINING

OF FUTURE PRIMARY EDUCATION TEACHERS OF HUNGARY

Starodub S.L.

USAGE OF ACTIVE FORMS AND METHODS OF TEACHING

THE PEDAGOGICAL SUBJECTS IN FUTURE TEACHERS TRAINING

Suprunchuk Yu.O.

SCIENTIFIC APPROACHES TO THE SPEECH COMPETENCE FORMATION

OF MILITARY STUDENTS OF MILITARY HIGHER EDUCATIONAL ESTABLISHMENTS

IN THE PROCESS OF INDEPENDENT LEARNING.

Tymoschuk N.M.

MULTIMEDIA IN TEACHING FOREIGN LANGUAGES

Fihol N.A.

PEDAGOGICAL EXCELLENCE AS A FACTOR OF MANIFESTATION

OF PROFESSIONALISM OF A TEACHER OF HIGHER EDUCATION INSTITUTION

Fodor K.Y.

METHODOLOGICAL FUNDAMENTS OF FORMING SOCIO-CULTURAL COMPETENCE

OF FUTURE BACHELORS OF ARTS IN FOREIGN LANGUAGES ON THE BASIS

OF INTERDISCIPLINARY INTEGRATION.

Khamska N.B., Kynal A.Yu.

WAYS OF SELF-STUDY WORK ACTIVATION IN THE FUTURE

TEACHERS-PHILOLOGISTS' INFORMATION COMPETENCE FORMATION.

Chovhan 0.0.

PSYCHO-PEDAGOGICAL AND METHODICAL ASPECTS OF TRAINING USE

IN PROFESSIONAL TRAINING OF FUTURE SOCIAL WORKERS 
Sharavara V.V.

STRUCTURE OF PROGNOSTIC COMPETENCE OF FUTURE BACHELORS OF COMPUTER SCIENCE....159

Shportiuk O.M.

COMPONENTS, CRITERIA AND LEVELS OF PROFESSIONAL READINESS OF FUTURE

PROBATION OFFICERS FOR SOCIAL AND EDUCATIONAL WORK WITH JUVENILES

Shtefan L.V.

INNOVATIVE COMPETENCE OF A MODERN TEACHER.

Yaremenko-Hasiuk O.O., Petrovska O.Ya.

TRANSLATION ASPECT IN MODERNIZATION OF TRAINING FOR FUTURE NON-LANGUAGE

SPECIALTIES TEACHERS (ON THE MATERIAL OF FRENCH LANGUAGE).

\section{SECTION 4. THEORY AND METHODOLOGY OF EDUCATION}

Babkina M.I.

PHILOSOPHICAL VIEWS ON THE EDUCATION FOR CITIZENSHIP.

Krasin S.A.

THEORETICAL FOUNDATION OF PEDAGOGICAL CONDITIONS

OF THE FORMATION OF READYNESS FOR THE CONSCIOUS PATERNITY

OF STUDENTS OF HIGHER EDUCATION INSTITUTIONS.

Okhrimenko Z.V.

THE CONTENT ASPECTS OF FORMATION OF PROFESSIONAL

AND VALUE ORIENTATIONS OF STUDENTS TO EMPLOYMENT.

Khurtenko O.V., Biloshytskyi V.V., Vlasko C.V., Partyka S.S., Konovalov D.O.

PEDAGOGICAL CONDITIONS FOR THE FORMATION OF THE PSYCHOLOGICAL PROFILE

OF HIGHLY QUALIFIED WOMEN ENGAGED IN MARTIAL ARTS.

Chahovets A.I., Pyvovarenko M.S.

HISTORICAL OVERVIEW OF THE PROBLEM OF MORAL AND AESTHETIC EDUCATION

OF PRESCHOOL CHILDREN BY MUSICAL AND RHYTHMIC GYMNASTICS.

\section{SECTION 5. INFORMATION AND COMMUNICATION TECHNOLOGIES IN EDUCATION}

Antoniuk D.S., Vakaliuk T.A., Didkivskyi V.V., Vizghalov O.Yu.

NECESSITY OF THE PERSONAL FINANCE MANAGEMENT SIMULATION DEVELOPMENT.

Bryndikov Yu.L.

OPTIMIZATION OF THE STUDENT'S COGNITION THROUGH

THE VISUAL COMPONENT OF THE LECTURE.

Hou Kvandenh

PERSONALIZED LEARNING FOR COLLEGE STUDENTS IN THE DIGITAL ENVIRONMENT

OF THE PEOPLE'S REPUBLIC OF CHINA

Hrabovska N.A., Tsymbaliuk T.P.

INFORMATION TECHNOLOGIES IN FOREIGN LANGUAGE EDUCATION

Kaidalova L.H., Sabatovska-Frolkina I.S., Fesenko V.Yu.

INTRODUCTION OF A DISTANCE FORM OF TEACHER TRAINING

ON INNOVATIVE TEACHING TECHNOLOGIES.

Palamarchuk Yu.H., Pylypchak I.V., Pylypchak V.V., Vasylenko M.M.

FEATURES OF USE OF MODERN TECHNICAL MEANS OF TRAINING SPORTSMEN

OF HIGH QUALIFICATION IN CONDITIONS OF ISOLATION.

Protasova A.S.

PREPARATION OF FUTURE EDUCATORS FOR THE PROCESS

OF PHYSICAL EDUCATION OF PRESCHOOL CHILDREN BY MEANS

OF INFORMATION AND COMMUNICATION TECHNOLOGIES.

Khodunova V.L.

DISTANCE TRAINING OF PEDAGOGICAL EMPLOYEES

OF PRESCHOOL EDUCATION INSTITUTIONS 
РОЗВИТОК НАУКИ В НІМЕЦЬКОМОВНИХ КРАЇНАХ ЄВРОПИ НАПРИКІНЦІ XX - НА ПОЧАТКУ XXI СТОЛІТТЯ ТА ПЕРСПЕКТИВНI НАПРЯМИ ЕКСТРАПОЛЯЦІЇ В СИСТЕМУ ОСВІТИ УКРАЇНИ

\author{
THE DEVELOPMENT OF SCIENCE IN GERMAN-SPEAKING COUNTRIES \\ OF EUROPE IN THE LATE $20^{\mathrm{TH}}-$ EARLY $21^{\text {ST }}$ CENTURIES \\ AND PERSPECTIVE DIRECTIONS OF EXTRAPOLATION \\ TO THE EDUCATION SYSTEM OF UKRAINE
}

у статті досліджено етапи становлення науки в німецькомовних країнах Європи наприкінці XX - на початку XXI століття. Визначено, що за зазначений період Німеччина, Австрія, Швейцарія, Люксембург та Ліхтенштейн стали учасниками «Болонського процесу» (1999 р.) та «Європейського простору вищої освіти» (2010 р.), які разом із «Зальцбурзькими принципами» (2005 р.) мали значний вплив на розвиток освіти та науки зазначених країн. Встановлено, що на цьому ж етапі було завершено перехід до сучасних форм здобуття докторського та постдокторського ступенів. Проаналізовано діяльність провідних наукових інституцій у німецькомовних країнах Європи, зокрема, Товариства ім. М. Планка для сприяння розвитку наук, Товариства сприяння прикладним дослідженням ім. Фраунгофрера, Товариства німецьких дослідницьких центрів ім. Гельмгольца, Наукового Товариства ім. Г.В. Лейбніца, Німецької служби академічних обмінів, Австрійської служби академічних обмінів, Швейцарського національного фонду наукових досліджень, Швейцарського агентства з підтримки інновацій. Основну увагу було приділено програмам розвитку науки, інтернаціоналізації німецькомовної науки, популяризації наукових досліджень, налагодженню партнерських відносин між наукою, бізнесом та суспільством. На основі аналізу досвіду німецькомовних країн Європи виокремлено та сформульовано перспективні напрями екстраполяції в систему освіти та науки України. Виділені напрями систематизовано за групами у відповідності до ключової мети: сприяння інтернаціоналізації вітчизняної науки; популяризація наукових досліджень; налагодження партнерських відносин між наукою, бізнесом та суспільством; розвиток науки. Узагальнено, що виділені напрями екстраполяції не можуть бути впроваджені в систему освіти та науки України одночасно, адже мають свої переваги та недоліки, а також потребують нерівнозначних фрінансових, часових та трудових ресурсів. Запропоновано подальше групування виділених напрямів екстраполяції за пріоритетами впровадження - на коротко-, середньо- та довгострокову перспективу.

Ключові слова: розвиток освіти та науки, становлення науки в німецькомовних країнах Європи, перспективні напрями екстраполяції, інтернаціоналізація науки, популяризація наукових досліджень, партнерські відносини між наукою, бізнесом та суспільством.

The article highlights the stages of science formation in German-speaking countries of Europe in the late $20^{\text {th }}$ - early $21^{\text {st }}$ centuries. It has been determined that during this period Germany,
Austria, Switzerland, Luxembourg and Liechtenstein have become participants of the "Bologna Process" (1999) and the "European Higher Education Area" (2010), which, together with the "Zalzburg Principles" (2005), had a significant impact on science and education development in these countries. It has been established that the transition to modern forms of obtaining doctoral and postdoctoral degrees was completed at the same stage. The activity of leading scientific institutions in German-speaking countries has been analyzed, in particular, the Max Planck Society for the Advancement of Science (German: Max-Planck-Gesellschaft zur Förderung der Wissenschaften), Fraunhofer Society for the Advancement of Applied Research (German: Fraunhofer-Gesellschaft zur Förderung der angewandten Forschung), the Helmholtz Association of German Research Centres (German: Helmholtz-Gemeinschaft Deutscher Forschungszentren), the Leibnitz Association (German: Leibniz-Gemeinschaft), the German Academic Exchange Service (German: Deutscher Akademischer Austauschdienst), the Austrian Exchange Service (German: Österreichischer Austauschdienst), the Swiss National Science Foundation (German: Schweizerischer Nationalfonds zur Förderung der wissenschaftlichen Forschung ), Innosuisse - Swiss Innovation Agency (German: Innosuisse - Schweizerische Agentur für Innovationsförderung). Much attention has been paid to the development of science, programmes of German-speaking science internationalization, popularization of scientific research, the establishment of partnership between science, business, and society. Based on the analysis of the experience of the German-speaking countries of Europe, promising areas of extrapolation to the education and science system of Ukraine have been identified and formulated. The selected areas have been grouped according to their key goal: the promotion of Ukrainian science internationalization; scientific research popularization; the establishment of partnership between science, business, and society; the development of science. It has been summarized that the selected directions of extrapolation cannot be integrated into the system of education and science of Ukraine at the same time, because they have their advantages and disadvantages and also require unequal financial, time and working resources. It has been suggested to continue grouping the selected areas of extrapolation by implementation priorities - for the short, medium and long term.

Key words: science and education development, science formation in the German-speaking countries of Europe, perspective directions of extrapolation, science internationalization, popularization of science, partnering with science, business and society. педагогічного університету імені Михайла Коцюбинського 


\section{Постановка проблеми у загальному} вигляді. 3 моменту проголошення незалежності Україна перебуває на етапі рефрормування системи освіти ${ }^{1}$ та прагне інтегруватися до європейського та світового освітнього простору. Цей процес набув нових перспектив, коли 19 травня 2005 р. на Конореренції міністрів країн Європи у м. Берген (Норвегія) Україна офріційно приєдналася до Болонського процесу, зобов' язавшись внести відповідні зміни у національну систему освіти та приєднатися до роботи над визначенням пріоритетів у процесі створення єдиного Європейського простору вищої освіти до 2010 р. [2]. 23 березня 2016 р. Кабінетом Міністрів України було прийнято порядок підготовки здобувачів вищої освіти ступеня доктора фрілософії та доктора наук у закладах вищої освіти (наукових установах) [3]. 32017 р. в Національній академії наук України за участю незалежних зарубіжних експертів було впроваджено оцінювання академічних установ [4] на основі системи оцінювання Наукового товариства імені Лейбніца (Німеччина) [5]. 6 березня 2019 р. Кабінет Міністрів України прийняв постанову про проведення експерименту 3 присудження ступеня доктора фрілософрії [6], i, нарешті, в 2020 р. - проєкт про порядок присудження наукових ступенів доктора наук і доктора фрілософії спеціалізованими вченими радами закладів вищої освіти (наукових установ) [7].

Підхід до оцінювання академічних установ $€$ не єдиним здобутком системи освіти та науки німецькомовних країн, який може бути екстрапольований в український освітній простір. Німецькомовні країни Європейського Союзу належать до найінноваційніших країн світу. Так, відповідно до рейтингу "Global Innovation Index" у 2019 р. Швейцарія посідає лідируючі позиції у світі, утримуючи цю позицію з 2013 р., Німеччина - 9 місце, Люксембург - 18 місце, Австрія - 21 місце, тоді як Україна посідає 47 місце [8].

Окрім того, німецькомовні країни Європи належить до провідних держав світу у сорері розвитку освіти і науки.

По-перше, німецькомовні країни належать до країн світу, які інвестують у наукову діяльність близько 3\% свого валового внутрішнього продукту (в 2019 р. Швейцарія посіла 4 місце 3 показником 3,4\%, Австрія - 6 місце з показником 3,2\%, Німеччина - 8 місце 3 показником $3 \%$, Люксембург - 29 місце з показником 1,3\%). Для порівняння в Україні цей показник станом на 2019 р. становить 0,4\%, і вона посідає 67 місце в рейтингу [9]. Навіть більше, до 2025 р. в Німеччині заплановано збільшення цих видатків до щонайменше 3,5\% [10]

\footnotetext{
${ }^{1}$ Згідно Закону України «Про освіту» вітчизняна структура освіти включає: дошкільну освіту; загальну середню освіту; позашкільну освіту; професійно-технічну освіту; вищу освіту; після дипломну освіту; аспірантуру; докторантуру; самоосвіту [1].
}

По-друге, більшість німецькомовних країн Європейського Союзу належать до провідних країн світу за кількістю цитованих матеріалів та показником індексу Гірша (англ. "Citable documents H index") відповідно до рейтингу "Global Innovation Index" (станом на 2019 р. Німеччина посідає 3 місце в світі, Швейцарія - 9 місце, Австрія - 17 місце), тоді як Україна перебуває на 49 позиції [11].

По-третє, більшість німецькомовних країн належать до десятки країн 3 найбільшою кількістю нобелівських лауреатів (Німеччина - 3 місце (108 лауреатів), Швейцарія - 7 місце (28 лауреатів), Австрія - 10 місце (22 лауреати), тоді як Україна посідає 25 місце та має 6 лауреатів [12].

3 огляду на вищезазначені фрактори дослідження особливостей розвитку науки в німецькомовних країнах Європи набуває особливої актуальності.

Аналіз останніх досліджень і публікацій. Розвиток освіти та науки в провідних країнах світу і німецькомовних країнах зокрема $€$ предметом дослідження вітчизняних науковців. А. Гаврилюк охарактеризувала основні тенденції розвитку класичних університетів Німеччини, а саме доступність освіти, диференціацію оплати за навчання, тісний взаємозв'язок промисловості та університетських досліджень [13]. Міжнародно-правовий аспект розвитку наукової діяльності в зарубіжних країнах проаналізовано у дослідженні Н. Христиченко, яка обґрунтувала провідну позицію Німеччини у світовій науковій спільноті [14]. В. Мороз та С. Мороз порівняли німецьку модель підготовки науково-педагогічних кадрів з вітчизняною моделлю [15]. І. Литвин та А. Мельник дослідили фрормування інноваційних екосистем стартапів на прикладі вищих навчальних закладів Німеччини, охарактеризували університетські інкубатори Німеччини та виділили привабливі сорери для створення стартапів при вищих навчальних закладах Німеччини [16]. Л. Отрощенко дала оцінку досвіду менеджменту системи вищої освіти Німеччини, виділила внутрішні фрактори успіху освітнього менеджменту Німеччини та відзначила вплив інтернаціоналізації системи вищої освіти Німеччини на менеджмент освіти країни [17], а М. Дебич проаналізувала теоретичні засади інтернаціоналізації вищої освіти [18]. О. Чорна підкреслила необхідність дослідження елементів прогресивного досвіду інших країн та обґрунтувала особливості розвитку системи моніторингу якості вищої освіти в Німеччині [19].

Заслуговують на увагу доробки зарубіжних дослідників з вищезазначеної проблематики. Так, наприклад, у працях Х. Гуммеля (H. Gummel) узагальнено історію наукових досліджень в Німеччині до 1938 р. [20]. А. Вольтер (А. Wolter) досліджував підвищення кваліфрікації наукових кадрів у Німеччині в контексті освіти впродовж життя [21]. 
Х. Гезер (H. Geser) проаналізував переваги та недоліки шкільної освіти в Швейцарії 3 погляду роботодавця [22].

Виділення не вирішених раніше частин загальної проблеми. У зазначених дослідженнях вітчизняних та зарубіжних науковців найбільшу увагу було приділено розвитку освіти та науки в Німеччині. Водночас малодослідженим залишився досвід інших німецькомовних країн Європейського союзу, а саме Австрії, Швейцарії, Люксембургу та Ліхтенштейну. Однак на етапі реформування науки України, а також становлення системи здобуття наукових ступенів дослідження розвитку науки в усіх німецькомовних країнах Європи набуває особливої актуальності. У цьому контексті важливим $€$ проаналізувати та систематизувати досвід становлення розвитку освіти та науки усіх німецькомовних країн Європейського Союзу (як Німеччини, так і Австрії, Швейцарії, Люксембургу та Ліхтенштейну) та виокремити перспективні напрями екстраполяції в систему освіти та науки України.

Метою статті $€$ аналіз розвитку науки в німецькомовних країнах Європи наприкінці XX - на початку XXI століття, обґрунтування перспективних напрямів екстраполяції в систему освіти України.

Досягнення вищезазначеної мети передбачає виконання таких завдань:

- дослідити етапи становлення науки в німецькомовних країнах Європи;

- проаналізувати діяльність їх провідних наукових інституцій;

- обґрунтувати перспективні напрями екстраполяції в систему освіти України.

Виклад основного матеріалу дослідження. Наприкінці XX - на початку XXI століття відбулось становлення сучасної системи освіти в німецькомовних країнах Європейського союзу.

У травні 1998 р. з нагоди 900-річчя Сорбонського університету у Сорбонні (Франція) відбулася зустріч міністрів освіти Великобританії, Італії, Франції, Німеччини, які обговорили необхідність зустрітися в Болоньї наступного року 3 метою обговорення сучасного стану та перспектив подальшого розвитку освіти та науки в країнах Європи [23].

18-19 червня 1999 р. в м. Болонья (Італія) відбулася міністерська конфреренція, в процесі якої 29 держав-учасниць, усвідомлюючи необхідність подальшої незалежності та самостійності вищих навчальних закладів, висловили бажання взяти на себе зобов'язання підвищити конкурентоспроможність «Європейського простору вищої освіти». У результаті конореренції була підписана «Болонська декларація», усі положення якої були встановлені не лише як пункти обов'язкового договору, а й як заходи добровільного процесу гармонізації. Одним із ключових завдань конференції було визначити часові рамки бакалаврату та магістратури (а саме 3 роки для навчання на бакалавраті та 2 роки для здобуття магістерського ступеня) [24]. Це дозволило унісікувати часові рамки здобуття бакалаврського та магістерського ступенів та стало передумовою для обговорення розвитку подальших рівнів (докторського, постдокторського).

19-20 вересня 2003 р. відбулася зустріч Міністрів вищої освіти в м. Берлін (Німеччина), під час якої здобуття докторського та постдокторського рівнів було включено до «Болонських декларацій». Було прийнято рішення стосовно важливості мультидисциплінарності навчального процесу, спрямованого на здобуття докторського та постдокторського рівнів, а також спільного присудження вчених ступенів (англ. "joint degrees") університетами різних країн. Крім того, було обговорено важливість формування «трансорерабельних навичок» (англ. "transferable skills")2, які б уможливлювали фахову мобільність [25; 26]. Було прийнято рішення віднести розвиток вищезазначених навичок до програм докторської освіти 3 метою якісної підготовки докторантів до працевлаштування поза академічним світом [27].

3-5 лютого 2005 р. у м. Зальцбург (Австрія) відбувся семінар «Докторські програми для європейського суспільства знань» (англ. "Doctoral Programmes for the European Knowledge Society"), за результатами якого були прийняті 10 «Зальцбурзьких принципів».

11-12 березня 2010 р. у м. Будапешт (Угорщина) та м. Відень (Австрія) відбулась конференція, під час якої міністри, відповідальні за розвиток вищої освіти в країнах - учасницях Болонського процесу, заснували «Європейський простір вищої освіти» (англ. “European Higher Education Area") [29].

Таким чином, за період кінець XX - початок XXI століття німецькомовні країни Європейського Союзу (Німеччина, Австрія, Швейцарія, Люксембург, Ліхтенштейн) стали учасниками Болонського процесу (1999 р.) [30] та «Європейського простору вищої освіти» (2010р.) [29], якіразоміз «Зальцбурзькими принципами» (2005р.) [28] мали значний вплив на розвиток освіти та науки. Також на цьому було завершено перехід до сучасних фрорм здобуття докторського та постдокторського ступенів.

На цей час провідними організаціями, які здійснюють наукову діяльність та/або підготовку фахівців на докторському та постдокторському рівнях у німецькомовних країнах Європи, є:

1. Товариство ім. М. Планка для сприяння розвитку наук ${ }^{3}$ (нім. "Max-Planck-Gesellschaft zur Förderung der Wissenschaften") [31];

\footnotetext{
${ }^{2}$ Навики та уміння, які актуальні та корисні в різних ссрерах життя: соціальній, професійній та освітній сферах.

${ }^{3}$ Тут та далі переклад автора.
} 
2. Товариство сприяння прикладним дослідженням ім. Фраунгофера (нім. "Fraunhofer-Gesellschaft zur Förderung der angewandten Forschung") [32];

3. Товариство німецьких дослідницьких центрів ім. Гельмгольца (нім. "Helmholtz-Gemeinschaft Deutscher Forschungszentren") [33];

4. Наукове Товариство ім. Г. В. Лейбніца (нім. "Wissenschaftsgemeinschaft Gottfried Wilhelm Leibniz") [34];

5. Німецька служба академічних обмінів (нім. "Deutscher Akademischer Austauschdienst", DAAD) [35];

6. Австрійська служба академічних обмінів (нім. "Österreichischer Austauschdienst", OeAD) [36];

7. Швейцарський національний фонд наукових досліджень (нім. "Schweizerischer Nationalfonds zur Förderung der wissenschaftlichen Forschung", SNF) [37];

8. Швейцарське агентство з підтримки інновацій (нім. "Innosuisse - Schweizerische Agentur für Innovationsförderung") [38].
Товариство ім. М. Планка для сприяння розвитку наук (нім. "Max-Planck-Gesellschaft zur Förderung der Wissenschaften") $є$ найуспішнішою дослідницькою організацією Німеччини з моменту свого заснування в 1948 р. Воно включає в себе 78 інститутів та інших дослідницьких установ. Серед його дослідників - 18 лауреатів Нобелівської премії. Результати дослідницької роботи оприлюднюються у більш ніж 15 тисяч публікацій у найавторитетніших наукових виданнях світу щороку, багато з яких є одними з найбільш цитованих у відповідних предметних галузях.

Науково-дослідні інститути Товариства ім. М. Планка для сприяння розвитку наук створюються лише навколо провідних світових дослідників, які визначають власні теми, отримують найкращі умови праці та мають можливості вільного підбору співробітників. Вищезазначені умови $€$ суттю «принципу Харнака» (нім. "HarnackPrinzip"), сфрормульованого А. срон Харнаком (A. von Harnack), першим президентом засно-

Таблиця 1

«Зальцбурзькі принципи»

\begin{tabular}{|c|c|c|}
\hline № & Принцип & Коментар \\
\hline 1 & $\begin{array}{l}\text { Підвищення кваліфікації } \\
\text { з урахуванням вимог } \\
\text { ринку праці }\end{array}$ & $\begin{array}{l}\text { Основним компонентом підготовки докторів наук під час проведення науко- } \\
\text { вих досліджень є підвищення кваліфікації. При цьому відзначається, що таке } \\
\text { навчання має все більше відповідати не лише потребам наукових установ, } \\
\text { а й вимогам ринку праці. }\end{array}$ \\
\hline 2 & $\begin{array}{l}\text { Навчальний план, спря- } \\
\text { мований на просресійний } \\
\text { розвиток та кар'єрне } \\
\text { зростання }\end{array}$ & $\begin{array}{l}\text { Важливим є урахування внутрішньої політики та стратегії розвитку університету. } \\
\text { Це передбачає відповідальність за забезпечення освітніх докторських програм } \\
\text { та дослідницьку роботу. Навчальний план повинен бути спрямований на вирі- } \\
\text { шення нових завдань та включати в себе відповідні можливості професійного } \\
\text { розвитку та кар'єрного зростання. }\end{array}$ \\
\hline 3 & $\begin{array}{l}\text { Можливості спільного } \\
\text { здобуття докторського } \\
\text { ступеня } \\
\end{array}$ & $\begin{array}{l}\text { Особливу увагу слід приділити різноманітності, зокрема можливості спільного } \\
\text { здобуття докторського ступеня (англ. "joint doctorates"), що є важливою іннова- } \\
\text { цією, на яку має спиратися якість освіти та обґрунтована практика. }\end{array}$ \\
\hline 4 & $\begin{array}{l}\text { Профресійне визнання } \\
\text { кандидатів на здобуття } \\
\text { докторського ступеня }\end{array}$ & $\begin{array}{l}\text { Кандидати на здобуття докторського ступеня як дослідники на початковій стадії } \\
\text { повинні бути визнані як профресіонали - із сумірними правами - які вносять клю- } \\
\text { човий внесок у створення нових знань. }\end{array}$ \\
\hline 5 & $\begin{array}{l}\text { Вирішальна роль керів- } \\
\text { ництва та оцінювання }\end{array}$ & $\begin{array}{l}\text { Відповідно до особистості кандидатів на здобуття докторського ступеня, меха- } \\
\text { нізми керівництва та оцінювання повинні базуватися на прозорій договірній } \\
\text { основі та розподіленні обов'язків між здобувачами докторського ступеня, науко- } \\
\text { вими керівниками та науковими установами, включаючи інших партнерів. }\end{array}$ \\
\hline 6 & $\begin{array}{l}\text { Досягнення критичного } \\
\text { значення }\end{array}$ & $\begin{array}{l}\text { Докторські програми повинні прагнути досягти критичного значення та спира- } \\
\text { тися на різноманітні види інноваційної практики, що активно впроваджується } \\
\text { в університетах по всій Європі, з урахуванням того, що рішення можуть варі- } \\
\text { юватися відповідно до різних контекстів, зокрема, у великих та менших за } \\
\text { розмірами європейських країнах. Вони можуть варіюватися від аспірантських } \\
\text { програм великих університетів до регіонального, національного та міжнародного } \\
\text { співробітництва між університетами. }\end{array}$ \\
\hline 7 & Тривалість & $\begin{array}{l}\text { Іокторські програми повинні тривати певний визначений період часу (зазвичай } \\
\text { ри-чотири роки з відривом від виробництва). }\end{array}$ \\
\hline 8 & $\begin{array}{l}\text { Сприяння інноваційним } \\
\text { структурам }\end{array}$ & $\begin{array}{l}3 \text { метою вирішення проблеми міждисциплінарної підготовки (англ. “interdiscipli- } \\
\text { nary training") та розвитку «трансферабельних навичок» (англ. "transferable } \\
\text { skills") докторські програми повинні сприяти інноваційним структурам. }\end{array}$ \\
\hline 9 & Підвищення мобільності & $\begin{array}{l}\text { Докторські програми повинні сприяти географрічній, міждисциплінарній та між- } \\
\text { галузевій мобільності та участі в програмах міжнародного партнерства в рамках } \\
\text { інтегрованої співпраці між університетами та іншими партнерами. }\end{array}$ \\
\hline 10 & $\begin{array}{l}\text { Забезпечення відповід- } \\
\text { ного фрінансування }\end{array}$ & $\begin{array}{l}\text { Розвиток якісних докторських програм та успішне виконання досліджень вимага- } \\
\text { ють сталого фрінансування. }\end{array}$ \\
\hline
\end{tabular}

Складено за джерелом [28] 
ваного у 1911 р. Товариства Кайзера Вільгельма (нім. "Kaiser-Wilhelm-Gesellschaft"). Відповідно до цього орієнтованого на особистість принципу науково-дослідні інститути Товариства ім. М. Планка продовжують традиції своєї попередньої установи і донині. Інститути Товариства ім. М. Планка беруть участь у науково-дослідних ссрерах, які $\epsilon$ особливо інноваційними та потребують спеціальних фрінансових чи часових витрат.

Варто відзначити постійний розвиток дослідницького спектру: в процесі пошуку відповідей на наукові питання засновуються нові інститути або розвиваються вже наявні, що дає змогу швидше реагувати на нові наукові розробки. За прогнозами експертів, країни Європейського Союзу очікують на демографрічні зміни. Прогнозується, що починаючи 32030 р. буде на 50 тисяч випускників менше, ніж у 2005 р. Особливо десріцит молодих фрахівців буде спостерігатися у природничих та технічних науках. Саме тому вже зараз важливо зацікавити молодих людей у вивченні вищезазначених дисциплін на початковому етапі. Вирішальну роль у цьому процесі наразі відіграють учителі, саме тому інститути Товариства ім. М. Планка для сприяння розвитку наук надають їм активну інформаційну підтримку, забезпечуючи їх так званими «Максзошитами» (нім. "MAX-Heften") [39], в яких актуальні теми дослідження подаються таким чином, щоб вони могли мотивувати школярів до поглибленого вивчення відповідних предметів [31].

Товариство сприяння прикладним дослідженням ім. Фраунгофера (нім. "Fraunhofer-Gesellschaft zur Förderung der angewandten Forschung") $€$ провідною дослідницькою організацією у Європі. Наукові галузі товариства орієнтовані на головні потреби людей, а саме: здоров'я, безпека, зв'язок, мобільність, енергія та навколишнє середовище. Результати досліджень товариства сприяють вирішенню різноманітних соціальних проблем у різних ссрерах, наприклад, у ссрері зміни клімату, здоров'я чи охорони навколишнього середовища. Важливу роль також відіграє активна передача знань у політичну сферу та суспільство, а також участь у соціальних дебатах [32].

Товариство німецьких дослідницьких центрів ім. Гельмгольца (нім. "Helmholtz-Gemeinschaft Deutscher Forschungszentren") ставить перед собою завдання реалізувати довгострокові наукові цілі держави та суспільства, а також підтримувати та покращувати життєдіяльність людей. 3 цією метою вищезазначене товариство визначає та досліджує основні та нагальні питання суспільства, науки та бізнесу шляхом реалізації стратегічних та програмно-орієнтованих досліджень у шести основних напрямах: енергетика, Земля та довкілля, здоров'я, авіація, космос і транспорт, матерія та ключові технології. Науковці товариства зосереджуються на дослідженні систем високої складності, насамперед на забезпеченні мобільності та енергозабезпечення, підтримці неушкодженого середовища для майбутніх поколінь або пошуку терапії для невиліковних раніше захворювань, що має суттєвий вплив на людей та навколишнє середовище [33].

Наукове Товариство ім. Г.В. Лейбніца (нім. "Wissenschaftsgemeinschaft Gottfried Wilhelm Leibniz") [34] об'єднує 96 незалежних наукових установ. Їх спрямованість варіюється від природничих, інженерних та екологічних наук до економічних, просторових, соціальних та гуманітарних. Ці установи консультують та інсрормують політику, науку, бізнес та громадськість. Наукове товариство імені Лейбніца підтримує тісну співпрацю з університетами шляхом організації «наукових таборів» (нім. "WissenschaftsCampi") [40], а також $з$ промисловістю, іншими партнерами в країні та за кордоном. Інститути наукового товариства ім. Г.В. Лейбніца підлягають прозорому та незалежному процесу оцінювання, у них працює близько 20 тисяч людей, у тому числі 10 тисяч науковців. Заслуговує на увагу такий напрям роботи товариства, як «дослідницькі музеї» (нім. "Forschungsmuseen"). Вісім дослідницьких музеїв наукового товариства збирають та досліджують актуальну інфрормацію. їх колекційні архіви включають у себе понад 100 мільйонів предметів та складають основу для дослідження історії землі та біорізноманіття, історії культури та технологій, збереження наукової та культурної спадщини. Завдяки їхнім постійним та спеціальним виставкам на базі досліджень у 12 місцях Німеччини мільйони людей щороку відвідують музеї та роблять важливий внесок у передачу знань [41].

Німецька служба академічних обмінів (нім. "Deutscher Akademischer Austauschdienst", DAAD) підтримує міжнародну академічну мобільність та $є$ найбільшою в світі організацією, яка фінансує міжнародний обмін студентами та науковцями. Вищезазначена організація була заснована 1 січня 1925 р. на базі приватної студентської ініціативи під назвою «Служба академічних обмінів» (нім. "Akademischer Austauschdienst", AAD) у м. Гейдельберг (Heidelberg). У 1943 р. ця організація була знищена в результаті бомбардувань та розпущена у 1945 р. 5 серпня 1950 р. організацію було відновлено під назвою «Німецька служба академічних обмінів». 3 моменту свого заснування Німецька служба академічних обмінів підтримала понад 2,3 млн вчених у Німеччині та за кордоном, що $є$ найвищим показником у світі. Окрім того, вищезазначена організація сприяє міжнародності німецьких університетів та популяризації німецької мови, підтримує країни, що розвиваються, у створенні ефективних університетів та консультує тих, хто приймає рішення щодо культурної політики, освітньої політики та політики розвитку. Німецька 
служба академічних обмінів підтримує понад 250 освітніх та наукових програм і в 2017 р. профрінансувала участь близько 140 тисяч німців та іноземців у цих програмах [41]. Вищезазначені програми включають в себе пропозиції семестрового навчання молодих студентів за кордоном, стажування, гостьові лекції, навчання на докторському та постдокторському рівнях. Крім того, Німецька служба академічних обмінів підтримує міжнародну діяльність німецьких університетів через маркетингові послуги, публікації, програми підвищення кваліфікації. Інфрормація про стипендії для іноземців надається через посольства Німеччини, відділення DAAD, інфрормаційні центри (IC), лекторів DAAD та університети-партнери за кордоном. Німецькі студенти підтримують зв'язок 3 DAAD через міжнародний офріс університету. Варто відзначити, що Німецька служба академічних обмінів $€$ національним агентством 3 координації та реалізації програм "Erasmus” Європейського Союзу [35].

Окрім того, Німецька служба академічних обмінів фрінансує чисельні стипендійні програми, а саме: для студентів, які навчаються на бакалаврських програмах (літні курси у Німеччині для іноземних студентів, групові поїздки для студентів (нім. "Studienreisen"); для випускників (стипендії на навчання для випускників вищих навчальних закладів з усіх спеціальностей, ERP-стипендії на навчання для випускників у галузі економіки, стипендії для підвищення кваліфікації для фрахівців у галузі німецької мови); для аспірантів (короткі стипендії, річні стипендії, аспірантура 3 подвійним науковим керівництвом, повна аспірантура у Німеччині); для молодих науковців (короткі стипендії, річні стипендії); для викладачів (наукові стажування для іноземних викладачів вищих навчальних закладів та науковців, двосторонній обмін науковцями, організація міжгалузевих досліджень). Окрім того, Німецька служба академічних обмінів надає повторні запрошення колишнім стипендіатам DAAD [35].

Цікавим $€$ інформаційний сайт Німецької служби академічних обмінів «Компас по вищим навчальним закладам» (нім. "Hochschulkompass"), на якому можна знайти корисну інфрормацію та посилання на сайти державних та визнаних державою вищих навчальних закладів Німеччини. Крім того, на ньому наведена інформація про перспективні напрями навчання, можливості здобуття докторського ступеня, можливості міжнародного співробітництва, пропоновані німецькими та зарубіжними університетами [43].

Також варто відзначити інформаційний сайт Німецької служби академічних обмінів «Вибір навчального закладу» (нім. "Studienwahl"), на якому можна знайти короткий огляд усіх навчальних напрямів та інформаційну базу з інформацією про всі можливі навчальні напрями та відповідні посилання. Крім того, відвідувачі сайту можуть дізнатися про актуальну ситуацію на ринку праці, різні види навчальних закладів, можливості для фрінансування навчання, питання стосовно страхування і багато інших [43].

ще одним підрозділом Німецької служби академічних обмінів $€$ «Німецький студентський союз» (нім. “Das Deutsche Studentenwerk"), який об'єднує 58 студентських спілок Німеччини. Вищезазначена організація підтримує близько 2 мільйонів студентів у Німеччині, пропонуючи багато пропозицій, пов'язаних із їхнім навчанням. На цій платорормі іноземні студенти можуть знайти інфрормацію 3 таких питань, як особливості вступу, отримання дозволу на проживання, страхування, фрінансування, правила зарахування тощо. Крім того, відвідувачам сайту пропонується пройти опитування стосовно навчання в Німеччині. Також наводиться пояснення ключових освітніх понять, наприклад, «тестове оцінювання» (нім. "Feststellungsprüfung"), «підготовчий коледж» (нім. "Studienkolleg"). На цьому інформаційному сайті можна знайти посилання на німецькі студентські профспілки [45].

Австрійська служба академічних обмінів (нім. "Österreichischer Austauschdienst", ОеAD) сприяє забезпеченню міжнародної кооперації та мобільності в освіті та науці. 3 бюджетом понад 70 мільйонів євро та штатом працівників, який включає в себе більш ніж 250 співробітників станом на 2020 р. ця організація забезпечує участь освітян та науковців у орієнтованих на майбутнє програмах в галузях освіти, науки та культури. Заслуговують на увагу дослідницькі проєкти, спрямовані на співпрацю науки, шкільної освіти та суспільства. Департамент «громадських наук» (англ. "Public science") забезпечує фрінансування від Федерального міністерства освіти, науки та досліджень (нім. "Bundesministerium für Bildung, Wissenschaft und Forschung") та програму фрінансування від імені Фонду інноваційної освіти, в якому школи та зацікавлені громадяни співпрацюють 3 науковцями, дослідниками та експертами у відповідних галузях. Участь у дослідженнях та проєктах надає зацікавленим сторонам можливість здобувати нові знання, підтримувати дослідників у їхній роботі та сприяти розвитку нових наукових знань [36].

Цікавою $€$ дослідницька програма Австрійської служби академічних обмінів «Ігриста наука» (англ. "Sparkling Science"), в рамках якої починаючи 32007 р. Федеральне міністерство освіти, науки та досліджень надало фрінансову підтримку 299 дослідницьким проєктам (станом на липень 2019 р.), спрямованих на співпрацю науковців та школярів. До участі у програмі було залучено 102 тисячі представників із 200 науково-дослідних установ та майже 530 шкіл, які спільно працюють над вирішенням наукових питань. Наприклад, у рамках проєкту «Міські дерева» (нім. "Stadtbäume") 
був досліджений вплив міських дерев на зміну клімату. Також варто відзначити історичну виставку, присвячену темі «Європейське рабство» (нім. "Europäische Sklaverei"). Робота над вищезазначеними проєктами сприяла пробудженню інтересу дітей та підлітків до науки [36].

Ініціатива Австрійської служби академічних обмінів «Найвища громадянська наука» (англ. “Тор Citizen Science") сприяла залученню раніше профінансованих проєктів «Ігриста наука» для подання розширених проєктів у галузі громадянської науки та відкритих інновацій. Завдяки власним умінням, досвіду, допитливості та готовності до співпраці громадяни зробили свій внесок, який сприяв появі нових результатів дослідження. У рамках ініціативи 31 науково-дослідний проєкт отримав фрінансування понад 1,5 млн євро, у тому числі 14 наукових проєктів на суму 600 тисяч євро [36].

У червні 2018 р. була запущена нова програма Австрійської служби академічних обмінів «Створення цифрових навчальних матеріалів та навчальних матеріалів 3 використанням методів громадянської науки» (нім. "Erstellung von digitalen Lehr- und Lernmitteln mit Citizen-ScienceMethoden"), яка фрінансувалася Фондом інноваційних освітніх програм. Відповідно до цієї програми на першому етапі передбачалося подання проєктів щодо перегляду наявних цифрових навчальних матеріалів 3 «громадянськими вченими» (англ. "Citizen Scientists"), а саме школярами, студентами, вчителями, викладачами. На другому етапі вищезазначені «громадянські вчені» разом із іншими громадянами створили нові цифрові засоби для навчання та викладання. За змістом розроблені навчальні посібники стосувалися міждисциплінарних тем, таких як мобільність, міграція, демократія тощо. Інтеграція проєктів у навчальне середовище сприяла створенню інноваційних та практично-орієнтованих навчальних матеріалів, які надалі були доступні як відкриті освітні ресурси (англ. "Open Educational Resources") на навчальній платформі "Eduthek" за відкритою безкоштовною ліцензією. Заявки на участь у проєкті могли подавати науково-дослідні установи, школи, неприбуткові установи та компанії. Усього було виділено фрінансування на суму 250 тисяч євро у рамках першого етапу та 575 тисяч євро у рамках другого етапу, що дало змогу профрінансувати 21 запропонований проєкт [36].

Швейцарський національний фонд наукових досліджень (нім. "Schweizerischer Nationalfonds zur Förderung der wissenschaftlichen Forschung", SNF) фрінансує наукові дослідження та підтримує молодих учених у Швейцарії. Стратегія та цілі фонду спрямовані на покращення якості наукових досліджень у Швейцарії, наближення фрінансування досліджень до потреб дослідників, підтримку поширення набутих знань у суспільстві та демонстрацію цінності наукових досліджень. Цілі Швейцарського національного фронду наукових досліджень зазначені в багаторічній програмі та плані дій. Багаторічна програма розрахована на 2017-2020 роки та включає в себе інорормацію про пріоритети та цілі фонду, які випливають із викликів, які стоять перед швейцарським суспільством, а також заходи, спрямовані на досягнення цих цілей та можливості для фрінансування цих заходів. Весною 2019 р. Швейцарський національний фронд наукових досліджень подав на розгляд швейцарського уряду багаторічну програму на 2021-2024 роки, яка зосереджена на 4 пріоритетах, а саме: сприянні досконалості серед різноманітності; зміцненні міжнародного лідерства шляхом співпраці; підтримці інфраструктури даних та послуг для відкритої наукової системи; підвищенні важливості досліджень для суспільства [37].

Швейцарське агентство 3 підтримки інновацій (нім. "Innosuisse - Schweizerische Agentur für Innovationsförderung") $€$ фредеральною установою 3 публічного права зі своєю власною правосуб'єктністю. Головним завданням агентства $€$ сприяння науковим інноваціям в інтересах бізнесу та суспільства. Швейцарське агентство 3 підтримки інновацій визначає поєднання знань, досвіду, досліджень та розробок як ключову запоруку успіху в умовах сьогодення. Діяльність цієї організації спрямована на співпрацю науки та бізнесу в рамках реалізації інноваційних проєктів, що сприяє виникненню успішних стартапів, продуктів та послуг та створює передумови для розвитку економіки. Агентство дотримується принципу субсидіарності та надає підтримку проєктам лише тоді, коли інновації не відбудуться без фрінансування, або якщо ринковий потенціал не використовується [38].

Висновки. Наприкінці $X X$ - на початку XXI століття систему освіти та науки німецькомовних країн Європи було повністю сорормовано. В її основі лежать положення «Болонської декларації», «Європейського простору вищої освіти» та «Зальцбурзькі принципи». Вищезазначена система знайшла відображення у діяльності провідних наукових організацій німецькомовних країн Європейського Союзу, аналіз діяльності яких дав змогу виокремити перспективні напрями екстраполяції в систему освіти України.

Всі виокремлені напрями можна об' єднати у такі групи відповідно до мети їх впровадження:

Інтернаціоналізація вітчизняної науки:

- впровадження аспірантури 3 подвійним науковим керівництвом (приклад - досвід Німецької служби академічних обмінів);

- надання стипендій для навчання та здійснення наукових досліджень в Україні талановитим іноземним студентам та науковцям (приклад досвід Німецької служби академічних обмінів); 
- організація освітніх порталів та інорормаційних сайтів про наукові досягнення провідних дослідних установ України іноземною мовою (приклад-досвідНімецькоїслужбиакадемічнихобмінів).

Популяризація наукових досліджень:

- організація освітніх порталів та інфрормаційних сайтів про наукові досягнення провідних дослідних установ українською мовою (приклад досвід Німецької служби академічних обмінів);

- розробка та впровадження нових засобів для навчаннятавикладанняуцифровуепоху (прикладдосвід Австрійської служби академічних обмінів);

- залучення науковців до спільної роботи зі школярами над вирішенням наукових питань у рамках популяризаторських проєктів (приклад проєкт «Ігриста наука» Австрійської служби академічних обмінів);

- впровадження методів «громадянської науки» 3 метою фрормування розгалуженої спільноти «громадянських вчених» (приклад - досвід Австрійської служби академічних обмінів);

- залучення науковців до розробки популяризаторських навчальних матеріалів з природничих та технічних дисциплін для учнів загальноосвітніх шкіл (приклад - «Макс-зошити» (нім. "МАХHeften"), розроблені науковцями Товариства ім. М. Планка для сприяння розвитку наук);

- організація «наукових таборів» та «дослідницьких музеїв» в Україні (приклад - досвід Наукового Товариства ім. Г.В. Лейбніца).

Налагодження партнерських відносин «наукабізнес-суспільство»:

- фрінансування науково-дослідних проєктів у рамках громадських ініціатив (приклад - ініціатива «Найвища громадянська наука» Австрійської служби академічних обмінів);

- організація співпраці науки та бізнесу в рамках інноваційних проєктів (приклад - досвід Швейцарського агентства з підтримки інновацій).

Розвиток науки:

- впровадження між- та трансдисциплінарних досліджень (приклад - досвід Товариства сприяння прикладним дослідженням ім. Фраунгофрера).

- наближення фрінансування досліджень до загальноєвропейської практики (приклад - досвід Швейцарського національного фонду наукових досліджень);

- демонстрація цінності наукових досліджень (приклад - досвід Швейцарського національного оронду наукових досліджень);

- підтримка інфраструктури даних та послуг для відкритої наукової системи (приклад - досвід Швейцарського національного фронду наукових досліджень).

Екстраполяція зазначених напрямів сприятиме інтернаціоналізації вітчизняної науки, популяризації наукових досліджень, налагодженню партнерських відносин «наука-бізнес-суспільство» та розвитку науки. Водночас очевидно, що вони не можуть бути впроваджені в систему освіти та науки України одночасно, адже мають свої переваги та недоліки, а також потребують нерівнозначних фрінансових, часових та трудових ресурсів. Саме тому напрямом подальших досліджень має стати поглиблений аналіз запропонованих заходів щодо їх дієздатності в соціально-економічних умовах України та їх подальше групування за пріоритетами впровадження - на коротко-, середньо- та довгострокову перспективу.

\section{БІБЛІОГРАФІЧНИЙ СПИСОК:}

1. Закон України «Про освіту». Відомості Верховної ради України, 2019. №2657-VIII. 2661. VIII. URL: https://zakon.rada.gov.ua/laws/show/2145-19.

2. Achieving the Goals. Communique of the Conference of European Ministers Responsible for Higher Education, Bergen, 19-20 May 2005. The European Higher Education Area, 2005. 6 p. URL: https://www.eurashe.eu/ library/modernising-phe/Bologna_2005_BergenCommunique.pdf (дата звернення: 28.02.20ㅡㄹ).

3. Постанова Кабінету Міністрів України «Про затвердження Порядку підготовки здобувачів вищої освіти ступеня доктора орілософрії та доктора наук у вищих навчальних закладах (наукових установах)» № 261 від 23.03.2016 р. Урядовий кур'єр, 27.04.2016. № 80.

4. Методика оцінювання ефективності діяльності наукових установ НАH України. URL: http://www.nas.gov.ua/text/pdfNews/metodyka_text.pdf (дата звернення: 28.02.2020).

5. Leibniz Gemeinschaft. Quality assurance by Scientific Advisory Boards at Leibnizinstitutions. Матеріали сайту Leibniz Association. URL: http://www.leibnizgemeinschaft.de/en/about-us/ evaluation/quality-assurance-by-scientific-advisoryboards-at-leibniz-institutions/ (дата звернення: 28.02.2020).

6. Постанова Кабінету Міністрів України «Про проведення експерименту 3 присудження ступеня доктора фрілософії» № 167 від 06.03.2019. Урядовий кур'єр, 19.03.2019. №53.

7. Проєкт «Порядок присудження наукових ступенів доктора наук і доктора фрілософії спеціалізованими вченими радами закладів вищої освіти (наукових установ)» 2020. URL: https://cutt.ly/eybOGiU (дата звернення: 17.04.2020).

8. Global Innovation Index 2019. Матеріали сайту World Intellectual Property Organization. URL: https://www.wipo.int/global_innovation_index/en/2019/ ?fbclid=IwAR3RBFdcFUog 5 NX5KsF̄9eRYYto9twO Jn5Ty-yokuUhhv1-j7ZvabLgRuoY (дата звернення: 17.04.2020).

9. Gross expenditure on research and development, 2019. Матеріали сайту KNOEMA. URL: https://cutt.ly/ 7yEaVtT (дата звернення: 17.04.2020).

10. Країна потужної науки. Матеріали сайту Факти проНімеччину, 2018.URL:https://www.tatsachen-ueberdeutschland.de/uk/kategoriyi/osvita-i-nauka/krayinapotuzhnoyi-nauky (дата звернення: 28.02.2020).

11. Citable documents $\mathrm{H}$ index, 2019. Матеріали сайту KNOEMA. URL: https://cutt.ly/hyEswXJ (дата звернення: 17.04.2020). 
12. Nobel Prize Winners by Country. Матеріали сайту World Atlas. URL: https://cutt.ly/5yEsacX (дата звернення: 17.04.2020).

13. Гаврилюк А.В. Тенденції розвитку класичних університетів Німеччини : дис. канд. пед. наук : 13.00.01. Київський університет імені Б. Грінченка, 2016. 228 с.

14. Христинченко Н. Міжнародно-правовий аспект розвитку наукової діяльності в зарубіжних країнах. Актуальні проблеми правознавства. 2017. № 2. C. $46-50$.

15. Мороз В.М., Мороз С.А. Німецька модель підготовки науково-педагогічних кадрів: особливості розбудови та перспективи використання для розвитку трудового потенціалу вітчизняних ВНЗ. Теорія і практика управління соціальними системами: фрілософія, психологія, педагогіка, соціологія, 2016. № 2. С. 87-96.

16. Литвин І.В., Мельник А.В. Формування інноваційних екосистем стартапів на прикладі вищих навчальних закладів Німеччини. Молодий вчений. 2018. №4 (2). С. 799-805.

17. Отрощенко Л.С. Досвід менеджменту системи вищої освіти Німеччини. Вісник Київського національного університету культури і мистецтв. Серія: Менеджмент соціокультурної діяльності. 2018. № 2. C. 120-133.

18. Дебич М.А. Теоретичні засади інтернаціоналізації вищої освіти: міжнародний досвід : монографрія. М.А. Дебич. Ніжин : ПП Лисенко, 2019. 408 с.

19. Чорна О.В. Розвиток системи моніторингу якості вищої освіти України: актуальність використання досвіду Німеччини. Науковий вісник Ужгородського національного університету. Серія: Педагогіка. Соціальна робота. 2015. № 37. С. 209-213.

20. Gummel H. Forschungsgeschichte in Deutschland. Berlin: Walter de Gruyter $\mathrm{GmbH}$ \& Co KG, 1938. $483 \mathrm{~S}$.

21. Wolter A. Die Entwicklung wissenschaftlicher Weiterbildung in Deutschland: Von der postgradualen Weiterbildung zum lebenslangen Lernen. Beiträge zur Hochschulforschung, 2011. № 33(4). S. 8-35.

22. Geser H. Mängel der Schulausbildung aus Arbeitgebersicht. Zürich: Soziologisches Institut der Universität Zürich, 1999. URL: http://socio.ch/work/geser/07.htm (дата звернення: 28.02.2020).

23. Sorbonne Joint Declaration. European Higher Education Area. URL: http://www.ehea.info/media. ehea.info/file/1998_Sorbonne/61/2/1998_Sorbonne Declaration_English_552612.pdf (дата звернення: 28.02.2020).

24. The Bologna Declaration of 19 June 1999. Матеріали сайту European Higher Education Area. URL: http://www.ehea.info/media.ehea.info/file/Ministerial conferences/02/8/1999 Bologna_Declaration English_553028.pdf (дата зверннення: 28.02.2020).

25. $\bar{M} c G$ rath S., Rogers L. Developing transferable skills. Edge Future Learning, 2019. P. 9-15. URL: https://cutt.ly/zyPd9ZB (дата звернення: 28.02.2020).

26. Transferrable Skills. Матеріали сайту Skills you need. URL: https://www.skillsyouneed.com/general/ transferable-skills.html (дата звернення: 17.04.2020).

27. Realising the European Higher Education Area. Матеріали сайту European Higher Education Area. URL: http://ehea.info/Upload/document/ministerial declarations/2003_Berlin_CCommunique_English_57̄̄284. pdf (дата звернення: 17.04.2020).
28. Conclusions and recommendations. Bologna Seminar on "Doctoral Programmes for the European Knowledge Society". Матеріали сайту European University Association. Salzburg, 2005. 3 p. URL: https://cutt.ly/RygZNW8 (дата звернення: 17.04.2020).

29. Budapest-Vienna Declaration on the European Higher Education Area. Матеріали сайту European Higher Education Area. URL: https://cutt.ly/QyPftSQ (дата звернення: 28.02.2020).

30. Full Members. Матеріали сайту European Higher Education Area. URL: http://www.ehea.info/ page-full_members (дата звернення: 28.02.2020).

31.Ein Porträt der Max-Planck-Gesellschaft. Матеріали сайту Max-Planck-Gesellschaft. URL: https://www.mpg.de/de (дата звернення: 17.04.2020).

32. Forschung im Auftrag der Zukunft [Електронний ресурс]. Матеріали сайту Fraunhofer. URL: https://www.fraunhofer.de/(датазвернення: 17.04.2020).

33. Über uns. Матеріали сайту Helmholz-Gemeinschaft, 2020. URL: https://www.helmholtz.de/ (дата звернення: 17.04.2020)

34. Über die Leibniz-Gemeinchaft. Матеріали сайту Leibniz-Gemeinchaft. URL: https://www.leibniz-gemeinschaft.de/ (дата звернення: 17.04.2020).

35. Organisation. Матеріали сайту Deutscher Akademischer Austauschdienst. URL: https://www.daad.de/ de/ (дата звернення: 17.04.2020).

36. Organisation und Aufgaben. Матеріали сайту Österreichischer Austauschdienst. URL: https://oead.at/ (дата звернення: 17.04.2020).

37. Strategy. Матеріали сайту Schweizerischer Nationalfonds zur Förderung der wissenschaftlichen Forschung. URL: http://www.snf.ch/en/Pages/default. aspx (дата звернення: 17.04.2020).

38. Über uns. Матеріали сайту Innosuisse. Schweizerische Agentur für Innovationsförderung. URL: https://www.innosuisse.ch/inno/de/home.html (дата звернення: 17.04.2020).

39. Max-Hefte. Матеріали сайту Max-Wissen. URL: https://www.max-wissen.de/(датазвернення:17.04.2020).

40. Leibniz-WissenschaftsCampi. Матеріали сайту Leibniz-Gemeinschaft. URL: https://www.leibnizgemeinschaft.de/forschung/leibniz-wissenschaftscampi.html (дата звернення: 17.04.2020).

41. Leibniz-Forschungsmuseen. Матеріали сайту Leibniz-Gemeinschaft. URL: https://www.leibniz-gemeinschaft.de/forschung/forschungsmuseen.html (дата звернення: 17.04.2020).

42. Weiterer Aufwärtstrend bei Stipendien und Programmen: DAAD zieht positive Bilanz für den Wissenschftsaustausch, 2017. Матеріали сайту Deutscher Akademischer Austauschdienst. URL: https://www2.daad.de/ presse/pressemitteilungen/de/64076-weiterer-aufwaertstrend-bei-stipendien-und-programmen-daad-zieht-positive-bilanz-fuer-den-wissenschaftsaustausch-2017/ (дата звернення: 17.04.2020).

43.Der Hochschulkompass - ein Überblick. Матеріали сайту Hochschulkompass. URL: https://www. hochschulkompass.de/ (дата звернення: 17.04.2020).

44. Alle Studienfelder im Überblick. Матеріали сайту Studienwahl.de. URL: https://studienwahl.de/ (дата звернення: 17.04.2020).

45. Informationen für Internationale Studierende. Матеріали сайту Deutsches Studentenwerk. URL: http://www.internationale-studierende.de/ (дата звернення: 17.04.2020). 


\section{ВНЕСОК ЛЬВІВСЬКОЇ ХУДОЖНЬО-ПРОМИСЛОВОЇ ШКОЛИ У ПРОЦЕС ВПРОВАДЖЕННЯ НАВЧАННЯ ДЕКОРАТИВНОГО МИСТЕЦТВА В СИСТЕМУ ХУДОЖНЬОЇ ОСВІТИ УКРАЇНИ (ДРУГА ПОЛОВИНА ХІХ - ПОЧАТОК ХХ СТОЛІТТЯ) CONTRIBUTION OF LVIV ART-INDUSTRIAL SCHOOL IN THE PROCESS OF INTRODUCING DECORATIVE ARTS TEACHING IN THE SYSTEM OF ART EDUCATION OF UKRAINE (SECOND HALF OF THE XIX - EARLY XX CENTURY)}

\begin{abstract}
У статті проаналізовано особливості становлення Львівської художньо-промислової школи в контексті дослідження процесу впровадження навчання декоративно-прикладного мистецтва на західноукраїнських землях, які у другій половині XIX - на початку XX століття знаходилися під владою Австро-Угорської імперії. В історико-педагогічному руслі простежено історичні віхи становлення провідного навчального закладу художньо-промислової освіти на теренах Західної України. Встановлено зміни статусу, підпорядкування і назв художньо-промислової школи внаслідок перепрофрілювання й розширення напрямів освітньої діяльност в галузі декоративно-ужиткового мистецтва за спеціальностями: художня обробка дерева (столярство, сницарство) й металу (слюсарство, ковальство), художній текстиль (гаптування й мереживо), художнє малярство. Показано, що творчі здобутки учнів з успіхом демонструвалися на виставках різних рівнів (у тому числі Європейських, Міжнародних, Всесвітніх).

Виявлено пріоритетну мету діяльності Львівського художньо-промислового музею: удосконалення промислів і ремесел краю в технічному та естетичному напрямі та з'ясовано його роль у створенні художньопромислової школи у Львові. Визначено аспекти взаємодії музею та школи: культурно-просвітницький, освітньо-професійний з пріоритетом виставкової роботи в усіх напрямах.
\end{abstract}

Зроблено висновки щодо діяльності Львівської художньо-промислової школи в контексті впровадження процесу навчання декоративного мистецтва в систему вітчизняної художньої освіти другої половини XIX - початку XX століття, яка відзначилася: використанням організаційно-педагогічного досвіду фуннкиіонування аналогічних закладів Австро-Угорщини; створенням відділів архітектурно-будівничого та художнього напрямів з перевагою мистецького; формуванням пріоритетного напряму художньої, художньо-промислової й художньо-ремісничої освіти західноукраїнської мистецької школи: використання синтезу образотворчого й декоративно-прикладного мистецтва з домінуванням декоративного.
Ключові слова: Львівський художньо-промисловий музей, Львівська художньо-промислова школа, навчання декоративно-прикладного мистецтва.

The article analyzes the peculiarities of formation of Lviv Art-Industrial School in the context of studying the process of teaching arts and crafts in Western Ukraine, which in the second half of the $X I X$ - early $X X$ century were under the rule of the Austro-Hungarian Empire. In the historicalpedagogical direction, the historical milestones of the formation of the leading education institution of art-industrial education in Western Ukraine are traced. Changes in the status, subordination and names of art-industrial schools due to re-profiling and expansion of the educational activities in the field of decorative and applied arts are defined in the following specialties: artistic woodworking (carpentry) and metal (metalwork, blacksmithing), artistic textiles (quilting and lace), artistic painting. It is shown that students' creative achievements were successfully demonstrated at exhibitions of various levels (including European, International, World).

The priority goal of Lviv Art-Industrial Museum is revealed: improvement of crafts and handicrafts of the region in the technical and aesthetic direction and its role in the creation of the art-industrial school in Lviv. Aspects of interaction between the muse um and the school are determined: culturaleducational, educational-professional with the priority of exhibition work in all directions.

Conclusions are made on the activities of Lviv Art-Industrial School in the context of introduction of decorative arts teaching in the system of domestic art education of the second half of the XIX - early XX century, which was marked by: implementation of the organizational and pedagogical experience of similar institutions in Austria-Hungary; creation of departments of architectural-building and art directions with prevalence of art; formation of the priority direction of art, art-industrial and art-craft education of the western Ukrainian art school: use of synthesis of fine and decorative-applied arts with dominance of decorative.

Key words: Lviv Art-Industrial Museum, Lviv Art-Industrial School, teaching of decorative and applied arts. канд. пед. наук,

скульптор, незалежний діяч
УДК 377/378.09:74/75(477)«18/193 6085/2020/24-2.2

Постановка проблеми. У сучасних реаліях розвитку українського суспільства необхідним $€$ пошук нових шляхів для вдосконалення навчально-виховного процесу у розвитку вітчизняної художньої освіти. Одним із аспектів нової освітньої парадигми $€$ ретельне вивчення історико-педагогічної спадщини минулого задля використання позитивного досвіду попередників (педагогів - митців-художників, майстрів декоративно-прикладного мистецтва, діячів культури й освіти) у розбудові Нової української школи.

Аналіз останніх досліджень і публікацій. Проблема розвитку мистецької освіти на західноукраїнських землях XIX - початку XX століття 
розглядалася й досліджувалася у різних аспектах багатьма вітчизняними вченими. Зокрема, в контексті вивчення загальноісторичних процесів розвитку художньої освіти в Україні становлення Львівської мистецької школи висвітлювали П. Андріюк, О. Іванкова-Стецюк, Р. Орлов, В. Радкевич, Л. Соколюк, Р. Шмагало, В. Щербак та інші. О. Волинська, А. Волощук, М. Дяків, С. Мільчевич, О. Нога, Р. Одрехівський, О. Попик, К. Сусак, В. Цісарук виявляли регіональну специфіку розвитку художньо-промислової освіти західних регіонів України досліджуваного періоду. Історичні віхи становлення художньо-ремісничого закладу у Львові в контексті фрормування культурно-освітнього життя Галичини прослідкували Я. Бабош, С. Гелей, М. Варвух, Л. Синишин та інші. М. Маковецька, Н. Мартиненко розглядали значення Львівської художньо-промислової школи у зародженні і розвитку вітчизняного дизайну. Вплив музеїв та виставок рукоділля й традиційних промислів на становлення художньо-промислової школи в Галичині другої половини XIX - початку XX століття виявляли С. Король, Л. Оршанський, Л. Молоствова, О. Ямборко та інші.

Виділення не вирішених раніше частин загальної проблеми. Як показує аналіз літературних джерел, у контексті Нової української школи традиційна система мистецької освіти не задовольняє повною мірою запити сучасного суспільства на використання історико-педагогічного досвіду навчання декоративно-прикладного мистецтва у закладах художньої, художньо-ремісничої та художньо-промислової освіти різних регіонів України другої половини XIX - початку XX століття.

Мета статті - схарактеризувати внесок Львівської художньо-промислової школи у процес впровадження навчання декоративно-прикладного мистецтва в систему художньої освіти другої половини XIX - початку XX століття.

Виклад основного матеріалу. Аналіз архівних матеріалів і літературних джерел дає підстави стверджувати, що Львівську художньо-промислову школу було започатковано 1876 року за сприяння новоствореного Міського промислового музею у м. Львові. Організацію вказаного музею прискорила Всесвітня Віденська виставка художніх промислів 1873 року. У процесі підготовки майстрів-ремісників та їхніх учнів до участі в означеній виставці постала проблема необхідності започаткування системи художньо-промислової освіти 3 метою підготовки фахівців декоративно-прикладного мистецтва європейського рівня [1; 9]. Постановка проблеми полягала у вирішенні організаційно-педагогічних завдань для створення низки навчальних закладів художньо-ремісничого профрілю з відповідним теоретико-методичним забезпеченням. Наслідуючи позитивний приклад художніх музеїв Кракова та Відня, які закуповували на міжнародних виставках експонати для навчальних закладів, Музейний комітет (організований громадськістю Львова) для навчальних цілей теж придбав 1873 і 1874 року на Віденських Всесвітніх виставках художніх промислів експонати, а також твори декоративно-прикладного мистецтва та промислові вироби для фрахової підготовки майстрів-ремісників Львова і Галичини [7; 8]. Означений фракт вказує на взаємодію культурно-просвітницької й освітньо-професійної діяльності музею і навчального закладу.

За допомогою дослідженням наукових праць Л. Оршанського встановлено, що свою діяльність новостворений музей розпочав із організації і проведення виставок виробів традиційних художніх промислів, адже згідно зі Статутом Міського промислового музею Львова, головною метою його функціонування було підтримувати розвиток промисловості художньої галузі і рукоділля в регіоні [6, с. 20]. Зауважимо, що у першому параграфі Статуту була задекларована 1874 року і затверджена Міською радою пріоритетна мета діяльності промислового музею «удосконалення промислів і ремесел краю в технічному та естетичному напрямах через систематичне збирання допоміжних засобів, які поширюють науку та мистецтво» [3, с. 9]. Збирання допоміжних засобів передбачало поповнення музейних збірок, бібліотечних фрондів, проведення виставок, видання часописів, мистецьких журналів і альбомів, облаштування експозицій виробів традиційного мистецтва для розширення навчально-методичного наповнення змісту навчальних дисциплін художньо-ремісничої освіти. Досвід Австро-Угорщини, де вже функціонували художньо-промислові школи, став прикладом для створення професійного навчального закладу-Львівської художньо-промислової школи.

У процесі дослідження з'ясовано, що відповідно до наказу Міністерства освіти й віросповідання 18 грудня 1876 року при Художньо-промисловому музеї відбулося відкриття Львівської промислової школи рисунку і моделювання [13]. Основним завданням новоствореного навчального закладу була підготовка молоді до навчання у вищих мистецьких школах. У 1882 році у зв'язку 3 перепрофрілюванням заклад було перейменовано у Школу художнього (артистичного) промислу [14] та відкрито відділення фрахової підготовки столярів, сницарів, токарів. Від 1885 року розпочався рух за надання школі статусу державної. Згодом, у 1891 році, заклад було об'єднано зі Школою будівельних майстрів і реорганізовано у Державну промислову школу [15, с. 25]. Варто вказати, що 20 січня 1893 року директором школи було призначено запрошеного 3 Німеччини архітектора Зигмунта Горголевського. Від цього часу школа здійснювала навчально-виховний процес за двома провідними напрямами: будівельного 
промислу (підготовка фрахівців будівельної галузі, підлеглої архітектурному мистецтву) і промислу мистецького (навчання різновидам декоративноужиткового мистецтва). Загалом заклад зазнав ще низку перейменувань і реорганізацій, наразі за школою закріпилася загальноприйнята назва «Львівська художньо-промислова школа».

За розвідками Л. Глембоцької, мистецькоосвітня діяльність школи значною мірою була скерована митцями-педагогами, випускниками Мюнхенської і Краківської академії мистецтв, Віденської художньо-промислової школи. Так, започаткований першими викладачами-художниками (С. Вигжевальським, К. Ольпінським, К. Сіхульським) напрям синтезу образотворчого й декоративного мистецтва з домінуванням декоративно-ужиткового мистецтва був і залишається пріоритетним напрямом розвитку художньо-промислової освіти Львівської мистецької школи у всі історичні етапи розвитку мистецької освіти Західної України [2, с. 2]. Творчі здобутки учнів 3 успіхом демонструвалися на виставках різних рівнів, що підтвердило правильно обраний курс орієнтації на виконання ужиткових виробів за традиційними мотивами й усталеними композиційними рішеннями регіону [6].

Аналіз розвідок Р. Шмагала $[10 ; 11 ; 12]$ дозволив виявити, що у 1886/87 навчальному році було відкрито відділи гаптів і мережива, різьбярський відділ та засновано курси для вчителів народних шкіл. Факти розширення напрямів фрахової підготовки майстрів різних видів декоративного мистецтва регіону засвідчує успіх у молоді, що бажала здобути відповідну художньо-професійну освіту, а також підтримка громадськості регіону та схвальні відгуки в пресі [10]. Підтримка художньо-промисловій школі була надана також на державному рівні. Зокрема, у березні 1890 року «президент» (за сучасною термінологією «мер») міста Львова п. Мохнацький займався питанням школи у Відні щодо надання статусу державної. Клопотання п. Мохнацького було вирішено позитивно, і заклад було реорганізовано у Державну промислову школу [11]. Цього ж року було відкрито відділ художнього металу, декоративного малярства і скульптури. Загалом Статут реорганізованої Державної школи засвідчив у її складі чотири відділи: будівельного і художнього слюсарства; будівельного і меблевого столярства; токарства; сницарства. Крім того, у фрормі окремої майстерні при школі функціонували два винятково жіночі відділення гаптів і мережива [5, с. 20].

Як зазначив Т. Максисько, кількісне збільшення спеціальностей відбулося завдяки побудованому у 1892 році новому приміщенню для закладу, а також завдяки залученню до реалізації проєктів міста викладачів і учнів школи. Наступне розширення навчальних площ закладу сталося у 1909/10 навчальному році [4]. У вказа- ний період підготовка учнів проходила за тринадцятьма спеціальностями 3 перевагою художньомистецького напряму.

Таким чином, можна підсумувати, що за сприяння художньо-промислового музею творчі декоративно-ужиткові вироби учнів школи систематично демонструвалися на виставках у Львові, Відні, Празі та інших містах України й Європи. Вагомим доказом плідної співпраці художньо-промислового музею та художньо-промислової школи Львова у сорері дослідницької й освітньо-виховної роботи слід вважати серійне видання зі зразками народного мистецтва В. Вербицького «Взори промислу домашнього селян на Руси» (1880), публікацію альбомів виробів місцевих майстрів та зразків традиційних орнаментів, великої кількості мистецтвознавчих і етнограсрічних праць [12], що сприяли наповненню змісту теоретико-методичних основ навчання декоративного мистецтва у закладах художньої, художньо-промислової, художньоремісничої освіти України досліджуваного періоду.

Висновки. Таким чином, вищевикладене дає нам підстави стверджувати, що діяльність Львівської художньо-промислової школи в контексті процесу впровадження навчання декоративного мистецтва в систему вітчизняної художньої освіти другої половини XIX - початку XX століття характеризувалася: використанням організаційно-педагогічного досвіду функціонування аналогічних закладів Австро-Угорщини; створенням відділів архітектурно-будівничого та художньопромислового напрямів з перевагою мистецького; формуванням пріоритетного напряму художньопромислової освіти західноукраїнської школи: використання синтезу образотворчого й декоративного мистецтва з домінуванням декоративного.

Перспективи подальших наукових пошуків у цьому напрямі вбачаємо у ретельному вивченні методичного складника навчання декоративноприкладного мистецтва у Львівській художньопромисловій школі другої половини XIX - початку XX століття.

\section{БІБЛІОГРАФІЧНИЙ СПИСОК:}

1. Ваврух М. Львівський державний коледж декоративного і ужиткового мистецтва імені І. Труша. Енциклопедія Львова / за ред. А. Козицького. Львів : Літопис, 2012. Т. 4. С. 331-334.

2. Глембоцька Л. 1876-1938. Історія закладу на тлі розвитку художньої освіти у Львові (середина XIX ст. - 1938 р.). Галицька брама, 1996. № 20. С. 2-5.

3. Лукіянович Д. Замітки для ведення музейної і виставочної справи для піднесення інтересу до художнього промислу, ширшого розповсюдження його виробів серед нашого загалу. Неділя. Львів, 1912. 4. 42. С. 8-9.

4. Максисько Т. До історії Львівської школи художніх промислів та декоративно-ужиткового мистецтва. Українське мистецтвознавство : Республіканський міжвідомчий збірник, 1971. Вип. 5. С. 110-121. 
5. Оршанський Л., Молоствова Л. Вплив музеїв на становлення і розвиток художньо-промислової освіти Галичини (II половина XIX - поч. XX ст.). Молодь і ринок, 2010. № 7/8 (66-67). С. 19-23.

6. Оршанський Л., Силко Р. Готфррід Земпер та художньо-промислова освіта Західної Європи та України. Дрогобич : Видавничий відділ Дрогобицького державного педагогічного університету імені Івана Франка, 2016. 281 с.

7. Радкевич В. Теоретичні і методичні засади профресійного навчання у закладах профтехосвіти художнього профрілю : монографрія / за ред. Н. Ничкало. Київ : УкрІНTEI, 2010. 420 с.

8. Синишин Л. Розвиток художньо-промислової освіти Галичини (кінець XIX - перша половина XX ст.) : дис. ... канд. пед. наук 13.00.01. Київ, Київський університет імені Бориса Грінченка. 2019. 270 с.

9. Цісарук В. Особливості становлення системи художньо-промислової освіти на території Правобережної України (друга половина XIX ст. 1936 р.). Науковий вісник Кременецької обласної гуманітарно-педагогічної академії імені Тараса Шевченка. Серія : Педагогіка. Вип. 11. С. 54-61. URL: http://nv-kogpi.ucoz.ua/vupysk5/ Tsisaruk.pdf.
10. Шмагало Р. Історичні віхи Художньо-промислової школи у Львові в контексті розвитку світової мистецької освіти другої половини XIX - XX ст. Вісник Львівської національної академії мистецтв, 2017. Вип. 31. С. 9-25.

11. Шмагало Р. Історичний шлях Художньо-промислової школи у Львові. Бюлетень Львівської фрілії Національного науково-дослідного реставраційного чентру України, 2006. № 2 (8). С. 170-175.

12. Шмагало Р. Роль музеїв у становленні художньо-промислової освіти України наприкінці XIX початку XX століття. Мистецтвознавство'99. Львів : CKIM, 1999. C. 79-92.

13. Grankin P. Lwowska Szkoła Przemysłowa : dzieje gmachów na tle historii zakładu. Schola Architecturae. Budynki szkół architektury. Wrocław : Wydawnictwo Politechniki Wrocławskiej, 2005. S. 31-46.

14. Lewicki J. Między tradycją a nowoczesnością : architektura Lwowa lat 1893-1918. Warszawa : Neriton, 2005. S. 77-82.

15. Jackowowa M. Lwowska Szkoła Sztuk Zdobniczych oraz Przenmysłu Artystycznego. Barwa $i$ Rysunek (dodatek do "Gazety Malarskiej"). 1932. № 4. S. 25-26. 


\title{
ОСОБЛИВОСТІ ВИХОВАННЯ ДИТИНИ ВІД НАРОДЖЕННЯ ДО 7 РОКІВ У СХІДНОСЛОВ'ЯНСЬКІЙ ПЕДАГОГІЦІ (В ЕТНОГРАФІЧНИХ ДЖЕРЕЛАХ ХІХ - ПЕРШОЇ ЧВЕРТІ ХХ СТ.)
}

\author{
PECULIARITIES OF RAISING CHILD FROM BIRTH 7 YEARS \\ OF AGE IN EAST SLAVIC PEDAGOGY (IN THE ETHNOGRAPHICAL \\ SOURCES OF THE 19TH - FIRST QUARTER OF THE 20TH CENTURY)
}

У cmammi на основі аналізу етнограсріч них джерел XIX - першої чверті XX cm. схарактеризовані особливості виховання малої дитини (від народження до 7 років) у східнослов'янській народній педагогіці. У публікації наголошується, що з першого дня народження на виховання та сочіалізацію дитини впливала традиційна сільська сім'я. Спосіб життя родини й особливості спілкування 3 малям були визначальними щодо фрормування в дитини перших навичок, від яких значною мірою залежала ї майбутня поведінка. Дітей у сім'ї з наймолодшого віку долучали до традицій, найважливішими 3 яких були: традиції духовно-морального виховання, моральної поведінки дітей і молоді; провідна роль родинних стосунків; повага до батьків і старших узагалі; батьківське благословення; знання свояків і членів роду; повага до традицій предків; суворість і вимогливість у сімейних взаєминах; особиста відповідальність кожного члена сім' за доручену йому справу; взаємодопомога та взаємовиручка; сумлінність, доброзичливість, скромність, слухняність; повага до праці та інші.

Автор зупиняється на особливостях соціалізачії дітей від народження до 7 років, що охоплювала комплекс інкорпоруючих обрядодій, які були спрямовані на поступове залучення новонародженого в систему соціальних від носин та культурний простір селянської спільноти (роду, сім'ї, громади) тощо.

На підставі вивчення досліджень етнограсрів автор робить висновок, що основним завданням східнослов'янської педагогіки XIX - першої чверті $X X \mathrm{~cm}$. було забезпечення нормального фрізичного розвитку малих дітей. Особливого догляду потребували немовлята, їх супроводжували різноманітні охоронно-профрілактичні обряди: перше купання; перше вкладання в колиску; перші кроки. 3 перших днів народження батьки піклувалися про харчування дитини, прищеплювали основи гігієни тіла та середовища, у якому мешкала дитина. Окремі етапи дитячого зросту символізувалися вмінням сидіти, повзати, ходити, говорити тощо. Як засоби фрізичного розвитку малої дитини використовувались спеціальні дитячі «меблі»: колиски, сиділки, стоялки, ходуниі, бігуниі.

у статті виокремлюється основний засіб виховання малих дітей - іграшки, більшість яких виготовлялася в домашніх умовах. Малюки мали іграшки-брязкальця, глиняні свистуниі, зооморфні та орнітоморфні фігурки, іграшкові знаряддя пращі, посуд. Діти 5-6 років гралися переважно саморобними іграшками з природних матеріалів (хлопчики - тарадайками, візочками, млинками тощо, дівчатка - ляльками), самостійно діти виготовляли і музичні інструменти (дудки, «гуркалки», «жухалки», свистки, пищала, «цюрюк»).

Ключові слова: народна педагогіка східнослов'янська педагогіка XIX - першо чверті XX cm., східнослов'янська етнографрія
XIX - першої чверті XX cm., східні слов'яни, традиційне суспільство, народна фрілософрія, соціалізація, виховання, мала дитина.

In the article based on the analysis of ethnographic sources of the XIX - first quarter of the $X X$ century the features of upbringing of a small child (from birth to 7 years) in East Slavic folk pedagogy are characterized.

The article notes that from the first day of birth, the upbringing and socialization of the child was influenced by the traditional rural family. The lifestyle of the family and the peculiarities of communication with the child were decisive for the formation of the child's first skills, those that largely influenced on a child's future behavior.

Children in the family from an early age were included in the traditions, the most important of which were: the traditions of spiritual and moral education, moral behavior of children and youth; leading role of family relations; respect for parents and elders in general; parental blessings; knowledge of relatives and family members; respect for ancestral traditions; severity and exactingness in family relationships; personal responsibility of each family member for the task entrusted to him; mutual assistance; honesty, benevolence, modesty, obedience; and respect for work. The author dwells on the peculiarities of socialization of children from birth to 7 years, which included a set of incorporating rituals, which were aimed at gradually involving the newborn in the system of social relations and cultural space of the peasant community (family, community, etc.). Based on the study of ethnographers' research, the author concludes that the main task of East Slavic pedagogy of the XIX - first quarter of the $X X$ century was to ensure the normal physical development of young children.

Infants needed special care, they were accompanied by various protective and preventive rites including the first bath; the first investment in the cradle and first steps. From the first days of birth, parents took care of the child's nutrition, instilled the basics of body hygiene and the environment in which the child lived. Some stages of a child's growth were symbolized by the ability to sit, crawl, walk, talk, and so on. As a means of physical development of a small child, special children's "furniture" were used such as cradles, seats, stands, walkers and runners.

The article highlights the main means of raising young children - toys, most of which were made at home. The kids had rattles, clay whistles, zoomorphic and ornithomorphic figurines, toy tools and utensils. Children 5-6 years old played mainly with homemade toys made of natural materials (boys - taradaykas, carts, grinders, etc., girls - mostly dolls), children also made musical instruments (pipes, "rattles", "cheats", whistles, whistles and the "tsyuryuk").

Key words: folk pedagogy, the Eastern Slavic pedagogy of the 19th - first quarter of the 20th century, the Eastern Slavic ethnography of the 19th - the first quarter of the 20th century, the Eastern Slavs, traditional society, folk philosophy, socialization, upbringing, small child. 
Постановка проблеми у загальному вигляді. Усі розвинені країни сучасного світу, до яких належить і Україна, внаслідок глобалізаційних процесів та особливостей історичного розвитку $є$ полікультурними. Відповідно, фрормування особистості, соціокультурний та водночас етнокультурний досвід, який дозволяє нашій країні успішно самоорієнтуватися і самовизначатися у полікультурному середовищі, $€$ важливою педагогічною проблемою сьогодення. Одним із шляхів її реалізації $€$ звернення до власного народно-педагогічного надбання минулих епох.

Народна педагогіка фрормувалась упродовж багатьох століть. Однак її вивчення та письмова фріксація починається 3 розвитком етнографії. У XIX ст. поглиблюється інтерес європейських учених до історії виникнення та генези слов'янських народів. Наголосимо, що народна педагогіка XIX - першої чверті XX ст. - це окрема галузь знань $з$ чітко означеною метою виховання та засобами для її досягнення і водночас частина життєдіяльності людського суспільства.

Аналіз останніх досліджень і публікацій. У сучасній історико-педагогічній науці лише частково звернено увагу на вивчення східнослов'янської педагогіки в дослідженнях етнограсрів.

3-поміж українських істориків педагогіки, об'єктом дослідження яких була народна педагогіка, виділяємо Є. Сявавко, яка у монографії «Українська етнопедагогіка в її історичному розвитку» (1974) першою наголосила на важливості етнографрічних джерел для вивчення історії народного виховання.

Досліджуючи народну педагогіку українців на основі етнографрічних та фрольклорних матеріалів, Н. Жмуд приділяє увагу дитині як архетипу етнічної культури XIX - початку XX ст. $(2003,2008)$.

Спеціальним об'єктом дослідження став процес виховання дітей давніх східних слов'ян у монографрії О. Радул «Виховання дітей у процесі життєдіяльності давніх східних слов'ян (VI-XIII ст.)» (2013).

Окремі питання виховання дітей у східнослов'янських народів розглядаються в дисертаційних дослідженнях. У роботах українських учених І. Щербак «Діти в обрядах та віруваннях українців XIX -початку XX ст. (статевовіковий аспект традиційної культури)» (2004), Н. Побірченко «Педагогічна й наукова просвітницька діяльність громад у контексті сучасного руху Наддніпрянської України (другої половини XIX - початку ХХ століття)» (2001).

Науково-інфрормаційний пошук засвідчив, що цілісно та системно східнослов'янська педагогіка в дослідженнях етнограсрів (XIX - перша чверть XX ст.) у вітчизняній історико-педагогічній науці не вивчалась.

Виділення не вирішених раніше частин загальної проблеми. В історико-педагогічній науці особливості виховання малої дитини в східнослов'янській педагогіці в площині етнографрії XIX - першої чверті XX ст. не було темою спеціального наукового дослідження. Наявна достатня кількість досліджень, у яких науковці зверталися до вивчення розвитку педагогічної науки, спадщини видатних педагогів, розвитку шкільництва, але недостатньо уваги приділяли народному досвіду виховання дітей та молоді, хоча близько 90\% українців, білорусів, росіян було зайнято сільським господарством, а їхні діти виховувались за традиціями народної педагогіки.

Мета статті - на основі аналізу етнографрічних джерел XIX - першої чверті XX ст. охарактеризувати особливості виховання малої дитини (від народження до 7 років) у східнослов'янській педагогіці.

Виклад основного матеріалу. Наголосимо, що життя малої дитини та способи її виховання висвітлювались східнослов'янськими етнографами упродовж усього означеного періоду. Так, у першій половині XIX ст. дитина від народження до 7 років як об'єкт дослідження в контексті вивчення різнобічних аспектів традиційного життя народу потрапляє до поля зору етнографрів Н. Анімелле, П. Кіреєвського, М. Макарова, А. Машкіна, І. Сахарова, І. Снєгірьова, А. Терещенка.

Важливим джерелом для вивчення дитини від народження до 7 років стали дослідження етнограсрів другої половини XIX ст., зокрема, А. Афранасьєва, О. Афранасьєва-Чужбинського, Я. Головацького, О. Єфименко, Ю. Крачковського, Д. Лепкого, Й. Лепкого, А. Малинки, В. Маракуєва, В. Милорадовича, І. Морачевича, М. Сумцова, К. Шейковського, В. Ястребова, Х. Ящуржинського та інших.

У першій чверті XX ст. вивченням особливостей життя дітей від народження до 7 років займались етнографи Г. Виноградов, Ф. Вовк, Мр. Грушевський, Н. Заглада, Д. Зеленін, П. Шейн та інші.

За свідченнями етнографрів XIX - першої чверті XX ст., східнослов'янські народи дитину до 7 років здебільшого називали «малою дитиною». Так, у публікації Н. Анімелле «Быт белорусских крестьян» (1834) виокремлена вікова група дітей від народження до 6-7 років, яка названа групою «малих дітей» [1, с. 67-68].

Етнографр А. Машкін у праці «Быт крестьян Курской губернии, Обоянского уезда» (1842) називав дітей від народження до 7 років «малими дітьми» [4, с. 79].

Дослідник В. Ястребов у статті «Обрядовое пострижение детей» (1895), засвідчував, що у системі статево-вікової страфрікації східнослов'янської дитини окреме місце посідала вікова група з народження до 7 років [5, с. 1-2]. Водночас М. Грушевський наголошував, що «малою дитиною» в Україні XIX ст. називали грудне немовля [2, с. 69]. Зі свого боку 3. Кузеля наполягав на думці, що саме семирічна дитина вважалася «справжньою дитиною», 
зі своїм характером та особливостями, а до 7 років українці називали її «малою дитиною» [2, с. 98].

У праці «Побут селянської дитини» (1926) етнографр Н. Заглада запропонувала власну вікову періодизацію дитинства. Зокрема, до «першої верстви» - вікової групи малих дітей - вона відносить дітей, які вимагали догляду і цілковитої уваги всієї родини [3, с. 27].

Отже, на основі вивчення етнографрічних матеріалів XIX - першої чверті XX ст. можна припустити, що східнослов'янська дитина від народження до 7 років уважалась «малою дитиною».

Східнослов'янська сім'я була інститутом, у якому формувався перший і найцінніший досвід: діти набували важливих трудових навичок, засвоювали основні норми та правила поведінки.

Характеристика дитини від народження до 7 років як об'єкта та суб'єкта народного виховання показує, що вона була образом трансформованого тотемного предка, який забезпечував інтегруючу фрункцію міжпоколіннєвих зв'язків, що підтверджується своєрідністю низки соціальних явищ (багатодітність, заборона і гріховність переривання вагітності, засудження народження позашлюбних дітей, опікунство та усиновлення тощо), які культивувались нормами звичаєвого права в системі ціннісних орієнтацій східнослов'янських народів.

Метою східнослов'янської педагогіки на цьому етапі дитячого життя було прагнення дорослих захистити життя і здоров'я дітей, відлякати ворожі сили і привернути добрі, що зумовило існування оберігальної педагогіки, яка виникла ще в язичницькі часи і не втратила свого значення і в XIX першій чверті XX ст. Вона складалася із:

- особистих дитячих речей-талісманів («крижмо» - одяг, у якому хрестили немовля, іграшки, колиски, речі чи предмети сімейного побуту, різноманітні предмети праці, які мали магічне та охоронне значення);

- обрядів охоронного призначення, пов'язаних насамперед із народженням дитини та першими днями її життя (відрізання пуповини, залучення до сім'ї, сільської громади як рівноправного члена, перша купель, перше вкладання в колиску, перші кроки), з використанням води, вогню, солі, металевих знарядь праці, предметів червоного кольору, зілля з маку, часнику тощо;

- оберігальних ритуальних дій під час дитячих хвороб та загрози життю дітей (обрядові дії баби-повитухи, імітація поховання дитини, танок «смерті» навколо хворої дитини, обряд «перенародження», передавання дитини через вікно, удаваний «продаж» та «викуп» батьками, принесення у жертву тварин (або ляльок), захист дитини за допомогою природних сил);

- слів охоронного призначення (приховування імені, заміна імені або «викидання імені на сміття», називання негарним ім'ям, заклинальні та відлякувальні пісні, що застосовувалися з метою обману смерті).

Одне із центральних місць у східнослов'янській педагогіці XIX - першої чверті XX ст. посідали магічні обряди, що спрямовувались на наділення немовляти вродою; забезпечення в майбутньому добробуту та багатства, створення власної сім'ї; фрормування позитивних рис характеру, від яких значною мірою залежала майбутня поведінка та соціалізація.

Малу дитину виховували та доглядали насамперед матір, старша сестра, бабуся і дідусь, а також представники громади - повитуха, куми, сусіди [1, с. 92]. Фізичний контакт батька із малими дітьми був обмеженим, що притаманне усім традиційним суспільствам.

Основне завдання східнослов'янської педагогіки у період життя дитини від народження до 7 років - їі фрізичний розвиток. Більшість здійснюваних після народження дитини обрядодій були спрямовані на ії̈ загальний стан здоров'я («виліплювання» немовляти, «міряння» тіла дитини матір'ю після першої купелі, «дороблення», «перероблення»), забезпечення сну (колихання в колисці), ходіння («перерізання пут» між ногами). Засобами фрізичного розвитку малої дитини були спеціальні дитячі «меблі»: колиски, сиділки, стоялки, ходунці, бігунці, які виготовлялись у кожному домі.

Для забезпечення нормального фрізичного розвитку малої дитини східнослов'янські батьки піклувалися про її харчування (з народження годували материнським молоком, із шести місяців пригодовували кашами), гігієну (підтримання тіла та волосся в чистоті, миття у ночвах, бані з додаванням різних трав), а згодом - загартування [1, с. 168].

У період життя дитини від народження до 7 років відбувалась первинна соціалізація дитини - обрядова діяльність суспільства, пов'язана з народженням дитини (так зване «соціальне народження»), що спрямовувалась на ії̈ включення у свою корпоративну групу як потенційно повноправного ії члена.

У процесі соціалізації східнослов'янських дітей до 4 років спостерігалася статева аморфність та гомогенність. Перехідним етапом у соціалізації східнослов'янських дітей XIX - першої чверті XX ст. був 5-7-річний вік, з якого починалися відмінності у соціалізації хлопчиків та дівчаток у межах родини та громади. У східнослов'янській педагогіці цей вік пов'язувався 3 новою зміною статусних позицій дітей шляхом включення їх у трудову діяльність сім'ї, зміною гардеробу, що супроводжувався збільшенням компонентів одягу (у хлопчиків - перші штанці, у дівчаток - перша спідничка).

Одним із засобів виховання малих дітей були іграшки, які виготовлялись батьками й самими дітьми з різноманітних підручних матеріалів [1; 5]. 
Для малюків виготовлялись іграшки-брязкальця, глиняні свистунці, зооморфні та орнітоморфні фрігурки, іграшкові знаряддя праці, посуд [3, с. 48]. У східнослов'янських хлопчиків 5-6 років найпоширенішими були саморобні іграшки 3 дерева, соснової кори, рослин (іграшкові візочки, млинки, човники та більш складні технічні іграшки - тарадайки) [2, с. 78]. Східнослов'янські дівчатка грались переважно ляльками. Із природних матеріалів хлопчики та дівчатка виготовляли музичні інструменти (дудки, «гуркалка», «жухалка», свистки, пищала, «цюрюк») [4, с. 19].

Висновки. Отже, одним із найважливіших періодів життя дитини, в якому закладалися основи фрізичного, трудового, морального, розумового виховання, був період від народження до 7 років. У східнослов'янській педагогіці побутували уявлення про позачасовість дитячого віку, що втілювалися у збірній назві «малі діти». Східнослов'янська педагогіка XIX - першої чверті XX ст. була оберігальною за своєю суттю, спрямованою на захист життя, здоров'я та первинну соціалізацію малої дитини.

На нашу думку, подальшого вивчення потребує питання виховання малих дітей у взаємодії із навколишнім середовищем.

\section{БІБЛІОГРАФІЧНИЙ СПИСОК:}

1. Анимелле Н. Быт белорусских крестьян. Санкт-Петербург, 1834. 238 с.

2. Грушевський Мр. Дитина в звичаях та віруваннях українського народу. Матеріали з полудневої Київщини. Обробив 3. Кузеля. Львів, 1907. 144 с.

3. Заглада Н. Побут селянської дитини. Матеріяли до монографрії с. Старосілля. Т. 1. Київ : Держтрест «Київ-Друк», 1926. 260 с.

4. Машкин А. Быт крестьян Курской губернии, Обоянского уезда. СПб., 1842. 119 с.

5. Ястребов В. Обрядовое пострижение детей. Киевская Старина. 1895. № 10-12. Отд. 2. С. 1-12. 


\section{ДОСВІД ВНУТРІШНЬОЦИКЛОВОЇ ІНТЕГРАЦІЇ ДИСЦИПЛІН EXPERIENCE OF INTRA-CYCLE INTEGRATION OF DISCIPLINES}

Стаття присвячена одній з актуальних проблем сучасної педагогіки - запровадженню інтегративного підходу до викладання дисциплін. Зокрема, показано, що інтегративний підхід сьогодні переходить від узгодження змісту освіти до глибокої взаємодії, обгрунтованої інтеграції знань, умінь та елементів мислення майбутнього. У статті зазначено, що загальнопедагогічна фрункція інтеграції знань полягає насамперед у забезпеченні єдиного підходу до розуміння ролі і можливостей знань у навчальному, розвиваючому та виховному аспектах. Показано, що проблема інтеграції змісту освіти набула особливо важливого значення у зв'язку з тим, що його оновлення передбачає включення в чей зміст не тільки нової інфрормації з традииійних шкільних предметів та нових наук і галузей знань, які раніше не вивчалися в школі. Підсумовано, що таке розширення змісту освіти не може здійснюватися чисто механічно, шляхом простого додавання до вже наявних нових навчальних курсів і предметів, бо це може призвести до ще більшого перевантаження учнів, яке і так $є$ надмірним. Лише частково може бути розв'язана ия проблема иляхом перерозподілу часу між традиційними і новими навчальними предметами, ще меншою мірою - шляхом заміни одних навчальних предметів іншими. Тому суперечність, яка існує $і$ весь час загострюється між обмеженістю навчального часу і обсягом матеріалу і постійним зростанням обсягу наукової інфрормації, може бути подолана лише шляхом ущільнення чієі інсрормації, їі відповідної інтеграції. Зазначається, що взаємозв'язки гуманітарних і загальнотехнічних дисциплін приховані. Інтегративний підхід до вивчення різноциклових дисциплін ірунтується на взаємодії понять $і$ образів із використанням наукового і художнього способів освоєння дійсності. Таким чином, інтеграція знань здійснюється в різноманітних формах на різних рівнях і в різних галузях пізнання. Ключові слова: різночиклові дисци пліни, навчальними предмети, інтегра- ція змісту освіти, інтегративний підхід, зміст освіти.

The article is devoted to one of the current problems of modern pedagogy - the introduction of an integrative approach to teaching disciplines. In particular, it is shown that the integrative approach today goes from harmonizing the content of education to deep interaction, sound integration of knowledge, skills and thinking elements of the future. The article states that the general pedagogical function of knowledge integration is primarily to provide a unified approach to understanding the role and opportunities of knowledge in the educational, developmental and educational aspects. It has been shown that the problem of integrating the content of education has become especially important due to the fact that its updating involves the inclusion in this content not only new information on traditional school subjects, but also new sciences and fields of knowledge not previously studied in school. It is concluded that such an expansion of the content of education cannot be done purely mechanically, by simply adding to existing new courses and subjects, because it can lead to even greater overload of students, which is already excessive. This problem can only be partially solved by redistributing time between traditional and new subjects, and even less by replacing some subjects with others. Therefore, the contradiction that exists and is constantly exacerbated between the limited study time and the amount of material and the constant growth of scientific information can be overcome only by consolidating this information, its appropriate integration. It is noted that the relationship between the humanities and general technical disciplines is hidden. The integrative approach to the study of various cycles is based on the interaction of concepts and images with the use of scientific and artistic methods of mastering reality. Thus, the integration of knowledge takes place in various forms at different levels and in different fields of knowledge.

Key words: multicycle disciplines, subjects, integration of educational content, integrative approach, educational content.
Постановка проблеми в загальному вигляді. У педагогіці останніх десятиліть XX ст. змінюється функція інтеграції в освіті, стаючи механізмом процесу гуманізації як нової парадигми сучасної освіти та науки. Тому у процесі оновлення змісту освіти принцип інтеграції робиться необхідним компонентом для організації навчально-виховного процесу.

Початковим етапом формування системи гуманітарних знань $€$ формування менших за обсягом і кількістю елементів систем, які базуються на декількох курсах гуманітарних дисциплін. Зв'язки між гуманітарними дисциплінами $є$ епізодичними, зазвичай кожна 3 дисциплін вивчається ізольовано. Це зумовлює фррагментарні знання студентів із гуманітарних дисциплін. Міжпредметні зв'язки неспроможні виконати системотвірну фрункцію у фрормуванні системи гуманітарних знань, тому саме інтеграція є дійовим засобом гуманітаризації знань, оскільки передбачає фрормування цілісної системи гуманітарних знань.

Аналіз останніх досліджень і публікацій. За останні десятиліття інтеграцію дисциплін та різних педагогічних явищ досліджували С. Гончаренко, Р. Гуревич, Л. Дольнікова, Б. Камінський, I. Козловська. Загалом проблема інтеграції змісту у межах природничих і гуманітарних дисциплін досліджувалася доволі широко, однак доволі однобічно. Більшість праць стосуються правової, економічної чи мистецької підготовки. Не завжди автори вказують підставу інтеграції. Спостерігаються випадки, коли інтеграцією називають міжпредметні зв'язки. 
Виділення не вирішених раніше частин загальної проблеми. Педагоги західних країн докладають значних зусиль 3 метою гуманізації та гуманітаризації змісту освіти, модернізації змісту навчальних предметів з урахуванням реалій наукового та культурного поступу, впливу глобалізаційних та інтеграційних процесів на розвиток національних освітніх систем, а також з метою забезпечення високої якості знань, системного і систематичного їх надання усім і кожному протягом усього життя.

Проблема співвідношення гуманітарних і природничо-математичних дисциплін у змісті знань була і залишається однією 3 найбільш дискутованих. У вітчизняній педагогіці проблема внутрішньоциклової інтеграції змісту є не до кінця дослідженою і тому потребує розгляду й аналізу.

Мета статті - висвітлити загальнопедагогічний характер проблеми інтеграції змісту природничих й гуманітарних дисциплін; показати, що інтегративні освітні процеси у сорері навчальних дисциплін базуються на методологічних та загальнонаукових передумовах інтеграції гуманітарних та природничих наук, а також наголосити на важливості запровадження інтегративного підходу до викладання дисциплін.

Виклад основного матеріалу. Інтеграція гуманітарних знань «як основний інструментарій їх фрормування у цілісну систему дає можливість реально сорормувати фрункціонально повний мінімум гуманітарних знань на противагу простому збільшенню обсягу гуманітарних знань, яке перевантажує навчальний процес i не спроможне позитивно впливати на розвиток загальної та професійної культури фрахівця» [1]. Інтеграція гуманітарних знань орієнтує на пошук не лише зовнішніх засобів гуманітаризації і розширення у навчальних планах циклу гуманітарних дисциплін, а й на пошук якісно нових інтегративних підходів до структурування та мотивацій знань з гуманітарних дисциплін. Водночас гуманітарні дисципліни доцільно розглядати не тільки як складник професійної підготовки спеціалізованих знань, а як атрибутивний компонент відтворення цілісної соціально-культурної особистості. Інтегративний підхід передбачає координацію цілей навчання гуманітарних дисциплін, фрормування профресійної та загальної культури студентів, фрормування мінімальної функціонально повної бази гуманітарних знань для цього тощо.

Загальною тенденцією сучасної освіти є прямий зв'язок між престижністю вищого навчального закладу і кількістю годин на вивчення мов, історії, культури, незалежно від спеціальності. Поліцентрична інтегративна модель навчального плану за умов ідейного і культурного плюралізму, безперечно, є спробою стабілізувати світоглядну культуру майбутнього спеціаліста, відкриває пер- спективи для розвитку його особистості та відтворення продуктивної моделі його професійної діяльності. Цікавим для вітчизняної педагогічної освіти є також зарубіжний досвід актуалізації аксіологічного потенціалу культурологічного знання. Знання, що базуються на цінностях та індивідуальному життєвому досвіді майбутніх учителів, сприймаються ними як значущі, фрормують усталену систему цінностей, що реалізується у практичній діяльності. «Інструментальне розуміння культурологічної освіти як засобу фрормування творчої особистості майбутнього спеціаліста поширене у зарубіжній педагогічній теорії та практиці, оскільки воно пов'язане із соціальним замовленням на спеціалістів, здатних до активної творчості у нестандартних професійних ситуаціях у сучасному динамічному світі» [2].

О. Столяренко обґрунтовує потребу інтеграції всіх людинознавчих дисциплін для якісного засвоєння знань, важливих для фрормування гуманістичного світогляду. На його думку, це сприятиме розвитку гуманістичного виховання взагалі, за умов глобалізації сучасного світу зокрема [3]. Загроза бездуховності спричинюється і тим, що в процесі практичної діяльності виявлені закономірності природи отримують утилітарне призначення. Таке виявлення і застосування законів об'єктивного світу, по суті, є творчим процесом. Подальше ж багаторазове використання відкритого природного і сконструйованого технологічного процесу вже не вимагає ні нових знань, ні нового творчого, духовного акту. Настає етап, «коли духовність "виштовхується" з трудового процесу, а сама праця набуває ознак рутинності, бездуховності» [4]. Така метаморфоза засобу і мети дає згубні наслідки у сорері духовності, створюючи умови і водночас виступаючи причиною деградації людських ідеалів, моральних засад.

Зараз гостро стоїть питання про необхідність включення в зміст шкільної освіти різноманітних знань про суспільство: фрілософрських, соціологічних, економічних, політологічних, правничих, культурологічних, демографрічних, етнографрічних та інших. Включити усі ці знання в зміст шкільної освіти у вигляді окремих навчальних предметів, як уже зазначалося, неможливо. Обмежитися лише введенням окремих з цих курсів, наприклад «Основ правознавства», або вкрапленням елементів цих знань у шкільні курси історії та географрії, як це робиться зараз, теж недостатньо, оскільки у цьому разі наукова галузь суспільствознавства відображається у змісті шкільної освіти лише фррагментарно. Тому і тут найбільш оптимальним виходом з цієї ситуації уявляється інтеграція змісту суспільствознавчої шкільної освіти.

Єдиним сьогодні обов'язковим суспільствознавчим шкільним курсом $€$ курс 3 основ правознавства, певними модифікаціями якого висту- 
пають також шкільні курси 3 прав людини та громадянознавства. Повністю визнаючи необхідність правової освіти і правового виховання школярів, водночас необхідно зазначити, що правові знання, навіть коли вони доповнюються політологічними знаннями, теж $€$ недостатніми для цілісного, багатогранного розуміння суспільства, яке вимагає включення в зміст освіти також соціологічних, культурологічних, економічних та інших знань про суспільство. Проте включення усіх цих знань у зміст шкільної освіти у вигляді окремих навчальних предметів через різні причини і насамперед через обмеженість навчального часу - неможливе. Це також є свідченням того, що єдино можливий шлях представлення змісту суспільствознавства у змісті шкільної освіти створення і запровадження інтегрованих шкільних курсів. Порівняння змісту розроблених на релігійній («Основи християнської етики», «Мій світ і я» та інші) чи фрілософрській («Вступ до світу ідей», «Філософрія для дітей», «Світ і людина») основі світоглядних курсів свідчить про те, що в деяких 3 них суспільствознавча тематика або зовсім не представлена, або представлена дуже бідно. Головним принципом у процесі глобальної освіти визнається принцип цілісності, згідно 3 яким головний предмет вивчення - суспільство - повинен зберігати свій цілісний характер, щоб гарантувати розуміння взаємозалежності сьогоднішнього світу. Така цілісність забезпечується шляхом інтеграції змісту освіти на основі концептуальних тем і ключових понять, таких як взаємозалежність, зміна, культура, національний та інтернаціональний розвиток, екологічні проблеми, права людини та інших.

На цьому етапі розглядаються фрорми інтеграції суспільствознавчого змісту в інтегрованих шкільних курсах «Суспільствознавство», «Людина і суспільство», «Людина і світ», «Світ сучасної людини». [5] Аналіз змісту наявної суспільствознавчої шкільної освіти з погляду його відповідності змісту і структурі сучасних знань про суспільство дає можливість встановити, що, по-перше, далеко не всі важливі науки про суспільство представлені у змісті освіти, а по-друге, під час визначення змісту освіти не враховуються різні структурні рівні, на яких існує сучасне суспільствознавство. Обсяг часу, який виділяється зараз на вивчення в школі суспільствознавчих дисциплін, є недостатнім для реалізації попередніх чинників, тому він повинен бути збільшений. Але якщо враховувати потреби й інших освітніх галузей, таке збільшення не може бути дуже значним, тому найбільш перспективним розв'язанням означеної проблеми може бути лише включення в зміст базової шкільної освіти інтегрованих суспільствознавчих курсів, які б доповнювалися фракультативними курсами з окремих суспільних наук.
Значна кількість праць присвячена професійній підготовці економістів. Серед цих праць заслуговує уваги докторська дисертація $€$. Іванченко [6] щодо системи інтегрованої підготовки економістів, метою і результатом якої $є$ фрормування мультиплікативної компетентності майбутнього економіста, визначено її компоненти, критерії ефективності ії фрункціонування та їх показники; систематизовано інтегративні процеси у просресійній підготовці майбутніх фрахівців, які виокремлено у види інтеграції: інтеграція наукових знань; інтеграція досвіду різних наукових шкіл у процес навчання фрахівців; інтеграція інорормаційних технологій в освіту майбутніх фрахівців; соціокультурна інтеграція; інтеграція «безкоштовної» освіти для всіх та платних послуг за вибором студентів або батьків; територіальна інтеграція; міжпредметна інтеграція; інтеграція теоретичного та виробничого навчання; інтеграція інноваційних технологій в освіту майбутніх фрахівців; інтеграція суб'єктів навчально-виховного процесу; інтеграція знань, практичних умінь, навичок, якостей, досвіду профресійної та соціальної діяльності.

Останнім часом увагу дослідників привертає проблема інтеграції мистецьких знань, зокрема, в системі професійної художньо-естетичної підготовки майбутніх вчителів музики і світової художньої культури. Водночас інтегративний підхід до вивчення мистецтва, на думку науковців, дає можливість розглядати зміст художньої освіти як складну цілісну систему. В педагогічному аспекті просторові компоненти музичного образу в комплексі 3 іншими художніми компонентами можуть стати засобом реалізації принципу широкої інтеграції у діалозі з іншими видами мистецтв: «горизонтально» (використання власного чуттєвого досвіду під час вивчення різноманітних мистецьких творів); «вертикально» (відчуття «зв'язку часів», наскрізний погляд на історичний аспект діалогу мистецтв і культур). У системі гуманітарних дисциплін інтеграція правових знань займає значне місце. Яскравим прикладом цього є дисертація В. Смірнової [7], у якій вона розробила та обґрунтувала структуру змісту правових знань для студентів професійно-педагогічного коледжу як основу їх інтеграції, а також виявила організаційно-методичні умови реалізації інтегрованого підходу до структурування змісту правових знань у процесі професійної підготовки майбутніх фрахівців у профресійно-педагогічному коледжі. Йдеться про те, що інтегрується зміст правових знань, а саме теоретичні знання, знання про способи діяльності та знання, що регулюють правову поведінку, з технологіями реалізації інтегрованих знань в умовах, наближених до реальних професійних ситуацій. Для реалізації інтегрованого підходу до структурування змісту правових знань, на думку В. Смірнової, варто використовувати інтерактивні форми і методи навчання правових дисциплін, а 
інтегрований зміст правових знань спрямувати на фрормування у майбутніх фрахівців мотивації учіння. Також у своїй праці вона визначила критерії ефрективності реалізації інтегрованого підходу до структурування змісту правових знань в умовах профресійно-педагогічного коледжу, уточнила теоретичний зміст понять «структурування змісту правових знань», «юридична клініка у професійнопедагогічному коледжі», теоретично обґрунтувала рівні інтеграції правових знань, що своєю чергою дало їй змогу удосконалити деякі програми навчальних дисциплін, зокрема: «Основи правознавства», «Правознавство», програму спецкурсу «Юридична клініка», комплекс методичного забезпечення дисциплін «Основи правознавства», «Правознавство» для студентів вищих навчальних закладів I-II рівнів акредитації.

Висновки. У педагогіці XXI ст. фрункція інтеграції в освіті змінюється, стає механізмом процесу гуманізації як нового рівня розвитку сучасної освіти та науки. Можна зробити висновок, що важливо і доцільно розглядати гуманітарні та природничі знання у єдиній системі. Саме тому принцип інтеграції стає важливим етапом у фрормуванні стратегії оновлення змісту освіти, організації навчальновиховного процесу.

\section{БІБЛІОГРАФІЧНИЙ СПИСОК:}

1. Вознюк О.М. Формування системи гуманітарних інтегрованих знань студентів технічних університетів : дис. ... канд. пед. наук : 13.00.04. «Теорія та методика освіти». Вінниця, 2004. 270 c.

2. Шевнюк О.Л. Культурологічна підготовка вчителя: теорія і практика. Київ, 2003. с. 252.

3. Столяренко О. Інтеграція людинознавчих знань у гуманістичному вихованні школярів. Рідна школа. 2006. № 4. С. 14-18.

4. Мельник В.П. Філософрські проблеми технікознавства (гносеологічні та предметно-перетворювальні аспекти). Львів : Світ, 1994. 180 с.

5. Арцишевська М.P. Теоретико-методичні засади інтеграції знань про суспільство у змісті шкільної освіти : дис... канд. пед. наук : 13.00.09. Луцьк, 2000. 188 с.

6. Іванченко $€$.А. Теоретико-методичні засади системи інтегративної професійної підготовки майбутніх економістів : дис. ... на здобуття наукового ступеня доктора педагогічних наук 13.00.04 /. Одеса, 2011. 395 с.

7. Смірнова В.О. Інтегрований підхід до структурування змісту правових знань у професійнопедагогічному коледжі : автореф. дис... канд. пед. наук : спец. 13.00.04 «Теорія та методика профресійної освіти». Київ, 2009. 20 с. 


\section{ФАКУЛЬТЕТИ ХІМІЇ УКРАЇНСЬКИХ ВИЩИХ НАВЧАЛЬНИХ ЗАКЛАДІВ У ПЕРІОД ДРУГОї СВІТОВОЇ ВІЙНИ}

\section{FACULTIES OF CHEMISTRY OF UKRAINIAN HIGHER EDUCATIONAL INSTITUTIONS DURING THE SECOND WORLD WAR}

У статті автором порушено проблему актуалізації вивчення діяльності окремих факультетів хімії в українських вищих навчальних закладах у період Другої світової війни. Через поширення у світі пандемі 2019-2020 років особливого значення набуває вивчення досвіду організації профресійної освіти у складних умовах. У статm зазначено, що окупаційні режими докорінно змінювали навчальний процес у вищих навчальних закладах. Тогочасна війна надзвичайно негативно позначилася на всіх напрямах життя і діяльності педагогічної і наукової спільноти, студентства. у статmі автор представив загальний огляд діяльності Харківського, Дніпровського, Чернівецького університетів, де діяли фракультети хімії. Окремі висновки зроблено на підставі вивчення матеріалів про роботу Об'єднаного українського університету, що фоункціонував в Уфрі в евакуації.

Теоретичною основою дослідження обрано історико-педагогічний, френомено логічний, герменевтичний підходи. Автором зазначено, що чі підходи дають змогу розкрити історико-культурні засади педагогічної теорії і практики досліджуваного феномену. Відповідно до обраної проблеми використано загальнонаукові методи (аналіз, синтез, узагальнення), історикопедагогічні методи (ретроспективний, зіставно-порівняльний аналіз наукової літератури), що дозволило розглядати історико-педагогічні явищі, фракти, провідні педагогічні ідеї в контексті обраноі проблеми в часовій динаміці.

Автором зазначено, що в умовах Друго світової війни робота кафредр хімії у вищих навчальних закладах в умовах евакуації не повторювала досвід довоєнних освітніх практик. Водночас було вжито серйозних контрольних заходів щодо зміцнення трудової і навчальної дисципліни серед студентів. Було скорочено термін навчання через оптимізацію змісту навчальних планів і програм. Усі форми і види навчальної, науково-дослідної роботи студентів були чітко визначені і набули статусу обов'язкових. Обов'язковими стали консультації та додаткові заняття з викладачем для студентів у позааудиторний час. Організаційно, методично викладачі мали враховувати складні умови навчання і життя студентів в евакуації.

3 досвіду роботи Харківського університету доцільно актуалізувати в сучасних умовах приклади організаційно-методичного забезпечення науково-дослідної роботи зі студентами 3 опорою на самоврядування і свободу наукових досліджень. Доцільним є введення елементів науково-дослідної роботи в лекційні курси, залучення студентів до проведення самостійних досліджень різного рівня та професійного спрямування.

Ключові слова: хімія, навчання, науководослідна робота, студенти, війна, евакуація.
In the article the author raises the problem of actualization of studying of activity of separate faculties of chemistry in the Ukrainian higher educational institutions during the Second World War. In the context of the spread of the 2019-2020 pandemic, the study of the experience of organizing vocational education in difficult conditions becomes especially important. The article states that the occupation regimes radically changed the educational process in higher education institutions. The war of that time had an extremely negative effect on all areas of life and activity of the pedagogical and scientific community, students.

In the article the author presented a general overview of the activities of Kharkiv, Dnipro, Chernivtsi universities, where the faculties of chemistry operated. Some conclusions were made on the basis of a study of materials on the work of the United Ukrainian University, which operated in Ufa during the evacuation. Historical-pedagogical, phenomenological, hermeneutic approaches are chosen as the theoretical basis of the research. The author notes that these approaches make it possible to reveal the historical and cultural foundations of pedagogical theory and practice of the studied phenomenon. According to the chosen problem, general scientific methods (analysis, synthesis, generalization), historical and pedagogical methods (retrospective, comparative analysis of scientific literature) were used, which allowed to consider historical and pedagogical phenomena, facts, leading pedagogical ideas in the context of the chosen problem in time dynamics.

The author notes that during the Second World War the work of chemistry departments in higher educational institutions in the conditions of evacuation did not repeat the experience of pre-war educational practices. At that time, serious control measures were taken to strengthen labor and academic discipline among students. The training period was shortened due to the optimization of the content of curricula and programs. All forms and types of educational, research work of students were clearly defined and became mandatory. Consultations and additional classes with the teacher for extracurricular students have become mandatory. Organizationally, methodologically, teachers had to take into account the difficult conditions of study and life of students in the evacuation.

From the experience of Kharkiv University, it is advisable to update in modern conditions examples of organizational and methodological support of research work with students based on self-government and freedom of research. It is advisable to introduce elements of research work during lecture courses, involving students in independent research of various levels and professional orientation.

Key words: chemistry, training, research work, students, war, evacuation. 
Вступ. Минає 75 років від часу завершення Другої світової війни. Широке коло науковців різних галузей знань описують і аналізують той важкий період у житті всього людства. Актуальним залишається питання дослідження історії освіти і розвитку науки у вищих навчальних закладах України того часу. В історіограсрії Польщі, Румунії, Німеччини, Франції, інших європейських країн чимало праць присвячено цій темі. В українському науковому просторі бракує системних досліджень становища викладачів, науковців-дослідників, життя українського студентства в роки Другої світової війни й окупаційних режимів. У статті запропоновано стислий огляд діяльності окремих українських вищих навчальних закладів, де діяли фракультети хімії. Сучасне прочитання і ретельний аналіз педагогічного досвіду сприятимуть осмисленню світоглядних орієнтирів розвитку вищої освіти в Україні в період складних економічних і соціальних перетворень.

Мета і завдання дослідження - актуалізувати потребу розкриття особливостей діяльності українських вищих навчальних закладів, де діяли фракультети хімії, у період Другої світової війни для конкретизації світоглядних орієнтирів розвитку вищої освіти в Україні в умовах сьогодення.

Методи дослідження. Відповідно до обраної наукової проблеми використано комплекс загальнонаукових методів (аналіз, синтез, узагальнення), історико-педагогічних методів (ретроспективний, зіставно-порівняльний аналіз наукової літератури), що дозволить розглядати історикопедагогічні явищі, фракти, провідні педагогічні ідеї в контексті обраної проблеми в часовій динаміці.

Теоретичним базисом дослідження $€$ історикопедагогічний підхід, коли аналізується предмет дослідження в історичній послідовності, феноменологічний підхід, який дає змогу осмислити значення суб'єктивного досвіду як основного вимірника сутності людської особистості. Герменевтичний підхід передбачає розуміння, пояснення текстів у контексті розвитку культури й освіти конкретного історичного періоду. Указані підходи дають змогу розкрити історико-культурні засади педагогічної теорії і практики.

Результати. Аналіз останніх досліджень і публікацій, у яких започатковано розв'язання цієї проблеми, свідчить про те, що більшість дослідників розкривають роботу факультетів хімії крізь призму історії конкретного вищого навчального закладу [1]. Відомо про непоправні втрати, які принесли війна й окупаційні режими українській нації. Варто зосередити увагу на тому, як науковцям, професорам, викладачам, студентству в таких надскладних умовах вдалося зберегти науку і здійснювати педагогічний процес. Невирішеним питанням залишається аналіз діяльності українських вищих навчальних закладів, де діяли фракультети хімії, здійснювалася підготовка вчителів цього профрілю.

У процесі проведеного дослідження з'ясовано, що на початок Другої світової війни організація діяльності фракультетів хімії в українських вищих навчальних закладах була на досить високому рівні. Це підтверджено досить активним залученням студентства до науково-дослідної роботи. Наприклад, у роботі Харківського університету організаційно-методичне забезпечення науководослідної роботи зі студентами спиралося на самоврядування і свободу наукових досліджень, цілеспрямовану систематичну науково-дослідну роботу під час опанування лекційних курсів, проведення самостійних досліджень різного рівня та професійного спрямування. Особлива увага зверталася на науковість і фрундаментальність лекційного викладу. У процесі наукової і педагогічної підготовки студенти Харківського університету залучалися до роботи в бібліотеці, фрізичному кабінеті, астрономічній обсерваторії, хімічній лабораторії, анатомічному театрі й інших науково-дослідних установах залежно від обраного студентами фраху.

До наукових досліджень залучалися студенти. Аналіз історичних документів засвідчив, що в 1940-1941 навчальному році студенти Харківського університету відвідували 44 гуртки. Охоплено загалом гуртковою роботою 728 студентів. Це становило 20\% студентів стаціонарного відділу навчання. Того ж навчального року було проведено шість університетських науково-практичних студентських конференцій, на яких було представлено 137 доповідей [2]. Так само активну науководослідну роботу вели викладачі і студенти Дніпропетровського й Одеського університетів [3].

Загалом, у 1939 р. у вищих навчальних закладах України розроблялося 1422 тем, було виконано понад 500 наукових досліджень, за участю студентів було проведено 32 науково-практичних збори (семінари, сесії, консреренції), на яких заслухано понад 600 наукових доповідей [4]. Активне залучення до науково-дослідної роботи давало змогу студентам опанувати практику досліджень, заявити себе як майбутні викладачі.

Один із найстаріших фракультетів у Дніпровському університеті - хімічний. Підготовка хіміків велася 3 перших днів його заснування (1918р.). Біля витоків фракультету стояли академік Л. Писаржевський, засновник Дніпровської наукової школи хіміків, творець електронної хімії, академік Д. Коновалов, академік О. Бродський, засновник школи 3 хімії ізотопів. Наукові та педагогічні ідеї цих учених забезпечили високий рівень науково-дослідних робіт, визначили тематику та стиль наукових досліджень на хімічному фракультеті в довоєнні та перші повоєнні роки [5]. Відомо, що довоєнний період у співпраці з науковцями Інституту фізичної хімії Академії наук (далі - АН) Української Радян- 
ської Соціалістичної Республіки (далі - УРСР) у Дніпропетровську велось вивчення проблем електрохімії розчинів та теорії каталізу (В. Фінкельштейн, профр. В. Ройтер), механізму органічних реакцій (Ф. Березовська), здійснювалися розробки нових методів фрізико-хімічного аналізу (А. Занько, В. Стефрановський), пошуки інгібіторів корозії металів (М. Розенберг) [6].

Напередодні Другої світової війни набув піднесення і Київський університет, де з 1934 р. завдяки зусиллям ученого і педагога О. Палладіна відкрито кафредру біохімії. Завдяки зусиллям О. Палладіна на новоствореній кафедрі було обладнано лабораторію, підібрано кадри викладачів. 3 перших днів кафедра займалася навчальною і науковою роботою в галузях нейрохімії, біохімії м'язів та харчування. О. Палладін став засновником низки таких актуальних наукових напрямів, як біохімія вітамінів, гіпо- й авітамінозних станів, порівняльна й еволюційна біохімія. Відзначимо тут, що саме О. Палладін заклав традицію кафедри та всього біологічного фракультету навчати студентів у тісній взаємодії з академічною наукою [7]. Цьому сприяло виконання курсових та дипломних робіт студентами на академічному обладнанні в лабораторіях, залучення студентів до широкомасштабних наукових досліджень [8].

У роки Другої світової війни О. Палладін із колегами і студентами займався розробкою ліків, які б сприяли припиненню кровотеч та загоюванню ран. Під час евакуації Інституту біохімії в Уфру за активної участі О. Палладіна та колег Уфимський вітамінний завод запустив синтезований новий водорозчинний аналог вітаміну К, названий вікасолом - препарат, який одразу ж став широко використовуватися у шпиталях.

О. Палладін був яскравим лектором та вихователем, автором першого вітчизняного підручника з біологічної хімії. За його ініціативи в навчальні плани були введені дисципліни з біохімії харчування, фрерментології, порівняльної біохімії, біохімії рослин, ендокринології, спецкурси з біохімії м'язів та біохімії нервової системи. Учений створив школу біохімічних кадрів. Під його керівництвом було підготовлено понад 150 докторів та кандидатів наук.

Після визволення Києва в 1944 р. наукову і педагогічну роботу кафредри біохімії було відновлено. Будівлю університету внаслідок військових дій було зруйновано, усе обладнання кафедри було втрачено. Тому спочатку заняття і наукова робота здійснювалися у приміщенні Інституту біохімії АН УРСР. Після отримання приміщення у відбудованому університеті в 1951 р. педагогічна та наукова робота кафедри налагодилася.

У Чернівецькому університеті хімією вчені займались із 1875 р. У 1919 р., коли Чернівці ввійшли до складу Румунії, на науковому факультеті відкрито дві кафедри (інститути) - неорга- нічної й аналітичної хімії, органічної хімії. Після приєднання Буковини до Радянської України (1940 р.) колишній Чернівецький університет реорганізовано в Чернівецький державний університет з українською мовою викладання. На початку хімічний фракультет мав дві кафедри - неорганічної й аналітичної хімії. Швидкий процес становлення і розбулдови фракультету відбувався завдяки забезпеченню кадрами викладачів і науковців 3 усіх куточків України.

Освітній процес Чернівецького університету позначився одночасністю періоду формування і росту хімічного фралкультету і його трагічним завершенням. Відомо, що частина студентів Чернівецького університету переїхали у віддалені райони Радянського Союзу і там продовжили навчання. Більшість тих, хто лишився, загинули під час окупаційних подій [9].

Обговорення. Аналіз джерел свідчить про те, що в умовах Другої світової війни робота вищих навчальних закладів в евакуації не повторювала досвід довоєнної освітньої практики. А було вжито певні заходи, які докорінно різнилися 3 попередньою освітньою практикою. Першочергово в зазначений історичний період проводилися заходи щодо зміцнення трудової і навчальної дисципліни серед студентів. Проблемні аспекти роботи вищих навчальних закладів - нерегулярні відвідування студентами занять, скорочені терміни навчання - не повинні були негативно позначитися на якості професійної підготовки. Тому всі фрорми і види навчальної, науково-дослідної роботи студентів були чітко визначені і були обов'язковими. Їхній зміст конкретизувався в навчальних планах та програмах. Обов'язковими стали консультації та додаткові заняття для студентів у позааудиторний час. Були переглянуті навчальні програми з фрахових дисциплін. В організаційному, методичному аспекті розроблялися питання врахування специфрічних умов навчання в евакуації. Так, наприклад, студентам читали лекції в більш розгорнутому вигляді, оскільки слухачі обмежувалися в можливості самостійної роботи в бібліотеках. Кафедри були зобов'язані забезпечити видання конспектів лекцій, множення окремих розділів і підручників, а також проводилася робота з виготовленню власними зусиллями необхідних навчальних посібників та лабораторного устаткування [10].

Наприклад, у Харківському державному університеті для проведення практичних занять на хімічному фракультеті заняття будували з таким розрахунком, щоб хімічні речовини, які одержували студенти молодших курсів, могли бути використані для практикумів студентами старших курсів [10].

Варто зазначити, незважаючи на скрутні побутові умови і недостатню матеріально-технічну базу, студенти вищих навчальних закладів в умовах евакуації отримали змогу здобути якісну під- 
готовку у скорочені терміни. В Об'єднаному українському державному університеті працювали студентські наукові гуртки 3 хімії, наукові та творчі студії. Звичайно, розмах студентської навчальної, практичної, наукової роботи був дуже спрощений порівняно $з$ довоєнним періодом. Проте наукове і навчальне сумління сприяло кращій підготовці майбутніх спеціалістів [10].

На період завершення Другої світової війни у вітчизняній педагогічній думці несприятливі умови наполегливо і системно долалися для прогресування науки і піднесення професійної освіти.

Висновки. Підсумовуючи вищевикладене, варто зазначити, що протягом Другої світової війни робота кафредр хімії у вищих навчальних закладах в умовах евакуації не повторювала досвіду довоєнних освітніх практик. На це варто спиратися під час розробки сучасних ресурсів дистанційної фрахової освіти в умовах пандемії 2019-2020 рр. У той надскладний час було вжито серйозних заходів, як-от: контрольні заходи щодо зміцнення трудової і навчальної дисципліни серед студентів, скорочення терміну навчання через оптимізацію змісту навчальних планів і програм. Усі форми і види навчальної, науководослідної роботи студентів були чітко визначені і були обов'язковими. Обов'язковими також стали консультації та додаткові заняття для студентів у позааудиторний час. Організаційно, методично передбачувалися складні умови навчання і життя студентів в евакуації.

Кафедри були зобов'язані забезпечити видання конспектів лекцій, множення окремих розділів і підручників, а також проводилася робота 3 виготовлення власними зусиллями необхідних навчальних посібників та лабораторного устаткування.

Означена стаття мала на меті актуалізувати питання висвітлення діяльності вищих навчальних закладів у складних умовах пограничних подій життєдіяльності суспільства. Перспективами подальших наукових розвідок визначено аналіз змістового і методичного компонентів підготовки вчителів хімії в період окупаційних процесів у 1940-1945 рр. на підставі вивчення архівних матеріалів, спогадів очевидців, сучасних дослідницьких інтерпретацій.

\section{БІБЛІОГРАФІЧНИЙ СПИСОК:}

1. Матвієнко Г. Окупаційна повсякденність у діяльності Львівського університету (1939-1944). Історична панорама. 2015. Вип. 20. С. 52-80. URL: http://nbuv.gov.ua/UJRN/Istp_2015_20_6.

2. Короткі нариси 3 історії Харківського державного університету. Харків : Вид-во Харківського ун-ту, 1940. $300 \mathrm{c.}$

3. Майборода В. Вища педагогічна освіта в Україні : Історія, досвід, уроки (1917-1985 рр.). Київ : Либідь, 1992. 145 с.

4. Вища школа СРСР за 50 років (1917-1967) / за ред. В. Єлютіна. Москва : Вища школа, 1967. 272 c.

5. Дніпровський національний університет імені Олеся Гончара. URL: library.dsu.dp.ua/ Metodichki/pisarjevskiy.pdf.

6. Дніпровський національний університет імені Олеся Гончара. URL: http://www.dnu.dp.ua.

7. Інститут біології та медицини : навчальнонауковий центр. URL: https://biology.univ.kiev.ua/ institute-activity/educational/kafedry/kafedrabiochemistry/history.html.

8. Назаренко В., Бєлік Я. Наукова, науковоорганізаційна та педагогічна спадщина О.В. Палладіна. Інститут біохімії ім. О.В. Палладіна НАН України - 80 (1925-2005) / відп. ред. С. Комісаренко. Київ : Альфа-Прайм, 2005. 496 с.

9. Чернівецький національний університет імені Юрія Федьковича. URL: http://ibhb.chnu.edu. ua/dpt/inorgchem/pro-kafedru.

10. Вища школа : збірка постанов, наказів, інструкцій : у 2-х ч. / за ред. Є. Войленко. Москва : Вища школа, 1978. 400 с. Ч. І ; Ч. ІІ. 360 с. 


\section{КОМПЕТЕНТНІСНИЙ ПІДХІД В ОСВІТІ ЯК УМОВА ПРОФЕСІЙНОГО РОЗВИТКУ ВЧИТЕЛІВ \\ COMPETENCE APPROACH IN EDUCATION AS A CONDITION FOR TEACHERS' PROFESSIONAL DEVELOPMENT}

\author{
Стаття присвячена питанням підго- \\ товки та перепідготовки педагогічних \\ кадрів в системі підвищення кваліфікації. \\ Зосереджено увагу, на вимогах до осо- \\ бистості, сучасного фрахівця педагогіч- \\ ної галузі в трансорормаційних процесів \\ в освіті. 3 метою впровадження компе- \\ тентнісного, особистісно-орієнтованого \\ підходу в педагогічній освіті задля забез- \\ печення фрормування загальних (ключових) \\ компетентностей вчителів. Основна \\ увага зосереджується на теоретико- \\ методичних засадах розвитку профре- \\ сійної компетентності вчителів у сис- \\ темі підвищення кваліфікації. Зокрема, \\ розкрито нові можливості професійного \\ поступу вчителя шляхом формальної, \\ несрормальної та інфрормальної освіти. \\ Обірунтовано, що для реалізації компе- \\ тентнісного навчання у закладі освіти \\ має працювати компетентний вчитель, \\ який готовий постійно самовдоскона- \\ люватися, опановувати нові знання і \\ змінюватися відповідно до вимог часу \\ та соціально-економічного розвитку \\ суспільства. Розкрито питання настав- \\ ництва та педагогічної інтернатури \\ у закладі освіти, розроблення шкільноі \\ документації, що регламентує розвиток \\ профресійної компетентності вчителів у \\ закладі освіти. Висвітлюються питання \\ профресійного розвитку вчителів та мож- \\ ливих шляхів розбудови власної освітньоі \\ траєкторії впродовж життя. На основі \\ аналізу теоретико-методологічної літе- \\ ратури виявлено, що «освіта впродовж \\ життя» базується на чотирьох аспек- \\ max: навчитися пізнавати, навчитися \\ робити, навчитися жити разом, навчи- \\ тися жити» та розкрито суть таких \\ тверджень. В ході дослідження було \\ виявлено, що всебічний розвиток профе- \\ сійної компетентності педагогів забез- \\ печується поєднанням методологічного, \\ теоретичного та методичного аспектів \\ в системі підвищення кваліфікації педаго- \\ гічних працівників.
}

Ключові слова: компетентнісний підхід, інтернатура, наставництво, профресійний розвиток, підвищення кваліфрікащії.

The article deals with the issues of teachers training and retraining in the advanced training system. The attention is focused on the requirements to the personality, a modern specialist of the teaching industry in the transformation processes in education. In order to implement a competence, learner-centered approach in pedagogical education to ensure the formation of common (key) teachers' competencies. The main attention is paid to the theoretical and methodical bases for the teachers professional competence development in the advanced training system. In particular, some new opportunities for teachers' professional development by means of formal, non-formal and informal education are revealed.

It is proved that for the implementation of competence-based training in an educational institution, a competent teacher should work. The teacher should be ready to constantly improve herself or himself, master new knowledge and change in accordance with the requirements of the time and socioeconomic development of society. The issues of tutorship and pedagogical internship in an educational institution, the development of school documentation, regulating the development of teachers' professional competence in an educational institution, are discussed. The issues of teachers' professional development and possible ways of personal lifelong educational path are covered. Based on the analysis of theoretical and methodological literature, it is revealed that "lifelong education" is based on four aspects: learning to know, learning to do, learning to live together and learning to be. The essence of these statements is revealed in the article. The study shows that the comprehensive development of teachers' professional competence is provided by a combination of methodological, theoretical and methodical aspects in the teachers' advanced training system.

Key words: competence approach, internship, tutorship, professional development, advanced training.
Постановка проблеми у загальному вигляді. Сучасний стан розвитку системи освіти, рефрормування всіх її ланок створює нові вимоги до особистості вчителя та рівня його профресійної компетентності. На думку багатьох дослідників, сьогодні виникає необхідність готувати фрахівців, які вміють вирішувати проблеми, виявляють ініціативність та здатні орієнтуватися в сучасних умовах. Відтак, виникає необхідність під час підготовки та перепідготовки вчителів віддавати перевагу освіті на компетентнісних засадах.

Аналіз останніх досліджень і публікацій засвідчив, що проблема підготовки та перепідготовки педагогічних працівників на засадах ком- петентнісного підходу в освіті, набуває все більш поширеної практичної значущості. Запровадження компетентнісного підходу в освітньому процесі розглядалися у роботах вітчизняних науковців О. Савченко, Н. Бібік, Л. Ващенко, О. Пометун, О. Овчарук та багатьох інших. Дослідники зазначають, що новий зміст освіти, який оснований на реалізації компетентнісного підходу в освіті, фрормуванні ключових компетентностей особистості є беззаперечною перевагою у вихованні та навчанні підростаючого покоління. Водночас, стверджують, що реалізація компетентнісного підходу в освіті, потребує підготовленого компетентного педагога - цілісної гармонійної особистості, яка здатна 
постійно підвищувати професійну майстерність, прагне до особистого зростання та самовдосконалення. Поняття «педагогічна майстерність» як системо утворюючий чинник професійної підготовки вивчали Ю. Азаров, Є. Барбіна, В. Бондар, Л. Крамущенко, Н. Кузьміна, О. Мороз, О. Мудрик, О. Пехота, М. Поташник, В. Сластьонін, Н. Тарасевич, К. Ушинський та інші. Слід зазначити, що інтерес до професійного розвитку педагогів завжди займав чільне місце серед науковців, як найбільш оптимальну й перспективну основу навчання й розвитку фрахівця, зокрема й педагога, досліджувану проблему вивчали: Н. Протасова, Л. Набока, В. Пуцов та інші. Теорія компетентнісного підходу в освіті досліджувалась і була представлена в наукових працях зарубіжних учених Р. Бадера, Д. Мертенса, Б. Оскарсона, А. Шелт та інших. Вдосконалення професійної компетентності вчителів на основі компетентнісного підходу досліджували В. Адольср, І. Зимня, І. Єрмаков, В. Мельник, О. Огієнко, І. Підласий, О. Савченко й багато інших корифреїв науки.

Виділення не вирішених раніше частин загальної проблеми. Сучасний стан освіти перебуває в стані активного ресрормування, пошуку нових шляхів підготовки та перепідготовки фрахівців освітньої галузі, які здатні реалізувати засади нового вектора освіти, де особистість в освітньому процесі творить саму себе і своє життя. А «Знаннєва» парадигма, яка домінувала в традиційній школі постіндустріального суспільства, все більше вступає в суперечність 3 сучасними умовами нестабільності та динамічності освітніх процесів.

Мета статті. Дослідити сучасні тенденції перепідготовки педагогічних працівників та розглянути нові можливості розвитку професійної компетентності вчителів у системі підвищення кваліфікації та освіти впродовж життя.

Виклад основного матеріалу. Початок XXI століття - це час розвитку і вдосконалення освіти. 3 прийняттям Концепції «Нова українська школа» система освіти отримала новий зміст заснований на формуванні ключових компетентностей необхідних для успішної самореалізації впродовж життя. Поняття «освіта», «освітній процес» у сучасному розумінні означають навчання, виховання і розвиток. Виховний процес стає невідільною складовою частиною всього освітнього процесу, що орієнтується на загальнолюдські цінності. В концепції освіти XXI століття, за висновками комісії ЮНЕСКО, зазначається, що система освіти має вирішувати численні проблеми, що ставить перед нею інсрормаційне суспільство в перспективі неперервного збагачення знань і виконання обов'язків громадянина, який відповідає вимогам нашого часу. У Державній національній програмі «Освіта» (Україна XXI століття) зазначається: динамізм, притаманний сучасній цивілізації, зростання соці- альної ролі особистості, гуманізація і демократизація суспільства, інтелектуалізація праці, швидка зміна техніки та технології в усьому світі - усе це потребує створення умов, за яких народ України став би нацією, яка постійно навчається [1].

За визначенням комісії ЮНЕСКО: «Освіта впродовж всього життя стоїть на чотирьох стовпах: навчитися пізнавати, навчитися робити, навчитися жити разом, навчитися жити». «Навчитися пізнавати» - уміння вчитися для того, щоб використати можливості, які надає система неперервної освітити, поєднуючи достатньо широку загальну культуру з поглибленої роботи з обмеженою кількістю дисциплін. «Навчитися робити» - не лише здобути бути кваліфікацію, а й опанувати відповідні професійні компетентності, які дають змогу виконувати професійні функції: вміння співпрацювати в команді, здатність логічно обґрунтовувати позицію, критично мислити, уміння вирішувати проблеми, оцінювати ризики. «Навчатися жити разом» передбачає вміння висловити думку, конструктивно керувати емоціями, розуміти іншого і відчувати взаємозалежність, реалізувати спільні проєкти і бути готовим до врегулювання конфлліктних ситуацій в умовах поваги до особистості, взаєморозуміння та миру. «Навчитися жити» - сприяти розвитку власної траєкторії, бути здатним діяти, проявляючи незалежність, самостійність мислення і особисту відповідальність [2].

Сучасний стан розвитку цивілізації характеризується прискореним розвитком людства за допомогою інформаційних технологій, зростанням транскордонної міграції та докорінними змінами на ринку праці. Із прийняттям нових законів «Про освіту», «Про вищу освіту», «Про повну загальну середню освіту» в змісті фрормальної загальної середньої, профресійної (профресійнотехнічної), фрахової перед вищої та вищої освіти все більше уваги приділено формуванню та розвитку загальних (універсальних, ключових тощо) компетентностей і наголошується на необхідності вміння безперервного навчання протягом життя. Завдяки розвитку інформаційно-комунікаційних технологій зростання об'єму корисних знань дедалі більше супроводжується їх відкритістю та доступністю для всіх людей. Це спричиняє збільшення розмаїття в способах та фрормах здобуття знань і разом з тим зростає роль неформальної та інформальної освіти.

Так, з метою вдосконалення системи педагогічної освіти підготовки та перепідготовки педагогічних працівників, становлення і розвитку сучасних альтернативних моделей безперервного професійного та особистісного розвитку педагогів у 2018 році затверджено Концепцію розвитку педагогічної освіти [3]. Сучасна підготовка та перепідготовка педагогічних працівників має відповідати суспільним запитам, які сформульовані 
в профресійних стандартах та стандартах освіти, а також враховувати світові тенденції та рекомендації міжнародних організацій щодо підготовки та перепідготовки педагогічних кадрів. 3 метою перепідготовки педагогічних кадрів та впровадження Концепції реалізації державної політики у сорері рефрормування загальної середньої освіти «Нова українська школа» Міністерством освіти і науки України було передбачено модернізацію освітніх програм з підготовки та перепідготовки вчителів на засадах впровадження компетентнісного, особистісно-орієнтованого підходу в педагогічній освіті, забезпечення формування загальних (ключових) компетентностей, набуття педагогічними працівниками вмінь та досвіду фрормування компетентностей в учнів, опанування педагогічних технологій, в тому числі, з використанням інформаційно-комунікаційних технологій, посилення практичної складової педагогічної освіти, максимальне наближення психолого-педагогічної та методичної підготовки до умов практичної фрахової діяльності, запровадження принципу дитиноцентризму й педагогіки партнерства, що ґрунтується на співпраці учня, вчителя, батьків і громадськості з урахуванням принципів інклюзивної освіти [2].

Необхідність профресійно-особистісного розвитку фрахівця визначається сучасними вимогами до рівня його профресійної компетентності та готовності розвивати власну професійну траєкторію у відповідності до швидких трансорормаційних процесів в освіті [4, с. 175]. Від рівня кваліфрікації, педагогічного досвіду та професійної майстерності залежить конкурентоспроможність педагогічного працівника на ринку праці. Сучасний вчитель має постійно підвищувати рівень власного професіоналізму, вдосконалювати наявні професійно значущі якості, зокрема мобільності, особистої відповідальності 3 а власний неперервних професійний розвиток.

Підвищення кваліфікації педагогічних працівників у закладах загальної середньої освіти плануватиметься у два етапи. Спочатку здійснюватимуть перспективне планування у поточному році на наступний календарний рік. Згодом, після затвердження кошторису закладу розроблятимуть план підвищення кваліфрікації на відповідний рік. До орієнтовного плану підвищення кваліфікації педагогічного працівника варто внести таку інформацію: тема (напрям, найменування) відповідної програми (курсу, лекції, модуля тощо); суб'єкт (суб'єкти) підвищення кваліфікації; обсяг (тривалість), вид; форма (форми), строки; вартість і за можливості джерела фрінансування. За результатами розгляду та обговорення педагогічна рада закладу затверджує план підвищення кваліфікації на відповідний рік [5, с. 28-30].

Загальна кількість академічних годин для підвищення кваліфрікації педагогічного працівника впродовж п'яти років не може бути меншою
150 годин, з яких певна кількість годин має бути на вдосконалення знань, вмінь і практичних навичок у частині роботи з дітьми з особливими освітніми потребами, запобігання та протидії домашньому насильству, булінгу. В умовах динамічних змін професійний розвиток учителя вимагає безперервного навчання, прагнення до самовдосконалення й самоосвіти.

Безперервний профресійний розвиток може здійснюватися шляхом фрормальної, неформальної та інформальної освіти, а його результати міститися в електронному накопичувальному портфроліо педагогічного працівника. Результати, які здобуті шляхом фрормальної освіти не потребують окремого визнання чи підтвердження педагогічною радою закладу і можуть бути підставою для присвоєння професійних та здобуття повних освітніх кваліфікацій. Значної уваги потребує безперервне підвищення кваліфікації, яке спрямоване на підвищення та розвиток в опануванні інорормаційно-комунікаційними технологіями, медійної грамотності, іншомовної компетентності педагогічних працівників. Традиційним видом підвищення кваліфрікації є курси підвищення кваліфрікації при обласних інститутах підвищення кваліфікації, які мають ліцензію на провадження освітньої діяльності за акредитованими освітніми програмами. До інших видів підвищення кваліфікації можемо віднести педагогічне стажування (інтернатура), участь у сертифікаційних програмах, тренінгах, семінарах, семінарах-практикумах, семінарах нарадах, семінарах-тренінгах, вебінарах, майстер-класах, у тому числі, за кордоном (педагогічна мобільність).

У статті 23, Закону України «Про повну загальну середню освіту» (2020 рік), розкрито суть поняття «педагогічна інтернатура». Педагогічна інтернатура - система заходів, спрямованих на підтримку педагогічного працівника закладу освіти, призначеного вперше, у провадженні ним педагогічної діяльності та набутті його фрахової майстерності [6]. Педагогічна інтернатура організовується на підставі Положення про педагогічну інтернатуру і відповідно до наказу керівника закладу освіти, що видається в день призначення особи на посаду педагогічного працівника. Педагогічна інтернатура у закладі освіти організовується для осіб, які не мають досвіду педагогічної діяльності та приймаються на посаду педагогічного працівника. Метою педагогічної інтернатури є забезпечення здобуття та/або вдосконалення професійних компетентностей і педагогічної майстерності протягом першого року професійної діяльності педагогічного працівника. Може передбачати: супровід та підтримку у педагогічній діяльності з боку досвідченого педагогічного працівника (педагоганаставника); різні фрорми професійного розвитку (відвідування навчальних занять, опрацювання відповідної літератури тощо). 
Удосконалення знань, умінь і практичних навичок у частині інформаційно-комунікаційних та цисррових компетентностей вчителя має здійснюватися відповідно до стандарту циоррової компетентності педагогічного працівника. Нова інституція, Державна служба якості освіти, на підставі конкретного переліку значущих профресійних досягнень, включаючи наявність документа про проходження фрахової сертифікації, має розмістити реєстр педагогічних працівників (наставників), які можуть виступати в ролі наставників. Такі педагогічні працівники можуть залучатися до педагогічної експертизи освітніх програм, проєктів підручників, цифррових освітніх ресурсів тощо. Наставництво у закладі загальної середньої освіти може бути використане в процесі підготовки вчителів до сертифікації, а також у разі відновлення педагогічної діяльності після тривалої перерви.

Черговою новацією, як вид підвищення кваліфрікації, нової значимості набуває педагогічне стажування у кращих педагогічних працівників. Такий вид підвищення кваліфрікації спрямований на поширення ефективної практики та передового педагогічного досвіду висококваліфікованих педагогічних кадрів. Наразі розглядається як пріоритетний і передбачає атестацію стажерів у фрормі розроблення методичних напрацювань (уроків, сценаріїв), у тому числі, з використанням циоррових освітніх ресурсів (відео, аудіо матеріалів, електронних підручників, сайтів, блогів тощо).

Підвищення кваліфікації шляхом інорормальної освіти потребує розроблення програми 3 самоосвіти вчителя, з описом запланованих до набуття нових, або вдосконалення раніше набутих компетентностей і визначенням результатів навчання. Підвищення кваліфікації у фрорматі інфрормальної освіти потребує попереднього затвердження педагогічною радою закладу, фрінансування може здійснюватися на підставі рішення про визнання результатів навчання. Алгоритм самоосвітньої діяльності педагога охоплює: участь в організованих фрормах навчання - семінарах, конференціях, педагогічних читаннях, робота 3 літературними джерелами, написання ресрератів, підготовка матеріалів та участь в семінарах, вивчення досвіду педагогів, самоспостереження тощо [5].

Висновки. Компетентнісний підхід в реалізації державної освітньої політики, знаменував переорієнтацію домінуючої освітньої парадигми $з$ її переважною трансляцією знань, умінь і практичних навичок на створення умов для всебічного розвитку особистості. Сучасний учитель має оволодіти комплексом компетентностей, що забезпечать йому здатність до якісної професійної діяльності, а також ефективно діяти й швидко адаптуватися до мінливих умов сьогодення. Якісним зрушенням у системі профресійного розвитку вчителів $є$ створення й фрункціонування конкурентоспроможного ринку освітніх послуг, що розвивається. Можливість вибору педагогічним працівником закладу в якому він буде підвищувати кваліфікацію, сприятиме вдосконаленню освітніх послуг у сорері безперервного профресійного розвитку педагогічних працівників.

\section{БІБЛІОГРАФІЧНИЙ СПИСОК:}

1. Про державну національну програму «Освіта» («Україна XXI століття») : Постанова Кабінету Міністрів України від 29 травня 1996 р. № 896-93-п / Верховна Рада України. URL: https://zakon.rada.gov.ua/laws/show/896-93-\% D0\%BF.

2. Драйден Г., Вос Дж. Глобальні виклики і пріоритети освіти XXI століття. URL: http://dlse. multycourse.com.ua/ua/page/15/50.

3. Про затвердження концепції розвитку педагогічної освіти : Наказ Міністерства освіти і науки України від 16 липня 2018 р. № 776 / Міністерство освіти і науки України. URL: https://mon.gov.ua/ua/ npa/pro-zatverdzhennya-koncepciyi-rozvitkupedagogichnoyi-osviti.

4. Ціпан Т.С. Профресійна компетентність сучасного вчителя. Інноватика у вихованні. 2016. № 3. С. 174-181.

5. Святенко О.В. План підвищення кваліфікації: що треба знати педагогу. Заступник директора школи. 2020. № 4. С. 28-30.

6. Про повну загальну середню освіту : Закон України від 16 січня 2020 р. № 463-ІХ / Верховна Рада України. URL: https://zakon.rada.gov.ua/laws/ show/463-20. 


\title{
ВНЕСОК ВАСИЛЯ АНТОНОВИЧА ФЛОРОВСЬКОГО В РОЗВИТОК НАВЧАЛЬНОГО ЗАКЛАДУ ПРАВОСЛАВНОЇ ЦЕРКВИ НА ЄЛИСАВЕТГРАДЩИНІ
}

\author{
VASYL ANTONOVYCH FLOROVSKY'S CONTRIBUTION \\ TO THE DEVELOPMENT OF THE EDUCATIONAL INSTITUTION \\ OF THE ORTHODOX CHURCH IN YELISAVETHRAD REGION
}

у статті розкрито особливості становлення й розвитку Єлисаветградського духовного училища, внесок Василя Флоровського в розбудову навчального закладу Православної черкви на Єлисаветградщині.

Аналіз стану дослідженості означеної проблеми засвідчує: на сучасному етапі значно зріс інтерес науковців як до системи духовної освіти, так і до особливостей розвитку окремих навчальних закладів Православної черкви на Єлисаветградщині. Науковиі прагнуть більш об'єктивно оцінити здобутки у сфрері духовної освіти в регіоні, що пов'язано з відкритістю архівів і доступністю нових джерел.

З'ясовано, що значну частину джерел, зокрема архівних матеріалів, ще не введено в науковий обіг, а накопичений досвід організації закладів православної церкви регіону, роль окремих постатей, які зробили вагомий внесок у розвиток духовної освіти на Єлисаветградщині, висвітлено недостатньо. у ході наукового пошуку встановлено, що історія духовної освіти була визначною сторінкою історії Єлисаветградського краю дореволючійного періоду. З'ясовано, що Єлисаветградське духовне училище, засноване у 1820 р., було одним із найстаріших середніх навчальних закладів регіону. Головною метою училища було виховання в дусі православ'я й церковності дітей духовенства Єлисаветградського й Олександрійського повітів Херсонської губернії, а також початкове навчання дітей світського стану, переважно жителів Єлисаветграда. Учні вивчали російську з черковнослов'янською, грецьку й латинську мови, арифрметику та геограсрію, мали заняття з чистописання, церковного співу.

Значно активізував діяльність Єлисаветградського духовного училища смотритель навчального закладу Василь Антонович Флоровський, який влаштував при училищі церкву, служив у ній, спорудив нову будівлю для училища, сприяв наданню грунтовної освіти в училищі.

Перспективи подальших досліджень вбачаємо в розкритті особливостей виховної роботи в навчальних закладах Православної церкви регіону.

Ключові слова: Єлисаветградщина, духовна освіта, навчальні заклади Православної церкви, В. Флоровський.
The article reveals the peculiarities of the formation and development of the Yelisavethrad Theological Seminary, the contribution of Vasyl Florovsky to the development of the educational institution of the Orthodox Church in the Yelisavethrad region.

The analysis of the state of research of this problem shows that at the present stage the interest of scientists in the system of spiritual education and in the peculiarities of the development of certain educational institutions of the Orthodox Church in Yelisavethrad region has significantly increased. Scholars seek to more objectively assess the achievements in the field of spiritual education in the region, due to the openness of archives and the availability of new sources.

It was found that a significant part of sources, including archival materials, have not yet been put into scientific circulation, and the accumulated experience of organizing Orthodox churches in the region, the role of individual figures who have made a significant contribution to the development of spiritual education in Yelisavethrad.

In the course of scientific research it was established that the history of spiritual education was one of the brightest and richest pages in the history of the Yelisavethrad region of the pre-revolutionary period. It was found that the Yelisavethrad Theological Seminary, founded in 1820, was one of the oldest secondary schools in the region. Its main purpose was to educate the clergy of the clergy of Yelisavethrad and Alexandria counties of Kherson province in the spirit of Orthodoxy and ecclesiology, as well as the initial education of secular children, mostly residents of Yelisavethrad. Students studied Russian with Church Slavonic, Greek and Latin, arithmetic and geography, had classes in calligraphy, church singing.

Vasyl Antonovych Florovsky, the caretaker of the educational institution, significantly intensified the activity of the Yelisavethrad Theological Seminary.

We see prospects for further research in revealing the features of educational work in educational institutions of the Orthodox Church in the region.

Key words: Yelisavethrad region, spiritual education, educational institutions of the Orthodox Church, V. Florovsky. педагогічного університету імені Володимира Винниченка

Постановка проблеми в загальному вигляді. Суспільно-педагогічний рух кінця 50-60-х рр. XIX століття змусив царизм, його міністерство народної освіти та церковне відомство православної віри звернути увагу на освіту. Почали розроблятись і втілюватись у життя відповідні реформи в галузі освіти, зокрема церковної. 31 серпня 1859 р. київський митрополит Ісидор (Нікольський) видав розпорядження, згідно з яким у всіх містах і селах, де не було навчальних закладів, школи відкривались у будинках священників, якщо були відсутні належні приміщення [8, с. 73].

На сучасному етапі значно зріс інтерес науковців як до системи духовної освіти, так і до особливостей розвитку окремих навчальних закладів Православної церкви на Єлисаветградщині. Нау- 
ковці прагнуть більш об'єктивно оцінити здобутки у сфері духовної освіти в регіоні, що пов'язано з відкритістю архівів і доступністю нових джерел.

Аналіз останніх досліджень і публікацій. Питання розвитку духовної освіти на теренах Єлисаветградщини були об'єктом вивчення науковців [1; 11]. Аналіз стану дослідженості означеної проблеми засвідчує, що значну частину джерел, зокрема архівних матеріалів, ще не введено в науковий обіг, а накопичений досвід організації закладів православної церкви регіону, роль окремих постатей, які зробили вагомий внесок у розвиток духовної освіти на Єлисаветградщині, висвітлено недостатньо.

Виділення не вирішених раніше частин загальної проблеми. Історія розвитку закладів Православної церкви на Єлисаветградщині представлена невеликою кількістю наукових розвідок. Цілісна історія розвитку духовної освіти регіону другої половини XIX - початку XX ст., внесок окремих постатей в розвиток закладів Православної церкви на теренах краю ще належно не висвітлено в історіограсрії.

Мета статті. Завданням статті було розкрити внесок Василя Флоровського в розвиток духовної освіти на Єлисаветградщині.

Виклад основного матеріалу. У XIX ст. духовна та світська освіта за структурою майже не відрізнялися. Світська освіта складалася з народних училищ (які фрактично відповідали рівню сучасної початкової школи), спеціалізованих училищ - реальних, ремісничих, комерційних тощо (4-9 класи за сучасними мірками) та гімназій (4-11 класи). Майже така сама система була й у духовній освіті: церковноприходська школа, духовне училище (4-9 класи), духовна семінарія. Випускники гімназій могли продовжити освіту в духовній академії, а випускники семінарій - в університетах. Часто випускники духовних училищ вступали до 5-6 класу класичної гімназії. Програма духовного училища майже не відрізнялася від гімназійної. Крім Закону Божого, тут викладали російську, церковнослов'янську, грецьку мови, латинь, арифрметику, природознавство, церковні співи, чистописання, малювання та креслення. Але приймали сюди, звичайно, тільки православних [3].

У 1820 р. було засновано Єлисаветградське духовне училище, яке стало першим середнім навчальним закладом у місті. Головною його метою було виховання в дусі православ'я й церковності дітей духовенства Єлисаветградського й Олександрійського повітів Херсонської губернії, а також початкове навчання дітей світського стану, переважно жителів Єлисаветграда [7, с. XXXVII-XXXIX].

На початку 1870-х рр. коштом духовенства для училища збудували великий двоповерховий будинок на розі вулиць Вокзальна та Київська. Тепер у цьому приміщенні працює школа № 14.
Училище було створено для безкоштовного навчання дітей священнослужителів. Проте скоро сюди почали за плату приймати дітей дворян, міщан і селян. Плата була великою - від 60 крб. за рік у першій половині XIX ст. до 140 крб. на початку XX ст. Але для батьків хлопчиків це було зручніше, ніж реальне училище чи гімназія. Учнів забезпечували житлом у гуртожитку та повним пансіоном. При училищі були власна церква, лікарня й навіть баня. А. Шмідт у «Матеріалах для географрії та статистики по Херсонській губернії» зазначав, що в 1846 р. в училищі було 83 учні, у 1852-му - 110. Через кілька десятиліть в Єлисаветграді почали відкриватися інші навчальні заклади для хлопчиків: гімназія, реальне, комерційне училище тощо Але кількість учнів у духовному училищі не зменшилася. Відомо, що в 1915 р. тут навчалися 169 хлопчиків [2].

Значно активізував діяльність Єлисаветградського духовного училища священник Василь Антонович Флоровський. Він народився 15 березня 1852 р. в селі Флоровське Новгородського повіту. Закінчив Новгородську духовну семінарію (1873 р.) й Московську духовну академію (1877р.). До Єлисаветграда священник Василь Антонович Флоровський з родиною прибув з Одеси в 1883 р. Із цього ж року він обіймає посаду смотрителя Єлисаветградського духовного училища. Влаштував при училищі церкву, служив у ній, спорудив нову будівлю для училища (1894р.). Протоієрей Василь Флоровський також був законовчителем Єлисаветградського земського реального училища (1886-1894рр.) та чоловічої гімназії (18901894 рр.), священником церкви Різдва Пресвятої Богородиці при гімназії. 31894 р. жив в Одесі. Ректор Одеської духовної семінарії, редактор «Херсонских епархиальных ведомостей» і голова Св. Андріївського братства Херсонської єпархії (3 1909 р.). 3 1905-го по 1920 р. - настоятель одеського Кафедрального Преображенського собору. У 1914 р. нагороджений Золотим Хрестом $з$ прикрасами. У 1924 р. служив священником храму Св. Олександра Невського в Софії, отримав від болгарського уряду Хрест IV ступеня «За громадські заслуги» [1, с. 319].

Священник Василь Флоровський був у Єлисаветграді людиною помітною. Херсонське єпархіальне начальство звернуло увагу на молодість, ґрунтовну освіту й велику працездатність сина причетника Новгородської єпархії, кандидата богослов'я, що в 1877 р. закінчив Московську духовну академію. Восени того ж року він почав викладацьку діяльність у різних єпархіальних навчальних закладах Одеси. Викладав грецьку мову, Закон Божий, педагогіку й дидактику [11, с. 3].

У жовтні 1882 р. його затверджують на посаду смотрителя (директора в сучасному розумінні) Єлисаветградського духовного училища. Цей 
навчальний заклад за статутом належав до нижчого рівня духовної освіти. Надавав початкові знання, а також готував дітей до служби православній церкві. Подібно до інших 185 духовних училищ, які працювали по різних губерніях Російської імперії в останню чверть XIX ст., Єлисаветградська духовна школа мала чотири класи, навчальна програма яких майже копіювала гімназійну програму за чотири роки навчання [6, с. 486-487]. Учні вивчали російську з церковнослов'янською, грецьку й латинську мови, арифметику та географрію, мали заняття з чистописання, церковного співу [7, с. XXXVII-XXXIX]. Як бачимо, заклад мав духовне спрямування.

На підготовче відділення Єлисаветградського духовного училища приймали дітей віком від 9 до 11 років різного походження. Діти, які походили з родини духовенства, навчалися безплатно $[10$, с. 259$]$.

Для вступу до підготовчого класу училища потрібно було знати:

- закон Божий (головні молитви);

- російську мову (добре читати прості оповідання й переказувати прочитане своїми словами);

- церковнослов'янську мову (читати на церковнослов'янській Євангеліє й Часослов);

- арифрметику (рахувати до 20).

На жаль, архів Єлисаветградського духовного училища не знайдено, вважають, не зберігся. А все, що можна дізнатися про рівень роботи Василя Антоновича на посаді смотрителя цього навчального закладу, має пізнішу редакцію, до того ж ювілейну: «3 тих часів і надалі Ваша постійна енергійна та суттєва за наслідками пасторська діяльність виявлялась і виявляється все сильніше та яскравіше. Ви високо підняли Єлисаветградське училище в усіх відношеннях і дуже вдало сприяли його внутрішньому й зовнішньому благоустрою» $[4 ; 5]$.

Відомості про протоієрея Василя Флоровського на 1902-1903 навчальний рік(тодіректора Одеської духовної семінарії) надають можливість з'ясувати, які посади він обіймав в Єлисаветграді. По-перше, смотрителем Духовного училища він значився з 26 жовтня 1882 р. по травень 1890 р. Тоді ж служив настоятелем церкви Св. Василя Парійського при училищі. Потім читав Закон Божий в одному 3 найкращих навчальних закладів міста - Єлисаветградському земському реальному училищі 31 серпня 1886-го по 23 червня 1894 р. 3 лютого 1890-го по червень 1894 р. - законоучитель Єлисаветградської чоловічої гімназії [9, с. 1-2].

Упродовж свого існування Єлисаветградське духовне училище випустило зі своїх стін для подальшої освіти багатьох відомих постатей, серед яких священники-краєзнавці початку XX ст. Г. Сорокін і В. Нікіфоров, заслужений профресор Новоросійського університету протоієрей М. Пав- ловський, відомий в єпархії викладач Одеської семінарії протоієрей Г. Попруженко, єпископ Алеутський й Аляскинський Миколай, автор музики до пісні «Реве та стогне Дніпр широкий» Д. Крижанівський. Зауважимо, що професійним композитором Д. Крижанівський не був, він навчався хорового співу в Єлисаветградському духовному училищі, а потім в Одеській семінарії. Священником він теж не став; закінчивши семінарію, вступив до Новоросійського університету, викладав російську та старослов'янську мови в Болградській гімназії. Там він створив хор хлопчиків і на дозвіллі писав твори для цього хору, а також романси й пісні [2].

Висновки. Отже, історія духовної освіти була однією з яскравих і насичених сторінок історії Єлисаветградського краю дореволюційного періоду. Єлисаветградське духовне училище, засноване в 1820 р., було одним із найстаріших середніх навчальних закладів регіону. Головною його метою було виховання в дусі православ'я й церковності дітей духовенства Єлисаветградського й Олександрійського повітів Херсонської губернії, а також початкове навчання дітей світського стану, переважно жителів Єлисаветграда. Учні вивчали російську $з$ церковнослов'янською, грецьку й латинську мови, арифрметику та географію, мали заняття 3 чистописання, церковного співу. Як бачимо, заклад мав духовне спрямування.

Значно активізував діяльність Єлисаветградського духовного училища смотритель навчального закладу Василь Антонович Флоровський, який влаштував при училищі церкву, служив у ній, спорудив нову будівлю для училища, сприяв наданню ґрунтовної освіти в училищі.

Перспективи подальших досліджень вбачаємо в розкритті особливостей виховної роботи в навчальних закладах православної церкви регіону.

\section{БІБЛІОГРАФІЧНИЙ СПИСОК:}

1. Босько В.М. Визначні постаті Степової Еллади: до 250-річчя заснування фрортеці Святої Єлизавети, міста Єлисаветграда та 65-річчя утворення Кіровоградської області. Кіровоград : Інформаційна мережа, 2004. 4. 1. 376 с.

2. Для кого створили перше училище в Єлисаветграді. URL: http:// dozor.kr.ua > post > dlya-kog.

3. Перерва В.С. Церковні школи в Україні (кінець XVIII - поч. XX ст.): забутий світ. Загальна історія. Біла Церква : Видавець Піонтковський О. В. 2014. T. 1.576 c.

4. Празднование двадцатипятилетия священства кафедрального протоиерея одесского Преображенского собора Василия Антоновича Флоровского. X.E.B. 1910. № 4. C. 97-104.

5. Празднование двадцатипятилетия священства кафедрального протоиерея одесского Преображенского собора Василия Антоновича Флоровского. X.E.B. 1910. № 5. C. 118-130.

6. Россия в конце XIX века. Санкт-Петербург. 1900. C. $486-487$. 
7. Сведения о состоянии Елисаветградского духовного училища за 1905 год. Народное образование в Елисаветградском уезде Херсонской губернии в 1905 году: приложения. Елисаветград : Тип. Гольденберга, 1906. С. XXXVII-XXXIX.

8. Сесак I.В. Школи грамоти Правобережної України (друга половина XIX - початок XX ст.). Освіma, наука і культура на Поділлі. Т. 24. С. 70-88.
9. Херсонские епархиальные ведомости. 1902. № 3. C. 1-2.

10. Херсонские епархиальные ведомости. 1907. № 14. С. 259-262.

11. Чуднов О. Дещо до біографрії фрілософра та богослова отця Георгія Флоровського. Єлисавет. 1993. 29 квітня. 


\section{ДО ПРОБЛЕМИ ВИВЧЕННЯ МІЖКУЛЬТУРНОЇ КОМУНІКАЦІЇ У ПРОЦЕСІ НАВЧАННЯ ІНОЗЕМНОÏ МОВИ

\author{
TO THE PROBLEM OF STUDYING INTERCULTURAL COMMUNICATION \\ IN THE PROCESS OF LEARNING A FOREIGN LANGUAGE
}

У статті йдеться про одне з найважливіших питань у сучасній педагогіці - навчання майбутніх фрахівців іноземних мов у процесі міжкультурної комунікації. Сьогодні викладання іноземних мов і міжкультурну комунікацію не можна роздивлятися окремо. Ці два поняття існують паралельно та в тісному взаємозв'язку одне з іншим. Ми розглядаємо питання теоретико-методологічних основ у процесі міжкультурної комунікації в аксіологічному аспекті. Насамперед визначається поняття міжкультурної комунікації в найбільш широкому сенсі, простежується ступінь вивчення і розвитку міжкультурної комунікації як соціолінгвістичного явища та як наукової дисципліни в зарубіжній літературі та вітчизняній освіті. Найбільший вплив на закладення основ вивчення та висвітлення цієї проблеми здійснили праці таких зарубіжних лінгвістів, як Г. Трейгера, Е. Голла, Г. Гофрштеда, Г. Гірша. Виявлено, що у вітчизняній педагогіці проблема дослідження міжкультурної комунікації перебуває на стадії формування. Серед українських дослідників слід виділити насамперед праці таких педагогів і фрілологів, як І. Бахова, М. Богатирьової, П. Донця, О. Зеліковської, Т. Колбіної.

У статті ми виокремлюємо та розглядаємо контексти, різні види та фрорми міжкультурної комунікації з позицій вербальних і невербальних кодів, виявляємо та обгрунтовуємо умови та фрактори есрективного фрормування міжкультурної комунікації у процесі навчання іноземної мови.

Головна мета сучасного викладача іноземних мов - не просто навчити здобувача вищої освіти іноземної мови, а допомогти йому інтегруватися в іншомовне середовище, подолати труднощі та культурні бар'єри на шляху інтеграції, зрозуміти особливості менталітету, культури, звичок носіїв чієї мови. Одним із основних труднощів є те, що ми сприймаємо інші культури крізь призму своєї власної культури. Ось чому важливо враховувати чей фракт і правильно обрати методи навчання й підготувати фоннціональну технічну базу.

Стаття є стислим нарисом вищезазначеної проблеми, і нею ми готуємо підгрунтя для подальшого більш докладного та глибокого аналізу цього питання.

Ключові слова: міжкультурна комунікація, види міжкультурної комунікації, навчання іноземних мов, педагогіка, вітчизняна освіта.
The article reveals one of the most important issues in modern pedagogy - teaching foreign languages to the students via intercultural communication. Today foreign language teaching and intercultural communication are definitely interwoven (can not be considered as two different spheres). These two concepts exist in parallel and in close connection with each other. We consider the issues of theoretical and methodological foundations in the process of intercultural communication in the axiological aspect.

We also observe the concept of intercultural communication in the broadest sense as it might be defined; the degree of study and development of intercultural communication as a sociolinguistic phenomenon and as a scientific discipline in foreign literature and domestic education has also been at our glimpse of interest. The greatest influence on the foundation for the study and introduction of this problem was exerted by the works of such foreign linguists as $G$. Traiger, E. Hall, G. Hofstede, G. Hirsch.

It is revealed that in domestic pedagogy the problem of research of intercultural communication is at the stage of formation. Among Ukrainian researchers, whose works are worth studying, are such teachers and philologists as I. Bakhov, M. Bohatyriova, P. Donets, O. Zelikovska, and T. Kolbina.

In this article we identify and consider contexts, different types and forms of intercultural communication from the aspects of verbal and nonverbal codes; we also identify and justify the conditions and factors of effective formation of intercultural communication in the process of foreign language learning.

The main goal of a modern foreign language teacher is not just to teach a student a foreign language, but to help him to integrate into a foreign language environment, overcome difficulties and cultural barriers, to understand the mentality, culture and habits of native speakers. One of the main difficulties is that we perceive other cultures through our own culture. That is why it is important to take this fact into account and choose the right teaching methods and prepare a functional technical base.

This article is a brief outline of the above-mentioned problems and we are working at further and more detailed and deep analysis of this issue.

Key words: intercultural communication, types of intercultural communication, teaching foreign languages, Pedagogy, domestic education.
Постановка проблеми в загальному вигляді. Процес глобалізації, розвиток і вдосконалення новітніх технологій, розширення просресійних і дружніх контактів між представниками різних націй і народів, тобто різних культур, мобільність, відкритість кордонів - усе це сприяє росту наукового та практичного інтересу до процесу міжкультурної комунікації. Цей фракт знаходить своє відображення насамперед у процесі навчання у вітчизняних і зарубіжних університетах, перед 
якими постає завдання формування не тільки професійних знань і навичок випускників, але й підготовки студентів до взаємодії із представниками країн з іншими, відмінними соціальними традиціями, суспільним устроєм і культурою.

У сучасному світі важко уявити молодого перспективного фахівця, який не володів би іноземними мовами, не подорожував та не спілкувався би 3 представниками інших культур. Іноземна мова сьогодні - реальний і повноцінний інструмент комунікації. Володіння іноземними мовами руйнує бар'єри у спілкуванні, відкриває його нові грані та можливості, сприяє більшому взаєморозумінню людей і зближує культури.

Невіддільними показниками підготовки майбутніх фахівців стають засвоєні норми та правила міжкультурного спілкування для фрормування позитивного досвіду взаємодії людей різних культур і національностей. Сучасному суспільству потрібні ділові, заповзяті, кваліфріковані кадри, які можуть свідомо та відповідально приймати рішення, які здатні здійснювати демократичні реформи, виявляти творчість, які були б мотивовані та заохочені до вдосконалення своєї кваліфікації та майстерності, які б мали професійні компетенції. Підготовка здобувачів вищої освіти до міжкультурної комунікації дає змогу не тільки фрормувати позитивний досвід взаємодії з людьми інших культур, але й передбачає розвиток особистості студента, фрормування якостей, необхідних для спілкування та плідної співпраці з представниками різних культур.

Отже, актуальними постають питання розкриття змісту й виділення специфрічних рис міжкультурної комунікації в освітньому середовищі через вивчення іноземних мов у сучасних університетах.

Метою статті $€$ розглядання теоретико-методологічних основ у процесі міжкультурної комунікації в аксіологічному аспекті. У зв'язку з цим необхідно визначити поняття міжкультурної комунікації; простежити ступінь вивчення і розвитку міжкультурної комунікації як соціолінгвістичного явища та як наукової дисципліни у літературі та вітчизняній освіті; виокремити та розглянути контексти, види та фрорми міжкультурної комунікації; дослідити проблему міжкультурної комунікації в навчанні студентів іноземних мов; визначити труднощі міжкультурної комунікації у процесі навчання іноземних мов; виявити й обґрунтувати фрактори та умови ефрективного фрормування міжкультурної комунікації у процесі навчання іноземної мови.

Як кожна людина не може існувати ізольовано від інших людей, так і жодна культура не може повноцінно функціонувати ізольовано від культурних досягнень і здобутків інших народів. Ми всі під час своєї життєдіяльності так чи інакше повинні постійно звертатися до свого минулого або ж до досвіду інших культур. 3 розвитком технологій на планеті майже не залишилося ізольо- ваних одна від одної культурних спільнот. Як правило, народи відкриті для взаємного сприйняття культур й обміну досвідом та інорормацією, вони спілкуються та розділяють один з одним здобутки власної культури. Така взаємодія між культурами та представниками різних народів отримала назву «міжкультурна комунікація».

Міжкультурна комунікація - порівняно молода наука. Вона була започаткована в середині $\mathrm{XX}$ століття. Ії̈ поява була зумовлена практичними інтересами американських політиків і бізнесменів, які усвідомили, що для успішної роботи в інших країнах необхідне вивчення не тільки мови, але й культур інших народів, їхніх традицій, звичаїв, норм поведінки. Отже, своєю появою молода наука зобов'язана практичній необхідності знаходити корені проблем, що виникають під час спілкування представників різних культур, допомагати розв'язувати ці проблеми.

Поняття міжкультурної (кроскультурної, міжетнічної) комунікації було введено до наукового обігу Г. Трейгером і Е. Голлом у праці «Культура і комунікація. Модель аналізу» ("Culture as Communication", 1954 р.). Вони визначили її як ідеальну мету, до якої повинна йти людина у своєму прагненні якомога краще та ефективніше адаптуватися до навколишнього середовища. Потім основні положення та ідеї міжкультурної комунікації були більш докладно розвинено у відомій праці Е. Голла «Німа мова» ("The Silent Language", 1959 р.). У своїй роботі автор показав тісний взаємозв'язок між культурою та комунікацією. Розвиваючи свої ідеї щодо взаємозв'язку між культурою та комунікацією, Е. Голл дійшов висновків про необхідність навчання культури. Він уважав, що якщо культуру можна вивчати, то в такому разі їі можна і необхідно викладати. Отже, Е. Голл першим запропонував зробити проблему міжкультурної комунікації не тільки предметом наукових досліджень, але й самостійною навчальною дисципліною.

Великий вплив на сучасні дослідження міжкультурної комунікації здійснили теорія діалогу культур М. Бахтіна і теорія місцевих (локальних) культур Ю. Лотмана.

Відтоді багато зарубіжних і російських учених та дослідників зробили свій внесок у розроблення цього френомена, визначили його характерні риси (А. Кребер, К. Бергер, С. Гангтінгтон, М. Бергельсон, Т. Грушевицька, Д. Гудков, В. Зінченко, В. Зусман, 3. Кирноз, В. Кочетков, В. Попков, О. Садохін, С. Тер-Мінасова, О. Тімашева та інші).

Сутність і структуру міжкультурної компетенції висвітлено у працях російських дослідників: Т. Астафурової (докторська дисертація на тему «Стратегії комунікативної поведінки у професійно-значущих ситуаціях міжкультурного спілкування», Москва, 1997), Є. Верещагіна, Р. Гришкової, І. Зимньої (монографрії «Психологічні 
аспекти навчання говоріння іноземною мовою»; «Психологія навчання іноземних мов у школі»; «Взаємозв'язане навчання видів мовленнєвої діяльності»), Г. Копил, В. Костомарова, І. Лейфри, 3. Нікітенко, Ю. Пассова, В. Сафронової, Г. Томахіна, О. Фролової (докторська дисертація на тему «Формування міжкультурної компетенції студентів вищих навчальних закладів економічного профілю в сучасних умовах», Москва, 2003), І. Халеєвої, Л. Харченкова, І. Цатурової та інших. Російський лінгвіст Н.Г. Комлєв увів у лінгвістику поняття культурно-історичного компонента значення.

У вітчизняній педагогіці проблему фрормування досвіду у студентів міжкультурної комунікації майже не вивчено. Дослідження міжкультурної комунікації саме на стадії фрормування. Серед українських дослідників слід виділити насамперед праці таких педагогів і фрілологів, як: І. Бахова (кандидатська дисертація на тему «Формування професійної міжкультурної компетентності майбутніх перекладачів у вищому навчальному закладі», Київ, 2011), М. Богатирьової, П. Донця (докторська дисертація на тему «Теорія міжкультурної комунікації: Специфріка культурних змістів і мовних фрорм», Харків), О. Зеліковської (монографрія «Формування міжкультурної компетенції студентів економічних спеціальностей у процесі фрахової підготовки», Київ, 2012), Т. Колбіної (докторська дисертація на тему «Теоретико-методологічні та технологічні засади фрормування міжкультурної комунікації студентів вищих навчальних закладів економічного профрілю», Запоріжжя, 2010; монографрія «Формування міжкультурної комунікації майбутніх економістів: теоретико-методологічний аспект», Харків, 2008; навчальний посібник «Основи міжкультурної комунікації для студентів-економістів», Харків, 2008). Цю проблему частково розроблено в різнопланових працях В. Андрущенка, О. Гриценко, І. Дзюби, А. Єрмоленко, Г. Касьянова, М. Кушнарьової, П. Скрипки, А. Приятельчука.

Зокрема, поміж іншого було зазначено, що міжкультурна комунікація здійснюється, коли відправник та отримувач повідомлення належать до різних культур, коли учасники комунікативного процесу розуміють культурні відмінності один від одного. По суті, міжкультурна комунікація - це завжди міжперсональна комунікація у спеціальному контексті, коли один із учасників виявляє культурні відмінності іншого.

До найбільш відомих теорій міжкультурної комунікації належать теорія високо- і низькоконтекстуальних культур Е. Голла, теорія культурних вимірів Г. Гофштеда, теорія культурної письменності Г. Гірша.

Сьогодні перед викладачем іноземної мови постає актуальна проблема - допомогти студентам подолати не тільки мовний, але й культурний бар'єр у спілкуванні. Зараз не досить про- сто навчити іноземної мови, правил граматики, синтаксису та орфографії, навичок говоріння або письма, але стає необхідним насамперед допомогти майбутнім фрахівцям гармонійно інтегруватися в іншомовне середовище, зважаючи на відмінності та особливості світогляду, менталітету, культури представників різних країн, тобто навчити їх основ міжкультурної комунікації.

Не викликає жодного сумніву той фракт, що сьогодні попит на вивчення іноземних мов значно підвищився. Як наслідок, викладання іноземних мов потребує новітніх, більш ефективних для засвоєння методів навчання. Спеціалісти наголошують насамперед на комунікативному та дійовому методах, які зарекомендували себе як найбільш фрункціональні та практичні. Теоретичні аспекти мови, ґрунтовна граматика цікавлять насамперед майбутніх викладачів іноземних мов, а для закладів, які не готують фрілологів, мова $є$ ключем реального спілкування та одним із багатьох інших інструментів профресійної інтеграції.

Викладання іноземних мов і міжкультурну комунікацію не можна роздивлятися окремо. Це два поняття, які існують паралельно та в тісному взаємозв'язку одне 3 іншим. На кожному занятті 3 іноземної мови студенти зустрічаються напряму або опосередковано з іншою культурою, поступово знайомляться 3 менталітетом носіїв цієї мови, їхніми традиціями, звичками, релігією, моральними та духовними цінностями. Мова - це провідник у цей складний і багатогранний світ. Через неї віддзеркалюється та відображається душа нації. Ось чому під час викладання іноземних мов ми повинні враховувати всі лінгвокультурні фрактори.

Наприклад, усі ми добре розуміємо, що між культурами Америки, Азії, Європи, Африки є певні відмінності, які необхідно враховувати під час спілкування між їхніми представниками. Вміння визначати культурні особливості різних народів є надзвичайно важливим, тому що воно сприяє взаєморозумінню та взаємному визнанню. Головна перепона, яка заважає взаєморозумінню між представниками різних народів, полягає в тому, що ми сприймаємо інші культури крізь призму своєї власної культури. Усвідомлення відмінностей і культурних особливостей між різними народами є запорукою успішного встановлення ділових і дружніх контактів.

Однією з головних причин невдач і непорозумінь у міжкультурній комунікації $€$ слабке або поверхневе володіння одним із комунікантів знаннями про культуру іншого, адже до цих знань співрозмовник постійно звертається у своїй промові прямо або опосередковано, спирається на них під час побудови тексту й ведення діалогу, вони відображаються та закріплюються в семантиці мовних одиниць, система цінностей і норм культури зумовлює правила вербальної (мовленнєвої) і невербальної поведінки мовної особистості і т. ін. 
Володіння основами культури тієї лінгвокультурної спільноти, мовою якої ведеться спілкування, $€$ необхідною та обов'язковою умовою успішності цього спілкування.

Будь-який процес комунікації складається 3 вербальних і невербальних кодів. Те, як ці коди інтерпретуються обома учасниками процесу спілкування, свідчить про ступінь їхньої підготовки до процесу міжкультурної комунікації. Основні труднощі у спілкуванні зумовлюються міжкультурними відмінностями. Важливо правильно інтерпретувати всі вербальні та невербальні коди. Зазначимо, що на процес інтерпретації впливають вік, стать, професія, соціальний статус комунікантів, їхня толерантність, заповзятливість, власний досвід.

У міжкультурній комунікації виокремлюють чотири основні форми: пряму, посередню (непряму), опосередковану і безпосередню.

Під час прямої комунікації інорормація, яку відправник адресує безпосередньо отримувачу, може здійснюватися як в усній фрормі, так і в письмовій. При цьому найбільший ефект досягається завдяки усній мові, у якій поєднуються вербальні та невербальні засоби.

Процес непрямої комунікації має переважно однобічний характер і відбувається через сприйняття різних інформаційних джерел. Це можуть бути газети або журнали, радіо або телепередачі, твори мистецтва або літератури тощо.

Опосередкована й безпосередня форми комунікації розрізняються наявністю або відсутністю проміжної ланки, яка виступає у ролі посередника між партнерами. Таким посередником може бути людина або технічний засіб. Комунікація, яка опосередкована технічними засобами, може залишатися прямою (розмова по телефону, листування по електронній пошті), але при цьому виключається можливість використання невербальних засобів.

Залежно від способів, прийомів і стилів спілкування в комунікативістиці прийнято виокремлювати три основні види міжкультурної комунікації вербальну, невербальну і паравербальну.

Вербальна комунікація - це безпосередньо мовне спілкування, яке проявляється в обміні інфрормацією, думками, емоціями учасників комунікативного процесу. Відбувається у фрормі монологу або діалогу.

Невербальна комунікація охоплює немовні засоби, символи і знаки, які використовуються для передачі інформації та повідомлень у процесі спілкування. В основі невербальної комунікації лежать два джерела - біологічне і соціальне, природжене і набуте під час соціального досвіду людини. Коли ми говоримо про цей тип міжкультурної комунікації, то маємо на увазі рухи тіла, жести, пози, мимовільні дотики до партнера тощо. Докладно складники невербальної комунікації вивчаються відповідними науками: кінетикою, сенсорикою, такесикою, проксемікою, хронемікою.

Паравербальна комунікація складається з паравербальних засобів. Ідеться про сукупність звукових сигналів, які супроводжують усну мову та привносять у неї додаткові значення. Значення репліки може змінюватися залежно від інтонації, тембру, пауз, темпу, висоти голосу, фрразових або логічних наголосів співбесідника. Усе це $є$ паралінгвістичними засобами.

У міжкультурній комунікації окремо виділяють два контексти комунікації: зовнішній і внутрішній.

До зовнішнього контексту належать місце, час та умови спілкування. Місце, де відбувається комунікація, визначає фрон цього процесу. Наприклад, учасник комунікативного процесу, який перебуває на своїй території, відчуває себе комфортніше та краще орієнтується. Також характер спілкування буде відрізнятися залежно від того, де ведеться спілкування, - удома чи на робочому місці. Говорячи про часовий контекст, ідеться про хронологічний період, у якому проходить спілкування. У різні періоди часу взаємовідносини між партнерами комунікації складаються по-різному. Хронологічно виокремлюють такі види комунікації: одночасні (які відбуваються шляхом особистих контактів, по телефону, в інтернет-просторі - онлайн) і різночасні.

До внутрішнього контексту відносять фронові знання, ціннісні і культурні установки, індивідуальні особливості та навіть психологічний настрій співрозмовників.

Завдяки вищезазначеним дослідженням, доведенню наукової та практичної важливості, доцільності та перспективності міжкультурна комунікація стала самостійною навчальною дисципліною. Вивчення цього курсу тісно пов'язане 3 такими дисциплінами, як «Практичний курс іноземної мови», «Культурологія», «Культура мови і мовленнєвий етикет», «Вітчизняна історія», «Соціологія», «Мова ділового спілкування".

В останнє десятиліття у зв'язку 3 розвитком нових навчальних напрямів, введенням нових вишівських спеціальностей, наприклад «Лінгвістики і міжкультурної комунікації», різко зріс інтерес до взаємодії та взаємовпливу мов і культур. Різко змінилася і ситуація 3 лінгвістично орієнтованими дослідженнями міжкультурної комунікації. Така ситуація й реалії сьогодення висувають усе більше суворих вимог до майбутніх фрахівців, нині студентів вітчизняних університетів, щодо володіння іноземними мовами та навичок спілкування 3 носіями інших мов і культур. Як наслідок, цей фракт впливає на зміст та якість вітчизняної освіти загалом і критерії, яким повинен відповідати сучасний викладач іноземної мови, методи навчання та зміст інорормації, яку він намагається донести до здобувачів вищої освіти. 
Уважаємо за доцільне розглянути основні фрактори, які впливають на формування досвіду міжкультурної комунікації у студентів.

По-перше, на нашу думку, слід виокремити особистість викладача, рівень його професіоналізму, його власний досвід, набуті навички та вміння, широту його світогляду, прагнення до постійного самовдосконалення, відкритість до всього нового, особистістні й профресійні якості.

Другим важливим фрактором цього процесу $\epsilon$ обрані викладачем методи навчання. Нові умови та вимоги суспільства спонукають викладача до постійного пошуку нових методів і прийомів викладання, їх удосконалення, до постійного збагачення власної «професійної скарбнички». Максимальний розвиток комунікативних здібностей студентів - ось основна мета викладача іноземної мови. Розв'язання цього завдання має на меті оволодіння новітніми методиками і підходами викладання, а також сучасними інноваційними технологіями, наприклад використанням на заняттях інтерактивних цифррових дощок. Ці складники процесу викладання спрямовані на розвиток усіх чотирьох рівнів володіння мови (письмо, читання, мовлення, розуміння).

М. Чернова вважає одним із найбільш перспективних методів навчання іноземних мов у процесі форомвання досвіду міжкультурної комунікації інорормативні бесіди, оскільки вони «є основною формою прояву міжкультурної комунікації в межах процесу навчання у вищому навчальному закладі. У своїй роботі дослідник підкреслює, що для того щоб проведення інформативної бесіди стало справді звичним і ефрективним, важливо дотримуватися певної градації в ускладненні її структури: від підготовленої бесіди до експромтної, від однотемної до багатотемної, від переважання коротких монологічних повідомлень до діалогічної фрорми мовлення, а в ії межах - від фронтальної бесіди «викладач - група» через кероване й ініціативне взаємне опитування й розгорнуту відповідь до групової бесіди, від визначення учасників бесіди до вільної участі в ній, від використання жорстких правил і підготовленої бази до безопорної бесіди, від завчених реплік до все більш вільного варіювання, від словесних стимулів для управління бесідою до все більш широкого застосування системи умовних сигналів і т. ін.» [6, с. 122].

Володіння іноземною мовою $є$ невіддільним показником професійної компетенції майбутніх випускників фракультету міжнародних економічних відносин, менеджерів туризму та т. ін. Наприклад, під час підготовки фрахівців-економістів насамперед треба сорокусуватися не на теоретичних, суто лінгвістичних або історичних аспектах мови, а головним чином на її функціональному, практичному та країнознавчому складниках із метою їхнього безпосереднього використання у різних сорерах життя (економіки, техніки, науки, бізнесу). 3 цією метою викладач повинен розширити та поглибити лінгвокультурознавчий зміст свого предмета на основі методів активного комунікативного навчання (використання діалогів, робота у команді або групі, метод співпраці у проєкті тощо) та підбору мовленнєвого матеріалу, який орієнтовано на розвиток навичок міжкультурної комунікації студентів. Для реалізації цього завдання вважаємо доцільним упровадження спеціальних програм або тренінгів із психологічної та професійної підготовки викладачів іноземних мов у межах міжкультурного спілкування.

По-третє, окремо необхідно наголосити на такому фракторі, як спрямованість викладача на розвиток особистісних якостей студентів (мобільності, емпатії, толерантності, патріотизму), які $€$ необхідними складниками для ефективного здійснення міжкультурного спілкування й одночасно основою для самоосвіти, саморозвитку та самовдосконалення у сорері міжкультурної взаємодії.

По-четверте, на нашу думку, було б корисним та ефективним залучити у навчальний процес курси (або їхні часткові складники) зі спеціальних дисциплін, таких як лінгвокультурологія, соціокультурологія, країнознавство та інші, для здобувачів вищої освіти неорілологічних напрямів.

Одним із головних труднощів орормування досвіду міжкультурної комунікації у студентів є той фракт, що викладачі не достатньою мірою використовують ефрективну практику фрормування у студентів поведінки в складних ситуаціях, що виникають під час їх спілкування з представниками інших культур, і розвитку якостей особистості, необхідних для культурної та комунікативної компетенції, оптимального міжкультурного спілкування.

ще одним фрактором, який становить складність у повноцінному залученні студентів до ефективного процесу міжкультурної комунікації, $є$ традиційна методика викладання іноземних мов, яка головним чином завжди ґрунтувалася на читанні текстів іноземною мовою. Студентам пропонувалися тексти, далекі від сучасної реальності, або вони зовсім не орієнтували їх на те, як правильно поводити себе в тій чи іншій мовленнєвій ситуації, як застосувати свої знання в конкретній ситуації на практиці. Як наслідок, усе це приводило до непорозумінь і невдач спілкування між співрозмовниками, які були зумовлені слабким або поверхневим оволодінням одним із комунікантів знаннями про культуру іншого.

Серед чотирьох вищеперелічених рівнів володіння мовами читання $€$ найпасивнішим. Викладання іноземної мови раніше базувалося здебільшого на розвитку саме цього аспекту, що, у свою чергу, не сприяло набуттю власного лінгвістичного досвіду і не містило в собі майже жодної практичної цінності. Сьогодні викладання іноземних мов 
у сучасних університетах має на меті насамперед розвинути навички та вміння спілкування в повсякденному житті з носіями іншої культури у різноманітних ситуаціях.

3 цього робимо висновок, що навчання міжкультурної комунікації тісно пов'язане з навчанням лінгвокраїнознавства і вони не можуть відбуватися окремо один від одного.

Основною метою викладання іноземних мов сьогодні повинно стати навчання мови як реального та повноцінного способу комунікації. Рішення цього практичного завдання можливе лише на фундаментальній теоретичній базі. Для створення такої ґрунтовної бази необхідно пристосувати результати теоретичних праць із фрілології до практики викладання іноземних мов, а також теоретично усвідомити, обміркувати та узагальнити величезний практичний досвід викладачів іноземних мов.

ще одним важливим складником на шляху формування у майбутніх фрахівців досвіду міжкультурного комунікації у процесі вивчення іноземної мови є організація безпосереднього живого спілкування 3 представниками інших мов і культур, якому сприяють міжнародні програми з обміну студентами різних країн, студентські табори праці та відпочинку з метою підготовки майбутніх фрахівців до подальшого стажування за кордоном, літні школи, а також систематичне відвідування спеціальних мовних клубів, які надають можливість прямої комунікації та встановлення дружніх відносин із іноземцями.

Отримані знання з іноземних мов будуть доповнені знаннями відмінностей та особливостей культури, усвідомленням причини міжкультурного непорозуміння, наявністю практичних навичок і вмінь у поведінці, які дадуть змогу краще розуміти представників інших культур. Не менш важливим $\epsilon$ той фракт, що знайомство $з$ іншими культурами дасть змогу краще пізнати свою власну культуру, побачити її у новому ракурсі, а це означає краще зрозуміти себе і свою власну поведінку.

Отже, проведений стислий аналіз видів і фрорм міжкультурної комунікації, ії̈ контекстів, базових теорій і позицій, причин труднощів і перепон у цьому багатогранному процесі, переліку основних фракторів, які впливають на фрормування досвіду міжкультурної комунікації у студентів, - дає можливість зрозуміти важливість і неоднозначність проблеми дослідження міжкультурної комунікації у процесі викладання іноземних мов у вітчизняних університетах, а також доводить подальшу необхідність її детального вивчення.

Ми вважаємо, що міжкультурну комунікацію слід розглядати як сукупність різноманітних фрорм відносин і спілкування між індивідами та групами, які належать до різних культур. Процес міжкультурної комунікації є специфрічною фрормою діяльності, яка не обмежується лише знаннями з іноземних мов, а вимагає також знань із матеріальної та духовної культур інших народів, релігій, цінностей, етичних установок, світоглядних уявлень і т. ін., які в сукупності визначають модель поведінки партнерів у процесі комунікації.

Такі вчені, як Г. Трейгер, Е. Голл, Е. Гірш, Г. Гофштед, розробили основи теорій міжкультурної комунікації та дали базові напрями для подальшого вивчення процесу міжкультурної комунікації вітчизняними і закордонними вченими. Серед російських учених великий внесок у висвітлення цієї проблеми зробили М. Бахтін та Ю. Лотман. У вітчизняній педагогіці проблема дослідження міжкультурної комунікації перебуває на стадії фрормування. Серед українських дослідників слід виділити насамперед праці таких педагогів і фрілологів, як І. Бахова, М. Богатирьової, П. Донця, О. Зеліковської, Т. Колбіної.

Оскільки за останній час суттєво змінилися мотиви вивчення мови (іноземна мова постала в іншому ракурсі, не як самоціль), виникла нагальна необхідність докорінно перебудувати, переосмислити процес викладання іноземних мов, створити спеціальність «Лінгвістика і міжкультурна комунікація» та розпочати в педагогічних університетах підготовку викладацьких кадрів нового типу.

Сучасним навчальним закладам необхідно визначити ефективні форми й методи роботи зі студентами, що дадуть змогу розв'язувати завдання підготовки до міжкультурної взаємодії. Заняття з міжкультурної комунікації мають на меті підготувати студентів до міжкультурних контактів на рівні повсякденного спілкування. Як доводить практика, найбільш ефективним засобом освоєння цієї дисципліни є поєднання лекційних і практичних занять, під час яких студенти отримують можливість пережити відчуття та емоції, які виникають у реальних ситуаціях міжкультурного спілкування, проаналізувати й обдумати власну поведінку та поведінку і реакцію партнерів. А одним із найбільш ефективних методів $€$ різні види інформативних бесід (підготовлені або експромтні, однотемні або багатотемні, фрронтальні, 3 переважанням коротких монологічних повідомлень або діалогічних фрорм мовлення).

Серед головних труднощів фрормування досвіду міжкультурної комунікації у здобувачів вищої освіти $€$ недостатня міра використання викладачем ефективної практики та методів фрормування у студентів поведінки в реальних ситуаціях спілкування з представниками інших культур, а також традиційна методика викладання іноземних мов, яка базується головним чином на простому читанні текстів іноземною мовою.

Для вдалого, приємного дружнього або продуктивного ділового спілкування, ефективного подолання мовного та культурного бар'єрів й уникнення непорозумінь між представниками різних націй 
і культур не досить лише гарно володіти іноземною мовою, а потрібно брати до уваги цілий спектр соціокультурних критеріїв і педагогічних фракторів, a саме: особисті характеристики та досвід самого викладача, спрямованість викладача на розвиток особистісних якостей студентів (мобільність, емпатію, толерантність, патріотизм), застосовані викладачем методи навчання, технічну базу, спеціальні заходи, спрямовані на фрормування та вдосконалення професіоналізму викладачів, упровадження нових дисциплін або їхніх елементів у вже розроблені курси, організацію стажувань, студентських обмінів, мовних клубів. Урахування всіх перелічених фракторів має на меті сорормувати та розвинути у студентів досвід міжнародної комунікації під час навчання в закладах вищої освіти.

На щастя, у сучасних університетах усе частіше впроваджується викладання міжкультурної комунікації як окремої дисципліни. У Харківському національному університеті імені Семена Кузнеця на кафредрі іноземних мов і міжкультурної комунікації ця дисципліна викладається вже декілька років і отримує багато позитивних відгуків від студентів завдяки корисному, цікавому та нестандартному викладенню матеріалу.

\section{БІБЛІОГРАФІЧНИЙ СПИСОК:}

1. Основы межкультурной коммуникации : учебник для ВУЗов / Т.Г. Грушевицкая, В.Д. Попков, А.П. Садохин ; под ред. А.П. Садохина. Москва : Юнити-Дана, 2002. 350 с.

2. Колбіна Т.В. Формування у студентів досвіду міжкультурної комунікації студентів вищих навчаль- них закладів економічного профрілю // Основи сучасної педагогіки : монограсрія / Т.О. Дмитренко, К.В. Яресько, Т.В. Лаврик, В.М. Нагаєв, Н.Н. Шоєв, Т.В. Колбіна, С.В. Копилова, Н.Д. Кабусь, О.В. Купенко. Херсон : ПП Вишемирський В.С., 2016. С. 159-251.

3. Колбіна Т.В. Теоретико-методологічні підходи до комунікативної підготовки студентів у закладах вищої освіти. Наукові записки. Серія: Педагогічні науки. Вип. 174. Кропивницький : РВВ ЦДПУ ім. В. Винниченка, 2019. С. 40-45.

4. Саблина С.Г. Барьеры коммуникации в межкультурной среде. Сборник научных трудов «Актуальные проблемы теории коммуникации». СанктПетербург : Изд-во СПбГПУ, 2004. С. 52-74.

5. Тер-Минасова С.Г. Язык и межкультурная коммуникация. Москва : Слово/Slovo, 2000. 260 с.

6. Чернова М.М. Основи розвитку й реалізації міжкультурної комунікації в навчанні студентів іноземних мов. Збірник наукових праць «Актуальні питання фрілології». Вип. 1. Київ, 2011. С. 120-125.

7. Hall E., Hall M. Hidden Differences. Studies in International Communication. How to communicate with Germans. Hamburg, 1983. 98 p.

8. Hirsh E.D. Cultural Literacy. N. Y., 1987. 124 p.

9. Hofstede G. Cultures and Organizations. Software of the Mind. L., 1991. 190 p.

10.URL: http://nauka-pedagogika.com/pedagogika13-00-01/dissertaciya-razvitie-navykov-mezhkulturnoykommunikatsii-v-protsesse-prepodavaniya-delovogoangliyskogo-yazyka\#ixzz2Jrd8o5la.

11. URL: http://www.dissercat.com/content/podgotovkauchitelya-inostrannogo-yazyka-k-mezhkulturnoikommunikatsii-v-usloviyakh-pedagogi\#ixzz2Jr9AwVgS.

12. URL: http://www.grandars.ru/college/sociologiya/ mezhkulturnaya-kommunikaciya.html. 


\section{PECULIARITIES OF THE COMMUNICATIVE METHOD USE OF TEACHING FOREIGN LANGUAGES AT NON-LINGUISTIC HIGHER EDUCATIONAL ESTABLISHMENTS}

\section{ОСОБЛИВОСТІ ВИКОРИСТАННЯ КОМУНІКАТИВНОГО МЕТОДУ ВИКЛАДАННЯ ІНОЗЕМНИХ МОВ У НЕЛІНГВІСТИЧНИХ ВИЩИХ НАВЧАЛЬНИХ ЗАКЛАДАХ}

UDC 378.147:811.111

DOI https://doi.org/10.32843/2663-

$6085 / 2020 / 24-2.9$

Kormiltsyna S.Yu., Lecturer of the Department of Foreign Languages of Professional Orientation Chernihiv National University of Technology

Hrechok L.M., Senior Lecturer of the Department of Foreign Languages of Professional Orientation Chernihiv National University of Technology
The article deals with the communicative method as an active type of teaching foreign languages to students at non-linguistic higher educational establishments. The main objective of teaching foreign languages is to form the communicative competence of future professionals who are able to communicate in a foreign language. The authors identify the peculiarities of the communicative method use of teaching foreign language, its features and basic principles of learning applied within it. The concept under consideration is the importance of speech activity in a foreign language. The issue of learning a foreign language using a communicative method is becoming relevant nowadays. Therefore, it is necessary to form a tendency to strengthen the communicative orientation of the educational process. Communicative competence is to be of primary importance for the methodological content of a foreign language class. The analysis of many works has been made to show the problem of activating the process of learning a foreign language by means of communicative method. The main features of the communicative method have been given. It has been proved that the communicative method is the most progressive and effective method of learning a foreign language. This method clearly shows the great importance of speech skills, and offers exercises for their consistent formation. All this in turn gives grounds to assert that the communicative method of teaching is of paramount importance in foreign language learning. The conclusion has been made that the essence of the communicative method of teaching foreign languages at non-linguistic universities is to develop the student's personality, prepare them for intercultural communication and develop their selfeducational potential to meet personal interests in learning a foreign language.

Key words: communicative method, learning, speech, new techniques, competence, communicative competence, language competence, social competence.

у статті розглядається комунікативний метод як активний тип навчання іноземних мов студентів у нелінгвістичних вищих навчальних закладах. Основна мета навчання іноземних мов - ссрормувати комунікативну компетентність майбутніх фрахівців, які вміють спілкуватися іноземною мовою. Автори визначають особливості використання комунікативного методу навчання іноземної мови, його особливості та основні принципи навчання, що застосовуються в ньому. Розглянуто концепцію важливості мовленнєвої діяльності іноземною мовою. Питання вивчення іноземної мови за допомогою комунікативного методу стає актуальним нині. Тому необхідно фрормувати тенденцію до посилення комунікативної спрямованості навчального процесу. Комунікативна компетентність має мати першочергове значення для методичного змісту класу іноземної мови. Проведено аналіз багатьох наукових праць, щоб показати проблему активізації процесу навчання іноземної мови завдяки комунікативному методу. Наведено основні особливості комунікативного методу. Доведено, що комунікативний метод $\epsilon$ найбільш прогресивним та ефрективним методом вивчення іноземної мови. Цей метод наочно показує велике значення мовленнєвих навичок і пропонує вправи для їх послідовного формування. Все че, у свою чергу, дає підстави стверджувати, що комунікативний метод навчання має першорядне значення в навчанні іноземної мови. Зроблено висновок, що суть комунікативного методу викладання іноземних мов у нелінгвістичних закладах вищої освіти полягає у формуванні особистості студента, підготовці його до міжкультурного спілкування та розвитку його самоосвітнього потенціалу для задоволення особистих інтересів у вивченні іноземної мови.

Ключові слова: комунікативний метод, навчання, мовлення, нові прийоми, компетентність, комунікативна компетентність, мовна компетентність, соціальна компетентність.
Problem statement in general. Nowadays, a foreign language is not just a part of a nation's culture, but it is also the key to the of students' future careers' success. With the growing demand for specialists with knowledge of a foreign language, the requirements for the efficiency and quality of their training are growing. The search for new teaching methods, their improvement, development and implementation of new techniques in the educational process is intensive. Achieving a high level of language proficiency is impossible without fundamental language training in higher education. The main objective of teaching foreign languages is to form the communicative competence of future professionals who are able to communicate in a foreign language within the communication topics and situations proposed by the curriculum. It should be noted that the new curriculum is based on the recommendations of the Council of Europe, which focus on the formation of socio-cultural competence and the need to teach intercultural communication, which within the socio-cultural approach to foreign language learning is defined as functionally 
conditioned communicative interaction of people with different cultural values, their independent awareness to different subcultures.

In this regard, the issue of learning a foreign language using a communicative method is becoming relevant.

Therefore, it is necessary to form a tendency to strengthen the communicative orientation of the educational process, its closeness to the real communicative process. In our opinion, communicative competence is to be of primary importance for the methodological content of a foreign language class.

Current research analysis. In the methodological literature, the issue of teaching communicative competence has been repeatedly raised. The communicative method was initiated by the works of E.P. Shubin. The ideas of the communicative method of teaching were developed by other authors (H.V. Rogova, Y.I. Passov, V.L. Skalkin, L.P. Malyshevska, A.P. Starkov). This method was developed on the basis of the ideas of linguists, psychologists and methodologists (V.A. Artemov, I.M. Berman, V.A. Buchbinder, O.O. Leontiev, M.V. Lyakhovytsky and others). The communicative method is actively studied in foreign methodology by $\mathrm{K}$. Black, E.Y. Joyner, H. Besse. Analysis of these works shows that the problem of activating the process of learning a foreign language by means of the communicative method has received considerable attention.

The objective of the article is to identify the peculiarities of the communicative method use of teaching foreign languages at non-linguistic higher educational establishments.

Presenting the main material. The communicative method is based on the idea that a language is used for communication and, therefore, the purpose of language learning should be of communicative competence, which includes language competence (mastering language material and its employment in speech patterns), sociolinguistic communication (ability to use language units in accordance with communication situations), competence discourse (the ability to understand and achieve coherence in the perception and generation of individual utterances within the meaningful communicative-language clusters), so-called "strategic competence" (degree of acquaintance with the socio cultural context of language functioning) social competence (ability and readiness to communicate with others). The emergence of the communicative method and the very term "communicative competence" was influenced by the concept of language competence of N. Khomsky, which means the ability of the speaker to generate grammatically correct structures.

The main features of the communicative method: 1) task - to teach students to speak a foreign language, if not at the level of the native speaker, then at least at the level necessary for further work; 2) teach- ing aids - business games that simulate real communication situations, most typical for this group of students. Mastering the means of communication (phonetic, lexical, grammatical), as well as types of speech activity (speaking, listening, reading and writing) occurs during the practical application of these means and types of speech activity in the process of communication; 3) limited use of native speech while learning a foreign language. In fact, instead of translating lexical units from a foreign language into the native language, the lecturer at the initial stages uses visual aids (drawings, photographs, etc.) and at subsequent stages - the explanation of foreign words in a foreign language; 4) the study of grammar is mostly intuitive, i. e, in contrast to traditional methods, where grammar and vocabulary are the main subjects of learning, when learning the communicative method, grammar is needed only for correct sentence construction, but students are required not to memorize grammatical rules mechanically, but with intuitive feeling of correctly built speech patterns; 5) contextual learning of lexical material, i. e not isolated units as in the traditional methodology goes, but only in the context during its application.

Communicative method of teaching foreign languages is today the most popular in the world. And even those who have a bad idea of what this method is, firmly believe that it is the most progressive and effective method of learning a foreign language [3, p. 67].

J.M. Kolker dwells in detail on the following point: "In recent decades, traditional foreign language teaching is opposed to communicative and intensive methods" [1, p. 48].

Communicative learning of foreign languages is an activity, because language communication is carried out through "language activities", which, in its turn, serves to solve the problems of productive human activity in terms of social human communication (V.A. Zimova, R.A. Kitaygorodskaya, A.A. Leontiev). The participants of the communication try to solve real and imaginary problems of joint activity with the help of a foreign language.

The activity type learning peculiarity is associated primarily with a particular type of speech activity, so we find its application while reading, listening, translating, etc. And only the common method displays the features of activity type of learning as a whole.

According to O.V. Passov, the author of the communicative method, communicativeness presupposes the speech orientation of the educational process, which is not so much that the speech practical goal is pursued (in fact, all areas of the past and present set such a goal), but practical language application. Practical speech orientation is not only the goal, but also the means, where both are dialectically interconditioned.

In fact, at all stages of learning the process is communicative. But there are a number of points that require special training. Thus, for the ability to 
communicate a special role is played by: the ability to enter into communication, to stop it and start; the ability to pursue their strategic line in communication, to implement it in tactics of behavior contrary to the strategies of those who communicate; the ability to select new (several) language partners each time, change the roles of partners, or the direction of communication, the ability to probabilistically predict the behavior of language partners, their statements, the issue of a situation.

The modern communicative method is a harmonious combination of many ways of learning foreign languages, being probably at the top of the evolutionary pyramid of different educational methods.

At the present stage of learning foreign languages, most linguists consider "communicative" to be the most effective and criticize traditional methods that work on the principle of "from grammar to vocabulary, and then the transition to consolidation exercises". Artificially created exercises do not shape the user of the language, and a person who learns the language by this method will be silent rather than say the wrong phrase. And "communicativeness", on the contrary, is bound "to break the ice".

The Communicative Approach develops all language skills, from speaking to reading and listening. Grammar is mastered in the process of communication in the language: a student first memorizes words, expressions, language patterns and only then begins to understand what they are in the grammatical sense. The goal is to teach a student to speak a foreign language not only fluently but also correctly.

Rules, meanings of new words are explained by the teacher with the help of familiar vocabulary, grammatical constructions and expressions, with gestures and facial expressions, drawings and other visual aids. Computers with CDs, the Internet, TV programs, newspapers, magazines, etc. can also be of help. All this facilitates students' interest to history, culture, country traditions in the process of learning.

At foreign language classes, the teacher creates situations in which students communicate in pairs with each other, in groups. This makes the lesson more diverse. Working in a group, students show language independence. They can help each other; successfully correct the statements of their partners.

The teacher in the class assumes the functions of the organizer of communication, asks questions, and pays attention to the original opinions of the participants, acts as an arbiter in the discussion of controversial issues.

Unlike audio-lingual and other methods based on repetition and memorization, the communicative method sets the exercises "with an open ending": students themselves do not know what will turn into their activities in the classroom, everything will depend on the reactions and answers. Every day new situations are employed. This keeps the students' inter- est going: after all, everyone wants to communicate on the topic.

Speaking takes up most of the class time (though reading and writing are of great importance too).

It is necessary to name also the basic principles of learning which are applied within the communicative method in a foreign language [2, p. 57]. They include:

1) The principle of speech orientation or the principle of communicativeness. It consists not so much in the pursuit of a speech practical goal, but in the fact that the path to this goal is the practical use of the language itself.

2) The principle of individualization. It is always necessary to take into account the individual - psychological characteristics of students, their abilities to carry out speech and educational activities, and mainly their personal properties.

3) The principle of authenticity. This principle means that the most important characteristic of the communicative approach is the use of authentic materials, such as those used by native speakers.

4) The principle of interactivity. According to this principle, learning takes place mainly in groups, because group interaction creates mutual information fund to research a subject, which they use together.

5) The principle of intensive use of students' background knowledge. This principle is extremely relevant at non-language higher education institutions. After all, the main task is to teach students to work with texts in their specialty, to understand professional terminology. According to the communicative method, students must be able not only to read and translate texts in a professional field, but also to talk on these topics.

6) The principle of situationality or contextual conditionality. It means that language and language techniques are used within the relevant social context, i. e situationally. It is namely context allows to recognize, semantize and memorize the meaning of each new lexical unit [2, p. 97].

Regarding to the mentioned above communicative method of teaching a foreign language allows us to state that the subject of study in this case is speech activity in a foreign language. This method clearly shows the great importance of speech skills, and offers exercises for their consistent formation. All this in turn gives grounds to assert that the communicative method of teaching is of paramount importance in foreign language learning.

Conclusions. Thus, the essence of the communicative method of teaching foreign languages at non-linguistic universities is to develop the student's personality, prepare them for intercultural communication and develop their self-educational potential to meet personal interests in learning a foreign language.

The prospect of further research of this problem is open for consideration with other methods used to increase the students' knowledge in the process of learning a foreign language. 


\section{REFERENCES:}

1. Колкеря.М.,УстиноваЕ.С.,ЕналиеваТ.М.Практическая методика обучения иностранному языку: учебное пособие. Москва : Академия, 2000. 264 с.

2. Пассов Е.И. Коммуникативный метод обучения иноязычному говорению. Москва : Просвещение, 1991. 223c.
3. Пассов Е.И. Коммуникативный метод обучения иноязычному говорению. Москва, 1985. 208 c.

4. Threshold 1990. Pergamon Institute of English (Oxford): materials for language and practice Threshold Series. J.A. van Ek, J.L.M. Trim, Council of Europe. Cambridge University Press. 1988. 184 p. 


\section{PEDAGOGICAL CONDITIONS FOR FORMING METHODOLOGICAL COMPETENCE OF EDUCATORS IN THE PROCESS OF PEDAGOGICAL PRACTICE \\ ВПРОВАДЖЕННЯ ПЕДАГОГІЧНИХ УМОВ ФОРМУВАННЯ МЕТОДИЧНОЇ КОМПЕТЕНТНОСТІ ЗДОБУВАЧІВ ОСВІТИ В ПРОЦЕСІ ПЕДАГОГІЧНОЇ ПРАКТИКИ}

\begin{abstract}
The article in the context of improving and reforming the modern system of education of primary school teachers in Ukraine substantiates the relevance of the formation of methodological competence. It is emphasized that in the conditions of modern transformation of education it is extremely important to move from the traditional accumulation of student's knowledge to mastering the skills of self-seeking information, self-education and practical use of the acquired knowledge in their professional activity. From the second year of study, future primary school teachers will join hands-on teaching in pedagogical practice.
\end{abstract}

The possibilities of pedagogical practice in forming methodological competence of future teachers are revealed in the didactic potential of each type of practice that students undergo. This is facilitated by the creation of real conditions of the educational process in secondary schools, immersion in a dynamic school world, direct communication with the students of the junior school, teachers, a school management.

In the course of pedagogical practice, students evaluate their willingness to solve professional tasks related to education, development and upbringing of modern students. In order to overcome the difficulties that arise in the process of practical training students need to be clearly aware of the importance of methodological competence, were aware of its nature and content. Introduction of pedagogical conditions of forming of methodical competence of future primary school teachers in the course of pedagogical practice draws students' attention to methodical aspects during the course of pedagogical practice, methodical skills and knowledge, teaches to design the educational process, to reflect and correctly evaluate their own activities in order to acquire modern vectors of the learning process of younger students.

Key words: methodical competence, elementary school teacher, pedagogical practice, educational process, pedagogical conditions.

Стаття присвячена актуальній проблемі формування методичної компетентності в контексті вдосконалення та реформування сучасної системи освіти вчителів початкових класів в Україні. Підкреслюється, що в умовах новітньої трансформації освіти надзвичайно важливим є перехід від традиційного накопичення знань учнів до оволодіння навичками самостійного пошуку інформації, самоосвіти та практичного використання набутих знань у своїй профресійній діяльності. 3 іншого боку навчання майбутніх вчителів початкових класів поєднується 3 практичним викладанням у процесі педагогічної практики.

Можливостіпедагогічноїпрактикищодо фор мування методичної компетентності майбутніх вчителів розкриваються в дидактичному потенціалі кожного з видів практичної підготовки, яку проходять здобувачі освіти. Цьому сприяють створені реальні умови освітнього процесу в загальноосвітніх школах, занурення в динамічний шкільний світ, безпосереднє спілкування з учнями молодшої школи, вчителями, керівничтвом школи. У процесі педагогічної практики студенти оцінюють свою готовність вирішувати профресійні завдання, пов'язані з навчанням, розвитком i вихованням сучасних учнів. Для подолання труднощів, що виникають у процесі практичного навчання, здобувачам освіти необхідно чітко усвідомлювати важливість методичної компетентності, ї̈ характер і зміст.

Впровадження педагогічних умов орормування методичної компетентності майбутніх вчителів початкових класів у процесі педагогічної практики звертає увагу студентів на методичні аспекти під час проходження педагогічної практики, методичні вміння і знання, вчить проектувати освітній процес, рефлексувати та правильно оцінювати власну діяльність з метою набуття сучасних векторів процесу навчання молодших школярів.

Ключові слова: методична компетентність, вчитель початкових класів, педагогічна практика, навчальний процес, педагогічні умови.
Problem statement. The modern development of education determines such social processes as integration, globalization and digitalization of the educational space that predetermines also dynamics of change of an educational system in general: from cognitive focused to personally focused. It entailed emergence and the statements of a competence-based paradigm of education, which acquired the status of the latest international educational strategy [2].

The transition to the latest educational paradigm increases the attention of domestic and foreign scientists to the problem of formation a competent teacher. Its solutions derogation from standard accumula- tion by the student of pedagogical institutions of the higher education knowledge, skills (knowledge paradigm) to the formation of future teachers the ability to learn, master information search skills, develop the self-learning ability and quick response to inquiries of time and opportunities to be integrated in society.

Studying the concept of «future teacher competence», we rely on the works of A. Khutorsky [7], S. Shishov, Yu. Tatur [8], A. Markova who understand it as personal new growths, internal quality, ability to act based on the got knowledge, readiness and ability to successful activity, thereby emphasize a multidimensionality of this term. We consider methodical 
competence of future teacher as one of types of its professional competences and readiness and ability to pedagogical activity.

The necessity to develop the methodological competence of a primaryschool teacher is defined by the fact that it itself contains a set of professional knowledge, skills and personal qualities which enable the teacher to design, adapt, organize, motivate, to investigate and control the cognitive, educational and developing aspects of education of primary students and provide efficiency of his professional and pedagogical activity.

Analysis of recent research and publications. There is intense debate in the scientific community about the nature and structure of teacher professional competence. Scientists such as V. Adolph [1], O. Larionova, O. Lebedeva, N. Seleznev, N. Kuzmina [3], A. Markova, L. Shkerina rightly distinguished different types of professional competence, which is caused by multifunctional and the multidimensional nature of pedagogical activity.

Among the types of professional competence of elementary school teachers is a special place methodical competence, because it, integrating a number of key vocational and pedagogical competences, largely determines the level of professionalism of the teacher.

A number of scientific and pedagogical studies have highlighted some aspects of the problem of formation of methodological competence and methodological culture (T. Alekseeva, S. Baranov, A. Kochetov, O. Larionova, O. Lebedeva); methodological preparation (N. Svitlovska, M. Soloveychik); methodological thinking (O. Goncharuk, G. Sukhobskaya); methodical reflection (O. Anisimov, N. Postaliuk) of future teachers. The theoretical analysis of the psycho-pedagogical literature has shown that the methodological competence of future primary school teachers is considered rather fragmentary and in combination with other types of professional competence [6]

Selection of previously unsolved parts of the overall problem. There is still no single approach to determining the methodological competence of the elementary school teacher, its structure, the issues of content, forms and methods, the conditions for forming such competence as a holistic phenomenon remain insufficiently explored. Since methodological competence combines the system of special scientific, psychological, pedagogical, methodological knowledge and skills, its formation occurs in the process of pedagogical, special, didactic, practical training of the future specialist. Of particular importance is the pedagogical practice, in which the future teacher acquires the experience of applying the acquired knowledge and skills in the real educational process.

Formulation of the goals of the article. The purpose of the study is to clarify the pedagogical conditions of forming the methodological competence of future primary school teachers in the process of pedagogical practice.
The results of the research. The main types of pedagogical practice of future primary school teachers in forming their methodological competence are [9]:

- practice on educational work provides mastering skills of education comprehensively and harmoniously developed personality;

- while practicing students assist the teacher in preparation and holding mass educational actions, in carrying out work in clubs, production of visual aids, issue of wall newspapers, etc.; fill out diaries of pedagogical observations, carry out individual work with separate pupils of a class;

- trial lessons at school. This type of practice promotes mastering students an algorithm of preparation for a lesson, assimilation a technique of writing of abstracts of lessons, carrying out lessons in primary classes according to the schedule, etc.);

- summer pedagogical practice contributes to deepening the educational competence of the future primary school teacher. During practice, students perform the duties of the out-of-town health improvement and recreation leaders, carry out individual work with children of the appropriate age category, prepare and conduct camp events;

- the first days of a child at school. Such practice gives students an opportunity to study features of the period of adaptation of first graders to the school mode; the procedure and methods of manning the first classes, planning work for the first week, etc;

- the work (undergraduate) practice (responsibilities of primary school teacher) provides the improvement of the methodological knowledge and skills acquired by students studying at higher education institute.

Besides, pedagogical institutions of the higher education additional and innovational types of practice, such as science and local history practice, introduction to specialty, extracurricular educational work, non-traditional trial lessons, one-day practice, etc. Natural and local studies practice prepares students for complex tasks of studying nature, nurturing in them the ability to properly deal with natural objects and nature, the formation of future teachers of elementary classes of knowledge and skills necessary for the lessons of science and extracurricular classes topics that enable future educators to acquire methodological competence in complex tasks of environmental education.

The practice of "Introduction to a specialty", organized for first-year students, promotes adaptation and their practical acquaintance with future profession and the chosen additional specialization. Didactic potential of pedagogical practice "Preparation for extracurricular work", which students have at the first year training to form the methodological competence of the future primary teacher is defined by the fact that to the maintenance of the course "Technique of Educational Work" students seize in that time when do 
practical training from out-of-class educational work at school (second year) and therefore, are forced to extracurricular activities without proper theoretical and methodological training.

During pedagogical practice "Preparation for extracurricular work" students get acquainted with a technique of drawing up the individual thematic plan of educational work, write plans of the extracurricular lessons of various forms and types, conduct observation, learn to fill in the extracurricular student teaching diary. In some pedagogical educational institutes teachers introduce a practice of one working day, unconventional trial lessons which also have the considerable didactic potential for forming methodical competence of future teachers, because in the course of such practices students attend demonstrative lessons of the best teachers, observe the methods of teaching to fully immerse yourself, have an opportunity to plunge fully into teaching and educational process of primary school, to get practical abilities and experience of pedagogical activity [9].

Summarizing the experience of organizing different types of teaching practice and the results of research on the raised problem suggest that the introduction of new types of teaching practice is associated with the lack of readiness of young primary school teachers to solve professional problems, taking into account a wide range of specific conditions in the groups of children in the process pedagogical activity at modern school. Formation and actualization of motives for pedagogical activity occurs immediately before one or another type of practice during special psychological and pedagogical training. The purpose of such work is to develop a positive motivation for mastering in pedagogical practice professional competence in general and methodological competence in particular.

Determining the second condition for forming the methodological competence of a future elementary school teacher was based on the requirements for the preparation of a modern teacher, who require students to acquire basic and professional basic knowledge, and the development of innovative pedagogical thinking in combination with practical-oriented, research-based solutions. They described it as this: ensuring the effectiveness of methodological knowledge by fulfilling the tasks of students of educational and research character, studying pedagogical experience and its creative use in various types of pedagogical practice.

At the same time, the analysis of scientific works and their own observations give grounds to conclude that creative implementation of professional and methodological activity is not possible without a deep study and analysis of pedagogical experience, because most pedagogical innovations have a combinatorial character [5]. Involvement of students in the research work during the passage of various types of pedagogical practice creates conditions for stu- dents to develop a desire for self-education, creative activity, development of creative approach in solving problematic pedagogical tasks, mastering general and special methods of research, facilitates mastery of information - diagnostic, reflexive and research skills, the formation of which determines the level of methodological competence of future teachers.

Another area of work to ensure the effectiveness of methodological knowledge is to familiarize students with traditional and innovative pedagogical experience. Students have the opportunity to study advanced pedagogical experience in open and demonstrative lessons and lessons during observation; listening to oral reports on the pedagogical results of teachers at conferences, round tables, special meetings of methodological associations, workshops, etc.; study of materials, generalization of advanced pedagogical experience in the form of methodological letters, methodical developments, articles in newspapers and magazines and published brochures, monographs, collections of materials of conferences and seminars, etc.

Pedagogical practice is an important element in the formation of self-esteem of professionally important qualities, awareness of himself as a future teacher. Understanding this is the impetus for self-improvement, the development of personal professionally significant qualities, professional orientation that characterize the methodical competence of the future teacher [4]. Reflective actions of trainee students should be the subject of the means, methods and techniques of their own activities, processes of making practical decisions, the analysis of which helps students to understand the difficulties that may arise in their work and find the right ways to solve them.

Conclusions. The methodical competence of a future primary school teacher is defined as an integrated quality, characterized by a set of knowledge, skills and personal and professional qualities of a specialist, who function as the ability to design, adapt, organize, motivate, research and control and train developmental aspects of the education of primary students in classroom and extracurricular educational work.

Pedagogical conditions for effective formation of methodological competence of future primary school teachers in the process of pedagogical practice are: implementation of purposeful personality-oriented psychological and pedagogical preparation of students for pedagogical practice, ensuring the effectiveness of methodological knowledge by performing the tasks of students of educational and research character and studying the best and advanced pedagogical experience of primary school teachers, its creative use in various types of pedagogical practice, introduction by students of comprehensive reflection of own professional and pedagogical activity. 
Certain pedagogical conditions are closely interrelated; they complement each other, providing effective implementation of the developed model of forming methodological competence of future primary school teachers.

\section{REFERENCES:}

1. Адольф В.А. Теоретические основы формирования профессиональной компетентности учителя : автореф. дис. доктора пед. наук: 13.00.01. Москва, 1998. $49 \mathrm{c}$.

2. Гура О.І. Психолого-педагогічна компетентність викладача вищого навчального закладу: теоретико-методологічний аспект : монограсрія. Запоріжжя : ГУ «ЗІДМУ», 2006. 332 с.

3. Кузьмина Н.В. Профессионализм личности преподавателя и мастера производственного обучения. Москва : Высш. шк., 1990. 117 с.
4. Микитюк С.О. Теоретико-методологічні та науково-методичні засади ресурсного підходу до просресійної підготовки майбутнього вчителя : дис. доктора пед. наук: 13.00.04. Харків, 2013. 504 с.

5. Попова О.В. Становлення і розвиток інноваційних педагогічних ідей в Україні у XX столітті. Харків : «ОВС», 2001. 256 с

6. Савченко О.Я. Цілі й цінності реформування сучасної школи. Шлях освіти. 1996. № 1. С. 20-23.

7. Хуторской А.В. Современная дидактика. СПб : Питер, 2007. 544 с.

8. Татур Ю.Г. Компетентность в структуре модели качества подготовки специалистов. Высшее образование сегодня. 2004. № 3. С. 154-161.

9. Kharkivska A.A., Dmitrenko K.A., Sirova Yu.V, Tkachenko K.G. (2013). Polozhennya pro provedennya praktiki studentiv akademiyi [Regulations on the practice of students of the Academy]. Kharkiv : KZ "HGPA" HOR, $27 \mathrm{~s}$. 
УДОСКОНАЛЕННЯ МЕТОДИЧНОЇ ПІДГОТОВЛЕНОСТІ КУРСАНТІВ ВИЩИХ ВІЙСЬКОВИХ НАВЧАЛЬНИХ ЗАКЛАДІВ У СИСТЕМІ ФІЗИЧНОЇ ПІДГОТОВКИ

\author{
IMPROVEMENT OF METHODOLOGICAL PREPAREDNESS \\ OF CADETS OF HIGHER MILITARY EDUCATIONAL INSTITUTIONS \\ IN THE SYSTEM OF PHYSICAL TRAINING
}

УДК 355.233.2:796

DOI https://doi.org/10.32843/2663-

$6085 / 2020 / 24-2.11$

\section{Петрачков О.В.}

канд. пед. наук, доцент, начальник Навчально-наукового інституту фрізичної культури та спортивно-оздоровчих технологій

Національного університету оборони

України імені Івана Черняховського

Білошицький В.В.,

начальник науково-дослідної

лабораторії наукового супроводження розроблення нормативів і стандартів фрізичної підготовки і спорту Науково-дослідного центру проблем фрізичного виховання, спеціальної фрізичної підготовки і спорту Навчально-наукового інституту фрізичної культури та спортивно-оздоровчих технологій

Національного університету оборони

України імені Івана Черняховського

Любчич P.I.,

старший викладач кафедри фрізичної

підготовки та спорту

Національної академії

Національної гвардії України

\section{Коновалов Д.О.,}

науковий співробітник науководослідного відділу розвитку фізичного виховання, спеціальної фрізичної підготовки і спорту

Науково-дослідного центру проблем фізичного виховання, спеціальної фрізичної підготовки і спорту Навчально-наукового інституту фрізичної культури та спортивно-оздоровчих технологій

Національного університету оборони України імені Івана Черняховського

\section{Василенко М.М.,}

викладач кафедри службово-бойового застосування підрозділів

Національної гвардії України

Київського фракультету

Національної академії

Національної гвардії України
Стаття присвячена актуальним питанням удосконалення індивідуального рівня методичної підготовленості з фрізичної підготовки (спеціальної фрізичної підготовки) майбутніх офріцерів командного напряму підготовки Збройних Сил України (ЗСУ) та Національної гвардії України (НГУ). Головною метою роботи є розвиток та удосконалення методичних знань та практичних умінь у проведенні різних форм фрізичної підготовки майбутніми офріцерами командного напряму підготовки ЗСУ та НГУ в системі їх профресійної освіти. Під час дослідження членами науково-дослідної групи використані такі методи: теоретичний аналіз та узагальнення науково-методичної (спеціальноі) літератури; моніторинг інтернет-ресурсів; педагогічні спостереження; контрольне тестування рівня теоретичних знань та практичних умінь [12], методи математичної статистики; технічні засоби. 3 метою визначення ефективності запропонованоі нами моделі удосконалення методичних знань та практичних умінь у проведенні форм фрізичної підготовки курсантами старших курсів вищих військових навчальних закладів ЗСУ та НГУ (командного напряму підготовки) в системі їх фрізичної підготовки було проведено педагогічний експеримент (серпень 2018 - червень 2020 р.р.). На початку педагогічного експерименту досліджувані цих груп за рівнем розвитку методичних знань та практичних умінь в проведенні форм фрізичної підготовки достовірно не відрізнялися ( $P>0.05)$. Досліджувані контрольної групи (Кг) під час педагогічного експерименту використовували традиційну методику удосконалення методичних знань та практичних умінь. Представники Ез додатково використовували експериментальну модель розвитку й удосконалення методичних знань та практичних умінь у проведенні фором фрізичної підготовки. Наприкінці педагогічного експерименту відповідно до плану дослідження було проведено визначення рівня сформованості методичних знань та практичних умінь курсантів Ег та Кг. Порівнюючи показники до та після використання запропонованої нами «Моделі» розвитку та удосконалення методичних знань та практичних умінь у проведенні форм фрізичної підготовки курсантами Ег та Кг встановлено, що результати, отримані після педагогічного експерименту у досліджуваних групах, суттєво підвищилися у порівнянні із вихідними даними, і ці відмінності здебільшого достовірні (Е2, Р<0,05). Ключові слова: військовослужбовці, майбутні офріцери, модель, методична підго- товленість, освітній процес, просресійна підготовленість, технічні засоби, фрізичне виховання.

The article is devoted to topical issues of improving the individual level of methodical training in physical training (special physical training) of future officers of the command direction of training of the Armed Forces of Ukraine (AFU) and the National Guard of Ukraine (NGU). The main purpose of the work is to develop and improve methodological knowledge and practical skills in conducting various forms of physical training by future officers of the command direction of training of the AFU and the NGU University in the system of their professional education. During the research the members of the research group used the following methods: theoretical analysis and generalization of scientific-methodical (special) literature; monitoring of Internet resources; pedagogical observations; control testing of the level of theoretical knowledge and practical skills [12], methods of mathematical statistics; technical means. In order to determine the effectiveness of our proposed model of improving methodological knowledge and practical skills in conducting forms of physical training by senior cadets of higher military educational institutions of the AFU and NGU (team training) in the system of their physical training was conducted pedagogical experiment (August 2018 - June 2020). At the beginning of the pedagogical experiment, the studied groups did not differ significantly in the level of development of methodological knowledge and practical skills in the forms of physical training $(P>0.05)$. The subjects of the control group $(K g)$ during the pedagogical experiment used the traditional method of improving methodological knowledge and practical skills. Representatives of Eg additionally used an experimental model of development and improvement of methodical knowledge and practical skills in carrying out forms of physical training. At the end of the pedagogical experiment, in accordance with the research plan, the level of formation of methodological knowledge and practical skills of cadets $\mathrm{Eg}$ and $\mathrm{Kg}$ was determined. Comparing the indicators before and after the use of our proposed "Model" of development and improvement of methodological knowledge and practical skills in conducting forms of physical training cadets $\mathrm{Eg}$ and $\mathrm{Kg}$ found that the results obtained after a pedagogical experiment in the study groups significantly increased compared to baseline and these differences in mostly reliable $(E g, P<0,05)$. Key words: servicemen, future officers, model, methodical training, educational process, professional training, technical means, physical education.
Постановка проблеми у загальному вигляді. Сьогодні в Україні спостерігаються процеси інтеграції до європейського співтовариства. Ці про- цеси охоплюють всі ланки державного управління, а також сореру оборони України. Не оминає євроінтеграція й силові структури, такі як Збройні 
Сили України, Національна гвардія України, Національна поліція України та інші збройні фрормування. Своєю чергою трансорормація Збройних сил України (ЗСУ) та Національної гвардії України (НГУ) до стандартів НАТО, «гібридна» війна на сході України, військова агресія 3 боку Російської Федерації вимагає від сучасних військовослужбовців високої професійної підготовленості, адже завдання, які вони виконують, забезпечують мир та спокій в Україні.

Варто також зауважити, що високий рівень бойової готовності військових частин ЗСУ та НГУ загалом забезпечується постійним процесом професійної підготовки військ, який організований із урахуванням бойового досвіду, основних дидактичних принципів навчання та вимог сьогодення, тому пошук сучасних технологій та методик (моделей) підготовки військовослужбовців із урахуванням вищезазначеного є приорітетним напрямом наукових досліджень. Також важливою сьогодні $\epsilon$ організація різнопланової та ефективної підготовки майбутніх офріцерів ЗСУ та НГУ, які надалі відповідно до своїх посадових обов'язків будуть навчати військової справи підлеглий особовий склад.

Система профресійної підготовки в ЗСУ та НГУ передбачає проходження військовослужбовцями різних предметів бойової підготовки, основу яких складають: тактична підготовка, вогнева підготовка та фрізична підготовка. Слід відмітити, що фрізична підготовленість військовослужбовців напряму забезпечує їх високу індивідуальну професійну придатність, адже неможливо виконати бойове завдання без значних фрізичних зусиль. Під час службово-бойової діяльності військовослужбовців ЗСУ та НГУ виникає потреба у спеціалізованих фрізичних рухах, які розвиваються та удосконалюються в процесі навчально-тренувальних занять 3 фрізичної підготовки (спеціальної фрізичної підготовки), а також проведення інших фрорм фрізичної підготовки.

У військових частинах ЗСУ та НГУ навчальнотренувальні заняття 3 фрізичної підготовки, проведення інших фрорм фрізичної підготовки забезпечується безпосередньо командирами підрозділів, а також начальником фрізичної підготовки та спорту, який, крім цього, надає командирам всіх ланок методичну допомогу за фрахом. Відповідним чином прослідковується важливість методичної підготовленості командирів підрозділів з фрізичної підготовки в організації навчально-тренувальних занять й інших фрорм фрізичної підготовки. Оптимальне поєднання сучасних методів тренування із теоретичними знаннями забезпечує відсутність травмувань під час практичних занять з фрізичної підготовки (спеціальної фрізичної підготовки) та, безсумнівно, інтенсифрікує навчальний процес, що забезпечує поступове зростання фрізичного роз- витку підлеглого особового складу, яке позитивно відображається на виконанні військовослужбовцями завдань за призначенням загалом.

На сучасному етапі рефрормування систем ЗСу та НГУ застарілість методичного аспекту фрізичної підготовки у вищих військових навчальних закладах освіти (ВВН3), які готують майбутніх офріцерів, вимагає змін наявної методики фрізичної підготовки особового складу, а отже, удосконалення методичної підготовленості курсантів ВВН3 ЗСУ та НГУ в системі їх фрізичного виховання із використанням новітніх методик (моделей) $€$ актуальним напрямом наукових досліджень.

Дослідження виконано відповідно до плану науково-дослідної роботи і дослідно-конструкторських робіт науково-дослідної лабораторії наукового супроводження розроблення нормативів і стандартів фрізичної підготовки і спорту науково-дослідного центру проблем фрізичного виховання, спеціальної фрізичної підготовки і спорту навчально-наукового інституту фрізичної культури та спортивно-оздоровчих технологій Національного університету оборони України імені Івана Черняховського (2019-2020 р.р.).

Аналіз останніх досліджень і публікацій. У результаті аналізу науково-методичної та спеціальної літератури нами встановлено, що питанням удосконалення методичної підготовленості військовослужбовців ЗСУ та НГУ присвячені наукові праці А.С. Андреса, В.М. Афоніна, Д.С. Грищенка, С.І. Глазунова, О.М. Ольхового, А.П. Петрука, О.Г. Піддубного, Романчука С.В., Хацаюка О.В., чуха А.М. та інших провідних учених і практиків.

Подальший моніторинг науково-методичної літератури у напрямі удосконалення методичної підготовленості майбутніх офіцерів ЗСУ та НГУ в системі фрізичного виховання, анкетування провідних фрахівців 3 фрізичної підготовки силових структур України, результати попередніх науководослідних робіт [1-3] цієї спрямованості, власний бойовий та педагогічний досвід підтверджують необхідність постійного удосконалення системи методичної підготовленості військовослужбовців та працівників силових структур і спеціальних служб України.

Надалі нашу увагу привернули роботи С.В. Романчука [4], О.В. Воронцова [5], А.П. Петрука [6], у яких розкриті питання вирішення проблеми недостатнього рівня методичної підготовленості курсантів командного напряму підготовки ВВН3 ЗСУ, але які з плином часу є застарілими та потребують внесення відповідних змін (модернізації).

Своєю чергою шляхи та ключові напрями удосконалення системи підготовки керівників занять 3 фрізичної підготовки із військовослужбовцями різних кваліфікацій відображено в роботах: С.М. Жембровсього [7], С.В. Романчука [8], С.І. Глазунова [9]. 
Якісний стан сорормованості рівня методичної підготовленості з фрізичного виховання у курсантів-випускників ВВН3 ЗСУ висвітлено в роботах: О.М. Ольхового [10], С.В. Номеровського [11]. На підставі практичних результатів вищезазначених авторів нами були визначені основні складники організації дослідження.

Виділення не вирішених раніше частин загальної проблеми. Аналіз науково-методичної та спеціальної літератури (Інтернет-ресурсів) в обраному напрямі дослідження дозволив нам визначити такі суперечності між:

- високим рівнем індивідуальної фрізичної підготовленості майбутніх офіцерів командного напряму підготовки та недостатнім рівнем теоретичних знань і практичних умінь в організації та проведенні фрорм фрізичної підготовки;

- потребою у всебічно розвинутих (підготовлених) офіцерах командного напряму та неефективними педагогічними умовами фрормування практичних навичок та теоретичних знань (методичної підготовленості);

- наявністю розвинутої навчально-матеріальної бази (технічних засобів навчання) та відсутністю повного її використання у напрямі всебічного розвитку майбутніх офріцерів.

Попри значну кількість робіт цього напряму наукових розвідок, присвячених питанням розробки сучасної моделі удосконалення методичної підготовленості майбутніх офріцерів ЗСУ та НГУ в системі фрізичного виховання на основі використання новітніх засобів навчання, нами не виявлено, що підкреслює актуальність дослідження.

Мета статті - розвиток та удосконалення методичних знань та практичних умінь у проведенні різних фрорм фрізичної підготовки майбутніми офріцерами командного напряму підготовки ЗСУ та НГУ в системі їх профресійної освіти.

Для досягнення мети дослідження планувалося вирішити такі завдання:

- провести аналіз стану та науково-теоретичних передумов удосконалення методичної підготовленості військовослужбовців різних силових відомств у процесі фрізичної підготовки;

- дослідити ефективність наявної педагогічної моделі розвитку та удосконалення методичної підготовленості курсантів ВВНЗ ЗСУ та НГУ в системі їх фрізичного виховання;

- апробувати експериментальну модель із сучасними засобами навчання, яка спрямована на розвиток і удосконалення теоретичних знань та практичних умінь у проведенні форм фрізичної підготовки (методичної підготовленості) майбутніми офріцерами ЗСУ та НГУ в системі їх професійної освіти.

Виклад основного матеріалу. 3 метою визначення ефективності запропонованої нами моделі удосконалення методичних знань та практичних умінь у проведенні фрорм фрізичної підготовки курсантами старших курсів ВВН3 зСУ та НГУ (командного напряму підготовки) в системі їх фрізичної підготовки було проведено педагогічний експеримент (серпень 2018 - червень 2020 р.р.), у якому взяли участь курсанти навчально-наукового інституту фрізичної культури та спортивнооздоровчих технологій Національного університету оборони України імені Івана Черняховського (n=18 чол., експериментальна група) та Національної академії Національної гвардії України (n=22 чол., контрольна група). На початку педагогічного експерименту досліджувані цих груп за рівнем розвитку методичних знань та практичних умінь у проведенні фрорм фрізичної підготовки достовірно не відрізнялися ( $\mathrm{P}>0.05)$.

Досліджувані контрольної групи (Кг) під час педагогічного експерименту використовували традиційну методику удосконалення методичних знань та практичних умінь, передбачених робочими програмами навчальних дисциплін «Фізичне виховання та методика фрізичної підготовки» та «Методична підготовка військовослужбовців НГУ» з підготовки курсантів Національної академії Національної гвардії України.

Своєю чергою представники Ег додатково використовували експериментальну модель (надалі «Модель») розвитку й удосконалення методичних знань та практичних умінь у проведенні форм фрізичної підготовки курсантами навчально-наукового інституту фрізичної культури та спортивнооздоровчих технологій Національного університету оборони України імені Івана Черняховського в процесі вивчення навчальних дисциплін «Теорія і методика викладання фізичного виховання» та «Теорія і організація фрізичної підготовки у військах (силах)». Розроблена нами «Модель» впроваджувалась у 2 етапи.

На першому етапі (серпень 2018 р. - вересень 2019 р.) курсантами в рамках самостійної роботи вивчалися керівні документи з організації фрізичної підготовки в ЗСУ та НГУ. Крім цього, під час практичних занять 3 фрізичної підготовки відпрацьовувалися тестові завдання (на персональних комп'ютерах). Варто підкреслити, що тестові завдання були створені на базі програмного засобу "TestYourSelf" [12].

Прикладна програма "TestYourSelf" створена для тестування здобувачів вищої освіти. Тематика тестів визначається викладачем, який має можливість підключити для створення питань графрічні (jpg, bmp), аудіо- (wav, mp3) або відеофайли (avi, mpeg). Тест складається 3 питання й 4-х можливих варіантів відповіді, серед яких той, кого контролюють, повинен обрати вірний. У налаштуваннях програми можливо визначити критерії тестування (4-бальна шкала, у відсотках 12-бальна шкала, «Болонська» система оцінювання знань та інше), 
$€$ також можливість дозволити режим підказок (зі зниженням результату або без нього), забезпечити роботу з паролем.

Паралельно із систематичним тестовим контролем курсантам у години самостійної роботи демонструвалися навчально-методичні фрільми, які розкривають методичні особливості проведення форм фрізичної підготовки в підрозділах ЗСУ та НГУ. Слід зазначити, що в рамках першого етапу дослідження викладачами (організаторами педагогічного експерименту) також акцентувалася увага на вірній та ефективній методиці проведення навчальних занять з різних розділів фрізичної підготовки.

Своєю чергою під час другого етапу (жовтень 2019 - червень 2020 р.р.) під час практичних занять з різних розділів фрізичної підготовки, ранкової фрізичної зарядки, спортивно-масової роботи курсанти Ег виконували методичні завдання. Виконання методичного завдання оцінювалося відповідно до встановлених вимог керівних документів з організації фрізичної підготовки в ЗСУ та НГУ. Крім цього, досліджуваним Ег на період військового стажування були видані для практичного відпрацювання індивідуальні завдання. Повнота та ефективність їх виконання враховувалась під час щомісячної (річної) атестації за період навчання. Слід зазначити, що обов'язковою умовою реалізації поставлених перед нами завдань було проведення постійного педагогічного контролю на всіх етапах дослідження. Це дозволяло своєчасно вносити корективи у тренувальні програми та методичні завдання.

Наприкінці педагогічного експерименту відповідно до плану дослідження було проведено визначення рівня сорормованості методичних знань та практичних умінь курсантів Ег та Кг. Порівнюючи показники до та після використання запропонованої нами «Моделі» розвитку та удосконалення методичних знань та практичних умінь у проведенні форм фрізичної підготовки курсантами Ег та Кг встановлено, що результати отримані після педагогічного експерименту у досліджуваних групах суттєво підвищилися у порівнянні із вихідними даними, і ці відмінності здебільшого достовірні (Ег, Р<0,05).

Висновки. Таким чином, у результаті дослідження розвинуті та удосконалені методичні знання та практичні уміння в проведенні фрорм фрізичної підготовки майбутніми офріцерами командного напряму підготовки ЗСУ та НГУ в системі їх профресійної освіти.

Крім цього, відповідно до результатів моніторингу науково-методичної та спеціальної літератури розроблено та практично апробовано модель удосконалення методичної підготовленості курсантів зазначених категорій (груп). Результати педагогічного експерименту підтверджують високу ефективність запропонованої нами моделі розвитку та удосконалення методичних знань у галузі теорії та методики фрізичної підготовки військовослужбовців ЗСУ та НГУ.

Під час педагогічного експерименту апробовані сучасні тестові програми, навчально-методичні фрільми з проведення фрорм фрізичної підготовки, навчальні посібники 3 організації фрізичної підготовки в ЗСУ та НГУ, а також методичні комплекси (індивідуальні завдання), які спрямовані на розвиток і удосконалення теоретичних знань та практичних умінь в проведенні форм фрізичної підготовки в ЗСУ та НГУ.

Отже, мета роботи досягнута, а поставлені перед нами завдання виконані. Результати дослідження впроваджені в освітній процес здобувачів вищої освіти (майбутніх офріцерів) Національної академії Національної гвардії України. Перспективи подальших досліджень передбачають розроблення методичних рекомендацій з організації та проведення спортивних заходів (спортивних свят, спортивних вечорів та інших заходів) в підрозділах ЗСУ та НГУ.

\section{БІБЛІОГРАФІЧНИЙ СПИСОК:}

1. Камаев О.И., Пилипец А.В., Белошенко Ю.К. Оптимизация соотношения фризической и методической подготовки курсантов командного факультета Академии внутренних войск МВД Украины. Физическое воспитание студентов. 2011. № 2. С. 47-49.

2. Маракушин А.И., Поддубный А.Г., Коновалов В.В., Кирпенко В.Н. Формирование и диагностика уровня педагогических умений студентов в процессе фризического воспитания. Слобожанський науковоспортивний вісник. 2015. № 1 (45). С. 75-80.

3. Шлямар І.Л. Методична підготовленість командира - основа фрізичної підготовки підрозділу. Фізична підготовка особового складу Збройних сил, інших військових формувань та правоохоронних органів України: досвід, сучасність проблеми та перспективи розвитку. 2014. № 1. С. 358-363.

4. Романчук С.В. Методична підготовленість командирів підрозділів щодо організації фрізичної підготовки курсантів військових навчальних закладів. Молода спортивна наука України. 2009. № 13 (Т.4). C. 178-181.

5. Петрук А.П, Воронцов О.О, Демків А.С, Биков Р.Г, Бичихін Ю.І. Методична підготовка курсантів у процесі фрізичного виховання у командних вищих військових навчальних закладах збройних сил України. Спортивний вісник Придніпров'я. 2016. № 3. C. 164-168.

6. Петрук А.П. Програма формування методичної підготовленості курсантів ВВНЗ в процесі фрізичної підготовки. Науково-педагогічні проблеми фрізичної культури (фрізична культура і спорт). 2017. № 5. С. 256-261.

7. Жембровський С.М. Шляхи вдосконалення системи підготовки керівників занять з фрізичної підготовки 3 офріцерами органів управління. Молода спортивна наука України. 2009. № 13 (Т.4). С. 68-74.

8. Романчук С.В., Романчук В.В, Боярчук О.М., Гусак О.Д. Підготовка керівників фрізичної підготовки під час навчання у військових навчальних 
закладах. Молода спортивна наука України. 2011. Вип. 13 (Т.4). С. 126-130.

9. Глазунов С.І. Шляхи підвищення ефективності самостійних занять з фрізичного вдосконалення військовослужбовців. Теорія та методика фрізичного виховання. 2009. № 11. С. 45-48.

10. Ольховий О.М. Модульно-рейтингова система підготовки офріцерів - керівників занять 3 фрізичної підготовки : авторефр. дис. ... канд. наук. 3 фріз. вих. і спорту. Львів : ЛДУФК, 2005. 20 с.
11. Номеровський С.В. Проблемні питання сучасного стану методичної підготовки курсантів військовоморських навчальних закладів під час вивчення навчальної дисципліни «Фізичне виховання, спеціальна фрізична підготовка і спорт». Сучасні тенденції та перспективи розвитку фізичної підготовки військовослужбовців. 2011. № 1. С. 137-145.

12. Test Yourself 2.0. (2020). Программа для тестирования знаний школьников и студентов. URL: http://soft-arhiv.com/load/27-1-0-598. 


\section{ЕФЕКТИВНІ ТЕХНОЛОГІЇ НАВЧАННЯ ЗАРУБІЖНОЇ ЛІТЕРАТУРИ EFFECTIVE TECHNOLOGIES OF TEACHING FOREIGN LITERATURE}

Сучасна освіта вимагає використання в школі нових сучасних технологій. Завдання сучасної школи полягає не лише в наданні учням певного обсягу знань, а й в розвитку умінь навчатися протягом життя, самостійно знаходити інформацію, аналізувати іï, застосовувати набуті знання на практиці, бути конкурентоспроможними, креативними. Проєктна діяльність саме й розрахована на вільний вибір теми й особисті інтереси конкретного учня, на самостійну творчу роботу (індивідуальну, парну чи групову). Вона передбачає використання вчителем різноманітних технологій, спрямованих на розвиток основних компетенцій, і полягає в постійній взаємодії вчителя та учнів, причому вчитель у такому прочесі $\epsilon$ координатором, консультантом, порадником. Кожен з учасників несе відповідальність за навчально-проєктний результат. Це відповідає програмним вимогам навчання зарубіжної літератури.

Проєктна технологія на уроках зарубіжноі літератури надає вчителю безмежні можливості для виконання навчальних завдань i розвитку творчих здібностей учнів. Робота $з$ використанням проєктних технологій заохочує учнів до вивчення творів зарубіжної літератури, вчить оперувати набутими вміннями й навичками в процесі читання художніх текстів різних жанрів, розвиває уміння визначати в прочитаному творі тему, основні проблеми, передавати сюжет, відтворювати елементи композиціі, розрізняти жанри, створювати характеристики. Основною метою застосування проєктних технологій на уроках зарубіжноі літератури $\epsilon$ розвиток основних компетениій: пізнавальних навичок учнів, уміння орієнтуватися в різних джерелах інформації, застосовувати на практиці отриман знання, виділяти проблеми й визначати шляхи їхнього розв'язання, планувати, прогнозувати, аналізувати, зіставляти, оцінювати, робити висновки, виробляти особисту думку, презентувати результати проєктної діяльності. Проєктна технологія сприяє вихованню толерантності й комунікативності, адже передбачає роботу в групах, у парах, вимагає співробітниитва учнів різного віку. Таким чином, метод проєктів $\epsilon$ сучасною педагогічною технологією, використання якої створює умови для всебічного розвитку дитини в процесі організації творчої діяльності.
Ключові слова: метод, прийом, проєктна діяльність, проєктні технології, технологіі навчання.

Modern education requires applying new modern technologies at school. The task of a modern school is not only to provide students with a certain amount of knowledge, but also to develop skills to learn throughout life, independently find information, analyze it, apply the acquired knowledge in practice, be competitive and creative. Project activity is designed to ensure free choice of topic and student's personal interests, independent creative work (individual, pair or group). It involves the use of various technologies by the teacher aimed at developing basic competencies and includes a constant interaction between a teacher and his or her students, and the teacher in this process is supposed to be a coordinator, a consultant, or an advisor. Each participant is responsible for the learning and project result. This meets the program requirements for teaching foreign literature.

Project technology at the lessons of foreign literature provides the teacher with endless opportunities for learning tasks and developing students' creative abilities. Working with project technologies encourages students to study works of foreign literature, teaches to operate the acquired skills and abilities while reading literary texts of various genres, develops the ability to identify the theme, main problems, convey the plot, reproduce composition elements, distinguish genres, create characteristics. The main purpose for applying project technologies at the lessons of foreign literature is the development of basic competencies: students' cognitive skills, ability to orient themselves within the different information sources, apply knowledge, identify problems and their solutions, plan, predict, analyze, compare, evaluate, conclude, develop personal opinion, present the results of project activities. Project technology contributes to developing tolerance and communication skills, because it involves working in groups and in pairs, requires the cooperation of students of all ages. Thus, the project-based learning is a modern pedagogical technology which creates conditions for the comprehensive development of the child while organizing creative activities.

Key words: method, technique, project activity, project technologies, teaching and learning technologies. неперервної освіти» Дніпропетровської обласної ради

Постановка проблеми в загальному вигляді. Сучасна освіта вимагає використання в школі нових сучасних технологій. Завдання сучасної школи полягає не лише в наданні учням певного обсягу знань, а й в розвитку умінь навчатися протягом життя, самостійно знаходити інфрормацію, аналізувати іï, застосовувати набуті знання на практиці, бути конкурентоспроможними, креативними. Проєктна діяльність саме й розрахована на вільний вибір теми й особисті інтереси конкретного учня, на самостійну творчу роботу (індивідуальну, парну чи групову) й передбачає використання вчителем різноманітних технологій, спрямованих на розвиток основних компетенцій [6, с. 7-8].

Проєктна технологія на уроках зарубіжної літератури надає вчителю безмежні можливості для виконання навчальних завдань і розвитку творчих здібностей учнів. Проєктна діяльність полягає в постійній взаємодії вчителя та учнів, причому вчитель у такому процесі $€$ координатором, консультантом, порадником. Кожен з учасників несе відповідальність за навчально-проєктний результат [5, с. 7]. Це відповідає програмним вимогам зарубіжної літератури. 
Робота над проєктними технологіями заохочує учнів до вивчення творів зарубіжної літератури, вчить оперувати набутими вміннями й навичками в процесі читання художніх текстів різних жанрів, розвиває уміння визначати в прочитаному творі тему, основні проблеми, передавати сюжет, відтворювати елементи композиції, розрізняти жанри, створювати характеристики.

В основі проєктної технології на уроках зарубіжної літератури лежить розвиток основних компетенцій: пізнавальних навичок учнів, уміння орієнтуватися в різних джерелах інформації, застосовувати на практиці отримані знання, виділяти проблеми й визначати шляхи їхнього розв'язання, планувати, прогнозувати, аналізувати, зіставляти, оцінювати, робити висновки, виробляти особисту думку, презентувати результати проєктної діяльності [2, с. 13-15]. Проєктна технологія сприяє вихованню толерантності й комунікативності, адже передбачає роботу в групах, у парах, вимагає співробітництва учнів різного віку. Таким чином, метод проєктів є сучасною педагогічною технологією, використання якої створює умови для всебічного розвитку дитини в процесі організації творчої діяльності.

Аналіз останніх досліджень і публікацій. Метод проєктів відомий у світовій педагогіці з кінця XIX - початку XX століття як метод проблем. Він пов'язувався з ідеями гуманістичного спрямування у фрілософії та освіті, розробленими американським фрілософом і педагогом Дж. Дьюї, а також його учнем В. Х. Кілпатріком. У 1910-ті роки американський професор Коллінгс першим у світі запропонував класифікацію навчальних проєктів [1].

Науковці О. Пєхота, А. Кіктенко, О. Любарська [8] використовують поняття «навчальне проєктування», «проєктна технологія», «метод проєктів». На думку дидактів, у навчально-виховному процесі загальноосвітнього навчального закладу має вияв технологія проєктування, що «передбачає розв'язання учнем або групою учнів якої-небудь проблеми, яка окреслює, з одного боку, використання різноманітних методів, засобів навчання, а з другого - інтегрування знань, умінь із різних галузей науки, техніки, творчості» [8, с. 150].

Науковець А. Цимбалару [9] наголошує, що в педагогічній науці виокремлюють три напрями тлумачення терміна «проєкт»: «По-перше, як попередній, приблизний текст повного документа (проєкт програми тощо). По-друге, під проєктом розуміють певну акцію, сукупність заходів, що мають спільну програму, передбачають цілеспрямовану діяльність, організаційну фрорму тощо (видавничий проєкт, телевізійний проєкт). По-третє, проєкт визначають як завершений цикл продуктивної діяльності (колективної, групової, індивідуальної тощо), як фрорму побудови спільної цілеспрямованої діяльності людей» [9, с. 6].
I. Єрмаков вважає, що важливим сутнісним показником в умовах проєктної навчальної діяльності є докорінна зміна у відносинах «учитель - учень», а саме: учень визначає мету діяльності - учитель допомагає йому в цьому; учень відкриває нові знання - учитель рекомендує джерела знань; учень експериментує - учитель розкриває можливі форми й методи експерименту, допомагає організувати пізнавально-практичну продуктивну діяльність; учень обирає - учитель сприяє прогнозуванню результату вибору; учень активний - учитель створює умови для розвитку активності; учень - суб'єкт навчання, учитель партнер; учень відповідає за результати своєї діяльності - учитель допомагає оцінити отримані результати й виявити способи вдосконалення діяльності [5].

Виділення невирішених раніше частин загальної проблеми. У роботі викладено питання про впровадження проєктної технології на уроках зарубіжної літератури як важливого засобу для духовного саморозвитку, самореалізації та самоутвердження школяра, фрормування критичного мислення, що є основним у вихованні соціально активної особистості, здатної творчо засвоювати знання та використовувати їх на практиці, особистості, від якої залежить майбутнє нашої держави.

Мета статті - визначити специфічні особливості проєктної технології як інноваційного засобу сучасної освіти, проаналізувати основні атрибути проєкту як неформального методу розв'язання будь-якої проблеми; спроєктувати всі переваги застосування проєктних технологій на уроках зарубіжної літератури, які лише розширюють спектр навчального процесу.

Виклад основного матеріалу. У сучасному розумінні слово «проєкт» означає намір, який буде здійснено в майбутньому й передбачає сукупність певних дій, документів, текстів, створення різного роду теоретичного чи практичного продукту. Це особливий тип інтелектуальної діяльності учнів, що активізує їхнє мислення, увагу, пам'ять, мовлення, волю, міжособистісне спілкування; вимагає широкого використання на уроках індивідуальної, парної та групової організації навчальної діяльності учнів, самодіяльного характеру їхньої творчої активності; створення соціально-педагогічних умов для самоствердження кожної дитини в учнівському колективі.

Метод проєктів - це освітня технологія, спрямована на здобуття учнями знань у тісному зв' язку 3 реальною життєвою практикою, фрормування в них специфічних умінь і навичок завдяки системній організації проблемно-орієнтованого навчального пошуку. Суть проєктної технології полягає в стимулюванні інтересу учнів до розв'язання однієї або цілої низки проблем, що передбачає опанування певною сумою знань [7]. 
Сучасні дослідники виділяють такі типи проєктів:

1. За методом, домінуючим у проєкті: дослідницькі, творчі, ігрові, інформаційні, практико-орієнтовані.

2. За характером координування проєкту: 3 явною координацією, з прихованою координацією.

3. За характером контактів: внутрішні (регіональні) й міжнародні.

4. За кількістю учасників: індивідуальні, парні, групові.

5. За тривалістю проведення: короткострокові, середньої тривалості, довгострокові [7].

Дослідницький проєкт активізує і розвиває пізнавальні, розумові й мовленнєві здібності, пам'ять, привчає до уважності, спостережливості, відповідальності. Цей метод містить обґрунтування обраної теми, постановку задачі, фрормулювання проблеми, визначення предмету дослідження, висунення гіпотези з подальшою ії перевіркою, обговорення та аналіз отриманих результатів.

До дослідницьких проєктів можна віднести створення порівняльних характеристик героїв, дослідження мовних засобів, створення подорожей місцями, пов'язаними 3 творчістю письменників.

До інфрормаційних проєктів відносять повідомлення про цікаві біографрічні фракти, виразне читання та аналіз віршів, дослідження історії створення твору, складання карти подорожей літературних героїв.

Ігрові проєкти дають широкі можливості застосовувати інтерактивні фрорми роботи, розвивають комунікативні, мовленнєві й акторські здібності.

До таких видів проєктної діяльності відносять інсценування окремих епізодів твору, рольові ігрові ситуації, екскурсії, інтерв'ю, реклами творів.

Творчі проєкти сприяють розвитку творчих здібностей учнів, розвивають вміння виділяти головне у творі, вчать працювати як індивідуально, так і в групі однодумців, дають можливість самореалізуватися, сприяють розвитку міжпредметних зв'язків (література й образотворче мистецтво, фотографрія, кіно, театр) [2, с. 13-14].

До творчих проєктів відносять створення ілюстрацій до творів, збірок різної тематики, альманахів, присвячених творчості письменників, літературних композицій до ювілеїв, випуск літературних газет, фротопроєктів, написання творчих робіт, складання віршів.

Прикладні або практико-орієнтовані проєкти розвивають творче мислення, розширюють словниковий запас, вчать бачити перспективу власної діяльності. До практико-орієнтованих проєктів відносять складання словників, програм, хронік, рекомендацій тощо.

Науковці виділяють таку послідовність роботи над проєктом:

1. Підготовчий етап, який містить: фрормування проєктної групи; визначення проєкту дослідження; визначення теми дослідницької роботи; обґрунтування методів дослідження; розроблення плану дослідницької діяльності; пошуки інфрормації, визначення літератури.

2. Дослідницький етап, який передбачає: збирання інформації 3 використанням відповідних методів дослідження; обробку й аналіз отриманих результатів; підготовку висновків; оформлення результатів дослідження та підготовку презентації.

3. Етап представлення отриманого результату: публічна презентація отриманого результату; аналіз обробки виконаної роботи; оцінка роботи проєктної групи чи окремого учня, що виконав роботу [7].

Найдоцільнішим буде використання методу проєктів на оглядових уроках, на уроках вивчення біографії письменника, систематизації та узагальнення вивченого матеріалу, уроків позакласного читання, уроках із розвитку мовлення.

Перед початком роботи над будь-яким проєктом варто чітко окреслити низку завдань, які сприятимуть виконанню таких фрункцій:

- активізувати пізнавальні інтереси щодо читання художніх творів;

- фрормувати й розвивати творчий підхід до виконання домашніх завдань;

- створювати «ситуацію успіху» й давати можливість кожному проявити свої здібності.

Важливо чітко визначити мету діяльності дітей. Оскільки метод проєктів належить до технологій особистісно-орієнтованого навчання, то й мета роботи повинна бути спрямована на розвиток в учнів дослідницького й пізнавального інтересу, уміння самостійно знаходити інформацію, аналізувати й узагальнювати ії, детально працювати з текстом художнього твору, уміння презентувати інфрормацію у вигляді офрормленого результату діяльності, уміння самостійно й критично мислити, висловлювати власну думку, бути ініціативним і наполегливим, розвивати здатність працювати як індивідуально, так і в колективі. Важливим на початку роботи над проєктом $€$ налаштування учнів на успішне його виконання та презентацію. Узагальнений успіх буде залежати від зусиль і відповідальності кожного учня. Учитель виконує роль помічника, партнера, порадника, який допоможе визначити завдання, розставити акценти, знайти оптимальні форми роботи, накреслити шляхи до поставленої мети [5, с. 10].

Завдяки проєктуванню на уроках літератури учні вчаться усвідомлювати мету, планувати свою роботу, прогнозувати можливі результати, використовувати різні джерела інфрормації (літературні твори, дослідження літературознавців, матеріали преси, Інтернет-сайти тощо), самостійно здобувати й накопичувати матеріали, аналізувати й зіставляти різні фракти, доводити свої погляди, приймати самостійні рішення, активізувати соціальні контакти (працювати спільно, розподіляти доручення), створювати матеріальні носії проєктної 
діяльності (сценарії, альманахи, журнали, фротоальбоми, ілюстрації, музейні експонати тощо).

Проєктні технології зацікавлять дітей із різним рівнем знань грамотно організувати роботу над проєктом. По-перше, необхідна стійка мотивація. По-друге, треба правильно розподілити обов'язки між учнями під час роботи над проєктом. По-третє, вдало обрана тема проєкту - 100 \% успіху.

Презентація готового проєкту (публічний захист проєкту) - надзвичайно важливий етап. Учитель як координатор проєкту має чітко спланувати цей етап. Потрібно надати можливість кожній групі підбити підсумки своєї роботи в проєкті й презентувати кінцевий продукт. Група сама вирішує, чи це буде лідер групи, чи це творче представлення роботи із залученням усіх її учасників. Специфіка предмету «зарубіжна література» дозволяє пропонувати учням різноманітні проєкти, які відповідають уподобанням дітей і спрямовані на розвиток різних типів інтелекту. Наприклад: «Я - художник», «Я - мистецтвознавець», «Я - літературний критик», «Я - актор», «Я - поет, «Я - дослідник», «Я - перекладач», «Я - лінгвіст», «Я - дизайнер», «Я - сценарист», «Я - музикант», «Я - модельєр», «Я - маркетолог», «Я - скульптор», «Я - знавець техніки», «Я - режисер», «Я - науковець», «Я оратор», «Я - учитель», «Я - журналіст».

Якщо вчитель творчо організує роботу за методом проєктів, запропонує як універсальні, так і ситуативні проєкти, чітко складе інструкції для кожної групи з урахуванням вікових можливостей дітей, знайде потрібні слова, щоб підбадьорити учнів, створити творчу атмосферу, ситуацію успіху, то результатом стане краще розуміння художнього твору, його аналіз, побудова власних інтерпретацій, розвиток творчих здібностей учнів.

Висновки. Отже, реалізація методу проєктів на уроках зарубіжної літератури обов'язково приведе до зміни позиції вчителя. 3 носія готових знань він перетвориться в організатора пізнавальної діяльності учнів. Зміниться також психологічний клімат у класі, тому що вчитель переорієнтовує репродуктивну навчальну діяльність учнів на різноманітні види самостійної діяльності: дослідницьку, пошукову, творчу. Учні сприймають вчителя як порадника, довіряють йому, не хочуть підвести, тому така робота заздалегідь скоординована на успіх. Інтерактивні форми роботи сприяють розвитку творчих здібностей учнів, навичок колективної роботи, умінню співпрацювати для досягнення певної мети, реалізовувати набуті знання, орієнтуватися в непередбачуваних ситуаціях. Головна мета педагогів - спрямувати роботу учнів, координувати дії на виконання певного об'єму роботи, мотивувати діяльність і допомогти спрогнозувати кінцевий результат.

\section{БІБЛІОГРАФІЧНИЙ СПИСОК:}

1. Байнякшина О. Є. Метод проєктів як засіб ефективного та якісного навчання молодших школярів. URL: http://journal.osnova.com.ua/article/38542Метод_проектів_як_засіб_ефективного_та якісного_навчання_молодших_школ(датазвернёння: 08.06.2020).

2. Богослав І.І. Тиждень проєктів. Завуч. 2007. № 4. C. 13-24.

3. Волощук Є.В. Проблеми вивчення зарубіжної літератури XX століття в школі. Всесвітня література в середніх навчальних закладах України. 2006. № 11. С. 39-41.

4. Волощук Є.В. Час збирати каміння (Про оновлення концепції та шляхи подальшого розвитку предмета «Зарубіжна література»). Всесвітня література в середніх навчальних закладах України. 2006. № 2. C. 110-120.

5. Єрмаков І.Г. Компетентнісний потенціал проєктної діяльності. Проєктна діяльність у школі / упорядн. М.М. Голубенко. Київ : Шкільний світ, 2006. С. 5-18.

6. Ковбасенко Ю.І. Про місце і роль предмета «Зарубіжна література» в системі літературної освіти української школи та про шляхи підвищення есрективності його викладання. Всесвітня література в середніх навчальних закладах України. 2006. № 11. C. 7-10.

7. Мірошник C.I. Теоретичні основи навчальної проєктної діяльності учнів. URL: https://www.narodnaosvita.kiev.ua/?page_id=2383 (дата звернення: 08.06.2020).

8. Освітні технології : навчально-методичний посібник / за заг. ред. О.М. Пєхоти. Київ : АСК, 2002. 255 c.

9. Педагогічне проєктування / авт.-упорядн. А.Д. Цимбалару. Київ : Шкільний світ, 2009. 128 с.

10. Сіптарова С.В. 3 досвіду застосування методів проєктів. Всесвітня література в середніх навчальних закладах України. 2004. № 1. С. 4-5. 
ТИПОЛОГІЙНІ ВИЯВИ СИНТАКСИЧНОГО ЗВ'ЯЗКУ В СЛОВОСПОЛУЧЕННІ: ЛІНГВІСТИЧНИЙ I ЛІНГВОДИДАКТИЧНИЙ АСПЕКТИ

TYPOLOGICAL OCCURRENCES OF SYNTACTICAL CONNECTION IN WORD COMBINATIONS: LINGUISTIC AND LINGUODIDACTIC ASPECTS

\begin{abstract}
у статті здійснено аналіз теорій, присвячених проблемі класифрікації синтаксичних зв'язків словосполучення крізь призму мовознавчої та лінгводидактичної літератури з метою уточнення змісту курсу «Сучасна українська літературна мова. Синтаксис» для навчання майбутніх учителів української мови та літератури, що спрямований на розвиток професійного кругозору студентів з урахуванням формування в них синтаксичної компетентності. Увагу акцентовано на диференціації двох типів синтаксичного зв'язку на рівні словосполучення: сурядний, підрядний / підрядний.

Аналіз навчально-методичної літератури показав, що проблема типології синтаксичних зв'язків на сьогодні є невирішеною: одні дослідники говорять про наявність сурядного та підрядного зв'язку у словосполученні, інші - існування тільки другого. Така розбіжність, на нашу думку, спричинена тим, що, по-перше, вчені досі по-різному визначають словосполучення як синтаксичну одиницю, по-друге, виокремлюючи словосполучення у межах речення, деякі науковці звертають увагу на характер ускладнення (однорідні члени речення
\end{abstract}

Зауважено, що поширеним підходом під час вивчення словосполучення в закладах загальної середньої освіти та закладах вищої освіти був та залишається другий підхід - словосполучення утворюється підрядним зв'язком, у якому можна визначити головне та залежне слова, де найяскравіше простежуються особливості валентних потенцій повнозначних слів. Закцентовано на тому, що, визначаючи дидактичний зміст навчання майбутніх учителів української мови та літератури, педагогові слід зауважувати про існування різних поглядів на типи синтаксичного зв'язку в словосполученні, а доцільність їх розгляду під час занять визначається викладачем.

Перспективу подальших досліджень убачаємо в теоретичному осмисленні сурядних сполучень слів, їх вияв та фуункії на комунікативному рівні; розробленні дидактичного матеріалу з використанням інфрормаційнокомунікаційних технологій.

Ключові слова: дидактичний матеріал, підрядний зв'язок, синтаксичні зв'язки, словосполучення, сурядний зв'язок, сурядні сполучення слів.
The article analyzes the theories concerning the problem of classification of syntactic connection of word combinations through the prism of linguistic and linguo-didactic literature in order to clarify the content of the course "Modern Ukrainian Literary Language. Syntax" for teaching future teachers of Ukrainian language and literature, which is aimed at developing students' professional outlook taking into account the formation of their syntactic competence. Attention is focused on the differentiation of two types of syntax connection at the level of word combination coordinative, subordinative / subordinative.

The analysis of the educational literature has revealed that the problem of typology of syntactic connections is still unresolved: some researchers say that there is the coordinative and subordinative connection within the word combination, while others refer to the existence of only the second one. This discrepancy, in our opinion, is due to the fact that, firstly, scientists still differently define the word combination as a syntactic unit, and secondly, while distinguishing the word combination within the sentence, some scholars pay attention to the nature of the complication (homogeneous members of the sentence).

It has been noted that the most common approach in the study of word combination in general secondary and higher education institutions was and remains the second one - the word combinations is formed by a subordinate connection, in which we may differentiate the principal and dependent words where the peculiarities of valence potentials are most clearly traced. It is emphasized that determining the didactic content of teaching future teachers of Ukrainian language and literature, the lecturer should note the existence of different views on the types of syntactic connection within the word combination and the relevance of their consideration in the classroom is determined by the teacher.

The perspective of further research is seen in the theoretical understanding of the coordinated combinations of words, their manifestations and functions at the communicative level; development of didactic material using information and communication technologies.

Key words: didactic material, subordinate connection, student-philologists, syntactical connections, word combination, coordinative connection, coordinative word combinations.

Київського університету

імені Бориса Грінченка

Постановка проблеми у загальному вигляды. Словосполучення як одиниця синтаксису реалізується синтаксичними зв'язками, що відмінні від речення. На сьогодні у лінгвістиці та лінгводидактиці виконано низку вагомих наукових студій, що презентують різні підходи до аналізу синтаксичного зв'язку між компонентами словосполучень. Їх теоретичне опрацювання представлене в працях таких лінгвістів, як С.П. Бевзенко [22], В.А. Бєлошапкова [19], В.В. Виноградов [4], І.Р. Вихованец [5,6], М.О. Вінтонів [8], Г.Н. Глуш- кова [9], Н.В. Гуйванюк [18], А.П. Загнітко [12, 11], Б.М. Кулик [13], О.С. Мельничук [21] та інших; лінгводидаків О.М. Біляєва [23], С.О. Караман [20], О.В. Караман [20], К.М. Плиско [14] та інших.

Виділення невирішених раніше частин загальної проблеми. Питання типології синтаксичного зв'язку остаточно не розв'язане. Воно $є$ важливим під час навчання майбутніх учителів української мови та літератури. Отже, саме відсутність фрактичної однобічної версії зумовлює актуальність запропонованого дослідження. 
Мета наукової роботи полягає в аналізі теорій, присвячених проблемі класифрікації синтаксичних зв'язків словосполучення крізь призму мовознавчої та лінгводидактичної літератури для встановлення дидактичного матеріалу навчання майбутніх учителів української мови та літератури, що спрямований на розвиток професійного кругозору студентів з урахуванням формування в них синтаксичної компетентності.

Реалізація поставленої мети передбачає розв'язання низки завдань: окреслити поняття «синтаксичний зв'язок»; висвітлити основні погляди лінгвістів та лінгводидактів на типологію синтаксичного зв'язку словосполучення; сфокусувати увагу на своєрідності виділення типів синтаксичного зв'язку на рівні словосполучення.

Виклад основного матеріалу. Одними із завдань дисципліни «Сучасна українська мова. Синтаксис» $\epsilon$, по-перше, засвоєння студентамифрілологами теоретичних знань із синтаксису сучасної української мови, що дасть змогу краще й повніше кваліфікувати й аналізувати словосполучення та просте двоскладне речення як основні синтаксичні одиниці з опертям на лінгводидактичні принципи викладання граматики (синтаксису) у середній школі, по-друге, ознайомлення третьокурсників із дискусійними питаннями сучасної синтаксичної науки та їх відображенням у підручниках для суб'єктів навчання різних рівнів навчальних закладів.

Між компонентами словосполучення - мінімальними синтаксичними одиницями, наявний синтаксичний зв'язок, що виражає специсріку їх поєднання. «Синтаксичний зв'язок» І.М. Арібжанова потрактовує, як «формальне вираження відношень між фрункційними компонентами, тобто спосіб вираження семантико-синтаксичних відно- шень» [2, с. 75]. К.Ф. Шульжук означене поняття тлумачить так: «фрормальний зв'язок між компонентами синтаксичної одиниці (словосполучення, простого речення, складного речення), виражений відповідними мовними засобами» [24, с. 17].

Аналіз лінгвістичної та лінгводидактичної літератури дав змогу констатувати, що думки вчених розбіжні в окресленні типів синтаксичних зв'язків словосполучення:

1) два види зв'язків: підрядний (односпрямована залежність) та сурядний (відсутність залежності) розглядають такі вчені, як В.А. Бєлошапкова, І.Р. Вихованець, С.О. Караман, В.О. Караман, Б.М. Кулик, М.Я. Плющ, О.С. Мельничук, К.Ф. Шульжук та інші;

2) підрядний зв'язок, заперечуючи сурядний, описано у працях С.П. Бевзенка, Г.Н. Глушкової, В.В. Виноградова, А.П. Загнітка, К.М. Плиско, Н.Ю. Шведової та інших.

Означені підходи ми можемо простежити у десрініціях деяких науковців (див. табл. 1).

Виділення І.Р. Вихованцем сурядного типу словосполучень, пов'язано з тим, що є «спрямованість наускладнення базової реченнєвої схеми» [7, с. 51]. До цього типу мовознавець відносить тільки конструкції 3 однорідними членами речення, що фрункціонують в простому ускладненому реченні. Натомість, О.С. Мельничук виділення означеного типу вбачає у розумінні синтаксичної природи, що проявляється в деяких особливостях структури самих підрядних словосполучень [21, с. 60].

Такі ідеї були підтримані лінгвістами К.Ф. Шульжуком, П.С. Дудиком та Л.В. Прокопчук, де перший дослідник розглядає сурядні словосполучення, в яких однофункціональні компоненти поєднуються за допомогою сполучників сурядності (єднальних, зіставно-протиставних, розділових) та

Таблиця 1

\begin{tabular}{|c|c|}
\hline Сурядний та підрядний зв'язок у словосполученні & Підрядний зв'язок у словосполученні \\
\hline $\begin{array}{l}\text { Словосполучення є непредикативною синтаксичною } \\
\text { одиницею, непредикативним поєднанням на основі } \\
\text { підрядного чи сурядного зв'язку слова з формою слова } \\
\text { або форми слова з формою слова (І.Р. Вихованець) } \\
\text { [5, с. 182-183]. }\end{array}$ & $\begin{array}{l}\text { Словосполучення - це синтаксична одиниця, яка утво- } \\
\text { рюється підрядним прислівним синтаксичним зв'язком } \\
3 \text { двох або більше повнозначних слів } 3 \text { метою розгорну- } \\
\text { того називання певного явища (А.П. Загнітко) } \\
{[12, \text { с. 10]. }}\end{array}$ \\
\hline $\begin{array}{l}\text { Словосполучення - будь-яке поєднання слів, зокрема } \\
\text { і сурядне, тільки не предикативне (В.А. Бєлошапкова) } \\
{[19, \text { с. 548]. }}\end{array}$ & $\begin{array}{l}\text { Словосполучення - це те синтаксичне об'єднання, } \\
\text { яке утворюється поєднанням знаменного слова та } \\
\text { іншого знаменного слова на основі підрядного зв'язку } \\
\text { (Н.Ю. Шведова) }[17, \text { с. } 6] \text {. }\end{array}$ \\
\hline $\begin{array}{l}\text { Словосполучення - синтаксична конструкція, утворена } \\
\text { з двох чи більше повнозначних слів, поєднаних підряд- } \\
\text { ним і сурядним зв'язком (К.Ф. Шульжук) [24, с. 32]. }\end{array}$ & $\begin{array}{l}\text { Словосполучення - це така синтаксична одиниця, що } \\
\text { утворюється поєднанням двох або більше повнознач- } \\
\text { них слів, пов'язаних між собою підрядним зв'язком і } \\
\text { певними лексико-граматичними відношеннями і вира- } \\
\text { жає єдине, але розчленоване поняття (С.П. Бевзенко) } \\
\text { [22, с. 14]. }\end{array}$ \\
\hline $\begin{array}{l}\text { Словосполучення - синтаксична одиниця-конструкція, } \\
\text { яка становить синтаксичну й лексико-семантичну ціліс- } \\
\text { ність щонайменше двох повнозначних слів, поєднаних } \\
\text { підрядним або сурядним зв'язком (П. С. Дудик) } \\
\text { [10, с. 21]. }\end{array}$ & $\begin{array}{l}\text { Словосполучення - це поєднання двох чи більше } \\
\text { повнозначних слів на основі підрядного зв'язку } \\
\text { (І.І. Слинько, Н.В. Гуйванюк, М.Ф. Кобилянська) } \\
{[18, \text { с. } 61] .}\end{array}$ \\
\hline
\end{tabular}


безсполучниково, другі - зауважують, що «сурядні словосполучення створюються паратаксичним (координаційним, узгодженим) зв'язком одиниць, які рівноправні і виконують у реченні ту саму синтаксичну функцію» [10, с. 33].

Виділення сурядних словосполучень простежено в працях лінгводидактів Б.М. Кулика [13], О.В. Караман [20]. Б.М. Кулик звертає увагу на те, що сурядні словосполучення $є$ синтаксично однотипні одиниці та виражають рядпонять, а О.В. Караман зазначає, що вони «утворенні з двох і більше однорідних членів речення, які синтаксично однофункціональні, відповідають на однакове запитання й поєднанні сурядним зв'язком» [20, с. 318].

Отже, виділяючи поряд із підрядними словосполученнями сурядні, науковці говорять про наявність в останніх таких ознак як:

1) компоненти словосполучення поєднуються за допомогою єднальних, зіставно-протиставних, розділових сполучників або без сполучників;

2) їх складники рівноправні (однофрункціональні);

3) компоненти здебільшого морфологічно однакові та виступають однорідними членами речення (однофункціональні).

Втім більш переконливими видається думка вчених, що заперечують сурядний зв'язок на рівні словосполучення. Зокрема, Г.Н. Глушкова, заперечуючи сурядний зв'язок у словосполученні, зауважує: «визначаючи характер сурядного зв'язку, треба мати на увазі, що сурядність - це, перш за все, зв'язок між двома предикативними центрами, між двома орормантами, характер якого кваліфікується як незалежна координація» [9, с. 14].

Т.М. Радіонова, досліджуючи статус, семантику і фрункції ряду в структурі простого речення, наголошувала на тому, що сурядний зв'язок абсолютно не показує одноманітних семантичних відношень між елементами ряду, що спонукає до заперечення однієї з ознак сурядних словосполучень однофункціональність компонентів [16].

А.П. Загнітко, виділяючи три типи синтаксичних зв'язків - 1) реченнєвотвірні, 2) реченнєвомодифрікаційні, 3) словосполученнєвотвіні, до останнього відносить прислівниковий підрядний зв'язок, а «зарахування сурядного зв'язку до цього типу, вбачає у модисрікаційному вияві підрядного словосполучення, що ґрунтується на фрормальному співвияві» [11, с. 17]. Отже, ті поширені словосполучення, у яких наявна однорідність реалізують підрядний зв'язок. Наприклад: зустрівся з мамою i татом $\leftarrow$ зустрівся 3 мамою + зустрівся 3 татом. На думку науковця, «вирізнення сурядних словосполучень на рівні їх відтворюваності $€$ некоректним, що й засвідчує їх констатація як вторинних елементів синтаксичної системи» [11, с. 51].

М.О. Вінтонів зазначає, що «на рівні словосполучення функціює тільки підрядний прислівний синтаксичний зв'язок, який диференціюють а) за семантичною наповненістю (1) сильний; 2) напівслабкий; 3) слабкий), б) за фрормальним виявом» [8].

С.Г. Алексєва вважає, що сурядні словосполучення доцільно кваліфрікувати як сурядні сполучення слів на підставі принципової відмінності - за характером ускладнення; за принципом утворення; за характером синтаксичного зв'язку, його засобах і відношеннях; за обсягами та принципами структурної організації; за характером фрункціонування у структурі речення [1].

Лінгводидакти К.М. Плиско [14] та О.М. Біляєв [23], М.І. Пентелюк [15], підтримуючи ідеї В.В. Виноградова (структура словосполучення характеризується тим, що воно організується біля одного головного слова, що є стрижневим), зауважують, що слова у словосполученні поєднуються підрядним зв'язком (узгодженням, керуванням, приляганням).

Аналіз шкільних підручників 3 української мови восьмого класу 2016 року випуску авторів О.В. Заболотного, В.В. Заболотної; С.О. Карамана, О.М. Грошкіної, О.В. Караман, Л.О. Попової; О.П. Глазової; О.М. Авраменка, Т.М. Борисюк, О.М. Почтаренко дає можливість констатувати, що лінгводидакти підтримують вузький підхід до класифрікації словосполучень. Усіма авторами зазначено, що словосполучення складається з головного та залежного слів, а в переліку, що не $\epsilon$ словосполученням уточнено: однорідні члени речення, поєднання підмета та присудка, складена форма майбутнього часу, складена фрорма ступенів порівняння прикметників і прислівників, складені числівники, сполучення службових слів із самостійними, стійкі сполучення слів і власні назви.

Висновки. Аналіз навчально-методичної літератури показав, що проблема типології синтаксичних зв'язків на сьогодні $€$ невирішеною: одні дослідники говорять про наявність сурядного та підрядного зв'язку у словосполученні, інші - існування тільки другого. Така розбіжність, на нашу думку, спричинена тим, що, по-перше, вчені досі по-різному визначають словосполучення як синтаксичну одиницю, по-друге, виокремлюючи словосполучення у межах речення, деякі науковці звертають увагу на характер ускладнення (однорідні члени речення).

На нашу суб'єктивну думку, необхідно все ж таки наголосити на дисреренціації згаданих типів зв'язку. Саме тому, серед двох репрезентованих концепцій, ми підтримуємо думку тих учених, що виділяють у словосполученні лише підрядний зв'язок.

Поширеним підходом під час вивчення словосполучення у закладах загальної середньої освіти та закладах вищої освіти був та залишається другий підхід - словосполучення утворюється підрядним зв'язком, у якому можна визначити головне та залежне слова, де найяскравіше простежуються особливості валентних потенцій повнозначних слів. 
Визначаючи дидактичний матеріал навчання майбутніх учителів української мови та літератури, педагогові слід зауважувати про існування різних поглядів на типи синтаксичного зв'язку у словосполученні, а доцільність їх розгляду під час занять визначається викладачем.

Перспективу подальших досліджень убачаємо в теоретичному осмисленні сурядних сполучень слів, їх вияв та фрункції на комунікативному рівні; розробленні дидактичного матеріалу з використанням інформаційно-комунікаційних технологій.

\section{БІБЛІОГРАФІЧНИЙ СПИСОК:}

1. Алексеєва С.Г. Сурядні сполучення слів та їх співвідношення зі словосполученнями. Науковий часопис Національного педагогічного університету імені МП Драгоманова. Серія 10 «Проблеми граматики і лексикології української мови» : збірник наукових праць. Київ : Вид-во НПУ імені МП Драгоманова, 2005. Вип. 1. С. 30-37.

2. Арібжанова І.М. Сучасна українська мова. Базові поняття синтаксису : навчальний посібник. Київ : ВПЦ «Київський університет», 2016. 159 с.

3. Балко М.В. До питання про статус сурядних конструкцій у їх співвідношенні 3 категорією словосполучення. URL: http://boOk.net/index.php?p=chapter \&bid=1434\&chapter $=1$.

4. Винградов В.В. Избраные труды. Иследование по русской грамматике. Москва : Наука, 1975. 560 с.

5. Вихованець І.Р. Граматика української мови. Синтаксис : підручник для студентів фрілологічних фракультетів вузів. Київ : Либідь, 1993. 365 с.

6. Вихованець І.Р. Нариси 3 фрункціонального синтаксису української мови : монографрія / відп. ред. К.Г. Городенська. Київ : Наукова думка, 1992. 224 с.

7. Вихованець І.Р. Проблема словосполучення. Українське мовознавство. Вип. 16. Київ : Вища школа, 1989.

8. Вінтонів М.О. Керування як різновид прислівного синтаксичного зв'язку. Українська мова і літераmура. 2017. № 2. С. 3-7.

9. Глушкова Г.Н. Структурно семантичні типи сурядності : автореф. дис. ... канд. фрілол. наук : 10.02.01. Дніпропетровськ, 1998. 16 с.

10. Дудик П.С., Прокопчук Л.В. Синтаксис української мови : підручник. Київ : Академія, 2001. 380 с.
11. Загнітко А.П. Теоретична граматика української мови : Синтаксис : монографрія. Донецьк : ДонНУ, 2001. 662 с.

12.Загнітко А.П. Український синтаксис: теоретико-прикладний аспект. Донецьк, 2009. 137 с.

13. Кулик Б.М. Курс сучасної української літературної мови : у 2 ч. Ч. 2 : Синтаксис : підручник для фракультетів мови і літератури педагогічних інститутів. 1961.284 с.

14.Плиско К.М. Викладання синтаксису української мови. Київ : Рад. школа, 1978. 184 с.

15.Практикум 3 методики навчання української мови в загальноосвітніх закладах: модульний курс : посібник для студентів педагогічних університетів та інститутів / кол. авторів за ред. М. І. Пентилюк. Київ : Ленвіт, 2011. 366 с.

16. Радіонова Т.М. Статус, семантика і функції ряду в структурі простого речення : автореф. дис. ... канд. фрілол. наук : 10.02.01. Донецьк, 2004. 19 с.

17. Русская граматика / гл. ред. Н.Ю. Шведова. Мовсква : Наука, 1980, Т. 2. 717 с.

18. Слинько І.І., Гуйванюк Н.В., Кодилянська Н.Ф. Синтаксис сучасної української мови : проблемні питання : навчальний посібник. Київ : Вища шк., 1994. $670 \mathrm{c}$

19. Современный руский язык : учебник для фрилологических специальностей / под. ред. В.А. Белошапковой. 2-е изд., испр. и доп. Москва : Висш. шк., 1989. $800 \mathrm{c}$.

20.Сучасна українська літературна мова : навчальний посібник для студентів вищих навчальних закладів / С.О. Караман та ін. ; за ред. С.О. Карамана. Київ : Літера ЛТД , 2011. 560 с.

21. Сучасна українська літературна мова. Синтаксис / за заг. ред. І.К. Білодіда. Київ : Наукова думка, 1972. $516 \mathrm{c}$

22. Сучасна українська мова. Синтаксис : навчальний посібник / С.П. Бевзенко, Л.П. Литвин, Г.В. Семеренко. Київ : Вища шк., 2005. 270 с.

23. Українська мова : підручник для 10-11 класів загальноосвітніх навчальних закладів 3 українською та російською мовами навчання / О.М. Біляєв та ін. 7-ме вид., перероб і доп. Київ : Освіта, 2004. 384 c.

24.Шульжук К.Ф. Синтаксис української мови : підручник. Київ : Видавничий центр «Академія», 2004. 408 c. 


\section{ІГРОВІ ТЕХНОЛОГІЇ В МОВНІЙ ПІДГОТОВЦІ ІНОЗЕМНИХ СТУДЕНТІВ GAME TECHNOLOGIES IN THE LANGUAGE TRAINING OF FOREIGN STUDENTS}

УДК 372.881.161.1

DOI https://doi.org/10.32843/2663-

$6085 / 2020 / 24-2.14$

\section{Цимбал Т.М.,}

старший викладач

кафредри мовної підготовки

Харківського національного

автомобільно-дорожнього університету
Статтю присвячено використанню ігрових технологій у мовній підготовці іноземних студентів. Метою статті є аналіз специфоки гри, виділення переваг ігрових методів перед традиційними, характеристика фрункчій ігрової діяльності в мовній підготовці іноземних студентів, специфріки навчальноі гри й етапів їі конструювання, видів ігрових завдань.

Незважаючи на неоднозначність трактувань терміна «гра», загальним для всіх підходів $\epsilon$ розгляд гри як виду діяльності, мотивом якої є отримання позитивних емоцій, нових знань, умінь і навичок, розвиток особистісних якостей і відносин з оточуючими. Гра- це універсальна форма діяльності, яка спрямована на репрезентацію $і$ засвоєння соціального досвіду, створення творчої індивідуальної свідомості. Головними особливостями ігрової діяльності є двоплановість, активність i зацікавленість учасників, колективність, моделювання, проблемність, емоційність, творчий характер. Все че визначає ряд переваг ігрових методів перед традиційними.

Акцентовано увагу на ффункціях ігровоі діяльності в мовній підготовці іноземних студентів.

Підкреслено відмінні риси навчальних ігор: чітко поставлена мета навчання і відповідний їй результат, структурованість, чіткий алгоритм дій. Відповідно, конструювання навчальної гри проходить у чотири етапи.

Залежно від методичних завдань у мовній підготовиі іноземних студентів виділяють базові типи ігрових завдань: некомунікативні, передкомунікативні й комунікативні. Часто ігрові завдання побудовані на основі «ігрових оболонок», які наповнюються конкретним мовним і мовленнєвим матеріалом відповідно до вимог конкретного заняття.

Таким чином, ігрові технології у мовній підготовиі іноземних студентів дають можливість викладачам оптимально використовувати всі рівні засвоєння знань, сприяють більш ефективному досягненню навчальних цілей і гармонізації відносин у студентському колективі.

Ключові слова: ігрові технології, ігрове навчання, навчальна гра, етапи конструювання гри, ігрові завдання.
The article is devoted to the use of gaming technologies in the language training of foreign students. The purposes of the article are to analyze the specifics of the game, highlight the advantages of the game methods over traditional ones, figure out the game activity functions in the language training of foreign students, and describe the specifics of the educational game \& its stages, as well as types of the game tasks. Despite the ambiguity of the definition of the "game" term, the common thing for all approaches is to consider the game as a type of activity with the goal to obtain positive emotions, new knowledge \& skills, develop certain personal qualities and relationships with others. The game is a universal form of activity, which is aimed at the representation and assimilation of social experience and developing of the creative individual consciousness. The main features of the gaming activity are the two-dimensional nature, activity and interest of the participants, teamwork, modeling, problematic, emotional and creative nature. All of this determines a number of advantages of the gaming methods over the traditional ones.

The focus is on the functions of game activity in the language training of foreign students.

A distinctive feature of educational games is emphasized - a clearly set learning objective and the expected result, clear structure and a precise algorithm of actions. Accordingly, the design of the educational game consists of the four stages.

Depending on the methodological tasks in the language training of foreign students, there are three basic types of the game tasks: non-communicative, pre-communicative and communicative. The game assignments are often built as "game shells» that are filled with the specific language and speech material in accordance with the requirements of a particular lesson.

Thus, the gaming technologies in the language training of foreign students enable teachers to effectively use all levels of knowledge acquisition, contribute to more effective achievement of educational objectives and harmonization of the relations in the students' teams.

Key words: game technologies, game training, educational game, game design stages, game tasks.
Постановка проблеми в загальному вигляді. Сучасні соціально-історичні зміни, нові технології, розширення міжнародних зв'язків зумовлюють необхідність постійного вдосконалення системи і практики освіти. Головні тенденції в освіті свідчать про перехід від традиційного підходу у викладанні, сорокусованого на діяльності викладача та навчальному змісті, до особистісно-діяльнісного підходу, де в центрі уваги знаходиться студент, його пізнавальна діяльність. Кардинально змінюється і технологія навчання, суть якої полягає в тому, щоб пробудити пізнавальну активність студента, сприяти становленню самостійності в мисленні й діяльності.
У даний час питання якості мовної підготовки іноземних студентів у начальному закладі вищої освіти отримують особливу значимість у зв'язку 3 тим, що студенти-іноземці першого курсу мають різний рівень мовної підготовки, часто недостатній. Це створює певні складнощі як в організації процесу навчання, так і участі студентів у навчальному процесі. Водночас різко знижується їхня мотивація. Заняття з мовної підготовки перестають бути єдиним і основним джерелом мовних засобів повсякденного спілкування. А включення іноземних студентів у навчальний процес, де відсутня спеціальна орієнтація на їхні мовні вміння, де до якості вмінь і навичок у мовленнєвій діяльності 
на мові навчання пред'являються набагато менші вимоги, ніж до засвоєння знань зі спеціальних дисциплін, створюють у студентів ілюзію достатності вмінь у здійсненні комунікації мовою навчання.

Не менш важливим фрактором $є$ специфіка мовної підготовки: мова навчання $є$ не тільки метою, але й засобом навчання. Це також до певної міри ускладнює навчальну діяльність.

Підвищити мотивацію вивчення мови, інтенсифікувати процес навчання, зробити його активним, плідним і наближеним до природного процесу комунікації рідною мовою, зняти мовний бар'єр здатні ігрові технології.

Саме зростаючий інтерес до нетрадиційних фрорм проведення занять, пошук ефективних способів засвоєння мови навчання, а також комунікативна спрямованість сучасних освітніх технологій визначають актуальність дослідження.

Аналіз останніх досліджень і публікацій. Застосування ігрових технологій в освітньому процесі - проблема не нова. Дослідженням френомену гри займалися Л.С. Виготський, С.Л. Рубінштейн, Д.Б. Ельконін, А.Н. Щукін та ін. [5; 15; 18; 17].

Проблеми стимулювання та мотивації до вивчення іноземної мови з використанням цікавих матеріалів та ігрових прийомів навчання представлені в наукових дослідженнях І. Бім, С.Т. Полат, Є.І. Пассова та ін. [2; 11; 13].

Використання ігрових технологій у середній та вищій школі вивчали А. Панфрілова, А. Вербицький, М. Кларін та ін. [12; 4; 8].

Про значний інтерес педагогів до ігрових методик на уроках російської мови як іноземної свідчить і велика кількість навчальних посібників для викладачів з методичними і навчальними іграми (А.О. Акішина [1], Т.Б. Клементьєва [9], О.Е. Чубарова [16], Т.В. Губанова, О.А. Нівін [7] та інші).

Гра розглядається як основа сучасного уроку, вивчаються особливості використання і включення гри в освітній процес під час освоєння нового матеріалу, процесу підготовки гри, розробки конкретних ігор.

Рік від року ігрові технології стають все більш досконалими. Вони створюються в інноваційному векторі так званого ігрового навчання. Потік навчальних ігор настільки великий, що неможливо встежити за всіма новими розробками та публікаціями в цій галузі, які розкидані по численних журналах. Природно, що це ускладнює знайомство 3 ними широкого кола викладачів і дослідників.

Виділення невирішених раніше частин загальної проблеми. Незважаючи на значну кількість досліджень, проблема використання ігор в освітньому процесі вищої школи залишається актуальною. Подальшого дослідження потребує теоретичне і практичне забезпечення впровадження ігрової технології та методики її застосування в мовній підготовці іноземних студентів.
Метою статті $€$ аналіз специфріки гри як основного елементу ігрових технологій, виокремлення переваг ігрових методів перед традиційними, характеристика фрункцій ігрової діяльності у мовній підготовці іноземних студентів, специоріки навчальної гри та етапів її конструювання, видів ігрових завдань.

Виклад основного матеріалу. Неодноразово виникала спроба наукового визначення гри якимнебудь одним вичерпним поняттям, але на цей момент науково визначені лише зв'язки між грою і людською культурою, з'ясовано значення, яке надає гра розвитку особистості дитини і дорослого, емпіричним шляхом виявлена біологічна природа гри і її зумовленість психічними і соціальними чинниками.

Слід зазначити, що, незважаючи на існуючу неоднозначність трактувань терміна «гра», загальним для всіх підходів є розгляд гри як виду діяльності, мотивом якої $є$ отримання позитивних емоцій, нових знань, умінь і навичок, розвиток особистісних якостей і відносин з оточуючими.

3 точки зору сучасних педагогів гра $€$ універсальною фрормою діяльності, всередині якої відбуваються найбільш прогресивні зміни. Вона спрямована на репрезентацію і засвоєння соціального досвіду, створення творчої індивідуальної свідомості.

Головною особливістю ігрової діяльності $€$ іiі двоплановість. 3 одного боку, гра виконує реальну діяльність, вирішує конкретну задачу, а $з$ іншого боку, ряд моментів діяльності носить умовний характер, дозволяє відволіктися від реальної ситуації. Саме двоплановість зумовлює розвиваючий еорект гри, допомагає зняти психічну напругу, оскільки в разі невдачі гру можна повторити кілька разів. Особливо це відноситься до імітаційних ігор.

Інші особливості гри - це активність учасників, цікавість, колективність, моделювання, проблемність, творчий характер, емоційна забарвленість.

Характеризуючи навчальні ігри у вищій школі, А. Панфрілова називає такі переваги ігрових методів перед традиційними:

- цілі ігрових технологій більшою мірою узгоджуються із практичними потребами студентів;

- навчальна гра дозволяє поєднати широке охоплення проблем, глибину і багатоаспектність їх осмислення;

- ігрова фрорма включає момент соціальної взаємодії, готує до конструктивного професійного спілкування;

- ігрові компоненти сприяють більшому включенню учасників взаємодії у процес навчання, спонукають їх до мимовільної активності;

- ігрові технології насичені зворотним зв'язком, більш змістовним і багатогранним порівняно із традиційними методами; 
- в іграх фрормуються ціннісні орієнтації та настанови професійної діяльності, легше переборюються стереотипи, коригується самооцінка;

- в іграх виявляється особистість учасника, її індивідуальні особливості, стиль ділового партнерства;

- ігрове моделювання сприяє включенню учасників в рефлексію, надає можливість усебічного аналізу, інтерпретації, осмислення отриманих результатів [12, с. 234-235].

У мовній підготовці іноземних студентів ігрова діяльність виконує такі функції:

- пізнавальну (пробудити інтерес до нових знань, нової мови і культури);

- навчальну (розвиток пам'яті, уваги, сприйняття інформації, розвиток основних навчальних умінь і навичок);

- виховну (виховання уважного і гуманного ставлення до партнерів по грі, до інших людей, розвиток почуття взаємодопомоги і взаємопідтримки в особистісному і професійному планах, оскільки, крім спонтанного мовлення, студенти навчаються певним фрразам - кліше мовного і ділового етикету);

- розважальну (створення сприятливої атмосфери на занятті, перетворення заняття в нестандартну подію, що підвищує мотивацію до навчання іноземної мови);

- комунікативну (освоєння діалектики спілкування створення атмосфрери іншомовного спілкування, встановлення нових емоціонально-комунікативних відносин, заснованих на взаємодії іноземною мовою);

- самореалізації в грі як полігоні людської практики;

- релаксаційну (зняття емоційної напруги, що спричинена інтенсивним навчанням іноземної мови);

- ігротерапевтичну (подолання різних труднощів, що виникають як у предметній області, так і в дотичних з нею інших видах життєдіяльності);

- діагностичну (виявлення відхилень від нормативного рівня знань, компетенцій, як в області предметного, так і особистісного розвитку, самопізнання в процесі гри);

- функцію корекції і розвитку (внесення позитивних змін у структуру особистісних і предметних показників в ігрових моделях, наближених до життєвих ситуацій, гармонійний розвиток особистісних якостей і предметних компетенцій, активізація резервних можливостей особистості);

- міжкультурної комунікації (засвоєння єдиних для всіх людей соціально-культурних цінностей);

- соціалізації (включення в систему суспільних відносин, засвоєння норм людського спілкування і взаємодії, занурення в іншомовне середовище і менталітет країни навчання) [10; 6; 18].

Відмінною особливістю навчальних ігор від ігор взагалі $€$ чітка структурованість, наявність явно прописаного алгоритму дій, наявність рольового набору або загальної для всіх учасників ролі. Суттєвою ознакою педагогічної гри є чітко поставлена мета навчання і відповідний їй педагогічний результат, які можуть бути обґрунтовані, виділені в явному вигляді й характеризуються навчальнопізнавальною спрямованістю.

Конструювання навчальної гри охоплює чотири етапи.

На першому етапі визначається мета ігрового заняття. Вона формується, виходячи із завдань навчання, змісту теоретичних проблем, що вивчаються, і тих умінь, які мають бути сорормовані учасниками у процесі гри.

Другий етап присвячений визначенню змісту гри. У процесі конструювання гри варто добирати ситуації, найбільш типові за структурою діяльності для майбутнього фрахівця, що забезпечує профресійне спрямування гри.

На наступному етапі відбувається розроблення ігрового контексту. Він $€$ специярічним й обов'язковим компонентом у конструкції гри і забезпечується введенням комплексу ролей, нових правил, прав і обов'язків учасників, розробленням системи оцінювання, прогнозуванням кінцевих результатів.

На останньому етапі складається структурнофрункціональна програма ігрового заняття, що містить цілі й завдання, опис ігрової обстановки, іï̈ організаційну структуру і послідовність, перелік учасників гри, їхні фрункції, питання і завдання, систему оцінювання тощо [14, с. 106].

Залежно від тих методичних завдань, які вирішуються в процесі гри, у мовній підготовці розрізняють такі базові типи ігрових завдань: некомунікативні, передкомунікативні, комунікативні [3].

Некомунікативні завдання служать для відпрацювання мовних форм і мовних моделей, лексичногоматеріалу, дляфрормуваннямовнихмеханізмів.

Завдання цього типу забезпечують багаторазове повторення, необхідне для засвоєння мовних форм, лексики, інтонаційних конструкцій, мовних моделей.

До ігрових передкомунікативних завдань відносяться завдання для відпрацювання мовних кроків, діалогічної взаємодії. Це своєрідний перехід від оволодіння мовою до оволодіння мовним спілкуванням. Зазвичай це складання діалогів за заданою моделлю або ситуацією, словесних портретів. Багато представлених у навчальній літературі передкомунікативних завдань націлені на розвиток навичок діалогічного мовлення, допомагають учням освоїти форми вираження різних інтенцій і способи їх вживання в мові.

У комунікативних ігрових завданнях передбачається, що досягнення мовного завдання здійснюється в разі самостійного вибору студентами мовних і мовленнєвих засобів. До ігрових завдань такого типу відносяться ток-шоу, постановка п'єс, участь 
у конкурсах та конференціях, рольові та ділові ігри. Комунікативними іграми слід завершувати роботу над темою, використовувати їх для активізації пасивних знань учнів, для мовної та соціокультурної адаптації. Ігрові комунікативні завдання дозволяють організувати на уроці інтенсивне мовне спілкування, максимально наближене до реальної комунікації.

Виявлено, що під час відбору комунікативних завдань для проведення заняття 3 російської мови як іноземної потрібно враховувати: мовний рівень студентів; психологічний вік; темперамент, особливості сприйняття, особливості поведінки (навчання) в групі; умови навчання (діяльність на занятті або самостійна робота). У використанні ігрових технологій навчання найбільшу увагу має бути приділено саме внутрішній мотивації учнів.

Ігрові завдання часто побудовані на основі деяких «ігрових оболонок», які відповідно до потреб конкретного заняття наповнюються різним мовним і мовленнєвим змістом (ігри типу «Лото», «Снігова куля», «Естафрета», ігри «Угадайки» тощо). Однак важливо зауважити, що практично будьяким неігровим завданням викладач може надати ігрову форму, тим самим збільшивши ефективність виконання завдання за рахунок підвищення вмотивованості учнів.

Під час знайомства 3 описом ігрових завдань викладачеві-практику важливо не тільки зрозуміти хід виконання завдання, а й чітко визначити методичні завдання, які вирішуються за допомогою даного завдання. Освоєння викладачем деякої кількості таких ігрових оболонок дозволяє йому використовувати в практиці необмежену кількість ігрових завдань, що складаються самим викладачем для конкретного контингенту і конкретної навчальної ситуації. При цьому мета гри і мета викладача не є одним і тим же. Крім того, як вважає Н.Б. Бітехтіна, ігрові завдання доцільно вводити на всіх етапах роботи над темою [3].

Висновки. Виділені ознаки дозволяють визначити навчальну гру як особливий вид навчальної діяльності, в якій відтворюється соціально-економічна ситуація і відносини між людьми поза реальної практики.

Складність застосування ігрової технології визначається різноманіттям фрорм гри, способів участі в ній студентів і алгоритмами проведення гри. У процесі гри освоюються правила поведінки студентів у соціумі, здобуваються навички спільної колективної діяльності, відпрацьовуються індивідуальні характеристики студентів. Ігрові фрорми навчання дають можливість викладачам оптимально використовувати всі рівні засвоєння знань: від відтворюючої діяльності до творчо-пошукової діяльності. Ігрові технології займають важливе місце в освітньому процесі - вони сприяють не тільки вихованню пізнавальних інтересів та активізації діяльності учнів, а й фрормуванню загальних і професійних компетенцій.

\section{БІБЛІОГРАФІЧНИЙ СПИСОК:}

1. Акишина А.А. Русский язык в играх. Москва : Русский язык. Курсы, 2011. 64 с.

2. Бим И.Л. Некоторые актуальные проблемы современного обучения иностранным языкам. Иностранный язык в школе. 2001. № 4. С. 3-7.

3. Битехтина Н.Б. Игровые задания в обучении русскому языку как неродному : сб. науч.-образ. материалов для учителей рус. яз. московских школ / сост. Н.В. Кулибина. Москва : Гос. ИРЯ им. А.С. Пушкина, 2010. С. 23-60.

4. Вербицкий, А.А. Активное обучение в высшей школе: контекстный подход. Москва : Высшая школа, 1991. 207 c.

5. Выготский Л.С. Детская психология. Собрание сочинений : в 6 т. Москва: Педагогика, 1984. Т. 4. 432 с.

6. Григорьева Е.Я. Типы заданий на развитие лингвистической и речевой компетенции. Язык и культура: проблемы, поиски, решения : материалы II межд. науч.-практ. заочной конф. Ульяновск : УлГОУ, 2009. С. 179-189

7. Губанова Т.В., Нивина Е.А. Русский язык в играх : учебно-методическое пособие. Тамбов : Изд-во ТГТУ, 2007. $80 \mathrm{c}$

8. Кларин М.В. Инновации в мировой педагогике: обучение на основе исследования, игры, дискуссии. (Анализ зарубежного опыта). Рига : НПЦ «Эксперимент», 1995. 176 с.

9. Клементьева Т.Б. Играй и запоминай русские слова. Москва : Русский язык. Курсы, 2014. 26 с.

10. Кречетников К.Г., Ковылина Е.В. Модель применения ролевой игры в обучении иностранным языкам при культурологическом подходе. Инновационные направления в педагогическом образовании : материалы III Всероссийской науч.-практ. Интернет-консреренции, 2010. URL: http://econf.rae.ru/ article/5264 (дата обращения: 10.05.2020).

11. Новые педагогические и информационные технологии в системе образования : учеб. пособие для студ. высш. учеб. заведений / под ред. Е.С. Полат. 4-е изд., стер. Москва : Издательский центр «Академия», 2009. 272 с.

12. Панфрилова А. Игровое моделирование в деятельности педагога : учебное пособие для студентов высших учебных заведений / под общ. ред. В. Сластенина, И. Колесниковой. Москва : Академия, 2006. 368 C.

13.Пассов Е.И. Основы методики обучения иностранным языкам. Москва : Русский язык, 1988. 222 c.

14. Педагогические технологии : учебное пособие для студентов педагогических специальностей / под общ. ред. В. Кукушина. Москва : Март, 2004. 336 с.

15. Рубинштейн С.Л. Основы общей психологии. Москва, 2004. 487 с.

16. Чубарова О.Э. Глаголы движения с приставками: пособие-игра по русскому языку. Москва : Русский язык. Курсы, 2009. 20 с.

17. Щукин А.Н. Современные интенсивные методы и технологии обучения иностранным языкам. Москва : Икар, 2008. 114 с.

18.Эльконин Д.Б. Психология игры. Москва : Просвещение, 1987. 350 с. 


\section{ROLE OF STUDENTS' INDIVIDUAL WORK IN ACQUISITION OF A FOREIGN LANGUAGE РОЛЬ САМОСТІЙНОÏ РОБОТИ СТУДЕНТІВ У ПРОЦЕСІ ОПАНУВАННЯ ІНОЗЕМНОЇ МОВИ}

The article focuses on the essence of individual work for mastering a foreign language, describes the ways of improving students' individual work, highlights the importance of this form of activity in stimulating the speech, improving educational and professional competence. The paper strives to illuminate that one of the most affordable ways to enhance the foreign language competence is by means of activating students' work as an appropriate organization of independent study.

Types, forms and means of individual work used in the higher educational establishment are represented. The content and the objective of student's individual work, plan, methodical literature and assessment are outlined for proper organization of individual work. The article emphasizes the benefits of applying information technologies during students' individual work such as electronic textbooks, multimedia devices, the Internet network, synchronic and postponed teleconferences for communication, blogs, Web-browsers, data bases, searching systems, automatic libraries and electronic magazines specialized sites etc. in order to foster the students' linguistic competence and brush up their foreign language skills. Information and communication technologies are currently of a great interest because they play a crucial role in students' independent work. The ultimate goal of information technologies is to oblige teachers to guide their students to meaningful, ethical and healthy digital literacy as well as provide opportunities for creation of new forms of independent activities, and is characterized by great didactic stimulus and potential.

The necessity of striking a balance between traditional educational technologies and modern information technologies is accentuated. Extensive coverage is given to self-guided work which is to embrace individualization and intensification of the educational process, promotes responsibility for making independent decisions concerning students' activity, planning, organization, assessing, monitoring their performance. Out-of-class independent work guarantees wide opportunities for a student's independence self-improvement, assists in attaining various creative goals, stimulates a cognitive interest and, consequently, increases a steady motivation for the educational process. The research points out that students' independent work is built upon the stimulation of mental activity and creative potential of students, reliance on the previously gained knowledge, diversity of forms and elements of novelty. The findings confirm that proper organization of students' independent work is to intensify future specialist's cognitive activity, facilitate conscious search and analysis of scientific and methodological materials, encourage self-development and motivate to self-study as well as acquire necessary knowledge and skills.

Key words: individual work, homework, information technologies, cognitive activity, foreign language learning, linguistic competence.

у статті порушено тему особливостей організації самостійної роботи студентів у прочесі вивчення іноземної мови, описано шляхи іï вдосконалення, наголошено на важливості чієї фрорми роботи як засобу стимулювання мовлення, вдосконалення навчальної та профресійної компетентності студентів. Обгрунтовано ідею про те, що одним із найдоступніших способів підвищення мовленнєвої компетентності студентів з іноземних мов є активізація самостійної роботи студентів.

Виділено й описано характерні типи, фрорми та засоби самостійної роботи, які використовуються у вищих навчальних закладах. Окреслено зміст та мету самостійної роботи, раціональне планування завдань, підбір навальних матеріалів 3 високим навчально-методичним рівнем та довідковим апаратом, впровадження об'єктивного оцінювання для належної організації самостійної роботи студентів. Запропоновано можливості оптимізації процесу вивчення іноземних мов, зокрема шляхом удосконалення самостійної діяльності студентів.

у статті висвітлено переваги використання інформаційних технологій під час індивідуальної роботи студентів, таких як електронні підручники, мультимедійні пристрої, мережа Інтернет, телеконференції, блоги, веб-браузери, бази даних, системи пошуку, автоматичні бібліотеки та електронні журнали, спеціалізовані сайти тощо, для сприяння мовленнєвої компетентності студентів та підвищення їхніх лінгвістичних знань. Узагальнено практичний досвід використання інформаційних технологій, які відіграють вирішальну роль у самостійній роботі студентів.

Увагу в роботі акцентовано на ролі викладача та його впливі на організацію самостійної роботи студентів закладів вищої освіти, враховуючи індивідуальні особливості студентів. Доведено, що під час застосування інформаційних технологій викладач зобов'язаний орієнтувати своїх студентів на змістовну, етичну та правильну цисррову грамотність. Адже інформаційні технологі покликані надавати можливості для створення нових фрорм самостійної діяльності та характеризуються великим дидактичним стимулом та потенціалом. Наголошується на необхідності досягнення балансу між традиційними освітніми технологіями та сучасними інсрормаційними технологіями. Особливо варто відмітити, що самостійна робота, яка охоплює індивідуалізацію та інтенсифікацію навчально-виховного процесу, сприяє прийняттю самостійних рішень щодо планування та організації самостійно роботи студентів, оцінювання їхніх знань та контролю за їх виконанням. Підкреслюється доцільність автоматизованого контролю та оцінювання знань студентів, який повинен бути регулярним, усебічним і глибоким, спрямованим на виявлення того, чому зміг студент навчитися самостійно, а вже потім на ретельний аналіз помилок у його роботі, ймовірних шляхів і способів їхньої корекції.

Позакласна самостійна робота гарантує широкі можливості для вдосконалення самостійності учня, допомагає досягти різних творчих чілей, стимулює пізнавальний 
інтерес та підвищує стійку мотивацію до навчального процесу. Отримані результати підтверджують, що коректна та виважена організація самостійної роботи студентів це активізація пізнавальної діяльності майбутніх фрахівців, сприяння свідомому пошуку та аналізу наукових та методичних матері- алів, заохочення до саморозвитку та мотивація до самостійного навчання та набуття необхінних знань та навичок.

Ключові слова: самостійна робота, домашні завдання, інорормаційні технології, пізнавальна діяльність, вивчення іноземної мови, мовна компетенція.
Training students in modern higher educational establishments requires a proper organization of the students' independent work which creates the grounds for continuing education, gives the opportunity to improve their various skills and fosters willingness to self-education. A new paradigm to learning a foreign language involves finding the solution to an effective way of training future competitive professionals by developing the skills of independent work, rational application of methods for teaching students to master various language skills and their professional and subject competence.

The study of the student's independent work in the process of language acquisition is relevant under the conditions of tertiary education modernization because it enables the students to activate their potential to learn a foreign language independently, shapes necessary communication skills in every day professional situations.

The reform of various levels of educational establishments involves increasing students' independent activity substantially, which is an important prerequisite for further self-education.

The main objective is to investigate methods for improving students' independent work.

The scientific works of V. Buriak, O. Hurska, Demchenko, I. Dychkivska B. Yesipov, P. Pidkasystyi [1; 2; $3 ; 4 ; 6]$ highlight the essence of the concept, the principles as well as classifications, methods, forms and means of conducting and assessing independent work.

Autonomous learning is researched by I. Bim, I. Zadorozhna, I. Zymnia, S. Nikolaieva, E. Esh, D. Little, W. L. Littlewood, R. Prégent, etc. [10; 11]. W. Littlewood defines autonomy as a certain psychological attitude to the process and the content of educational activities [10, p. 79]. I. Zymnia stresses motivational factor that influences the effectiveness of independent educational activities. General didactic, psychological, methodological aspects of the individual work are researched by $\mathrm{O}$. Hurska [2].

The independent work of students in learning a foreign language envisages processing lexical and grammatical material, developing reading and writing skills, consulting textbooks, dictionaries, reference books, application of computer and multimedia technical modes, the Internet. All of these means provide ample possibilities for students to study the material independently and advance the knowledge of a foreign language.

However, the teacher is in charge of appropriately organizing independent work of students. He/ she is responsible for instructing the students how to manage their independent work in the most productive way, use and filter different sources of information in order to minimize the efforts but maximize the expected outcomes. The teacher's aim is not only to acquaint students with the subject but also to interest them, create conditions for the activation of cognitive activity, arouse desire to study. He/she is able to form the appropriate goals and motives for learning, set the tone, show the direction of the educational movement, determine the individual trajectory of educational activities for each student. Students want to see the lecturers who are capable of conducting a dialogue with the students, an experienced person, who does not teach according to the synopsis, but applies practical experience; the one who makes convincing arguments, giving and analyzing examples from practice; someone who is not only in charge of controlling the students' performance, but also plays an important role as a mentor to the learners, the one who gives guidelines and gives a helping hand with recommendations what material to study and inspires to benefit from self-study.

According to the methodological literature the independent work in a foreign language is understood as an independent educational and cognitive activity of students, which is an integral part of the system organization of the educational process aimed at mastering a foreign language as a means of solving professional problems. It is carried out in collaboration with the teacher, but without his/her direct participation [3, p. 69].

Independent work can be divided into several types: it is conducted during classroom hours, under the supervision of a teacher in the form of consultations, taking tests and exams; outside the classroom when students do homework or make project works.

The organization of independent work precisely is determined by the curriculum and methodological recommendations, and usually consists of the following types of activities:

- preparation for classroom lessons (lectures, practical lessons, seminars, etc.);

- carrying out practical tasks and exercises during the semester;

- independent elaboration of separate themes of the educational discipline due to the curriculum;

- translation of various foreign texts;

- fulfilment of all types of control papers, tests and exams (state exams, graduation qualification works);

- work in student scientific circles, seminars;

- participation in scientific and practical conferences, competitions etc; 
- provision of other types of activities initiated by the university, faculty, department [3].

One of the types of individual work is homework which should be wisely dosed. Homework creates opportunities for training receptive skills, brushing up vocabulary, improving different competences. Home assignments include various exercises that revise the worked-out material and are intended to familiarize the students with new information that will be studied in the classroom [6, p. 18]. The tasks focus on grammar and vocabulary (substitution, use of the necessary forms, sentence transformation, error correction, etc.). When planning homework, the teacher is obliged to be aware of the factors that are related to the students' interest, to the topic and the form of work, their ability to perform the tasks at allocated time.

It is advisable to use the method of project work which is aimed at achieving the predicted positive results of independent work. It allows integrating students' knowledge from different areas for solving various problems, applying the acquired knowledge in practice, generating new ideas. This project work is applicable if the teacher organizes a set of actions which are expected to be performed independently by students and the outcome is the creation of a creative product. The project is valuable because students are taught how to acquire knowledge independently, express their own viewpoints, communicate feelings, gain level of foreign language proficiency, observe the progress made. The project work shows students' active involvement in the real activity, acceptance of personal responsibility for advancement in training. It is intended to transform foreign language lessons in a debate and research club, which solves practical, significant and relevant issues for students.

The project undergoes the following main phases: preparatory, organizational, executive and reflexive. The teacher is to organize strict monitoring of learner's performance to ensure active participation of all students in project activities.

A series of recent studies has indicated that information technology and the Internet also play an important role in organization of the independent work of students. These modes open up new frontiers for securing individualized learning, using forms of pair and group work, and, of course, for optimizing students' independent work.

The independent work of students with the use of information technology embraces a few aspects:

- work with electronic publications in the library;

- performance of individual tasks on the basis of information technologies use;

- electronic testing;

- application of educational sites and automated training software.

Advantages of multimedia training programs are as follows:

- clarity of the material presentation (use of color, illustrations, sound, videos, animations, etc.);
- variety of activities;

- quick feedback (built-in test systems provide instant control over the assimilation of material);

- interactive mode allows controlling the speed of educational material processing and grasping [4, p. 82-85].

Information technology is beneficial in terms of organizing effective and productive individual work. Students can be suggested to write and defense reviews, scientific reports, make profound presentations, prepare and elaborate a report on the specific topic related to the specialism. In that case the following Internet tools are recommended: chat technology, video conferencing, blogs, e-mail, mailing lists, forums. Web forums and chats help students communicate in a foreign language as well as gain experience in intercultural communication. They will not only promote the development of speech skills, but will also have a positive effect on the development of the logical thinking, the ability to respond clearly and quickly to the situation, the formulation of ideas. E-mail is the most well-known and frequently used Internet technology, which allows you to receive written assignments and send checked papers, provide additional support on moot points. Online dialogues can be designed for handling conversations with native speakers and discussing peculiar topics or conducting interviews. The results of the project works are reflected in the form of PowerPoint presentations in the blog of the group, followed by a discussion of the work [5].

Most Internet users fancy blogging, describing things at work, hobbies, their pets, social and political issues. They encourage to use website Blogger (www.blogger.com) or WordPress.

In addition, there are various reference materials in electronic form, dictionaries and encyclopedias namely the ABBYY Lingvo, Oxford, Webster's Dictionary, Longman Dictionary, Macmillan English Dictionary and Britannica Encyclopedia. These resources guarantee fast search for a word with all its definitions and possible grammatical forms, allow listening to the sounded transcription and viewing sentences using this word to better understand its meaning in different contexts $[4 ; 5]$.

Programs for testing a linguistic competence (electronic testing with TOEFL, IELTS, CAMBRIDGE, PTE, FCE etc.) are used to test and control knowledge, determine general level of foreign language proficiency [8, p. 92-95].

These above mentioned examples highlight that information technology gives the opportunity to receive information directly from the Internet, teaches the users not to be limited to only general dictionaries, but also search necessary information from professional topics in explanatory dictionaries, improve reading skills by mastering texts from the Internet, increase listening competence while listening to the authentic materials. Working with audio 
and video services promotes the development of listening and speaking skills [9]. The effectiveness of tasks for self-listening or watching videos in a foreign language as well as creating audio and video files has been proven. Students are eager to use podcast services with audio or video recordings available for download, listening or viewing. It is proved that such materials diversify the activities of students, increase level of motivation to learn a foreign language, enable the students to work with authentic language samples, create a foreign language environment. The effectiveness of videos for communicative language teaching is obvious.

Before being engaged in video activities, students are supposed to do preparatory exercises, a teacher provides students with a series of questions and tasks to predict the content of the film, and checks their readiness to perceive the information. The other exercises assess comprehension of the video extract, as well as the final set of activities concerning the discussion of the video material and completion of grammar, lexical and creative written tasks.

Watching movies and doing exercises promotes memory, attention, logical and creative thinking, as well as deepens students' knowledge about the cultural peculiarities of the language which is being studied [7]. It is vital to remember to strike a balance between traditional educational technologies and modern information technologies. Only in that case the success is guaranteed.

This paper shows that qualitative independent work largely depends on the control exercised under the guidance of a teacher. The control should be regular, comprehensive and deep, aimed primarily at identifying what exactly the student was able to learn independently, and only then include the careful analysis of student's errors, pragmatic ways and means of their correction.

Assessment is also one of the positives factors of intrinsic motivation of the student, as it enhances learning success. Exercises, tests of different levels, situational tasks, role-playing games, project technologies are individual forms of independent work control. The organization of individual work assessment includes specific stages: determination of the purpose of control, development of the content of control tasks and their sequence, choice of forms of control, design of the criteria for evaluating the results of control tasks and requirements for their analysis. Assessment of independent work is also carried out during training sessions. The method of current assessment includes: testing, oral interviews, discussions of the report, active self-control.

The broad implication of the research is that the productivity of students' individual work depends on the objectives and ways of achieving them; cognitive interests and motivation of students; quality of the educational information content for self-study; creation of advantageous conditions for self-realization of a student; the methodological provision of the discipline, its precise planning, organization and management; the competent use of various forms of current and periodic assessment.

The analysis leads to the following conclusions that the use of modern information technology in the organization of independent work of students in the process of a foreign language acquisition in compliance with certain methodological recommendations will promote not only effective elaboration of educational materials, the formation of communicative competence, but also the development of independence as a personality trait, shaping skills of independent search activity, ability to take on responsibility, independently make decisions on planning, organizing, evaluating, testing own activity and its results.

Thus, students of higher education institution should polish the technique of self-study for the subsequent independent acquisition of knowledge. Content, purpose and methodological basis should be clearly defined while preparing for independent work.

Prospects for further research envision the creation of a special methodological support for improving the independent work of students in order to master a foreign language and provision of favorable conditions for the student's self-fulfilment.

\section{REFERENCES:}

1. Буряк В.К. Самостійна робота як системоутворюючий елемент навчальної діяльності студентів. Вища школа. 2008. № 5. С. 10-24.

2. Гурська О.В. Основні аспекти та проблеми організації самостійної роботи студентів ВНЗ. Матеріали Міжнародної науково-практичної конфреренції «Педагогіка А.С. Макаренка в полікультурному освітньому просторі», присвячена 125-й річниці 3 дня народження А.С. Макаренка (м. Полтава, 12-14 березня 2013 р.). С. 78-121.

3. Демченко О. Дидактична система організації самостійної роботи студентів. Рідна школа. 2006. № 5. С. $68-70$.

4. Дичківська І.М. Інноваційні педагогічні технології. Київ : Академвидав, 2004. 351 с.

5. Есенина Н.Е. Обзор электронных образовательных и инсормационных ресурсов для обучения иностранному языку. Информатика и образование. 2006. № 12. C. 103-105.

6. Есипов Б.П. Самостоятельная работа учащихся на уроках. Москва : Просвещение, 1961. 239 с.

7. Літвінчук С.Б. Сучасні підходи до організації самостійної роботи студентів у вищій школі. Наукові праці. Педагогіка. 2012. Випуск 146. Том 158. С. 66.

8. Ніколаєва С.Ю. Сучасні технології навчання іноземних мов і культур у загальноосвітніх і вищих навчальних закладах. Київ : Ленвіт, 2015. 444 с.

9. Олійник Л.Й. Інноваційні технології викладання іноземних мов. URL: http://www.rusnauka.com/ Page ru.htm.

10. Littlewood W. Self Autonomy and independence in language learning. London and New York : Longman, 1997. P. 79-91.

11. Prégent, R. Charting your Course: How to Prepare to Teach More Effectively. Madison : Magna Publications, 1994. 229 p. 


\title{
ПЕДАГОГІЧНА ТЕХНОЛОГІЯ ОРГАНІЗАЦІЇ ПРОФЕСІЙНОГО РОСТУ КОМАНДИРІВ КУРСАНТСЬКИХ ПІДРОЗДІЛІВ ВИЩИХ ВІЙСЬКОВИХ НАВЧАЛЬНИХ ЗАКЛАДІВ ЗБРОЙНИХ СИЛ УКРАЇНИ В СИСТЕМІ ФІЗИЧНОÏ ПІДГОТОВКИ
}

\author{
EDUCATIONAL TECHNOLOGY ORGANIZATION \\ OF PROFESSIONAL DEVELOPMENT OF COMMANDERS OF CADET \\ DIVISIONS OF HIGHER MILITARY EDUCATIONAL ESTABLISHMENTS \\ OF ARMED FORCES OF UKRAINE IN THE SYSTEM OF PHYSICAL TRAINING
}

УДК 355.233.22:355.12

DOI https://doi.org/10.32843/2663-

6085/2020/24-2.16

\section{Шемчук В.A.,}

канд. пед. наук,

начальник науково-дослідного відділу

розвитку фрізичного виховання,

спеціальної фізичної підготовки і спорту

Науково-дослідного центру проблем

фрізичного виховання, спеціальної

фрізичної підготовки і спорту

Петрачков О.В.,

канд. пед. наук, доцент, начальник

Федоренко О.О.,

науковий співробітник

науково-дослідного відділу

розвитку фрізичного виховання,

спеціальної фрізичної підготовки і спорту

Муштатов Ю.В.,

старший науковий співробітник

науково-дослідного відділу

розвитку фрізичного виховання,

спеціальної фрізичної підготовки і спорту

Коновалов Д.О.,

науковий співробітник

науково-дослідного відділу

розвитку фізичного виховання,

спеціальної фрізичної підготовки і спорту

Науково-дослідного центру проблем

фрізичного виховання, спеціальної

фрізичної підготовки і спорту

Навчально-наукового інституту

фрізичної культури

та спортивно-оздоровчих технологій Національного університету оборони

України імені Івана Черняховського
Стаття присвячена актуальним питанням удосконалення системи самоосвітньої діяльності ооріцерів-командирів курсантських підрозділів у напрямі організації та проведення фрорм фрізичної підготовки 3 підлеглим особовим складом (курсантами вищих військових навчальних закладів Збройних Сил України). Головною метою роботи $\epsilon$ визначення, теоретичне обгрунтування та практична апробація педагогічних умов, необхідних для вдосконалення якості керівниитва самоосвітою командирів курсантських підрозділів вищих військових навчальних закладів (ВВНЗ) Збройних Сил України (ЗСУ) у напрямі організації та проведення форм фрізичної підготовки з підлеглим особовим складом. Під час дослідження членами науково-дослідної групи використані такі методи: теоретичний аналіз та узагальнення науково-методичної (спеціальноі) літератури; аналіз інтернет-ресурсів; анкетування; педагогічні спостереження; методи математичної статистики; науковий інструментарій. У результаті дослідження нами встановлено, що педагогічне керівництво самоосвітою орріцерів курсової ланки є відносно тривалим процесом, який включає у свою структуру декілька етапів (мотиваційний, фрункціональний, прикладний, стресостійкий). Динаміка цього процесу залежить від індивідуально-типологічних та психологічних особливостей особистості офріцера, його професійної підготовленості та педагогічного уміння, а також рівня розвитку мотивації, уміння організувати самостійну роботу. Крім чього, під час саморозвитку проявляється ряд особливостей та залежностей, знання та облік яких дозволяє есрективно та раціонально використовувати технологію педагогічного управління зазначеним процесом. Результати дослідження впроваджені в систему профресійної підготовки командирів курсантських підрозділів навчально-наукового інституту фрізичної культури та спортивно-оздоровчих технологій Національного університету оборони України імені Івана Черняховського. Перспективи подальших досліджень, передбачають розроблення комплексу тестових завдань, спрямованих на формування у командирів курсантських підрозділів ВВНЗ ЗСУ методичних знань та практичних навичок у проведенні форм фозичної підготовки. Ключові слова: готовність, етапи, курсанти, методика, офріцери, педагогічні технології, теорія, практична підготовленість, професійна підготовка, самоосвіта, фрізична підготовленість.

The article is devoted to topical issues of improving the system of self-educational activities of officers-commanders of cadet units in the direction of organizing and conducting forms of physical training with subordinate personnel (cadets of higher military educational institutions of the Armed Forces of Ukraine). The main purpose of the work is to determine, theoretically substan tiate and practical approbation of pedagogical conditions necessary to improve the quality of self-education management of commanders of cadet units of higher military educational institutions (HMEI) of the Armed Forces of Ukraine (AFU) in organizing and conducting forms of physical training with subordinate personnel. During the research the members of the research group used the following methods: theoretical analysis and generalization of scientific-methodical (special) literature; analysis of Internet resources; questionnaires; pedagogical observations; methods of mathematical statistics; scientific tools. As a result of the study, we found that the pedagogical guidance of selfeducation of course officers is a relatively long process, which includes in its structure several stages (motivational, functional, applied, stressresistant). The dynamics of this process depends on the individual-typological and psychological characteristics of the officer's personality, his professional training and pedagogical skills, as well as the level of development of motivation, ability to organize independent work. In addition, during self-development there are a number of features and dependencies, knowledge and accounting of which allows you to effectively and efficiently use the technology of pedagogical management of this process. The results of the research are introduced into the system of professional training of commanders of cadet divisions of the educational-scientific institute of physical culture and sports-improving technologies of the National University of Defense of Ukraine named after Ivan Chernyakhovsky. Prospects for further research include the development of a set of test tasks aimed at forming in the commanders of cadet units of higher educational institutions of the Armed Forces of Ukraine methodological knowledge and practical skills in conducting forms of physical training.

Key words: readiness, stages, cadets, methods, officers, pedagogical technologies, theory, practical training, professional training, self-education, physical readiness.
Постановка проблеми у загальному вигляді. Результати контрольних перевірок із фрізичної підготовки офріцерів-командирів курсантських підрозді- лів вищих військових навчальних закладів (ВВН3) Збройних Сил України (ЗСУ) свідчить про те, що наявний рівень індивідуальної фрізичної підготовле- 
ності забезпечує виконання ними завдань за посадовими обов'язками. Однак під час контрольних заходів, спрямованих на визначення рівня сорормованості теоретичних знань та практичних умінь у проведенні фрорм фрізичної підготовки офріцерами курсової ланки, встановлено, що зазначені знання та практичні навички сорормовані на недостатньому рівні та потребують відповідної корекції. Крім цього, контроль за самоосвітньою діяльністю офріцерів курсової ланки в системі їхньої професійної підготовки свідчить про недостатній рівень ії ефективності, що потребує внесення відповідних змін та підкреслює актуальність обраного напряму дослідження.

Зв'язок роботи 3 науковими програмами, планами та темами. Дослідження виконано у відповідності до плану науково-дослідної роботи і дослідно-конструкторських робіт науково-дослідного відділу розвитку фрізичного виховання, спеціальної фрізичної підготовки і спорту науково-дослідного центру проблем фрізичного виховання, спеціальної фрізичної підготовки і спорту навчально-наукового інституту фрізичної культури та спортивно-оздоровчих технологій Національного університету оборони України імені Івана Черняховського (2019-2020рр.).

Аналіз останніх досліджень і публікацій. Система організації професійної підготовки командирів курсантських підрозділів ВВНЗ ЗСУ та інших силових структур України в напрямі їх фрізичного удосконалення розкриті в наукових працях: Балагури Л.О., Болотіна А.Є., Гладкова Г.І., Дудуса А.М., Жембровського С.М., Марищука В.Л., Ольхового О.М., Романчука С.В., Толока І.В., Червоного П.Д., Уліча В.Л., Чуха А.М., Шлямара І.Л., Щьоголєва В.А., та інших учених.

Питанням фрормування педагогічних умов професійного самовдосконалення майбутніх офріцерів із використанням сучасних методів моделювання педагогічних систем і процесів присвячені роботи науковців: Діденка О.В. [1], Кошолапа А.С. [2], Лодатка Є.О. [3], Некрасова С.М. [4], Огнистого А.Н. [5] та інших провідних фрахівців обраного напряму дослідження.

У роботах Піддубного О.Г., Лисака Г.Г., Смірнова Б.П. [6], Ольхового О.М. [7], Глазунова С.І. [8], Романчука С.В. [9] та інших учених розглядаються актуальні питання мотивації до фрізичного виховання офріцерів Збройних Сил України, в тому числі й офріцерів - командирів курсантських підрозділів.

Технології самоосвіти в галузі фрізичної підготовки розкриваються в наукових працях: Перкатого Р.І. [10], Довмантовича Н.Г. [11] та інших фрахівців (Авдеєва А.П., Жорова І.Я., Князєва М.Л., Кузьменко Т.О., Назаренка Л.М.) вище зазначеного напряму.

Варто також зауважити, що самоосвіта здійснюється у відповідності до самоорганізованості та дисциплінованості особистості офріцера у від- повідності до їхніх індивідуально-типологічних та психологічних особливостей, крім цього, враховуються особливості організації та проведення форм фрізичної підготовки з курсантами ВВНЗ ЗСУ (Любчич Р.І., Турчинов А.В., Хацаюк О.В., Ярещенко О.А., та ін.).

Виділення невирішених раніше частин загальної проблеми. Моніторинг науково-методичної та спеціальної літератури (інтернет-джерел) в напрямі організації та проведення форм фрізичної підготовки 3 підлеглим особовим складом офріцерами курсантських підрозділів ВВН3 ЗСУ, а також наявний недостатній рівень сорормованості їхньої самоосвітньої діяльності дозволив нам визначити такі суперечності між:

1) високим рівнем індивідуальної фрізичної підготовленості офріцерів курсової ланки та низьким рівнем теоретичних знань і практичних умінь в організації та проведення фрорм фрізичної підготовки з підлеглим особовим складом;

2) потребою у високопрофресійних кадрах курсової ланки та недостатніми педагогічними умовами формування навичок самоосвітньої діяльності, а також необхідних професійних компетентностей осріцерів.

Слід також зауважити, що, не дивлячись на значну кількість наукових робіт в обраному нами напрямі дослідження, питанням фрормування педагогічних умов необхідних для удосконалення якості керівництва самоосвітою командирів курсантських підрозділів ВВН3 ЗСУ у напрямі організації та проведення фрорм фрізичної підготовки з підлеглим особовим складом нами не виявлено, що потребує додаткового дослідження. Таким чином, у відповідності до моніторингу науково-методичної та спеціальної літератури, попередніх досліджень в зазначеному напрямі [12] нами визначено сутність самоосвіти командирів курсової ланки ВВНЗ у напрямі фрізичного розвитку та удосконалення військовослужбовців ЗСУ, що дозволяє скорегувати тему та завдання дослідження.

Мета статті - визначити, теоретично обґрунтувати та практично апробувати педагогічні умови, необхідні для вдосконалення якості керівництва самоосвітою командирів курсантських підрозділів ВВН3 3СУ у напрямі організації та проведення фрорм фрізичної підготовки з підлеглим особовим складом.

Для досягнення мети дослідження планувалося вирішити такі завдання:

1) здійснити аналіз науково-методичної та спеціальної літератури в напрямі організації професійної підготовки командирів курсантських підрозділів ВВНЗ ЗСУ та інших силових структур України в системі фрізичної підготовки військовослужбовців;

2) визначити кореляційний зв'язок встановлений між стійкою мотивацією до самоосвіти у командирів курсової ланки ВВНЗ ЗСУ в галузі фрізичної 
підготовки та якісної організації фрорм фрізичної підготовки з підлеглим особовим складом;

3) визначити структуру готовності командирів курсової ланки до самоосвіти в системі професійної підготовки;

4) визначити умови, які необхідні для покращення якості педагогічного керівництва самоосвітою офріцерів курсової ланки ВВНЗ ЗСУ;

5) апробувати педагогічні умови, необхідні для вдосконалення якості керівництва самоосвітою командирів курсантських підрозділів ВВНЗ ЗСУ у напрямі організації та проведення фрорм фрізичної підготовки з підлеглим особовим складом.

Виклад основного матеріалу. Дослідження проведено на базі навчально-наукового інституту фрізичної культури та спортивно-оздоровчих технологій Національного університету оборони України імені Івана Черняховського (2019-2020 р.р.). 3 метою якісного відпрацювання завдань та досягнення мети дослідження було створено науководослідну групу, до якої були залучені провідні учені та практики обраного напряму дослідження (к.п.н., доц. Петрачков О.В., к.п.н. Шемчук В.А., заслужений тренер України Хацаюк О.В., Федоренко О.О., Муштатов Ю.В. Коновалов Д.О.).

На першому етапі дослідження (лютий - квітень 2019 рр.) здійснено аналіз науково-методичної та спеціальної літератури в напрямі організації професійної підготовки командирів курсантських підрозділів ВВН3 ЗСУ та інших силових структур України в системі фрізичної підготовки військовослужбовців. Проведений нами моніторинг самоосвітньої діяльності командирів курсової ланки зазначеної силової структури в системі фрізичної підготовки свідчить про те, що педагогічне керівництво цим процесом повинно бути спрямоване на: визначення основних способів самонавчання та самостійної роботи; розвиток в офріцерів курсової ланки внутрішніх мотивів до самоосвіти; розвиток впевненості у власних силах та здібностях під час самоосвітньої діяльності.

На другому етапі дослідження (травень 2019 - травень 2020 рр.), членами науково-дослідної групи було визначено найбільш високий кореляційний зв'язок між стійкою мотивацією до самоосвіти в офріцерів курсової ланки в системі фрізичної підготовки і ефрективної організації та проведення ними фрорм фрізичної підготовки (результати аналізу кореляційних зв'язків викладені у табл. 1).

У відповідності до отриманих результатів, викладених у табл.1, а також в процесі подальшого дослідження та аналізу самоосвітньої діяльності командирів курсової ланки в системі фрізичної підготовки нами визначено структуру їхньої готовності до самоосвіти.

Зазначена структура складається із трьох рівнів, а саме: на першому рівні фрормується готовність до інтерпретуючої діяльності; на другому рівні формується готовність до відтворювальної діяльності та спостерігається збереження домінування зовнішньої мотивації; на третьому рівні формується готовність до особистісної самоосвітньої діяльності.

3 метою визначення умов, які необхідні для покращення якості педагогічного керівництва самоосвітою офріцерів-командирів курсантських підрозділів, нами було проведено анкетування, у якому взяли участь викладачі та офріцери курсо-

Таблиця 1

Аналіз кореляційного зв'язку ефективності професійної діяльності із урахуванням основних компонентів готовності до самоосвіти офріцерів-командирів курсової ланки ВВН3 зСУ

\begin{tabular}{|c|c|}
\hline $\begin{array}{c}\text { Компоненти готовності офіцерів до самоосвіти } \\
\text { в системі фрізичної підготовки }\end{array}$ & $\begin{array}{c}\text { Ефективність професійної } \\
\text { діяльності командирів } \\
\text { курсової ланки }\end{array}$ \\
\hline 1) потреба у всебічному індивідуальному фрізичному розвитку & +61 \\
\hline $\begin{array}{l}\text { 2) розвиток комунікаційних здібностей із метою вирішення службових питань, які } \\
\text { виникають під час виконання фуункціональних обов'язків }\end{array}$ & +59 \\
\hline $\begin{array}{l}\text { 3) стійка мотивація до самоосвітньої діяльності в системі фрізичної підготовки } \\
\text { військовослужбовців }\end{array}$ & +57 \\
\hline $\begin{array}{l}\text { 4) прагнення та пошук нових більш дієвих способів вирішення військово-профе- } \\
\text { сійних завдань засобами фрізичної підготовки військовослужбовців різних вікових } \\
\text { груп та категорій }\end{array}$ & +53 \\
\hline $\begin{array}{l}\text { 5) удосконалення рівня розвитку теоретичних знань, практичних умінь в організа- } \\
\text { ції та проведенні різних форм фрізичної підготовки }\end{array}$ & +41 \\
\hline $\begin{array}{l}\text { 6) посадова потреба у срізичному розвитку підлеглого особового складу під час } \\
\text { фрорм фрізичної підготовки }\end{array}$ & +40 \\
\hline 7) впевненість у власних силах та здібностях в процесі самоосвіти & +39 \\
\hline $\begin{array}{l}\text { 8) зацікавленість сучасними освітніми технологіями, системами підготовки висо- } \\
\text { копрофесійних фрахівців за військово-обліковими спеціальностями }\end{array}$ & +31 \\
\hline $\begin{array}{l}\text { 9) потреба у формуванні індивідуальної методики організації та проведенні спор- } \\
\text { тивно-масової роботи з підлеглим особовим складом }\end{array}$ & +29 \\
\hline $\begin{array}{l}\text { 10) уміння під час самостійної роботи працювати із сучасною науково-методичною } \\
\text { та спеціальною літературою (інтернет-ресурсами) }\end{array}$ & +34 \\
\hline
\end{tabular}


Аналіз виділення компонентів у структурі самоосвітньої діяльності офіцерів-командирів 2 курсової ланки ВВНЗ зСУ в напрямі фрізичної підготовки та спорту

\begin{tabular}{|c|c|c|c|c|}
\hline \multirow{2}{*}{ Учений } & \multicolumn{4}{|c|}{ Компонент } \\
\hline & I компонент & II компонент & III компонент & IV компонет \\
\hline Бойко О.В. & мотиваційний & ціннісний & пізнавальний & $\begin{array}{l}\text { діяльнісний, } \\
\text { особистісний }\end{array}$ \\
\hline Галімов А.В. & $\begin{array}{c}\text { ціннісно- } \\
\text { орієнтаційний }\end{array}$ & $\begin{array}{c}\text { інфрормаційно- } \\
\text { змістовий }\end{array}$ & діяльнісно-технологічний & $\begin{array}{c}\text { узагальнено- } \\
\text { прогностичний }\end{array}$ \\
\hline Кубіцький С.О. & $\begin{array}{c}\text { ціннісно- } \\
\text { мотиваційний }\end{array}$ & когнітивний & практичний & оцінний \\
\hline Маріонда І.І. & змістово-цільовий & мотиваційний & $\begin{array}{l}\text { організаційно- } \\
\text { дііяльнісний }\end{array}$ & $\begin{array}{c}\text { контрольно- } \\
\text { регульований }\end{array}$ \\
\hline Павлов Я.В. & мотиваційний & змістовий & аналітико-оцінний & - \\
\hline Сіцінський А.С. & мотиваційний & когнітивний & операціональний & емоційно-вольовий \\
\hline Старчук О.О. & $\begin{array}{l}\text { особистісно- } \\
\text { мотиваційний }\end{array}$ & змістово-діяльнісний & оцінно-рефрлексивний & - \\
\hline Троцький Р.С. & $\begin{array}{l}\text { мотиваційно- } \\
\text { ціннісний }\end{array}$ & понятійно-змістовий & операційно-діяльнісний & емоційно-вольовий \\
\hline
\end{tabular}

вої ланки ( $\mathrm{n}=27$, осіб). Отриманні результати спеціального анкетування дозволили нам обґрунтувати та здійснити ранжування педагогічних умов, які необхідні для покращення якості педагогічного керівництва самоосвітою офіцерів курсової ланки в напрямі фрізичної підготовки та спорту.

Надалі, у відповідності до аналізу науковометодичних джерел 3 обраного напряму дослідження, нами визначено ряд компонентів, які $€$ спільними (табл. 2).

У відповідності до вище викладеного вважаємо, що структура готовності офріцерів-командирів курсової ланки ВВНЗ ЗСУ до самоосвітньої діяльності в напрямі фрізичної підготовки та спорту містить такі компоненти:

1) мотиваційний - розуміння труднощів службово-бойової діяльності та їх подолання, оцінювання своїх можливостей стосовно управління психічним та фрізичним станом; вирішення завдань 3 оцінки початкового рівня підготовленості офіцерів у галузі фрізичної підготовки різних груп населення, наявність потреби в самоосвітній діяльності та її мотивах, рівня сфрормованості в осріцерів навичок та умінь до самостійної роботи у напрямі фрізичної підготовки;

2) фуункціональний - формування та розвиток необхідних компетентностей, які необхідні для виконання завдань за призначенням у різних умовах службово-бойової діяльності; вирішення завдання 3 планування мети, змісту самостійної роботи, визначення складності завдань, призначених для відпрацювання під час самостійної роботи, враховуючи індивідуальні можливості офріцерів, проведення спеціальних інструктажів перед початком самостійної роботи;

3) прикладний - забезпечення розвитку військово-профресійних рухових дій засобами спеціальної фрізичної підготовки та засобами різних форм фрізичної підготовки; вирішення завдання
3 надання методичної допомоги офріцерам під час відпрацювання самостійних завдань та своєчасного дієвого реагування на пропозиції офріцерів курсової ланки щодо покращення якості організації та проведення фрорм фрізичної підготовки з курсантами різних років навчання;

4) стресостійкий - формування високої психологічної стійкості військово-службовців до несприятливих сракторів службово-бойової діяльності; виховання психофрізичної готовності до проведення контрольних заходів у напрямі організації самоосвітньої діяльності офріцерів досліджуваної категорії; внесення коректив у процес самоосвіти, враховуючи вимоги керівних документів, а також здійснення аналізу ступеня зростання професійної майстерності та досягнення намічених цілей у напрямі самоосвіти офріцерів у галузі фрізичного виховання різних груп населення.

Зазначена технологія була апробована під час педагогічного експерименту. Отримані нами результати свідчать про високу ефективність розробленої технології педагогічного керівництва самоосвітньою діяльністю командирів курсової ланки ВВНЗ ЗСУ. Варто зауважити, що динаміка рівня саморозвитку офіцерів курсової ланки в напрямі фрізичної підготовки та спорту експериментальної групи (Ег, n=15 осіб) була достовірно вищою, ніж у представників контрольної групи (Кг, n=15 осіб). Крім цього, наприкінці педагогічного експерименту рівень саморозвитку у представників Ег склав 4,01 бали (за 5-ти бальною шкалою оцінювання), на відміну від представників Кг, у яких зазначений показник склав 3,71 бали відповідно (при $\mathrm{P} \leq 0,05$ ).

У свою чергу, ссрормованість загальнопедагогічних умінь, теоретичних знань та практичних навичок у проведенні форм фрізичної підготовки 3 курсантами у офріцерів Ег курсової ланки була достовірно вищою, ніж у представників Кг. 
Висновки. Таким чином, у відповідності до вищевикладеного необхідно підкреслити, що педагогічне керівництво самоосвітою офріцерів курсової ланки є відносно тривалим процесом, який включає у свою структуру декілька етапів. Динаміка цього процесу залежить від індивідуально-типологічних та психологічних особливостей особистості офріцера, його профресійної підготовленості та педагогічного уміння, а також рівня розвитку мотивації, уміння організувати самостійну роботу. Крім цього, під час саморозвитку проявляється ряд особливостей та залежностей, знання та облік яких дозволяє ефективно та раціонально використовувати технологію педагогічного управління зазначеним процесом.

Отже, мета роботи досягнута, а поставлені перед нами завдання - виконані. Результати дослідження впроваджені в систему професійної підготовки командирів курсантських підрозділів навчальнонаукового інституту фрізичної культури та спортивнооздоровчих технологій Національного університету оборони України імені Івана Черняховського.

Перспективи подальших досліджень, передбачають розроблення комплексу тестових завдань, спрямованих на формування в командирів курсантських підрозділів ВВНЗ ЗСУ методичних знань та практичних навичок у проведенні фрорм фрізичної підготовки.

\section{БІБЛІОГРАФІЧНИЙ СПИСОК:}

1. Діденко О.В. Педагогічні умови професійного самовдосконалення майбутніх офріцерів : автореф. дис. ... канд. пед. наук : 13.00.04 / НДПсу. Хмельницький, 2003. 13 с.

2. Кошолап А.С. Педагогічні умови підготовки майбутніх учителів до фрізичного самовдосконалення : автореф. дис. ... канд. пед. наук : 13.00.04 / Вінницький державний педагогічний університет імені Михайла Коцюбинського. Вінниця, 2009. 20 с.

3. Лодатко Є.О. Моделювання педагогічних систем і процесів : монографія / Сумський державний педагогічний університет. Слов'янськ, 2010. 148 с.

4. Некрасов С.М. Готовність педагога до прооресійного саморозвитку: сутність, структура, проблеми дослідження. Науковий вісник Меліто-польського державного педагогічного університету імені Богдана Хмельницького. 2010. № 5. С. 200-207.

5. Огнистий А.В., Бірюков О.В. Самостійна робота як шлях мінімізації аудиторних занять з фрізичного виховання у вищому навчальному закладі. Теорія та методика фрізичного виховання. 2009. № 2. С. 38-43.

6. Піддубний О.Г., Лисак Г.Г., Смірнов Б.П. Аналіз існуючої системи підготовки офріцерів та вимог до керівників, що залучені до проведення занять в період первинної військово-професійної підготовки. Педагогіка, психологія та медико-біологічні проблеми фрізичного виховання і спорту. 2004. № 1. С. 41-42.

7. Ольховий О.М. Модульно-рейтингова система підготовки офріцерів-керівників до занять 3 фрізичної підготовки : автореф. дис. ... канд. наук з фріз. виховання і спорту : 24.00.02 / Львівський державний університет фрізичної культури. Львів, 2005. С. 14-15.

8. Глазунов С.І. Проблемы мотивации к физическому совершенствованию офицеров Вооруженных сил Украины. Педагогіка, психологія та медикобіологічні проблеми фрізичного виховання і спорту. 2007. № 1. C. 16-20.

9. Романчук С.В. Недостатки программы формирования мотивации курсантов ВНЗ к занятиям фризической подготовкой и спортом : монографія / ХДАДМ (ХХПІ). Харків, 2007. С. 173-176.

10.Перкатий P.I. Сутність, зміст та структура самоосвітньої компетентності майбутніх офріцерів національної поліції. URL : http:// nbuv.gov.ua/UJRN/ znpnadpcpn_2016_4_19.

11. Довмантович Н.Г. Самоосвітня компетентність майбутніх фрахівців у педагогічній теорії. Педагогічний процес: теорія і практика. 2014. № 3. С. 18-22.

12. Хацаюк О.В. Сутність та структура готовності майбутніх офріцерів НГУ до виконання завдань за призначенням засобами спеціальної фрізичної підготовки. Педагогіка фрормування творчої особистості у вищій і загальноосвітній школах. 2019. № 65 (Т. 2). C. $144-155$ 


\title{
МАСОВІ ВІДКРИТІ ОНЛАЙН-КУРСИ ЯК ІНСТРУМЕНТ ІНТЕРНАЦІОНАЛІЗАЦІЇ ПРОФЕСІЙНОЇ ПІДГОТОВКИ МАЙБУТНЬОГО ПЕРЕКЛАДАЧА
}

\author{
MASSIVE OPEN ONLINE COURSES \\ AS A TOOL OF THE INTERNATIONALIZATION \\ OF PROFESSIONAL TRAINING OF WOULD-BE TRANSLATORS
}

Процеси глобалізації та вдосконалення цифрових технологій підвищують значення інтернаціоналізації вищої освіти завдяки МВОК (масовим відкритим онлайнкурсам) - новому формату віртуальних навчальних середовищ, призначених для участі великої кількості географрічно розпорошених студентів.

Мета. Стаття присвячена виявленню особливостей МВОК як фрактора інтернаціоналізації вищої освіти та можливостей їх використання для професійної підготовки перекладача якміжкультурного посередника. Методологія. Дослідження ґрунтується на результатах аналізу різних наукових поглядів на роль МВОК, відповідних статистичних даних та досвіду їх впровадження в навчальний прочес в Івано-Франківському національному технічному університеті насрти і газу. Результати. Новий тренд, започаткований МВОК в освіті та академічній культурі, сприяє поширенню знань та вдосконаленню змісту і форм навчальної діяльності. Вони стимулюють університети задуматися над викликами інституційної інтернаціоналізації, спрямованої на підвищення та забезпечення якості освіти. МВОК $\epsilon$ ерективними інструментами для навчання протягом усього життя та розвитку професійної компетентності.

Новизна. Досвід використання майбутніми перекладачами МВОК для вивчення англійської мови та теорії і практики комунікації, які розміщені на онлайн-платформі Coursera, підтвердив їхню результативність (76\%) виявив певні труднощі їх освоєння студенmaмu.

Рекомендації. Зважаючи на ефективність МВОК та їхню можливість долати міжкультурні бар'єри у комунікації, запропоновано екстраполювати здобутий досвід у модель змішаного навчання у профресійній підготовці майбутніх перекладачів.

Ключові слова: інтернаціоналізація вищо освіти, масові відкриті онлайн-курси, платформа онлайн-освіти, Coursera, профресійна підготовка, навчання впродовж життя, змішане навчання, перекладач, міжкультурний посередник, міжкультурна компетентність, діалог культур.
Globalization process and the expansion of digital technology are increasing the importance of internationalization of higher education by offering MOOCs (Massive Open Online Courses) a new format of virtual teaching and learning environments designed for the participation of large numbers of geographically dispersed students.

Objective. The article explores MOOCs as an instrument of institutional internationalization of higher education and their opportunities for the professional training of translators as intercultural mediators.

Methodology. This research is based on the study of various publications revealing a diversity of opinions about the role of MOOCs on higher education, MOOCs statistics and the outcomes of pilot investigation of MOOCs potential at the Ivano-Frankivsk National Technical University of Oil and Gas.

Findings: MOOCs are described as an innovative trend in educational policies and academic culture and a rich opportunity to disseminate knowledge and improve content and learning experiences. They are presented as an incentive for universities to reflect on the challenges of institutional internationalization aiming at providing quality enhancement and assurance. Being an important online training system, MOOCs are effective tools for lifelong learning and professional competence development.

Value Added. Several MOOCs provided by Coursera have been effectively integrated into translator training curriculum as they encompass various topics in language learning and communication theory and practice. Within the framework of our research, analytical studies of the MOOCs have shown their merits as well as various educational constraints.

Recommendations. As MOOCs overcome various cross-cultural barriers in communication, they can become an integral part of universities' Translation Studies course offerings in blended learning models.

Key words: internationalization of higher education, MOOC (massive open on-line courses), MOOCs-providers, Coursera, professional training, lifelong learning, blended learning, translator, intercultural mediator.
Постановка проблеми. В умовах глобалізації світових ринків, «розмивання» національних кордонів та невпинного розвитку цифрових технологій вища освіта як важлива сфрера суспільного розвитку переживає складні трансформаційні процеси, результатом яких є створення транснаціонального інтелектуального простору та зближення різних національних освітніх систем завдяки їх інтернаціо- налізації. Один із фракторів, що перетворює освітнє середовище на глобальний простір, є масові відкриті онлайн-курси (далі - MBOK ) (англ. Massive Open Online Courses - MOOCs) 3 різних галузей знань, які можна успішно використовувати і для професійної підготовки майбутніх перекладачів.

Аналіз останніх досліджень і публікацій. МВОК як порівняно новий феномен в інтернаціо- 
налізації освіти є об'єктом активних досліджень. Чимало дискусій ведеться щодо різних аспектів МВОК, зокрема таких як: 1) вплив МВОК на процес інтернаціоналізації вищої освіти (Г. Боул (H. Boal), Р. Гудзон (R. Hudson), Дж. Гудзік (J. Hudzik), Е. ЕгронПолак (E. Egron-Polak)); МВОК як фрактор трансорормації вищої освіти України (Г. Кузьменко, В. Осецький, І. Татомир, О. Хорольський); соціальні смисли, загрози та можливості МВОК (А. Калашникова); 2) теоретичні і методичні засади освітньо-наукової підготовки магістрів в умовах МBOK (І. Бацуровська); методичні аспекти використання МВОК у процесі підготовки майбутніх фрахівців 3 початкової освіти (Л. Колесник), енергетики (В. Олійник), психології (Б. Шуневич) та ін.

Виділення не вирішених раніше частин загальної проблеми. Незважаючи на доволі широке тло розроблення науковцями різних теоретичних та практико-орієнтованих аспектів досліджуваної проблеми, особливості використання МВOК у перекладознавчій освіті потребують глибшого вивчення, що підтверджується незначною кількістю загальнодоступних відповідних наукових інтернет-публікацій.

3 огляду на це мета статті - охарактеризувати особливості МВОК як фрактора інтернаціоналізації вищої освіти та можливості їх використання для профресійної підготовки перекладача як міжкультурного посередника.

Виклад основного матеріалу. Дослідження порушеної проблеми передбачає передусім аналіз основних понять, які відображають ії сутність, та опис МВОК, ефективність використання яких підтверджена практикою їх використання у профресійній підготовці майбутніх перекладачів в Івано-Франківському національному технічному університеті нафтти і газу.

Інтернаціоналізація. Серед часто вживаних у сучасному науково-педагогічному дискурсі термінів, що відображають трансорормації у вищій освіті у глобальному вимірі, - планетаризація, глобалізація, культурна гомогенізація, знаннєва дипломатія, мобільність, трансфер знань, бінаціональні програми, які нерозривно пов'язані з процесом інтернаціоналізації, яка за останні десятиліття перетворилася, за словами Дж. Найт (J. Knight) та Г. де Уіт (H. de Wit), з маргінального концепту на глобальний, стратегічний, основноположний фактор у вищій освіті [10].

Не можна не відзначити, що поняттю «інтернаціоналізація освіти/вищої освіти» притаманна багатоаспектність, що засвідчують наведені нижче визначення вітчизняних та зарубіжних дослідників:

Національний освітній глосарій: інтернаціоналізація (Internationalisation). У вищій освіті це процес інтеграції освітньої, дослідницької та адміністративної діяльності вищого навчального закладу/закладу вищої освіти чи наукової установи з міжнародним складником: індивідуальна мобільність (студентів, науковців, викладачів, адміністративного персоналу); створення спільних міжнародних освітніх і дослідницьких програм; фрормування міжнародних освітніх стандартів 3 метою забезпечення якості; інституційне партнерство, створення освітніх і дослідницьких консорціумів, об'єднань [2, с. 25];

С. Шитікова: інтернаціоналізація вищої освіти процес розвитку вищої освіти на основі міжнародної співпраці та синергії заходів на глобальному, регіональному, національному та інституційному рівнях задля забезпечення і покращення якості вищої освіти відповідно до сучасних викликів [3, с. 11];

Дж. Найт: інтернаціоналізація на національному, секторальному й інституційному рівнях - це процес інтегрування міжнародного, міжкультурного або глобального, вимірів у мету, фрункції або надання послуг у системі вищої освіти [9].

Як засвідчують наведені дефініції, виокремлюють декілька ступенів освітньої інтеграції: глобальний, національний, регіональний, секторальний та інституційний, хоча загалом увиразнюють два основні аспекти: зовнішній і внутнішній - на рівні навчального процесу окремого 3ВО. Одним 3 агентів внутрішньої, інституційної інтернаціоналізації виступають нові онлайн-постачальники, які пропонують великий масив навчальних програм та нові способи надання освіти, зокрема МBOK.

МВОК як освітній формат. Термін "massive open online course", як і акронім "МООС", авторство яких належить визначному канадському лідеру МBOK-руху Д. Корм'є (D. Cormier), інтегрує чотири окремі поняття: Massive/масовий - передбачає велику кількість учасників з усього світу; Open/відкритий - безплатний, на який може зареєструватися будь-хто; Online/онлайн - є у відкритому доступі в мережі Інтернет; Course/курс [6].

Д. Корм'є та інші сподвижниками забезпечення освіти для всіх завдяки цифровим технологіям так визначають МВОК (мовою оригіналу): 1) А МOOC is a course that is open, participatory, distributed, and supports life-long networked learning... A MOOC is not just an online course, it's a way to connect and collaborate while developing digital skills. It's a way of engaging in the learning process that engages what it means to be a student. It's an event where people who care about a topic can get together and work and talk about it in a structured way [6]; 2) A MOOC is an online course with the option of free and open registration, a publiclyshared curriculum, and open-ended outcomes. MOOCs integrate social networking, accessible online resources, and are facilitated by leading practitioners in the field of study. Most significantly, MOOCs build on the engagement of learners who self-organize their participation according to learning goals, prior knowledge and skills, and common interests [18, c. 10]. 
Отже, МВОК - безкоштовні, масові, загальнодоступні онлайн-курси з великомасштабною інтерактивною участю та відкритим доступом через Інтернет, фрормат яких вирізняється відповідністю запитам студента, структурованістю, інтегруванням соціальної та змістової компонент навчання, гнучкими можливостями навчання впродовж життя на фрормування нових компетентностей.

Акцентуючи на потенціалі МВОК, закордонні дослідники так характеризують цей феномен: ключовий інструмент просування освіти на основі компетентностей; цінна освітня ініціатива; педагогічна інновація, визнаний агент змін та фрасилітатор процесу переходу до відкритої освіти, переходу від традиційної освіти в університеті до відкритих онлайн-арен, що збільшує доступ студентів до навчання упродовж життя; агент змін для посилення інновацій у вищій школі; часткові прискорювачі навчання; постачальник інтернетконтенту, який доповнює традиційні заняття під керівництвом викладача [14].

Для визначення сутності МВОК як глобального інноваційного френомена використовують метафрору «фронтир», яка $€$ еквівалентом англомовного "frontier" і яку трактують як рухомий кордон, що розділяє старе і нове, передове і відстале, зрозуміле і незрозуміле та допомагає осмислити явища цифрового суспільства, зокрема Інтернет (Є. Довбиш [1]): фрронтир для інтернаціоналізації (В. Реда (V. Reda), Р. Kepp (R. Kerr) [15]); новий навчальний (I. де Вард (I. de Waard) [7]); новий цифровий контентний фрронтир (P. Даєр (R. Dyer) [8]); фрронтир для відкритої та дистанційної освіти, що дає змогу безкоштовно поширювати курси 3 різноманітним масивом цифрового контенту з точних та гуманітарних наук, мистецтва та бізнесу [8].

МВOK як багатоаспектне явище стало об'єктом для розроблення типологій за різними ознаками. Дж. Реіч (J. Reich) виділив три типи МВОК: 1) ринково-орієнтовані; 2) орієнтовані на відкритий навчальний ресурс; 3) орієнтовані на теорію Дж. Дьюі [16]. Л. Лейн (L. Lane) також виокремив три типи МВОК, однак за іншими ознаками: 1) орієнтовані на створення мереж; 2) орієнтовані на завдання; 3) орієнтовані на контент [11]. 3 огляду на особливості конективістського та когнітивнобігевіористського підходів, Г. Сіменс (G. Siemens) поділив МВOK на дві великі групи: 1) cMOOs, де студент навчається 3 викладачем та 3 іншими учасниками в онлайн-просторі, а успіх навчання залежить від уміння студента працювати з великим обсягом неструктурованої інорормації, орієнтуватися в мережі, фрормувати власне навчальне середовище, експліцитно артикулювати особисті цілі; 2) xMOOCs, де домінує традиційний когнітивно-бігевіористський підхід з традиційною структурою курсу, програмним матеріалом у фрормі високоякісного відеоконтенту та методикою, у якій превалює цілепокладання та автоматизований контроль викладача [17]. У класифікації Д. Кларка (D. Clark), що ґрунтується на навчальних фрункціях, вісім типів МВОК: 1) TransferMOOCs - трансферні курси, аналогічні традиційним щодо передачі контенту: лекції, тексти, оцінювання, короткі екзамени; 2) MadeMOOCs - курси більш інноваційного напряму, які ефективно використовують інтерактивне відео і якісніший супровід; мають більш професійний характер; орієнтовані на більш формальний, якісно-орієнтований підхід до створення навчального матеріалу та складніші завдання, вирішення проблем та набуття інтерактивного досвіду на основі складного програмного забезпечення; передбачає співпрацю учасників та експертну оцінку; 3) SynchMOOCs - синхронні курси $з$ фріксованою датою початку та закінчення; 4) AsynchMOOCs - асинхронні курси 3 гнучкими датами початку i завершення навчання; 5) AdaptiveMOOCs - адаптивні курси, у яких навчання більше спрямоване на персоналізацію на основі збору даних і динамічної оцінки; 6) GroupMOOCs - групові курси, які передбачать співпрацю у малих групах; 7) ConnectivistMOOCs конективістські курси, у яких акцент спрямовано на зв'язки в мережі з колегами; 8) mini-MOOCs - курси для невеликої чисельності студентів [5].

Основними компонентами МВОК $\epsilon$, як правило, короткі тематичні відеолекції, практичні завдання, проміжні тести та фрорум для консультацій із викладачем та обговорення питань курсу 3 іншими учасниками. Персональний профріль учасника МВОК дає змогу викладачеві відстежувати загальну статистику перегляду відеоматеріалів, успішність виконання певного завдання, активність на фрорумі, враховуючи таким чином індивідуальні особливості кожного учасника.

Викладання МВОК забезпечують платформи онлайн-освіти, найпотужнішими серед яких, згідно 3 дослідженнями компанії “MarketsandMarkets's. Research Private Ltd.", є такі як: Coursera (США), edX (США), Pluralsight (США), Edureka (Індія), Alison (Ірландія), Udacity (США), Udemy (США), Miríadax (Іспанія), Jigsaw Academy (Індія), Simplilearn (США), Iversity (Німеччина), Intellipaat (Індія), Edmodo (США), FutureLearn (Великобританія), LinkedIn (США), NovoEd (США), Open2Study (Австралія), WizIQ (Індія), Skillshare (США), XuetangX (Китай), Federica (Італія), Linkstreet Learning (Індія), Khan Academy (США), Kadenze (Іспанія) [13].

Статистичні дані, які є у вільному доступі на платорормі "Class Central" [4], уможливлюють наочно увиразнити основні тренди динаміки зростання популярності МКОК (табл. 1) та їх розподіл за галузями знань (табл. 2).

Дослідження маркетингової компанії "Maximize Market Research, Pvt. Ltd." указують на безсумнівні 
перспективи зростання ринку МВОК. Учені передбачають, що величина інвестицій у розроблення онлайн-платфрорм та контенту досягне у 2026 році 20 мільядів доларів на противагу 4,8 мільярда доларів у 2018 році [12].

МВОК для майбутніх перекладачів. Серед МВOК, які пропонують онлайн-платформи, чимало курсів, щодаютьзмогумодернізуватизмісттаформи професійної підготовки майбутнього перекладача, який у мінливому світі глобальних трансорормацій покликаний стати посередником у діалозі культур для подолання дистанції між комунікантами, що належать до різних лінгвокультурних ареалів.

Одним із безперечних лідерів у наданні МВОК, які сприяють фрормуванню різних компонентів профресійної компетентності перекладача, $€$ "Coursera". Деякі із запропонованих на платформі курсів, різноманітних за тематикою і тривалістю та обов'язковим урахуванням рівня мовної підготовки студентів, були апробовані в групах студентів I-III курсів спеціальності «Філологія (Германські мови та літератури (переклад включно)» (перша мова англійська) в Івано-Франківському національному технічному університеті нафти і газу.

Ефективним доповненням до курсу практичної фонетики став МВОК "Tricky American English Pronunciation", який включає вступ і чотири модулі: "Tricky Consonant Sounds" - 9 відео (58 хв.), 8 матеріалів для самостійної роботи, 5 тестів; "Tricky Vowel Sounds" - 9 відео (50 хв.), 7 матеріалів для самостійної роботи, 5 тестів; "The Music of American English Pronunciation" - 11 відео (66 хв.), 8 материалов для самостійного вивчення, 5 тестів; "Other Tricky Things" - 8 відео (45 хв.), 8 мате- ріалів для самостійної роботи, 5 тестів (https:// www.coursera.org/learn/tricky-american-englishpronunciation\#syllabus).

Студенти другого курсу закінчили курс з граматики та пунктуації "Learn English: Advanced Grammar and Punctuation", який охоплює декілька важливих тем, зокрема: Verb Tenses and Passives; Conjunctions, Connectives, and Adverb Clauses; Noun Clauses and Conditionals; Advanced Grammar \& Punctuation Project. Виконання проєкту передбачає створення граматичного портфоліо вивчених складних англійських граматичних структур, самостійне знімання двох коротких відео, у яких студент демонструє вміння використовувати певні граматичні явища (https://www.coursera.org/ specializations/advanced-grammar-punctuation).

Сприяв набуттю практичного досвіду спілкування студентів інтегративний курс "Speak English Professionally: In Person, Online \& On the Phone". Серед його завдань - поглиблення соціокультурних та прагматичних знань, зокрема усвідомлення значення впливу культури на мовлення, інтеграції вербальних і невербальних засобів комунікації, розпізнавання різних типів мовленнєвих актів та адекватний вибір мовних структур у межах певної ситуації для здійснення відповідного прагматичниого впливу на відносно типового отримувача інфрормації (https://www.coursera.org/learn/speakenglish-professionally\#syllabus).

Пошук МВОК 3 міжкультурної комунікації, які безпосередньо спрямовані на фрормування міжкультурного складника компетентності майбутнього перекладача як надзвичайно важливого аспекту досягнення крос-культурного діа-

Таблиця 1

Динаміка зростання чисельності студентів на МВОК (без урахування Китаю)

\begin{tabular}{|c|c|c|c|c|c|}
\hline № & Провайдер & 2019 & 2018 & 2017 & 2016 \\
\hline 1 & Coursera & $45 \mathrm{млн}$ & 37 млн & 30 млн & $23 \mathrm{млн}$ \\
\hline 2 & edX & 24 млн & 18 млн & 14 млн & 10 млн \\
\hline 3 & Xuetang $\mathrm{X}$ & дані відсутні & $14 \mathrm{млн}$ & 9,3 млн & $6 \mathrm{млн}$ \\
\hline 4 & Udacity & 11,5 млн & 10 млн & $8 \mathrm{млн}$ & $4 \mathrm{млн}$ \\
\hline 5 & FutureLearn & $10 \mathrm{млн}$ & 8,7 млн & 7,1 млн & 5,3 млн \\
\hline 6 & Swayam & 10 млн & дані відсутні & дані відсутні & дані відсутні \\
\hline
\end{tabular}

Таблиця 2

Розподіл МВОК за галузями знань (\%)

\begin{tabular}{|c|c|c|c|c|}
\hline Галузь знань & 2019 & 2018 & 2017 & 2016 \\
\hline Комп'ютерні технології, програмування & 19,8 & 20,4 & 19,9 & 17,4 \\
\hline Бізнес & 19,7 & 18,2 & 18,5 & 19,3 \\
\hline Суспільні науки & 11 & 11,5 & 10,6 & 9,82 \\
\hline Природничі науки & 9,2 & 9,4 & 10 & 10,4 \\
\hline Гуманітарні науки & 8,9 & 9,4 & 9,5 & 9,82 \\
\hline Освіта і навчання & 8,0 & 8,6 & 8,5 & 9,26 \\
\hline Інженерна справа & 7,8 & 7,0 & 7,1 & 6,32 \\
\hline Здоров'я і медицина & 7,4 & 7,2 & 7,2 & 6,78 \\
\hline Мистецтво і дизайн & 5,2 & 5,1 & 5,5 & 6,47 \\
\hline Математика & 2,9 & 3,1 & 3,3 & 3,64 \\
\hline
\end{tabular}


Позитивні характеристики МВОК та проблеми їх використання

\begin{tabular}{|c|c|}
\hline Позитивні характеристики & \\
\hline $\begin{array}{l}\text { - можливість навчання з представниками академічної спільноти } \\
\text { різних університетів світу та професіоналами-практиками; } \\
\text { - доступ до навчальної інорормації, поданої у формі коротких } \\
\text { відеолекцій, кліпів, відео-хостингів, текстових інтернет-ресурсів, } \\
\text { блогів, графрічних матеріалів: діаграми, графріки, таблиці; практичних } \\
\text { завдань та проєктів; } \\
\text { - автоматизована перевірка результатів виконання завдань; поєд- } \\
\text { нання тестів з множинним вибором і відкритих завдань; } \\
\text { - подолання стереотипу щодо вивчення «непотрібних» теоретичних } \\
\text { навчальних дисциплін таустарілого контенту, які пропонуєуніверситет; } \\
\text { - усвідомлення причетності української освіти до міжнарожного } \\
\text { освітньо-прооресійного контексту; } \\
\text { - інтерактивність, наявність декількох каналів зворотного зв'язку } \\
\text { (учасник-викладач, учасник-учасник); } \\
\text { - розуміння навчального процесу як цілеспрямованої діяльності, за } \\
\text { результати якої студент несе відповідальність; } \\
\text { - самостійний аналіз навчальних проблем, вироблення алгоритму } \\
\text { прийняття рішення, пошук альтернативних шляхів їх розв'язання; } \\
\text { - перенесення набутих знань і вмінь у незвичні контексти спілку- } \\
\text { вання та їх актуалізація; } \\
\text { - прозора діяльність учасників; } \\
\text { - чітке визначення кінцевих термінів виконання завдань для плану- } \\
\text { вання власного темпоритму навчання, власної траєкторії засвоєння } \\
\text { матеріалу, підвищення самоорганізованості студентів; } \\
\text { - неорормальна обстановка; } \\
\text { - фрормування уміння неординарно підходити до мовного матеріалу } \\
\text { як засобу комунікації; } \\
\text { - урізноманітнення особистих контактів, фрормування просресійно- } \\
\text { мережевої культури та відчуття приналежності до інфрормаційної } \\
\text { цивілізації та глобального світотворення }\end{array}$ & $\begin{array}{l}\text { тнє вміння орієнтуватися в } \\
\text { рованих масивах інорормації, } \\
\text { іні фрормалізовані формати прак- } \\
\text { вдань для забезпечення автома- } \\
\text { ньої перевірки; } \\
\text { ве оцінювання викладачами } \\
\text { сників; } \\
\text { ння можливостей зворотного } \\
\text { удента і викладача; } \\
\text { навчання та взаємоконсульту- } \\
\text { оруми для обговорень матеріалу } \\
\text { учасниками не завжди допо- } \\
\text { зирішити навчальну проблему } \\
\text { к недостатньої компетентності } \\
\text {; } \\
\text { ання самостійної роботи; } \\
\text { ттій рівень самомонеджменту } \\
\text { ивації, самоконтролю, самодис- } \\
\text { ощо); } \\
\text { наслідок взаємодії з глобальними } \\
\text { ційними мережами; } \\
\text { ятня підговленість студентів для } \\
\text { ня матеріалу з вибраного курсу } \\
\text { к низького рівня як лінгвістичної, } \\
\text { матичної компетентності, яка } \\
\text { ає наявність вміння враховувати } \\
\text { регістр, атмосфреру та тональ- } \\
\text { унікації } \\
\text { авершили навчання і отримали } \\
\text { тивні традиційні завдання) }\end{array}$ \\
\hline
\end{tabular}

логу, засвідчив наявність 55 курсів на платфрормі "Coursera" (станом на 20 березня 2020). До найпопулярніших належать: "Business English for Crosscultural Communication", "Effective Communication in the Globalised Workplace", "International and Cross-Cultural Negotiation"; "Intercultural Management", "Communication strategies for a virtual age"; "Communication in the 21st century workplace"; "Intercultural Communication and Conflict Resolution", "Establishing a professional 'self' through effective intercultural communication", "Engaging in Persuasive and Credible Communication", "Storytelling and influencing: Communicate with impact". Студенти вибирали курс за власним уподобанням.

Результати. Досвід роботи в складних умовах карантину у зв'язку 3 коронавірусною пандемією засвідчив, що МВОК можна ефективно використовувати як складник дистанційного навчання майбутніх перекладачів. Водночас наш експеримент продемонстрував як позитивні характеристики МВОК, так і певні труднощі їх використання. Оминаючи технічні аспекти, зупинимося на деяких ключових моментах, пов'язаних зі змістом, фрормою й оцінюванням, які узагальнені в табл. 3 (без групування та ранжування).

Таким чином, попри наявність зазначених проблем, МВОК виявилися досить ефективним засо- бом фрормування різних складників компетентності студентів. Це дає змогу зробити висновок, що МВОК як компонент внутрішньої інтернаціоналізації освіти, що створює широкий контекст для практики міжкультурної комунікації, доцільно інтегрувати в модель змішаного навчання для професійної підготовки майбутнього перекладача, здатного руйнувати міжмовні та міжкультурні бар'єри в глобальному світі.

Висновки. МВОК як новітнє явище стає невід'ємним елементом глобального освітнього простору. Насамперед вони вистуають одним із агентів інтернаціоналізації ЗВО, покликаної підвищити якість освітніх послуг та подолати бар'єри у процесі переходу від традиційного до змішаного навчання. МВОК як міжнародний компонент збагачує освітній ландшафт, уможливлює їх творче використання для професійної підготовки конкурентоздатних фрахівців, зокрема перекладачів.

У цьому контексті перспективним напрямом дослідження може стати проблема включення МBOK у навчальний процес для створення підвалин незворотного руху української перекладознавчої освіти до міжнародних стандартів професійної компетентності, гармонізації освітньо-професійних програм та інтеграції в глобальну профресійну й освітню спільноту. 


\section{БІБЛІОГРАФІЧНИЙ СПИСОК:}

1. Довбыш Е.Г. Электронный фрронтир как метафора. Журнал фрронтирных исследований. 2016. № 1. C. 100-115.

2. Національний освітній глосарій: вища освіта. 2-е вид., перероб. і доп. / авт.-уклад.: В.М. Захарченко, С.А. Калашнікова, В.І. Луговий, А.В. Ставицький, Ю.М. Рашкевич, Ж.В. Таланова; за ред. В.Г. Кременя. Київ : ТОВ «Видавничий дім «Плеяди», 2014. $100 \mathrm{c}$.

3. Шитікова С.П. Реалізація програм міжнародної співпраці Європейського Союзу як механізм інтернаціоналізації вищої освіти України : авторефр. дис. ... канд. пед. наук : 13.00.06. Ін-т вищої освіти НАПН України. Київ, 2019.18 с.

4. By The Numbers: MOOCs in 2019. Class Central MOOC Report. URL: https://www.classcentral.com/ report/mooc-stats-2019/https://www.classcentral.com/ report/.

5. Clark D. MOOCs: taxonomy of 8 types of MOOC URL: http://donaldclarkplanb. blogspot.com/2013/04/ moocs-taxonomy-of-8-types-of-mooc.html.

6. Cormier D. What is a MOOC? URL: http://www.youtube.com/watch?v=eW3gMGqcZQc.

7. De Waard I. Explore a New Learning Frontier: MOOCs. Learning Solutions Magazine. 2011. July 25. URL: https://learningsolutionsmag.com/articles/721/ explore-a-new-learning-frontier-moocs.

8. Dyer R. Exploring the Relevancy of Massive Open Online Courses (MOOCs): A Caribbean University Approach. Information Resources Management Journal. 2014. (IRMJ), 27 (2). Pp. 61-77.

9. Knight J. Higher Education in Turmoil. The Changing World of Internationalization. Rotterdam, NZ : Sense Publishers, 2008. URL: https://www.sensepublishers.com/media/475-higher-education-inturmoil.pdf.

10. Knight J., de Wit $H$. Internationalization of Higher Education: Past and Future. International higher education. Number 95: Fall 2018. Pp. 2-4. URL: https://doi.org/10.6017/ihe.2018.95.10715.

11. Lane L. Three kinds of MOOCs. Lisa's teaching blog. 2012. URL: http://lisahistory.net/wordpress/2012/08/three-kinds-of-moocs/.

12. Market Scenario. Global MOOC market - Industry Analysis and Forecast (2019-2026). By Type, Course, User, and Geography. URL: https://www.maximizemarketresearch.com/market-report/global-mooc-market/22155/\#.

13. MOOC Market by Component. URL: https://www.marketsandmarkets.com/Market-Reports/ massive-open-online-course-market-237288995.html.

14. Ossiannilsson E., Altinay F., Altinay Z. MOOCs as Change Agents to Boost Innovation in Higher Education Learning Arenas. Education Sciences.2016, 6(3), 25. URL: https://eric.ed.gov/?id=EJ1116796.

15. Reda M. The MOOC BA, a New Frontier for Internationalization. LWMOOCS $V$ - Learning with MOOCS 2018. 26-28 September 2018. Pp. 94-97. URL: https://www.semanticscholar.org/paper/The-MOOCB A \% 2 C - a - N e w - Frontier-for-Reda-Kerr/ 76026c89190462e7add5b264088bc8c1f12e24a3.

16. Reich J. Summarizing all MOOCs in one slide: Market, open and Dewey. EdTech Researcher. Education Week. 2012: URL: http://blogs.edweek.org/edweek/ edtechresearcher/2012/05/all_moocs_explained_market_open_and_dewey.html.

17. Siemens G. MOOCs are really a platform. Elearnspace: Learning, Networks, Knowledge, Technology, Community. 2012. URL: http://www.elearnspace.org/ blog/2012/07/25/moocs-are-really-a-platform/.

18. The MOOC Model for Digital Practice. SSHRC Application, Knowledge Synthesis for the Digital Economy /McAuley A., Stewart B., Siemens G., Cormier D. CC Attribution, University of Prince Edward Island. 2010. URL: https://www.oerknowledgecloud.org/archive/ MOOC_Final.pdf. 
МОТИВАЦІЙНО-ЦІННІСНІ ЗАСАДИ ФОРМУВАННЯ ГОТОВНОСТІ МАЙБУТНІХ ПЕДАГОГІВ ДОШКІЛЬНОЇ ОСВІТИ ДО ЗАСТОСУВАННЯ STЕМ-ТЕХНОЛОГІЙ У ПРОФЕСІЙНІЙ ДІЯЛЬНОСТІ

\section{MOTIVATIONAL-VALUE FOUNDATIONS OF THE FORMATION OF FUTURE PRESCHOOL EDUCATION TEACHERS' READINESS TO USING STEM TECHNOLOGIES IN PROFESSIONAL ACTIVITY}

Статтю присвячено одній 3 актуальних проблем професійної підготовки майбутніх педагогів закладів дошкільної освіти - мотиваційно-ціннісним засадам формування готовності до застосування STEM-технологій у професіійній діяльності. Зокрема, розкрито сутність таких понять, як: «готовність майбутніх фрахівців дошкільної освіти до профресійної діяльності», «фрормування готовності майбутніх педагогів дошкільної освіти до застосування STEM-технологій у профресійній діяльності».

3 огляду на теорію вмотивованості суб'єкта до перетворення об'єктів своєі діяльності з новими властивостями та якостями, зосереджено увагу на мотиваційно-ціннісних засадах формування готовності майбутніх педагогів дошкільної освіти до застосування STEMтехнологій у профессійній діяльності. На основі аналізу наукового доробку про те, що мотивація є регулятором профресійно діяльності та впливає на їі продуктивність, провідним компонентом у структурі готовності майбутніх педагогів дошкільної освіти до застосування STEMтехнологій у профресійній діяльності виділено мотиваційно-ціннісний компонент. Обгрунтовано структуру мотиваційноціннісного компонента, а саме: ступінь сорормованості STEM-освітніх иіннісних орієнтацій; самоаналіз особистості 3 позиції STEM-діяльності; особистісний сенс STEM-діяльності.

У результаті проведеного анкетування визначено основні мотиви, які спонукають майбутніх педагогів дошкільної освіти до застосування STEM-технологій у професійній діяльності: розуміння перспектив саморозвитку в профресії; розвиток творчого мислення; інтелектуальний розвиток; підвищення професійної компетентності; мотив ігри і розваги; досягнення нових педагогічних цілей; соціальна відповідальність.

Окреслено перспективи подальших досліджень у напрямі обірунтування інших компонентів у структурі готовності майбутніх педагогів дошкільної освіти до застосування STEM-технологій у профресійній діяльності: когнітивного, діяльнісного і рефлексивного.
Ключові слова: заклади дошкільної освіти, майбутні педагоги, STEMтехнології, STEM-освіта, професійна підготовка.

The article is devoted to one of the urgent problems of professional training of the future teachers of preschool education institutions - motivational-value foundations of forming readiness for using STEM technologies in professional activity. In particular, the study reveals the essence of such concepts as: "readiness of future preschool education specialists for professional activity", "formation of future preschool education teachers' readiness for using STEM technologies in professional activity".

Given the theory of the subject's motivation for transforming the objects of their activities with new properties and qualities, it is focused on the motivational-value foundations of forming future preschool teachers' readiness to use STEM technologies in professional activities. Based on the analysis of scientific achievements that motivation is a regulator of professional activity and affects its productivity, the leading component in the structure of future preschool teach ers' readiness to using STEM technologies in professional activity is a motivational-value component. The structure of the motivationalvalue component is substantiated, namely: the degree of formation of STEM-educational value orientations; self-analysis of the personality from the standpoint of STEM activity; personal meaning of STEM activity.

As a result of the survey, the main motives that motivate future preschool education teachers to use STEM technologies in professional activity are identified: understanding the prospects of self-development in the profession; development of creative thinking; intellectual development; increase of professional competence; motive of game and entertainment; achievement of new pedagogical goals; social responsibility.

The prospects for further research are seen in substantiation of other components in the structure of future preschool teachers' readiness to use STEM technologies in professional activities: cognitive, activity and reflexive. Key words: preschool education institutions, future teachers, STEM technologies, STEM education, professional training.
Постановка проблеми у загальному вигляді. У сучасному розвитку суспільства спостерігаються важливі процеси, спрямовані на вдосконалення системи профресійної освіти.

Формування готовності майбутніх педагогів дошкільної освіти до застосування STEMтехнологій у професійній діяльності нині $€$ актуальним завданням, що стоїть перед закладами вищої педагогічної освіти.
Дослідження проблеми фрормування готовності до професійної діяльності неможливо здійснювати, не включивши систему активних відносин суб'єкта до об'єкта діяльності, які виражаються у мотивації профресійної діяльності. Домінантною стає підготовка фрахівця, який усвідомлює свою соціальну відповідальність за творчий розвиток особистості дитини, постійно дбає про особистісне і професійне зростання, вміє досягти нових педагогічних цілей. 
Аналіз останніх досліджень і публікацій. Сучасні дослідження провідних науковців розкривають різні аспекти готовності майбутніх педагогів дошкільної освіти. Зокрема, питання теорії та практики фрормування готовності фрахівців закладів дошкільної освіти досліджують: Г. Бєлєнька, А. Богуш, Н. Гавриш, К. Крутій, І. Луценко та інших.

Актуальність запровадження STEM-освіти у профресійній освіті обґрунтовано у роботах науковців О. Патрикеєвої, О. Лозової, С. Горбенко та інших.

Психолого-педагогічний аспект фрормування готовності студентів до розвитку професійних умінь майбутнього педагога у системі дошкільного виховання розглядається у працях: 3. Борисової, Л. Завгородньої, Є. Карпової, О. Кучерявого, Н. Лисенко, Г. Сухорукової та інших.

Проблема мотиваційної готовності є однією із головних у підготовці майбутнього педагога.

Нині держава відводить одну з провідних ролей мотивації навчальної та професійної діяльності. Це пов'язано з тим, що суспільство вимагає від людини активної життєвої позиції, усвідомленості своїх виборів, прийняття відповідальності за життєве самовизначення, готовність підвищувативласний особистісний і професійний рівень, ставити й уміти вирішувати завдання самовдосконалення.

Це сприяє більш якісній підготовці майбутніх фрахівців дошкільної освіти до професійної діяльності, яка потребує нині сорормованих ключових компетентностей концепції «Нової української школи», а саме математичної грамотності, компетентності в природничих науках і технологіях, інорормаційно-цифррової грамотності, уміння навчатися впродовж життя, соціальної й громадянської компетентності, підприємливості, загальнокультурної грамотності, екологічної грамотності і здорового життя, гармонійно входять у систему STEM-освіти, створюючи основу для успішної самореалізації особистості і як фрахівця, і як громадянина [6, с. 21].

Саме мотиваційний компонент навчання не лише забезпечує високі результати за умови безпосереднього педагогічного впливу, а гарантує пролонговану пізнавальну активність у будь-яких ситуаціях життєдіяльності [4, с. 68].

Виділення не вирішених раніше частин загальної проблеми. У результаті аналізу джерельної бази наукових досліджень з'ясовано, що проблема фрормування готовності майбутніх фрахівців дошкільної освіти до професійної діяльності засобами STEM-технологій залишається відкритою. Відсутні дидактичні і методичні аспекти розвитку мотивації та ціннісного ставлення до застосування STEM-технологій у дошкільній освіті.

Мета статті. Метою нашого дослідження було обґрунтування мотиваційно-ціннісних засад готовності майбутніх педагогів до застосування STEM- технологій у професійній діяльності та визначення основних мотивів, спрямованих на фрорсування позитивної мотивації майбутніх педагогів до STEM-освіти, які сприятимуть творчому професійному розвитку; з'ясування значення професійноціннісних орієнтацій, які забезпечують усвідомлену потребу оволодіння основами STEM-діяльності.

Виклад основного матеріалу. Вирішення проблеми формування мотиваційної готовності майбутніх педагогів до застосування STEM-технологій у профресійній діяльності потребує розкриття понять «професійна готовність» та «готовність майбутніх педагогів дошкільної освіти до застосування STEM-технологій у професійній діяльності».

Відповідно до сучасного тлумачного словника: «Готовність - стан, за якого все зроблено, все готово для чого-небудь» [10, с. 32].

А. Леонтьєв визначає готовність як процес формування певних умінь, які своєю чергою проходять такі етапи становлення: 1) процес, що спостерігається ззовні; 2) опанування способами діяльності; 3) готовність особистості самостійно виконувати дії [8, с. 274].

Формування готовності майбутніх фрахівців дошкільної освіти до профресійної діяльності - це накопичення знань, умінь і навичок практичної діяльності у галузі дошкільної освіти. Формування готовності майбутніх фрахівців до практичної роботи спрямоване на підготовку їх до раціональної і досконалої професійної діяльності 3 дітьми дошкільного віку. Від ступеня сорормованості готовності майбутніх фрахівців до подальшої професійної діяльності залежить успішність та ефрективність їх самореалізації у вибраній профресії фрахівця дошкільного освітнього закладу [9, с. 73].

Сучасний процес професійної підготовки майбутніх фрахівців дошкільної освіти ґрунтується на засадах STEM-освіти і використанні STEMтехнологій [3; 7].

Отже, формування готовності майбутніх педагогів дошкільної освіти до застосування STEMтехнологій у професійній діяльності ми розуміємо як інтегральну, профресійну й особистісну характеристику майбутнього педагога, що дає змогу забезпечити раціональну і досконалу профресійну діяльність із дітьми дошкільного віку, основою якої $€$ методологічна єдність природничих, технічних і соціально-гуманітарних наук, що проявляється у застосуванні спільного математичного апарату, інформаційно-комунікаційних технологій, моделювання та міждисциплінарної взаємодії.

Одним із найбільш важливих компонентів готовності до професійно-педагогічної діяльності окремі автори (В. Асєєв, А. Маркова, Дж. Олпорт та інші) виділяють мотиваційну готовність до пошуку і вирішення завдань за межами будь-якого зовнішнього контролю. 
Вітчизняні та зарубіжні вчені Л. Божович, Є. Ільїна, А. Маслоу, А. Матюшкіна, О. Виготський, C. Рубінштейн та інші довели, що мотивація, як рушійна сила діяльності людини, посідає значне місце у структурі особистості. Одні дослідники визначають мотив як предмет задоволення потреби, інші - як спонукальну силу. Найбільш поширеною є думка, що мотивом діяльності є усвідомлена потреба [1, с. 216].

І. Войтович у своїх дослідженнях наголошує, що мотивація є регуляторним компонентом навчальної діяльності, який забезпечує високу результативність навчання унаслідок педагогічного впливу та прогнозує пізнавальну активність студентів і перетворює зовнішню регуляцію на саморегуляцію [2].

Вивчення професійної готовності неможливе без урахування особистісної направленості суб'єкта професійної діяльності. Тому, моделюючи готовність майбутніх педагогів дошкільної освіти до застосування STEM-технологій у вигляді його структури, ми передусім розглядаємо мотиваційноціннісний компонент. Основний зміст цього компонента складається у вмотивованості суб'єкта до перетворення об'єктів своєї діяльності з новими властивостями та якостями; у його прагненні до розвитку наукових знань про об'єкт діяльності; у потребі практичного використання методологічних підходів для вивчення об'єкта та його перетворень.

Ми виходимо з того, що під мотивом («мотив від лат. - спонукати, надавати руху) потрібно розуміти предметний зміст потреби, для задоволення якої суб'єкт здійснює активну, спрямовану діяльність», а «мотивація - спонукання до діяльності людини, пов'язана із задоволенням певних потреб як процес дії мотиву... » [10, с. 66].

Мотиваційно-ціннісний компонент, на думку О. Акімової, являє собою сукупність соціальних установок, мотивів, нахилів, інтересів, потреб, ціннісних орієнтацій і сорормованих психологічних властивостей, які визначають рівень розвитку мотиваційної сорери майбутніх педагогів до вирішення педагогічних проблем та спонукають здійснювати професійну діяльність, спрямовану на вирішення цих проблем [1, с. 146].

А. Маркова зазначає, що мотив у навчанні $\epsilon$ спрямованістю особистості на окремі сторони навчальної роботи, яка виражає внутрішнє ставлення особистості до роботи. Дослідниця поділяє мотиви навчальної діяльності на: 1) пізнавальні мотиви, що мають такі рівні: широкі пізнавальні мотиви (орієнтація на оволодіння новими знаннями), навчально-пізнавальні мотиви (орієнтація на засвоєння способів оволодіння знаннями, прийомів самостійної пізнавальної діяльності), мотиви самоосвіти (орієнтація на набуття додаткових знань і потім на побудову спеціальної програми самовдосконалення); 2) соціальні мотиви, які можуть мати такі рівні: широкі соціальні мотиви (обов'язок і відповідальність, розуміння соціальної значимості учіння), вузькі соціальні (прагнення зайняти певну позицію у стосунках з оточуючими, отримати їхнє схвалення), мотиви соціального співробітництва (орієнтація на різні способи взаємодії з іншими людьми) [4, с. 76].

Мотивація $€$ рушійною силою зовнішньої і внутрішньої активності суб'єкта та посідає провідне місце в структурі особистості [5].

Мотиваційна готовність до професійно-педагогічної діяльності передбачає наявність активної позиції з перетворення дійсності. Відповідно, «мотиваційна готовність до застосування STEMтехнологій» передбачає фрормування позитивного ставлення до впровадження STEM-технологій, наявність певних ціннісних орієнтацій, що базуються на знаннях із галузі STEM-освіти, переконаність у необхідності здійснення STEM-діяльності.

У нашому дослідженні мотиваційно-ціннісний компонент характеризується наявністю у майбутніх педагогів дошкільної освіти системи цінностей, інтересів, потреб і мотивів засвоєння змісту теоретичних та процесуально-методичних аспектів застосування STEM-технологій у професійній діяльності.

Отже, «мотиваційна готовність до застосування STEM-технологій» включає в себе: фрормування позитивної мотивації на здійснення STEM-освіти в професійній діяльності (професійний мотив); емоціонально-особистісний апарат професійної діяльності (комплекс особистісних властивостей, що впливають на мотиви професійної діяльності із забезпечення STEM-освіти учасників освіти).

Такий компонент готовності до професійнопедагогічної діяльності вважаємо за можливе співвіднести з такою характеристикою готовності до застосування STEM-технологій, як дієвість.

Дієвість представимо як «мотиваційну готовність до STEM-освіти», яка припускає спрямованість особистості на STEM-освіту, формування позитивної мотивації на STEM-діяльність.

Мотиваційна готовність до застосування STEMтехнологій передбачає ініціативність педагога, яка проявляється в прагненні до здійснення інноваційної діяльності, підприємливість і здатність до самостійних дій, спрямованих на всебічний розвиток особистості дитини. Таким чином, мотиваційну готовність до застосування STEM-технологій вважаємо за можливе співвіднести 3 ініціативністю педагога. Ініціативність передбачає: здійснення самоосвіти і підвищення професійно-педагогічної кваліфрікації з питань STEM-освіти; потребу педагога у творчому розвитку дітей; здатність спланувати й організувати власне дослідження в аспекті STEM-технологій.

Мотиваційний компонент, що виконує стимулюючу функцію, містить у своїй структурі ціннісні 
орієнтації та мотиви, сукупність яких відображає психологічну готовність до застосування STEMтехнологій у майбутній профресійній діяльності, а також відповідну установку на професійну діяльність, а саме:

1) ступінь сорормованості STEM-освітніх ціннісних орієнтацій;

2) самоаналіз особистості 3 позиції STEM діяльності;

3) особистісний сенс STEM діяльності;

Мотиваційно-ціннісний компонент готовності майбутніх педагогів до застосування STEMтехнологій у професійній діяльності включає в себе:

- усвідомлене розуміння актуальності STEMдіяльності майбутнього педагога дошкільної освіти;

- бажання оволодіти теорією і практикою STEM-освіти у дошкільних закладах;

- мотивацію на підвищення профресійної компетентності у галузі STEM-технологій;

- мотиваційну спрямованість особистості майбутнього педагога на застосування STEMтехнологій і усвідомлену потребу передати їі дітям, пізнавальний інтерес і прагнення до STEMдіяльності, пропаганду STEM-технологій в освітньому процесі;

- творчий підхід до пошуку раціональних засобів STEM-освіти, до впровадження в практику дошкільних заходів інноваційних педагогічних методів, засобів і прийомів навчання, виховання і розвитку дітей;

- ціннісне ставлення до оволодіння основами STEM-освіти як умови підвищення результативності професійної діяльності;

- інтерес до STEM-діяльності, прагнення самостійно ставити і досягати мети такої діяльності, до особистісного саморозвитку, професійного самовдосконалення, самореалізації.

Для визначення основних мотивів, що спонукають майбутніх педагогів дошкільної освіти до застосування STEM-технологій у професійній діяльності, нами проведено анкетування, в якому взяли участь 120 студентів фракультету дошкільної освіти Глухівського національного педагогічного університету імені Олександра Довженка та студентів навчально-наукового інституту педагогіки і психології Сумського державного педагогічного університету імені А.С. Макаренка.

За допомогою анкетування ми з'ясували, що найбільш вираженими мотивами є такі:

- розуміння перспектив саморозвитку в профеciї - 54,17\%;

- розвиток творчого мислення - 48, 33\%;

- інтелектуальний розвиток - 42,50\%;

- підвищення профресійної компетентності $40,83 \%$;

- мотив ігри і розваги - 26,67\%;
- досягнення нових педагогічних цілей $24,17 \%$

- соціальна відповідальність - 20,83\%.

Зміст провідних мотивів указує на усвідомленість вибору цієї профресії більшістю респондентів та розуміння перспектив подальшого професійного розвитку. У багатьох студентів спостерігається позитивне ставлення до діяльності, спрямованої одночасно на STEM-освіту та всебічний розвиток особистості дітей. Виявлялась упевненість, що така діяльність необхідна. Однак при цьому активність більшості майбутніх педагогів у набутті і накопиченні досвіду відповідної діяльності залишалася низькою.

Відповіді на питання анкети показують, що майбутні фрахівці дошкільної освіти розуміють роль STEM-технологій для своєї профресійної діяльності. Водночас вони не володіють достатньою мірою засобами STEM-технологій, оскільки недостатньо отримують відповідні знання в процесі профресійної підготовки, хоча вважають, що дисципліни базового циклу мають досить вагомий вплив для їхньої STEM-освіти.

Серед найменш актуальних мотивів зазначена висока відповідальність вибраної професії, що вказує на невпевненість майбутніх педагогів дошкільної освіти у власній готовності до застосування STEM-технологій у професійній діяльності.

Висновки. Готовність майбутніх педагогів дошкільної освіти до застосування STEMтехнологій у професійній діяльності ми розуміємо як інтегральну, професійну й особистісну якість, що дає змогу забезпечити раціональну і досконалу професійну діяльність із дітьми дошкільного віку, основою якої є методологічна єдність природничих, технічних і соціально-гуманітарних наук, що проявляється у застосуванні спільного математичного апарату, інформаційно-комунікаційних технологій, моделювання та міждисциплінарної взаємодії.

3 огляду на те, що мотивація є регулятором професійної діяльності та впливає наїї продуктивність, провідним компонентом у структурі готовності майбутніх педагогів дошкільної освіти до застосування STEM-технологій у професійній діяльності ми виділяємо мотиваційно-ціннісний компонент.

Мотиваційно-ціннісний компонент передбачає фрормування потреб, інтересів, професійних цінностей, що пробуджує у майбутніх педагогів дошкільної освіти відповідальне ставлення до професійної діяльності, мотивує до засвоєння інноваційних технологій, профресійно спрямовує і слугує орієнтиром у професійному саморозвитку.

Мотиваційний компонент утворює основу для реалізації інших структурних компонентів професійної готовності, тому що саме він характеризує смислову спрямованість особистості майбутнього педагога дошкільної освіти на STEM-освіту та STEM-діяльність. 
Перспективи подальших досліджень ми вбачаємоувизначенніта обґрунтуванні інших компонентів структури готовності майбутніх педагогів дошкільної освіти до застосування STEM-технологій у професійній діяльності, а саме: когнітивного, діяльнісного і рефлексивного.

\section{БІБЛІОГРАФІЧНИЙ СПИСОК:}

1. Акімова О.В. Теоретико-методичні засади формування творчого мислення майбутнього вчителя в умовах університетської освіти : дис. ... доктора пед. наук : 13.00.04. Вінниц. держ. пед. ун-т ім. М. Коцюбинського. Вінниця, 2011. 534 с.

2. Войтович І.С. Мотивація навчання майбутніх учителів у процесі їх підготовки до профессійної діяльності. Наукові записки. Серія: Педагогіка. 2014. № 4. C. 47-59.

3. Малишевська В.О. Проблема використання STEM-технологій у теорії і практиці професійної підготовки майбутніх педагогів дошкільної освіти. Вісник Глухівського національного університету імені Олександра Довженка. Педагогічні науки. 2019. Вип. 3 (41). С. 219-228.

4. Маркова А.К. Психология профессионализма. Москва : Междун. гуман. фонд «Знание», 1996. 309 c.
5. Нечипоренко М. Мотивація як ключовий фрактор майбутніх учителів іноземних мов до профресійно особистісного саморозвитку. Наукові записки. Серія: Педагогіка. 2017. № 2. C. 102-109.

6. Нова українська школа : порадник для вчителя / за ред. Н.М. Бібік. Київ : ТОВ «Видавничий дім «Плеяда», 2017. 206 с.

7. Патрикеєва О., Лозова О., Горбенко С. STEMосвіта: умови впровадження у навчальних закладах України. Управління освітою. 2017. № 1. C. 28-31.

8. Пантюк T.I. Суспільно-педагогічні детермінанти підготовки дітей до школи в Україні: теорія і практика (1945-2017 рр.) : дис. ... докт. пед. наук : 13.00.01. Дрогоб. держ. пед. ун-т ім. Івана Франка; Житомир. держ. ун-т ім. Івана Франка, 2018. 544 c.

9. Бєлєнька Г.В. Підготовка майбутніх вихователів до роботи 3 дітьми дошкільного віку: компетентнісний підхід : монографія / за заг. ред. Г.В. Бєлєнької, О.А. Половіної. Умань : ВПЦ «Візаві», 2015. 208 с.

10. Сучасний тлумачний словник: 65000 слів / за заг. ред. В.В. Дубічинського. Харків : Школа, 2012. $100 \mathrm{c}$. 


\section{МЕТОДОЛОГІЧНІ ЗАСАДИ ФОРМУВАННЯ КУЛЬТУРИ КОНКУРЕНТНИХ ВІДНОСИН У МАЙБУТНІХ ФАХІВЦІВ 3 БІЗНЕС-АДМІНІСТРУВАННЯ \\ METHODOLOGICAL PRINCIPLES OF FORMATION OF THE CULTURE OF COMPETITIVE RELATIONS IN FUTURE PROFESSIONALS FROM BUSINESS ADMINISTRATION}

Стаття присвячена актуальній темі-виявленню та обгрунтуванню методологічних засад формування культури конкурентних відносин у майбутніх срахівців з бізнес-адміністрування. Описані положення $і$ характеристики, отримані в процесі аналізу системного, компетентнісного і діяльніснокультурологічного підходів. Визначено, що формування культури конкурентних відносин у майбутніх фрахівців з бізнес-адміністрування є структурним компонентом загальної системи професійної підготовки профрільних фрахівців у вищій школі, відповідно, має властивості педагогічної системи: ї̈ внутрішній зміст визначається логікою педагогічного процесу і включає в себе мобілізаційний, змістовно-координаційний процесно-моделюючий і контрольно-корегуючий компоненти; структурним елементом $\epsilon$ педагогічна задача, вирішення якої відбувається на різних етапах і стадіях процесу; цілісність системи забезпечується наявністю різноспрямованих зв'язків: прямих, зворотних, паралельних. Обгрунтовано, що компетентність майбутніх фрахівців 3 бізнес-адміністрування можна визначити як наявність умінь, знань та навичок в їх синергетичному взаємозв'язку та взаємозалежності, сорормованих на базі загальної освіти, здатність до їх постійного оновлення, а також особисті якості індивіда, які з набут тям досвіду використовуються під час профресійної діяльності. До основних компетениій належать: інтегральна компетент ність, загальні компетентності, спеціальні (фахові, предметні) компетентності. Встановлено, що діяльнісно-культурологічний підхід - це орієнтація дослідження на вивчення явищ з освоєння особистістю культури, що забезпечує створення культурних цінностей. Формування культури конкурентних відносин ми розглядаємо як діяльність, здійснювану викладачем і студентами, спрямовану на виникнення особистісного новоут ворення - культури конкурентних відносин. Нами було розглянуто зміст і суть цих підходів. Це дало розуміння побудови навчального процесу у вищій школі для підготовки майбутніх фрахівців з бізнес-адміністрування. Положення і характеристики, отримані в процесі аналізу системного, компетентнісного і діяльнісно-культурологічного підходів стосовно проблеми фрормування культури конкурентних відносин у майбутніх фрахівців з бізнес-адміністрування, можуть бути використані як методологічна основа для розробки комплексу методичних умов та інших педагогічних компонентів.

Ключові слова: методологія, підхід, фрормування культури конкурентних відносин, майбутні фрахівиі з бізнес-адміністрування, системний підхід, компетентнісний підхід і діяльнісно-культурологічний підхід.

The article is devoted to a topical issue - the identification and justification of methodological principles of forming a culture of competitive relations in future professionals in business administration. The provisions and characteristics obtained in the process of analysis of systemic, competence and activity-cultural approaches are described. It is determined that the formation of a culture of competitive relations in future specialists in business administration is a structural component of the general system of professional training of specialized specialists in higher education, respectively, has the properties of pedagogical system: its internal content is determined by the logic of pedagogical process, process modeling and control-correcting components; the structural element is a pedagogical task, the solution of which occurs at different stages and stages of the process; the integrity of the system is ensured by the presence of multidirectiona connections: direct, inverse, parallel. It is substantiated that the competence of future business administration specialists can be defined as the presence of skills, knowledge and skills in their synergetic relationship and interdependence, formed on the basis of general education, the ability to constantly update them, as well as personal qualities of an individual, used in professional activities. The main competencies include: integrated competence, general competencies, special (professional, subject) competencies. It is established that the activity-cultural approach is the orientation of the research on the study of the phenomena of personal development of culture, which ensures the creation of cultural values. We consider the formation of a culture of competitive relations as an activity carried out by teachers and students, aimed at the emergence of a personal innovation - the culture of competitive relations. We have considered the content and essence of these approaches. This gave an understanding of the construction of the educational process in higher education to train future professionals in business administration. Provisions and characteristics obtained in the process of analysis of systemic, competency and activity cultural approaches to the problem of forming a culture of competitive relations in future business administration professionals can be used as a methodological basis for developing a set of methodological conditions and other pedagogical components.

Key words: methodology, approach, formation of culture of competitive relations, future specialists in business administration, system approach, competence approach and activity-culturological approach.
Постановка проблеми у загальному вигляді. Аналіз різних досліджень показує, що дотепер у теорії і практиці науки зібраний достатній обсяг інсрормації з проблем профессійної підготовки майбутніх срахівців різного спрямування й срормування у них професійної культури. Водночас проблема 
фрормування у майбутніх фрахівців з бізнес-адміністрування культури конкурентних відносин досі розроблена слабо: відсутні публікації з такої тематики, процес не систематизований, не розроблено змістове наповнення, етапи, стадії, критерії оцінки сорормованості такого виду культури. Тому першочерговим завданням нашого дослідження $€$ розробка деяких основ педагогічної системи, що органічно вписуються в процес професійної підготовки майбутніх фрахівців у ЗВО і дають змогу цілеспрямовано фрормувати культуру конкурентних відносин.

Зокрема, ключовою вимогою у виборі стратегії педагогічного дослідження $є$ визначення методологічних засад наукового пошуку, сукупності способів, засобів і прийомів наукового пізнання, які визначають тактичні вектори реалізації поставлених завдань. Йдеться про те, що засобами методологічного аналізу варто визначити такий понятійно-категоріальний апарат, відібрати таку номенклатуру методів дослідження, які були б адекватними вибраній стратегії.

Аналіз останніх досліджень та публікацій. Напрацювання у сорері методології педагогіки як теорії методів науково-педагогічного дослідження, як основи професійної підготовки майбутніх фрахівців різних напрямів представлені у дослідженнях низки вчених (І. Андрощук [1]; Г. Євтушенко [2]; А. Жиліна [3]; В. Кизенко і Д. Трубачова [4]; Р. Кубанов [6]; О. Очарук [9]; Т. Сорочан, А. Данильєв, Б. Дьяченко, О. Рудіна [11] та ін.).

Метою статті $€$ виявлення та обґрунтування методологічних засад формування культури конкурентних відносин у майбутніх фрахівців з бізнесадміністрування.

Виклад основного матеріалу. Культура конкурентних відносин, як зазначалося раніше, є інтегративним особистісним новоутворенням і вимагає цілеспрямованого фрормування. Для цього нам необхідно розробити основніелементи методології.

Методологію в педагогіці розглядають як «сукупність теоретичних положень про педагогічне пізнання і перетворення дійсності» [10, с. 147]. До методологічних основ у сучасній науці прийнято відносити підходи. Зокрема, поняття «підхід» використовується як сукупність наукових ідей, методів, принципів, що знаходяться в основі рішення проблем. На думку Е. Яковлєва, у наукових дослідженнях «підхід» розглядається як складне явище, що являє собою комплекс парадигматичних, синтагматичних і прагматичних структур та механізмів у пізнанні та практиці. Ми, приймаючи точку зору і погоджуючись 3 думкою автора, бачимо методологічну роль підходів у поданні сукупності узагальнених наукових положень із досліджуваної теми, в характеристиці різних напрямів її дослідження і в організації діяльності самого дослідника [12, с. 41]. Отже, методологічний підхід - це коли на базі емпіричних і теоретичних досліджень формулюються загальні принципи і методи дослідження педагогічних явищ, побудови теорії.

Ми вважаємо за доцільне використовувати в нашому дослідженні кілька методологічних підходів, а саме: системний, компетентнісний і діяльнісно-культурологічний. Обґрунтуємо свій вибір. 3 огляду на те, що немає універсального підходу, здатного вирішити одночасно всі дослідницькі завдання, а також той фракт, що у кожного з підходів $є$ свої сильні і слабкі сторони, виникає необхідність використання декількох підходів.

Системний підхід $€$ загальнонауковою основою, що орієнтує нас підходити до досліджуваних явищ життя як до системи. Система являє собою «певний порядок, фрорму організації чогонебудь» [8, с. 719]; а система педагогічна - це «сукупність взаємопов'язаних засобів, методів і процесів, необхіднихдлястворенняорганізованого, цілеспрямованого педагогічного впливу на формування особистості із заданими якостями» [5, с. 136].

За переконанням А. Жиліної, прийнявши системний підхід як методологічну основу дослідження будь-якої педагогічної системи, необхідно встановити відповідність системних властивостей освітньої системи потребам суспільства. «Системний підхід - це насамперед сукупність методів пізнання (системний аналіз, системне програмування, системне проєктування та ін.), дослідження і конструювання дійсності, спосіб опису і пояснення природи аналізованих або штучно створюваних об'єктів або їх моделей» [3, с. 15]. Саме тому він дає змогу досліджувати кожен компонент системи професійної підготовки майбутнього фрахівця, сукупність структурних зв'язків між окремими елементами системи, визначати функції елементів системи й механізми їх функціонування, побудувати модель і систематизувати педагогічні умови щодо якісної підготовки фрахівця тощо. Р. Кубанов зазначає, що універсальність категорій «система», «елемент», «структура», які в сукупності характеризують системний підхід, дають можливість їх використання для різних об'єктів пізнання, зокрема і до явищ правового характеру [6, с. 15].

У ході теоретико-методологічного аналізу ми з'ясували, що системними характеристиками будь-якого досліджуваного френомена (а в нашому випадку - це «формування культури конкурентних відносин у майбутніх фрахівців з бізнес-адміністрування») $\epsilon$ елемент, компонент, зв'язки та системоутворюючі чинники. Далі розглянемо ці характеристики стосовно нашої проблеми дослідження. По-перше, слід зазначити, що фрормування культури конкурентних відносин у майбутніх фрахівців 3 бізнес-адміністрування $€$ структурним компонентом загальної системи професійної підготовки профрільних фрахівців у ЗВО. По-друге, такий френомен має характеристики, що прийнятні для будьякої педагогічної системи, а саме: відкритість, 
гнучкість, керованість, безперервний розвиток, варіативність тощо. По-третє, з огляду на те, що досліджуваний френомен $є$ компонентом системи професійної підготовки майбутніх фрахівців з бізнес-адміністрування у ЗВО, то, відповідно, має властивості педагогічної системи: 1) її внутрішній зміст визначається логікою педагогічного процесу і включає в себе мобілізаційний, змістовнокоординаційний, процесно-моделюючий і контрольно-корегуючий компоненти; 2) структурним елементом $€$ педагогічна задача, рішення якої відбувається на різних етапах і стадіях процесу; 3) цілісність системи забезпечується наявністю різноспрямованих зв'язків: прямих, зворотних, паралельних тощо.

Отже, процес фрормування культури конкурентних відносин у майбутніх фахівців з бізнес-адміністрування ми розглядаємо як педагогічну систему, що характеризується цілісністю, змістовністю і взаємозв'язками елементів.

Далі розглянемо компетентнісний підхід. Головним напрямом розроблення проблеми підготовки майбутніх фрахівців з бізнес-адміністрування у вищій освіті $€$ узагальнення конкретно-емпіричного досвіду сумісної діяльності учасників цього процесу за крайньої абсолютизації його психологічного й суб'єктивно-особистісного аспектів. Головна мета - фрормування компетентності у майбутнього фрахівця.

Ідея компетентнісного підходу - одна 3 відповідей на запитання: який результат освіти необхідний особистості і сучасному суспільству? У процесі розв'язання цього завдання вирішується проблема фрормування професійної компетентності фрахівця, що передбачає посилення практичної спрямованості освіти за умови збереження ії фундаментальності. Компетентнісний підхід включає два поняття «компетентність/компетенція». Т. Сорочан стверджує, що компетенція - це повноваження профресіонала на певній посаді, а компетентність - це загальна здатність до їх реалізації у профресійній діяльності [11, с. 23].

У наукових дослідженнях європейської системи освіти компетентність трактується дослідниками як спроможність особистості сприймати та відповідати на індивідуальні та соціальні потреби, комплекс ставлень, цінностей, знань і навичок [9, с. 7]. На думку В. Маслова, компетентність виявляється у готовності людини на професійному рівні виконувати свої посадові та фрахові обов'язки відповідно до сучасних теоретичних надбань, кращого досвіду, наближення до світових вимог і стандартів. Компетентність $€$ поєднанням такого рівня науки і практики у діяльності конкретної людини, який дає їй змогу постійно забезпечувати високий кінцевий результат, досягати ефективної організації особистої й колективної праці та $є$ результатом ґрунтовної базової підготовки, творчої діяль- ності [7, с. 82]. Зважаючи на наведені трактування терміна «компетентність», можна побачити, що їх більшість стосується досить широкого кола професійних умінь та навичок фахівців, що достатньою мірою володіють ними і здатні професійно виконувати поставлені завдання, спрямовані на управління підприємством певної галузі. Зазначене визначення дає змогу зрозуміти, що під час підготовки фрахівців закладам вищої освіти потрібно орієнтуватись на певну галузеву специфріку. Разом 3 тим $€$ більш важливі чинники, які потрібно враховувати під час формування вмінь і навичок майбутніх фрахівців 3 бізнес-адміністрування.

Ми погоджуємося 3 думкою Г. Євтушенко і В. Куценко, що велике поширення та проникнення різних загальних та специфічних тенденцій розвитку світової економіки забезпечує специфіку менеджменту на підприємствах та породжує необхідність вирішення різнопланових завдань. Ці обставини вимагають зміни та пристосування освітніх програм з підготовки майбутніх фрахівців для фрормування їхньої професійної компетентності. У майбутньому вимоги до управління підприємствами постійно зростатимуть, що в теперішніх умовах потребує забезпечення передумов до розвитку профресійної компетентності фрахівців, здатних аналітично та творчо мислити, впроваджувати інноваційні розробки, раціонально вирішувати поставлені завдання [2, с. 15].

Аналіз психолого-педагогічних праць [1-12] показує, що у наукових дослідженнях розглядаються різні види компетентності: ключові (у складі ціннісно-смислових, соціально-трудових і особистісного удосконалення), загальнопредметні, предметні, загальнопрофресійні, психологічна, спеціальна, інтелектуальна, інфрормаційно-комунікативна, вищі, спеціально-педагогічна, науковопедагогічна, методична, управлінська, дидактична, дослідницька, творча, етична, міжкультурна, полікультурна, білінгвальна, подвійна, інформаційна, загальнокультурна тощо.

На нашу думку, об'єднавши результати досліджень, можна виділити найбільш важливі компетенції, які висувають нині умови ринку для фрахівців з бізнес-адміністрування:

1. Інтегральну компетентність: здатність розв'язувати складні, спеціалізовані задачі та практичні проблеми у сорері управління або у процесі навчання, що передбачає застосування теорій та методів менеджменту та економіки, характеризується комплексністю і невизначеністю умов.

2. Загальні компетентності: здатність проведення досліджень на відповідному рівні; здатність спілкуватися 3 представниками різних професійних груп та у міжнародному контексті; навички використання інформаційно-комунікаційних технологій для пошуку, оброблення, аналізу інфрормації з різних джерел та прийняття 
рішень; здатність організовувати та мотивувати людей різних національностей рухатися до спільної мети, працювати в команді; здатність діяти на основі етичних міркувань, соціально відповідально і свідомо; вміння виявляти та вирішувати проблеми, генерувати нові ідеї; здатність до абстрактного мислення, пошуку, опрацювання, аналізу, синтезу та встановлення взаємозв'язків між явищами та процесами; здатність забезпечити безпечні умови праці та цивільний захист.

3. Спеціальні (фахові, предметні) компетентності: вміння вибирати та використовувати концепції, методи та інструментарій фрінансового менеджменту, у тому числі відповідно до міжнародних стандартів; встановлювати критерії, за якими організація визначає подальші напрями розвитку, розробляти і реалізовувати стратегії та плани; здатність до саморозвитку, навчання впродовж життя та ефективного самоменеджменту;

- здатність до еорективного використання та розвитку людських ресурсів в організації; вміння створювати та організовувати ефективні комунікації в процесі управління територіально віддаленими фріліями та суб'єктами, із застосуванням різноманітних сучасних трафіків; навички формування та демонстрації лідерських якостей; здатність розробляти проєкти та управляти ними, виявляти ініціативу та підприємливість; здатність використовувати психологічні технології роботи 3 персоналом; здатність аналізувати й структурувати проблеми організації, ухвалювати управлінські рішення та забезпечувати умови їх реалізації; здатність до управління організацією, її змінами; вміння застосовувати основи педагогіки і психології у навчально-виховному процесі у закладах вищої освіти; знання основних сучасних положень фрундаментальних наук стосовно походження, розвитку та будови організації, здатність їх застосовувати для фрормування світоглядної позиції;

- вміння застосовувати технології розвитку і бізнес-реінжинірингу, генерувати нові ідеї.

Таким чином, компетентність майбутніх фрахівців з бізнес-адміністрування можна визначити як наявність умінь, знань та навичок в їх синергетичному взаємозв'язку та взаємозалежності, сорормованих на базі загальної освіти, здатність до їх постійного оновлення, а також особисті якості індивіда, які з набуттям досвіду використовуються під час профресійної діяльності. До основних компетенцій відносимо: інтегральну компетентність, загальні компетентності, спеціальні (фахові, предметні) компетентності.

Як зазначалося раніше, ми приходимо до необхідності доповнення системного і компетентнісного підходів ще одним - діяльнісно-культурологічним.

Діяльнісний підхід є загальноприйнятим у педагогіці та психології і тлумачиться як планування й організація освітнього процесу, в якому визначальне місце відводиться максимально активній пізнавальній діяльності студентів, яка б забезпечувала їх активність у пізнанні, спілкуванні, саморозвитку [4, с. 42]. Слід підкреслити, що освітній процес у ЗВО забезпечує якісну підготовку майбутніх фрахівців з бізнес-адміністрування у тому разі, якщо відбувається у формі освітньої діяльності, яка спрямована не лише на засвоєння знань, умінь і навичок, але й на опанування певною сукупністю способів діяльності майбутньої профресійної сфери.

Культурологічний підхід у професійно-освітній діяльності розуміється як інтегративний метод системної організації цілісного освітнього процесу, що зумовлює сукупність вимог до відбору змісту і технологічних процедур; створення оптимальних педагогічних умов освітнього процесу відповідно до концептуально-базових положень, що забезпечують формування особистості студента як суб'єкта культури. Слід зазначити, що більшість дослідників, які працюють у річищі культурологічного підходу, вбачають його мету у подоланні явищ дегуманізації в освіті. У цьому контексті принципи розбудови освітнього процесу окреслюються кількома концептуальними положеннями, а саме: сутність культурологічного підходу полягає у вивченні світу людини в контексті її культурного існування; культурологічний підхід зумовлений об'єктивним зв'язком людини 3 культурою як системою цінностей і дає змогу розглядати педагогічні явища та педагогічну діяльність як сукупність культурних компонентів на широкому культурному фроні соціуму з урахуванням локальної культурної ситуації [1, с. 121].

3 огляду на думки дослідників і свої наукові уявлення, ми вважаємо, що діяльнісно-культурологічний підхід - це орієнтація дослідження на вивчення явищ 3 освоєння особистістю культури, що забезпечує створення культурних цінностей. Формування культури конкурентних відносин ми розглядаємо як діяльність, здійснювану викладачем і студентами, спрямовану на виникнення особистісного новоутворення - культури конкурентних відносин.

Процес орормування культури конкурентних відносин у майбутніх фрахівців з бізнес-адміністрування було вивчено нами в контексті діяльніснокультурологічного підходу, в ході дослідження отримані такі характеристики: 1) діяльнісно-культурологічний підхід зумовлює вибір специфічних методів, засобів і форм педагогічної діяльності; напрямів реалізації програми; організацію способів теоретичної і практичної діяльності; особливостей взаємодії із зовнішнім середовищем загалом і ринком праці зокрема; можливостей вдосконалення навчального процесу та процедур корекції; 2) його мета - високий рівень сорормованості куль- 
тури конкурентних відносин у майбутніх фрахівців з бізнес-адміністрування; суб'єктами взаємодії, що забезпечують управління і співуправління, виступають викладач і студент (або викладач і група студентів); а також представники зовнішнього середовища; об'єктом у профресійному і культурному плані є особистість майбутнього фахівця, що формується під впливом різних суб'єктів; 3) засобами фрормування культури конкурентних відносин $€$ матеріальні (наочні матеріали, фрінансова документація, навчальні посібники, мережеві ресурси, картки-завдання, експертні карти тощо) і духовні (норми моралі, особистісні та профресійні цінності тощо); 4) методами - педагогічні (бесіда, екскурсії, демонстрації, приклад тощо) і економічні (аналіз фрінансової звітності, SWOT-аналіз, бізнес-тренінг тощо); 5) результатом - сфрормована у майбутніх орахівців з бізнес-адміністрування культура конкурентних відносин.

Висновки. Таким чином, описані вище положення і характеристики, отримані в процесі аналізу системного, компетентнісного і діяльніснокультурологічного підходів стосовно проблеми формування культури конкурентних відносин у майбутніх фрахівців з бізнес-адміністрування, будуть використовуватися нами як методологічна основа для розробки комплексу методичних умов та інших педагогічних компонентів, представлених у наших подальших дослідженнях.

\section{БІБЛІОГРАФІЧНИЙ СПИСОК:}

1. Андрощук I.В. Реалізація системного підходу в навчальному процесі як педагогічна проблема. Проблеми підготовки сучасного вчителя. 2013. № 7. C. 8-14.

2. Євтушенко Г.І., Куценко В І. Формування менеджера як фрахівця: проблеми та перспективи. Науковий вісник НУДПС України. 2012. № 1. С. 12-21.
3. Жилина А.И. Системный подход как методология педагогического исследования. Человек $и$ образование: академический вестник Института образования взрослых Российской академии образования. 2007. № 10-11. С. 15-20.

4. Кизенко В., Трубачова Д. Реалізація діяльнісного підходу в навчанні студентів-срілологів з різним рівнем комунікативних здібностей. Рідна школа. 2014. № 11. С. 42-46.

5. Коджаспирова Г. М., Коджаспиров А. Ю. Педагогический словарь. Москва : Издательский центр «Академия», 2005. 176 с.

6. Кубанов Р. А. Методологічні засади використання системного підходу в дослідженні якості професійної підготовки студентів вищого навчального закладу. Психолого-педагогічні проблеми сільської школи : зб. наук. пр. Уманського державного педагогічного університету імені Павла Тичини / ред. кол.: Побірченко Н.С. (гол. ред.) та ін. Умань : ФОП Жовтий О.О., 2014. Вип. 49. С. 13-18.

7. Маслов В. І. Принципи менеджменту в установах освіти. Освіта і управління. 1997. № 1. C. 80-87.

8. Ожегов С.И. Толковый словарь русского языка. 100000 слов, терминов и выражений. Серия «Новые словари». Москва : Мир и Образование, 2015. 1376 c.

9. Очарук О. Ключові компетентності: Європейське бачення. Управління освітою. 2004. № 2. C. 6-9.

10. Сластенин В.А., Кашарин В.П. Психология и педагогика. Москва : Академия, 2003. 480 с.

11. Сорочан Т.М., Данильєв А.О., Дьяченко Б.А., Рудіна О.М. Професійний розвиток керівників і педагогічних працівників загальноосвітніх навчальних закладів у післядипломній педагогічній освіті регіонального рівня : монографрія. Луганськ : СПД Рєзніков В.С., 2013. 524 с.

12. Яковлев Е.В., Яковлева Н.О. Педагогическая концепция: методологические аспекты построения. Москва : ВЛАДОС, 2006. 239 с. 


\title{
СУКУПНІСТЬ КРИТЕРІЇВ ТА ПОКАЗНИКІВ ГОТОВНОСТІ МАЙБУТНІХ МАГІСТРІВ ПСИХОЛОГІЇ ДО ПРОФЕСІЙНОЇ ДІЯЛЬНОСТІ В УМОВАХ НЕФОРМАЛЬНОÏ ОСВІТИ ЗА ЇЇ КОМПОНЕНТАМИ
}

\author{
SET OF THE CRITERIA AND READINESS INDEXES OF FUTURE \\ PSYCHOLOGY MASTERS FOR PROFESSIONAL ACTIVITY IN CONDITIONS \\ OF INFORMAL EDUCATION BASED ON ITS COMPONENTS
}

у статті показано, що дослідження проблеми оцінки готовності майбутніх магістрів психології до профресійної діяльності в умовах неформальної освіти потребує об'єктивного й різнопланового вивчення. Метою статmі $\epsilon$ висвітлення авторської позичії щодо сукупності критеріїв та показників готовності майбутніх магістрів психології до професійної діяльності в умовах неформальної освіти за їі компонентами.

Педагогічний структурний компонент об'єктивується через: усвідомлення себе як педагога неформальної освіти; наявність психолого-педагогічних знань і вмінь із неформальної освіти, умінь встановлювати ефрективні взаємини з тими, хто навчається в неформальній освіті, умінь визначати та враховувати їхні потреби й інтереси.

Підприємницький структурний компонент готовності упредметнюється через. володіння нормативно-правовою базою неформальної освіти; розуміння сучасних освітніх, соціальних та економічних можливостей неформальної освіти; уміння презентувати себе; стійкість до психологічних навантажень; здатність діяти в умовах невизначеності; здатність до ухвалення обґрунтованих срінансових рішень; високий рівень особистої відповідальності Технологічний структурний компонент готовності реалізується через: обізнаність щодо технологій, їх видів, технологічних фрорм, методів і засобів нефрормальної освіти; обізнаність в електронних освітніх ресурсах, інтернет-сервісах, вебтехнологіях, розуміння їхньої ролі в неорормальній освіті; уміння проєктувати (планувати) власну профресійну діяльність на засадах технологічності й оптимальності; уміння використовувати офрісні технології; наявність аналітичного, абстрактного, алгоритмічного мислення тощо. Лідерський структурний компонент втілюється через: здатність здійснювати вплив на інших людей та переконувати їх; уміння вселяти впевненість у того, хто навчається; стійкість до стресів уміння створювати атмосферу співробітничтва, взаємодовіри, взаємоповаги та взаєморозуміння; здатність до співробітництва; здібність схоплювати суть справи інтуїтивно і швидко, здатність формувати довіру до себе та будувати позитивний імідж.

Емоційний інтелект $є$ останнім структурним компонентом і включає в себе усвідомлення можливості зміни емоції та свідомого виклику певної емоції або їіприпинення; здатність ефрективно розбиратися в емочійній сфрері людини (своїй та інших людей); здатність розуміти емоційне підгрунтя міжособистісних взаємин; контролювати та використовувати власні емоціі для створення необхідного настрою.
Ключові слова: професійна освіта, магістри психологіі,, неформальна освіта готовність, критерії, показники структурні компоненти.

The article demonstrates that estimation of the readiness of future psychology Masters for professional activity in conditions of informal education needs an objective and diverse research.

The aim of the article is to reveal the author's stance referring to the set of the criteria and readiness indexes of future psychology Masters for professional activity in conditions of informal education based on its components. A pedagogical structural component is objectified through self-perception as an educato of informal education: possession of psychological and pedagogical knowledge and skills in informal education; abilities to set efficient relationships with those, who study in informal education; skills to determine and take into account their needs and interests.

An entrepreneurial structural component of the readiness is revealed through: possessing of the informal education legal framework; understanding of modern educational, social and economic opportunities in informal education; ability to self-present; resistance to psychological pressure, being able to act in conditions of uncertainty; ability to take reasonable financial decisions; high level of a personal responsibility.

A technological structural component is realized through awareness of technology, its types, technological forms, methods and modes in informal education; awareness of electronic educational resources, Internetservices, web-technologies and their role in informal education; ability to plan (design) own professional activity on the basis of technological effectiveness and optimality; ability to use office technology, possession of analytical, abstract, algorithmic etc. thinking.

A leadership structural component is revealed through ability to influence other people and reassure them, ability to grant confidence in a student; stress-resistance, ability to create a cooperative atmosphere, mutual trust, respect and understanding: ability to cooperate; ability to grasp the essence intuitively and quickly; ability to create trust to oneself and build up a positive image.

Emotional intelligence is the last structural component and covers understanding of emotion change possibilities and conscious using or elimination of a certain emotion; ability to be good at emotional sphere (own and the one of other people); ability to understand emotional ground of interpersonal relations; control and use one's own emotions to create a certain mood.

Key words: professional education, Masters of psychology, informal education, readiness, criteria, indexes, structural components. 
Постановка проблеми в загальному вигляді. Дослідження проблеми фрормування готовності майбутніх магістрів психології до професійної діяльності в умовах нефрормальної освіти потребує об'єктивного й різнопланового вивчення деяких теоретичних та емпіричних підходів до оцінки такої готовності.

Зокрема, заслуговують на увагу питання побудови критеріальної бази дослідження, показників, рівнів готовності майбутніх магістрів психології до професійної діяльності в умовах неформальної освіти, вибірйобґрунтуваннядіагностичнихзасобів.

Теоретичні засади побудови критеріальної бази дослідження вже були предметом прискіпливого вивчення у працях О. Бородієнко [5], О. Жихорської [8], Л. Лебедик [13], Ю. Пологовської [14], Г. Ржевського [18], О. Самборської [19], Р. Чубук [23], А. Шабалдак [24] та інших науковців.

Мета статті - висвітлення авторської позиції щодо сукупності критеріїв та показників готовності майбутніх магістрів психології до профресійної діяльності в умовах неформальної освіти за її компонентами.

Виклад основного матеріалу. Перш ніж розпочати висвітлення авторської позиції на задекларовану проблему, зосередимо увагу на уточненні сутності педагогічних концептів «критерій», «показник» та «рівень» у сучасних дослідженнях.

Так, поняття «критерій» у довідниковій літературі визначається як «підстава для оцінки, визначення та класифрікації чогось; мірило» [6, с. 588]; «ознака, на підставі якої, дається оцінка будьякого явища; ознака, взята за основу класифікації» [16, с. 163]. Отже, критерій як педагогічний концепт є мірилом (ознакою), за допомогою якого можна оцінити або класифікувати певне педагогічне явище, у нашому дослідженні - готовність майбутнього магістра психології до профессійної діяльності в умовах неформальної освіти.

Десрініції науковців поняття «критерій» суголосні 3 поданими вище тлумаченнями та лише деталізують його окремі аспекти.

Так, О. Пометун визначає поняття «критерій» як стійку і постійну характеристику досліджуваного об'єкта, що відображає його суттєві ознаки та якості [15]. Таке бачення акцентує увагу на тому, що критерії повинні бути стійкими та постійними суттєвими ознаками досліджуваної готовності.

В. Беспалько розглядає критерій як «об'єктивну кількісну міру деякого явища, або кількісне виокремлення його сторін» [4]. Така авторська позиція дозволяє виокремити дві характеристики критерію як педагогічного конструкта, його різноаспектність та комплексність. Тобто критеріїв оцінювання готовності майбутнього магістра психології до профресійної діяльності в умовах неформальної освіти може бути декілька, але всі вони визначаються за більш простими компонентами, якими є їхні показники.
Підтвердження цьому знаходимо у працях багатьох науковців. Так, С. Іванова вважає, що критерії відображають динаміку вимірюваної якості у просторі й часі, яка розкривається через певні показники, за інтенсивністю прояву яких можна зробити висновок щодо рівня їхньої ссрормованості [10, с. 153]. О. Діденко наголошує на тому, що показники є складовими частинами певного критерію [7].

У довідниковій літературі поняття «показник» визначається як характеристика окремог аспекту критерію, яка $є$ мірою його фрормування або розвитку. Показником виступають певні ознаки досліджуваного френомену, якими можуть бути явище або подія, дані про якісь досягнення або їх кількість [6, с. 1024]. С. Решетник у своєму дослідженні акцентує увагу на двох головних характеристиках будь-якого «показника»: конкретності, що детермінує його більшу частковість порівняно із критерієм, до якого він належить, та діагностичності, що визначає його доступність для виявлення, спостереження й обліку. Водночас автор зазначає, що показники виконують дужу важливу роль у процедурі діагностування, адже тільки завдяки показникам можна судити про розвиток досліджуваного феномену [17, с. 218]. Отже, будь-який показник готовності майбутнього магістра психології до професійної діяльності в умовах неформальної освіти повинен бути конкретним та діагностованим.

Водночас, як зазначають А. Батаршев, І. Алексєєва й О. Майорова, показники виконують роль засобів якісної та кількісної оцінки відповідного критерію [3]. Отже, будь-який критерій досліджуваної готовності, крім якісних показників, за допомогою яких фріксується наявність або відсутність певної властивості, може визначати й кількісні показники, за допомогою яких фріксується міра сорормованості або розвитку певної властивості. Водночас зазначимо, що в педагогічних дослідженнях перевага віддається визначенню саме якісних показників досліджуваного френомену, що забезпечує високий рівень описовості наукових пошуків, проте значно ускладнює їх статистичну обробку та стандартизацію.

Отже, концепт «критерій» у нашому дослідженні тлумачиться як стійка та постійна ознака (індикатор), за допомогою якої можна оцінити стан готовності майбутнього магістра психології до професійної діяльності в умовах неформальної освіти. Критерій за своєю природою є різноаспектним та комплексним конструктом, що включає в себе відповідні якісні та кількісні показники, які виступають мірою його формування. Показниками відповідного критерію досліджуваної готовності можуть слугувати певне явище, певні досягнення або їх кількість.

Водночас критерій та його показники $€$ взаємопов'язаними та взаємозумовленими, отже, вибір певного критерію готовності майбутнього 
магістра психології до професійної діяльності в умовах неформальної освіти значною мірою детермінує систему його показників, а включення певного показника до відповідного критерію залежить від того, наскільки повно й об'єктивно цей показник характеризує визначений критерій.

Визначивши теоретичні засади побудови критеріальної бази дослідження, перейдемо до розгляду критеріїв та показників готовності майбутніх магістрів-психологів до професійної діяльності в умовах неформальної освіти за визначеними в авторській концепції структурними та змістовими компонентами.

Насамперед визначимо, які саме критерії та показники мають бути покладені в основу оцінювання рівня готовності майбутніх магістрів психології до професійної діяльності в умовах неформальної освіти.

Для цього проведемо аналіз сучасних педагогічних досліджень, у яких вивчалися питання визначення критеріїв оцінювання готовності майбутніх магістрів до професійної діяльності.

Так, Г. Ржевський пропонує за об'єкт оцінювання брати структурні компоненти психологічної готовності магістрів до педагогічної діяльності, a саме: мотиваційний, змістово-процесуальний та рефрлексивний. Зокрема, мотиваційний компонент відбиває ставлення магістранта до здійснення педагогічної діяльності, усвідомлення ним цінностей професії та спрямованість його особистісних настанов на опанування майбутньої профресії. Змістово-процесуальний компонент відображає загальноінтелектуальний рівень розвитку магістранта, рівень сформованості загальнонавчальних умінь та навичок та систему загальнопедагогічних і фрахово значущих знань і умінь їх застосовувати. Рефрлексивний компонент характеризує чітко виражену потребу магістранта в самоосвіті, рівень сформованості його вмінь і навичок із самостійної роботи, його адекватну самооцінку, наявність самоконтролю та стабільність коригуючої діяльності для усунення недоліків фахової підготовки [18, с. 76].

Дослідниця Ю. Тимцуник основними критеріями готовності майбутніх магістрів управління навчальними закладами до маркетингової діяльності вважає: мотиваційно-ціннісний, який відображає усвідомлення магістрантом необхідності здійснення маркетингової діяльності, позитивне ставлення до навчання, стійкість інтересу до здійснення маркетингової діяльності, а також прагнення до постійного самовдосконалення; когнітивно-операційний, який відбиває рівень володіння майбутнім магістром маркетинговими знаннями, уміннями та навичками здійснювати маркетингову діяльність; особистісний, який констатує наявність у магістранта профресійно важливих якостей, усвідомлення ним значущості цієї діяльності, а також його прагнення до підвищення професійної компетентності, самовдосконалення та саморозвитку; рефрлексивно-регулятивний, який відображає здатність магістранта до самооцінювання, рефлексії, а також сорормованість його навичок до самооцінювання рівня власної готовності до маркетингової діяльності [22, с. 55].

На думку Л. Лебедик, оцінювання рівня сорормованості профресійної компетентності магістрів педагогіки вищої школи може бути здійснене за когнітивним, діяльнісним та особистісним критеріями. Зокрема, когнітивний критерій передбачає оцінювання рівня засвоєння магістрантом тих педагогічних знань, які необхідні для вирішення професійних проблем, здатність аргументовано обґрунтовувати власне бачення вирішення професійних проблем, здатність магістрантів до швидкої адаптації у складних і змінних навчальних діях. Діяльнісний критерій пов'язаний з оцінюванням рівня ссрормованості в магістранта сукупності організаторських, комунікативних, експресивних, дидактичних та проєктувальних умінь, особливо діагностичних і прогностичних. Особистісний критерій відбиває вимоги до рівня розвитку професійно важливих якостей майбутнього магістра, зокрема: інтелект, креативність, гнучкість, передбачливість, широту наукового світогляду, працелюбність, уважне ставлення до обов'язків, дисциплінованість, самостійність, дотримання слова, авторитетність, енергійність тощо [13, с. 181-182].

Науковець А. Коркішко основними критеріями сорормованості професійного іміджу майбутніх магістрів педагогіки вищої школи вважає: мотиваційно-ціннісний, когнітивний, операційно-діяльнісний і оцінно-рефрлексивний. Зокрема, мотиваційно-ціннісний відображає ступінь сфрормованості професійно значущих потреб магістранта в майбутній педагогічній діяльності, когнітивний відбиває сорормованість знань майбутнього магістра про себе, майбутню профресію, розуміння ним специфріки та ролі іміджу у професії педагога, а також здатності до побудови власного професійного іміджу; операційно-діяльнісний характеризується сорормованістю культури зовнішнього вигляду, уміннями впроваджувати прийоми та методи формування профресійного іміджу й ознайомлювати 3 ними інших, а також відповідним рівнем сорормованості якостей, важливих для професійного іміджу педагога вищої школи; оцінно-рефлексивний відображає здатність магістранта до оцінки власного професійного іміджу, сорормованість рефрлексивних умінь, а також готовність до ефективної самопрезентації в різноманітних профресійно-педагогічних ситуаціях [12, с. 53-54].

Дослідниця О. Самборська до основних критеріїв готовності магістрів технологічної освіти до моніторингу навчальних досягнень студентів відносить такі: ціннісно-мотиваційний, когнітивний 
та праксеологічний. Ці критерії визначено відповідно до розроблених автором компонентів структури готовності майбутніх педагогів до моніторингу (мотиваційний, науково-теоретичний, когнітивний, оціночний, праксеологічний та психологічний компоненти). Зокрема, ціннісно-мотиваційний критерій відображає потреби магістранта у здійсненні об'єктивного й успішного моніторингу, його спрямованість на здійснення процесу моніторингу, психологічні настанови та виконання відповідних активних дій, а також його інтерес до здійснення моніторингу як процесу, когнітивний критерій відображає рівень фрундаментальних знань магістранта, необхідних для ефективної організації моніторингу (визначення цілей моніторингу, вибір методик та інструментарію, заходи з опрацювання отриманих даних, корекція та прогноз розвитку досліджуваного френомену); праксеологічний критерій демонструє професійні вміння та навички, необхідні для реалізації функцій моніторингу та забезпечення його ефективності, а також самооцінку магістранта щодо власної підготовленості та відповідності проведеного моніторингу еталонному зразку [19, с. 240-241].

Дослідниця А. Тимейчук за основні критерії сорормованості готовності майбутніх магістрів туризмознавства до професійної проєктної діяльності визначає: мотиваційно-ціннісний, когнітивний, професійний та креативний. Зокрема, мотиваційно-ціннісний критерій відбиває сорормованість у магістранта навчальних і пізнавальних мотивів та його бажання досягти певного професійного рівня; когнітивний критерій відображає сфрормованість у магістрантів певного рівня теоретичних знань щодо сутності, фрункцій, передумов подальшої професійної діяльності, а також відповідних конструктивних, евристичних та системних знань, умінь і навичок, необхідних для їхньої фрахової самореалізації; професійний критерій висвітлює вміння майбутнього магістра щодо розв'язання професійних завдань, а також його готовність до практичного застосування набутих знань, умінь і навичок у майбутній професійній діяльності, пов'язаній із розробленням та реалізацією туристських проєктів; креативний критерій відображає вміння магістранта нестандартно і креативно застосовувати результати свого навчання для здійснення професійних дій, а також творчо вирішувати складні професійні завдання [21, с. $127-128]$.

Отже, основні критерії оцінювання готовності майбутніх магістрів до професійної діяльності, які визначені у проаналізованих дослідженнях, можуть бути об'єднані в такі чотири групи:

1) професійно важливі знання (загальнонавчальні, загальнопедагогічні, фрахово значущі тощо);

2) професійно важливі вміння (організаторські, комунікативні, дидактичні, рефрлексивні тощо);
3) профресійно важливі ціннісні орієнтації особистості (ставлення до навчання та майбутньої професійної діяльності, усвідомлення цінностей професії, спрямованість особистісних настанов, стійкість інтересів, сорормованість професійно значущих потреб і навчально-пізнавальних мотивів та стійке бажання досягти певного професійного рівня);

4) профресійно важливі якості особистості (інтелект, креативність, гнучкість, передбачливість, широта наукового світогляду, працелюбність, дисциплінованість, самостійність, авторитетність, енергійність).

Водночас представлена класифікація включає тільки об'єктивні критерії, які відображають відповідність майбутнього магістра вимогам профресії та пов'язані з нормативними показниками успішності реалізації діяльності. Проте вона не відображає суб'єктивні критерії, які характеризують ступінь відповідності майбутньої професії вимогам магістранта, що зумовлено свідомим вибором магістранта галузі підготовки та спеціалізації.

Зазначимо, що критерії готовності майбутніх магістрів психології до професійної діяльності в неформальній освіті як педагогічний конструкт повинні відповідати певним вимогам.

Так, за О. Барабанщиковим та Н. Дерюгиним [2, с. 45], основними вимогами до критеріїв $€$ : об'єктивність (відповідність критеріїв оцінюваному педагогічному явищу); унікальність (критерії та їх показники не повинні взаємно перетинатися); повнота (охоплення критеріями найбільш значних та стійких сторін досліджуваного френомену); надійність (забезпечення достовірного результату за різних умов); зрозумілість (усі критерії та їх показники мають тлумачиться однозначно). На думку О. Жихорської, критерії також повинні: забезпечувати зв'язки між усіма компонентами досліджуваного феномену; відображати розвиток вимірюваної якості та забезпечувати єдність кількісних та якісних показників [8, с. 34]. Крім цього, для нашого дослідження цінними є вимоги до критеріїв, запропоновані Л. Задорожною-Княгницькою, як-от легкість вимірювання й обчислення, а також дотримання морально-етичних норм під час збору інорормації, необхідної для визначення показників відповідних критеріїв [9, с. 202].

На основі проаналізованих положень науковців про сутність критеріїв ї показників готовності майбутніх магістрів до профресійної діяльності та визначених вимог до критеріїв і показників ми дійшли висновку, що в основу оцінювання рівня готовності майбутніх магістрів психології до профресійної діяльності в умовах неформальної освіти можуть бути покладені такі критерії: когнітивний, операціональний і аксіологічний.

Когнітивний критерій відображає обсяг профресійно важливих знань майбутнього магістра психології, що забезпечують його ефективну 
професійну діяльність та реалізацію визначених ролей і функцій у неформальній освіті.

Операціональний критерій включає профресійно важливі вміння магістранта-психолога, необхідні для успішного виконання ролей педагога, психолога та підприємця, а також ефективної реалізації освітньої (просвітницької), коригувальної та розвивальної функцій магістра психології в нефрормальній освіті.

Аксіологічний критерій відображає професійно важливі мотиви, стимули, цінності, інтереси, прагнення й амбіції майбутнього магістра психології, які інтегруються у відповідні ціннісні орієнтації.

3 урахуванням особливостей та сутності досліджуваного френомену, проведеного аналізу наукових праць, а також беручи до уваги результати анкетування фрахівців-психологів, які працюють в умовах неформальної освіти, щодо визначення змістових компонентів готовності майбутніх магістрів психології до професійної діяльності в зазначених умовах, визначено показники за виділеними вище критеріями досліджуваної готовності.

Висновки. Концепт «критерій» варто розуміти як стійку та постійну ознаку (індикатор), за допомогою якої можна оцінити стан готовності майбутнього магістра психології до професійної діяльності в умовах неформальної освіти. Критерій за своєю природою є різноаспектним та комплексним конструктом, що включає в себе відповідні якісні та кількісні показники, які виступають мірою його формування. Показниками відповідного критерію досліджуваної готовності можуть слугувати певне явище, певні досягнення або їх кількість.

Співвідношення компонентів, критеріїв та показників готовності майбутніх магістрів психології до професійної діяльності в умовах неформальної освіти варто розглядати через педагогічний, підприємницький, технологічний, лідерський та емоційний структурні компоненти.

Педагогічний структурний компонент об'єктивується через: усвідомлення себе як педагога неформальної освіти; наявність психологопедагогічних знань і вмінь з неформальної освіти, умінь установлювати ефективні взаємини з тими, хто навчається в неформальній освіті, умінь визначати та враховувати їхні потреби й інтереси.

Підприємницький структурний компонент готовності упредметнюється через: володіння нормативно-правовою базою неформальної освіти; розуміння сучасних освітніх, соціальних та економічних можливостей неформальної освіти; уміння презентувати себе; стійкість до психологічних навантажень; здатність діяти в умовах невизначеності; здатність до ухвалення обґрунтованих фрінансових рішень; високий рівень особистої відповідальності.

Технологічний структурний компонент готовності реалізується через: обізнаність у технологіях, їхніх видах, технологічних фрормах, методах і засобах неформальної освіти; обізнаність в електронних освітніх ресурсах, інтернет-сервісах, вебтехнологіях, розуміння їхньої ролі в неформальній освіті; уміння проєктувати (планувати) власну професійну діяльність на засадах технологічності й оптимальності; уміння використовувати офісні технології; наявність аналітичного, абстрактного, алгоритмічного мислення тощо.

Лідерський структурний компонент утілюється через: здатність здійснювати вплив на інших людей та переконувати їх; уміння вселяти впевненість в того, хто навчається; стійкість до стресів; уміння створювати атмосореру співробітництва, взаємодовіри, взаємоповаги та взаєморозуміння; здатність до співробітництва; здібність схоплювати суть справи інтуїтивно і швидко, здатність фрормувати довіру до себе та будувати позитивний імідж.

Емоційний інтелект $€$ останнім структурним компонентом і включає в себе усвідомлення можливості зміни емоції та свідомого виклику певної емоції або її припинення; здатність ефективно розбиратися в емоційній сфері людини (своїй та інших людей); здатність розуміти емоційне підґрунтя міжособистісних взаємин; контролювати та використовувати власні емоції для створення необхідного настрою.

\section{БІБЛІОГРАФІЧНИЙ СПИСОК:}

1. Багрій В. Процес формування та удосконалення професійних умінь як основа для професійної інноваційної діяльності. Вісник Львівського університету. Серія «Педагогічна». 2009. Вип. 25. 4. 2. C. 82-91.

2. Барабанщиков А., Дерюгин Н. Военно-педагогическая диагностика. Москва : Высшая школа, 2005. 238 c.

3. Батаршев А., Алексеева И., Майорова Е. Диагностика профессионально важных качеств. Санкт-Петербург : Питер, 2007. 192 с.

4. Беспалько В. Слагаемые педагогической технологии. Москва : Педагогика, 1989. 192 с.

5. Бородієнко О. Критерії, показники, рівні сорормованості професійної компетентності керівників структурних підрозділів підприємств сорери зв'язку. Молодь і ринок. 2017. № 7. С. 109-115.

6. Великий тлумачний словник сучасної української мови (з дод. і допов.) / уклад. і голов. ред. В. Бусел. Київ ; Ірпінь : ВТФ «Перун», 2005. 1728 с.

7. Діденко О. Критерії, показники та рівні сорормованості творчості як професійної якості у майбутніх ооріцерів-прикордонників. Вища освіта України. 2007. Дод. 3. Т. 7. С. 218-223.

8. Жихорська О. Критерії, показники та рівні сорормованості професійної компетентності навчально-допоміжного персоналу вищого навчального закладу. Science and Education a New Dimension. Pedagogy and Psychology. 2015. Вип. 69 III (34). С. 33-38.

9. Задорожна-Княгницька Л. Деонтологічна підготовка менеджерів освіти в університетах: теорія і практика : монографрія. Маріуполь : МДУ, 2017. 372 с. 
10. Іванова С. Критерії та показники розвитку професійної компетентності вчителів біології в закладах післядипломної педагогічної освіти. Вісник Житомирського державного універси тету. Педагогічні науки. 2010. Вип. 52. С. 152-255.

11. Конаржевский Ю. Педагогический анализ как функция управления школой. Основы внутришкольного управления. Педагогика. 1987. C. 35-48.

12. Коркішко А. Критерії та показники діагностики сорормованості профресійного іміджу майбутніх магістрів ПВШ. Вісник Черкаського універсиmemy. 2018. Вип. № 2. С. 51-57.

13. Лебедик Л. Формування профресійної компетентності магістрів педагогіки вищої школи. Гуманітарний вісник Державного вищого навчального закладу «Переяслав-Хмельницький державний педагогічний університет імені Г.С. Сковороди». Педагогіка. Психологія. Філософрія. 2013. Вип. 28 (1). С. 180-185.

14. Пологовська Ю. Критерії, показники та рівні сорормованості профрорієнтаційної компетентності у майбутніх вчителів географії в умовах профільного навчання. Витоки педагогічної майстерності. 2018. Вип. 22. С. 174-180.

15. Пометун О. Теорія та практика послідовної реалізації компетентісного підходу в досвіді зарубіжних країн. Компетентнісний підхід у сучасній освіті: світовий досвід та українські перспективи. Київ : К.І.С., 2004. 112 с.

16. Профресійна освіта : словник : навчальний посібник / уклад. С. Гончаренко та ін. ; за ред. Н. Ничкало. Київ : Вища школа, 2000. 380 с.

17. Решетник С. Критерії, показники та рівні сорормованості готовності майбутніх офріцерів внутрішніх військ міністерства внутрішніх справ України до службової діяльності. Збірник науко- вих праць Хмельницького інституту соціальних технологій Університету «Україна». 2013. № 2 (8). С. 217-223.

18. Ржевський Г. Психологічна готовність магістрів до педагогічної діяльності. Вісник Київського національного торговельно-економічного універcumemy. 2012. № 4 (84). С. 73-89.

19. Самборська О. Критерії, показники та рівні готовності магістрів технологічної освіти до моніторінгу навчальних досягнень студентів. Науковий часопис Національного педагогічного університету імені М.П. Драгоманова. Серія 5 «Педагогічні науки: реалії та перспективи». 2015. Вип. 51. С. 239-244.

20. Словник-довідник 3 професійної педагогіки / за ред. А. Семенової. Одеса : Пальміра, 2006. 364 c.

21. Тимейчук А. Визначення ефективності підготовки майбутніх магістрів з туризмознавства до проектної професійної діяльності. Фізико-математична освіта. 2018. Вип. 2 (16). С. 126-130. DOI: 10.31110/2413-1571-2018-016-2-024.

22. Тимцуник Ю. Дослідження рівня сорормованості готовності майбутніх магістрів управління навчальними закладами до маркетингової діяльності. Актуальні проблеми соціології, психології, педагогіки. 2016. № 1. С. 52-60.

23. Чубук Р. Критерії, показники та рівні профресійної компетентності соціальних педагогів. Наукові записки Національного університету «Острозька академія». Серія «Психологія і педагогіка». 2008. Вип. 11. С. 253-263.

24. Шабалдак А. Компоненти, критерії, показники та рівні готовності курсантів військової академії до професійної діяльності на основі реалізації праксеологічного підходу. Молодий вчений. 2017. № 2. С. 563-567. 
ПРОФЕСІЙНА ГОТОВНІСТЬ МАЙБУТНІХ ФАХІВЦІВ

СОЦІОНОМІЧНИХ ПРОФЕСІЙ ДО ВПРОВАДЖЕННЯ

ІНКЛЮЗИВНОЇ ОСВІТИ: АКСІОЛОГІЧНІ ЗАСАДИ

\section{PROFESSIONAL PREPAREDNESS OF FUTURE SPECIALISTS OF SOCIONOMIC PROFESSIONS FOR THE INTRODUCTION OF INCLUSIVE EDUCATION: AXIOLOGICAL PRINCIPLES}

у статті актуалізовано важливість профресійної підготовки майбутніх фрахівців сочіономічних просресій до роботи з особами з особливими потребами. Дослідження даної проблеми унеобхіднило аксіологічне осмислення готовності студентів вищо школи до даного виду діяльності. Проаналізовано результати досліджень вітчизняних та закордонних науковців, які дали змогу стверджувати, що інклюзивне навчання в закладах освіти є дієвим за умов есективної готовності фрахівців до роботи з особами 3 особливими потребами, позитивного ставлення всього колективу та самих фрахівців до таких осіб, налагодження партнерських взаємин із батьками та командного підходу до вирішення інклюзивних проблемних завдань. Обгрунтовано, що формування цінностей інклюзивної культури в освітній організації та в суспільстві загалом є довготривалим процесом. Охарактеризовано можливість включення осіб з особливими потребами в освітні заклади, які передбачають спеціальну корекційну допомогу і психолого-педагогічну підтримку з боку фрахівиів. Наголошено на важливому завданні, яке нині ставиться перед закладами вищої освіти, підготовиі майбутніх фрахівців сочіономічних профресій до професійної інклюзивної діяльності на аксіологічних засадах. З'ясовано що вища школа сприяє фрормуванню особистісного сенсу, власної ціннісної мотивації, необхідних для роботи з дітьми з особливими потребами. Ефективне забезпечення своєрідної корекційної допомоги, соціальної та психолого-педагогічної підтримки супроводу осіб з обмеженими можливостями в освітнє середовище передбачає вирішення необхідних загальних і специфрічних завдань професійної діяльності. На аксіологічних засадах дієво окреслено специорічні напрями роботи майбутніх фрахівців соціономічних професій в інклюзивному оточенні. Зроблено висновок, що на готовність фрахівців соціономічних професій до впровадження освітніх інклюзій впливають аксіологічні засади професійної підготовки в закладах вищої освіти, які звернені до глибинних основ продуктивної міжособистісної взаємодії, переосмислення наявних стереотипів і подолання внутрішньоособистісних страхів і бар'єрів як у майбутніх фрахівців, так і в осіб з особливими потребами.

Ключові слова: майбутні фрахівці соціономічних професій, інклюзивна освіта, особи з особливими потребами, аксіологічні засади профресійної підготовки.

The importance of professional training of future specialists of socionomic professions to work with people with special needs are highlighted in the article. The study of this problem required axiological understanding of the readiness of high school students for this type of activity. The results of researches of domestic and foreign scientists, which allowed to state that inclusive education in educational institutions is effective under the conditions of effective readiness of specialists to work with people with special needs, positive attitude of the whole team and specialists to such people, establishing partnerships with parents and a team approach to solving inclusive problem tasks, are analyzed. It is substantiated that the formation of values of inclusive culture in the educational organization and in society as a whole is a long-term process. The possibility of including people with special needs in educational institutions, which provide special correctional assistance and psychological-pedagogical support from specialists, is characterized. Emphasis is placed on the important task currently facing institutions of higher education, that is the preparation of future professionals in socionomic professions for professional inclusive activities on an axiological basis. It was found that higher education contributes to the formation of personal meaning, self-worth motivation needed to work with children with special needs. Effective provision of a kind of correctional care, social and psychological-pedagogical support and support of people with disabilities in the educational environment involves solving the necessary general and specific tasks of professional activity. Specific areas of work of future specialists of socionomic professions in an inclusive environment are effectively outlined on the axiological basis. It is concluded that the readiness of specialists of socionomic professions to implementation of educational inclusions is influenced by axiological principles of professional training in institutions of higher education, which are addressed to the deep foundations of productive interpersonal interaction, rethinking existing stereotypes and overcoming interpersonal fears and barriers as by specialists, as by people with special needs. Key words: future specialists of socionomic professions, inclusive education, people with special needs, axiological principles of professional training.
Постановка проблеми в загальному вигляді. Нині інклюзивні практики актуалізували проблеми профресійної підготовки вчителів, психологів, соціальних працівників та фрахівців інших соціономічних професій до роботи 3 дітьми з особливими потребами. Набуття студентами у закладах вищої освіти (далі - ЗВО) необхідних для реалі- зації інклюзії особистісно-профресійних якостей та компетенцій, які б дозволяли успішно вирішувати практико-зорієнтовані завдання в даному напрямі фрахової діяльності, викликають у них труднощі як професійного, так і психологічного характеру. Це позначається на власній самооцінці та неготовності до діяльного фрункціонування з дітьми, яким 
властиві інклюзії. Тому на сучасному етапі дослідження даної проблеми виникає необхідність аксіологічного осмислення професійної готовності фрахівців до даного виду діяльності, що сповна б сприяло пошуку результативних організаційно-технологічних діяльнісних характеристик та віднаходженню шляхів побудови оптимальних паритетних взаємин між усіма учасниками освітньої взаємодії.

Аналіз останніх досліджень і публікацій. Проведений аналіз результатів наукових доробків вітчизняних і закордонних учених (В. Бондар, І. Гевко, Є. Клопота, А. Колупаєва, В. Ляшенко, Ю. Найда, О. Савченко, Н. Софрій, О. Фурман, Є. Кутепова, О. Кузьмна, Л. Ткаченко, В. Хитрюк, J. Ilan, A. Boer, L. Florian, H. Linklater, J. SagnerTapia, S. Shlessinger, R. Slee, K. Sutton та ін.) дозволяє говорити про низький рівень особистісної та профресійної готовності педагогів до роботи в умовах інклюзивної освіти. Науковець Л. Ткаченко зазначає, що інклюзивне навчання в загальноосвітніх закладах віддзеркалює одну із провідних демократичних ідей - «усі діти є цінними й активними членами суспільства», тому головне призначення інклюзії полягає в розкритті здібностей кожного вихованця за допомогою освітньої програми [8, с. 129]. Важливою слугує думка І. Гевко про те, що в освітньому процесі вищої школи потрібно здійснити перегляд змістового наповнення спеціальних навчальних дисциплін, загалом змінити підходи до використання методів підготовки фрахівців до роботи в інклюзивних умовах. Такі заходи сприяють реалізації освітньої парадигми, що спрямована на пізнання і врахування особистісних потреб особливих учнів відповідно до їхнього віку, специфрічного індивідуального характеру, ступеня фрізичного та психічного порушення, власних психологічних якостей особистості тощо [2, с. 56-57]. Інклюзивну освіту як альтернативну педагогіку розглядають L. Florian, H. Linklater, які наголошують на тому, що вона заснована не стільки на виділенні особливих потреб окремих учнів (констатація їхніх слабких потенцій та здібностей), скільки на гнучкій мисленнєвій діяльності педагога для вмілого реагування на різноманітність здатностей учнів, підтримування їх в інтегрованих групах [9]. Водночас всі науковці сходяться в тому, що запровадження в навчальному процесі технологій інклюзивної освіти вимагає підготовки всього учнівського колективу, позитивного ставлення самого вчителя до дитини, налагодження партнерських стосунків із батьками та командного підходу до вирішення інклюзивних питань.

Виділення не вирішених раніше частин загальної проблеми. Суттєвою проблемою освоєння інклюзивних практик $€$ особистісна неготовність фахівців соціономічних професій до результативного їх запровадження в навчальному процесі вихованців. Особистісне обґрунтування інклю- зивних практик тісно пов'язане 3 думками про ставлення до людей з інвалідністю та їхню значущість для соціуму. Тому якісно нові засади-характеристики інклюзивного освітнього середовища зумовили необхідність введення в педагогічний дискурс інклюзивної готовності як важливого компонента професійної компетентності майбутнього фахівця, що означає його соціальну позицію та гуманістичну спрямованість. Отже, актуалізується проблема готовності майбутніх фрахівців до діяльності в інклюзивну освітньому середовищі, а саме ії аксіологічний компонент.

Мета статті полягає в розкритті аксіологічних засад профресійної готовності фахівців соціономічних профресій до інклюзивного навчання.

Виклад основного матеріалу. Формування цінностей інклюзивної культури в освітній організації та в суспільстві загалом є тривалим процесом. У Саламанкській декларації (1994р.) докладно визначено поняття «особливі потреби» та «діти 3 особливими потребами», що стосується чималої кількості дітей і молодих людей, у яких є різні фрізичні чи розумові утруднення в навчанні. Інакше ці потреби трактуються як «спеціальні освітні потреби на певних етапах навчання у школі» [7]. Великий вплив на становлення інклюзивної освіти мають міжнародні організації (ЮНЕСКО, Організація з безпеки та співробітництва в Європі тощо), Конвенції Організації Об'єднаних Націй «Про права дитини» та ін., які як пріоритетний розвиток системи освіти рекомендують інклюзивну освіту, спрямовану на реалізацію прав громадян, здобуття якісної освіти та соціальну інтеграцію.

Визнання Україною міжнародних стандартів щодо інклюзивної освіти [1] посилило увагу громадянського суспільства до проблем дітей, які мають ті чи інші відхилення в розвитку, та зумовило необхідність розробки цілеспрямованих дій державних органів влади щодо створення найсприятливіших соціальних і психолого-педагогічних умов для забезпечення їхньої самоактуалізації, життєвого і професійного самовизначення, активної участі в системі сучасних суспільних взаємин. Тому інклюзивна освіта з повним правом нині $€$ одним із пріоритетних напрямів державної освітньої політики України [5]. Сучасна парадигма освіти виходить з ідеї створення сприятливих умов для осіб із різними потребами як в навчанні, так і у вихованні.

Можливість включення дітей 3 особливими потребами в освітні заклади передбачає спеціальну корекційну допомогу і психолого-педагогічну підтримку, завданнями яких $€$ інспектування їхнбого розвитку, навчальної успішності, вирішенням проблем соціальної адаптації тощо [4]. Це спричинює підтримку високого рівня викладання, пошук викладачем власної манери поведінки в навчальній аудиторії, високого профресіоналізму й індивідуального підходу до кожного вихованця. 
Важливо, що для педагогічної спільноти ціннісне ставлення до дітей із нетиповим розвитком виступає життєво-професійним завданням, оскільки нині недостатньо констатувати неготовність включення дітей з особливостями розвитку в масові освітні організації, зміну базових принципів навчання, а потрібно допомогти педагогу виробити власні смисли даної практики. Тому вагомим завданням, яке ставиться перед закладами вищої освіти, є підготовка на аксіологічних засадах майбутніх фахівців соціономічних професій до професійної інклюзивної діяльності. Саме у вищій школі кожен майбутній фахівець повинен визначити особистісний сенс, ціннісну особистісну мотивацію необхідну для роботи з такими дітьми [3; 6]. Формування у студента цінностей інклюзивної культури - це тривалий процес (від першого до останнього років навчання у ЗВО), пов'язаний із переживанням набутого практичного досвіду. Цінності і смисли породжуються особистістю за допомогою духовно-душевних переживань, докладених внутрішніх зусиль, ситуативним переосмислення тощо. Не випадково ініціаторами включення особливих дітей в освітні практики є педагоги, психологи, соціальні працівники тощо, професійне життя яких пов'язано із проблемами осіб з інвалідністю (діти, родичі, близькі). Ця практика безпосередньо зумовлена гуманістичними основами, які слугують цінністю для студентів. Крім того, досить важливо у процесі підготовки фрахівців формувати в них позитивне ставлення до інклюзивної освіти. Тому ефрективним напрямом системної підготовки $€$ включення та зреалізування відповідних спеціальних тем під час вивчення традиційних навчальних дисциплін, що дозволяє актуалізувати та продукувати інклюзивну компетентність.

Підвищення рівня психолого-педагогічної підготовки фрахівців, які працюють із дітьми з особливими потребами в умовах загальної освіти, уможливлюється як в межах психолого-педагогічного напряму (бакалавр - магістр), так і через навчання бакалаврів-фрахівців (учителі, методисти, учителідефектологи, учителі-логопеди, соціальні працівники, психологи тощо) у магістратурі за напрямом підготовки «011. Освітні, педагогічні науки» (освітньо-профресійна програма «Інклюзивна освіта, корекційна педагогіка»). У підготовці майбутніх фахівців у вищій школі варто враховувати те, що інклюзивна освіта спрямована не на ліквідацію сорормованої системи спеціальної (корекційна) освіти, а на взаємопроникнення івзаємооб'єднання систем загальної та спеціальної освіти, оскільки провідною під час створення системи інклюзивної освіти $€$ наявність тих студентів, які готові до змін соціальних і особистісно-психологічних.

Майбутні фрахівці інклюзивної освіти повинні навчитися еоективно забезпечувати педагогічний супровід дітей з обмеженими можливостями в освітнє середовище, вирішувати як загальні завдання професійної діяльності, так і специфічні, що передбачають такі напрями майбутньої роботи:

- проведення діагностики для визначення типу психічного відхилення в осіб з інклюзіями;

- здійснення психологічного обстеження дітей різного віку з мовними і руховими порушеннями із використанням рекомендованого інструментарію, включаючи первинну обробку отриманих результатів і вміння складати психологічний висновок;

- прогнозування динаміки змін стану і розвитку дитини залежно від використовуваних педагогами впливів;

- ведення психотерапевтичної роботи з дорослими учасниками інклюзивного освітнього процесу, зокрема і з батьками дитини з обмеженими можливостями;

- фрормування толерантних взаємин в інклюзивну шкільному колективі та в колективі вчителів як дорослих учасників інклюзивного освітнього процесу;

- проєктування і розробку корекційно-розвивальних програм роботи з дітьми шкільного віку;

- визначення потреб конкретної дитини за певною освітньою програмою та ін.

Обов'язкове опанування майбутніми фахівцями у ЗВО професійно-аксіологічних компонентів компетентностей у сорері психолого-педагогічного супроводу дітей з обмеженими можливостями результативно впливає на прийняття теорії та методології інклюзивної освіти, організацію спільної та індивідуальної діяльності дітей із різними типами порушень у розвитку; уміння співвідносити освітні завдання і завдання соціальної адаптації, а також сприяє вмілому використанню рекомендованих методів та освітніх технологій, що дозволяють ефективно вирішувати діагностичні і корекційно-розвивальні завдання; збиранню і підготовці документації про особливості дитини для обговорення її проблем на психолого-медико-педагогічному консиліумі освітньої установи тощо.

Підсумовуючи вищевикладене, зазначимо, що ефрективне зреалізування інклюзивної освіти на аксіологічних засадах безпосередньо залежить від спеціальної психолого-педагогічної підготовки майбутніх фрахівців соціономічних професій у вищій школі.

Висновки. Основна мета зреалізування спеціальних навчальних програм, що забезпечують фрормування готовності майбутніх фрахівців до діяльності в освітніх інклюзивних умовах, передбачає побудову чітких уявлень про фрілософрькі, методологічні засади і принципи інклюзивної освіти, висвітлення проблеми нормативно-правового забезпечення інклюзивної освіти, практикування сучасних моделей психолого-педагогічного супроводу дітей зособливими освітніми потребами, фрормування профресійно-аксіологічних компетен- 
цій в організації інклюзивної практики. У процесі підготовки фрахівців початкових класів до інклюзивної освіти аксіологічні засади мають первинне, фундаментальне значення, оскільки звернені до глибинних основ продуктивної міжособистісної взаємодії. Пояснюючи природу індивідуальних смислів, аксіологія відкриває значущість ціннісного переживання педагогом і дитиною один одного, важливість переосмислення наявних стереотипів, внутрішньоособистісних страхів та бар'єрів.

\section{БІБЛІОГРАФІЧНИЙ СПИСОК:}

1. Адаптована конвенція ООН щодо осіб 3 особливими потребами. Нью-Йорк, 13 грудня 2006 p. URL: www.osmhi.org/index.php?page=200\& news $=401 \&$ pages.

2. Гевко І. Інклюзивна освіта в Україні: сучасний стан та проблеми розвитку. Науковий вісник Миколаївського національного університету імені B.О. Сухомлинського. Серія «Педагогічні науки». 2019. № 1 (64). С. 52-58.

3. Главацька О. Л. Самоменеджмент як засіб підвищення творчого потенціалу соціального працівника. Соціальна робота: виклики сьогодення : збірник наукових праць V Всеукраїнської науково-практичної конференції, м. Тернопіль, 26-27 квітня 2018 р. Тернопіль : ТНПУ імені В. Гнатюка, 2018. С. 25-28.
4. Колупаєва А., Сосрій Н., Найда Ю. Інклюзивна школа: особливості організації та управління : навчально-методичний посібник. Київ, 2010. 128 с.

5. Про внесення змін до Закону України «Про освіту» щодо особливостей доступу осіб з особливими освітніми потребами до освітніх послуг : Закон України від 23 травня 2017 р. № 2053-VIII. URL: https://zakon2.rada.gov.ua/laws/ show/2053-viii.

6. Ребуха Л. Інноваційно-технологічні процеси у фундаменталізації професійної підготовки майбутніх соціальних працівників. Інноваційна педагогіка. 2018. Вип. 3. С. 164-167.

7. Саламанська декларація та рамки дій щодо освіти осіб з особливими потребами, прийнята Всесвітньою конференцією щодо освіти осіб з особливими освітніми потребами: доступ і якість, 7-10 червня. Іспанія. 1994. URL : https://zakon.rada.gov.ua/laws/ show/995 001-94.

8. Ткаченко Л. Актуальні проблеми запровадження інклюзивної освіти в Україні. Сучасна українська освіта: стратегії та технології навчання молоді і дорослих : збірник наукових праць V Міжнародної науково-практичної інтернет-конференції, 27 лютого 2018 р. Переяслав-Хмельницький. 2018. C. 128-132.

9. Florian L., Linklater $\mathrm{H}$. Preparing teachers for inclusive education: using inclusive pedagogy to enhance teaching and learning for all. Cambridge Journal of Education. 2010. Vol. 40. Iss. 4. P. 369-386. 


\section{ВИЗНАЧЕННЯ ТЕРМІНІВ «ФАХІВЕЦЬ І3 ЗВ'ЯЗКІВ ІЗ ГРОМАДСЬКІСТЮ» ТА «МАЙБУТНІЙ ФАХІВЕЦЬ ІЗ ЗВ'ЯЗКІВ ІЗ ГРОМАДСЬКІСТЮ» У ВІТЧИЗНЯНОМУ НАУКОВОМУ ПЕДАГОГІЧНОМУ ПРОСТОРІ}

\section{THE DEFINITION "PUBLIC RELATIONS SPECIALIST" AND "FUTURE PUBLIC RELATIONS SPECIALIST" IN THE DOMESTIC SCIENTIFIC PEDAGOGICAL SPACE}

На основі аналізу наукових та законодавчих джерел автором статті було сформульовано поняття «фрахівець із зв'язків із громадськістю» та «майбутній фрахівець із зв'язків із громадськістю». Для цього окремо проаналізовані складники поняття «фрахівець із зв'язків із громадськістю», а саме: дефрініція терміна «фрахівець» та дерініція терміна «зв'язки із громадськістю». Автором було зазначено різноманіття підходів до визначення поняття «зв'язки із громадськістю», як результат - величезну кількість дефініцій цього поняття. Це зумовлене тим, що Public Relations дотичні до різних сорер професійної діяльності, тому поняття «зв'язки із громадськістю» потрактовуються тим способом, яким Public Relations пов'язані 3 окремою галуззю науки чи практики. Теоретиками та практиками Public Relations було сформульовано вимоги до профресійноі діяльності майбутніх фрахівців із зв'язків із громадськістю, які ґрунтуються на головних напрямах практичної діяльності Public Relations. Узагальнення основних вимоги до фрахівця із зв'язків із громадськістю, що базуються на головних напрямах практичної діяльності Public Relations, дало можливість автору статті сорормулювати визначення поняття «фрахівець із зв'язків із громадськістю». Отже, «фрахівець із зв'язків із громадськістю» - це особа, яка здобула спеціальну освіту, володіє високим рівнем кваліфрікації, здійснює всі види профресійної діяльності, що входять у сферу зв'язків із громадськістю. На основі цього поняття, спираючись на Закон України «Про вищу освіту» (2014 рік), автором було сфрормульовано поняття «майбутній фрахівець із зв'язків із громадськістю». А саме, «майбутній фрахівець із зв'язків із громадськістю» че особа, яка навчається у вищому навчальному закладі з метою здобуття відповідного ступеня й отримання кваліфрікації через засвоєння динамічної комбінації знань, умінь і практичних навичок, способів мислення, профресійних, світоглядних і громадянських якостей, морально-етичних чінностей $у$ галузі зв'язків із громадськістю.
Ключові слова: зв'язки із громадськістю, фрахівець, професійна підготовка, фахівець із зв'язків із громадськістю, майбутній фрахівець із зв'язків із громадськістю, ЗВО України.

Based on the analysis of scientific, scientific-pedagogical and legislative sources, the author of the article formulated the concepts of "public relations specialist" and "future public relations specialist". To this end, the components of the concept of "public relations specialist" were analyzed separately, namely: the definition of "specialist" and the definition of "public relations". The author noted the objective diversity of approaches to the definition of "public relations" and as a result a huge number of definitions of this concept. This is because PR is relevant to different areas of professional activity, so the concept of "public relations" is interpreted in the way that PR is related to a particular field of science or practice. Accordingly, PR theorists and practitioners have formulated requirements for the professional activities of future public relations professionals, which are based on the main areas of $P R$ practice. The generalization of the basic requirements for a public relations specialist, based on the main areas of PR practice, allowed the author to formulate a definition of "public relations specialist". Namely, a "public relations specialist" is a person who has received special education, has a high level of qualification, carries out all types of professional activities that fall within the area of public relations. Based on this concept and based on the Law of Ukraine "On Higher Education" (2014), this author formulated the concept of "future public relations specialist". Therefore, "future public relations specialist" is a person who studies at a higher education institution in order to obtain an appropriate degree and qualification through the acquisition of a dynamic combination of knowledge, skills and practical skills; ways of thinking; professional, ideological and civic qualities, moral and ethical values in the field of public relations.

Key words: public relations, specialist, professional training, public relations specialist, future public relations specialist, universities of Ukraine.
Постановка проблеми в загальному вигляді. Процес професійної підготовки майбутніх фрахівців із зв'язків із громадськістю в Україні має бути розглянутий на базі поняттєво-категоріального апарату вищої освіти. С. Сисоєва, І. Соколова наголошували на важливості осмислення базових термінів у контексті наукового дослідження і зазначають: «Оперування людиною різними тлумаченнями поняття відбувається, коли ми хочемо виділити або підкреслити особливі характеристики, істотні ознаки предмета. У цьому випадку йдеться про застосування різних десрініцій (лат. definitio), у яких подано точне логічне визначення, виділено істотні дефініційні ознаки, визначено зміст і межі застосування поняття» $[10$, с. 219]. Поділяємо думку цих науковців і робимо висновок про необхідність осмислити дефініційні ознаки базових понять нашого дослідження: «фрахівець», «зв'язки із громадськістю», що в подальшому $€$ основою для визначення термінів «майбутній фахівець із зв'язків із громадськістю», «фахівець із зв'язків із громадськістю» 3 погляду професійної підготовки таких фрахівців в Україні. 
Аналіз останніх досліджень і публікацій. Процесу формування та становлення зв'язків із громадськістю як профресійної сорери діяльності присвячено праці таких українських і закордонних науковців: В. Березенко, В. Іванова, М. Катліпа, С. Квіта, С. Коржова, В. Королька, А. Кривоносова, О. Некрасової, В. Різуна, Є. Тихомирової, Г. Почепцова, М. Шишкіної, А. Чумікова й інших. Різні аспекти проблеми профресійної підготовки майбутніх фрахівців із зв'язків із громадськістю в Україні розглядали В. Березенко, А. Зінченко, А. Киричок, В. Королько, Т. Коржова, О. Курбан, А. Мельниченко, О. Некрасова, А. Нуржинська, І. Тітаренко В. Шиян та інші.

Виділення не вирішених раніше частин загальної проблеми. Незважаючи на велику кількість наукових розвідок, присвячених проблемі профресійної підготовки фрахівців із зв'язків із громадськістю у закладах вищої освіти (далі 3ВО) України, поза увагою науковців залишилися питання, пов'язані 3 розумінням змісту дефініції терміна «майбутній фрахівець із зв'язків із громадськістю» у вітчизняному науковому педагогічному просторі, тому власне цей аспект актуалізує мету статті.

Мета статті - на основі аналізу наукових та законодавчих джерел сорормулювати визначення понять «фрахівець із зв'язків із громадськістю» та «майбутній фрахівець із зв'язків із громадськістю».

Виклад основного матеріалу. Для розкриття сутності терміна «майбутній фахівець із зв'язків із громадськістю» ми розглядатимемо дві ключові складові частини цього поняття: «фрахівець», «зв'язки із громадськістю». Ми будемо надавати характеристику цим поняттям у нашій науковій розвідці, спираючись, насамперед, на україномовні й іншомовні нормативно-правові, наукові джерела, у яких висвітлено результати наукових досліджень, присвячених питанню професійної підготовки фрахівців із зв'язків із громадськістю.

В українських сучасних довідкових джерелах зміст поняття «фрахівець» тлумачиться так: «Той, хто досконало володіє якимсь фрахом, має високу кваліфікацію, глибокі знання 3 певної галузі науки, техніки, мистецтва тощо; спеціаліст» [1, с. 1530]. Відповідно до ст. 1 Закону України «Про вищу освіту» (2014р.), фрахівець має отримати «сукупність систематизованих знань, умінь і практичних навичок, способів мислення, професійних, світоглядних і громадянських якостей, морально-етичних цінностей, інших компетентностей, здобутих у вищому навчальному закладі (науковій установі) у відповідній галузі знань за певною кваліфрікацією на рівнях вищої освіти, що за складністю є вищими, ніж рівень повної загальної середньої освіти» [2].

У нашому науковому дослідженні зміст поняття «фрахівець» визначаємо так: че особа, яка отри- мала вищу освіту, володіє високим рівнем кваліфрікації, може здійснювати всі види профресійної діяльності.

Розуміння змісту наступного базового поняття «зв'язки із громадськістю» як складової частини поняття «майбутній фрахівець із зв'язків із громадськістю» $€$ надзвичайно важливим, адже серед учених у цій галузі та PR-практиків немає єдності в розумінні змісту цього поняття, що створює складнощі для наповнення освітніх програм професійної підготовки майбутніх фрахівців у галузі зв'язків із громадськістю. Розуміння змісту поняття «зв'язки із громадськістю» необхідне і для створення переліку предметів, що входитимуть до освітніх програм, особливо з огляду на відсутність стандарту вищої освіти для професійної підготовки фрахівців у галузі зв'язків із громадськістю. Через відсутність стандарту вищої освіти для професійної підготовки фрахівців у галузі зв'язків із громадськістю немає чітко сорормулюваних компетентностей випускника: інтегральної компетентності, загальних компетентностей, спеціальних (фахові, предметні) компетентностей. Ми розлядатимемо напрацювання вчених та практиків у галузі Public Relations (далі - PR, ПР) щодо вимог, якостей, професійних завдань, знань і умінь фрахівця в галузі PR.

Нині існує величезна кількість дефініцій поняття «зв'язки із громадськістю», це зумовлено тим, що зв'язки із громадськістю як наука мають суспільний характер. Крім того, існують спільні та відмінні ознаки PR та інших сорер діяльності: інфрормаційно-комунікаційних технологій, журналістики, реклами; можливостей використання їхніх методів і засобів (агітація, пропаганда тощо). На думку В. Мойсеєва, «взаємодіючи із суміжними сорерами соціальної практики, ПР запозичують певні їхні методи і засоби. Однак вони не можуть цілком перейняти їх, оскільки є самодостатньою фаховою діяльністю, ґрунтуються на специфічних принципах і мають свій об'єкт впливу» [7, с. 18].

Натепер у науковому обігові існують різні підходи до визначення поняття «зв'язки із громадськістю», наведемо деякі з них. На думку О. Осипової, підґрунтям для класифікації підходів щодо означення поняття «зв'язки із громадськістю» $€$ цілі PR-діяльності, тому «сьогодні виділяють альтруїстичний, компромісний та прагматичний підходи» [8, с. 129] до визначення поняття «зв'язки із громадськістю» (див. таблицю 1).

Інша наукова класифрікація підходів до визначення змісту поняття «зв'язки із громадськістю» була сорормульована В. Корольком, О. Некрасовою [4, с. 23]. Узагальнення підходу до визначення поняття «зв'язки із громадськістю» за цими авторами унаочнено нами в таблиці 2.

Іншого бачення щодо класифікації підходів із визначення поняття «зв'язки із громадськістю» дотримується М. Шишкіна [13]. Цей науковець 
уважає, що всі існуючі поняття ПР можна поділити на п'ять основних груп. Основою поділу цієї класифікації виступають ключові слова, за якими приховано специфрічне розуміння онтологічного статусу PR. На думку М. Шишкіної, до першої групи належать усі визначення поняття «зв'язки із громадськістю», у яких PR розглянуто як науку та/ або мистецтво для вирішення необхідних для конкретної організації завдань. До такої групи визначення поняття "Public Relations" відносять дефініції за Е. Бернайзом, С. Блеком, Н. Арнольдом та ін. До другої групи, за М. Шишкіною, належать усі визначення поняття «зв'язки із громадськістю», де PR розглянуто як вид діяльності, як-от: управлінська, комунікаційна, організаторська тощо. До такої групи відносять дефрініції PR за А. Звєрінцевим, Г. Тульчинським, І. Яковлєвим, а також ті, що представлені у виданнях Британського інституту зв'язків із громадськістю (The Institute for Public Relations (IPR)) та інших. До третьої, найчисленнішої групи, за М. Шишкіною, належать усі визначення поняття «зв'язки із громадськістю», де PR розглянуто як специфічну фрункцію управління або фрункції менеджменту. До такої групи відносять десрініції PR за Р. Харлоу, І. Альошиною, М. Менчером та ін. До четвертої групи, за М. Шишкіною, належать усі визначення поняття «зв'язки із громадськістю», де PR розглянуто, на противагу попередній групі, не як функцію, а як власне управління або менеджмент (менеджмент комунікацій).

Таблиця 1

Основні підходи до визначення поняття «зв'язки із громадськістю» за О.Осіповою

\begin{tabular}{|c|c|l|}
\hline Номер підходу & Назва підходу & \multicolumn{1}{|c|}{ Вчені - представники підходу } \\
\hline Перший & Альтруістичний & С. Блек, Ф. Джефкінс, Ф. Буарі й інші. \\
\hline Другий & Компромісний & Е. Бернайз, Л. Невзлін та інші. \\
\hline Третій & Прагматичний & $\begin{array}{l}\text { Р. Харлоу, О. Чуміков, М. Бочаров, Д. Ньюсом, Дж. Тьорк, Д. Крукеберг } \\
\text { та інші. }\end{array}$ \\
\hline
\end{tabular}

Таблиця 2

Основні групи визначення поняття «зв'язки із громадськістю» за В. Корольком

\begin{tabular}{|c|c|l|}
\hline Номер групи & Назва групи & \multicolumn{1}{|c|}{ Характеристика групи } \\
\hline Перша & Ооріційна & $\begin{array}{l}\text { Віднесені ті визначення поняття «зв'язки із громадськістю», що мають інституціо- } \\
\text { нальний статус (статути національних та міжнародних Асоціацій РR). }\end{array}$ \\
\hline Друга & Канонічна & $\begin{array}{l}\text { Віднесені ті визначення поняття «зв'язки із громадськістю», що містяться у слов- } \\
\text { никах або енциклопедіях. }\end{array}$ \\
\hline Третя & Авторська & $\begin{array}{l}\text { Віднесені ті визначення поняття «зв'язки із громадськістю», що мають високий } \\
\text { науковий або професійний статус, зроблені авторитетними фахівцями соери PR. }\end{array}$ \\
\hline Четверта & Галузева & $\begin{array}{l}\text { Віднесені ті визначення поняття «зв'язки із громадськістю», що репрезентують } \\
\text { основні типи поглядів, думок стосовно природи РR. }\end{array}$ \\
\hline
\end{tabular}

Таблиця 3

Класифікація поняття «зв'язки із громадськістю» за М. Шишкіною

\begin{tabular}{|c|l|c|}
\hline Номер групи & \multicolumn{1}{|c|}{ Ключові слова } & Вчені - представники групи \\
\hline Перша & PR як наука та/або мистецтво & Е. Бернайз, С. Блек, Н. Арнольд \\
\hline Друга & PR як певного виду діяльність & А. Звєрінцев, Г. Тульчинський, І. Яковлєв \\
\hline Третя & $\begin{array}{l}\text { РR як специфічна фрункція управління або фрункції } \\
\text { менеджменту }\end{array}$ & Р. Харлоу, І. Альошина, М. Менчер \\
\hline Четверта & РR як управління або менеджмент & А. Вєкслєр, Дж. Грюніг, Т. Хант, Г. Почепцов \\
\hline П'ята & $\begin{array}{l}\text { РR через діяльнісний статус: суб'єкт, предмет, } \\
\text { мета, доцільний характер, засоби, результат і } \\
\text { власне процес діяльності }\end{array}$ & М. Шишкіна \\
\hline
\end{tabular}

Первинні властивості ідеального фрахівця у сфері PR за X. Берсоном

\begin{tabular}{|c|c|c|}
\hline № & Первинні властивості & Сутність властивості \\
\hline I. & $\begin{array}{l}\text { PR-фрахівець здібний, розумний, винахідливий, емо- } \\
\text { ційно незворушний, креативний, викликає довіру. }\end{array}$ & PR-срахівцю притаманні яскраві психологічні риси. \\
\hline II. & PR-срахівець швидко вчиться. & $\begin{array}{l}\text { PR-фрахівець вмотивований на постійне підвищення } \\
\text { своєї кваліфрікації. }\end{array}$ \\
\hline III. & $\begin{array}{l}\text { PR-срахівець уміє поводитися з людьми (колеги, } \\
\text { представники засобів масової інфрормації, клієнти). }\end{array}$ & $\begin{array}{l}\text { PR-срахівець володіє механізмами різноманітних } \\
\text { рорм і методів ділового спілкування. }\end{array}$ \\
\hline IV. & PR-фрахівець не піддається тиску, знає, що робити. & PR-фрахівець автономний у прийнятті рішень \\
\hline V. & $\begin{array}{l}\text { PR-срахівець уміє писати, уміє фрормулювати свої } \\
\text { думки в переконливій фрормі. }\end{array}$ & $\begin{array}{l}\text { PR-срахівець володіє знаннями, уміннями та нави- } \\
\text { чками журналістської профресійної діяльності. }\end{array}$ \\
\hline
\end{tabular}


До такої групи визначення поняття «зв'язки із громадськістю» відносять дефініції PR за А. Вєкслєр, Дж. Грюнігом, Т. Хантом, Г. Почепцовим та ін.

М. Шишкіна фрормулює власне визначення терміна «зв'язки із громадськістю», яке відносить до п'ятої групи дефрініцій PR. Ця дослідниця розглядає «зв'язки із громадськістю» 3 погляду діяльнісного статусу. Послідовно останній розглянуто вченою через елементи діяльнісного статусу, як-от: суб'єкт, предмет, мета, доцільний характер, засоби, результат і власне процес діяльності. М. Шишкіна пише (переклад із російської тут та далі наш - I. Р.): «Паблік рілейшнз - це управлінська комунікативна ринкова діяльність (сукупність соціальних практик), що спрямована на фрормування ефективної системи публічних дискурсів соціального суб'єкта, забезпечує оптимізацію його взаємодії зі значущими сегментами соціального середовища (з його громадськістю)» [13, с. 72]. Узагальнення підходу до визначення поняття «зв'язки із громадськістю» за М. Шишкіною нами унаочнено в таблиці 3.

Як бачимо, з моменту появи такого соціального інституту, як зв'язки із громадськістю, не припиняються суперечки про точність визначення змісту поняття «зв'язки із громадськістю».

Різноманіття підходів до визначення поняття «зв'язки із громадськістю» зумовлене тим, що PR $€$ дотичним до різних сорер людської діяльності, тому це поняття тлумачиться залежно від того, як PR пов'язаний з окремою галуззю науки чи практики. Теоретиками та практиками PR висуваються вимоги до професійної діяльності майбутніх фрахівців із зв'язків із громадськістю, які ґрунтуються на головних напрямах практичної діяльності PR. Такої думки дотримуються Є. Коханов, І. Сіняєва, які фрормулюють вимоги до знань та вмінь фрахівців із зв'язків із громадськістю, виходячи з їхніх головних напрямів та завдань професійної діяльності.

У теорії та практиці зв'язків із громадськістю існує уявлення про ідеального PR-фрахівця. Американський практик у галузі PR X. Берсон визначає чотири первинні властивості, притаманні ідеальному фахівцю в зазначеній сфрері (тут та далі переклад 3 англійської мови наш - І. Р.) [14, с. 78-79]. Первинні властивості ідеального PR-фрахівця, за цим автором, нами унаочнено в таблиці 4.

Науковець $€$. Коханов подає соціально-психологічний портрет ефективного (ідеального) PR-фрахівця [6, с. 58-59]. Однак одні дослідники, як-от X. Берсон, у визначенні рис ідеального фахівця в галузі PR роблять акцент на особистісні психологічні якості, а інші дослідники, як-от $€$. Коханов, у визначенні рис ідеального фрахівця в галузі PR акцентують соціальну роль такого фрахівця в суспільстві.

Щодо провідних рис ідеального фрахівця в галузі PR сучасний дослідник I. Сіняєва, яка у власній профресійній діяльності поєднала теоретичні підходи із практикою, зазначає: "PR-срахівець повинен досконало володіти механізмами різноманітних фрорм і методів ділового спілкування» [9, с. 42].

До фрахівців із зв'язків із громадськістю висуваються досить широкі (інтегральні) вимоги, що зумовлено викликами часу. Ф. Шарков уважає, що «у системі зв'язків із громадськістю необхідні не тільки знання 3 основ роботи 3 текстом, іноземних мов і технологій різноманітних 3MІ, але також і знання з менеджменту, економіки, соціології, психології, статистики та іншого» [12, с. 67].

На сучасному етапі розвитку суспільства особливого значення набувають інфрормаційно-комунікаційні технології. На думку Б. Кияка, сучасна «індустрія PR базується на науці з використанням найсучасніших комунікаційних і комп'ютерних технологій, баз даних, прес-моніторінгу, аналітики. До PR-технологій ставляться особливі вимоги і наявний високий стандарт» [3, с. 30]. Отже, сьогоднішній ринок праці характеризується появою самостійної спеціалізації PR-фрахівця в інтернеті. Деякі державні структури, великі корпорації, інфрормаційні та PR-агенства почали запрошувати на роботу фрахівців із зв'язків із громадськістю в Інтернеті. О. Чуміков, М. Бочаров, М. Тішкова виокремили професійні вимоги до такого PR-срахівця. На їхню думку, такий фахівець «покликаний створювати, координувати, коректувати, досліджувати зміст меседжів і контролювати актуальний рівень комунікацій» [11, с. 5].

Провідний вітчизняний науковець у сорері PR B. Королько висуває кваліфікаційні вимоги до дипломованого фрахівця із зв'язків із громадськістю в різноманітних сорерах життєдіяльності: у сфрерах планування, управління, реклами, аналітичної роботи, виробничих відносин, економічних відносин, комунікацій, соціальних відносин, політики, освіти [5, с. 44-45].

Узагальнюючи основні вимоги до фрахівця із зв'язків із громадськістю, що ґрунтуються на головних напрямах практичної діяльності PR, можемо дати таке визначення поняття: фахівець із зв'язків із громадськістю - це особа, яка отримала спеціальну освіту, володіє високим рівнем кваліфікації, здійснює всі види професійної діяльності, що входять у сореру зв'язків із громадськістю.

У ст. 1 Закону України «Про вищу освіту» (2014 р.) розкрито зміст таких понять: «здобувачі вищої освіти», «кваліфікація», «компетентність», «спеціалізація» та «спеціальність». Визначення таких понять в цьому Законі України подано так:

- здобувачі вищої освіти - особи, які навчаються у вищому навчальному закладі на певному рівні вищої освіти з метою здобуття відповідного ступеня і кваліфрікації;

- кваліфікація - офріційний результат оцінювання і визнання, який отримано, коли уповноважена установа встановила, що особа досягла ком- 
петентностей (результатів навчання) відповідно до стандартів вищої освіти, що засвідчується відповідним документом про вищу освіту;

- компетентність - динамічна комбінація знань, умінь і практичних навичок, способів мислення, професійних, світоглядних і громадянських якостей, морально-етичних цінностей, яка визначає здатність особи успішно здійснювати професійну та подальшу навчальну діяльність і $€$ результатом навчання на певному рівні вищої освіти [2].

Спираючись на вищенаведені визначення, можемо сорормулювати власну дефініцію поняття «майбутній фахівець із зв'язків із громадськістю». Ми вважаємо, що майбутній фрахівець із зв'язків із громадськістю - це особа, яка навчається у вищому навчальному закладі з метою здобуття відповідного ступеня й отримання кваліфрікації через засвоєння динамічної комбінації знань, умінь і практичних навичок, способів мислення, професійних, світоглядних і громадянських якостей, морально-етичних чінностей у галузі зв'язків із громадськістю.

Висновки. Відповідно до мети статті, на основі аналізу наукових та законодавчих джерел нами вперше в українському науковому обігові було сорормульоване визначено поняття «фрахівець із зв'язків із громадськістю» та «майбутній фрахівець із зв'язків із громадськістю».

\section{БІБЛІОГРАФІЧНИЙ СПИСОК:}

1. Великий тлумачний словник сучасної української мови / уклад. і голов. ред. В. Бусел. Київ ; Ірпінь : Перун, 2009. 1736 с.

2. Про вищу освіту : Закон України, 2014 р. URL: http://zakon2.rada.gov.ua/laws/show/155618/ print1382948206521198 (дата звернення: 11.03.2020)

3. Кияк Б. PR - стосунки із громадськістю : навчальний посібник для вищих навчальних закладів. Київ, 2009. 285 с.

4. Королько В., Некрасова О. Зв'язки 3 громадськістю : наукові основи, методика, практика. Київ : Києво-Могилянська академія, 2009. 831 с.

5. Королько В. Основы паблик рилейшнз. Москва ; Киев : Рефрл-бук ; Ваклер, 2001. 528 с.

6. Коханов Е. Теоретические и методологические основы PR-деятельности : социологический аспект : монография. Москва, 2004. 201 с.

7. Мойсеєв В. Паблік рілейшнз : навчальний посібник. Київ : Академвидав, 2007. 224 с.

8. Осипова Е. Социально-философрский анализ современных подходов к определению связей с общественностью. URL: http://cyberleninka.ru/ article/n/sotsialnofilosofskiyanalizsovremennyhpodho dovkopredeleniyusvyazeysobschestvennostyu (дата звернення: 12.01.2020).

9. Синяева И. Сорера PR в маркетинге : учебное пособие. Москва : Юнити-Дана, 2007. 383 с.

10. Сисоєва С. Проблеми неперервної професійної освіти : тезаурус наукового дослідження : наукове видання. Київ ; Маріуполь, 2010. 299 с.

11. Чумиков A. PR в Интернете : Web 1.0, Web 2.0, Web 3.0. Москва : Альпина, 2010. 130 с.

12. Шарков Ф. Паблик рилейшинз (связи с общественностью) : учебное пособие для вузов. Москва ; Екатеринбург : Академический проект ; Деловая книга, 2007. 304 c.

13. Шишкина М. Паблик рилейшнз в системе социального управления. Санкт-Петербург : Паллада-медиа ; Русич, 2002. 444 с.

14. Fraser P. Seitel. The Practice of Public Relations. New Jersey : Prentice Hall, Upper Saddle River, 1998. 556 p. 


\section{СУЧАСНІ ПІДХОДИ ДО ФОРМУВАННЯ КОМУНАКАТИВНО-МОВЛЕННЄВОЇ КОМПЕТЕНТНОСТІ СТУДЕНТІВ ГУМАНІТАРНО-ПЕДАГОГІЧНОГО КОЛЕДЖУ

\author{
MODERN APPROACHES TO THE FORMATION \\ OF STUDENTS' COMMUNICATIVE-SPEECH COMPETENCE \\ OF THE HUMANITARIAN-PEDAGOGICAL COLLEGE
}

\begin{abstract}
У статmі розглянуто сутність $і$ основні характеристики нових підходів як загальнодидактичних категорій, на які орієнтують чинні програми з української мови. Сучасна освіта в Україні виходить на якісно новий щабель, зумовлений змінами в суспільному житті. Від якості впровадження і застосування інноваційних підходів в освітньому просторі значною мірою залежить прогрес нашого суспільства. Формуються концептуальні засади національної системи освіти, народжуються нові концепції, дослідники створюють оригінальні навчальні та виховні системи, апробуються сучасні підходи до вивчення різних навчальних предметів, зокрема й української мови. Мета розвідки полягає в теоретичному обгрунтуванні та визначенні ефективних підходів щодо фрормування комунікативно-мовленнєвої компетентності студентів-фрілологів. Досягнення зазначеної мети студій залежить від удосконалення знань, умінь студентів під час вивчення лінгводидактичних дисциплін. Тобто ефрективне формування комунікативних, мовних, мовленнєвих умінь учасників освітнього процесу можливе за умови поєднання особистісно орієнтованого, професійно орієнтованого, комунікативного, діяльнісного, функціонально-стилістичного, соціокультурного та текстоцентричного підходів. Підхід до навчання визначено як основну лінгводидактичну категорію, яка визначає ефективність навчання мови та вибір принципів, технологій, методів і прийомів, засобів навчання лінгвістичних дисциплін, що реалізують цю ефрективність, а також фрормують окремі характеристики мовної особистості щодо вибору майбутньої профресії. Актуальність нашого дослідження зумовлена соціальним замовленням суспільства на підвищення результативності навчання, увиразнення мовлення, формування здатності спілкування в різних ситуаціях, жанрах, стилях, видах мовленнєвої діяльності (продуктивні та рецептивні). Ключові слова: сучасні підходи, компетентність, комунікативно-мовленнєва компе-
\end{abstract}

тентність, вчитель-фрілолог, фрормування мовної особистості студентів-словесників.

The article considers the essence and main characteristics of new approaches as general didactic categories, which are the focus of current programs in the Ukrainian language. Modern education in Ukraine is reaching a qualitatively new level due to changes in public life. The progress of our society largely depends on the quality of implementation and application of innovative approaches in the educational space. Conceptual foundations of the national education system are formed, new concepts are born, researchers are creating original educational systems, and modern approaches to the study of various subjects, including the Ukrainian language, are tested. The purpose of article is theoretically to substantiate and determine effective approaches to the formation of students-philologists' communicative and speech competence. Achieving this goal of studies depends on improving the knowledge and skills of students while studying linguodidactic disciplines. That is, the effective formation of participants' communicative, language, speech skills during the educational process is possible provided a combination of personality-oriented, professionally oriented, communicative, activity, functional-stylistic, socio-cultural and text-centric approaches. The approach to learning is defined as the main linguodidactic category, which determines the effectiveness of language learning and the choice of principles, technologies, methods and techniques, teaching aids of linguistic disciplines that implement this effectiveness, and form certain characteristics of language personality to choose future profession. The relevance of our study is due to the social order of society to increase the effectiveness of learning, speech expression, the formation of the ability to communicate in different situations, genres, styles, types of speech activity (productive and receptive). Key words: modern approaches, competence, communicative-speech competence, teacherphilologist, formation of language personality of students-linguists.
Постановка проблеми в загальному вигляді. Натепер існує багато сучасних підходів до фрормування мовної та мовленнєвої особистості студентів на заняттях із лінгводидактичних дисциплін. Інноваційний підхід до навчання рідної мови визначається основною фрунцією самої мови, спирається на рівень розвитку студентів, на динаміку формування комунікативно-мовленнєвих умінь і навичок за певною методикою, на ефективність методів, прийомів, технологій і засобів навчання.

Аналіз останніх досліджень і публікацій. Аналіз спеціальної літератури засвідчив, що проблема фрормування та впровадження сучасних під- ходів в освітній простір є предметом дослідження у працях науковців психологічної, лінгвопедагогічної галузей: 3. Бакум, Н. Голуб, О. Горошкіної, Г. Дідук-Ступ'як, Т. Донченко, В. Дороз, О. Караман, С. Карамана, О. Копусь, І. Кучеренко, Л. Мамчур, Н. Мордовцевої, А. Нікітіної, С. Омельчука, Н. Остапенко, М. Пентилюк, Л. Попової, Л. Рускуліс, О. Семеног, Т. Симоненко, Г. Шелехової та ін.

Виділення не вирішених раніше частин загальної проблеми. У сучасній лінгвометодичній базі науковці репрезентують такі підходи до навчання української мови, які поділяються на традиційні (лінгвістичний, педагогічний, психоло- 
гічний, моральний, естетичний) та нові (комунікативно-діяльнісний, когнітивний, функційно-стилістичний, соціокультурний, текстоцентричний тощо). Актуальна для нашої розвідки характеристика інноваційних дидактичних та лінгводидактичних підходів до навчання мови з метою розвитку комунікативно-мовленнєвих компетентностей студентів гуманітарно-педагогічного коледжу, що формуються на вміннях та навичках у продуктивних та рецептивних видах мовленнєвої діяльності.

Мета статті полягає в теоретичному обґрунтуванні та визначенні ефективних підходів щодо фрормування комунікативно-мовленнєвої компетентності студентів-срілологів. Досягненню мети сприятиме ґрунтовна характеристика взаємопов'язаних сучасних наукових підходів до навчання.

Виклад основного матеріалу. Сучасний заклад вищої освіти повинен насамперед піклуватися про розвиток особистостей. Нині інформатизований світ дуже стрімко змінюється, дедалі важче в ньому орієнтуватися викладачу та майбутньому вчителю-словеснику. Кожен педагог намагається відшукати ефективні методи, прийоми, форми та підходи роботи, обрати свій стиль викладання, а також створити умови для позитивного розвитку навчальних здібностей і увиразнення мовлення студентів.

Формування комунікативно-мовленнєвої компетентності в єдності 3 когнітивною компетентністю допоможе сорормувати мовну особистість, яка буде забезпечувати висококультурне інтелектуальне спілкування українською літературною мовою. Адже мовленнєвий розвиток у сучасній методичній науці відбувається у процесі мовленнєвої діяльності. На думку Т. Донченко, на нові підходи до вивчення мовних одиниць і категорій, на характер теоретичного і дидактичного матеріалу істотно впливає мовленнєва діяльність студентів [7, с. 5-11].

За Великим тлумачним словником, підхід - це «сукупність, способів, прийомів розгляду чогонебудь, впливу на кого-, що-небудь, ставлення до кого-, чого-небудь» [2, с. 969]. Підхід до навчання розглядається в методиці як базисна категорія, яка визначає стратегію навчання мови та вибір методу навчання, що реалізує цю стратегію [1, с. 200]. Варто зазначити, що «підхід» як лінгводидактична категорія не зафіксовано в педагогіч- них і методичних словниках і енциклопедіях. Ми підтримуємо погляди С. Омельчука, який розглядає поняття «підхід» як найвищий щабель в ієрархії лінгводидактичних категорій, що об'єднує в собі інші категорійні поняття. Учений визначає «підхід» як методологічну категорію лінгводидактики, що позначає складне багатовимірне явище, системну сукупність якого становлять принципи, технології, методи, прийоми, засоби й фрорми навчання, яке характеризується концептуальністю, процесуальністю, системністю, керованістю й дієвістю (табл. 1) [13, с. 3-4].

Основним підходом, що характеризує сучасний етап розвитку методичної науки, можна вважати особистісно зорієнтований підхід. За цього підходу визначальними мають бути робота в парах, групах, студентські диспути, рольові ігри, розігрування діалогів, ведення бесід, розвиток творчих здібностей, самооцінювання. Сутність підходу полягає в урахуванні вікових, психологічних, професійних інтересів, можливостей студентів, у здійсненні опори на принципи диореренціації, індивідуалізації навчання, в особистісному розвитку здобувачів освіти [6, с. 130]. М. Пентилюк розглядає цей підхід як послідовне ставлення педагога до учня як до особистості, самосвідомого відповідального суб'єкта власного розвитку та суб'єкта виховної взаємодії [21, с. 178]. Отже, особистісно зорієнтований підхід у нашому дослідженні має забезпечувати розвиток особистості, впливати на увиразнення мовлення студентів-фрілологів, ґрунтуючись на виявленні індивідуальних особливостей студента як суб'єкта пізнання і предметної діяльності.

М. Пентилюк одним 3 актуальних нині вважає компетентнісний підхід, ставить його поряд з особистісно та діяльнісно орієнтованим, когнітивно-комунікативним, функційно-стилістичним та ін. [15, с. 2]. Компетентнісний підхід робить акцент на тому, що знання повинні підпорядковуватися вмінням і навичкам. У сучасній парадигмі закладів вищої освіти компетентнісний підхід репрезентує якісно нові підходи, що відповідають інноваційним процесам в освіті. Сучасний випускник гуманітарно-педагогічного коледжу має знати не лише всі граматичні, орфограсрічні й пунктуаційні правила та винятки з них, а й уміло і легко використовувати відповідно до потреб комунікації мовні засоби, уміти грамотно говорити і писати, орієн-

Таблиця 1

Визначення поняття «підхід» у лінгводидактичній літературі

\begin{tabular}{|l|c|}
\hline \multicolumn{1}{|c|}{ Визначення } & Джерело \\
\hline $\begin{array}{l}\text { Г. Селевко трактує це поняття як методологічну орієнтацію вчителя, яка спонукає до вико- } \\
\text { ристання певної характерної сукупності взаємопов'язаних ідей, понять і способів педагогічної } \\
\text { діяльності. }\end{array}$ & [20, с. 48] \\
\hline $\begin{array}{l}\text { Н. Голуб переконує, що підхід - світоглядна категорія, «що відображає соціальні настанови } \\
\text { суб'єктів навчання як носіїв суспільної свідомості; як глобальна й системна організація й } \\
\text { самоорганізація освітнього процесу; як стратегія навчання, що поєднує в собі методи, фрорми, } \\
\text { прийоми навчання». }\end{array}$ & [3, с. 2] \\
\hline
\end{tabular}


туватися в мовленнєвому процесі. Девід Макклеланд стверджує, що становленню успішної життєвої діяльності особистості в навчанні сприяє саме компетентнісний підхід (табл. 2) [26].

Ми вважаємо, що побудову методичної системи формування комунікативно-мовленнєвої компетентності майбутніх учителів української мови необхідно пов'язати 3 комунікативно-діяльнісним підходом, адже студент може виявити власну комунікативну компетентність тільки в мовленнєвій діяльності серед членів не лише освітнього простору, а й суспільного середовища. На думку М. Пентилюк, О. Горошкіної, А. Нікітіна, в основу цього підходу покладено мовленнєву діяльність здобувачів освіти (аудіювання, говоріння, читання і письмо). Комунікативно-мовленнєві завдання мотивують і підтримують потребу студентів-словесників у спілкуванні, забезпечують перехід від репродукції мовлення до самостійного продукування, до непідготовленого мовлення в різноманітних ситуаціях спілкування. О. Горошкіна наголошує, що «повинен бути закладений весь методично адаптований матеріал комунікативно-базового ядра сучасної української літературної мови», а паралельно із цим необхідно «залучити до курсу етнокультурознавчий компонент, що відображає українознавство,

Таблиця 2

\section{Аналіз компетентнісного підходу (далі - КП) у лінгводидактичних працях}

\begin{tabular}{|l|c|}
\hline \multicolumn{1}{|c|}{ Визначення } & Джерело \\
\hline $\begin{array}{l}\text { М. Пентилюк зазначає, що КП - «своєрідний орієнтир, який спрямовує професійну діяль- } \\
\text { ність учителя на виконання головної мети мовної освіти - виховання мовної особистості, } \\
\text { яка володіє системою знань, умінь і навичок, що забезпечать її високий рівень спілкування } \\
\text { в різних життєвих ситуаціях». }\end{array}$ & {$[15$, с. 5] } \\
\hline $\begin{array}{l}\text { О. Пометун висловлює припущення, що КП потребує «трансформації змісту освіти, пере- } \\
\text { творення його з моделі, яка існує «об'єктивно» для «всіх», на суб'єктивні надбання одного, } \\
\text { конкретного здобувача освіти, надбання, що їх можна виміряти». }\end{array}$ & {$[18$, с. 47] } \\
\hline $\begin{array}{l}\text { Л. Овсієнко вказує на те, що КП реалізується «від передачі знань і вмінь предметного } \\
\text { змісту до фрормування майбутнього вчителя зі сфрормованими життєвими і профресійними } \\
\text { компетентностями». }\end{array}$ & {$[12$, с. 47] } \\
\hline $\begin{array}{l}\text { М. Фіцула зазначає, що КП передбачає «мотиваційну, рефлексивну, когнітивну, операційно- } \\
\text { технологічну та інші складові частини результатів навчання, що відбивають прирощення не } \\
\text { лише знань, умінь і навичок, а й досвіду емоційно-ціннісного ставлення». }\end{array}$ & {$[23$, с. 124] } \\
\hline Д. Макклеланд наголошує, що КП «повинен стати пріоритетним у навчанні». & {$[26$, с. 331] } \\
\hline
\end{tabular}

Аналіз компетентнісно-діяльнісного підходу (далі - КдП) у лінгводидактичних джерелах

Таблиця 3

\begin{tabular}{|c|c}
\hline Визначення & Джерело
\end{tabular}

Г. Шелехова акцентує увагу на тому, що КДП реалізується у процесі взаємопов'язаного вдосконалення чотирьох видів мовленнєвої діяльності учасників освітнього процесу аудіювання (слухання - розуміння), читання, говоріння, письма, а «робота над мовною теорією, формування вмінь з мови підпорядковується інтересам розвитку мовлення; передбачає широке застосування інтерактивних методів навчання, оптимальне поєднання фрронтальної, групової та індивідуальної фрорм організації навчального процесу».

Для М. Пентилюк КДП «полягає в такій організації навчання, коли засвоєння мови відбувається безпосередньо у процесі комунікативної діяльності з метою оволодіння комунікативними вміннями і навичками. Цей підхід спрямований на формування комунікативної компетентності - здатності користуватися мовою залежно від конкретної ситуації».

М. Пентилюк зауважує, що КДП до навчання української мови «як основа мовленнєвої діяльності мовців дає їм змогу виявляти свою компетентність за певних умов у специсрічному оточенні та в окремій сфрері діяльності».

\begin{tabular}{|c|c|}
\hline Джерело \\
\hline \\
{$[25$, с. 61$]$} \\
\hline \\
{$[21$, с. 7$]$} \\
\hline
\end{tabular}

Аналіз функційно-стилістичного підходу (далі - ФСП) у лінгводидактичних студіях

\begin{tabular}{|c|c|}
\hline Визначення & Джерело \\
\hline $\begin{array}{l}\text { Для В. Мельничайко ФСП є «одним із засобів удосконалення викладання рідної мови і } \\
\text { Ґрунтується на здійсненні взаємозв'язку стилістики з усіма іншими розділами». }\end{array}$ & {$[10$, c. 76$]$} \\
\hline $\begin{array}{l}\text { Г. Михайловська вважає, що цей підхід пов'язує мову (систему мови) й мовлення, пара- } \\
\text { дигматику й синтагматику, статику й динаміку, забезпечує перехід від мови як семіотичної } \\
\text { системи до мови як діяльності. }\end{array}$ & {$[11$, c. 93] } \\
\hline $\begin{array}{l}\text { М. Пентилюк зазначає, що «головне в організації такого навчання - йти від тексту, на } \\
\text { матеріалі текстів повторювати, узагальнювати і поглиблювати знання про систему мови, } \\
\text { активізувати засоби всіх мовних рівнів у їх взаємодії. За таких умов саме знання стилістики } \\
\text { сприяє піднесенню мовленнєвої культури людини, виробленню вмінь послуговуватися } \\
\text { мовними засобами в різних ссрерах спілкування й життєвих ситуаціях». }\end{array}$ & {$[14$, c. 2$]$} \\
\hline
\end{tabular}


Аналіз соціокультурного підходу в лінгводидактичних розвідках

Таблиця 5

\begin{tabular}{|c|c|}
\hline Визначення & Джерело \\
\hline $\begin{array}{l}\text { Шелехова Г. зазначає, що соціокультурний підхід у мовній освіті - це вивчення мови на основі } \\
\text { створеної українським народом оригінальної і яскравої культури, відображеної в міфології, } \\
\text { традиціях і звичаях, усній народній творчості, а також акумульованої в перекладних літера- } \\
\text { турних творах культур інших народів, трансформація студентом відомостей із мови, літе- } \\
\text { ратури, історії та інших предметів, власного життєвого досвіду, що відбувається у процесі } \\
\text { підготовки усних та письмових творів, під час виконання творчих робіт інших жанрів, } \\
\text { в особистісно неповторний погляд на життя, у переконання, світоглядні настанови, ідеали, } \\
\text { у знання культурних реалій, які забезпечують органічне входження в суспільство, визначення } \\
\text { свого місця в ньому. }\end{array}$ & [24] \\
\hline $\begin{array}{l}\text { Л. Мацько, О. Семеног наголошують, що «соціокультурний підхід сприяє розвитку духовної } \\
\text { сорери особистості, збагаченню словникового запасу, формуванню особистісних переконань, } \\
\text { самовдосконаленню особистості, створенню освітнього простору здобувачів освіти. Специ- } \\
\text { фріка реалізації зазначеного підходу полягає у фрормуванні умінь готувати тематичні екскурсії, } \\
\text { зустрічі, олімпіади, вікторини, ігри, конкурси, укладати тематичний словник-тезаурус, власну } \\
\text { електронну бібліотеку». }\end{array}$ & {$[9$, c. 50$]$} \\
\hline
\end{tabular}

Аналіз текстоцентричного підходу (далі - ТП) у лінгводидактичних джерелах

\begin{tabular}{|l|r|}
\hline \multicolumn{1}{|c|}{ Визначення } & Джерело \\
\hline $\begin{array}{l}\text { М. Пентилюк переконує, що ТП покликаний реалізувати низку завдань: формувати складники } \\
\text { культуромовної особистості (нормативність, правильність, точність, доречність, виразність } \\
\text { тощо); удосконалювати вміння практично використовувати моделі висловлень; розвивати } \\
\text { культуру ведення розмови; фрормувати мовленнєву компетентність мовця. }\end{array}$ & [16] \\
\hline $\begin{array}{l}\text { І. Дроздова вважає, що ТП «передбачає підбір текстів-зразків, що мають типологічні характе- } \\
\text { ристики певних жанрів мовлення, і подає мову як систему підсистем, що фрункціонує в різних } \\
\text { сорерах комунікації. }\end{array}$ & {$[5$, с. 264] } \\
\hline $\begin{array}{l}\text { Основною категорією ТПє текст, який визначено в науковій літературі як «писемний або } \\
\text { усний мовленнєвй масив, що становить лінійну послідовність висловлень, об'єднаних } \\
\text { у ближчій перспективі смисловими, фрормально-граматичними зв'язками, в в загальнокомпо- } \\
\text { зиційному, дискантному плані спільною тематичною і сюжетною заданістю». }\end{array}$ & [22, с. 627] \\
\hline $\begin{array}{l}\text { Н. Ковальчук уважає, що ТП «ураховує методичну систему роботи з текстами: від комплек- } \\
\text { сного аналізу готового чи створеного тексту до побудови власних висловлень різних типів } \\
\text { і стилів мовлення». }\end{array}$ & [8, с. 127] \\
\hline
\end{tabular}

репрезентує українську літературу не тільки як дидактичний матеріал, а як засіб духовного й естетичного виховання, фрормування комунікативномовленнєвої компетенції та мовної грамотності учасників освітнього простору» (табл. 3) [4, с. 95].

Метою фуунційно-стилістичного підходу $\epsilon$ практичне опанування усного і писемного мовлення, тому активне його використання на заняттях із мовних дисциплін під час виконання системи вправ і завдань комунікативно-мовленнєвого спрямування сприятиме формуванню комунікативномовленнєвої компетентності студентів-орілологів. А в його основу покладено принцип цілісного вивчення мови і мовлення - лексики, фонетики, граматики, синтаксису, риторики, стилістики (табл. 4).

Реалізацію соціокультурного підходу більшість лінгводидактів убачають в організації роботи з текстом чи системою текстів соціокультурного спрямування, побудови власних висловлень відповідної тематики, тому існує тісний взаємозв'язок між ним і текстоцентричним підходом (табл. 5).

В основі текстоцентричного підходу - осмислення тексту як мовленнєвого виразу, формування вмінь і навичок точно, доречно, виразно фрормулювати власні думки відповідно до встановлених правил побудови висловлень; удосконалення моделей висловлень; розвиток культури власного мовлення, що, безперечно, фрормує комунікативно-мовленнєву компетентність майбутніх учителів української мови, сприяє увиразненню їхнього мовлення (табл. 6) [19].

Ми вважаємо, що в методичній системі розвитку комунікативно-мовленнєвої компетентності студентів-словесників текстоцентричний підхід $€$ пріоритетним і реалізується на основі дібраних навчальних текстів, що використовуються якдидактичний матеріал мовної і мовленнєвої змістової лінії, а також за допомогою системи спеціально орієнтованих завдань, що передбачають оцінювання текстів, побудову на їх основі власних висловлень різних стилів і типів мовлення 3 метою ефективного формування комунікативно-мовленнєвої компетентності майбутніх педагогів-орілологів.

Висновки. Наше дослідження 3 позиції сьогодення спільною ознакою для всіх нових підходів виокремлює переосмислення освітньої парадигми, за якої можливим стає цілеспрямований перехід від накопичення теоретичних знань, умінь і навичок, опанування мовних і мовленнєвих правил до практичної мовленнєвої діяльності. Отже, 
базовими сучасними підходами до навчання мовних дисциплін 3 урахуванням увиразнення мовлення студентів $€$ ефективна взаємодія традиційних підходів у комплексі з інноваційними підходами вивчення лінгвістичних дисциплін студентами-словесниками в освітньому просторі.

\section{БІБЛІОГРАФІЧНИЙ СПИСОК:}

1. Азимов Э. Новый словарь методических терминов и понятий (теория и практика обучения языкам). Москва : Икар, 2010. 448с.

2. Великий тлумачний словник сучасної української мови (з дод. і доп.) / уклад. і голов. ред. В. Бусол. Київ ; Ірпінь : ВТФ «Перун», 2005. 1728 с.

3. Голуб Н. Підходи до навчання української мови в основній школі. Українська мова і література в школі. 2015. № 3. С. 2-10.

4. Горошкіна О. Лінгводидактичні засади навчання української мови у старших класах природничо-математичного профрілю : монографрія. Луганськ : Альма-матер, 2004. 362 с.

5. Дроздова І. Наукові основи фрормування українського профресійного мовлення студентів ВН3 нефілологічних спеціальностей : монографрія. Херсон : ХНАМГ, 2010. 320 c.

6. Зязюн І. Концептуальні засади теорії освіти в Україні. Педагогіка і психологія профресійної освіти. 2000. № 1. С. 11-24.

7. Інтеграція системно-описового, фрункціонально-стилістичного і комунікативно-діяльнісного підходів до вивчення української мови. Українська мова і література в школі. 2005. № 2. C. 5-11.

8. Ковальчук Н. Текстоцентричний підхід до вивчення української пунктуації. Педагогічні науки : збірник наукових праць. Херсон : Вид-во ХДУ, 2008. Вип. 47. 424 с.

9. Мацько Л., Семеног О. Компетентнісні підходи і програмні засади в навчанні української мови в 10-12 класах середньої школи (профріль - українська фрілологія). Українська мова в освітньому просторі. Київ : Вид-во НПУ імені М.П. Драгоманова, 2009. C. 44-60.

10. Мельничайко В., Пентилюк М., Рожило Л. Удосконалення змісту і методів навчання української мови. Київ : Рад. школа, 1982. 216 с.

11. Михайловская Г. Лингводидактические основы формирования речевых умений в процессе обучения русскому языку : монография. Киев : Изд. центр ОАОУКРНИИПСК, 1999. 208 с.

12. Овсієнко Л. Проблеми впровадження компетентнісного підходу в процес підготовки майбутніх педагогічних кадрів. Українська мова і література в школі. 2011. № 6. С. 46-48.

13. Омельчук С. «Підхід до навчання» як базова категорія сучасної лінгводидактичної науки. Українська мова і література в школі. 2013. № 2. С. 2-8.

14.Пентилюк М. Теоретичні основи навчання стилістики в середній школі : дис. ... докт. пед. наук: 13.00.02. Київ, 1996. 56 с.

15. Пентилюк М. Компетентнісний підхід до фрормування мовної особистості в євроінтеграційному контексті. Українська мова і література в школі. 2010. № 2. C. 2-5.

16. Пентилюк М. Текстоцентричний аспект формування риторичних умінь і навичок учнів. Актуальні проблеми сучасної лінгводидактики : збірник статей. Київ : Ленвіт, 2011. С. 96-108.

17.Пентилюк М. Актуальні проблеми сучасної лінгводидактики : збірник статей. Київ : Ленвіт, 2012. 256 c.

18. Пометун О. Теорія і практика послідовної реалізації компетентнісного підходу в досвіді зарубіжних країн. Компетентнісний підхід у сучасній освіті: світовий досвід та українські перспективи : Бібліотека з освітньої політики / за заг. ред. О. Овчарук. Київ : К.І.С, 2004. 112 с.

19. Рускуліс Л. Роль текстоцентричного підходу у процесі підготовки вчителя української мови. Педагогічні науки : збірник наукових праць. Херсон, 2013. Вип. 63. С. 317-323.

20. Селевко Г. Энциклопедия образовательных технологий : в 2-х т. Москва, 2006. Т. 1. 816 с.

21. Словник-довідник 3 української лінгводидактики : навчальний посібник / кол. авторів ; за ред. М. Пентилюк. Київ : Ленвіт, 2003. 320 с.

22. Українська мова : енциклопедія / редкол. : В. Русанівський (співголова) та ін. 2-ге вид., випр. і доп. Київ : Вид-во «Укр. енцикл.» ім. М.П. Бажана, 2004. 824 c

23. Фіцула М. Педагогіка : навчальний посібник для студентів вищих педагогічних закладів освіти. Тернопіль, 2008. 232 с.

24. Шелехова Г. Сучасні підходи до навчання рідної мови в загальноосвітній школі. Українська мова $і$ література в школі. 1998. № 1. С. 8-12.

25. Шелехова Г. Зміст і структура оновленої програми 3 української мови для основної школи крізь призму сучасних підходів. Українська мова і література в школі. 2013. № 2. С. 60-64.

26. McClelland D. Identifying competencies with behavioral-event interviews. Psychological Science. 1998. № 9. P. 331-339. 
СУЧАСНІ ТЕНДЕНЦІЇ ІНШОМОВНОЇ ПІДГОТОВКИ МАЙБУТНІХ УЧИТЕЛІВ
ПОЧАТКОВОЇ ЛАНКИ ОСВІТИ УГОРЩИНИ

CURRENT TRENDS IN FOREIGN LANGUAGE TRAINING OF FUTURE PRIMARY EDUCATION TEACHERS OF HUNGARY

Стаття присвячена актуальній проблемі сучасної педагогічної освіти - іншомовній підготовці майбутнього вчителя початкової школи. Підкреслено, що просресійна підготовка майбутніх педагогів початкової ланки освіти України нині модернізується з урахуванням потреб Нової Української Школи й досвіду провідних педагогічних закладів вищої освіти й сучасних підходів до мовного навчання в країнах Європейського Союзу й світу, тому викладено позитивний досвід такої підготовки в Угорщині. Сучасний педагог початкової ланки освіти повинен володіти іноземною мовою, адже це допомагає в його просресійній діяльності й сприяє колобації з колегами з усього світу; дозволяє реалізувати людиноцентричну парадигму навчання, що приводить до підвищення якості навчання іноземних мов і подальшої успішності молодших школярів у середній, старшій школі й вреuті в дорослому житті. Проаналізовано навчальні плани бакалаврського освіт нього рівня педагогічних фракультетів університетів і коледжів, що здійснюють навчання майбутніх учителів початкової школи Угорщини. Визначено пріоритетні завдання, змістові модулі й напрямки іншомовної підготовки. З'ясовано, що додатковою спеціалізацією педагога початкової ланки освіти чієї країни може бути «Вчитель іноземної мови« для дітей 6-12 років. Встановлено, що в Угорщині неможливо отримати бакалаврський диплом вчителя початкової школи, не опанувавши іноземною мовою на рівні В2, а в разі додаткової спеціалізації - на рівні С1. Такі вчителі вивчають теоретичні аспекти мови, дитячу літературу, лінгвокультурологічні й країнознавчі особливості країни, мова якоі вивчається; передбачено також опанування деяких дисциплін іноземною мовою, що надалі дозволяє реалізувати сучасні підходи навчання в початковій школі, інтеграцію змісту певних дисциплін з іноземною мовою та сорормувати в молодших школярів необхідні компетентності. Майбутні вчителі початкової ланки освіти Угорщини обов'язково опановують і методику раннього навчання іноземних мов.

Ключові слова: бакалаврський освітній рівень, додаткова спеціалізація, Європейський Союз, іноземна мова, іншомовна під- готовка, вчитель початкової школи, професійна підготовка, раннє навчання.

The article deals with the actual problem of modern pedagogical education - the foreign-language training of the future primary school teacher. It was underlined that the training of future teach ers at the primary level of education in Ukraine is being modernized to take into account the needs of the New Ukrainian School and the experience of the leading pedagogical institutions of higher education and modern approaches to language education in the countries the European Union and the article, therefore, highlights the positive experience of such training in Hungary. A modern primary education teacher must be able to speak a foreign language, which helps in his professional activities and promotes his socialization with colleagues from all over the world; it allows the realization of the human-centred paradigm of learning, improves the quality of foreign language teaching and the future success of junior students in secondary, high school and, after all, of adult life. The curricula of the Bachelor of Education of the Faculties of Pedagogical Education of Universities and Colleges teaching the future teachers of primary school in Hungary have been analysed. Priority tasks, substantive modules and foreign-language training have been identified. It is also defined that the additional specialization of the pedagogue of the primary education level of this country can be "The Teacher of the Foreign Language" for children 6-12 years old. It has been established that in Hungary it is not possible to obtain a bachelor's degree of primary education without proficiency in a foreign language at the level of $B 2$ and, in the case of an additional specialization, at the level of C1. Such teachers study the theoretical aspects of the language, children's literature, linguistics and country-specific features of the country under study. The study of certain subjects in a foreign language is also planned, which makes it possible to implement modern approaches to primary education, integration of the content of certain subjects with a foreign language and development of the necessary competences among younger pupils. Early learning in foreign languages is also compulsory for future teachers of primary education in Hungary.

Key words: additional specialization, Bachelor's level, the European Union, early learning, foreign language, foreign language training, primary school teacher, training.

Київського університету

імені Бориса Грінченка

Постановка проблеми в загальному вигляді. Володіння іноземною мовою не втрачає актуальності в сучасному глобалізованому й цифровому світі, тому потреба в учителях іноземної мови в усіх країнах світу постійна, а вимоги, що до них висуваються, високі. Відповідно, і якість іншомовної підготовки педагогів усіх освітніх рівнів, а насамперед учителів початкової ланки освіти, постійно перебуває в центрі уваги профрільних міністерств країн Європи, провідних науковців цієї галузі, освітніх установ усіх рівнів, які безпосередньо готують майбутніх педагогів і підвищують кваліфрікацію впродовж подальшої професійної діяльності. Тому одним із пріоритетних напрямків рефрормування української освітньої галузі нині $€$ оновлення ії початкової ланки освіти, яка повинна забезпечити подальше успішне навчання учнів у середній і старшій школі.

Як відомо, в Концепції Нової української школи (далі - НУШ) однією з компетентностей, яка пови- 
нна бути сорормована в учнів 1-4 класів, $є$ спілкування іноземною мовою [3, с. 11], опанування якою $€$ однією 3 ключових компетентностей сучасної людини [6]. Проте для успішного впровадження нових методик вивчення іноземних мов за вимогами НУШ необхідні й нові підходи до іншомовної підготовки майбутніх учителів початкової ланки освіти, а це неможливо без вивчення та аналізу досвіду такої підготовки в країнах Європейського союзу й подальшого впровадження найкращих практик у педагогічну профресійну освіту України.

Аналіз останніх досліджень і публікацій. Процес удосконалення всіх складових професійно-педагогічної підготовки й розробка нових шляхів фрормування професійної компетентності майбутнього педагога у ВН3 завжди були в центрі уваги науковців. Наукові розвідки присвячуються не тільки шляхам формування особистості вчителя початкової ланки освіти, а й визначенню сутності професійної готовності такого педагога й структури процесу її фрормування (Н. Абашкіна, Г. Андрущак, С. Власенко, В. Жуковський, Н. Заїченко, Л. Зязюн, К. Корсак, М. Лещенко, В. Поліщук та інші). Підвищений фраховий інтерес українських наукових пошуків визначає також провідний зарубіжний досвід підготовки педагогічних кадрів, тому аналізу такого досвіду в останній час присвячена низка досліджень (А. Вільчковська, В. Гаманюк, К. Годлевська, Н. Карпенко, М. Красовицький, А. Паринова, Л. Пуховська, М. Тадеєва й інші). Слід зазначити, що в значній кількості наукових робіт дослідники намагаються розв'язати проблеми змісту й шляхів фрормування іншомовної профресійної компетентності вчителів іноземних мов різних освітніх рівнів (О. Бігич, Н. Бориско, В. Буренко, С. Будак, Н. Гальскова, Н. Гез, О. Маслико, С. Ніколаєва, В. Редька, А. Тарнопільський та інші).

Виділення невирішених раніше частин загальної проблеми. В процесі впровадження НУШ для Міністерства освіти й науки України (далі - МOH) стало зрозумілим, що в стислі строки необхідна значна кількість вчителів іноземної мови, які опановують нові технології навчання іноземних мов учнів початкової школи, тому у 2016 р. МOH звернулося за допомогою до міжнародних інституцій в Україні, а саме до Британської Ради, Гете Інституту й Французького інституту, й з їхньою допомогою до 2018 р. було перепідготовлено 19 тисяч вчителів іноземних мов для НУШ. Такий захід, на нашу думку, був цілком правильним, тому що вчителі іноземних мов початкової ланки освіти України опанували надсучані методи навчання, але одночасно засвідчив неготовність українських педагогічних закладів вищої освіти до викликів, що стоять у сорері підготовки й перепідготовки вчителів іноземної мови початкової ланки освіти, адже МОН України фрактично визнав, що педагогічні ВНЗ та інститути післядипломної підготовки не здатні якісно й сучасно навчати й підвищувати професійні навички вчителів для НУШ. Саме тому всім педагогічним ВНЗ України необхідно перебудувати освітні програми іншомовної підготовки майбутніх учителів початкової ланки освіти, що своєю чергою вимагає поглибленого вивчення зарубіжного досвіду, відстеження нововведень і тенденцій із метою впровадження ефективних організаційних заходів, методів, фрорм підготовки фахівців цього освітнього напряму.

Мета статті - проаналізувати й систематизувати позитивні здобутки теорії та практики іншомовної підготовки вчителя початкової школи в Угорщині з метою впровадження його в педагогічних ВНЗ України.

Виклад основного матеріалу дослідження. Безсумнівно, що в глобалізованому суспільстві навчання іноземних мов продовжує відігравати важливу роль у фрормуванні висококультурної та конкурентоспроможної особистості, здатної не тільки успішно здійснювати пошук потрібної інформації, а й реалізовувати свою соціальну й професійну мобільність у процесі міжкультурного спілкування. Інтеграція України до європейського освітнього простору своєю чергою потребує розширення діапазону іншомовних професійних умінь майбутніх фрахівців початкової ланки освіти. Так, реалізація закладами вищої педагогічної освіти ідей Болонського процесу й Рекомендацій Ради Європи [6; 7] вимагає фрахівців нової генерації, здатних до активного життя, ефективного виконання своїх профресійних обов'язків, опанування як мінімум двома іноземними мовами й цифровою компетентністю. Свого часу, впровадження рекомендованої Радою Європи мовної політики на національних рівнях шкільної іншомовної освіти стало імпульсом для здійснення конкретних кроків у напрямі рефрормування, переорієнтації національних освітніх політик та організації раннього навчання іноземних мов, адже Європейська комісія в так званій «Білій книзі» ще у 2001 р. зазначила: «Після закінчення початкового навчання $<. .>$ кожен повинен володіти двома іноземними мовами» [13]. Вивчення двох іноземних мов стало пріоритетом у нових освітніх програмах країн Європи, а «фрокус уваги змістився на пошук методів раннього навчання іноземних мов і на питання організації професійної підготовки педагога з раннього навчання іноземних мов, <..> такого педагога необхідно спеціально готувати: він повинен опанувати спеціальні методи й прийоми, що враховують особливості дітей дошкільного й молодшого шкільного віку» [7, с. 122].

Зазначимо, що в країнах Європейського союзу накопичено багаторічний досвід підготовки педагогів до раннього навчання іноземних мов дітей дошкільного й молодшого шкільного віку, адже з 90-х рр. XX ст. у цих державах розроблено спеці- 
альні програми. Так, наприклад, Британська Рада як міжнародна просвітницька організація в співорінансуванні з Європейською Комісією просуває проєкт «Багатомовна Європа», метою якого є:

- «сприяти обміну успішним досвідом для забезпечення міжкультурного діалогу й соціальної інтеграції за допомогою мовної освіти;

- активізувати європейське співробітництво в галузі розроблення мовної політики й практики в декількох освітніх секторах, а також у суспільстві в цілому;

- підвищити поінформованість щодо рекомендацій Євросоюзу (EU) й Ради Європи (Council of Europe) 3 питань сприяння вивченню іноземних мов і мовного розмаїття в Європі» [1, с. 7].

Однією із численних ініціатив із боку Ради Європи та Європейського Союзу є розробка нових підходів до мовної підготовки й мовного навчання на всіх рівнях освіти. Власне бачення цього процесу Ради Європи зображено в низці документів, серед яких основними $€$ «Загальноєвропейські Рекомендації з мовної освіти: вивчення, викладання, оцінювання» [10] та «Європейське мовне портфоліо» ELP (European Language Portfolio), які визначили шляхи розвитку іншомовної освіти в наступні десятиліття. Зазначимо, що в системі початкової освіти Угорщини, як і в Україні, вивчення однієї іноземної мови обов'язкове, але, на відміну від України, саме школа обирає її, проте певна кількість навчальних закладів надає можливість вирішити учням та їхнім батькам, яку мову вивчати. Так, в Угорщині пропонуються такі іноземні мови, як англійська, французька, німецька, італійська чи російська. Зрозуміло, що іншомовна підготовка майбутніх педагогів початкової ланки освіти в країнах Східної Європи, в тому числі й в Угощині, відбувається з урахуванням процесів глобалізації, інтеграції, діджиталізації, гуманізації, універсалізації та впливу демографічних процесів. У країнах Східної Європи, зокрема в Угорщині, як і в Україні, системі професійної педагогічної підготовки майбутніх учителів початкової ланки освіти характерні спільні риси, оскільки впроваджена Болонська система вищої освіти, яка передбачає послідовне навчання на двох освітніх рівнях: «бакалаврському» й «магістерському». Втім, кожна країна йде власним шляхом освітніх реорорм, які визначаються впливом традицій, сукупністю внутрішніх чинників, серед яких домінуюча роль належить економічним, політичним і соціокультурним тощо.

Освітній процес і вимоги до нього в педагогічних ВНЗ Угорщини регламентуються постановою Міністерства Людських ресурсів «Про спільні вимоги підготовки педагогів і підготовчі вимоги певних педагогічних фракультетів» [1], а отже програми професійної підготовки педагогів початкової ланки кожного вищого навчального закладу базуються на державному стандарті вищої освіти. Для студентів педагогічних спеціальностей передбачено основну й додаткову спеціальність, водночас на дисципліни основної спеціальності на бакалаврському освітньому рівні виділено 100 кредитів, у той час як на вивчення додаткової - 50 кредитів. Передбачено не тільки отримання фрахових знань 3 основної та додаткової спеціальностей, а й 3 теоретичних основ професії педагога взагалі. Так, на опанування дисциплін психологічного й методичного блоку стандартом бакалаврського освітнього рівня передбачено 10 кредитів. Додаткові 10 кредитів майбутній педагог початкової ланки освіти опановує в межах виконання та успішного захисту бакалаврської дипломної роботи. Слід зазначити, що успішне складання екзамену з іноземної мови є умовою здобуття звання бакалавра [15]. Повертаючись до такої складової частини, як друга спеціальність, або спеціалізація, то найчастіше в Угорщині це «Вчитель іноземної мови». Характерною рисою освітніх програм із підготовки вчителів іноземних мов взагалі, а початкової ланки освіти зокрема, є впровадження «Європейського виміру» [16], що передбачає знайомство з мовною картиною країни, мова якої вивчається, виховання поваги до традицій, культури, мови й суспільноекономічного розвитку інших європейських країн і дозволяє сорормувати толерантну особистість, яка розумітиме інших європейців [8]. Відповідно, визначені стратегічні настанови знаходять своє відбиття як у закріпленій на законодавчому рівні обов'язковості вивчення щонайменше однієї іноземної мови, так і у визначенні мети й завдань іншомовної підготовки майбутніх педагогів початкової ланки, що передбачає викладення європейської специоріки в зміст окремих дисциплін навчального плану й викладання деяких дисциплін іноземною мовою, реалізацію рішень Болонського процесу й підвищення стандартів якості педагогічної освіти. Крім цього, широко заохочується участь майбутніх педагогів початкової ланки в європейських проєктах, реалізуються програми мобільності, які дозволяють не тільки розвивати дослідницькі навички, а й практикуватися в іншомовному спілкуванні [16, с. 23], адже опанування іноземною мовою не тільки сприяє професійному розвитку в подальшій педагогічній роботі й співпраці з колегами з інших країн, а й взагалі людина, яка «засвоїла граматику будь-якої мови, підготовлена до систематизації у всіх галузях знань, що потребують систематизації» [4]. Саме тому друга спеціалізація майбутнього вчителя Угорщини «Вчитель іноземної мови» така популярна.

Отже, підрозділи університетів і коледжі, що здійснюють підготовку вчителів початкової ланки освіти, складають навчальні плани самостійно, проте базуючись на вже згаданій постанові Міністерства Людських Ресурсів «Про спільні вимоги до 
підготовки педагогів і підготовчі й вихідні вимоги до певних педагогічних фракультетів» [11], з уточненнями й доповненнями до неї (2016 р.). У п. 5 постанови визначено кваліфікацію ступеня бакалавр як учительпочатковихкласів(tanító); встановленотермін навчання; роз'яснено мету навчання [11, с. 30]; окреслено основні знання, вміння та навички, компетентності, які повинні бути набуті в процесі навчання майбутнім вчителем початкової ланки освіти. Однією 3 таких компетентностей $€$ іншомовна комунікативна компетентність. У поправках 2016 р. звертається увага на дисципліни психолого-педагогічного циклу, їхнє професійне спрямування, а також на посилення опанування всіма фраховими методиками, зокрема методикою навчання іноземних мов дітей 6-12 років.

У Постанові значено також, що для отримання бакалаврського ступеня, студент - майбутній вчитель початкової школи зобов'язаний скласти іспит 3 іноземної мови й отримати сертифрікат щонайменше рівня В2. Ті ж, хто обрали іноземну мову як додаткову спеціалізацію, повинні скласти іспит рівня С1. Зазначимо, що ще у 2008 р. урядом Угорщини було прийнято постанову «Про визнаний державою екзамен 3 іноземної мови, що підтверджує знання мови, й про нострифрікацію в Угорщині свідоцтв про екзамен з іноземної мови, що підтверджують знання іноземної мови» [14], в якій прописані програмові вимоги й визначено необхідний рівень опанування іноземною мовою студентами-бакалаврами, зокрема й тими, що готуються педагогічними ВН3, та отримання ними сертиорікатів відповідних рівнів (А2 - C1), а також визначено вимоги до експертизи й акредитації закладів освіти, яким дозволяється надавати такі послуги.

У разі обрання майбутнім вчителем початкової ланки освіти спеціалізації «Іноземна мова» обов'язковим $€$ вивчення такими студентами певних дисциплін іноземною мовою, що дозволяє їм надалі якісно здійснювати навчання деяких предметів іноземною мовою в початковій школі, й це на практиці реалізує так зване двомовне навчання bilingual teaching - і дитиноцентриська концепція педагогічної підготовки - learner-centred approach, яка задекларована всіма країнами Європейського союзу [9]. Проте навіть у разі обрання додаткової спеціалізації, не пов'язаної з навчанням іноземної мови, іншомовній підготовці вчителя початкових класів в усіх педагогічних ВНЗ Угорщини виділено значний обсяг кредитів, про що свідчить аналіз навчальних планів цих установ, зокрема Університету рефрорматорської церкви ім. Каролі Гаспара [19], Католицького коледжу імені Вільмоша Апора [17], Сегедського університету [18].

Узагальнюючі відомості з навчальної документації педагогічних ВНЗ Угорщини, можна констатувати, що майбутні педагоги початкової ланки освіти, як правило, вивчають дві іноземні мови: англійську як першу, німецьку як другу, проте пропонуються і інші іноземні мови. Особливо привертає увагу зміст іншомовної підготовки майбутніх учителів початкової ланки освіти в Сегедському університеті [18]. Блоком «Англійськомовна підготовка до VMT-hez» передбачено такі дисципліни:

1. Мовнапрактиказкраїнознавством (2 кредити).

2. Систематизуюча, описуюча граматика I-III (4 кредити).

3. Фонетика, фронологія (2 кредити).

4. Мовна й стилістична практика I-III (5 кредитів).

Блоком «Німецька національна професійна галузь» передбачено такі дисципліни:

1. Німецька культура мови I-III (6 кредити).

2. Морфологія німецької мови I-II (6 кредити).

3. Синтаксис німецької мови (2 кредити).

4. Література німців в Угорщині I-II (4 кредити).

5. Дитяча й молодіжна література (2 кредити).

6. Національні знання I-II (4 кредити).

7. Звичаї німців в Угорщині (2 кредити).

8. Національні медіа (2 кредити).

9. Методика навчання німецької мови й літератури I-IV (8 кредити).

У блоці «Вибіркові дисципліни» пропонується: Німецька мова

1. Виникнення мови та її розвиток (німецькою) (3 кредити).

2. Міжкультурна комунікація (німецькою) (3 кредити).

3. Практичні труднощі розуміння німецької мовної культури (3 кредити).

4. Країнознавство (Німеччина, Австрія, Швейцарія) (3 кредити).

Англійська мова

1. Дитяча література I-III (6 кредитів).

2. Література (англійською) (1 кредит).

3. Інтеграція змісту й мови I-III (6 кредити).

4. Методика навчання предмету I-IV (10 кредити)

Відповідно до навчального плану Університету рефрорматорської церкви ім. Каролі Гаспара в частині «Обов'язкова варіативна дисципліна. Спеціальні модулі II (Денна)» передбачено вивчення німецької (8 кредитів) та англійської мови (8 кредитів) [19].

У Католицькому коледжі імені Вільмоша Апора блоком «Варіативні дисципліни (обов'язкові за вибором)» передбачено вивчення першої іноземної мови (4 кредити) й другої іноземної мови (4 кредити), а також дисципліни «Іноземна мова (раннє навчання)» (8 кредитів) [17].

Отже, аналіз освітніх планів підготовки вчителів початкової школи Угорщини засвідчують, що кількість годин відповідно до кредитів, виділених іншомовній освіті таких фрахівців, дозволяють досягти цілей навчання та успішно скласти обов'язкові екзамени на рівень опанування іноземною мовою. 
Зазначимо, що Київський університет імені Бориса Грінченка, а саме Педагогічний інститут, здійснює підготовку майбутніх педагогів початкової ланки освіти й постійно осучаснює свої навчальні плани. Так, іншомовна підготовка майбутніх учителів початкової школи в університеті, в якому автори статті $€$ науково-педагогічними співробітниками, на бакалаврському освітньому рівні здійснюється в межах освітньої лінії «Іншомовна освіта 3 методикою навчання» [21]. Студентами вивчається лише одна іноземна мова: англійська чи німецька. В межах означеної освітньої лінії передбачено не тільки підвищення іншомовної комунікативної компетентності студентів, а й методичний блок, зміст якого розроблено з урахуванням вікових особливостей молодших школярів. Колективом кафедри іноземних мов і методик їх навчання Педагогічного інституту укладено підручник «Методика навчання іноземних мов у початковій школі» 3 грифром МOH [5].

У блоці «Вибіркові дисципліни» студенти можуть обрати такі дисципліни: «Сучасна англійська/ німецька мова з практикумом», «Практикум з іншомовної міжкультурної комунікації». Також пропонується додаткова спеціалізація «нооземна мова», в межах якої відбувається як поглиблене вивчення іноземної мови, так і лінгвокраїнознавство, сучасні технології навчання іноземної мови в початковій школів тощо [21]. На нашу думку, з позитивного досвіду, який присутній в іншомовній підготовці вчителя початкової ланки освіти в Угорщині й вдосконалив би таку підготовку в нашому університеті, треба звернути увагу на поглиблення вивчення теоретичних аспектів іноземної мови, таких, як фонетика й граматика, а також на знайомство з дитячою літературою країни, мова якої вивчається.

Висновки. Отже, викладені тенденції іншомовної підготовки майбутніх учителів початкової ланки освіти в Угорщині засвідчують розуміння профрільного міністерства Угорщини й педагогічної спільноти в цілому значення такої підготовки в майбутній професійній діяльності педагога, адже досягти високого профресіоналізму, стати вчителем, для якого завжди цікаві сучасні освітні тренди, неможливо без опанування іноземною мовою на високому рівні, який дозволяє знайомитися з педагогічними дослідженнями передових науковців у галузі освіти, спілкуватися 3 колегами з усього світу й брати участь у програмах мобільності. Педагогічним ВНЗ України своєю чергою необхідно вивчати такий досвід і впроваджувати його в навчальну практику.

\section{БІБЛІОГРАФІЧНИЙ СПИСОК:}

1. Багатомовна Європа: тенденції у політиці і практиці мультилінгвізму в Європі. Київ, 2012. 168 с.

2. Загальноєвропейські Рекомендації 3 мовної освіти: вивчення, викладання, оцінювання / науковий редактор українського видання доктор пед. наук, профр. С.Ю. Ніколаєва. Київ : Ленвіт, 2003. 273 с.
3. Концепції Нової української школи. URL: https://www.kmu.gov.ua/storage/app/media/reforms/ ukrainska-shkola-compressed.pdf.

4. Ломб К. Как я изучаю языки. Москва, 2016. $240 \mathrm{c}$

5. Методика навчання іноземних мов у початковій школі : навчальний посібник для студентів ВН3 / О.В. Котенко, Р.О. Павлюк, А.В. Соломаха та ін. Київ : Київ. ун-т ім. Б. Грінченка, 2013. 354 с.

6. Про основні компетенції для навчання протягом усього життя : Рекомендація 2006/962/ЄС Європейського Парламенту та Ради (ЄС) від 18 грудня 2006 р. № 994 975. База даних «Законодавство України». URL: https://zakon.rada.gov.ua/laws/show/994_975.

7. Соломаха А.В. Застосування цифррових технологій для фрормування іншомовної граматичної компетенції у процесі раннього навчання іноземних мов (на прикладі німецької мови). Відкрите освітнє е-середовище сучасного університету : електронне наукове фрахове видання. № 8. С. 121-135. https://doi.org/10.28925/2414-0325.2020.8.11.

8. Тенденції рефрормування загальної середньої освіти у країнах Європейського Союзу : ТЗЗ монографрія / за ред. Н.М. Лавриченко. Ч. 1. Київ : Педагогічна думка, 2008. 146c.

9. Brown Kathy Laboard. From teacher-centered to learner-centered curriculum: improving learning in diverse classrooms. Education. 2003. Vol. 124. No. 1. P. 49 (дата звернення: 08.07.2020).

10. Common European Framework of Reference for Languages: Learning, Teaching and Assessment Council of Europe. 22 лютого 2001 р. 273 с.

11. EMMI-rendelet 8/2013 - 8/2013. (I. 30.) EMMIrendelet a tanári felkészítés közös követelményeiről és az egyes tanárszakok képzési és kimeneti követelményeiről URL: http://www.kozlonyok.hu/nkonline/ MKPDF/hiteles/MK16116.pdf.

12. European Language Portfolio. URL: www.coe.int/ portfolio.

13. Eurydice 2001a, 5.(EURYDICE. (2001a). Basic Indicators on the Incorporation of ICT into European Education Systems - Facts and Figures. European Commission. Brussels.

14.Korm. rendelet az idegennyelv-tudást igazoló államilag elismert nyelvvizsgáztatásról és a külföldön kiállított, idegennyelv-tudást igazoló nyelvvizsga-bizonyítványok Magyarországon történő honosításáról, 137/2008. (V. 16.) URL: https://net.jogtar.hu/jogszabaly? docid=a0800137. kor.

15. OKM rendelet az alap- es mesterkepzesi szakok kepzesi es kimeneti kovetelmenyeirol szolo 15/2006. (IV. 3.) OM rendelet modositasarol. Magyar kozlony. 2010. N. 79. P. 17527-17812.

16. The Training of Teachers of a Foreign Language : Developments in Europe : A Report to the European Commission Directorate General for Education and Culture / Michael Kelly, Michael Grenfell, Angella Gallagher-Brett, Diana Jones, Laurence Richard, Amanda Hilmarsson-Dunn. 89 p. URL: http://ec.europa. eu/education/languages/pdf/doc493 en.pdf.

17. Apor Vilmos Katolikus Főiskola. 2015. Tanító ba szak mintatanterv. URL: https://www.google.com.ua/ url? sa=t\&rct=j\&q=\&esrc=s\&source=web\&cd=1\&cad=rja\&uact=8\&ved=0ahUKEwj_gNmZ5ZbXAhVMBcAKH- 
V3FB5IQFggnMAA\&url=http\%3A\%2F\%2Fwww.avkf hu\%2Fsites\%2Fdefault\%2Ffiles\%2Ftanito_2016-2017 nappali uj kodokkal.xls\&usg=AOvVaw3Td4QWOmUF k7UeWloCsOvt.

18.Szegedi Tudományegyetem. 2014. A képzés programja, a szak tanterve (az óra és vizsgaterv táblázatos összegzése). URL: http://www.u-szeged.hu/ tanrend? browse $=$ tanszek \&tanszekld $=413 \&$ ciklu sld=2014-2015- 2\#browse.

19. Faculty of teacher training. KRE. URL: https://english.kre.hu/index.php/faculties/faculty-ofteacher-training.html.
20. Akkreditált Pedagógus Továbbképzés. URL: http://avkf.hu/index.php/kepzesek/akkreditaltpedagogus-tovabbkepzes/.

21. Alkalmazott Pedagógiai Intézet. URL: http://www.jgypk.u-szeged.hu/karrol/intezetektanszekek/alkalmazott-pedagogiai.

22. Перелік дисциплін на 2019-2020 н. р. Кафедра іноземних мов і методик їх навчання. Київський універcumem імені Бориса Грінченка : офріційний сайт. URL: https://pi.kubg.edu.ua/struktura/kafedry-instytutu/kafedrainozemnykh-mov-i-metodyk-ikh-navchannia/navchalnometodychna-robota/navchalni-dystsypliny.html. 


\section{ВИКОРИСТАННЯ АКТИВНИХ МЕТОДІВ І ФОРМ ВИКЛАДАННЯ ПЕДАГОГІЧНИХ ДИСЦИПЛІН У ПІДГОТОВЦІ МАЙБУТНІХ УЧИТЕЛІВ

\author{
USAGE OF ACTIVE FORMS AND METHODS OF TEACHING \\ THE PEDAGOGICAL SUBJECTS IN FUTURE TEACHERS TRAINING
}

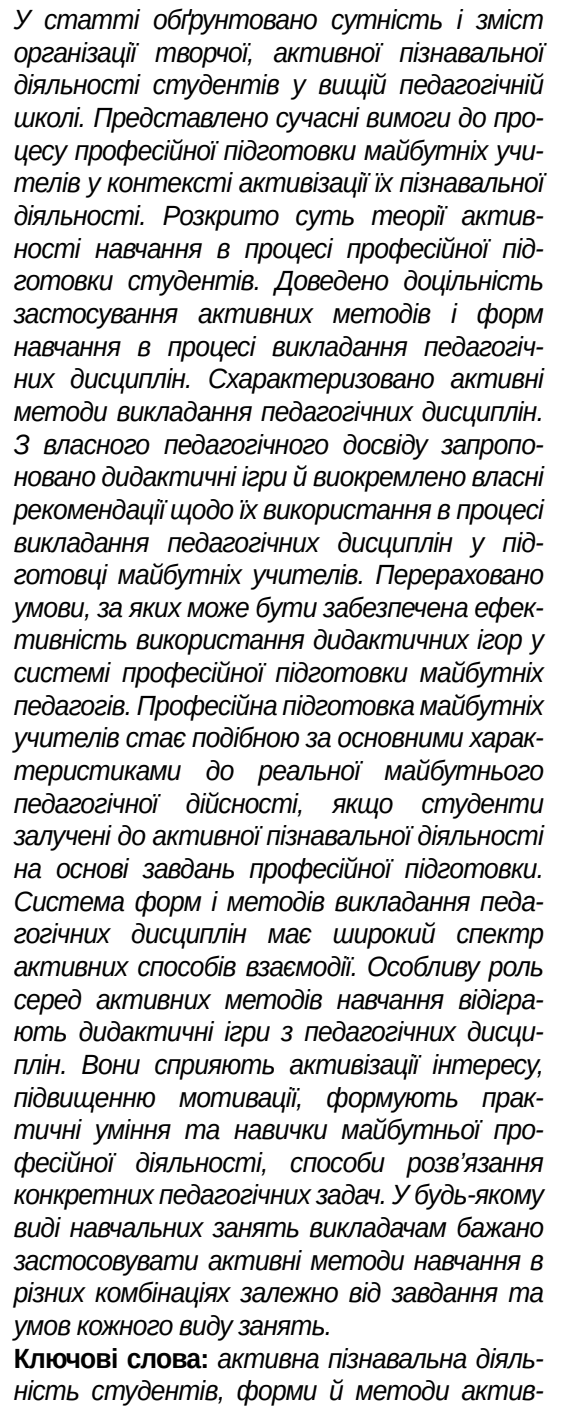

ного викладання педагогічних дисциплін, дидактична гра, підготовка майбутніх учителів.

The essence and content of organization the active cognitive activity of students in higher educational school are explained in the article. Modern requirements for future teachers training in the context of activation of their cognitive activity are presented. Also the essence of the theory of activity in future teachers training is considered. The expediency of usage the active forms and teaching methods in the process of teaching the pedagogical subjects is proved. Methods of active teaching the pedagogical subjects are defined and characterized. The experience of application the active forms of organization the teaching and cognitive activity of future teachers during their professional training are given. Own recommendations on the use of didactic games in future teachers training were determined. We offer detailed recommendations for every didactic game. Vocational training for future teachers becomes similar to the real future pedagogical activity, by the main characteristics, if students are involved in active cognitive activities based on vocational training tasks. The system of forms and methods of teaching pedagogical disciplines has got a wide range of active ways of interaction. Among the active methods of teaching a special role is given to didactic games in pedagogical disciplines. They help to stimulate learners' interest, increase their motivation, form their practical skills and skills of future professional activity, ways of sorting out specific pedagogical issues. Depending on the purposes and tasks of the lesson, it is advisable for teachers to apply active teaching methods in different combinations in any type of the training.

Key words: activation of students' cognitive activity, methods of active teaching the pedagogical subjects, didactic game, future teachers training.

педагогічний коледж

імені Т.Г. Шевченка»

Постановка проблеми. Сучасні соціальні умови підвищують вимоги до профресійного рівня спеціаліста, націлюють на формування особистості ініціативної, самостійної, наділеної творчим мисленням. Гостро стоїть проблема розвитку творчих здібностей особистості, творчої уяви, інтуїтивного мислення, оригінальних способів дії, відходу від шаблонів. Зокрема, вона націлює фрахівців професійної освіти на фрормування ініціативної, самостійної, мобільної, наділеної творчим мисленням особистості майбутнього вчителя. Інтенсивно проводяться пошуки ефективних методів і засобів розв'язання поставлених завдань удосконалення професійної підготовки майбутніх фрахівців у сорері освіти. Особлива роль у цьому процесі належить педагогічним дисциплінами [3; 4].
Аналіз останніх досліджень і публікацій. Нині зростає кількість вітчизняних і зарубіжних досліджень, що розкривають основи вдосконалення профресійної підготовки майбутніх учителів у процесі викладання педагогічних дисциплін (О. Антонова, Г. Васянович, С. Вітвицька, В. Гриньова, О. Коберник та інші), а також застосування сучасних методів організації активної взаємодії в умовах вищого педагогічного навчального закладу (Г. Коберник, О. Комар, І. Осадченко й інші).

Метою нашого дослідження $€$ аналіз сутності й змісту організації активної пізнавальної діяльності студентів у вищій школі й виокремлення власних рекомендації щодо використання активних методів і фрорм викладання педагогічних дисциплін у підготовці майбутніх учителів, як зазначає Г. Вася- 
нович, нині «педагогіка як наука <...> допомагає молодим людям знайти відповідь на питання сенсу життя, можливості розвитку й діяльності в умовах складного глобалізованого світу» [1, с. 189].

Виклад основного матеріалу дослідження. Важливу роль в освітньому процесі професійної підготовки відіграє творча активність студентів. Як зазначали психологи (В. Давидов, Л. Занков, Д. Ельконін та інші), фрормування знань іде тим успішніше, чим вище активність тих, кого навчають, і це приводить не тільки до кращого розуміння, запам'ятання, зберігання та відновлення інорормації, але й виробляє уміння застосовувати отриманні знання на практиці.

Суть теорії активності навчання полягає тому, що пізнання $є$ діяльністю, спрямованою на опанування предметного світу. Вступаючи в контакти 3 предметами зовнішнього світу, людина пізнає їх і збагачується практичним досвідом як пізнання світу (навчання та самонавчання), так і дії на нього. Пізнавальна діяльність людини проходить в умовах активно-випереджального сприйняття та зображення оточення, розв'язання різного роду проблемних ситуацій, без чого поставлена мета не може бути досягнута.

Активна пізнавальна діяльність майбутніх педагогів - це насамперед інтелектуальна робота, спрямована на фрормування нових знань, отриманих на основі використання власного досвіду, співставлення, аналізу й синтезу фактів, побудові висновків та узагальнень у процесі їх професійної підготовки. Найбільша активність студентів досягається тоді, коли навчання за своїм характером наближається до дослідного процесу, а освітне середовище створюється шляхом підвищеного інтересу до предмету, який вивчається.

Процес професійної підготовки майбутніх педагогів має:

- бути практико-орієнтованим, імітацією профресійного середовища майбутніх педагогів;

- містити конкретну мету й проблеми діяльності, що створюють ситуації розвитку особистості кожного студента;

- забезпечувати формування в майбутніх педагогів здатності розв'язувати практичні задачі.

В основі активного навчання лежить принцип безпосередньої участі, який зобов'язує викладача зробити кожного студента учасником освітнього процесу який шукає шляхи й способи розв'язання проблем. Активні методи й фрорми навчання дозволяють фрормувати знання, уміння та навички шляхом залучення студентів в активну навчальнопізнавальну діяльність.

До процесів творчості належать несвідомі дії, зокрема інтуїція, свідома діяльність і натхнення як своєрідне перекладання 3 несвідомої сфрери у свідомість уже готового висновку. Тобто творча діяльність включає гіпотезу, план, дію [1].
Заданий алгоритм надає мінімальну можливість для самостійного пошуку нетривіальних способів засвоєння знань. Це зовсім неприпустимо у відношенні до способів фрормування педагогічних умінь у майбутніх учителів.

Використання фрорм професійної підготовки, що активізують пізнавальну діяльність, творчість, закономірно веде до застосування методів активного навчання. До них відносимо такі фрорми роботи: проблемна лекція, лекція-дискусія, лекція з використанням елементів мозкової атаки, лекціядиспут, лекція з програванням конкретних педагогічних ситуацій, лекція з використанням технічних засобів навчання для зворотного зв'язку, лекціяпровокація, лекція з запланованими помилками, лекція-візуалізація, лекція «удвох» тощо; практичне заняття практико-орієнтованого характеру, імітаційні заняття, конкурс, олімпіада тощо.

Специфіка активізації пізнавальної діяльності студентів у процесі вивчення педагогічних дисциплін полягає в тому, що мислення та поведінка студентів примусово активізується, спілкування студентів із викладачем та один з одним відбувається на високому рівні мотивації, емоційності й творчості, фрормування в студентів педагогічних умінь здійснюється в обмежені строки. Форми активної взаємодії підтримують у студентів творче напруження, діловий азарт, позитивне збудження, емоційність, зацікавленість. Таке навчання нікого не залишає байдужим, значно підвищується культура спілкування, взаємодія з людьми в різних ситуаціях, інтенсивно фрормуються організаційні навички.

Проблемному викладу матеріалу з педагогічних дисциплін сприяють лекція-дискусія, лекція з використанням елементів мозкової атаки, лекція з програванням конкретних педагогічних ситуацій тощо.

Для активізації творчої діяльності студентів у процесі вивчення педагогічних дисциплін можна використовувати імітаційні заняття, зокрема аналіз конкретних педагогічних ситуацій, практичне заняття практико-орієнтованого характеру, круглі столи тощо.

У науковій літературі, згідно з класифрікацією $€$. Голанта, О. Пометун і Г. Фрейман, розрізняють методи навчання на пасивні (умовно-пасивні), активні й інтерактивні. О. Комар зазначає: «Якщо мова йде про активні методи, учні стають «суб'єктами» навчання, виконують творчі завдання, беруть участь у діалозі з учителем. Такі методи пов'язані з виконанням творчих завдань (часто вдома), питаннями від учня до вчителя та вчителя до учня (діалог), розвивають творче мислення» [3]. Сутність інтерактивних методів, на думку дослідниці, в тому, що навчання відбувається шляхом взаємодії всіх тих, хто навчається та навчає. Це навчання у взаємодії та співпраці, в якому й вчитель, і учні є суб'єктами навчання. Основний принцип інтеракції - постійна взаємо- 
дія учнів між собою, їхня співпраця, спілкування, співробітництво, на відміну від активних і «пасивних» методів, коли спілкування відбувається між учнями й вчителем [3].

Активними методами викладання педагогічних дисциплін ми вважаємо методи профресійної підготовки, які дозволяють інтенсифікувати процес розуміння, засвоєння, творче застосування знань під час розв'язання практичних завдань. Їх сутність полягає в тому, що студент отримує необхідні знання шляхом вивчення та аналізу різних джерел інформації та практичного виконання майбутніх профресійних завдань.

Вважаємо, що інтерактивні методи навчання можуть входити до групи активних, оскільки вони мають ознаки методу активного навчання: мета - засвоєння змісту освіти, єдність викладання та учіння, тобто бінарність навчання та активний характер способу засвоєння, спрямованого на кожний елемент змісту освіти.

До групи методів активного навчання включають такі методи: проблемна лекція, евристична бесіда, дискусія, диспут, конкурс, олімпіада, аналіз педагогічної ситуації, аналіз критичної ситуації, розв'язування конфрлікту, метод клініки, метод лабіринту, розігрування ролей, драматизація, дидактична й ділова гра тощо.

Поняття «методи активного навчання» розповсюджується на достатньо велику групу прийомів і способів проведення теоретичних і практичних занять. Це, наприклад, аналіз конкретних ситуацій, розв'язання проблемних задач, евристична бесіда, метод клініки, метод лабіринту, розігрування ролей, драматизація, дидактична й ділова гра тощо. Вибір будь-якого методу активного навчання залежить від конкретних завдань навчання, специоріки навчального процесу, підготовки викладача й студентів.

На основі власного досвіду викладання педагогічних дисциплін пропонуємо узагальнення щодо використання дидактичних ігор у програмі підготовки майбутнього вчителя.

Включення студентів у рольові й ділові ігри, імітаційне моделювання педагогічних ситуацій дає змогу шляхом активної взаємодії між студентами приймати рішення, засвоювати конкретні професійні уміння. Крім того, ділова гра сприяє створенню невимушеної, неформальної обстановки на заняттях, відвертих, доброзичливих і довірливих стосунків між студентами й викладачами, що формує в майбутніх вчителів вміння спілкуватися з учнями.

Курси педагогіки, історії педагогіки, теорії та методики виховання мають великі можливості для застосування навчальної ділової гри. Адже в історії розвитку педагогічної думки досить багато теорій і течій, які можна імітувати, застосовуючи різні змістовні позиції учасників. Неоднозначність рішень, наявність елементу невизначеності в ситу- ації гри забезпечує її проблемний характер та особистісний прояв кожного учасника. Найцікавішими серед ділових ігор, які ми застосовуємо в процесі вивчення історії педагогіки, $є$ «Суперечки сучасників», «Діалог із сучасністю», «Суди» (над школою 1920-х років, сучасною школою, пошуками нових шляхів оновлення школи тощо).

Рольові ігри найефективніше можна використовувати під час засвоєння таких тем, де виникає багато дискусійних питань, під час розв'язання яких з'являється можливість зіставляти альтернативні думки. Цікавіше проходить гра, коли в її хід ввести «катастрофру» - незаплановану, несподівану, невідому для учасників гри обставину: учасника 3 важливими матеріалами, фрактами, іншими елементами випадковості. Це примушує швидко зорієнтуватися, підключити свої знання та вміння 3 інших галузей знань, заставляє учасників гри висловлювати те, що вони не змогли б розповісти в інших умовах. Цьому сприяє емоційно-заразлива атмосорера інтелектуального й морального суперництва в ході гри. Обставини гри плануються, продумуються, аналізуються, підбираються викладачами завчасно.

Методичне забезпечення гри (структурна схема, об'єкт імітацій, комплект ролей, правила гри, система оцінювання тощо) сприяє чіткому її проведенню, активізує пізнавальну діяльність студентів, формує необхідні для педагога професійні якості.

Можна організувати обговорення фрахового підручника, яке проводиться у формі імпровізованого засідання конкурсної комісії. Студентська група поділяється на бригади, кожна з яких виконує роль авторського колективу окремого шкільного підручника. Під час обговорення бригади ознайомлюють із структурою підручника, демонструють прийоми роботи 3 ним на різних етапах уроку, показують можливість його використання із застосуванням активних методів навчання. Решта студентів у цей час виконують роль опонентів. Після презентації підручника вони задають «авторам» запитання, оцінюють методичний апарат, систему орієнтування підручника, висловлюють зауваження та пропозиції щодо його покращення. Потім відбувається ознайомлення $з$ наступним підручником і його обговорення. Таке опрацювання допоможе студентам краще познайомитись із побудовою підручника, його методичним апаратом та ефективніше використовувати його в роботі.

На основі аналізу навчально-методичної літератури й власного педагогічного досвіду пропонуємо використовувати в процесі викладання педагогічних дисциплін дидактичні ігри:

- «Педагогічний хокей». Група ділиться на дві команди, готуються питання один до одного. Починають «нападаючі». «Захисники» суперників повинні відповідати. Якщо «захисник» відповідає, то «гол» відбито, якщо ні, то питання йде до «воро- 
таря», а якщо й воротар не відповідає - команді зараховується гол;

- Гра «Педагогічний лексикон» складається із кількох етапів:

а) заповнення педагогічних кросвордів мінігрупами по черзі;

б) «Що? Де? Коли?», де мікрогрупа отримує картку з газетною статтею та має назвати педагогічні терміни, за допомогою яких можна зробити повідомлення на занятті;

в) «Бліц-турнір», де необхідно дати вірне визначення педагогічних термінів, їх походження;

- «Педсуперечка» - вміння відстояти свій погляд на поставлену проблему. Обговорення актуальних питань організації навчально-виховної діяльності в школі на основі дотримання правил ведення дискусії;

- «Подорож» у різні країни й століття, де треба вірно відтворити дух часу й розуміння проблем, концепцій, напрямків;

- «Знавці», суть якої полягає в тому, щоб забезпечити ефрективність засвоєння знань із педагогічних дисциплін на основі змагання.

Пропонуємо рекомендації щодо проведення такої дидактичної гри. Навчальна група ділиться на команди, які обирають своїх капітанів, мають свої назви й емблеми. На першому занятті виявляється команда «знавців». На наступному занятті команда «знавців» виступає в ролі суддів. Вона готує з викладачем питання наступного туру для інших команд та оцінює їхні відповіді.

Команді, яка виграє наступний тур, надається право вступити в боротьбу за місце за столом «знавців» у бліц-змаганні. Команди задають по три питання один одному. Час для обдумування відповідей - 2 хвилини. Відповіді оцінює викладач разом із капітанами інших команд. Переможець сідає за стіл «знавців». У кінці семестру або навчального року підбиваються підсумки змагань між командами. За результатами визначаються оцінки, заліки. В ході практичних занять, зокрема ігрових, викладач не повинен робити вигляд, що все знає, тому що це гальмує ініціативу студента. Він не повинен викликати діалог на себе, тому що заняття, як правило, перетворяться у звичайне опитування. Об'єктом критики повинна бути ідея, а не людина, що висунула цю ідею. Водночас потрібно пам'ятати, що критика має позитивну сторону (виявляються недоліки) й негативну (гальмуються вільні висловлювання оригінальних думок).

Важливо пам'ятати, що колективна ігрова діяльність передбачає розв'язування організаторських задач, які характеризуються рядом специфічних елементів: ознайомлення з правилами й нормами гри; підбір і розподіл учасників; організація допомоги в процесі гри; контроль за діями учасників; встановлення зв'язку між ними; знаходження най- оптимальнішого варіанту виконання поставлених задач; інструктаж під час пауз тощо.

Есективність дидактичних ігор у системі профресійної підготовки майбутніх педагогів може бути забезпечена, на нашу думку, за таких умов:

- позитивних соціальних установок студентів у сорері спілкування;

- усвідомлення та переживання ними суперечності між досягнутим і профресійно необхідним рівнем культури педагогічного спілкування;

- оптимального співвідношення та взаємозв'язку рольових ігор з іншими методами, засобами й формами підготовки студентів до педагогічного спілкування;

- системного підбору педагогічних ситуацій для програвання, що виступають моделями майбутньої діяльності;

- дотримання процесуальних аспектів рольових ігор;

- методично доцільного керівництва з боку викладача.

Вимоги можна поділити на чотири взаємопов'язані групи:

1) вимоги до навчального процесу в цілому;

2) вимоги до самих рольових ігор як методу навчання;

3) вимоги до студента;

4) вимоги до керівника-викладача.

Перераховані вище умови, сорормульовані в самому загальному вигляді, мають свої підструктури, нижчі рівні. Наприклад, системний вибір ситуацій-моделей для програвання можливий лише за таких умов: вибір ситуацій за певними критеріями; відповідна обробка ситуацій, тобто надання їм вигляду, прийнятого для програвання; класифікація ситуацій і фрормування їх у систему рольових ігор.

Отже, реалізація запропонованих дидактичних ігор в їх оптимальному поєднанні 3 іншими методами профресійної підготовки сприяє фрормуванню умінь застосовувати знання в нестандартних ситуаціях, знаходити оригінальні способи розв'язання проблем, використовувати інтуїцію як складову частину творчості.

Специфіка освіти за допомогою методів активного навчання полягає в тому, що мислення та поведінка студентів примусово активізується, спілкування студентів із викладачем та один з одним відбувається на високому рівні мотивації, емоційності й творчості, фрормування в студентів педагогічних умінь відбувається в обмежені строки. Методи активного навчання підтримують у студентів творче напруження, діловий азарт, позитивне збудження, емоційність, зацікавленість. Таке навчання нікого не залишає байдужим, значно підвищується культура спілкування, взаємодії з людьми в різних ситуаціях, фрормуються організаційні навички. 
Висновки дослідження і перспективи подальших розвідок. Професійна підготовка майбутніх учителів стає подібною за основними характеристиками до реальної майбутнього педагогічної дійсності, якщо студенти залучені до активної пізнавальної діяльності на основі завдань професійної підготовки. Система форм і методів викладання педагогічних дисциплін має широкий спектр активних способів взаємодії.

Особливу роль серед активних методів навчання відіграють дидактичні ігри з педагогічних дисциплін. Вони сприяють активізації інтересу, підвищенню мотивації, фрормують практичні уміння та навички майбутньої профеесійної діяльності, способи розв'язання конкретних педагогічних задач. У будь-якому виді навчальних занять викладачам бажано застосовувати активні методи навчання в різних комбінаціях, залежно від завдання та умов кожного виду занять.

\section{БІБЛІОГРАФІЧНИЙ СПИСОК:}

1. Васянович Г.П. Педагогіка іпсихологія. Вибрані твори : в 5 т. Т. 4 : Збірник наукових праць. Львів : Сполом, 2010. $512 \mathrm{c}$.

2. Дичківська І.М. Інноваційні педагогічні технології. Київ : Академвидав, 2012. 352 с.

3. Комар О.А. Інтерактивні методи навчання в сучасній дидактиці. URL: http://dspace.udpu.org.ua: 8080/jspui/handle/6789/374.

4. Пащенко М. І. Інноваційні педагогічні технології : навчально-практичний посібник. Умань : ПП Жовтий О.О., 2016. 269 с.

5. Пащенко М.І. Використання активних фрорм і методів викладання педагогічних дисциплін у підготовці майбутніх вчителів. Збірник наукових праць Уманського державного педагогічного університету імені Павла Тичини / гол. ред М.Т. Мартинюк. Умань : ПП Жовтий О.О., 2016. Частина I. C. $258-268 \mathrm{c}$. 


\section{НАУКОВІ ПІДХОДИ ДО ФОРМУВАННЯ МОВЛЕННЄВОЇ КОМПЕТЕНТНОСТІ КУРСАНТІВ ВІЙСЬКОВИХ ЗАКЛАДІВ ВИЩОЇ ОСВІТИ У ПРОЦЕСІ САМОСТІЙНОЇ ПІДГОТОВКИ}

\section{SCIENTIFIC APPROACHES TO THE SPEECH COMPETENCE FORMATION OF MILITARY STUDENTS OF MILITARY HIGHER EDUCATIONAL ESTABLISHMENTS IN THE PROCESS OF INDEPENDENT LEARNING}

\begin{abstract}
у статті обгрунтовано необхідність виокремлення дієвих наукових підходів до формування мовленнєвої компетентності курсантів у процесі самостійної підготовки як особливої фрорми навчання у військових закладах вищої освіти з метою забезпечення всебічної теоретичної та практичної мовної підготовки. В такому аспекті мовленнєва компетентність набуває особливого значення як така, що обслуговує всі сорери військової діяльності i $є$ невіддільною складовою частиною профресійної компетентності майбутнього офрічера. Кончепиія неперервної освіти визначає основу методології формування компетентностей курсантів для виконання різного роду спеціальних завдань. На основі аналізу сучасної освітньої методології визначені ключові наукові підходи до фрормування мовленнєвої компетентності курсантів військових закладів вищої освіти в процесі самостійної підготовки, а саме: компетентнісний, системний, діяльнісний, середовищний, лінгвокраїнознавчий та особистісно орієнтований. Визначено сутність і доцільність підходів, розглянуто їх реалізацію у формуванні мовленнєвої компетентності курсантів військових закладів вищої освіти в процесі самостійної підготовки. Наголошено, що визначені наукові підходи не суперечать один одному, а навпаки, реалізуються в комплексі, доповнюючи один одного. Перспективи подальших наукових розвідок полягають у розробці моделі фрормування мовленнєвої компетентності курсантів, створенні ефективних педагогічних умов самостійної підготовки курсантів із застосуванням доцільних фоорм, методів i технологій, що сприятимуть розвитку важливих професійних та особистісних якостей, необхідних для майбутньої службової діяльності.

Ключові слова: формування мовленнєвоі компетентності, самостійна підготовка, курсанти військових закладів вищої освіти,
\end{abstract}

наукові підходи, майбутня службова діяльнiсmь.

The article reveals the necessity to identify effective scientific approaches to the speech competence formation of military students in the process of independent learning as a special educational form at military higher educational establishments in order to provide comprehensive theoretical and practical language training. In this aspect, speech competence is of particular importance as it serves all areas of military activity and is an integral part of the professional competence of the future officer. The concept of lifelong learning determines the basis of the methodology for the formation of competencies of military students in order to perform various specific tasks. Based on the analysis of the modern educational methodology, key scientific approaches to the speech competence formation of military students of military higher educational establishments in the process of independent learning are identified, namely: competence, systems, practice, environmental, linguistics and learner-centered. The content and expediency of the given approaches are defined, their implementation in the speech competence formation of military students of military higher educational establishments in the process of independent learning is considered. It is emphasized that given scientific approaches do not contradict each other, on the contrary they are to be implemented in a complex, complementing each other. Prospects for further research are to develop a model of speech competence of military students, creating effective pedagogical conditions for independent learning of military students using appropriate forms, methods and technologies that will promote the development of important professional and personal qualities necessary for future service.

Key words: formation of speech competence independent learning, military students of military higher educational establishments, scientific approaches, future service activity.
Постановка проблеми в загальному вигляді. На сучасному етапі розвитку військової освіти особливої актуальності набуло питання запровадження нових стандартів підготовки курсантів військових закладах вищої освіти, що ґрунтуються на сучасних підходах щодо освітньої та профресійної діяльності. Специфічні умови навчання в військових закладах освіти визначають необхідність виокремлення дієвих підходів до фрормування мовленнєвої компетентності курсантів у процесі самостійної підготовки як особливої фрорми навчання у режимних навчальних закладах.

Години самостійної підготовки визначаються розпорядком дня військового навчального закладу, згідно якого тривалість занять самостійної підготовки у навчальний день - 2-4 години. Навчальний час, відведений на самостійну підготовку курсантів регламентується програмою навчальної дисципліни та робочою програмою навчальної дисципліни. Зміст роботи курсантів під час самостійної підготовки над конкретною дисципліною визначається робочою програмою навчальної дисципліни, методичними матеріалами, завданнями та вказівками викладача.

у межах дослідження ми проаналізували навчальні програми, навчальні плани, робочі навчальні програми кафедри іноземних мов Житомирського військового інституту імені С.П. Коро- 
льова з таких дисциплін, як: іноземна мова (англійська), іноземна мова (військово-спеціальна мовна підготовка (англійська), іноземна мова профресійного спрямування (англійська) та українська мова професійного спрямування, в яких розподіл годин для вивчення тем під час аудиторних занять та годин для опрацювання тем під час самостійної підготовки співвідноситься як 2:1. Тому одна 3 вимог до процесу навчання полягає в тому, щоб забезпечити всебічну теоретичну і практичну підготовку курсантів як під час аудиторних занять, так і під час самостійної підготовки, щоб грамотно й ефективно використовувати навчальний час.

За умов європейської інтеграції України та північноатлантичної інтеграції Збройних Сил України, стрімкого розвитку набуває військове співробітництво із закордонними державами, постійно організовуються та проводяться спільні навчання та підготовка військових кадрів, продовжується участь українських військових у миротворчих місіях та операціях, все зазначене в свою чергу зумовлює необхідність навчати курсантів, готових до адекватної взаємодії з представниками інших культурних співтовариств.

Зважаючи на потреби у військових фрахівцях 3 високим рівнем мовленнєвої компетентності варто зорієнтувати освітню політику військових закладів на взаємозв'язок професії та мови, на зближення військово-профресійної та мовної підготовки. Тому ми вважаємо мову (як українську, так і іноземну) невіддільною складовою частиною профресійної підготовки курсантів. В такому аспекті мовленнєва компетентність набуває особливого значення, як така, що обслуговує усі зазначені сорери службової діяльності, а проблема пошуку дієвих підходів до формування мовленнєвої компетентності курсантів військових закладах вищої освіти у процесі самостійної підготовки набуває особливої актуальності та потребує відповідного наукового дослідження.

Аналіз останніх досліджень і публікацій. Аналіз наукових праць засвідчив наявність значної кількості досліджень українських та зарубіжних вчених присвячених проблемі обґрунтування наукових підходів та принципів підготовки фахівців до різного роду діяльності. Особливостям освітньої методології присвятили наукові праці О. Вознюк, С. Гессен, С. Гончаренко, А. Дубасенюк, І. Зязюн та інші.

Проблема впровадження компетентнісного підходу в систему вищої освіти була предметом досліджень Н. Кузьміної, Н. Ничкало, В. Ягупова й інших. Важливість компетентнісного підходу в мовній освіті розкривається в дослідженнях Т. Вигранка, Т. Гнаткович, А. Кордонської, О. Кулик, О. Прокопової, І. Ренчка, К. Черниш. Особливості системного підходу й обґрунтування його реалізації у військовій педагогічній практиці знайшли своє відбиття в наукових розвідках О. Лагодинського, В. Рижикова,
В. Телелима, Ю. Шабанової та інших. На засадах системного підходу побудоване вивчення проблеми формування мовленнєвих компетентностей у дослідженнях Л. Березовської, Н. Доцової, В. Зінченко, Т. Люріної, Л. Шевцової. Діяльнісний підхід до освіти у своїх дослідженнях обирали О. Бойко, Н. Голуб, І. Кухарчук, О. Леонтьєв, Р. Торчевський. Дослідженню освітнього середовища вищого навчального закладу присвячені роботи О. Антонова, О. Білик, В. Биков, М. Братко, О. Горчакова, В. Желанова, А. Каташов, О. Якимович, В. Ясвін. В основу своїх досліджень середовищний підхід поклали А. Баль, В. Деміденко, Ю. Мануйлов, Л. Ордіна, Г. Полякова, І. Сидорук, С. Совгіра, О. Ярошинська. Питання застосування лінгвокраїнознавчого підходу до викладання мов вивчали А. Бронська, Г. Гритчук, Ю. Веклич, Г. Глубоковських, Т. Калинюк, Н. Марченко й інші.

Виділення не вирішених раніше частин загальної проблеми. Проте обґрунтування наукових підходів до фрормування мовленнєвої компетентності курсантів військових закладів вищої освіти в процесі самостійної підготовки не було предметом окремого наукового дослідження.

Мета статті - обґрунтування наукових підходів до орормування мовленнєвої компетентності курсантів військових закладів вищої освіти в процесі самостійної підготовки.

Виклад основного матеріалу. В залежності від поставлених завдань, об'єкта і предмета наукового пошуку, а також того чи іншого виду компетентності, науковці обирають різні наукові підходи, що покладені в основу їх досліджень. Спираючись на мету та завдання нашого дослідження, розглянемо сучасні підходи, які відповідають розв'язанню поставлених нами наукових завдань.

Оскільки головне місце в організації будь-якого навчального процесу займає процес окреслення цілей, маємо визначити якою є мета фрормування мовленнєвої компетентності курсантів у процесі самостійної підготовки, яку ми розглядаємо як частину загальної мовної підготовки у військових закладах вищої освіти. Для відповіді на це питання необхідно проаналізувати до яких завдань залучатимуть курсантів у майбутній службовій діяльності, що в свою чергу допоможе нам з'ясувати яким має бути зміст та результат її формування.

у службовій діяльності українські військові залучаються: до участі у міжнародних багатонаціональних навчаннях із безпосереднім спілкуванням іноземною мовою, де важливо розуміти накази, інструкції та команди, проводити брифрінги та наради; до участі у розробці та впровадженні документів та стандартів, а саме їх переклад та аналіз; до участі у проведенні заходів міжнародного співробітництва, де $€$ необхідним вміння вести дискусію, переговори, телефонну розмову, знати основи офріційного листування зі службових 
питань іноземною мовою; до участі у складі миротворчих місій та операцій, де виконувати завдання необхідно у складі міжнародних угруповань та у специфічних соціальних та міжкультурних умовах країн, де відбувається місія тощо.

Таким чином відмічаємо, що у подальшій службовій діяльності курсанти будуть виконувати цілий спектр важливих спеціальних завдань, для виконання яких необхідною умовою $є$ володіння мовленнєвою компетентністю, що потребує вдосконалення організації цілеспрямованого навчального процесу загалом та пошуку дієвих підходів фрормування мовленнєвої компетентності у процесі самостійної підготовки як обов'язкової складової навчального процесу у військовому закладі. Тому вважаємо, що на рівні загальнонаукової методології основними науковими підходами є компетентнісний, системний та діяльнісний. Серед конкретно-наукових підходів розглядаємо середовищний, лінгвокраїнознавчий та особистісно орієнтований.

3 огляду на те, що базовою ідеєю реформування освітньої галузі визнано компетентнісний підхід, військова освіта переходить на нові стандарти підготовки курсантів з урахуванням тенденцій, що притаманні сучасній освітній парадигмі. Концепція неперервної освіти визначає основу методології формування компетентностей курсантів для виконання різного роду спеціальних завдань. Отже логічно, що компетентнійсний підхід $€$ фрундаментальним у нашому дослідженні.

Його основна суть сорормувати в того, хто навчається вміння вчитись, самостійно здобувати інорормацію та знання, щоб в подальшому не лише вміти оперувати власними знаннями, а й бути готовими змінюватись та пристосовуватись до нових потреб професії та суспільства, оперувати й управляти інформацією, активно діяти, швидко приймати рішення, навчатись упродовж життя [1]. Погоджуємося 3 думкою О. Дубасенюк, що знання, на які традиційно була зорієнтована освіта, в наш час вже не вважаються головним критерієм, а цінуються вміння самостійно добути ці знання та компетентно їх використовувати [2, с. 160].

Компетентність - поняття, що логічно походить від ставлень до цінностей, та від умінь до знань. Тому розвиток курсантів має відбуватися на основі набуття ними комплексу знань та умінь, а також на основі врахування їх особистісних характеристик, як-от: цінності, потреби, мотиви, професійно важливі якості, ставлення до певного роду діяльності тощо.

В такому контексті процес фрормування мовленнєвої компетентності в процесі самостійної підготовки стає способом розвитку курсантів, що спрямований на формування мовленнєвих умінь і навичок, необхідних для якісної службової діяльності у майбутньому; вміння адекватно і доречно практично користуватися мовою в конкретних ситуаціях, використовуючи як мовні, так і позамовні засоби; здатності до профресійного усного та писемного мовлення у міжкультурному просторі та міжнародній співпраці.

Аналізуючи наукові підходи, наступним ми обрали системний підхід. Нами встановлено, що використання системного підходу до формування мовленнєвої компетентності курсантів спрямовано на те, щоб ссрормувати систему знань мовного спрямування, мовленнєвих умінь та навичок і вміло використовувати їх у майбутній службовій діяльності. Сутність системного підходу як методології досліджень полягає в дослідженні об'єкта як цілісної множини елементів в сукупності відношень і зв'язків між ними [3, с. 63]. Особливість системного дослідження в тому, що його предметом виступає об'єкт, який в свою чергу складає систему. Таким об'єктом у нашому дослідженні можна визначити фрормування мовленнєвої компетентності курсантів. Відповідно, ми розглядаємо процес формування їх мовленнєвої компетентності у процесі самостійної підготовки як структуровану педагогічну систему, що складається з елементів та їх взаємозв'язків. Вперше запровадила у наукову термінологію поняття педагогічної системи Н. Кузьміна [4]. Дослідниці належить першість у розробці педагогічної системи з чітко вираженою структурою та фрункціональними взаємодіями.

Ефективність такої системи залежить від таких чинників, як зміст, організація, взаємозв'язок та характер завдань, результат виконання. Згідно загальної теорії систем існує вісім аспектів практичного використання системного підходу: елементний, структурний, функціональний, цільовий, ресурсний, інтеграційний, комунікаційний, історичний [5, с. 33]. Враховуючи об'єкт нашого дослідження та зазначені чинники доцільним вважаємо виділення п'ятьох аспектів системного підходу. Пропонуємо таке їх зображення стосовно фрормування мовленнєвої компетентності курсантів військових закладів вищої освіти у процесі самостійної підготовки:

- елементний аспект включає виявлення елементів навчального процесу, що спрямовані на розвиток мовленнєвої компетентності курсантів, зокрема, цілі, зміст, створення педагогічних умов фрормування зазначеної компетентності в процесі самостійної підготовки;

- структурний аспект розглядає внутрішні зв'язки і залежності між цілями, змістом, організацією, технологіями та результатами формування мовленнєвої компетентності в процесі самостійної підготовки. Особливістю цього аспекту є внутрішньо дисциплінарні зв'язки, тобто кореляція змісту програм дисциплін для аудиторних занять та для самостійної підготовки;

- фрункціональний аспект виявляє фрункції 
сорормованості мовленнєвої компетентності. Результатом іï сорормованості $€$ успішне виконання курсантами всього спектру завдань, що передбачає майбутня службова діяльність;

- ресурсний аспект полягає у визначенні методів, засобів, завдань, технологій, матеріальної бази, необхідних для досягнення окреслених цілей;

- комунікаційний аспект виявляє зовнішні зв'язки мовленнєвої компетентності з професійною.

Отже, фрормування мовленнєвої компетентності курсантів у процесі самостійної підготовки можна представити як складову системи мовної підготовки курсантів у військовому закладі вищої освіти, що складається із сукупності взаємопов'язаних елементів (цілі, зміст, завдання, методи, умови, організація, засоби навчання, тощо), функціонує у полі різних аспектів (елементний, структурний тощо), а також виконує важливі фрункції, метою яких $€$ ефективне виконання мовленнєвої діяльності курсантів в межах майбутньої службової діяльності.

Оскільки для курсантів спілкування з цивільним населенням, колегами, командуванням, підлеглими, представниками інших держав та культур буде невіддільною складовою частиною службової діяльності, а мовленнєва компетентність одним із основних засобів досягнення мети і завдань, то специфріка наукового пошуку ґрунтується на застосуванні діяльнісного підходу. Він спрямовує навчальний процес на розвиток ключових компетентностей курсантів; на застосування теоретичних знань на практиці; на фрормування здібностей до самоосвіти й командної роботи; сприяє успішній самореалізації в навчанні.

У структурі навчальної діяльності психолог Д. Ельконін виділяє 5 компонентів: мотивацію, навчальні завдання, навчальні операції, контроль та оцінювання [6]. Тому діяльнісний підхід до навчання під час самостійної підготовки курсантів передусім має бути спрямований на розвиток їх вмотивованої самостійної роботи з покладеною метою, а також вміннями знаходити шляхи і засоби досягнення цієї мети та контролю й оцінки виконаної роботи.

Отже, можна зробити висновок про те, що діяльнісний підхід є однією з основних умов ефективного фрормування мовленнєвої компетентності курсантів військових закладів вищої освіти в процесі самостійної підготовки та характеризується: застосуванням методів навчання, які залучають курсантів до активної мовленнєвої діяльності; набуттям особистих якостей та вмінь, необхідних для самостійної пізнавальної діяльності; здійсненням курсантами рефлексивної діяльності, яка передбачає аналіз спільної продуктивної діяльності одногрупників, викладача і самих себе.

Наступним підходом ми обрали середовищний, так як конкретне середовище є сукупністю різно- манітних умов, які безпосередньо впливають на навчальний процес. Ми вважаємо, що саме умови, в яких проходить діяльність курсантів (аудиторні заняття, самостійна підготовка, позанавчальна діяльність) $є$ рушійною силою для фрормування компетентного фрахівця. В умовах вищої освіти науковці розглядають такі різновиди освітнього середовища, як навчальне, виховне, розвивальне, соціокультурне, інорормаційне, віртуальне, морально-психологічне тощо. Аналіз літератури дає можливість стверджувати, що єдиної класифікації освітніх середовищ немає.

Проте нам імпонує думкаЮ. Кулюткіна, який охарактеризував освітнє середовище як «сукупність соціальних, культурних, а також спеціально організованих в освітній установі психолого-педагогічних умов, у результаті взаємодії яких із індивідом відбувається становлення особистості» [7, с. 25]. 3 огляду на те, що військовий заклад вищої освіти це заклад зі специфічними умовами навчання, які вимагають від курсантів відповідної соціальної, моральної та психологічної готовності, ми вважаємо, що створення відповідних педагогічних умов морально-психологічного та соціокультурного середовищ, сприятиме ефективному формуванню мовленнєвої компетентності курсантів під час самостійної підготовки та дозволить курсантам мати кращі результати в навчанні загалом.

Лінгвіст С. Крашен вивів 5 гіпотез успішного вивчення іноземних мов: гіпотеза засвоєння та вивчення, гіпотеза контролера (редактора), гіпотеза природного порядку, гіпотеза вхідного матеріалу та гіпотеза афективного (емоційного) фрільтру [8]. Афрективний фрільтр - це умовна перешкода на шляху засвоєння та вивчення іноземної мови, що з'являється у людини, яка відчуває негативні емоції: страх, злість, роздратування тощо. Причинами появи афективного фрільтру у курсантів може бути погана адаптація до нових умов навчання у військовому закладі, стрес, погані стосунки з одногрупниками або викладачами, тривожність, недостатні знання та ін. Тому важливо при вивченні іноземної мови створити позитивне морально-психологічне середовище, що базується на довірі, повазі та взаємодопомозі, та спонукає до розвитку у курсантів мотивації до вивчення мови, бажання спілкуватися іноземною мовою, формує позитивне ставлення до мови та культури та сприяє впевненості в собі.

Одним із складників навчального середовища закладу вищої освіти Ю. Мануйлов вважає «ніші» [9]. Ніша - це певний простір можливостей, що дозволяє суб'єктам освіти задовольняти свої потреби [10, с. 103] (спортивна секція, гурток, спільне улюблене заняття, виконання проєкту тощо). Ніші як локальні осередки середовища поділяються на соціальні і культурні, тому ми їх розглядаємо як засіб організації сприятливого 
соціокультурного середовища у навчальному закладі. У Житомирському військовому інституті імені С.П. Корольова нами було створено гурток ораторського мистецтва й розмовний клуб, які мають на меті зняття мовних бар'єрів, тренування навичок говоріння та сприйняття на слух, демонстрація «практичного застосування» мови в житті, підвищення мовленнєвої культури, а також виконують фрункцію соціалізації курсантів.

Виконання зазначених вище завдань неможливе без сучасної навчально-матеріальної бази, як-от: комплексу матеріальних і технічних засобів навчання, спеціально обладнанихаудиторійтамовних лабораторій, класів та центрів самостійної підготовки, бібліотеки, локальної мережіта бази даних.

Узагальнюючи сказане, ми дійшли висновку, що для фрормування мовленнєвої компетентності курсантів військових закладів вищої освіти в процесі самостійної підготовки важливим є застосування середовищного підходу та розробка педагогічних умов, які забезпечать належне навчальне середовище та успішну підготовку компетентних військових фрахівців.

3 огляду на визначену нами мету формування мовленнєвої компетентності курсантів військових закладах вищої освіти під час самостійної підготовки та проаналізувавши спектр завдань, до яких залучаються курсанти у майбутній службовій діяльності, ми вважаємо, що застосування лінгвокраїнознавчого підходу є необхідним. Адже, на думку В. Маслової, «мова - складова частина культури, яку ми успадковуємо, та водночас її знаряддя. Культура народу вербалізується в мові, саме мова акумулює ключові концепти культури, транслюючи їх у знаковому втіленні - словах» [11]

Ми погоджуємося з О. Кондратьєвою в тому, що лінгвокраїнознавчий підхід забезпечує вирішення комплексних завдань 3 вивчення національних стереотипів поведінки, ціннісних орієнтацій, специфріки культури іншомовної країни [12]. В рамках майбутньої профресії курсанти будуть співпрацювати 3 представниками різних націй, тому вивчення принципів міжкультурної комунікації $€$ досить важливим, оскільки дозволяє передбачити проблеми у спілкуванні людей різних етнічних груп і запобігти непорозумінню у процесі спілкування.

Завдяки лінгвокраїнознавчій складовій фрормування мовленнєвої компетентності курсантів забезпечується психологічна готовність майбутніх фрахівців до залучення до різноманітних сфрер життєдіяльності (побутової та службової), дослідження особливостей (етнічних, культурних, релігійних) народу, його духовність, світогляд, спосіб мислення. Застосування лінгвокраїнознавчого підходу $є$ одним із важливих умов фрормування мовленнєвої компетентності курсантів, адже саме такий підхід забезпечує засвоєння національної та іншомовної культури, розвиток мовленнєвих та комунікативних умінь, розширюють світогляд курсантів, який орієнтований на взаємодію в умовах міжнародної співпраці.

Таким чином, ми вважаємо, що одним з пріоритетних підходів до фрормування мовленнєвої компетентності курсантів військових закладів вищої освіти в процесі самостійної підготовки є лінгвокраїнознавчий підхід, засади якого сприяють подоланню міжкультурних непорозумінь, консрліктних ситуацій, стереотипів у стосунках; пізнанню цінностей, традицій, побуту, етикету та особливостей національної та інших культур; свідомій мовленнєвій діяльності в полікультурному середовищі за наслідками вивчення рідної та іноземної мов.

3 обраними нами науковими підходами до фрормування мовленнєвої компетентності курсантів військових закладів вищої освіти в процесі самостійної підготовки тісно пов'язаний особистісно орієнтований підхід, який передбачає гнучкість у визначенні цілей, враховує особистісні нахили й інтереси курсантів, їх індивідуальні особливості та інтелектуальний розвиток, розвиває пізнавальні можливостітанавички самостійної роботи, створює передумови для успішних результатів навчання.

Враховуючи, що ми розглядаємо фрормування мовленнєвої компетентності саме у процесі самостійної підготовки, то в умовах особистісно орієнтованого навчання вона стає засобом фрормування самостійності курантів, сприяє підвищенню навчально-пізнавальної активності, надає курсантамвпевненостівсобітавіриусвоїсилиіможливості.

Підсумовуючи робимо висновок, що формування мовленнєвої компетентності курсантів на засадах особистісно орієнтованого підходу дає можливість обирати дієві фрорми, методи і прийоми організації самостійної роботи, що забезпечують адекватні умови для мовленнєвого розвитку курсантів, враховуючи їх індивідуальні особливості, моральні цінності, особистий досвід, риси характеру та інтереси.

Зауважимо, що описані нами вище підходи не виключають і не суперечать один одному, а навпаки доповнюють один одного, забезпечуючи нам вибір відповідних фрорм, методів, засобів і умов фрормування мовленнєвої компетентності курсантів військових закладів вищої освіти в процесі самостійної підготовки.

Висновки. Застосування настанов зазначених підходів до формування мовленнєвої компетентності курсантів у процесі самостійної підготовки дає можливості передбачати результати формування мовленнєвої компетентності; перевіряти рівень сорормованості мовленнєвої компетентності; обґрунтовувати умови щодо розроблення методів і технологій діагностування результатів формування мовленнєвої компетентності.

Реалізація ідей обраних підходів відповідно до мети нашого дослідження передбачає надалі 
розроблення моделі фрормування мовленнєвої компетентності курсантів, створення ефективних педагогічних умов самостійної підготовки курсантів із застосуванням доцільних фрорм, методів і технологій, що сприятимуть розвитку важливих профресійних та особистісних якостей, необхідних для майбутньої службової діяльності.

\section{БІБЛІОГРАФІЧНИЙ СПИСОК:}

1. Компетентнісний підхід у сучасній освіті: світовий досвід та українські перспективи. Бібліотека з освітньої політики / під заг. ред. О.В. Овчарук. Київ : "K.I.C.", 2004. 112 c.

2. Дубасенюк О.А. Наукові підходи до освіти дорослих : монографрія. Житомир : Вид-во Рута, 2016. C. 155-167.

3. Салига Н.М. Системний підхід у вищий школі : навчально-методичний посібник до курсу. Івано-Франківськ, 2016. С. 66-67.

4. Методы системного педагогического исследования : учебное пособие / Н.В. Кузьмина, Е.А. Григорьева, В.А. Якунин и др. Ленинград : Изд-во ЛгУ, 1980. $172 \mathrm{c}$.

5. Шабанова Ю.О. Системний підхід у вищій школі : підручник для студентів магістратури. Донецьк : НГУ, 2014. С. 33-35.
6. Эльконин Д.Б. Детская психология : учебное пособие для студентов высших учебных заведений. Москва: Издательский центр «Академия», 2007. 384 с.

7. Кулюткин Ю.Н., Тарасов С.В. Образовательная среда и развитие личности. Новые знания. 2001. № 1. URL: http://www.znanie.org/gurnal/nl_01/obraz_ sreda.html.

8. Krashen Stephen D. Principles and Practice in Second Language Acquisition. Prentice-Hall International, 1987. 209 p.

9. Мануйлов Ю.С. Концептуальные основы средового подхода в воспитании. Вестник Костромского государственного университета им. Н.А. Некрасова. 2008. Т. 14. № 1. С. 21-27.

10. Дубасенюк О.А. Методологія і методи науковопедагогічного дослідження : навчально-методичний посібник. Житомир : Полісся, 2017. 256 с.

11. Маслова В.А. Современная лингвистика наука о человеке, его сознании, языке и культуре. Филология: история и современность. 2018. С. 6-10. URL: http://www.zabwector.com

12. Кондратьєва О.М. Формування полікультурної компетентності майбутніх учителів початкової школи (на засадах лінгвокраїнознавчого підходу) : дис. ... канд. пед. наук : 13.00.04. Київ, 2017. 265 c. URL: https://npu.edu.ua/images/file/vidil_ aspirant/dicer/D_26.053.01/dis_Kondratieva.pdf. 


\section{MULTIMEDIA IN TEACHING FOREIGN LANGUAGES ЗАСОБИ МУЛЬТИМЕДІА У НАВЧАННІ ІНОЗЕМНИХ МОВ}

Multimedia has an enormous impact on the whole society since it is nowadays exploited in many industries (e.g. engineering or medicine) and as a common means of reference (e.g. encyclopedias or dictionaries). Thanks to its great potential for learning, multimedia is also widely used in the teaching of foreign languages. This article gives an explanation of the term multimedia; states reasons why it should be used in foreign language teaching; outlines its important role in the acquisition of second language learning; illustrates how multimedia is delivered in foreign language teaching.

Computer technology and Internet are inevitable new media in education methodology. Still, the central role in teaching belongs to humans. The power of Internet lies in offering authentic materials, software, education plans, list of exams, literature, etc. to schools, universities, and institutions all over the world but under the same conditions. Next to its commercial importance, it is seen as pedagogical tool for either the independent research or teamwork. The paper brings out positive and negative effects of new technology and its implementation in foreign language learning. Besides for the lessons learning, the idea of information literacy maintains crucial position in education. The new technology demands investment of time, effort, money, and self-education, so that the principal question remains if we are ready for new type of education in order to offer better teaching, more interesting lessons and more importantly, to prepare new generations for future challenges.

Multimedia practical lesson gives the opportunity to combine an incredible number of interesting tasks, attracting more and more students in one lesson. We see the directions of further work in solving the outlined problem in the creation of computer multimedia programs using an accessible interface for both teachers and students.

Key words: multimedia, multimedia technologies, Internet resources, computer technologies, students.

6085/2020/24-2.27

\section{Tymoschuk N.M.,}

Candidate of Philological Sciences, Associate Professor of Ukrainian and Foreign Languages Department Vinnytsia National Agrarian University ристовуються в навчанні іноземних мов. У роботі наведено визначення десрініції мультимедіа; схарактеризовано причини використання мультимедійних засобів у навчанні іноземних мов; обгрунтовано їх важливу роль у засвоєнні дисципліни.

Комп'ютерні технології та Інтернет - нові засоби масової інсрормації в освіті, однак чентральна роль у навчанні належить людині. Перевага Інтернету полягає в тому, щоб пропонувати автентичні матеріали, програмне забезпечення, плани навчання, список іспитів, літературу тощо для університетів і навчальних закладів у всьому світі, але за однакових умов. Інтернет розглядається як педагогічний інструмент як для незалежних досліджень, так і для роботи в команді. У публікації викладено позитивні й негативні наслідки нової технології та ї впровадження у викладання іноземних мов для студентів нелінгвістичних спеціальностей. Звісно, нова освітня технологія вимагає часу, зусиль, фрінансових інвестицій і самоосвіти, тому головним питанням залишається, чи готові ми до нового типу освіти, щоб ліпше викладати й підготувати нові покоління до майбутніх викликів.

Використання засобів мультимедіа значно розширює та диверсифрікує програми вивчення іноземних мов для студентів немовних спеціальностей, надає доступ до різноманітних автентичних матеріалів, посилює мотивацію студентів до навчання, надаючи можливість працювати над вивченням мови в індивідуальному режимі. Засоби мультимедіа забезпечують гнучкість та інтеграцію різних типів мультимедійноі навчальної інсрормачії.

Мультимедійне практичне заняття дає можливість комбінувати в одному занятті неймовірну кількість цікавих завдань, залучаючи все більшу й більшу кількість студентів. Напрями подальшої роботи в розв'язанні окресленої проблеми вбачаємо в створенні комп'ютерних мультимедійних програм із використанням доступного інтерфейсу як для викладачів, так і для студентів. Ключові слова: мультимедіа, мультимедійні технологіі, І Інтернет-ресурси, комп'ютерні технолосії, студенти.
Statement of the problem. The modern system of education is characterized by rapid changes, they also affect foreign language teaching for university students. Nowadays, the Internet has become a major component both of everyday life and the educational process. Students are more interested in computer technology than textbooks and manuals. Considering informatization of society and comprehensive spread of the Internet, the relevance of the multimedia technologies application in the educational process is obvious. Large international companies need specialists speaking foreign languages fluently. Thus, the status of a foreign language as a means of intercultural communication is growing rapidly. These factors necessitate the improvement of foreign language teaching methods. Students will create the business elite of the country in the future. That's why teachers should focus their efforts on improving the quality of foreign language teaching. It is important to use multimedia tools for language teaching, developing skills that would allow them to be mobile, informed, where language is a means of conveying information, especially through multimedia channels [2].

Multimedia is a useful and fruitful educational tool due to its inherent qualities of interactivity, flexibility, integration of different types of multimedia educational information, as well as the ability to take into account individual characteristics in learning, and to increase student motivation. 
Analysis of recent publications. Significant progress has been made in research of multimedia application in the process of a foreign language teaching. We should mention such Ukrainian scholars as M. Boremchuk, S. Kozhushko, V. Nasonova, A. Nisimchuk, E. Subotina, O. Tarnopolskyi and P. Shpirko. Foreign scientists (T. Hutchinson, A. Waters, P. Widdoswon, R. Bolitho) have developed a method of teaching foreign languages for professional purposes; it was introduced in the teaching of non-language specialties at Ukrainian universities. O. Bihych, M. Bovtenko, L. Skalii, S. Fomin are convinced that the Internet should be widely used for teaching English. The literature review indicates that question how to the quality of teaching improve is rather actual today.

The purpose of the article is to consider additional possibilities of using multimedia tools in the process of learning a foreign language by students of non-language specialties at universities.

The main part of the research. The more actively computers are used in the educational process the more effective are the learning outcomes. The computer promotes the development of independence and creativity of students, it also makes classes more visual and interesting. PC provides the individualization of learning, the formation of foreign language competence, and strengthens interdisciplinary links. The above-mentioned characteristics make it possible to improve the education quality. P. Shpirko has focused on certain contradictions in the formation of foreign language competence of students of nonlinguistic specialties, i.e.

1) theoretical and practical attitude to this problem;

2) understanding the need for foreign knowledge language by a modern specialist and his actual level of language knowledge;

3) understanding the need to use multimedia tools and technologies in teaching a foreign language using the Internet resources and the absence of any changes in planning the learning process and setting new goals, clarifying the purpose of each level of learning, developing a systematic approach to using multimedia learning tools, creation of new, more modern and effective technologies and teaching methods [5].

The introduction of modern and innovative approaches to teaching a foreign language requires the multimedia teaching aids application. Multimedia technologies have significantly affected the entire education system, i.e. its content, form and methods. It has caused a change in the requirements of the most modern students for the quality of education. L. Skalii offers a variety of methods of using computer technology in language teaching. We would like to mention the following ones:

1) management of educational staff, which allows the teacher to implement a differentiated and individual approach to learning, using selected from the Internet resources exercises and tasks;
2) the use of the Internet as a source of information, which allows teachers and students to access authentic texts [4].

Multimedia learning tools provide different types of activities based on the integrated application of various types of information processes, i.e. information technology in both frontal and group work; electronic textbooks application; creation of classes-presentations etc. A. Nisimchuk, O. Padalka, O. Shpak define multimedia technologies as a set of visual, audio and other means of displaying information that are integrated in an interactive software environment [3]. Creating multimedia presentations, the teacher must take into account such a sequence as motivation, goal setting, creating preconditions for the perception of educational material, the presentation of educational material and its evaluation, as well as take into account the relevant principles of classical didactics, but also specific principles of computer multimedia products.

Let's focus on the stages of preparation of a multimedia presentation: structuring of educational material; drafting an implementation scenario; presentation design development; preparation of media fragments; preparation of musical accompaniment; testing-verification. The forms and place a multimedia presentation application in a practical foreign language lesson depend on the content and the goal of this lesson. We would like to single out some general, most effective methods of multimedia presentations using, i.e. when studying new material, which allows to illustrate it with various visual aids. The application is especially advantageous in cases where it is necessary to show the dynamics of any process; to test students' academic achievements. Creating a script scheme you should be guided by the following principles: the presentation should be short, accessible and compositionally complete, lasting no more than 10-20 minutes; there should be nothing superfluous, and each slide should be a necessary link of studying of new material; do not overload the slides with unnecessary details, additional effects should be minimized and used to draw the student's attention to the key points of the demonstration.

Teachers need to take into account the peculiarities of the perception of information from the computer screen, to think about and maintain a common style of presenting information for the whole lesson and strive to unify the structure and form of educational material presentation. It is important to check the presentation for readability from the computer screen. It is recommended to use a concise, informative style of teaching material. Creating a multimedia presentation, you need to solve one of the main tasks: how to ensure maximum simplicity with the maximum information saturation. This can be achieved by limiting both the ways in which material is presented and the set of navigation objects. The student, quickly understanding the features of the interface of the pro- 
posed presentation, will not be distracted in the future, focusing on the content of educational information.

It is clear that classes with multimedia technologies require a lot of preparation. The teacher must be able to use a variety of programs, i.e. graphics, flesh-animation, web-editor, programs for creating presentations, programs for working with audio and video. It depends on how you decide to submit the information. It can be a video, presentation, webpage with various videos. In general, the choice is very large. You can use Internet resources to illustrate the training material.

Multimedia tools include special programs for listening, presenting, using a multimedia board, and multimedia guides. Multimedia teaching programs are used as a means of improving the effectiveness of the lesson, because by involving the simultaneous action of audio (sound) and visual information, they have a greater emotional charge and are able to increase the productivity of students. Therefore, it is important for foreign language teachers to master these multimedia technologies and learn to work with programs enabling them to be used in the educational process, namely: PowerPoint presentation program, Winamp audio and video playback program, video or slide show software and have basic skills with a multimedia board.

The multimedia board application provides an opportunity to learn English more effectively by involving specific human abilities; make exercises more interesting compared to textbooks; involve the whole group in the learning process; improve both picture and sound quality compared to computer training; draw, scale, underline and drag words and sentences directly on the board; easy to learn English, relieving stress during the lesson; unlimited use of any video, audio and Internet resources.

Let's define the positive aspects of the multimedia tools application in the educational process:

1) provide a high level of interactivity between the student and the material;

2) it is possible to develop and improve various learning styles and interactions, which became possible due to the use of interactive video;

3 ) there is a possibility of connection through a network that considerably saves time and money;

4) combines sound and images with PC-based learning;

5) prices for technical support for multimedia systems are relatively low;

6) attracts a significant number of learning students;

7) storing data in digital format provides greater opportunities for learning, the material can be considered step by step;

8) contributes to the motivation and encouragement of students;

9) the student can choose the pace and time of mastering the material.
Ukrainian scholar R. Hurevych has named the following disadvantages of multimedia technologies:

1) each student needs access to a multimedia computer;

2) special equipment is required for the operation of programs (multimedia complex);

3) development may require significant financial and time costs;

4) the Internet provides a huge amount of information that students cannot always adequately perceive;

5) low quality of communication;

6 ) it is impossible to convey a personal attitude or behavior;

7) some students find it difficult to perceive information from the screen;

8) there are practically no multimedia programs in the Ukrainian language [1].

Let's focus on the issue of providing the didactic functions of the educational and methodological complex to the multimedia presentation. There are the following requirements to the multimedia presentation, i.e. text fragments can be accompanied by audio or video information to highlight semantic accents. It is recommended to use a multi-window interface to present a variety of information; the multimedia presentation may contain additional material as well as material for in-depth study of the topic; the most important elements of a multimedia presentation should have hints or explanations; after studying each structural unit of educational material in the presentation is placed material for generalization; multimedia presentation should be open for development, and its text should have free access to copy and print. Creating a presentation, you should find as many points of contact between the training subject and external information flows. It makes the presentation more interesting, relevant and exciting for students. The multimedia tools used in the presentation help to interact more effectively with students. Flexibility is one of the foundations of a successful presentation. The teacher needs to be prepared to make changes in response to students' reactions.

Conclusions. The use of multimedia significantly expands and diversifies foreign language programs for students of non-language specialties, provides access to a variety of authentic materials, strengthens students' motivation to learn, providing an opportunity to work individually while learning language. Multimedia tools provide flexibility and integration of different types of multimedia educational information. Students of non-linguistic specialties become subjects of communication with the teacher in the educational process where computer technologies are used, they promote the development of their independence and creative approach in educational activities. An integrated approach to solving basic tasks, which combines a set of multimedia technologies with high didactic potential, computer learning of 
foreign languages and methods of intensive foreign language learning, should be considered a promising area of work in the system of intensive foreign language learning.

Systematic application of the computer at practical classes, in particular presentation systems, leads to improving the quality of the use of visual aids; increase productivity; establishing interdisciplinary links; there is an opportunity to organize project activities of students to create curricula under the guidance of teachers; the teacher who creates the presentation should pay attention to the sequence of presentation of educational material, which has a positive effect on the level of knowledge of students; change into better relationships with students who are interested in computer technology.

Prospects for further research. Multimedia practical lesson gives the opportunity to combine an incredible number of interesting tasks, attracting more and more students in one lesson. We see the directions of further work in solving the outlined problem in the creation of computer multimedia pro- grams using an accessible interface for both teachers and students.

\section{REFERENCES:}

1. Гуревич Р.С., Шестопалюк О.В., Шевченко Л.С. Застосування мультимедійних засобів навчання та глобальних інсрормаційних мереж у наукових дослідженнях : посібник. Вінниця : ДОВ «Вінниця», 2004. 135 c.

2. Корж В.В. Роль мультимедійних технологій у навчанні іноземної мови. URL: http://www. confcontact. Com/2008oktInet_tezi/iy_korzh.htm.

3. Нісімчук А.С., Падалка О.С., Шпак О.С. Сучасні педагогічні технології. Київ : Просвіта, 2000. 436 с.

4. Скалій Л.І. Поняття професійної компетенції вчителя іноземних мов у застосуванні сучасних інорормаційних технологій. Гуманізація навчальновиховного процесу: збірник наукових праць. Слов'янськ : СДПУ, 2003. С. 293-296.

5. Шпірко П.Ф. Сучасні та інноваційні підходи викладання англійської мови для студентів інженерних фракультетів. Вісник Національного технічного університету України «Київський політехнічний інститут». Київ : Політехніка, 2009. С. 196-200. 


\section{ПЕДАГОГІЧНА МАЙСТЕРНІСТЬ ЯК ФАКТОР ПРОЯВУ ПРОФЕСІОНАЛІЗМУ ВИКЛАДАЧА ЗАКЛАДУ ВИЩОЇ ОСВІТИ \\ PEDAGOGICAL EXCELLENCE AS A FACTOR OF MANIFESTATION OF PROFESSIONALISM OF A TEACHER OF HIGHER EDUCATION INSTITUTION}

\begin{abstract}
Ефективність фоункціонування системи вищої освіти в Україні значною мірою залежить від професіоналізму науково-педагогічних кадрів закладу вищої освіти. У статmі розкрито поняття профресіоналізму викладача закладу вищої освіти й педагогічної майстерності. $у$ повсякденному вжитку профресіоналізм педагога розуміється, по-перше, як норма, зразок виконання педагогічної діяльності відповідно до сучасного рівня педагогічних знань і чінностей, що $\epsilon$ регулятивним механізмом праці вчителя, викладача. По-друге, профресіоналізм педагога ототожнюється 3 підготовленістю, компетентністю, вправністю педагога, а по-третє, з особливим ставленням учителя до виконання своїх обов'язків на рівні покликання, місії. Головним у прочесі розвитку професіоналізму є не обсяг засвоюваної інфрормації, а вміння творчо користуватися нею, застосовувати для практичної діяльності. Близькість понять майстерності й профресіоналізму дає можливість співвідносити й характеризувати їх за певними ознаками. Педагогічна майстерність розглядається як комплекс властивостей особистості, що забезпечує самоорганізацію високого рівня професійної діяльності на рефлексивній основі. Також педагогічна майстерність викладача закладу вищої освіти зумовлюється індивідуально-творчими, психофізіологічними, віковими характеристиками, сорормованими соціальним і педагогічним досвідом особистості та забезпечує творчий підхід у педагогічній діяльності, викликає складний синтез усіх психічних сорер (пізнавальної, емоційної, вольової й мотивувальноі) особистості педагога.

Проаналізовано й узагальнено структурні компоненти педагогічної майстерності й розглянуто важливість їхнього впливу на підвищення та вдосконалення педагогічного профресіоналізму викладачів сучасних педагогічних закладів вищої освіти з метою покращення якості освітнього процесу. Визначено, що володіння сукупністю цих компонентів допомагає викладачеві досягти досить високого рівня своєї майстерності, від чого залежить якість підготовки фрахівців у вищому навчальному закладі.
\end{abstract}

Ключові слова: вища освіта, викладач закладу вищої освіти, професіоналізм, педагогічна майстерність.

The effectiveness of the higher education system in Ukraine largely depends on the professionalism of scientific and pedagogical staff of higher education institutions. The article reveals the concept of professionalism of a teacher of higher education and pedagogical skills. In everyday use, the professionalism of the teacher is understood, first, as a norm, a model of pedagogical activities in accordance with the current level of pedagogical knowledge and values, which acts as a regulatory mechanism of the teacher. Secondly, the professionalism of the teacher is identified with the readiness, competence, skill of the teacher, and thirdly - with the special attitude of the teacher to the performance of their duties at the level of vocation, mission. The main thing in the process of professionalism development is not the amount of assimilated information, but the ability to use it creatively, to apply it to practical activities. The closeness of the concepts of skill and professionalism allows you to correlate and characterize them on certain grounds.

Pedagogical skill is considered as a set of personality traits that provides self-organization of a high level of professional activity on a reflective basis. Also, the pedagogical skills of a teacher of higher education is determined by individual creative, psychophysiological, age characteristics, formed by social and pedagogical experience of the individual and provides a creative approach to teaching, causes a complex synthesis of all mental areas (cognitive, emotional, volitional and motivating) personality.

The structural components of pedagogical skills are analyzed and generalized and the importance of their influence on raising and improving the pedagogical professionalism of teachers of modern pedagogical institutions of higher education in order to improve the quality of the educational process is considered. It is determined that the possession of a set of these components helps the teacher to achieve a fairly high level of skill, which depends on the quality of training in higher education.

Key words: higher education, teacher of higher education institution, professionalism, pedagogical skill.
Постановка проблеми в загальному вигляді. Глибокі перетворення соціального, духовного й матеріально-технічного характеру, що відбуваються в житті нашої держави та світової громадськості, висувають до системи освіти вимоги, які покликані забезпечувати ці зміни. Останні дослідження свідчать про те, що центром системи освіти, зокрема вищої, стає особистість, її особливості та професійні здібності.

Ефективність фрункціонування системи вищої освіти в Україні значною мірою залежить від про- фресіоналізму науково-педагогічних кадрів закладу вищої освіти. Адже процеси інтеграції України до європейської спільноти, діяльність вітчизняної системи вищої освіти відповідно до вимог Болонської декларації, орієнтація на загальноєвропейські рекомендації щодо якості освіти передбачають ресрормування вищої школи, модернізацію профресійної підготовки не лише студентів, а насамперед їхніх викладачів. Розвиток профресіоналізму викладачів закладів вищої освіти робить ефективною їхню діяльність, через яку реалізується й 
державна політика - зміцнення інтелектуального й духовного потенціалу нації, розвиток науки, збереження й збільшення культурної спадщини.

Зміна орієнтації педагогічної діяльності, переоцінка духовних цінностей спричинили перебудову професійної підготовки викладачів, у якій особливо значущими стали питання вдосконалення педагогічного профресіоналізму викладачів з метою підвищення якості освітнього процесу, від якого залежить підготовка майбутніх фрахівців у сучасному закладі вищої освіти.

Аналіз останніх досліджень і публікацій. Проблема якості педагогічної діяльності завжди була в полі зору вчених. Різні аспекти педагогічної майстерності розглянуто в працях багатьох дослідників: С. Вітвицької, В. Гриньової, Л. Даниленко, М. Захарова, І. Зязюна, Б. Кобзаря, Я. Коломинського, О. Коваленко, А. Коломійця, Н. Ковтух, В. Маслова, О. Пєхоти, Л. Пуховської, І. Учитель, М. Романенко, О. Щербака. Теоретичною основою сучасних наукових підходів стосовно структури, сутності складових компонентів педагогічної майстерності викладача закладу вищої освіти є праці й дослідження Л. Заніна, Є. Ісаєва, Н. Кузьміної, Т. Леонтьєва, О. Лавриненко, О. Маркової, М. Солдатенка, М. Єрмоленко, Є. Шиянова, В. Сластьоніна. Також структуру педагогічної майстерності розкрили у своїх працях І. Зязюн, В. Кан-Калик, Д. Крамущенко, І. Кривонос, І. Учитель. Категорії профресіоналізму в теорії та практиці підготовки майбутнього педагога обґрунтувала Н. Гузій.

Виділення не вирішених раніше частин загальної проблеми. Словосполучення «професіоналізм педагога» активно використовується в сучасній педагогічній лексиці, однак здебільшого на емпіричному рівні, а в категоріальному апараті теоретичної педагогіки воно ще недостатньо розроблено.

Мета статті. Нами поставлено завдання розглянути поняття педагогічної майстерності, проаналізувати й узагальнити її структурні компоненти, а також виявити їхній вплив на прояв професіоналізму викладача закладу вищої освіти.

Виклад основного матеріалу. У повсякденному вжитку профресіоналізм педагога розуміється, по-перше, як норма, зразок виконання педагогічної діяльності відповідно до сучасного рівня педагогічних знань і цінностей, що є регулятивним механізмом праці вчителя, викладача. По-друге, профресіоналізм педагога ототожнюється 3 підготовленістю, компетентністю, вправністю педагога, а по-третє, з особливим ставленням учителя до виконання своїх обов'язків на рівні покликання, місії. Опис профресіоналізму педагога в категоріях повсякденної свідомості $€$ цінним накопиченням емпіричного досвіду, однак дещо поверхневим і тому недостатнім для характеристики френомена, що вимагає більш конкретного наукового пояснення.
Значення терміна «професіоналізм» майже вперше подається в «Енциклопедії професійної освіти», де це поняття трактується як особистісна властивість фрахівця, набута під час навчальної та практичної діяльності здатність до компетентного виконання оплачуваних функціональних обов'язків; рівень майстерності та вправності в певному занятті, що відповідає рівню складності виконуваних завдань [9, с. 111].

Водночас підкреслюється, що головним у процесірозвитку професіоналізмує не обсяг засвоюваної інфрормації, а вміння творчо користуватися нею, застосовувати для практичної діяльності [9, с. 124].

Визначення поняття професіоналізму вперше було запропоновано Н. Кузьміною в контексті ідей акмеології. Феномен професіоналізму розуміється якісною характеристикою суб'єкта діяльності представника певної професії, що визначається мірою володіння ним сучасним змістом і сучасними засобами виконання професійних завдань, продуктивними способами їх здійснення. Крім якісних критеріїв професіоналізму Н. Кузьміна вводить і кількісні, відзначаючи, що «міра цього оволодіння у різних людей різна, тому можна говорити про високий, середній, низький рівень професіоналізму представника тієї або іншої професії» [6, с. 11]. У такому тлумаченні профресіоналізму чітко простежується орієнтація на діяльнісні аспекти феномену, а його сутність пов'язується з вищими рівнями, вищими щаблями досконалості діяльності, досягнутими мистецтвом і майстерністю.

Близькість понять майстерності та професіоналізму дозволяє співвідносити й характеризувати їх за ознаками високої та стабільної продуктивності, ефективності діяльності; високого рівня кваліфікації та компетентності фахівця; оптимальної інтенсивності й напруженості праці; високої точності, надійності й організованості; низької опосередкованості, креативності, суб'єктності, спрямованості на досягнення позитивних соціально значущих цілей [2, с. 66-67].

Водночас автори, відзначаючи часте ототожнення майстерності 3 професіоналізмом, вважають, що категорія майстерності $€$ важливою складовою частиною категорії професіоналізму, близькою за змістом до професіоналізму діяльності, тому що йдеться переважно про розвиток практичних умінь і гнучких навичок, хоча водночас необхідно мати й особистісні якості як стартові можливості для опанування майстерністю [2, с. 66-67].

3 розвитком індивідуально орієнтованих методологічних підходів зростає увага дослідників до особистісних аспектів професіоналізму. На це прямо вказує $€$. Климов, вважаючи, що «не слід зводити ідею професіоналізму тільки до уявлення про високий рівень умілості професіонала <...>; профресіоналізм - це не просто певний вищий рівень знань, умінь і результатів людини в конкрет- 
ній галузі діяльності, а певна системна організація свідомості й психіки людини» [5, с. 287-289].

Профресіоналізм як умова суб'єктної реалізації індивіда пов'язується також із творчим потенціалом людини. У такому ракурсі К. Левітан визначає професіоналізм як творче оволодіння фрахом, a І. Зязюн і Г. Сагач - як достатній для творчого виконання завдань професійної діяльності рівень розвитку професійної культури й самосвідомості [4, с. 42].

На думку Н. Кузьміної, профресіоналізм педагогічної діяльності полягає в тому, що педагог володіє мистецтвом фрормування в учнів готовності до продуктивного вирішення задач у наступній освітній системі засобами свого предмета (фраху) за відведений на навчально-виховний процес час [6, с. 11]. «Профресіоналізм сучасної педагогічної діяльності, - пише автор, - полягає у привнесенні в неї елементів наукового дослідження 3 метою контролю й самоконтролю міри їі продуктивності, а продуктивність, інакше кажучи, - майстерність, що вимірюється» [6, с. 8]. На основі широкомасштабних експериментальних досліджень під керівництвом Н. Кузьміної рівні педагогічної діяльності диференціюються за ступенем продуктивності залежно від педагогічної майстерності й педагогічної творчості.

Дослідник В. Синенко вважає, що професіоналізм учителя визначається високим рівнем його психолого-педагогічних і науково-предметних знань й умінь у сполученні з відповідною культурою й моральним виглядом, що забезпечує на практиці соціально потрібну підготовку молодого покоління до життя [11, с. 47].

У монографії Н. Гузій наведено узагальнений аналіз різних дефрініцій «педагогічного профресіоналізму»:

- профресіоналізм педагога розглядається як компетентність, що полягає в єдності теоретичної та практичної готовності до здійснення педагогічної діяльності (В. Сластьонін);

- основу педагогічного професіоналізму становить таке складне особистісне утворення вчителя, як морально-психологічна готовність до професійної діяльності (Л. Кондрашова);

- сутність педагогічного професіоналізму полягає в індивідуальній неповторності комбінації якостей учителя (В. Горбенко й Т. Марина);

- профресіоналізм освітянських кадрів має інтегративну природу й цілісність (О. Дубасенюк, А. Маркова, Л. Гребенкіна) [9, с. 132-142].

Отже, останнім часом термін «педагогічний професіоналізм» стає одним із ключових понять теорії педагогічної праці й педагогічної освіти, проте його пояснення й інтерпретація й надалі залишається актуальним дослідницьким завданням, на вирішення якого спрямовані пошуки сучасних учених.

Аналізуючи наукову психолого-педагогічну літературу з проблеми праці педагога, до най- більш близьких педагогічному профресіоналізмові термінів як фрундаментальних понять одного ряду, які семантично близькі та мають смислові перетини, слід віднести педагогічну майстерність.

Зупинимося на основних підходах до розуміння педагогічної майстерності й визначимо співвідношення з педагогічним професіоналізмом.

Поняття педагогічної майстерності $€$ досить розробленим, хоча в науковій літературі воно трактується неоднозначно, з різних позицій. Перш за все нами проаналізовано спеціалізовані довідкові джерела, де знайдено різні дефініції поняття «педагогічна майстерність»:

- у термінологічному словнику-довіднику педагогічна майстерність визначається як інтегративна система, що проявляється у виробленій з досвідом новій якості профресійно-педагогічної дії, у найвищому рівні оволодіння професійно-педагогічною діяльністю; набутому компетентнісному досвіді (соціальному, особистісному, професійному); особистості вчителя, його акмеологічних інваріантах, тобто професійно-особистісних якостях, здібностях, властивостях, потенційних ресурсах, профресійно-педагогічних ціннісних орієнтаціях; організації гармонійного комунікативно-ситуативного простору, що полягає в профресійно-педагогічній взаємодії з усіма суб'єктами навчально-виховного процесу; акмеологічній спрямованості професійноособистісного самотворення, самоактуалізації та самовдосконалення (В. Сидоренко) [10, с. 50];

- характеристика високого рівня педагогічної діяльності, що ґрунтується на високому фраховому рівні педагога, його загальній культурі та педагогічному досвіді, необхідною умовою якої є гуманістична позиція педагога й професійно значущі особисті риси та якості (С. Гончаренко) [1, с. 251];

- педагогічна майстерність - це своєрідний сплав особистої культури, знань і світогляду педагога, його всебічної теоретичної підготовки 3 удосконаленням оволодіння прийомами навчання й виховання, педагогічною технологією та передовим досвідом; разом із тим це вид діяльності, який торкається переважно внутрішньої сорери, бажання стати майстром педагогічної справи, утвердження себе як фрахівця (О. Малнацька) [7, с. 64];

- представники Полтавської наукової школи І. Зязюна - Є. Барбіна, В. Гриньова, О. Дубасенюк, О. Пєхота, С. Сисоєва, Н. Тарасевич та інші педагогічну майстерність розглядають як комплекс властивостей особистості, що забезпечує самоорганізацію високого рівня професійної діяльності на рефлексивній основі [3, с. 9-10].

Для визначення структури педагогічної майстерності в контексті нашого дослідження доцільно проаналізувати різні наукові підходи до розуміння цього френомену як комплексного утворення, що має свою структуру й компонентний склад, як найвищого рівня профресійної педаго- 
гічної діяльності вчителя, як якості її результату, як вияву творчої активності особистості педагога, як психологічного механізму успішної діяльності на рівні профресіоналізму.

Загальновизнаним у педагогічних колах $\epsilon$ сорормульоване І. Зязюном визначення педагогічної майстерності. До таких взаємопов'язаних властивостей автор відносить гуманістичну спрямованість діяльності вчителя, його професійну компетентність, педагогічні здібності й педагогічну техніку, наголошуючи на властивому їм саморозвитку, а не лише зростанні під впливом зовнішніх чинників, і на таких особливостях:

1) педагогічна майстерність у структурі особистості - це система,здатна до самоорганізації, системотвірним чинником якої $€$ гуманістична спрямованість;

2) підвалиною профресійної майстерності $€$ профресійна компетентність (спрямованість і професійні знання становлять той кістяк високого профресіоналізму в діяльності, який забезпечує цілісність системи, що самоорганізовується);

3) педагогічні здібності забезпечують швидкість самовдосконалення;

4) техніка, що спирається на знання й здібності, дає змогу виявити внутрішній потенціал учителя, гармонізуючи структуру педагогічної діяльності [3, с. 30].

Педагогічна майстерність - це універсальна характеристика педагогічної реальності, що проявляється в різних формах свого існування: педагогічна культура суспільства, сім'я, школа, вищий навчальний заклад, окрема особистість. Також педагогічна майстерність викладача закладу вищої освіти зумовлюється індивідуально-творчими, психофрізіологічними, віковими характеристиками, сорормованими соціальним і педагогічним досвідом особистості й забезпечує творчий підхід у педагогічній діяльності, викликає складний синтез усіх психічних сорер (пізнавальної, емоційної, вольової й мотивувальної) особистості педагога.

Розглянемо варіанти визначення структури педагогічної майстерності, запропоновані різними авторами.

Структура педагогічної майстерності сучасного викладача вищого навчального закладу включає: профресійну компетентність як систему необхідних знань, умінь і навичок, володіння сучасними технологіями та стратегіями розв'язання дидактичних проблем, презентабельність особистого досвіду, здатність до одержання й трансформації необхідної інформації тощо; готовність до творчої професійної діяльності: вмотивоване профресійне самовизначення, здатність до рефлексії, досвід педагогічної роботи, професійна мобільність, наявність програми самовдосконалення тощо; педагогічні здібності: перцептивні, креативні, комунікативні, емоційно-регулятивні; особистісні якості, які проявляються в цілеспрямованості, толерантності, чесності, оптимізмі тощо; педагогічна техніка: мовлення, міміка, театралізація, організація педагогічної взаємодії, адекватне спілкування тощо. Таким чином, стверджує В. Орлов, педагогічна майстерність викладача - це синтез особистісно-ділових якостей і властивостей особистості, що визначає високу ефрективність педагогічного процесу [8, с. 12].

Підтримуючи думку Н. Гузій, Л. Гребенкіної та Л. Байкової, вважаємо, що педагогічна майстерність $€$ формою прояву професіоналізму вчителя в педагогічній діяльності як результату набутого досвіду; педагогічна творчість - здатністю педагога до постійного оновлення змісту, технологій організації педагогічного процесу на основі особистісних якостей [9].

Висновки. Отже, рівень педагогічної майстерності викладача педагогічного закладу вищої освіти є важливим чинником освітнього процесу, він позначається на результатах навчання студентів, на фрормуванні їх як особистостей. Своєю чергою розвиток педагогічної майстерності викладача тісно корелює 3 його ставленням до себе, вимогами до своєї діяльності, особистісними якостями. Можна вивчити свій фраховий предмет, можна мати систему психолого-педагогічних знань, але це не забезпечить відповідної майстерності. Майстром стає той, хто прагне цього, хто працює, хто осмислює власну діяльність.

\section{БІБЛІОГРАФІЧНИЙ СПИСОК:}

1. Гончаренко С.У. Український педагогічний словник. Київ : Либідь, 1997. 376 с.

2. Деркач А.А., Зазыкин В.Г., Маркова А.К. Психология развития профессионала. Москва : Изд-во РАГС, 2000. 124 C.

3. Зязюн І.А., Крамущенко Л.В., Кривонос І.Ф. Педагогічна майстерність : підручник / за ред. І.А. Зязюна. Київ : Вища школа, 2004. 422 с.

4. Зязюн І.А., Сагач Г.М. Краса педагогічної дії. Київ : Українсько-фрінський інститут менеджменту і бізнесу, 1997. 302 c.

5. Климов Е.А. Психология профеессионала. Воронеж : МОДЭК, 1996. 400 с.

6. Кузьмина Н.В. Профессионализм деятельности преподавателя и мастера производственного обучения. Москва : Высшая школа, 1989. 119 с.

7. Малнацька О., Мирончук Н. Педагогічна майстерність викладача ВН3. Модернізація вищої освіти в Україні та за кордоном : збірник наукових праць / за заг. ред. С. Вітвицької, Н. Мирончук. Житомир : Вид-во Житомирського державного університету ім. І. Франка, 2014. С. 61-64.

8. Орлов В.Ф., Фурса О.О., Баніт О.В. Теоретичні та методичні основи розвитку педагогічної майстерності викладача мистецьких дисциплін Педагогічна майстерність викладача мистецьких дисциплін : навчально-методичний посібник Київ : Едельвейс, 2012. С. 7-71. 


\section{ІННОВАЦИЙНА ПЕДАГОГІКА}

9. Педагогічна творчість, майстерність, професіоналізм у системі підготовки освітянських кадрів: здобутки, пошуки, перспективи : монографрія / керівн. авт. кол. Н.В. Гузій; Мін-во освіти і науки України, Національний пед. університет імені М.П. Драгоманова. Київ : Вид-во НПУ імені М.П. Драгоманова, 2015. $432 \mathrm{c}$.
10. Сидоренко В.В. Педагогічна майстерність учителя української мови і літератури в системі післядипломної освіти: акме-синергетичний аспект: термінологічний словник-довідник. Донецьк : Витоки, 2013. 100 c.

11. Синенко В.Я. Профессионализм учителя. Педагогика. 1999. № 5. С. 45-52. 
МЕТОДОЛОГІЧНІ ОСНОВИ ФОРМУВАННЯ СОЦІОКУЛЬТУРНОЇ

КОМПЕТЕНТНОСТІ МАЙБУТНІХ БАКАЛАВРІВ ІНОЗЕМНОЇ МОВИ

НА ЗАСАДАХ МІЖДИСЦИПЛІНАРНОї ІНТЕГРАЦІї

METHODOLOGICAL FUNDAMENTS OF FORMING SOCIO-CULTURAL COMPETENCE OF FUTURE BACHELORS OF ARTS IN FOREIGN LANGUAGES ON THE BASIS OF INTERDISCIPLINARY INTEGRATION

у статті здійснено обірунтування методологічних основ дослідження формування соціокультурної компетентності майбутніх бакалаврів іноземної мови на засадах міждисциплінарної інтеграції. Узагальнено, що методологія педагогіки в змістовому аспекті дає змогу співвідносити розуміння й пояснення структури освіти, в тому числі лінгвістичної, зі структурою світу в цілому й буття людини зокрема; прогнозувати напрям розвитку експериментальних освіт ніх систем; здійснювати проєктування й організацію освітнього процесу.

Узагальнено, що сукупність методологічних підходів наукової розвідки не лише віддзеркалює модель авторського бачення, розуміння й інтерпретації явищ, фрактів і подій педагогічної дійсності, але є своєрідним науково обірунтованим вектором чілісного аналізу та пояснення ії об'єкта, визначає кут зору на логіку й етапи розвитку дослідження, регламентує відбір й інтерпретацію фрактологічного матеріалу тощо.

Констатовано, що методологічною основою для аналізу проблеми фрормування соціокультурної компетентності майбутніх бакалаврів іноземної мови на засадах міждисциплінарної інтеграції $\epsilon$ сучасні наукові підходи до наукового пізнання: системний, синергетичний, культурологічний, інтегративний, технологічний та інші. Системний підхід до аналізу сутності загальнокультурної та професійної підготовки майбутніх бакалаврів іноземної мови визначає необхідність єдності та взаємодії різних складників досліджуваного процесу, визнання безперервного інтелектуального, творчого й профресійного розвитку особистості протягом усього життя в напрямі опанування соціокультурними компетенціями. Синергетичний підхід потребує опори на систему знань про індивідуальні особливості студентів, індивідуальні стилі суб'єктів освітнього процесу, прогнозування впливу на них інноваційних освітніх технологій, що сприятиме підвищенню успішності формування соціокультурної компетентності майбутніх бакалаврів іноземної мови на засадах міждисциплінарної інтеграції. Використання культурологічного підходу до обгрунтування теоретико-методологічних основ формування соціокультурноїкомпетентностімайбутніх бакалаврів іноземної мови на засадах міждисциплінарної інтеграції зумовлено специфрікою сучасної соціокультурної ситуації. Ключові слова: методологічні основи, підхід, методологія, соціокультурна компетентність, бакалаври іноземної мови, студенти.
The article substantiates the methodological foundations of the study of forming socio-cultural competence of future bachelors of arts in foreign languages on the basis of interdisciplinary integration. It is generalized in the article that the methodology of pedagogy in the substantive aspect allows to correlate the understanding and explanation of the structure of education, including linguistic aspect with the structure of the world in general and human existence in particular, to predict the direction of development of experimental educational systems and to design and organize the educational process.

It is concluded that the set of methodological approaches of scientific intelligence not only reflects the author's vision, understanding and interpretation of phenomena, facts and events of pedagogical reality, but also acts as a kind of scientifically based vector of holistic analysis and explanation of its object, determines the stages of research development, regulates the selection and interpretation of factual material, etc.

It is stated that the methodological basis for the analysis of the problem of forming sociocultural competence of future bachelors of arts in foreign languages on the basis of interdisciplinary integration are modern scientific approaches to scientific knowledge: systemic, synergetic, culturological, integrative, technological and others. A systematic approach to the analysis of the essence of general cultural and professional training of future bachelors of arts in foreign languages determines the need for unity and interaction of different components of the research process and for recognition of continuous intellectual, creative and professional development of personality throughout life towards mastering sociocultural competencies.

The synergetic approach requires reliance on the system of knowledge about individual characteristics of students, individual styles of subjects of the educational process, forecasting the impact of innovative educational technologies on these subjects, which will increase the success of sociocultural competence of future bachelors of arts in foreign languages on the basis of interdisciplinary integration.

The use of culturological approach to substantiate the theoretical and methodological foundations of forming sociocultural competence of future bachelors of arts in foreign languages on the basis of interdisciplinary integration is due to the specifics of the current sociocultural situation.

Key words: methodological fundaments, approach, methodology, sociocultural competence, bachelors of arts in foreign languages, students.

\footnotetext{
${ }^{1}$ Статтю написано за сприяння програми Колегіум Талентум (Угорщина, 2019 р.).
} 
Постановка проблеми в загальному вигляді. Система освіти України, як і будь-якої іншої країни, має відповідати сучасному рівню розвитку суспільних відносин, а тому потребує постійного вдосконалення. Прагнення України до інтеграції в європейський освітній простір обумовлює необхідність розв'язання комплексу задач, пов'язаних із підготовкою висококваліфікованих фрахівців зі знанням іноземної мови, зокрема майбутніх бакалаврів іноземної мови. Одним з актуальних завдань нині $€$ фрормування соціокультурної компетентності студентів цієї спеціальності. Організація наукового дослідження з формування соціокультурної компетентності майбутніх бакалаврів іноземної мови на засадах міждисциплінарної інтеграції потребує конкретизації методологічних основ наукової розвідки.

Аналіз останніх досліджень і публікацій. Концептуальні ідеї нової стратегії фрахової підготовки студентів у закладах вищої освіти (далі 3ВО), теоретико-методологічні та прикладні проблеми освітньо-педагогічної прогностики активно розробляються такими науковцями, як В. Вольнова [1], М. Максимець [4], С. Мельник [5], Є. Подольська [6], Г. Саволайнен [7; 8], Л. Смірнова [9], Т. Фоменко [10], А. Хом'як [11], Н. Чернуха [12], С. Шехавцова [13] та інші.

Виділення не вирішених раніше частин загальної проблеми. Різноманітність і багатогранність досліджень, присвячених фрормуванню компетенцій і компетентностей, вирізняються незаперечною науковою цінністю і практичною значущістю. Однак залишаються невирішеними проблеми фрормування соціокультурної компетентності майбутніх бакалаврів іноземної мови. Основними причинами є недостатність методик, спрямованих на використання інформаційного потенціалу дисциплін циклу профресійної підготовки, десіцит накопиченого міждисциплінарного професійно орієнтованого матеріалу, апробованого в лінгвістичному ЗВО, короткочасність педагогічної практики тощо.

Мета статті. Окреслені проблеми зумовлюють мету статті - обґрунтування методологічних основ дослідження формування соціокультурної компетентності майбутніх бакалаврів іноземної мови на засадах міждисциплінарної інтеграції.

Виклад основного матеріалу. Методологія педагогіки в змістовому аспекті дає змогу співвідносити розуміння й пояснення структури освіти, в тому числі лінгвістичної, зі структурою світу в цілому й буття людини зокрема; прогнозувати напрям розвитку експериментальних освітніх систем; здійснювати проєктування й організацію освітнього процесу. Результати осмислення методологічних проблем фрормулюються в межах тих чи інших методологічних підходів.

У фрілософрському тлумаченні термін «підхід» використовується для позначення сукуп- ності ідей, принципів, методів, що лежать в основі розв'язання певних проблем. За словами таких сучасних науковців, як М. Максимець [4], С. Мельник [5], Є. Подольська [6] та інших, підхід - це методологія вирішення проблеми, що розкриває основну ідею дослідження, соціальноекономічні, фрілософські, психолого-педагогічні передумови, цілі, принципи, етапи досягнення педагогічних цілей. Методологічний підхід в освіті розглядається як система принципів і методів вивчення, проєктування й організації освітнього процесу [8, с. 70], що сконструйована з урахуванням загальних і спеціальних закономірностей і законів взаємодії елементів освітнього процесу для врегулювання фрункціонування певної сорери буття студентів.

До аналізу категорії «підхід», на думку Г. Саволайнен, науковці зазвичай вдаються в період інтенсивного розвитку теоретичного знання про той чи інший вид діяльності. До XX ст. характеристики підходів обговорювалися у зв'язку з ретроспективним запереченням будь-якої теорії або використовувалися як аргументи в суперечці (номіналізм - реалізм) [8, с. 25]. У XX ст. методологізація наукового знання детермінувала конструювання різних методологічних підходів (френоменологія, екзистенціалізм, структуралізм, наукова організація праці тощо). Нині в конкретних науках розробляються різні підходи, де вони або змінюють один одного як етапи розвитку явищ/процесів (наприклад, революційна зміна освітніх парадигм), або співіснують, не порушуючи дисциплінарної цілісності, але створюючи поліпредметність у межах однієї дисципліни [3].

У сучасній вітчизняній педагогіці визнається той фракт, що сукупність методологічних підходів наукової розвідки не лише віддзеркалює модель авторського бачення, розуміння й інтерпретації явищ, фрактів і подій педагогічної дійсності, але також є своєрідним науково обґрунтованим вектором цілісного аналізу й пояснення ії об'єкта, визначає бачення логіки й етапів розвитку дослідження, регламентує відбір й інтерпретацію фрактологічного матеріалу тощо.

Методологічними основами для аналізу проблеми фрормування соціокультурної компетентності майбутніх бакалаврів іноземної мови на засадах міждисциплінарної інтеграції $€$ сучасні підходи до наукового пізнання: системний, синергетичний, культурологічний.

Системний підхід до аналізу сутності загальнокультурної та професійної підготовки майбутніх бакалаврів іноземної мови визначає необхідність єдності та взаємодії різних складників досліджуваного процесу, визнання безперервного інтелектуального, творчого й професійного розвитку особистості протягом усього життя в напрямі опанування соціокультурними компетенціями. 
Синергетичний підхід потребує опори на систему знань про індивідуальні особливості студентів, індивідуальні стилі суб'єктів освітнього процесу, прогнозування впливу на них інноваційних освітніх технологій, що сприятиме підвищенню успішності формування соціокультурної компетентності майбутніх бакалаврів іноземної мови на засадах міждисциплінарної інтеграції. Це вимагає більш плідного вивчення, класифрікації, розроблення та впровадження інноваційних освітніх технологій у навчальний процес. Основу методичних положень можуть становити такі компоненти: механізм виявлення індивідуальних здібностей студентів; здатність викладачів до впровадження інноваційних освітніх технологій у світлі Болонського процесу; дидактична орієнтація на мотивоване ставлення студентів до нового; тести оцінювання результатів діяльності; схема управління впровадженням інноваційних технологій згідно з європейськими освітніми вимогами;

Використання культурологічного підходу до обґрунтування теоретико-методологічних основ формування соціокультурної компетентності майбутніх бакалаврів іноземної мови на засадах міждисциплінарної інтеграції зумовлено специфікою сучасної соціокультурної ситуації. Спеціаліст у тій чи іншій фраховій галузі розглядається як людина культури, що сконцентрувала в собі всі культурні досягнення людства. Інструментально-нормативна модель підготовки майбутніх лінгвістів іноземної мови сьогодні має бути замінена культурнотворчою моделлю [8, с. 71].

Так, Є. Подольська зазначає, що під час підготовки майбутніх бакалаврів іноземної мови необхідно застосувати концептуальний підхід, який передбачає такі напрями, як-от:

1) орієнтація сучасного навчання на національні й загальнолюдські цінності, гармонія стосунків людини й навколишнього світу, суспільства й природи;

2) креативна співпраця педагога й студента 3 метоюформуваннятарозвиткуможливостейпостійного духовного самовдосконалення, максимального розвитку лінгвістичних, перекладацьких нахилів і здібностей під час опанування спеціальністю;

3) фрормування мовознавчого світогляду, належне ставлення до рідної та інших мов;

4) структурування знань як засобу цілісного розуміння й пізнання світу;

5) практичне оволодіння мовою й перекладом згідно з потребами сьогодення;

6) культура спілкування рідною й іноземними мовами в комунікативних актах у всіх сорерах громадського й особистого життя;

7) інтеграція науки й практики перекладу тощо [6, с. 113].

Методологічні основи підготовки майбутніх бакалаврів іноземної мови у світлі Болонського процесу поєднують базові загальні вміння та навички для майбутніх фрахівців, які розподіляють на такі типи: навчально-організаційні (способи виконання всіх складників навчальної діяльності, способи самостійного переходу від одного етапу роботи до іншого, способи зовнішньої організації своєї навчальної роботи); навчально-інтелектуальні (способи розумової діяльності, постановки й вирішення проблем, логічного мислення); навчальноінформаційні (оволодіння методами й прийомами самостійного здобуття знань, нової додаткової інформації та їх збереження), навчально-комунікаційні (способи побудови нових знань за отриманою інформацією) [12, с. 7].

Приєднання України до Болонського процесу потребує певних змін у роботі під час підготовки майбутніх бакалаврів іноземної мови, зокрема й у напрямі формування соціокультурної компетентності студентів:

1. Посилюється роль самостійної й самоосвітньої роботи студентів, впроваджуються міні-навчально-дослідні проєкти. Вони $є$ новою формою оптимізації позааудиторної роботи, елементом індивідуальної освітньо-професійної програми студентів і засобом кредитно-модульного навчання у ЗВО [7].

2. З'являються нові суспільні вимоги щодо навчання іноземної мови не лише як способу спілкування, а й для фрормування багатомовної особистості, яка ввібрала б у себе цінності рідної й іноземної культури, була б підготовлена до міжкультурного спілкування. Водночас профресійна підготовка майбутніх бакалаврів іноземної мови передбачає засвоєння студентами не лише іншомовної техніки спілкування, але й позамовної інформації, необхідної для адекватного спілкування та взаємодії (матеріальні духовні умови життя відповідних народів і країн, особливостей їхньої історії, культури, суспільно-політичного устрою, політичної системи тощо) [8, с. 210].

3. Важливим моментом у сучасних умовах фрормування соціокультурної компетентності майбутніх бакалаврів іноземної мови є підготовка студентів як майбутніх лідерів. Це потрібно для:

- розширення навчальних, соціальних й економічних зв'язків, інтеграції різних традицій і культур;

- внесення в сучасне суспільство позитивних змін, які безпосередньо залежать від активності, конкурентоспроможності молодих людей, їхньої здатності боротися, перемагати, будувати кар'єру (і ЗВО є тим осередком, що готує таку молодь);

- максимальної реалізації внутрішнього потенціалу майбутнього фрахівця в пізнанні власних якостей, у тому числі й лідерських; набуття професійної майстерності, досвіду творчої діяльності [4].

Таким чином, виявлення й розвиток лідерських якостей у студентів сприяє позитивній мотивації до саморозкриття майбутніми бакалаврами іно- 
земної мови власних здібностей, підвищенню якості засвоєння професійних знань і сорормованості інтелектуальних умінь [5, с. 9].

Одним із перспективних напрямів підвищення ефрективності формування соціокультурної компетентності майбутніх бакалаврів іноземної мови $є$ інтегративний підхід до розроблення навчальнометодичних матеріалів, який є основою міждисциплінарної інтеграції. 3 розвитком теорії та практики використання інтегративного підходу зусиллями науковцівіпедагогів-практиків запроваджуєтьсясистема інтегративно-предметного навчання, окреслюються принципи міждисциплінарної інтеграції, як-от:

- орієнтація навчання на сьогоденні вимоги суспільного розвитку;

- формування цілісної системи знань, єдиної картини світу, наукового світогляду;

- поєднання інтегративного й диференційованого підходів до навчання;

- безперервність освіти та її вихід на рівень просресійної освіти [2].

Під міждисциплінарною інтеграцією нині розуміємо взаємне проникнення змісту різних навчальних дисциплін і створення єдиного освітнього соціокультурного середовища шляхом використання інноваційних педагогічних методів, засобів і організаційних фрорм навчання, що складають основу інтерактивних технологій і забезпечать формування високого рівня соціокультурної компетентності майбутніх бакалаврів іноземної мови. Цілісний, інтегративний характер фрормування соціокультурної компетентності майбутніх бакалаврів іноземної мови на засадах міждисциплінарної інтеграції визначається також і технологічним підходом до опанування навчальних дисциплін, що передбачає визначення очікуваних результатів навчання, зумовлених його цілями, і базується на обґрунтуванні змісту навчання, виборі педагогічно доцільної структури (послідовності) вивчення змісту, засобів досягнення, контролю часу та рівня оволодіння студентами відповідним досліджуваним френоменом.

Виокремлені наукові підходи в контексті дослідження реалізуються комплексно, доповнюються і складають методологічні основи наукової розвідки.

Висновки. Соціокультурна компетентність майбутніх бакалаврів іноземної мови $є$ професійноособистісною характеристикою, яка виявляється в характері суб'єктивності студента в навчальнопрофесійній діяльності, забезпечує його готовність і здатність виконувати професійні функції відповідно до поставлених стандартів і вимог; бажання й уміння створювати нову профресійну реальність на рівні цілей, змісту технологій, а також розуміння й цілісне бачення майбутнім фрахівцем змісту професійної освіти й конкретної ситуації в ньому як гуманітарного ореномена. Методологічними основами дослідження визначено сукупність наукових підходів, що пояснюють особливості організації авторської наукової розвідки.
Перспективи подальших розвідок у цьому напрямі вбачаємо в окресленні особливостей організації педагогічного експерименту фрормування соціокультурної компетентності майбутніх бакалаврів іноземної мови в умовах оновлення педагогічної освіти.

\section{БІБЛІОГРАФІЧНИЙ СПИСОК:}

1. Вольнова Л.М. Соціокультурна компетентність як складова підготовки студентів - майбутніх фрахівців системи діяльності «людина - людина». Науковий часопис Національного педагогічного університету імені М.П. Драгоманова. 2009. Вип. 28 (52). С. 137-145.

2. Закір'янова І.А. Динаміка соціокультурної компетентності майбутніх педагогів. Теоретичні питання культури, освіти та виховання. 2002. Вип. 21. С. 183-Закір'янова І.А. Формування соціокультурної компетентності у майбутніх вчителів іноземної мови в процесі профессійної підготовки : автореф. дис. ... канд. пед. наук : спец. 13.00.04. Київ, 2006. 23 с.

3. Максимець М. Формування соціокультурної компетенції в процесі вивчення іноземної мови. Вісник Львівського університету. Серія педагогічна. 2006. Вип. 21. С. 211-218.

4. Мельник С.А. Інтегрований урок як засіб фрормування загальнокультурної компетентності учнів основної школи : автореф. дис. ... канд. пед. наук : 13.00.09. Харків. 2010. 20 с.

5. Подольська Є.А. Освіта як чинник розвитку особистості в соціокультурному контексті : монограсрія. Харків : Вид-во НФАУ : Золоті сторінки, 2002. 236 с.

6. Саволайнен Г.С. Модель социокультурной компетентности преподавателя высшей школы. Вестник Сибирского государственного аэрокосмического университета им. академика М.Ф. Решетнева. 2006. T. 3. C. 159-162.

7. Саволайнен Г.С. Социокультурное взаимодействие в образовательном процессе педагогического вуза и школы : обновление содержания, технологий подготовки и мониторинга : монографрія. Красноярский гос. пед. университет им. В.П. Астафьева. Красноярск, 2005. 316 с.

8. Смірнова Л.Л. Соціокультурна компетентність у структурі підготовки учителів іноземної мови в Польщі: авторефр. дис. ... канд. пед. наук : 13.00.04. Кіровоград, 2010. 20 с.

9. Фоменко Т.М. Визначення поняття «соціокультурна компетентність» у сучасній парадигмі вищої освіти. Засоби навчальної та науково-дослідної роботи. 2014. Вип. 42. С. 149-156.

10.Хом'як А.П. Педагогічні технології фрормування комунікативної компетентності старшокласників у процесі вивчення предметів гуманітарного циклу : автореф. дис. ... канд. пед. наук : 13.00.09. Київ, 2010. 20 c.

11. Чернуха Н.М., Мурзіна А.В. Умови фрормування соціокультурної компетентності майбутніх учителів-фрілологів. Вісник Луганського національного університету імені Тараса Шевченка. 2009. № 9 (172). С. 165-173.

12. Шехавцова С.О. Формування соціокультурної компетентності майбутніх учителів іноземної мови у позанавчальній діяльності університету : автореф. дис.... канд. пед. наук: 13.00.04. Луганськ, 2009. 20 с. 


\title{
ШЛЯХИ АКТИВІЗАЦІЇ САМОСТІЙНОЇ РОБОТИ У ФОРМУВАННІ ІНФОРМАЦІЙНОЇ КОМПЕТЕНТНОСТІ МАЙБУТНІХ УЧИТЕЛІВ
}

\author{
WAYS OF SELF-STUDY WORK ACTIVATION IN THE FUTURE \\ TEACHERS-PHILOLOGISTS' INFORMATION COMPETENCE FORMATION
}

УДК 378.14

DOI https://doi.org/10.32843/2663-

6085/2020/24-2.30

\section{Хамська Н.Б.,}

канд. пед. наук,

доцент кафедри педагогіки i

професійної освіти

Вінницького державного педагогічного

університету імені Михайла

Коцюбинського

\section{Киналь А.Ю.,}

асистент кафедри англійської фрілології Вінницького державного педагогічного університету імені Михайла Коцюбинського

\begin{abstract}
у статті обгрунтовано актуальність активізації самостійної роботи у фоомуванні інфрормаційної компетентності майбутнього вчителя в педагогічних закладах вищої освіти, визначено шляхи, що активізують цей процес: дифреренціація навчальних завдань, урізноманітнення їхнього змісту і характеру, організація контролю і самоконтролю освітньої діяльності; виконання індивідуальних навчально-дослідних завдань, написання курсових, дипломних та магістерських досліджень; використання технологій мобільного (m-learning) та технологій змішаного навчання (blended learning); самоосвітні заходи та онлайн-навчання.

Доведено есрективність практичного досвіду активізації самостійної роботи у формуванні інформаційної компетентност майбутніх учителів фрілологічних спеціальностей в інфрормаційному середовищі педагогічного університету в процесі вивчення педагогічних, фрахових дисциплін, різних видів практики на основі врахування чинників, що забезпечують чей прочес, зокрема: використання інформациійно-комунікаційних технологій, електронних засобів навчання, мобільних та комп'ютерних стосунків, онлайн-платорорм та конструкторів для формування іншомовної комунікативної компетентності; застосування технологій змішаного навчання, що передбачає вивільнення часу для формування практичних умінь та навичок завдяки випереджуючим завданням для самостійного опрацювання студентами теоретичного матеріалу до аудиторного заняття; залучення майбутніх педагогів до участі в міжнародних проектах з використанням інфрормаційно-комунікаційних технологій.

Підкреслено важливість взаємозв'язку використання інфоормаційно-комунікаційних технологій для організації самостійної роботи студентів та активізації самостійної роботи майбутніх учителів у фрормуванні інорормаційної компетентності, що забезпечить позитивну динаміку безперервноі профресійної самоосвіти та саморозвитку, а отже, успішної майбутньої профресійної діяльності.

Ключові слова: самостійна робота,
\end{abstract} саморозвиток, самовдосконалення, само- контроль, професійна компетентність майбутніх учителів, інформаційна компетентність майбутніх фахівців.

The article highlights the relevance of self-study work activation in the future teachers' information competence formation at pedagogical institutions of higher education; identifies the ways to activate this process: differentiation of educational tasks, diversification of their content and nature, organization of control and self-control of educational activities; accomplishment of individual educational and research tasks; carrying out course, diploma and master's researches; use of mobile (m-learning) and blended learning technologies; self-educational activities, participation in international projects and online educational programs.

The effectiveness of practical experience of selfstudy work activation in the future teachers of philological specialties information competence formation in the informational environment of the Pedagogical University in the process of pedagogical, professional disciplines study, different types of practice, based on the factors that ensure this process. In particular, the use of information and communication technologies, electronic learning tools, mobile and computer applications, online platforms for the foreign language communication competence development; application of blended learning technologies, which provides free time for the practical skills development due to advanced tasks for self-study of theoretical material by students before the lesson; involvement of future teachers in the international projects using information and communication technologies.

The importance of the interrelationship between the information and communication technologies use for students' self study work organization and future teachers' self-study activation in the process of information competence development, which will ensure positive dynamics of continuous professional self-education and self-development, and thus successful future professional activity.

Key words: self-study, self-development, selfimprovement, self-control, future teachers' professional competence, future specialists' information competence.
Постановка проблеми в загальному вигляді. В умовах глобалізації та інсоорматизації суспільства особливої актуальності набуває самостійна робота, в процесі якої майбутній фрахівець формує позицію щодо прийняття рішень у досягненні поставленої мети, розвиває навички самостійного здобування знання в інформаційному освітньому середовищі, удосконалення своєї фрахової майстерності. Особливого значення набуває самостійна робота у формуванні інформаційної компетентності майбутнього вчителя фрілологічних спеціальностей, адже вона передбачає активну пізнавальну діяльність майбутнього педагога, а також сприяє формуванню та розвитку творчої особистості, яка здатна оперативно приймати нестандартні рішення, діяти креативно, прагнути до постійного самовдосконалення.

Аналіз останніх досліджень і публікацій. Проблематику організації самостійної діяльності студентів у процесі профеесійної підготовки висвітлено в працях А. Алексюк, Ю. Бабанського, В. Буряка, О. Нільсона. У дослідженнях А. Алексюка, Б. Єсипова визначено самостійну роботу як одну з ефективних форм пізнавальної діяль- 
ності [1; 6]. Особливості організації самостійної роботи магістрів з використанням інформаційних технологій під час вивчення іноземної мови описано Я. Гулецькою [3]. У дослідженнях О. Хорошайло та М. Шуфнарович схарактеризовано вітчизняний і зарубіжний досвід та перспективи використання сучасних інфрормаційних технологій і прийомів у самостійній роботі студентів вищих навчальних закладів [12; 13]. У монографії Р. Гуревича, М. Кадемії, М. Козяр визначено роль інформаційно-комунікаційних технологій у професійній освіті, самостійній та позааудиторній роботі студентів, а також схарактеризовано особливості організації самостійної роботи студентів за допомогою веб-квестів [4].

Виділення не вирішених раніше частин загальної проблеми. Незважаючи на значну кількість праць щодо організації самостійної діяльності студентів у процесі професійної підготовки, проблематика активізації самостійної роботи у формуванні інфрормаційної компетентності майбутніх учителів фрілологічних спеціальностей недостатньо висвітлена.

Мета статті - схарактеризувати шляхи активізації самостійної роботи у формуванні інформаційної компетентності майбутніх учителів фрілологічних спеціальностей.

Виклад основного матеріалу. У сучасній педагогічній науці поняття самостійної роботи студентів розглядають у двох значеннях. У широкому - це активна пізнавальна творча діяльність студента, присутня в будь-якому виді навчальних занять. У більш вузькому значенні-це один із видів навчальних занять під методичним керівництвом викладача, але без його особистої участі [3, с. 751; 9, с. 352].

І. Лернер, Н. Половінкова, М. Скаткін визначають самостійну роботу як засіб залучення суб'єктів освітнього процесу до самостійної пізнавальної діяльності [5, с. 75]

С. Стрілець зазначає, що сутність самостійної роботи студентів полягає в тому, що вона $є$ сполучною ланкою між теоретичною підготовкою студентів і розвитком необхідного комплексу професійно значущих умінь і навичок: сприяє розвитку компетентності в області самоосвітньої діяльності, а також фрормує самостійне мислення і творчий підхід до вирішення поставлених завдань [11, с. 259].

А. Нєлєпова характеризує самостійну роботу як вид діяльності, що стимулює активність, самостійність, пізнавальний інтерес, а також як основу для самоосвіти, постійного самовдосконалення та підвищення кваліфікації у майбутній професійній діяльності в умовах науково-технічного прогресу, з одного боку, а $з$ іншого - як систему дій, що забезпечать управління самостійною діяльністю студентів [10, с. 201].

Самостійну роботу, на наш погляд, найбільш повно характеризує А. Зимня: самостійна робота - цілеспрямована, мотиваційна, структурована самим об'єктом у сукупності виконаних дій і коригується ним за процесом і результатом діяльності. Її виконання потребує досить високого рівня самопізнання, рефлективності, самодисципліни, особистої відповідальності, що приносить студентові задоволення як процес самовдосконалення та самопізнання [8, с. 33].

Таким чином, самостійна робота - це найвища форма навчальної діяльності студента, яка $€$ компонентом цілісного педагогічного процесу.

Слід зазначити, що в сучасних умовах глобалізації та науково-технічного розвитку майбутньому фрахівцеві вже недостатньо бути компетентним у галузі інорормаційних технологій: володіти різнобічними знаннями про інформаційні процеси та вміти застосовувати їх на високому професійному рівні в межах своєї спеціальності. Він має бути наділений особистісними якостями, що дозволяють ставитись до інформації як до абсолютної цінності та критично її оцінювати. Наявність певного рівня інформаційної компетентності є важливою складовою частиною готовності майбутнього фахівця до самоосвітньої діяльності. У сучасному суспільстві зі збільшенням обсягів інфрормації та швидкості її потоків особливо актуальними стають уміння, пов'язані зі сприйняттям, обробкою і переробкою інформації, що є одним із завдань освітнього процесу в закладі вищої освіти [7, с. 4].

Важлива роль належить самостійній роботі у фрормуванні інформаційної компетентності майбутніх учителів фрілологічних спеціальностей, оскільки саме ця форма навчання найбільш повно буде забезпечувати фрормування умінь працювати з базами даних, інфрормаційно-пошуковими, інформаційно-довідковими системами, автоматизованими бібліотечними системами, електронними журналами тощо; організовувати комунікацію в мережі Інтернет за допомогою електронної пошти, синхронних та відтермінованих коноеренцій, вебінарів, соціальних мереж та програм-комунікаторів; створювати та виконувати тематичні web-сторінки, web-квести, блоги, живі журнали, сторінки та групи в соціальних мережах [3, с. 78]; використовувати технології мобільного навчання (m-learning) 3 мобільних пристроїв та технологій змішаного навчання (blended learning); фрормувати у майбутніх фрахівців навички роботи 3 інфрормаційними джерелами, такими як виділення способів отримання необхідної інформації, орієнтування в потоці інфрормації, порівняння й оцінювання важливості та достовірності інорормації 3 різних джерел, організація та застосування інформації для виконання завдання тощо; фрормування у майбутніх фрахівців операцій розумової діяльності та критичного мислення (аналізу, синтезу, порівняння, виділення головного, абстрагування) [7, с. 4-7]. 
У дослідженні формування інформаційної компетентності майбутніх фрахівців А. Добровольської визначено умови успішної організації самостійної роботи, зокрема: умотивованість навчального завдання або запитання; чітка постановка пізнавального завдання; алгоритм, метод виконання роботи, а також знання суб'єктами освітнього процесу способів ії̈ виконання; чітке визначення викладачем обсягу роботи, яка виконується самостійно, термінів ії подання для оцінювання, а також форм звітності; критерії оцінювання, звітності тощо; види і форми контролю - практичні, розрахунковограсрічні, контрольні й курсові роботи, індивідуальні самостійні роботи, навчально-дослідницькі роботи, тестування, поточні й підсумкові модульні контролі, захист курсових, дипломних та магістерських робіт [5, с. 76$]$.

У процесі професійної підготовки майбутніх учителів фрілологічних спеціальностей у Вінницькому державному педагогічному університеті було впроваджено такі форми самостійної роботи: виконання IНД3, написання курсових, дипломних та магістерських досліджень; використання технологій мобільного (m-learning) та технологій змішаного навчання (blended learning); самоосвітні заходи та онлайн-навчання.

Активізацію самостійної роботи майбутніх фахівців ми забезпечували шляхом диференціації навчальних завдань, урізноманітнення їхнього змісту і характеру, організації контролю і самоконтролю освітньої діяльності.

Виконання ІНДЗ, написання курсових, дипломних та магістерських досліджень сприяло формуванню інформаційної компетентності майбутнього фахівця в багатьох аспектах. У процесі виконання дослідницької діяльності студенти розвивали інформаційно-технологічну компетентність (навички роботи з індрормаційними ресурсами, технологіями), інфрормаційну грамотність (уміння визначати, оцінювати, використовувати інформаційні ресурси), технологічну грамотність (розуміння основних концепцій інсрормаційних технологій та можливостей їх застосування для виконання завдань дослідження), комп'ютерну грамотність (знання щодо застосування інфрормаційних технологій у процесі написання та оформлення свого наукового дослідження), інформаційну культуру (дотримання норм, правил і стереотипів поведінки в процесі обміну інорормацією), академічної доброчесності (дотримання правил цитування, уникнення плагіату, збереження авторських прав тощо). Окрім того, деякі студенти вибирали теми ІНДЗ, курсових, дипломних та магістерських досліджень, що стосувались особливостей використання інсоормаційно-комунікаційних та медіатехнологій для організації освітнього процесу, наприклад: «Особливості використання онлайн-ігор для формування іншомовної граматичної компетент- ності на уроках німецької мови у середній школі», «Використання інформаційно-комунікаційних технологій на уроках іноземної мови в старшій школі», «Особливості організації взаємодії класного керівника та батьків засобами онлайн-технологій», «Педагогічні умови використання онлайн-технологій для підвищення мотивації старшокласників до навчання», «Роль комп'ютерних ігор на фоормування девіантної поведінки підлітків» тощо.

Використання технологій мобільного (m-learning) та змішаного навчання (blended learning) передбачало взаємодію студентів з технічними засобами навчання, наприклад, мобільними телесронами, планшетами та іншими гаджетами. Найбільш популярними мобільними додатками $€$ Duolingo, Lingualeo, Lingvist, Memrise, English Phrasal Verbs, Поліглот, Words. Перевагами зазначених мобільних додатків $є$ яскравий дизайн, легкий для використання інтерфейс, можливість вибрати необхідний рівень користувача, а також тематику лексичних одиниць для вивчення. Кожен із додатків маєсвою систему заохочень, можливості використання платного ексклюзивного контенту, налаштування нагадувань щодо регулярного виконання вправ тощо. Недоліком, характерним для всіх зазначених вище мобільних додатків, є стандартизований підхід до організації освітнього процесу. Лексико-граматичний інструментарій, запропонований авторами та розробниками популярних мобільних додатків, $є$ орієнтованим на середньостатистичного користувача, який може вибирати тематику лише із запропонованого списку.

Так, з метою фрормування іншомовної лексичної компетентності $з$ теми «Технології» студентами було запропоновано вивчати нові лексичні одиниці за допомогою платорорми Quizlet.com. Програма Quizlet $\epsilon$ одним із мобільних додатків, який $є$ зручним для організації самостійної роботи студентів, а також дозволяє індивідуалізувати процес вивчення іноземної мови. Програма Quizlet може бути використана як на комп'ютері, так і на мобільному телефоні або планшеті. Окрім того, Quizlet дозволяє користувачеві самостійно створювати свій власний навчальний контент, причому власне процес створення завдань не передбачає наявність умінь та навичок програмування. Користувачеві досить лише створити свій власний список лексичних одиниць іноземною мовою, зазначивши в паралельній колонці переклад цих лексичних одиниць (на початковому/середньому рівнях вивчення іноземної мови) або їх визначення іноземною мовою (на високому рівні відповідно). Більш того, додаток дозволяє додавати відповідні грасрічні зображення з метою візуалізації навчального процесу. Ще однією перевагою програми $є$ автоматичне озвучування лексичних одиниць іноземною мовою, що спрощує та вдосконалює формування іншомовної вимови. 
Елементи змішаного навчання було впроваджено в процес професійної підготовки майбутніх учителів фрілологічних спеціальностей на фракультетах іноземних мов Вінницького державного педагогічного університету імені Михайла Коцюбинського. Так, вивчення дисципліни «Методика викладання іноземних мов» передбачало такі етапи: самостійну роботу, яка передбачала самостійне оволодіння теоретичним матеріалом перед аудиторним заняттям, та аудиторне заняття, під час якого викладач організовував виконання практичних видів діяльності. Студенти отримали завдання підготувати теоретичний матеріал з теми «Огляд підходів до викладання іноземної мови» на платорормі GoogleClassroom для студентів своєї групи. 3 цією метою майбутні педагоги повинні були проаналізувати надані викладачем джерела, проаналізувати їх, систематизувати та оформити їх у такий спосіб, щоб студенти могли самостійно оволодіти цим матеріалом. Окрім того, майбутні педагоги розробили завдання для перевірки розуміння теоретичного матеріалу учасниками освітнього процесу на платформах GoogleForms, LearningApps.org, Wizer.me тощо. Наприклад, на етапі опрацювання аудіолінгвального методу навчання іноземних мов студенти переглядали навчальне відео, що містило фррагмент уроку англійської мови, а потім самостійно виконували тестове завдання, в якому вони визначали, які елементи аудіолінгвального методу використовував викладач з відео. Після опрацювання всіх підходів до навчання іноземної мови майбутні вчителі виконували завдання на платформі Wizer.Me, під час якого необхідно було співвіднести характеристики підходів з їхніми назвами.

За методикою змішаного навчання було також проведено заняття студентів 2-го курсу фракультету іноземних мов 3 дисципліни «Практика англійської мови». Майбутні вчителі розробляли власні презентації 3 поясненням теоретичного матеріалу, створювали інтерактивні онлайнвправи для формування іншомовної комунікативної компетентності 3 теми «Технології», розміщували ці вправи у своїх блогах та на електронних портсоліо, організовуючи, таким чином, самостійну роботу одногрупників. Отже, кожен із майбутніх педагогів мав можливість самостійно опрацювати теоретичний матеріал, використати власний підхід до пояснення теоретичного матеріалу одногрупникам, розробити систему контрольних та тестових завдань 3 метою перевірки якості засвоєних знань за допомогою різних інфрормаційно-комунікаційних технологій.

Під час самостійної підготовки до заліків з таких дисциплін, як «Основи педагогічної майстерності», «Методика виховної роботи», «Педагогіка», «Методика викладання іноземної мови», студентам було запропоновано тренувальні завдання
3 автоматичною перевіркою відповідей на платсрормах GoogleForms, LearningApps.org, Wizer.me.

Онлайн-навчання є найбільш складним іпрогресивним видом самостійної роботи, що передбачає допомогу як з боку викладача, так і з боку інших студентів, оскільки така форма організації навчання $\epsilon$ різноплановою і передбачає як особистісну взаємодію (студент-викладач, студент-студент, студент-запрошений експерт), так і неособистісну взаємодію (студент-інструмент (комп'ютер, телефон, планшет), студент-контент, студент-навколишнє середовище). Наприклад, під час взаємодії «студент-студент» більш адаптовані студенти можуть допомогти новачкам через дискусії, які охоплюють як контент, так і сам процес навчання, а робота з довідковим розділом «Часті запитання» (FAQ) здійснюється цілком самостійно [14, с. 154].

Завдяки сервісам Google (GoogleDocs, GoogleSheets, GoogleForms, GoogleSlides тощо) викладач і студент перебувають у постійному інорормаційнокомунікативному діалозі. Викладач дистанційно і опосередковано формує іншомовну комунікативну та інформаційну компетентність майбутнього вчителя фрілологічних спеціальностей, економить час аудиторного заняття, має можливість приділити достатньо уваги кожному студентові, проаналізувати його діяльність під час навчального процесу та надати методичні рекомендації щодо його покращення. Студент у свою чергу опрацьовує навчальний матеріал у власному темпі та режимі, що значно підвищує інтерес до навчання, створює умови для розвитку, активізує пізнавальну діяльність, удосконалює сенсомоторну сореру, розвиває зорову і слухову чутливість, фрормує вміння сприймати, розвиває спостережливість, сприяє розвитку перцептивної уваги.

На фракультеті іноземних мов Вінницького державного педагогічного університету з 2016 р. впроваджується проект Гете Інституту (Goethe Institut) 3 навчання методики викладання німецької мови за програмою онлайн-курсів «Вчимося навчати німецької» (DLL - Deutsch Lehrer Lehren). Ця програма спрямована на підвищення кваліфрікації вчителів та викладачів німецької мови, а також професійну підготовку майбутніх учителів німецької мови. Вона базується на сучасних досягненнях у галузі німецької мови як іноземної та інтегрує інноваційний підхід до навчання - дослідження через діяльність [2]. Тематика програми курсів складається 3 10-ти модулів, що охоплюють актуальні теми 3 педагогіки, методики викладання іноземних мов, особливостей впровадження інорормаційно-комунікаційних технологій в освітній процес, наприклад: «Навчальна компетенція та організація заняття», «Завдання, вправа, інтеракція», «Навчальні матеріали та мультимедійні засоби», «Навчальна програма та планування заняття», «Перевірка, тестування, оцінювання», «Німецька 
мова для дітей», «Німецька мова для підлітків» тощо. У рамках навчання згідно із зазначеною програмою студенти під керівництвом викладача-тьютора в режимі онлайн самостійно опрацьовували теоретичний матеріал та виконували 85 вправ різного рівня складності, що містили диференційовані тестові завдання, пов'язані 3 аналізом педагогічних та методичних особливостей організації освітнього процесу, аналізували сучасні підручники та навчально-методичні комплекси тощо; створювали власні фррагменти уроків з огляду на тему модуля, що вивчається. На особливу увагу заслуговує проведення експериментальної апробації власних розробок фррагментів уроків, що $€$ обов'язковою умовою для зарахування проходження курсу. Всі завдання мають чіткі терміни виконання та критерії оцінювання, передбачають високий рівень організованості та високий рівень вмотивованості майбутнього педагога, фрормують інформативну компетентність, зокрема: уміння знаходити, аналізувати, систематизувати, класиорікувати інформацію, створювати власний інформаційний продукт, працювати в різних інформаційних освітніх середовищах та програмах (платорорми Moodle, GoogleForms, програми MsWord, Adobe Reader, Google Sheet, MS Power Point) тощо.

Використання сучасних інфрормаційних технологій в організації самостійної роботи студента вищого навчального закладу сприяє результативному фрормуванню професійних умінь і навичок майбутніх фрахівців. Належний рівень сфрормованості інформаційної компетентності майбутніх учителів забезпечить належні умови для їхньої самостійної роботи, зокрема: вільний і постійний доступ до навчальних матеріалів з будь-якої локації та персонального пристрою, за наявності під'єднання до мережі Інтернет; скорочення часу студента під час пошуку потрібних навчальних документів, матеріалів, літератури, потрібних для самостійної підготовки до занять, виконання практичних завдань, курсових робіт, наукових проектів; підвищення наочності матеріалу та полегшення його сприйняття за рахунок допоміжних засобів (мультимедіа, тренажери, імітаційні моделі, комп'ютерні ігри); розширення та поглиблення змісту дисциплін, що вивчаються за рахунок великої кількості інфрормаційних ресурсів, організації навчальної інорормації, за допомогою гіпертекстових технологій, віртуальних середовищ, організації науково-дослідної роботи на основі проектування і моделювання; можливість участі в наукових проектах та роботи над поставленими завданнями як окремих студентів, так і групи поза аудиторією; можливість створення персонального простору студента з веденням блогу, сайту, живого журналу тощо для обговорення конкретно визначеної теми, пов'язаної 3 навчанням або майбутньою професійною діяльністю; здійснення оперативного контролю навчальних досягнень студента як проміжного, так і підсумкового контролю (за рахунок комп'ютерного тестування).

Висновки. Отже, фрормування інформаційної компетентності майбутніх учителів фрілологічних спеціальностей неможливе без чіткої цілеспрямованої організації самостійної роботи, що забезпечує розв'язання двох взаємопов'язаних завдань: розвиток у студентів самостійності в пізнавальній діяльності, навчання їх самостійному оволодінню знаннями, а 3 іншого боку - формування у студентів умінь самостійно застосовувати отримані знання не лише в навчальній, але й у професійній діяльності. Підвищення вимог до рівня професійної підготовки майбутніх фрахівців фрілологічних спеціальностей зумовлює необхідність ефективної організації самостійної роботи студентів у ЗВО. Формування інфрормаційної компетентності майбутніх учителів забезпечить позитивну динаміку безперервної профресійної самоосвіти та саморозвитку.

\section{БІБЛІОГРАФІЧНИЙ СПИСОК:}

1. Алексюк А. Педагогіка вищої освіти України. Історія. Теорія : підруч. для студентів, аспірантів та мол. викладачів вищ. навч. закл. Київ : Либідь, 1998. $558 \mathrm{c}$.

2. Вчимося навчати німецької. Проект Гете-Інститут. URL: https://www.goethe.de/ins/ua/uk/spr/unt/for/ gia/dll.html

3. Гулецька Я. Організація самостійної роботи магістрів 3 використанням інсрормаційних технологій при вивченні іноземної мови. Вісник НТУУ «КПІ». Філософрія. Психологія. Педагогіка. 2009. Випуск № 3. С. 75-80.

4. Гуревич Р., Кадемія М., Козяр М. Інформаційно-комунікаційні технології в профресійній освіті ; за ред. член-кор. НАПН України Р.С. Гуревича. Львів, 2012. 506 c.

5. Добровольська А. Самостійна робота як засіб фрормування IT-компетентності майбутніх лікарів і провізорів. Наука і освіта. 2016. № 12. С. 74-83.

6. Есипов Б. Самостоятельная работа учащихся на уроках. Москва : Государственное учебно-педагогическое издательство министерства просвещения РСФСР, 1961. 239 с.

7. Жукевич І. Педагогічні умови формування готовності до самоосвіти курсантів вищих навчальних закладів системи МВС України. Вісник Національного авіаційного університету. Серія: Педагогіка, Психологія. 2015. Випуск 7. С. 4-7.

8. Зимняя И. Педагогическая психология : учебник для вузов. Москва : Московский психологосоциальный институт ; Воронеж : НПО «МОДЭК», 2010. 448 c.

9. Калініченко А., Сікорська Л. Організація самостійної роботи з іноземної мови студентів вищих економічних навчальних закладів. Сучасні інформаційні технології та інноваційні методики навчання в підготовці фоахівців: методологія, теорія, досвід, проблеми. 2012. № 31. С. 352-357.

10. Нєлєпова А. Інформаційна компетентність викладача в управлінні самостійною роботою студен- 
тів під час організації інформаційного середовища. Науковий часопис НПУ імені М. П. Драгоманова. Серія 5. Педагогічні науки: реалії та перспективи. 2016. Випуск 53. С. 201-213.

11. Стрілець О., Кайдалова Л., Стрельников л. Самостійна робота студентів як засіб фрормування професійної компетентності студентів. Вісник Чернігівського національного педагогічного університету. Педагогічні науки. 2013. Випуск 103. C. 259-263.
12. Хорошайло О. Використання інноваційних технологій і прийомів для організації самостійної роботи студентів (аналіз зарубіжного досвіду). Освітологічний дискурс. 2011. № 1 (3). С. 24-34.

13. Шуфнарович М. Перспективи використання сучасних інорормаційних технологій у самостійній роботі студентів вищих навчальних закладів. Науковий вісник НЛТУ України. 2017. Т. 27. № 1. С. 222-225.

14. Anderson T., Elloumi F. Theory and Practice of Online Learning. Athabaska University, 2014. 421 p. 


\section{ПСИХОЛОГО-ПЕДАГОГІЧНІ ТА МЕТОДИЧНІ АСПЕКТИ ВИКОРИСТАННЯ ТРЕНІНГІВ У ПРОФЕСІЙНІЙ ПІДГОТОВЦІ МАЙБУТНІХ СОЦІАЛЬНИХ ПРАЦІВНИКІВ

\author{
PSYCHO-PEDAGOGICAL AND METHODICAL ASPECTS \\ OF TRAINING USE IN PROFESSIONAL TRAINING \\ OF FUTURE SOCIAL WORKERS
}

УДК 378:364.78]:37.091.33

DOI https://doi.org/10.32843/2663-

$6085 / 2020 / 24-2.31$

\author{
Човган 0.0., \\ канд. психол. наук, \\ доцент кафедри соціальної роботи \\ і соціальної педагогіки \\ Хмельницького національного \\ університету
}

\begin{abstract}
у статті обгрунтовано роль тренінгів для підвищення есрективності профресійної підготовки майбутніх соціальних працівників. Доведено вагому роль тренінгів під час удосконалення комунікативної компетент ності майбутніх фрахівців соціальної сфери. участь студентів у тренінгах позитивно впливає на зняття емоційного напруження, розвиток таких особистісно-професійних якостей, як ресрлексія, толерантність, асертивність та соціальна відповідальність. Проаналізовано психолого-педагогічні аспекти організації тренінгів, що передбачають поєднання традиційного та інноваційних підходів до організації освітнього процесу. З'ясовано, що суттєве підвищення результативності освітнього процесу можна отримати в тому випадку, коли будуть активно використані ігрове моделювання й імітаційні методи навчання.

У методичній площині окреслено основні цілі, які ставлять перед собою викладачі кафредри соціальної роботи та соціальної педагогіки під час організації соціально-психологічних тренінгів. Тренінг доцільно організовувати на принципах активності, творчої позиції та партнерського спілкування. Висвітлено найбільш перспективні методи, які володіють вагомим потенціалом у профессійній підготовці майбутніх соціальних працівників на основі використання тренінгової технології. 3 методичної точки зору доведено доцільність використовувати під час тренінгу різноманітні пізнавальні ігри та комунікативні ситуації. Увагу зосереджено на характеристиці ділових ігор, дискусій, евристичної бесіди, аналізі профресійних ситуацій, розігруванні ролей, які доцільно застосовувати викладачам під час організації та проведення тренінгів з майбутніми соціальними працівниками в ході їхньої профресійної підготовки в закладах вищої освіти.
\end{abstract}

Ключові слова: тренінг, майбутні соціальні працівники, професійна підготовка, особистісні якості, цілі, методи, срорми.

The article substantiates the role of trainings for improving the effectiveness of future social workers' professional training. The role of trainings in the improving of the communicative competence of future social experts has been proved. Participation of students in the training has a positive effect on the removal of emotional tension, the development of personal and professional qualities such as reflection, tolerance, assertiveness and social responsibility. Psychological and pedagogical aspects of the organization of trainings are analyzed, which involve a combination of traditional and innovative approaches to the organization of the educational process. It is found that a significant increase in the effectiveness of the educational process can be obtained when game modeling and simulation training will be actively used.

The main goals are outlined in the methodical plane, which teachers of the department of social work and social pedagogy set during the organization of social-psychological trainings. The training was organized on the principles of activity, creativity and partnership. The most promising methods that have significant potential in professional training of future social workers based on the use of training technology are highlighted. From a methodological point of view, it is proved to use a variety of educational games and communication situations during training. The focus is on the characteristics of business games, discussions, heuristic conversations, analysis of professional situations, role-playing that are appropriate for teachers to organize and conduct training for future social workers in their professional training in higher education institutions.

Key words: training, future social workers, professional training, personal qualities, goals, methods, forms.
Постановка проблеми у загальному вигляді. Нині спостерігається суттєве ускладнення комунікацій, зростає навантаження на людські ресурси, що зазвичай супроводжується розвитком засобів підготовки студентів до комунікативної взаємодії ще під час навчання у закладах вищої освіти (далі -3ВО). Для майбутнього соціального працівника комунікативна компетентність $€$ доволі вагомим аспектом, що визначає рівень його профресіоналізму. Виходячи з таких реалій, українська вища освіта має активно працювати над модернізацією освітнього процесу, причому ЗВО мають бути націлені на формування майбутнього професіонала, який ще під час навчання навчиться компетентно надавати соціальні послуги своїм майбутнім клієн- там. Так, в умовах соціальних реформ, які відбуваються в українському суспільстві, багато українських громадян із соціально незахищених верств населення (безробітні, пенсіонери, діти-сироти, вимушені переселенці, військові, які були задіяні у військових діях на Сході, особи, що потрапили в складні життєві ситуації) потребують соціальної допомоги і захисту. Саме на фрахівців соціальної сорери покладено чималий спектр посадових обов'язків, які стосуються реалізації соціальної політики та реалізації всього спектру соціальних послуг, а тому виникає нагальна потреба в якісній та продуктивній професійній підготовці.

Як свідчать фракти, традиційна пояснювальноілюстративна система організації освітнього про- 
цесу не забезпечує якісної професійної підготовки майбутнім фахівцям соціальної сорери. Нині незаперечним $€$ той фракт, що одним із найефективніших засобів, що впливає на рівень комунікативної компетентності, $€$ тренінг, який дозволить перенести центр уваги комунікативного навчання в освітнє середовище. Тренінг перетворюється в широко поширену практику, а викладач має опанувати роль тренера.

Аналіз останніх досліджень і публікацій. Слід відзначити, що за останні роки з'явився доволі великий об'єм інфрормації щодо розробки теорії, методології та практики організації й проведення тренінгів для студентської аудиторії. Зокрема, проблеми розвитку комунікативних умінь студентів на основі тренінгів були в центрі уваги Н. Волкової, В. Киричок, А. Панорілова, В. Тюріної В. Федорчук та ін. Напрацювання науковців вносять вагомий внесок у процес фрормування комунікативної компетентності майбутніх студентів, проте неповною мірою відображають усю специфріку майбутнього фраху та сучасні вимоги до фрахівців соціальної сорери.

Виділення невирішених раніше частин загальної проблеми. Чимало науковців (І. Вачков, Ю. Ємельянов, Н. Морєва, А. Панфілова, О. Пасічник, Л. Петровська, О. Сидоренко, В. Федорчук, Н. Хрящева та ін.) присвятили свої дослідження вивченню теорії та практики організації й проведення тренінгів. Проте ще й нині до кінця не з'ясовано місце тренінгової технології в процесі професійної підготовки майбутніх фрахівців соціальної сфрери до налагодження професійної комунікативної діяльності. Поза увагою дослідників залишилися методологічні аспекти розроблення й застосування тренінгів під час фрормування комунікативних умінь майбутніх соціальних працівників. Не до кінця розкриті ігровий потенціал та практична спрямованість тренінгів, не акцентовано достатню увагу на потенціалі тренінгів у контексті розвитку вмінь і навичок міжособистісної взаємодії та налагодження партнерського професійного спілкування.

Тренінг на наших очах перетворюється в освітню технологію та активно використовується в освітньому процесі, однак кількісне зростання далеко не завжди супроводжується досягненнями якісного характеру. Спостерігається розрив між практикою використання тренінгу і його методологічним наповненням. І справа не тільки в тому, що теорія не встигає услід за практикою, сама практика тренінгу доволі часто розробляється на основі застарілих концепцій, а тому стає малоефрективною. Причина певного розриву між теорією і практикою, на нашу думку, полягає не у відсталості практиків, а в тому, що від наукових розробок до їх використання немає прямого шляху. У нашому розумінні, перш ніж теоретичні напрацювання можуть бути продуктивно використані в освітньому процесі, вони повинні бути технологізовані, тобто перетворені в низку чітко систематизованих процедур із вбудованими в них засобами контролю ефективності. А це вимагає спеціально організованої роботи, що включає в себе проведення особливим чином спланованих методологічних досліджень. Наголосимо на тому, що під час осмислення практики тренінгу виник своєрідний парадокс: у той час як культивується «навчання, яке базується на досвіді» 3 активним експериментуванням і рефлексією, сама практика тренінгу осмислюється переважно емпірично, тобто лише з позиції відстороненого спостерігача.

3 огляду на ці аспекти мета статті - проаналізувати психолого-педагогічні та методичні аспекти використання тренінгів у професійній підготовці майбутніх соціальних працівників.

Виклад основного матеріалу. У педагогічному словнику [4] наукова десініція «тренінг» розглядається як форма інтерактивного навчання, метою якого $€$ розвиток міжособистісної та профресійної поведінки. Тобто тренінг розглядається як ефективний засіб впливу на розвиток знань, умінь, навичок, а також формування соціальних установок і досвіду в галузі міжособистісного спілкування, крім того, тренінг доцільно розглядати як чинник розвитку компетентності у спілкуванні.

Нині у психолого-педагогічних дослідженнях відзначено, що наукову дефініцію «тренінг» доцільно використовувати не лише для трактування методів навчання, але й для характеристики способів розвитку здібностей особистості до оволодіння конкретним видом професійної діяльності. Так, за основу в нашому дослідженні прийнято визначення, яке представила Н. Волкова в навчально-методичному посібнику «Інтерактивні технології навчання у вищій школі» [1]. Авторка вважає, що тренінг доцільно розглядати як «запланований процес модифікації (зміни) відносин, знання чи поведінкових навичок того, хто навчається, через набуття навчального досвіду 3 тим, щоб досягти ефективного виконання в одному виді діяльності або в певній галузі» [1, с. 124].

Науковці аргументовано довели, що активне використання тренінгів в освітньому процесі матиме позитивний вплив на вдосконалення комунікативної компетентності. Зокрема, як зазначає О. Пасічник, «активізуючий ефрект тренінгу зумовлений створенням особливої навчально-експериментальної ситуації, яка забезпечує розуміння учасниками тренінгової групи того, які індивідуальні та групові психологічні події розгортаються в процесі міжособистісного спілкування, створенням інтенсивного зворотного зв'язку і фрормування практичних умінь, які необхідні в повсякденній роботі» [5, с. 153].

Поділяємо позицію С. Калаур, що «тренінгова технологія спрямована на розвиток соціальних установок, поглиблення теоретичних знань, фрормування умінь, досвіду в галузі міжособистісного 
спілкування» [2, с. 88]. Зокрема, авторка [2; 3] наголошує на тому, що тренінги націлені на фрормування й розвиток у майбутніх фрахівців умінь, навичок ефрективного спілкування, а також сприяють самопізнанню, впливають на фрормування навичок активного слухання, вдосконалюють навички аргументування власної точки зору, допомагають послабити нервово-емоційне напруження, розвивають такі якості, як соціальна сенситивність, рефлексія, толерантність та асертивність.

Вважаємо, що у психолого-педагогічному контексті тренінгові технології користуються великою популярністю завдяки тому, що поєднують традиційне та нетрадиційне навчання, ігрове моделювання та імітаційні методи навчання. Тренінги, як доводить Н. Волкова [1, с. 125-126], зосереджені, головним чином, на виконання мотиваційної, навчальної, розвивальної, комунікативної та релаксаційної фрункцій. У своєму підручнику авторка представляє такий перелік видів тренінгів: тренінг комунікації, тренінг презентації, соціальнопсихологічний тренінг, тренінг особистісного зростання, тренінг сенситивності, методичний тренінг, імітаційний тренінг, тренінг «робота 3 індивідом», груповий тренінг, аутотренінг, практично-професійний тренінг [1, с. 128-130].

У методологічному контексті тренінг представляє собою активну групову фрорму навчання, засновану на спільному отриманні комунікативного досвіду. Ефректи тренінгу різноманітні й не зводяться тільки до приросту теоретичних знань і практичних умінь. Крім прямих (цільових) ефектів, виникає ряд супутніх, що мають іноді не менш важливе значення, ніж цільові. Так, деякі ефекти тренінгу обумовлені або задаються змістом і завданнями, а їхня вираженість та спрямованість залежать від позиціонування лідерського ядра групи і ступеня групової гетерогенності. Величина вираженості і характер есректів тренінгу багато в чому визначаються ступенем і характером активності учасників тренінгу. Саме активність учасників визначає успішність тренінгу в цілому і його окремих сторін і складників. У практичному контексті тренінг має організовуватися на принципах активності, творчої позиції та партнерського спілкування. Основу його проведення мають складати пізнавальні ігри та комунікативні ситуації, ділові ігри, дискусії, евристичні бесіди, аналіз профресійних ситуацій, розігрування ролей.

Беручи до уваги поради Л. Артемова, Н. Волкової, С. Кашлєва, В. Євдокимова, М. Мельничук, А. Панорілова, О. Пометун, Л. Романовської та ін., а також наш власний педагогічний досвід, у профресійну підготовку майбутніх соціальних працівників у Хмельницькому національному університеті активно впроваджуються соціально-психологічні тренінги, які насамперед спрямовані на фрормування комунікативної компетентності. Організову- ючи тренінги діяльності майбутніх соціальних працівників, ми переслідували такі цілі, як:

- підвищення мотивацій майбутньої профресійної діяльності;

- формування адекватної самооцінки;

- вдосконалення відповідальності студентів;

- цілеспрямоване руйнування неадекватних стереотипів, що можуть виникнути у професійній діяльності;

- налагодження ефективної міжособистісної взаємодії в групі.

Організовуючи тренінги, ми активно працювали над тим, щоб студенти усвідомили вагомість власної мотивації для ефрективної реалізації професійної діяльності. Зокрема, тренінгові вправи дозволяли студентам проаналізувати та переглянути власну мотивацію майбутньої діяльності й зробити найбільш оптимальний вибір необхідних особистісно-професійних установок. Як показав наш власний досвід, під час тренінгу у студентів проходила переоцінка ціннісних орієнтацій, змінювалося відношення осіб, які потрапили в складні життєві ситуації. Майбутні фрахівці отримали реальну змогу щиро відповісти на такі запитання: «Чому я обрав фрах соціального працівника? Які професійні цінності я прагну відстоювати в особистому житті та в профресійній кар'єрі?». Задля поглиблення професійної спрямованості професійної підготовки майбутніх соціальних працівників під час тренінгів студентам пропонувалося вивчати мовні прийоми, які акумулюють професійні установки, та проводити аналіз конкретних психологічних бар'єрів, які негативно позначаються на їхній майбутній професійній комунікативній взаємодії.

Під час тренінгів ми також цілеспрямовано працювали над формуванням у майбутніх соціальних працівників адекватної самооцінки, розвитком у них самоповаги. Як показало опитування студентів, вони змогли дещо відкоригувати власну «Я-концепцію», що сприяло на користь прогресивних змін у процес фрормування особистості майбутнього соціального працівника, у формування інноваційного стилю мислення. Вагомим фактом вважаємо те, що участь студентів у тренінгах мала позитивний вплив на розвиток таких особистісних якостей, як толерантність та емпатія.

У ході організації тренінгів ми цілеспрямовано вдосконалювали таку особистісну якість майбутніх соціальних працівників, як відповідальність за власну діяльність. У цьому контексті ми виходили з тих міркувань, що вагомість відповідальності підсилюється тим, що кожен студент мав змогу змінити свою позицію та власну думку без стороннього тиску лише тоді, коли був до цього готовий. Вважаємо, що така практична діяльність у контексті вдосконалення відповідальності допоможе студентам у майбутньому відповідально ставитися до виконання професійних обов'язків, 
а також дозволить усвідомити різницю між ідеальним та реальним уявленням про себе як про фрахівця соціальної сорери.

Беручи участь у тренінгах, студенти мали змогу спостерігати, як проходить руйнування рольових стереотипів та поведінкових стандартів. Зокрема, ми цілеспрямовано працювали над руйнуванням таких стереотипів, як «логічна помилка», «помилка соціального стереотипу», «помилка центральної тенденції», «помилка привабливості і взаємної симпатії», «помилка близькості». Студенти під час участі в спеціально розроблених професійно орієнтованих ситуаціях відчули на собі всі означені стереотипи, могли пояснити їхній негативний вплив, а тому робили акцент на спілкуванні без негативних стереотипів і поведінкових стандартів. Вагому роль під час роботи над усуненням негативних стереотипів ми відводили можливості вільного висловлення своїх думок та почуттів, що дозволило кожному студенту не лише побачити недоліки своїх одногрупників, а й власні недоліки та прорахунки, вільно обговорити їх i, таким чином, удосконалити комунікативну діяльність.

Організовуючи зі студентами спеціальності 231 «Соціальна робота» соціально-психологічні тренінги, ми приділяли увагу налагодженню ефективної міжособистісної взаємодії в групі. Така діяльність сприяла фрормуванню у студентів усвідомлення того, що кожен може у повній мірі реалізувати себе лише в контакті з іншими членами групи. Беручи до уваги той фракт, що професійна діяльність майбутніх соціальних працівників буде безпосередньо пов'язаною з роботою в колективі, налагодження співробітництва, як зі своїми колегами, так і з клієнтами, виступає вагомим аспектом професіоналізму. У практичній площині ми працювали над фрормуванням у студентів міжособистісної відкритості, яка $є$ головною умовою проведення тренінгів в освітньому процесі.

Під час проведення соціально-психологічних тренінгів зі студентами спеціальності 231 «Соціальна робота» активно використовуються такі методи активного навчання, як: дискусія, мозковий штурм, рольові ігри, розігрування професійних ситуацій, комунікативні й аналітичні вправи, імітаційні та ділові ігри, відеодемонстрації, відеолекторії. Серед методичних прийомів тренінгу перевагу слід надавати активним методам навчання, які зорієнтовані на широке використання ефекту групової взаємодії, вироблення оптимальних шляхів виходу зі складних комунікативних ситуацій, розвиток соціальної сензитивності, навичок рефлексії.

Отже, у найбільш загальному контексті участь студентів у тренінгах дозволяє сорормувати у них відповідальність, соціальну активність, готовність підтримати, прийти на допомогу, уміння організувати спільну діяльність, надає можливість молодим людям вчитися та реалізовувати себе через надання допомоги як окремій людині, так і суспільству в цілому, брати участь на добровільних засадах у соціальних програмах щодо попередження негативних явищ у соціальному середовищі та надавати допомогу іншим в їхньому розвитку, соціальному становленні й інтеграції в суспільство.

Висновки. 3 огляду на наведені фракти ми вважаємо, що викладацькому складу необхідно системно працювати над впровадженням педагогічних інновацій в освітній процес професійної підготовки майбутніх фрахівців соціальної сфери. Наголосимо на тому, що процеси загострення соціальної ситуації в Україні вимагають обґрунтування та розроблення механізмів якісного надавання соціальних послуг, а це, відповідно, базується на доцільності розроблення нових підходів до професійної підготовки кваліфрікованих кадрів для соціальної сорери.

Наголосимо, що якісна реалізація майбутніми соціальними працівниками соціальної діяльності має базуватися на інноваційних технологіях їхньої професійної підготовки відповідно до вітчизняних та світових стандартів, тенденцій інтеграції у світовий освітній простір, а також вона повинна носити випереджувальний характер. Отже, на нашу думку, участь студентів у тренінгах суттєво підвищує відповідальність, громадську активність, сприяє налагодженню емпатії й толерантності, підвищує рівень комунікабельності. 3 огляду на ці фракти вважаємо, що професійна підготовка майбутніх соціальних працівників у ЗВО потребує реального наповнення сучасними педагогічними інноваціями безпосередньо в площині впровадження тренінгів в освітній процес.

\section{БІБЛІОГРАФІЧНИЙ СПИСОК:}

1. Волкова Н.П. Інтерактивні технології навчання у вищій школі : навч-метод. посібник. Дніпро : Університет імені Альфреда Нобеля, 2018. 360 с.

2. Калаур С.М. Використання тренінгових технологій під час фрормування готовності майбутніх фахівців соціальної сфери до розв'язання конфлліктів у професійній діяльності. Професійна освіта: методологія, теорія та технології : зб. наук. праць. Переяслав-Хмельницький : ФОП Домбровська Я.М., 2017. Вип. 5/1. С. 86-98.

3. Калаур С.М. Використання проблемних ситуацій та завдань під час формування у майбутніх фахівців соціальної сорери готовності до розв'язування професійних конфрліктів. Оновлення змісту, форм та методів навчання і виховання в закладах освіти : зб. наук. праць : наук. записки РДГУ. Рівне : РДГУ, 2017. Вип. 17 (60). С. 171-175.

4. Коджаспирова Г.М. Коджаспиров А.Ю. Словарь по педагогике. Москва : ИКЦ «МарТ», 2005. 659 с.

5. Пасічник О.О. Навчальний тренінг як засіб формування комунікативних умінь майбутніх соціальних педагогів. Науковий вісник Ужгородського національного університету. Серія : Педагогіка. Соціальна робота. 2009. № 16-17. С. 152-155. 


\section{СТРУКТУРА ПРОГНОСТИЧНОЇ КОМПЕТЕНТНОСТІ МАЙБУТНІХ БАКАЛАВРІВ КОМП'ЮТЕРНИХ НАУК \\ STRUCTURE OF PROGNOSTIC COMPETENCE OF FUTURE BACHELORS OF COMPUTER SCIENCE}

у статті розглянуто проблему срориування прогностичної компетентності майбутніх бакалаврів комп'ютерних наук у процесі фрахової підготовки. Установлено, що прогностичну компетентність студентів варто розглядати як запоруку їхньОї прогностичної діяльності. Ураховуючи, що зазначена компетентність виступає багатовимірним і багатокомпонентним педагогічним феноменом, вона має складну структуру. Перший компонент - мотиваційно-ціннісний, він базується на самоактуалізації особистості та формуванні інтересу студентів до прогностичної діяльності. До нього відносять мету, інтереси, потреби, цінності та мотиви до здійснення прогнозування в галузі інфрормаційних технологій. Якісне виконання профессійної діяльності можливе за умов оволодіння певним рівнем відповідних знань, що зумовлює важливість наступного компонента компетентності - теоретичного. Його основою $\epsilon$ знання - інформація, досвід, ідеї, що підлягають засвоєнню й визначаються специсрікою галузі знань «Інфрормаційні технології». Зміст компонента подано у двох основних частинах (теоретичній та теоретико-технологічній). Технологічній компонент розкриває такі вміння: гностичні, проектувальні, конструктивні, організаторські, комунікативні. Контрольно-рефрлексивний компонент прогностичної компетентності відображає профресійне усвідомлення студента в межах реалізації прогностичної діяльності, окреслює самооцінку їі результативності, спонукає до подальшого науково-професійного самовдосконалення. Важливе місце відводиться корекції прогностичної діяльності на різних етапах ії реалізації. Останній компонент - особистісний, до його складу входять: аналітичність, гнучкість і креативність мислення, розвинуті емпатійні здібності, тактовність, організованість, дотримання відповідних профресійно-етичних норм і принципів, саморозвиток особистості, самопізнання, чітке усвідомлення майбутніми бакалаврами комп'ютерних наук значущості прогностичної діяльності та бажання ії здійснювати.

Ключові слова: прогностична компетентність, фоормування, бакалавр комп'ютерних наук, інфрормаційні технології, просресійна підготовка.

The article considers the problem of the formation of prognostic competence of future bachelors of computer science in the process of professional training. It is established that the prognostic competence of students should be considered as a guarantee of their prognostic activity. Taking into account, that this competence is a multidimensional and multicomponent pedagogical phenomenon, it has a complex structure. The first component is motivational-value, it is based on the self-actualization of personality and the formation of students' interest in the prognostic activity. It includes the purpose, interests, needs, values, and motives for forecasting in the field of informational technologies. Qualitative performance of a professional activity is possible under the conditions of mastering a certain level of relevant knowledge, which determines the importance of the next component of competence - theoretical. It is based on knowledge information, experience, ideas to be mastered and determined by the specifics of the field of knowledge "Informational Technology". The content of the component is presented in two main parts (theoretical and theoretical-technological). The technological competence reveals the following skills: gnostic, design, constructive, organizational, communicative. The control-reflexive component of prognostic competence reflects the professional awareness of the student within the implementation of the prognostic activity, outlines the self-assessment of its effectiveness, encourages further scientific and professional self-improvement. An important place is given to the correction of prognostic activity at different stages of its implementation. The last component is personal, it includes: analytical, flexibility and creativity of thinking, developed empathic abilities, tact, organization, compliance with relevant professional and ethical norms and principals, self-development of personality, self-knowledge, a clear understanding by future bachelors of computer science about the importance of prognostic activity and the desire to implement it.

Key words: prognostic competence, formation, bachelor of computer science, information technologies, professional training.
Постановка проблеми у загальному вигляді. Проблема формування прогностичної компетентності студентів $є$ однією з фундаментальних у сучасній вищій освіті та має давню історико-педагогічну традицію. Елементи передбачення знаходимо ще у творах відомих фрілософрів античності (Августин, Аристотель, Гіпократ, Демокрит, Квінтіліан, Конфуцій, Сократ, Платон та ін.). Аналіз наявних у науці наукових знань, що розкриває різні підходи та аспекти прогностичної компетентності, дозволив установити, що інтерес до зазначеної проблеми зумовлений потребою у фрахівцях, які здатні моделювати можливі професійні проблеми, заздалегідь знаходити шляхи їхнього ефективного вирішення, своєчасно реагувати на непередбачувані зміни в діяльності тощо. Підготовка студентів до прогностичної діяльності в галузі інформаційних технологій в умовах швидкого оновлення змісту, модернізації програмного забезпечення інсрормаційних систем та комп'ютерної техніки $є$ необхідною складовою частиною університетської освіти, запорукою ефективної майбутньої професійної діяльності. 
Аналіз останніх досліджень і публікацій. Теоретико-методологічні аспекти прогнозування подано в сучасних дослідженнях (І. Підласий, М. Коляда,Т. Бугайова, О. Кабанська, С. Боруха, У. Понзель, А. Присяжна, А. Карманчиков, Л. Кудринська, О. Попова, М. Шевчук та ін.). Сьогодні реалізовано низку досліджень із формування (або розвитку) прогностичної компетентності у студентів різних спеціальностей (або фрахівців): економістів, менеджерів (А. Антонець, Д. Прасол, К. Масленнікова, Т. Столяренко), лікарів (П. Хоменко, А. Гавриш, О. Погребняк, А. Денісієвська, С. Тарасова), правоохоронців (В. Сокуренко, І. Клименко), педагогів (Н. Давкуш, В. Демидова, М. Севастюк, А. Кінєшева, Т. Постоян, В. Гладуш, В. Суботін), війскових (І. Азаров, В Рябчук, О. Удовиця, В. Береговий, О. Тіханичев, А. Шулаков). Для реалізації окресленого завдання розроблено відповідний педагогічний інструментарій (умови, технології, супровід, фрорми та методи тощо)

Виділення не вирішених раніше частин загальної проблеми. Разом із тим недостатньо дослідженою залишається проблема визначення сутності та структури прогностичної компетентності фрахівців інформаційних технології, зокрема майбутніх бакалаврів комп'ютерних наук.

Мета статті - визначити структуру прогностичної компетентності майбутніх бакалаврів комп'ютерних наук.

Виклад основного матеріалу дослідження. На нашу думку, прогностична компетентність бакалаврів комп'ютерних наук - це інтегрована профресійно значуща якість особистості, що ґрунтується на системі прогностичних знань, умінь, навичок, попередньому досвіді та сприяє цілеспрямованому випереджувальному плануванню й передбаченню ймовірних змін у галузі інформатики та інформаційних технологій, знаходженню альтернатив і вибору найбільш доцільних варіантів рішень профресійних проблем 3 урахуванням потенційних ризиків і можливостей.

Ураховуючи, що прогностична компетентність майбутніх бакалаврів комп'ютерних наук є багатовимірним і багатокомпонентним педагогічним френоменом, вона має складну структуру. Відтак виникає необхідність конкретизувати зміст кожного 3 її складників, а також виокремити специфрічні особливості їх фрормування або розвитку. Нами було виокремлено такі складники прогностичної компетентності.

Перший компонент - мотиваційно-ціннісний. Він базується на самоактуалізації особистості та формуванні інтересу студентів до прогностичної діяльності. До нього ми відносимо мету, інтереси, потреби, цінності та мотиви до здійснення прогнозування в галузі інформаційних технологій. Мета формування прогностичної компетентності зумовлена загальною метою підготовки бакалаврів комп'ютерних наук, які здатні розв'язувати складні спеціалізовані задачі та практичні проблеми комп'ютерних наук. Це передбачає застосування теорій і методів інформаційних технологій та характеризується комплексністю та невизначеністю умов (відповідно до стандарту вищої освіти України першого (бакалаврського) рівня ступеня «бакалавр» за галуззю знань 12 «нфоормаційні технології» спеціальності 122 «Комп'ютерні науки» [1]).

Цей компонент передбачає усвідомлення значення прогностичної компетентності та базується на внутрішній вмотивованості майбутніми бакалаврами в необхідності постійного застосування прогнозування під час моделювання, проектування, розроблення та супроводу інфрормаційних технологій із метою підвищення результативності професійної діяльності. Зазвичай мотив пов'язаний із задоволенням певної потреби. В якості мотивів виступають ідеали, інтереси, переконання, установки, цінності тощо.

Вважаємо, що для мотиваційно-ціннісного компонента притаманні потреби особи в саморозвитку та самовдосконаленні. Для розкриття ціннісних установок особистості щодо реалізації ефективної професійної діяльності ми взяли за основу думку Д. Пузікова [2] та виокремили такі напрямки:

- ціннісне ставлення студентів спеціальності «Комп'ютерні науки» до майбутнього як умови реалізації мети та завдань професійної діяльності, самореалізації тощо;

- ціннісне ставлення до процесу й результатів науково обґрунтованого передбачення майбутнього загалом, до процесу й результатів використання цисррових технологій зокрема;

- ціннісне ставлення до наявного прогностичного знання, методів, прийомів і засобів прогнозування (наприклад, Novo Forecast, Statistica, Microsoft Excel, SPSS тощо);

- ціннісне ставлення до прогнозування розвитку сорери інфрормаційних технологій;

- ціннісне ставлення до процесу й результатів прогнозування розвитку загальних і спеціальних компетентностей, якими володіє особа;

- ціннісне ставлення до професійної комунікації, пов'язаної з організацією взаємодії суб'єктів прогностичної діяльності в галузі інфрормаційних технологій, обміном і поширенням необхідної прогностичної інсрормації.

Зрозуміло, що наявність мотивації - необхідна умова фрормування прогностичної компетентності студентів, але не достатня. Якісне виконання професійної діяльності можливе лише за умов оволодіння певним рівнем відповідних знань, що й зумовлює важливість наступного компонента компетентності - теоретичного. Його основою $€$ знання - інформація, досвід, ідеї, що підлягають засвоєнню й визначаються специфрікою галузі знань «Інформаційні технології». 
Розкриємо теоретичний компонент прогностичної компетентності. Його ми представляємо як дві основні частини (теоретичну та теоретикотехнологічну). До першої відносимо сукупність наукових знань:

- понятійно-категоріальний апарат прогностичної діяльності (мета, завдання, сутність, зміст, об'єкт, предмет, наукова проблема тощо);

- історія виникнення прогнозування, розвиток наукових шкіл sз прогнозування;

- методологія прогнозів; прогноз як результат прогнозування; порівняльна характеристика прогнозування, проектування, планування: співвідношення понять, ознак, особливостей;

- прогностична компетентність як запорука здійснення прогнозу;

- прогностична компетентність у професійній діяльності (аналіз профресійної діяльності фрахівців, обґрунтування актуальності прогностичної компетентності);

- інформаційні технології як об'єкт прогнозування; види й призначення прогнозної інфрормації та документації; інфрормаційний обіг (обмін, поширення прогнозної інфрормації) у галузі інформаційних технологій;

- правові засади прогностичної діяльності в сорері інфрормаційних технологій.

До другої теоретико-технологічної (операційної), частини ми відносимо такі наукові знання:

- технології й методики побудови прогнозів;

- шляхи застосування прогнозів у професійній діяльності, зокрема, в інформаційних технологіях;

- умови, ресурси та засоби, необхідні для прогнозування;

- результати прогнозування розвитку інфрормаційних технологій;

- системно-наукові прогностичні знання щодо тенденцій, закономірностей і механізмів розвитку інфрормаційних технологій.

Отже, теоретичний складник прогностичної компетентності $€$ певним смисловим відображенням мотиваційно-ціннісного компонента, що спонукає майбутніх бакалаврів комп'ютерних наук до прогностичної діяльності.

Обґрунтувавши теоретичний компонент прогностичної компетентності, варто перейти до його практичної інтерпретації, яка представлена в межах технологічного компоненту. Важливість технологічного підходу в освіті вдало окреслена в монографії С. Харченка. На думку автора, важливе значення в підвищенні ефективності освітнього процесу надається розробці та практичному використанню інноваційних педагогічних технологій. Але технологічний підхід до процесу навчання має право на існування в контексті нової освітньої парадигми лише в тому випадку, коли він трансорормується в інструмент, що забезпечує особистісно-орієнтований, гуманістичний характер цілісного освітнього процесу [3, с. 5].
Наповнення зазначеної класифікації здійснено відповідно до результатів досліджень науковців (І. Азаров, А. Кінєшева, Д. Прасол, Д. Пузіков):

Гностичні вміння:

оцінювати прогностичну ситуацію в сорері IT;

- аналізувати та прогнозувати розвиток інформаційних технологій;

- здійснювати конструювання моделі та управляти процесом ії реалізації;

- дотримуватися правових засад прогнозування в галузі інфрормаційних технологій;

- визначати мету та завдання прогностичної діяльності, розроблювати програму прогнозування в комп'ютерних науках.

Проектувальні вміння:

- встановлювати причинно-наслідкові зв'язки в контексті прогностичної діяльності;

- здійснювати відбір засобів і пошук шляхів досягнення прогнозованої мети;

- розробляти програми прогнозування з урахуванням особливостей об'єкту прогнозування;

- планувати та приймати рішення щодо використання цілепокладання, прийомів і методів прогнозування;

- виконувати перевірку, аналіз і коригування розробленої прогностичної моделі;

- передбачати труднощі в прогнозуванні;

- реалізовувати принципи етики в прогнозуванні;

- обирати способи власної поведінки, взаємодії у процесі прогнозування.

Конструктивні уміння:

- застосовувати різноманітний інструментарій прогнозування;

- здійснювати власну поведінку щодо взаємодії з іншими;

- створювати атмосореру, максимально придатну для реалізації завдань прогностичної діяльності;

- будувати ціннісні стосунки довіри, взаємоповаги та взаєморозуміння у професійній діяльності.

Організаторські вміння:

- створювати умови для пошуку та залучення ресурсів, необхідних для прогнозування;

- здійснювати збір діагностичної інфрормації;

- виявляти й долати проблеми, що можуть виникати в процесі прогнозування;

- ураховувати в прогностичній діяльності специфріку комп'ютерних наук, види та призначення прогнозної інорормації та документації;

- аналізувати, коригувати та регулювати власну ціннісну поведінку, критично аналізувати свої помилки та відповідати за них.

Комунікативні вміння:

- установлювати міжособистісні стосунки шляхом індивідуальної комунікації на основі взаємоповаги;

- фрормулювати, оцінювати та оприлюднювати результати прогнозування; 
- обґрунтовувати вибір і застосування різних видів й форм прогнозів.

Перейдемо далі до наступного компонента прогностичної компетентності - контрольно-рефрлексивного.

Звернемося також до авторитетної позиції І. Зязюна, що рефрлексія-це не лише знання чи розуміння суб'єктом самого себе, а з'ясування того, як інші знають і розуміють «рефрлексуючого», його особистісні характеристики, емоційні реакції, когнітивні (пізнавальні) уявлення» [4, с. 398]. Крім того, власний досвід реалізації фахової підготовки студентів дозволяє нам стверджувати, що рефлексія $€$ основою всіх видів освітньої діяльності в університеті.

Як бачимо, науковці фрактично суголосні у відзначенні важливості рефлексії для професійної, зокрема, прогностичної діяльності. Вони також вважають, що ресрлексія дозволяє студентам відшукувати сенс власної діяльності в результаті переосмислення та аналізу дій. Виокремлення контрольно-рефлексивного складника прогностичної компетентності пов'язано ще й з тим, що результат фрормування прогностичної компетентності в процесі фрахової підготовки бакалаврів комп'ютерних наук має бути співставний із метою та завданнями, що були сформульовані в межах мотиваційно-цільового складника. Зазначений компонент включає оцінку, аналіз, узагальнення результатів прогнозування, проблем, що виникли у процесі реалізації такої діяльності, визначення пріоритетних напрямків подальшої прогностичної діяльності тощо. Фактично контрольно-рефлексивний складник виконує моніторингову функцію з подальшим самоаналізом і самокоригуванням.

Отже, контрольно-рефрлексивний компонент прогностичної компетентності відображає професійне усвідомлення студента в межах реалізації прогностичної діяльності, окреслює самооцінку її результативності, спонукаєдоподальшогонауковопрофесійного самовдосконалення. Варто зазначити, що важливе місце ми відводимо корекції прогностичної діяльності на різних етапах її реалізації.

Останній компонент, який ми розглядаємо, особистісний. До його складу входять:

аналітичність. На думку В. Ягупова [5], це інформаційно-аналітичні знання, навички, уміння, здатності, професійно-важливі якості, особистий досвід у сфрері пошуку, оцінювання, використання, збереження, аналізу, офрормлення та передачі інформації за допомогою різних засобів, методів і форм діяльності дозволяють оперативно орієнтуватися в інформаційному просторі, брати участь у його формуванні, а також успішно реалізовувати інформаційно-аналітичну функцію. Згадаємо також висловлювання авторитетного науковця І. Підласого: «Основна задача прогнозування методів полягає в тому, щоб за допомогою наукового аналізу отримати знання про доцільність застосування тих чи інших методів для досягнення намічених цілей. Потрібно спиратися на аналітичну технологію, що гарантує надійні результати вибору методів прогнозування» [6, с. 357]. Ми впевнені, ураховуючи, що прогностична діяльність - це зазвичай діяльність 3 інформацією, характеристика прогностичної компетентності як аналітичної є доволі влучною;

гнучкість і креативність мислення (причому, на думку $€$. Рапацевича, саме завдяки гнучкості мислення людині вдається знайти новий підхід, нові способи вирішення, що найбільш повно відповідають вимогам певного завдання [7, с. 124-125]). Як зазначає Л. Петришин, сучасна професійна освіта вирізняється такою організацією навчання, виховання та розвитку креативної особистості, у якій як педагог, так і студент матиме сприятливі умови для самореалізації, буде прагнути отримати креативний продукт як результат інтелектуальної та професійної діяльності та буде здатним до прийняття самостійних креативних рішень [8, с. 53]. Ураховуючи, що процес прогнозування носить ймовірнісний характер, упевнені, що творчий підхід до його реалізації має бути основою реалізації такої діяльності;

- розвинуті емпатійні здібності, тактовність, яку ми трактуємо як здатність у процесі прогностичної міжособистісної взаємодії поставити себе на місце іншої особи, поглянути на проблему 3 іншого ракурсу, емоційно відгукнутися на питання іншої людини;

- організованість, дотримання відповідних професійно-етичних норм і принципів, саморозвиток особистості, самопізнання, коли спільна взаємодія базується на принципах взаємоповаги, взаємодопомоги та взаємодовіри;

- чітке усвідомлення майбутніми бакалаврами комп'ютерних наук значущості прогностичної діяльності та бажання її здійснювати;

- здатність до прогнозування, можливість відтворення (моделювання) [9, с. 97].

Отже, компонентно-структурний аналіз фрормування прогностичної компетентності майбутніх бакалаврів комп'ютерних наук дозволив нам чітко виявити сутність досліджуваного поняття та конкретизувати його зміст.

Висновки. Представлено авторське бачення дефініції «прогностична компетентність бакалаврів комп'ютерних наук», під якою розуміється інтегрована професійно значуща якість особистості, що ґрунтується на системі прогностичних знань, умінь, навичок, попередньому досвіді та сприяє цілеспрямованому випереджувальному плануванню й передбаченню ймовірних змін у галузі інформатики та інформаційних технологій, знаходженню альтернатив і вибору найбільш доцільних варіантів рішень професійних проблем з урахуванням потенційних ризиків і мож- 
ливостей. Установлено, що прогностичну компетентність майбутніх бакалаврів комп'ютерних наук варто розглядати як результат їхньої прогностичної діяльності. Визначено структуру прогностичної компетентності майбутніх бакалаврів комп'ютерних наук, що містить такі компоненти: мотиваційно-ціннісний, теоретичний, технологічний, контрольно-рефлексивний та особистісний. Загалом розглянуті теоретико-методологічні аспекти дослідження стали для нас міцним підґрунтям щодо переходу до наступного його етапу, пов'язаного з аналізом реальної практики фрормуванняпрогностичноїкомпетентностів3ВОУкраїни.

\section{БІБЛІОГРАФІЧНИЙ СПИСОК:}

1. Стандарт вищої освіти України першого (бакалаврського) рівня ступеня «бакалавр» за галуззю знань 12 «норормаційні технології» спеціальності 122 «Комп'ютерні науки URL : //mon.gov.ua/storage/ app/media/vishcha-osvita/zatverdzeni\%20standarty/ 2019/07/12/122-kompyuterni-nauki-bakala vr.pdf.

2. Пузіков Д.О. Навчально-методична література як засіб фрормування прогностичної компетентності сучасного вчителя. Проблеми сучасного підручника. 2018. Вип. 21. С. 358-371.

3. Педагогічні технології в сучасних наукових дослідженнях: досвід та інновації : моно- грасрія / за ред. С.Я. Харченка. Старобільськ : Вид-во ДЗ «ЛНУ імені Тараса Шевченка». 2017. 372 c.

4. Підготовка майбутнього вчителя до впровадження педагогічних технологій / за ред. І. Зязюна, О. Пєхоти. Київ, 2003. 240 с.

5. Ягупов В.В. Величко Н.О., Гириловська І.В., Гуралюк А.Г., Закатнов Д.О., Майборода Л.А., Паржницький В.В. Розвиток інфрормаційно-аналітичної компетентності педагогічних працівників ПТНЗ: теорія і практика : монографрія. ТОВ «НВП Поліграфрсервіс», 2014. 176 с.

6. Подласый И.П. Продуктивная педагогика : Книга для учителя. Москва : Народное образование, 2003. $496 \mathrm{c}$.

7. Психолого-педагогический словарь / под ред. Е.С. Рапацевич. Минск, 2006. С. 124-125.

8. Петришин Л.Й. Технологічний аспект фрормування креативності фрахівців соціальної сфрери у контексті фрахової підготовки. Педагогічні технології в сучасних наукових дослідженнях: досвід та інновації. Старобільськ : Вид-во ДЗ «ЛНУ імені Тараса Шевченка». 2017. С. 53-98.

9. Азаров І.С. Підготовка майбутніх офріцерів до прогностичної діяльності у процесі навчання у вищих військових навчальних закладах : дис. ... канд. пед. наук : 13.00.04. Київ ; Нац. ун-т оборони України ім. І. Черняховського. 2018. 270 с. 
КОМПОНЕНТИ, КРИТЕРІЇ ТА РІВНІ ПРОФЕСІЙНОЇ ГОТОВНОСТІ

МАЙБУТНІХ ОФІЦЕРІВ ОРГАНУ ПРОБАЦІЇ ДО СОЦІАЛЬНО-ВИХОВНОЇ РОБОТИ 3 НЕПОВОЛІТНІМИ

\section{COMPONENTS, CRITERIA AND LEVELS OF PROFESSIONAL READINESS OF FUTURE PROBATION OFFICERS FOR SOCIAL AND EDUCATIONAL WORK WITH JUVENILES}

УДК $371.3+37.013 / 015.4: 376.58$ DOI https://doi.org/10.32843/2663$6085 / 2020 / 24-2.33$

\section{Шпортюк О.М.,}

старший викладач кафедри педагогіки та гуманітарних дисциплін Академії Державної пенітенціарної служби
У статті розкрито актуальність спеціальної фрахової підготовки майбутніх офріцерів органу пробації для роботи з неповнолітніми. Проаналізовані підходи науковців до визначення десрініцій «підготовка», «професійна підготовка», «готовність», Розглянуто поняття та визначено структуру готовності майбутніх офріцерів органу пробації до соціально-виховної роботи з неповнолітніми.

Визначено ц̆ теоретично обрурунтовано компоненти готовності майбутніх офріцерів органу пробації до соціально-виховної роботи з неповнолітніми, які мають відповідні кількісно-якісні прояви - показники, що висвітлюють і розкривають зміст готовHOCMi.

Для визначення готовності офріцерів органу пробації до соціально-виховної роботи з неповнолітніми виділено мотиваційно-ціннісний, когнітивно-змістовий; діяльнісний та особистісно-комунікативний компоненти. Конкретизовано критерії просресійної готовності до соціально-виховної роботи за кожним компонентом. Кожен критерій включає сукупність якісних показників, що розкривають зміст та надають характеристику готовності офріцерів органу пробації до соціально-виховної роботи з неповнолітніми. Ураховуючи визначені компоненти та рівні готовності, виокремлено високий, достатній, середній та низький рівень готовності до соціально-виховної роботи майбутніх осріцерів органу пробації. Рівень готовності до соціально-виховної роботи з неповнолітнім майбутніх офріцерів органу пробачіі залежить від організації цілеспрямованої підготовки до соціально-виховної роботи з неповнолітніми, яка передбачає формування мотиваційно-ціннісного інтересу до змісту майбутньої діяльності, засвоєння соціальнопедагогічних знань та умінь проведення соціально-виховних заходів, а також наявність особистісних цінностей та оволодіння комунікативним уміннями та навичками, що необхідні для есективного виконання професійної діяльності.

Ключові слова: професійна підготовка, готовність, соціально-виховна робота, неповнолітні, компоненти готовності; критерії, показники, рівні готовності.

The article reveals the relevance of special professional training of future probation officers for work with juveniles. For social and educational work with juveniles probation officers must have new work approaches, which necessitates a wider range of professional competencies, liquid knowledge, skills and abilities that will allow them to perform productively the key tasks of the probation service. Scientists approaches of definitions determination of "training", "professional training", "readiness" are analyzed. The concept and structure of future probation officers probation officers readiness for social and educational work with minors are considered. By the definition of professional readiness for social and educational work with juveniles we mean the acquisition of social and educational competence by the future officers of the probation body, which includes a set of pedagogical, psychological, legal knowledge, formation of professional psychological and pedagogical skills, abilities and values that stipulates effective problem solving of probation in accordance with the principles, enshrined in legislation on probation taking considering characteristics of juveniles.

The components of readiness of future probation officers for social and educational work with juveniles have been identified and theoretically substantiated, which have appropriate quantitative and qualitative manifestations - indicators that reveal the content of they readiness. To determine the probation officers' readiness for social and educational work with juveniles, motivational, cognitive and meaningful content; active and personal-communicative components were highlighted in the article.

The criteria of professional readiness for social and educational work for each component are specified. Each criterion includes a set of qualitative indicators that reveal the content and characterize the probation officers' readiness for social and educational work with juveniles.

Given the identified components and levels of readiness, such levels as high, sufficient, medium, and low levels of readiness for social and educational work of future probation officers are highlighted. The level of readiness for social and educational work with juveniles of future probation officers depends on the organization of purposeful preparation for social and educational work with juveniles, which involves the formation of motivational and value interest in the content of future activities, learning socio-pedagogical knowledge and skills of social and educational activities, as well as the presence of personal values and mastery of communication skills and abilities necessary for the effective performance of professional activities.

Key words: professional training, readiness, social and educational work, juveniles, components of readiness; criteria, indicators, levels of readiness.
Постановка проблеми у загальному вигляді. Важливим аспектом впровадження ювенальної юстиції в пенітенціарній системі стала необхідність підготовки кваліфрікованих кадрів для роботи з неповнолітніми в органах пробації, слідчих ізо- ляторах та виховних колоніях. За останні декілька років різко скоротилась кількість неповнолітніх засуджених до покарань у виді позбавлення волі та знизилась кількість утримуваних у виховних колоніях. Основне завдання з виховання, виправлення 
та ресоціалізації неповнолітніх порушників закону покладено на органи пробації. Офріцери органів пробації та секторів ювенальної пробації відповідно до Закону України «Про пробацію» та Типового Положення про сектор ювенальної пробації здійснюють нагляд та соціально-виховні заходи стосовно неповнолітніх засуджених до покарань у вигляді позбавлення права обіймати певні посади або займатися певною діяльністю, громадських робіт, виправних робіт; неповнолітніх осіб, звільнених від відбування покарання з випробуванням і повинні володіти необхідним об'ємом знань та професійних навиків для проведення соціальновиховної роботи заходів щодо неповнолітніх, реалізації пробаційних програм; забезпечення взаємодії з органами і службами у справах дітей, що здійснюють їх соціальний захист і профрілактику правопорушень, під час здійснення заходів пробації щодо неповнолітніх; узагальнення та аналізу інформації про неповнолітніх осіб для визначення їх потреб у наданні соціально-педагогічних, соціально-медичних, соціально-економічних, психологічних, юридичних та інорормаційних послуг.

Як бачимо, перед офріцерами органу пробації стоїть значно ширше коло завдань та посадових обов'язків ніж перед їх попередниками (інспекторами кримінально-виконавчої інспекції), що стосується проведення соціально-виховної роботи 3 неповнолітніми, володіння новими підходам у роботі й зумовлює наявність більш розширеного спектру профресійних компетентностей, ліквідних знань, вмінь та навичок, які дозволять продуктивно вирішувати ключові завдання служби пробації у тому числі із застосуванням соціальновиховних заходів. Тому виникає необхідність для розробки спеціального курсу та створення моделі підготовки курсантів до роботи 3 неповнолітніми в органах пробації.

Аналіз останніх досліджень і публікацій. Проблема підготовки та готовності до професійної діяльності була предметом досліджень багатьох учених у різних галузях: педагогіки, психології та права. Питанням створення та розвитку служби пробації, а також підготовці кваліфрікованого персоналу для даної служби свої наукові праці присвятили О. Беца, О. Богатирьова, А. Галай, О. Дука, Д. Ягунов, І. Яковець, О. Янчук. Педагогічні аспекти готовності до професійної діяльності такими вченими як І. Богданова, Л. Григоренко, І. Зязюн, Г. Нагорна, М. Малькова, В. Поліщук. Підготовку до соціально-виховної роботи з неповнолітніми, які перебувають у конфлікті з законом у своїх наукових працях, вивчали В. Анголенко, Л. Завацька, А. Капська, О. Караман, О. Третяк О. Федоренко, однак проблема визначення компонентів, критеріїв та рівнів готовності майбутніх офріцерів органу пробації до соціально-виховної роботи з неповнолітніми є не достатньо розкритою.
Виділення невирішених раніше частин загальної проблеми. Мета -проаналізувавши актуальні наукові праці, які висвітлюють тематику дослідження, вимоги щодо компетентності працівника пробації та нормативну базу, що стосується завдань та повноважень офріцерів органу пробації та секторів ювенальної пробації, визначити компоненти, критерії та рівні професійної готовності офріцерів пробації до соціально-виховної роботи з неповнолітніми, які перебувають у конфлікті з законом.

Виклад основного матеріалу. Для реалізації мети дослідження пропонуємо розглянути підходи науковців щодо формулювання поняття професійної підготовки та готовності; визначення компонентів, критеріїв (показників) та рівнів готовності майбутніх фрахівців до проведення соціально-виховної роботи з неповнолітніми.

Так, Словник української мови трактує «підготовку» як запас знань, навичок, досвід, набутий у процесі навчання, практичної діяльності [10, с. 418]. У наукових працях «підготовку» розглядають як процес навчання, набуття навиків реальних та потенційних працівників, необхідних для виконання відповідної роботи, сукупності робіт; як навчання, тобто спеціально організований процес формування готовності до виконання майбутніх посадових обов'язків.

Педагогічна енциклопедія розкриває зміст «профресійної підготовки» як сукупності спеціальних знань, умінь, навичок, якостей, трудового досвіду, і норм поведінки, що забезпечують можливість успішної роботи з певної професії; процес повідомлення учням відповідних знань і умінь [6, с. 573].

Так, професійна підготовка будь-якого фрахівця - це процес і результат фрормування їхньої готовності до роботи за фрахом, що здійснюється шляхом оволодіння сукупністю відповідних знань, вмінь та навичок. У Законі України «Про вищу освіту» зазначається, що професійна підготовка - це здобуття кваліфрікації за відповідним напрямом підготовки або спеціальністю [8].

Профресійна готовність до конкретного виду діяльності, як узагальнював дослідження вчених Ф. Думко, - це цілеспрямоване вираження особистості, що обіймає установку, погляди і переконання, систему відносин, мотивацію, емоційно-вольові та розумові якості, професійну компетентність та навички і вміння їі практичного втілення [2]. Поняття «готовність до роботи» на думку В. Поліщук, розглядається як прояв професійної компетентності майбутнього фрахівця, яка $€$ своєрідним синтезом професійних знань, індивідуального стилю професійної діяльності, творчого підходу до професійної діяльності, педагогічної реорлексії [7]. Л. Григоренко характеризує готовність як сукупність професійно-педагогічних знань, умінь, навичок та особистісних якостей, які забезпечують результативність роботи [1]. Готовність 
до соціально-виховної роботи 3 неповнолітніми М. Малькова визначає як засвоєння профресійних знань стосовно особливостей розвитку підлітків, специфіки соціально-педагогічної взаємодії $з$ дітьми підліткового віку, а також оволодіння толерантним стилем педагогічного спілкування 3 неповнолітніми [4].

Призначення готовності полягає в забезпеченні високих результатів під час виконання будь-якої роботи. Аналізуючи наукові джерела, можемо дійти висновку, що готовність передбачає:

1) наявність внутрішньої мотивації, позитивне ставлення до професійної діяльності, стійку зацікавленість цією діяльністю;

2) відповідні вимогам професійної діяльності риси характеру і здібності;

3) отримання необхідних знань, умінь та набуття певних професійних навичок.

Готовність фрахівця до виконання професійних обов'язків науковці досить часто розглядають у психологічному аспекті, який проявляється у суті властивостей та стані особистості. Із психологічного погляду готовність може визначатися як певна зібраність особистості, яка допомагає їй актуалізувати і використовувати свої можливості для успішних дій, тобто це є внутрішнє налаштування на певну поведінку в процесі виховної діяльності, що вимагає розуміння профресійних завдань, усвідомлення своєї відповідальності та бажання досягти успіхів [11, с. 160-171].

Отже, можна стверджувати, що у структурі педагогічного розуміння поняття «готовності» $€$ психологічний контекст, який включає в себе моральні і психологічні якості і можливості особистості.

Соціально-виховна робота $€$ одним із основних напрямів діяльності офріцера органу пробації. Під професійною готовністю до соціальновиховної роботи з неповнолітніми ми розуміємо набуття майбутніми офріцерами органу пробації соціально-виховної компетентності, що включає в себе сукупність педагогічних, психологічних, юридичних знань, сорормованість професійних психолого-педагогічних умінь, навичок та ціннісних орієнтирів, що зумовлюють ефективне вирішення завдань пробації відповідно до принципів, закріплених законодавством про пробацію та з урахуванням особливостей неповнолітніх; здійснення соціально-виховних, корекційних, профрілактичних заходів щодо неповнолітніх суб'єктів пробації.

Тому для визначення рівня підготовки майбутніх офріцерів органу пробації до соціально-виховної роботи з неповнолітніми, педагогічних умов та розробки моделі підготовки необхідно установити компоненти професійної готовності.

Під час дослідження компонентів готовності до соціально-виховної роботи 3 неповнолітніми майбутніх офріцерів органу пробації постає необхідність у визначенні базових понять, таких як «крите- рій», «показник». Можна стверджувати що критерії це ознака, на основі якої проводиться оцінювання; засіб перевірки, мірило оцінювання. У теорії пізнання - ознака істинності чи правильності [5].

Тобто критерії - це показники, за допомогою яких можна судити про розвиток та/або якогось явища або процесу. У науковій теорії під критерієм розуміють властивості, якості певного явища, що відображають його суттєві характеристики і підлягають оцінюванню. Критерії та показники повинні бути об'єктивними; включати найістотніші аспекти досліджуваного об'єкта чи явища; формулюватися конкретно, ясно й точно; вимірювати саме те, що хоче дослідник [3]. Критерій передбачає низку показників. Поняття «показник» означає характерну рису або відмінність досліджуваного об'єкта, своєрідний індикатор його якісні чи кількісних властивості, а також результати конкретного виду діяльності або процесу.

На підставі проаналізованої літератури та наукових підходів нами виокремлено компоненти готовності до соціально-виховної роботи 3 неповнолітніми майбутніх офріцерів органу пробації та їхні критерії (показники)

На наш погляд, готовність до соціально-виховної роботи 3 неповнолітніми майбутніх офріцерів органу пробації повинна складатись із таких компонентів:

1) мотиваційно-ціннісного;

2) когнітивно-змістового;

3) діяльнісного;

4) особистісно-комунікативного.

Мотиваційно-ціннісний компонент готовності майбутніх офріцерів органу пробації до соціально-виховної робот з неповнолітніми виражається у професійній зацікавленості майбутньою роботою в органах пробації, де знаходяться на обіку неповнолітні, які перебувають у конфлікті 3 законом. Даний компонент зумовлений структурою системи підготовки, яка повинна починатись 3 формування позитивної мотивації до навчання, усвідомлення необхідності такої підготовки. На необхідність формування мотивації професійної діяльності вказували такі відомі науковці, як М. Ануфррієв, О. Бандурка, В. Васильєв, Н. Гранат, І. Жданова, В. Кожевніков, Л. Корнєва, А. Маркова, В. Соболєв, О. Столяренко, О. Ярмиш та інші. Необхідність формування мотиваційного компоненту зумовлена логікою процесу підготовки, яка починається 3 фрормування позитивної мотивації до навчання, усвідомлення необхідності такої підготовки. Поняття мотивації є комплексним і включає в себе установки, мотиви, потреби, ціннісні орієнтації, ставлення й інтереси. Причому мотиваційний компонент професіоналізму поєднує в собі два види мотивації: пізнавальну та професійну. 3 одного боку, пізнавальна мотивація (пізнавальні потреби, інтереси, установки) необхідна для якіс- 
ного засвоєння знань, умінь та навичок, які треба засвоїти у процесі підготовки до профресійної діяльності. 3 іншого боку, враховуючи специсріку роботи офріцерів пробації й роботи 3 неповнолітніми зокрема, необхідно у процесі професійної підготовки формувати і професійну мотивацію, оскільки саме її сорормованість забезпечує якісне виконання професійних обов'язків, усвідомлення необхідності і важливості своєї профресії, установки на досягнення цілей та високих результатів у роботі, інтересу та позитивного ставлення до неї [9].

Сорормованість мотивації та усвідомлення суспільної значущості виконуваної роботи, а саме проведення соціально-виховної роботи з неповнолітніми забезпечує якісне виконання професійних обов'язків, установки на досягнення цілей, інтересу до взаємодії з неповнолітніми, позитивне ставлення як до неповнолітніх так і до самої роботи.

Мотиваційно-ціннісний компонент готовності майбутніх офріцерів органу пробації до соціально-виховної роботи 3 неповнолітніми характеризується розвитком профресійних інтересів, мотивів, установок, потреб, прагнень ефективно здійснювати діяльність, бажання виявити та реалізувати свої професійні здібності;

Якісні показники (критерії) готовності за цим компонентом визначаються:

- інтересом до обраної профресії, особистою зацікавленістю майбутнього офіцера органу пробації до проведення соціально-виховної роботи 3 неповнолітніми;

- стійкою мотивацією курсантів до організації професійної соціально-виховної роботи з неповнолітніми порушниками закону;

- ціннісними орієнтаціями (гуманність, толерантність, тактовність, справедливість, соціальна активність та небайдужість, відповідальність, добропорядність, прагнення до саморозвитку);

- позитивним ставленням до навчання, до проходження ознайомчої практики та стажування;

- стійкими мотивами до поглиблення й успішного вивчення фрахових дисциплін, потребою в досягненні позитивних результатів у навчанні та практичній діяльності, зацікавленістю у вирішенні соціальних та виховних питань неповнолітніх;

- інтересом до практичної роботи з неповнолітніми, які перебувають у консрлікті із законом, упровадженням диореренційованого виховного впливу;

- усвідомленням значущості та розуміння необхідності проведення соціально-виховної роботи 3 неповнолітніми, які знаходяться на обліку в органах пробації.

Когнітивно-змістовий компонент готовності майбутніх офріцерів органу пробації до соціально-виховної роботи 3 неповнолітніми характеризується змістом теоретичних знань про соціально-виховну роботу 3 неповнолітніми (понять, визначень, термінів, принципів, наукових теорій) та методичних знань (обізнаністю з фрормами, методами та програмами соціально-виховної роботи 3 неповнолітніми, які перебувають на обліку в органах пробації), засобів впливу на особистість, знання певних процедур, алгоритмів та взаємодій різних інституцій).

Якісними показниками (критеріями) готовності за цим компонентом вважаємо:

- якісне оволодіння майбутніми офріцерами органу пробації теоретичними знаннями із соціальної та пенітенціарної педагогіки, загальної та пенітенціарної психології, права, соціальної роботи, соціально-виховної роботи із засудженими;

- засвоєння засад кримінальної юстиції щодо неповнолітніх, міжнародних стандартів поводження 3 неповнолітніми порушниками закону, а також основ державної політики та соціальноправового захисту неповнолітніх, які перебувають у конорлікті із законом;

- засвоєння знань щодо основних соціальнопедагогічних понять і методичних інструментів роботи офріцера пробації з неповнолітніми та їхнім оточенням;

- оволодіння знаннями щодо теорії фрормування протиправної поведінки та фракторів, що зумовлюють її розвиток у підлітків;

- набуття курсантами знань щодо особливостей підліткового віку, специфріки потреб та інтересів неповнолітнього, кола проблем підліткового середовища, причин їх виникнення та механізмів нейтралізації;

- оволодіння основами кейс-менеджменту та умовами ефрективної профрілактичної/корекційної роботи 3 неповнолітніми;

- засвоєння змісту та різновидів пробаційних програм щодо неповнолітніх та алгоритму їх застосування.

Діяльнісний компонент готовності майбутніх офріцерів органу пробації до соціальновиховної роботи з неповнолітніми включає в себе професійні компетентності, що проявляються в уміннях і навичках організовувати та ефективно здійснювати практичну діяльність відповідно до завдань пробації та принципів, закріплених законодавством про пробацію та з урахуванням особливостей неповнолітніх суб'єктів пробації.

Якісними показниками (критеріями) діяльнісного компоненту готовності курсантів до професійної роботи у вказаному напрямку вважаємо:

- здатність використовувати теоретичний і методичний багаж знань у площині практичної професійної діяльності, самостійно здійснювати планування, організацію та аналіз соціальновиховної роботи;

- оволодіння методикою оцінки вірогідності вчинення повторного кримінального правопорушення неповнолітньою особою; 
- набуття вмінь щодо проведення оцінки ризиків та потреб у межах проведення соціальновиховної роботи із засудженими неповнолітніми в органах пробації;

- набуття вмінь проведення інтерв'ю $з$ метою збору інфрормації та проведення встановлення довіри з неповнолітнім;

- набуття навичок ведення випадку (кейсменеджмент);

- набуття навичок ефективної профрілактичної/ корекційної роботи з неповнолітніми;

- освоєння навичок реалізації пробаційних програм для неповнолітніх суб'єктів пробації;

- освоєння вмінь когнітивно-поведінкового втручання, мотиваційного консультування та набуття медіативних навичок;

- набуття вмінь взаємодії 3 державними та недержавним інституціями в тому числі волонтерськими організаціями.

Особистісно-комунікативний компонент готовності майбутніх офріцерів органу пробації до соціально-виховної роботи 3 неповнолітніми характеризується особистісно-ціннісними, професійними та комунікативними якостями та психологічними характеристиками майбутнього офріцера органу пробації, які сприятимуть його фаховим здібностям організовувати та проводити соціально-виховні заходи 3 неповнолітніми, а також есрективно спілкуватися, встановлювати з ними контакт та довірливі стосунки.

Якісними показниками (критеріями) готовності за цим компонентом вважаємо:

- особистісний - емпатія; спостережливість; толерантність; відповідальність; педагогічний такт; нервово-психічна стійкість; оптимізм; працездатність; уважність; ввічливість;

- комунікативний - вміння слухати; щирість; небайдужість; доброзичливість; відкритість; відсутність стигми; прийняття; уміння чітко та послідовно викладати інорормацію при спілкуванні; простота та зрозумілість фрраз при побудові речень, відсутність незрозумілих термінів; уміння фрормулювати закриті та відкриті запитання; уміння чітко відповідати на запитання неповнолітніх; уміння активно слухати, інтерпретувати, перефразовувати.

Ураховуючи зазначені компоненти та критерії готовності майбутніх офріцерів органу пробації до соціально-виховної роботи 3 неповнолітніми, на нашу думку, доцільно виділити три рівні сорормованості: низький, середній, достатній, високий:

Низький рівень готовності характеризується навчанням без особливої зацікавленості, відсутністю прагнення пізнавати нову інфрормацію, низькою активністю, відсутністю зацікавленості роботою за фрахом, байдужістю до проведення соціально-виховної роботи з підлітками, неусвідомленням значення необхідності профрілактики агресивної поведінки, мотивації позитивних змін особистості неповнолітнього та поліпшення соціальних стосунків; мають фрагментарні теоретичні знання, не вміють враховувати індивідуальні особливості підлітків та їхню специфіку у практичній соціально-виховній діяльності, не вміють аналізувати власні професійні дії та результати, не спроможні без допомоги викладача здійснювати планування та організацію індивідуальної соціально-виховної роботи $з$ неповнолітніми; відсутність прагнення в подальшому удосконалення та розвитку свої знань та умінь, не вміють аналізувати свої професійні дії та результати .

Середній рівень готовності характеризується такими рисами: переважають зовнішні мотиви до навчання, оволодіння фраховими знаннями та вміннями; нестійкою мотивацією до нових знань, періодичним прагненням до оволодіння уміннями та навичками; недостатньою мотивацією щодо проведення соціально-виховної роботи з неповнолітніми; виконує завдання, але без творчого підходу, безініціативність, недостатня активність, недостатня допитливість, недостатня уважність; неналежне оволодіння умінням спілкування $з$ неповнолітніми; недостатній рівень самостійності, слабо виражене бажання самостійно визначати напрямок подальших дій, неналежний рівень оцінки результативності своєї діяльності.

Достатній рівень готовності до соціальновиховної роботи з неповнолітніми характеризується: позитивним ставленням до освоєння теоретичних знань та практичних навиків; наявністю внутрішніх пізнавальних мотивів, які визначають їхнє прагнення оволодіти фраховими знаннями та уміннями; професійна спрямованість та здібності виявляються, як правило, під час вивчення професійно орієнтованих дисциплін; усвідомленням значення соціально-виховного впливу на неповнолітніх в органах пробації; достатнім оволодінням теоретичними знаннями та практичними уміннями щодо організації соціально-виховної роботи з неповнолітніми з ефективною реалізацією її ключових аспектів; умінням використовувати педагогічний інструментарій та комунікативні здібності; здатністю до здійснення адекватної оцінки своєї роботи.

Високий рівень готовності до соціальновиховної роботи з неповнолітніми в органах пробації характеризується: чітко вираженим інтересом до опанування знаннями, уміннями та навичками щодо проведення соціально-виховної роботи; освоєнням вітчизняного законодавства та міжнародних стандартів у сорері кримінальної юстиції щодо неповнолітніх; чітким усвідомленням необхідності проведення соціально-виховних заходів із неповнолітніми суб'єктами пробації; чітко визначеною професійною спрямованістю; у навчальній діяльності просліджується необхідність набуття досвіду, вмінь самостійно приймати рішення; наявністю системних знань про суть, зміст, фрорми та 
методи соціально-виховної роботи 3 неповнолітніми; мають місце стійкі прояви ініціативи, активності, критичного мислення; прояви допитливості та старанності; оволодіння методиками оцінки вчинення повторного кримінального правопорушення, застосування пробаційних програм, технологій кейс-менеджменту; знання вікових психологічних особливостей неповнолітніх; володіння комунікативними технологіями спілкування 3 неповнолітніми; наявність бажання працювати з підлітками,

Висновок. Визначені компоненти, показники та критерії готовності майбутніх офріцерів органу пробації до соціально-виховної роботи 3 неповнолітніми не вичерпують усебічність професійної підготовки курсантів до цього виду діяльності, однак дають змогу окреслити напрямки та змоделювати структуру підготовки у даному напрямку.

Таким чином, можна зробити висновок, що рівень готовності до соціально-виховної роботи 3 неповнолітнім майбутніх офріцерів органу пробації залежить від організації цілеспрямованої підготовки до соціально-виховної роботи 3 неповнолітніми, яка передбачає орормування мотиваційно-ціннісного інтересу до змісту майбутньої діяльності, засвоєння соціально-педагогічних знань та умінь проведення соціально-виховних заходів, а також наявність особистісних цінностей та оволодіння комунікативним уміннями та навичками, що необхідні для ефективного виконання професійної діяльності.

Перспективами подальших розробок вважаємо розроблення моделі підготовки до соціальновиховної роботи з неповнолітніми майбутніх офріцерів органу пробації.

\section{БІБЛІОГРАФІЧНИЙ СПИСОК:}

1. Григоренко Л.В. Формирование готовности студентов педвуза к профессиональной деятельности в процессе самостоятельной работы : дис. ... канд. пед. наук : 13.00.04. Кривой Рог, 1991. 162 с.
2. Думко Ф.К. Підготовка курсантів до професійнопедагогічної роботи 3 неблагополучними сім'ями : автореср. дис. ... канд.. пед. наук : 13.00.04 / Пвденноукраїнський держ. пед. ун-т ім. К.Д. Ушинського. Одеса, 2000. 29 с.

3. Дьяченко М.И., Кандыбович Л.А. Психологические проблемы готовности к деятельности. Минск : ГБУ, 1978. 182 с.

4. Малькова М. Формування майбутньої профресійної готовності майбутніх соціальних педагогів до взаємодії з девіантними підлітками : автореф. дис. ... канд. пед.. наук : 13.00.05. Луганський нац. пед.. ун-т ім. Т. Шевченка, Луганськ, 2006. 22 с.

5. Ожегов С.И. Словарь русского языка: Около 70000 слов / под ред. Н.Ю. Шведовой. Москва : Русский язык, 1991. 917 с.

6. Педагогическая энциклопедия / за ред. А.И. Каирова. Москва : Сов. энциклопедия. 1998. T. $3.880 \mathrm{c}$.

7. Поліщук В. А. Теорія і методика профресійної підготовки соціальних педагогів в умовах неперервної освіти : дис. ...д-ра. пед. наук : 13.00.04 / Тернопільський нац. пед. ун-т імені Володимира Гнатюка. Тернопіль, 2006. 454 с.

8. Про вищу освіту : Закон України від 01.07.2014 р. № 1556-VII. Відомості Верховної Ради України. 2014. № 37-38. Ст. 2004.

9. Просресійно-психологічна підготовка працівників слідчих підрозділів. Мотивація професійної діяльності працівника OBC URL : http://megalib.com. ua/content/9724_Motivaciya_profesiinoi_diyalnosti_ pracivnika_OVS.h̄tml.

10. Словник української мови: в 11 т. АН Української РСР, Ін-т мовознав. ім. О.О. Потебні / за ред: І.К. Білодід. Київ : Наук. думка, 1970-1980. Том 6. С. $832 \mathrm{c}$.

11. Федоренко О. Система підготовки майбутніх працівників міліції до соціальної та виховної роботи з підлітками. Професійно-педагогічна підготовка - вимоги сьогодення: збірник наукових праць. Луганська державна академія культури і мистецтв. Харківський обласний метод. каб. учб. закл. культури і мистецтв. Харків, 2007. 


\section{ІННОВАЦІЙНА КОМПЕТЕНТНІСТЬ СУЧАСНОГО ПЕДАГОГА INNOVATIVE COMPETENCE OF A MODERN TEACHER}

УдК 378.147

DOI https://doi.org/10.32843/26636085/2020/24-2.34

\section{Штефан л.В.,}

докт. пед. наук, профресор, профресор кафедри педагогіки, методики та менеджменту освіти Української інженерно-педагогічної академії
Статтю присвячено дослідженню теоретичних основ інноваційної компетентності сучасних фрахівців педагогічної галузі. Спираючись на наукові підходи до розуміння суті поняття «компетентність», виділено два напрями його аналізу. Серед них: розуміння компетентності з позиції здатності до виконання певних дій та розуміння компетентності з позиції синтезу певних компонентів. 3'ясовано, що в межах кожного із цих напрямів суть компетентності визначається з певними відмінностями. Результатом проведеної роботи стало тлумачення компетентності як інтегративного утворення сучасного фрахівця, яке визначає його здатність якісно розв'язувати профресійні завдання на основі синтезу відповідних знань, умінь, досвіду діяльності та професійних якостей.

Зважаючи на те, що інноватизація освітньої діяльності підвищила увагу науковців до інноваційної компетентності фрахівців педагогічної галузі, проведено встановлення їі суті та специсріки.

На основі системного підходу структурними складовими частинами інноваційної компетентності педагога визначено розуміння ним значущості педагогічних інновацій як професійної цінності, володіння системою знань з організації інноваційної діяльності та вмінь з їі реалізації в освітньому процесі, досвід втілення інновацій завдяки ссрормованості комплексу особистісних якостей (креативність, відповідальність за свої дії, активність, наполегливість). Виходячи із цих висновків, інноваційну компетентність педагогів розглянуто як інтегративне особистісне утворення, яке визначає їхю здатність якісно розв'язувати завдання педагогічної діяльності на базі педагогічної інноватики через синтез необхідних знань, умінь, досвіду діяльності за умови сформованості відповідних профресійних якостей.

Ключові слова: інноваційна компетентність, компетентнісна парадигма, компетентність, фрахівці педагогічної галузі, структура інноваційної компетентHOCmi.

The article is devoted to the study of the theoretical foundations of innovative competence of modern specialists in the pedagogical field. Based on scientific approaches to understanding the essence of the concept of "competence", two areas of its analysis are identified. Among them: understanding the competence from the standpoint of the ability to perform certain actions and understanding the competence from the standpoint of the synthesis of certain components. It was found that within each of these areas, the essence of competence is defined with some differences. The result of this work was the interpretation of competence as an integrative education of a modern specialist, which determines his ability to qualitatively solve professional problems based on the synthesis of relevant knowledge, skills, experience and professional qualities.

Considering that the innovation of educational activity has increased the attention of scientists to the innovative competence of specialists in the pedagogical field, its essence and specificity have been established.

Based on a systematic approach, the structural components of the teacher's innovative competence determine his understanding of the importance of pedagogical innovations as a professional value, possession of a system of knowledge on the organization of innovative activities and skills in its implementation in the educational process, experience in implementing innovations, activity, persistence). Based on these conclusions, the innovative competence of teachers is considered as an integrative personal education, which determines their ability to qualitatively solve problems of pedagogical activity on the basis of pedagogical innovation through the synthesis of necessary knowledge, skills, experience provided they have the appropriate professional qualities.

Key words: innovative competence, competence paradigm, competence, specialists of pedagogical branch, structure of innovative competence.
Постановка проблеми у загальному вигляді. Сучасна освіта активно розвивається у напрямі реалізації компетентнісної парадигми, оскільки головним критерієм якості професійної підготовки виступає профресіоналізм фахівця. Водночас сьогодні перед освітою стоїть й завдання формування спеціалістів, здатнихтворчопідходитидовиконання профресійних завдань. Виходячи 3 цього, нагальною $€$ проблема фрормування інноваційної компетентності сучасного педагогічного працівника.

Аналіз останніх досліджень і публікацій. Аналіз наукової літератури свідчить про значну увага вчених до питань формування компетентності фахівців різноманітних профресійних напрямів (М. Головань, Дж. Равен, А. Садохін, Н. Сидорчук, та ін.), серед яких є і спеціалісти педагогічної галузі (М. Болотов, С. Гончаренко, І. Демура, Е. Зеєр,
В. Зінченко, О. Лебедєв, Н. Микитенко, І. Пометун, В. Ягупов та ін.). Останнім часом у числі різних видів компетентностей учені все частіше відзначають інноваційну компетентність спеціалістів різних фрахових ссрер (Н. Алексєєнко, О. Євдокімова, А. Постряков та ін.). Активізували дослідження у цьому напрямі й науковці з педагогічної галузі (Е. Артамонова, І. Дичківська, О. Ігнатович, Н. Калюжка та ін.)

Виділення невирішених раніше частин загальної проблеми. Сьогодні учені активно вивчають проблему реалізації компетентнісного підходу в педагогічній освіті. I це зрозуміло, оскільки саме цей підхід найбільшою мірою відповідає запитам соціально-економічного розвитку суспільства. Водночас вимоги до компетентності фрахівців педагогічної галузі посилюються необхід- 
ністю урахування при ії формуванні їхнього інноваційного потенціалу. Таким чином, $є$ актуальною проблема формування інноваційної компетентності сучасних педагогів.

Метою статті $€$ з'ясування поняття інноваційної компетентності сучасних педагогів, спираючись на наукові підходи до розуміння суті компетентності фрахівців.

Виклад основного матеріалу. Поняття «компетентність», не дивлячись на велику кількість досліджень щодо з'ясування його суті, все ще знаходиться у числі тих, наукове становлення яких ще триває. У цьому контексті цікавим $€$ фрілософрське розуміння компетентності як соціальної якості, що означає силу і впевненість, джерелом яких $€$ відчуття власної успішності та користі, що сприяє усвідомленню особистістю власної здатності есрективно взаємодіяти з оточенням [5, с. 51]. Історичні витоки такого його тлумачення беруть свій відлік з 60-х років XX століття, коли представники біхевіористського підходу прагнули розробити критерії з визначення ефективності діяльності людини в різних сфрерах суспільного життя [16]. У подальшому в 1986 році в Англії на урядовому рівні була розроблена Концепція компетентностей як різноманітних готовностей і вмінь виконувати певну роботу; набору поведінкових норм, що впливають на ефрективність праці [17].

Аналіз наукових джерел дозволив виявити такі напрями у розумінні суті компетентності як наукового терміна:

1. Розуміння компетентності з позиції здатності до виконання певних дій. Як таку ії розглядає Дж. Равен, наголошуючи, що компетентність - специфрічна здатність 3 ефективного виконання певних дій у конкретній професійній сфері $[13$, с. 30]. О. Лебедєв дає більш узагальнене визначення компетентності як здатності «діяти в ситуації невизначеності» [9, с. 4].

Н. Сидорчук, посилює психологічний аспект розуміння компетентності як складної інтегральної характеристики особистості, що визначається через «здатність вирішувати проблеми і типові завдання, які виникають у реальних життєвих ситуаціях, у різних сорерах діяльності на основі використання знань, навчального й життєвого досвіду відповідно до засвоєної системи цінностей» [15, с. 80]

Більш конкретно трактує компетентність І. Зязюн, наголошуючи, що це здатність вирішувати професійні задачі певного визначеного класу, що вимагає наявності реальних знань, умінь, навиків, досвіду [7, с. 14]. І. Демура розширює таке розуміння аналізованого поняття, стверджуючи, що компетентність - це здатність виносити кваліфріковані судження, приймати адекватні відповідальні рішення в проблемних ситуаціях, планувати й виконувати дії, що приводять до раціонального й успішного досягнення поставлених цілей [3, с. 66].
2. Розуміння компетентності з позиції синтезу певних компонентів. Таке тлумачення знаходимо в праці Н. Микитенко, де стверджується, що компетентності $€$ комплексом знань, умінь і ставлень, що набуваються у процесі навчання i дозволяють людині розуміти і оцінювати проблеми, характерні для різних сорер діяльності у різних контекстах [10, с. 33-34]. У цьому ж ракурсі розглядає це поняття й В. Зінченко, розуміючи його як спосіб існування знань, умінь, освіченості, який сприяє особистісній самореалізації, знаходженню свого місця у світі, внаслідок чого освіта постає як високовмотивована й особистісно орієнтована; як постійне оновлення знань, оволодіння новою інфрормацією для успішного вирішення професійних завдань у певний час і умовах [6, с. 36]. Знову як «сукупність знань і вмінь, необхідних для ефективної професійної діяльності: вміння аналізувати, передбачати наслідки діяльності, використовувати інфрормацію» визначається компетентність у словнику з профресійної освіти [12, с. 89].

М. Головань робить наголос на психологічній суті компетентності й розглядає ії як інтегративне утворення особистості, що інтегрує в собі знання, уміння, навички, досвід і особистісні властивості, які зумовлюють прагнення, здатність і готовність розв'язувати проблеми і завдання, що виникають у реальних життєвих ситуаціях, усвідомлюючи при цьому значущість предмету і результату діяльності» [2, с. 29].

Компетентність із позиції ступеня сорормованості навичок і вмінь, необхідних індивіду для здійснення відповідної діяльності, а також його здатності використовувати їх для реалізації своїх цілей розглядає аналізоване О. Садохін [14, с. 80].

Таким чином, у межах кожного з визначених нами напрямів розуміння суті компетентності $€$ певні нюанси. Дотримуватимося позиції В. Болотова та В. Серикова, які наголошують, що компетентність визначається не так знаннями, уміннями, навичками, як досвідом людини. Вчені зазначають, що вона постає як складний синтез когнітивного, предметно-практичного й особистісного досвіду» [1, с. 12].

Спираючись на проведений аналіз, розумітимемо компетентність як інтегративне утворення сучасного фахівця, яке визначає його здатність якісно розв'язувати професійні завдання на основі синтезу відповідних знань, умінь, досвіду діяльності та профессійних якостей.

Останнім часом через інноватизацію освітньої діяльності посилилась увага науковців до становлення суті та специфіки інноваційної компетентності фрахівців педагогічної галузі. Так, І. Дичківська розглядає цю компетентність через систему мотивів, знань, умінь, навичок, особистісних якостей педагога, що забезпечують ефеективність використання нових педагогічних технологій у роботі 
[4, с. 338]. 3 цієї ж позиції трактує інноваційну компетентність й О. Ігнатович. Вчена визначає їі як сукупність «спеціальних теоретичних знань з педагогічної інноватики та теорії інноваційної педагогічної діяльності, умінь ефективно застосовувати їх, практичних навиків» [8, с. 273].

Таким чином, поняття інноваційної компетентності педагога у цілому відтворює загальне розуміння суті компетентності фрахівця з акцентуванням уваги на інноваційній складовій його діяльності.

Представляє науковий інтерес трактування аналізованого поняття, представлене О. Постряковим [11]. Згідно з ним інноваційна компетентність фрахівця передбачає наявність інноваційного сприйняття суб'єкта, яке включає сприйняття власних інновацій і взагалі інновацій або відкриттів, здатність побачити елементи нового у відносно сталому та здатність запропонувати принципово нове розв'язання проблеми. Трансорормуючи таке тлумачення цієї компетентності у педагогічну площину, спираючись на системний підхід, відзначимо, що її структурними складовими частинами слід вважати розуміння педагогом значущості педагогічних інновацій як професійної цінності, володіння системою знань з організації інноваційної діяльності та вмінь з її реалізації в освітньому процесі, досвід втілення інновацій завдяки сфрормованості комплексу особистісних якостей (креативність, відповідальність за свої дії, активність, наполегливість тощо).

Підсумовуючи проведений аналіз, інноваційну компетентність педагогів розглядатимемо як інтегративне утворення, яке визначає їхню здатність якісно розв'язувати завдання педагогічної діяльності на базі педагогічної інноватики через синтез необхіднихзнань, умінь, досвідудіяльностізаумови сорормованості відповідних професійних якостей.

Виконання завдання з фрормування інноваційної компетентності фрахівців педагогічної галузі потребує кардинальних змін у змісті, фрормах, методах та засобах їхньої профресійної підготовки. Принципові зрушення повинні відбутися у системі підвищення кваліфікації профресорськовикладацького складу закладів вищої педагогічної освіти, оскільки, згідно з законом подібності, креативного студента може виховати лише креативний педагог. Особливої уваги потребує зміцнення зв'язків вишів 3 роботодавцями на взаємовигідній основі, гарантованій законодавчо-нормативною базою. Інноваційна освіта потребує значних фрінансових вкладень, які повинні витрачатись як на оновлення матеріально-технічної бази закладів вищої освіти, так і на стимулювання викладачів до інноваційної діяльності.

Таким чином, проведена робота дозволила сорормулювати такі висновки. Становлення педагога значною мірою відбувається на основі сорормованості у нього інноваційної компетентності, яка виступає базою його професіоналізму в сучасних умовах розвитку суспільства. На основі аналізу наукових джерел надано авторське тлумачення суті поняття «компетентність». Беручи до уваги системний підхід та напрацювання вчених, запропоновано структуру інноваційної компетентності педагога та надано визначення аналізованого поняття.

Перспективними напрямами проведеного дослідження $€$ визначення технологічних підходів до фрормування інноваційної компетентності майбутніх педагогів у закладах вищої освіти, з'ясування підходів до підвищення кваліфрікації професорсько-викладацького складу вишів, пошук шляхів дієвої взаємодії зі стейкхолдерами.

\section{БІБЛІОГРАФІЧНИЙ СПИСОК:}

1. Болотов В.А., Сериков В.В. Компетентностная модель от идеи к образовательной программе. Педагогика. 2003. № 10. С. 8-14.

2. Головань М.С. Компетенція і компетентність: досвід теорії, теорія досвіду. Вища освіта України. 2008. № 3. С. 23-30.

3. Демура І. Сутність профресійних компетентностей. Гуманізація навчально-виховного прочесу : зб. наук. праць. Слов'янськ : Видавництво центр СДПУ, 2007. Вип. XXXVIII. C. 64-71.

4. Дичківська І.М. Інноваційні педагогічні технології: навч. посіб. Київ : Академвидав, 2004. 352 с.

5. Залібовська-Ільницька 3.В. Професійно-педагогічні засади фрормування комунікативної компетентності молодших школярів : монограсрія. Житомир : вид-во ЖДУ ім. І. Франка, 2012. 240 с.

6. Зінченко В.П. Формування профорієнтаційної компетентності педагога: теорія і практика : монографія. Глухів : РВВ ГНПУ ім. О. Довженка, 2010. 198 с.

7. Зязюн І.А. Філософрія педагогічної якості в системі неперервної освіти. Вісник Житомирського державного університету імені Івана Франка. 2005. № 25. C. 13-18.

8. Ігнатович О.М. Специфріка фрахової інноваційної культури педагогічних працівників вищих навчальних закладів. Проблеми сучасної психології: зб. наук. праць Кам'янець-Подільського національного університету ім. І. Огієнка, Інституту психології ім. Г.С. Костюка АПН України /за заг. ред. С.Д. Максименка, Л.А. Онуфррієвої. Кам'янець-Подільський: Аксіома, 2009. Вип. 6, Ч. 1. С. 272-282.

9. Лебедев О.Е. Компетентностный подход в образованиии. Школьные технологии. 2004. № 5. C. 3-12.

10. Микитенко Н.О. Технологія формування іншомовної комунікаційної компетентності майбутніх фрахівців природничого профрілю: монографрія / за ред. Г.В. Терещука. Тернопіль : ТНПУ, 2011. 411 с.

11. Постряков А.А. Инновационная культура и креативность. Теория и методология творчества: итоги и перспективы : сб. трудов. Москва, Институт фрилософиии РАН, Российское фрилософрское общество, 2001.

12. Профресійна освіта : Словник : навч. посіб. / уклад. С.У. Гончаренко та ін. ; за ред. Н.Г. Ничкало. Київ : Вища школа, 2000. 149 с. 
13. Равен Дж. Компетентность в современном обществе: выявление, развитие и реализация. Москва : Когито-Центр, 2002. 396 с.

14. Садохин А.П. Компетентность и компетентностный подход в диалоге культур. Журнал социологии и социальной антропологии. Т. ХІ. 2008. № 2. C. 80-92.

15. Сидорчук Н.Г. Порівняльний аналіз понять «компетенція» та «компетентність» як складних психолого-педагогічних феноменів. Проблеми освіти: зб. наук. праць. Спецвипуск. Вінниця-Київ, 2015. C. 78-81.

16. Mertens L. Labour competence : emergence, analytical frameworks and institutional models. Cambridge : Cambridge University Press, 1999. 119 p.

17. Ruben B. Guidelines for Cross-Cultural Communication Effectiveness Readings in Cross-Cultural Communication. Cambridge, 1987. P. 36-46. 


\section{ПЕРЕКЛАДАЦЬКИЙ АСПЕКТ У МОДЕРНІЗАЦІЇ ПІДГОТОВКИ МАЙБУТНІХ ПЕДАГОГІВ НЕМОВНИХ СПЕЦІАЛЬНОСТЕЙ (НА МАТЕРІАЛІ ФРАНЦУЗЬСЬКОЇ МОВИ)

\author{
TRANSLATION ASPECT IN MODERNIZATION \\ OF TRAINING FOR FUTURE NON-LANGUAGE SPECIALTIES TEACHERS \\ (ON THE MATERIAL OF FRENCH LANGUAGE)
}

В умовах реформування освіти підготовка майбутнього педагога вимагає фрормування у студента здатності до навчання впродовж життя та безперервного поповнення й інтенсифрікації власного досвіду. Застосування новітніх технологій та підходів неабияк може допомогти в цьому прочесі. Стаття описує деякі важливі чинники модернізації та інтенсифрікації освітнього процесу в контексті перекладацького аспекту іншомовної підготовки майбутніх педагогів немовних спеціальностей. Виходячи із завдань, які стоять перед фрормуванням компетентності в перекладі текстів за фахом у майбутніх педагогів немовних спеціальностей, автори підходять до розкриття теми через пояснення поняття іншомовної комунікації та її складових частин, що дозволяє вичленувати важливі змістовні та організаційні моменти освітнього процесу. Серед важливих елементів такого прочесу та враховуючи сучасні прочеси комп'ютерізації освіти, автори роблять акцент на застосуванні інфрормаційних технологій та створення інфрормаційноосвітнього середовища вищого навчального закладу, що надає змогу суттєво впливати на зміст, форми, методи та засоби підготовки майбутніх педагогів.

Другим чинником є педагогічний дизайн, або педагогічне проектування, яке можна розглядати «як вид профресійної діяльності» майбутнього педагога і як необхідний елемент в організації освітнього процесу для підготовки у вищому педагогічному закладі освіти, адже воно дозволяє ретельно вибудовувати загальну структуру та конкретний зміст заняття.

Тому саме змістове наповнення кожного заняття, тобто опрацювання навчальної інформації відповідно до цілей підготовки майбутніх педагогів, $є$ важливим елементом, що дозволяє керувати процесом формування перекладацької компетентності в майбутніх педагогів немовних спеціальностей та корегувати їхні навчальні резульmamu.

Саме в контексті змістового наповнення освітнього процесу автори розглядають різноманітні класифікації вправ для навчання перекладу та пропонують на розгляд зведену таблицю видів вправ із зазначенням прі- оритетних типів завдань та діяльностей, надаючи конкретні практичні розробки для кожного виду.

Ключові слова: проектування, педагогічний дизайн, види іншомовної діяльності, перекладацька діяльність, IT в освіті.

In the context of education reformation, the future teachers training requires the student's ability to learn throughout life and constant replenishment and intensification of their own experience. The use of the IT technologies and approaches can help considerably. The article describes some important factors of modernization and intensification of the educational process in the context of foreign language translation learning for future teachers of non-language specialties. The authors approach the disclosure of the topic by explaining the concept of foreign language communication and its components, which allows to highlight important content and organizational aspects of the educational process.

Among the important elements of this process, taking into account modern processes of computerization of education, the authors emphasize the use of information technology and the creation of information-educational environment, which allows to significantly influence the content, forms, methods and means of future teachers training.

The second factor is instructional design, which can be considered as a kind of future teacher professional activity and as a necessary element in organizing the educational process, because it allows you to carefully build the overall structure and specific content of such process.

Therefore, the content of each lesson, or the processing of educational information in accordance with the objectives of future teachers training, is an important element that allows you to manage the process of translation competence formation for future teachers of non-language specialties and adjust their learning outcomes.

It is in the context of the content, that the authors consider various classifications of exercises for teaching translation and suggest a summary table of types of exercises with priority tasks and activities, providing specific practical developments for each type.

Key words: instructional design, types of foreign language activities, translation activities, IT in education.
Постановка проблеми. Процес підготовки компетентного фрахівця $є$ однією з головних проблем сучасної освіти. Відповідно до цього і мета освіти зараз спрямована на фрормування базових компетентностей, що містять особистісні (не лише інтелектуальні, а й емоційні та моральні) складові частини, які повинні бути сорормовані у процесі навчання й одночасно містити знання, вміння та навички діяльності разом із поведінковими моделями.

Аналіз останніх досліджень. Велика кількість сучасних досліджень присвячена проблемам підготовки педагогів певного профрілю (С.К. Голубєва, Л.О. Харитонова), питання компетентності були розглянуті дослідниками В.П. Безпалько, В.С. Безрукової, Т.В. Добудько 
та ін. Взагалі можна виділити декілька напрямів у проблемі формування базових компетентностей майбутніх педагогів: це й діяльнісний підхід (Н.В. Кузьмін, О.М. Шиян), і трактування професійної компетентності як характеристики особистості (Є.В. Арцишевська), їі якості (Р.Х. Шакуров) або рівня освіченості (Б.С. Гершунський).

Виділення не вирішених раніше проблем. Але за останні роки виявилися суперечності між соціальним замовленням, пов'язаним з підготовкою фрахівця, майбутнього педагога, та традиційною практикою, що відображає орієнтацію, головним чином, на репродуктивний тип виконання його дидактико-педагогічних функцій. Це вимагає перебудови самої структури педагогічної діяльності через застосування новітніх технологій та підходів задля фрормування спроможності студента до навчання впродовж життя та безперервного поповнення й інтенсифікації власного досвіду та активної його передачі у своїй майбутній професії.

Формулювання цілей. На наш погляд, важливими елементами такої інтенсифрікації $€$ використання освітніх можливостей Інтернету та мультимедійних засобів навчання, ефективна організація освітнього середовища (його педагогічний дизайн) та ретельний підбір й підготовка змістової складової частини освітнього процесу. Розглянемо послідовно ці компоненти в контексті перекладацького аспекту іншомовної підготовки майбутніх педагогів немовних спеціальностей

Виклад основного матеріалу. Слід зазначити, що розвиток Інтернету - це найбільше відкриття людства. Сьогодні Інтернетом користується понад $50 \%$ світового населення, оскільки його застосування можна знайти у всіх сорерах життя. Інфрорматизація та комп'ютеризація освітнього середовища вимагає від майбутнього викладача такі знання, уміння та навички, які знадобляться йому в умовах інфрормаційного суспільства.

До того ж більшість навчальних матеріалів, навчальних платфрорм доступних сьогодні в Інтернеті розроблені в Європі чи Північній Америці, тому мережа $€$ незрівнянним засобом розширення освітніх можливостей. Разом із тим слід зазначити той фракт (останні події, пов'язані 3 карантином доводять це), що багато університетів (в тому числі й вітчизняних) зараз перенаправляють програми дистанційного навчання до Інтернету.

«Такі перетворення вимагають якісно нової підготовки фрахівця, здатного швидко орієнтуватися в інорормаційному просторі, знаходити нові шляхи вирішення виробничих проблем, спроможного систематично використовувати джерела інсрормації іноземною мовою» [2, с. 73].

Вітчизняні вчені Биков В.Ю., Жук Ю.О. [1] говорять про важливість включення інфрормаційної складової частини до профресійної компетентності майбутнього вчителя, а отже, й відповідної їх під- готовки, що має включати фрормування наступних знань і умінь:

1) знання основ науково-інфрормаційної діяльності;

2) знання основ організації навчального процесу в середовищі інфрормаційно-комунікаційних технологій;

3) вміння використовувати традиційні і мережеві ресурси (Інтернет та ін.) для пошуку та відбору інорормації;

4) вміння володіти принципами і методами аналітико-синтетичної обробки інформації;

5) знання і вміння використання аудіовізуальних та інтерактивних засобів навчання тощо.

Також слід зазначити й необхідність фрормування певних особистісних характеристик сучасного фрахівця: готовність до впровадження нових методів, креативність в рамках освітньо-технологічних можливостей, навички та вміння працювати з інфрормацією та адаптувати матеріал за певними потребами, навички критичного мислення тощо.

Окрім інформаційної складової частини, вплив всесвітньої мережі - Інтернету, яка забезпечує доступ до різних галузей та надбань іноземними мовами, з одного боку, і необхідність швидко і якісно реалізовувати їх на практиці, з іншого, вимагає від майбутніх педагогів якісно нових навичок i вмінь іншомовної комунікації.

Розглянемо більш детально це поняття. На думку багатьох учених, іншомовна комунікація - це комплекс явищ, пов'язаних з обміном інфрормацією між людьми за посередництвом універсальної системи звукових або графічних знаків, мови. При цьому треба пам'ятати про наявність і немовної комунікації, що здійснюється за допомогою жестів, міміки будь-яких умовних сигналів і т.д.

Усі види немовної комунікації $€$ другорядними порівняно 3 комунікацією мовною, або мовленнєвою діяльністю. По-перше, мовна комунікація універсальна, оскільки вона обслуговує всі сорери розумової і фрізичної діяльності людини, немовна ж - використовується або в спеціальних ситуаціях, або як допоміжна по відношенню до мовної. По-друге, мовна комунікація первинна, оскільки на ній базується мислення людини.

Комунікативні явища, які стосуються передачі повідомлень, називаються продуктивними, а до прийому повідомлень - рецептивними. I відповідно, види комунікативної діяльності теж будуть продуктивними і рецептивними. Слід зазначити, що підготовка студента до здійснення комунікативної діяльності має проводитись в обох напрямках.

Нижче наведена схема класифрікації видів іншомовної комунікативної (мовленнєвої) діяльності (таблиця 1).

3 таблиці видно, що до усних видів іншомовної мовленнєвої діяльності належать говоріння передача звукових повідомлень, і слухання - при- 
Види іншомовної мовленнєвої діяльності

\begin{tabular}{|l|c|c|c|}
\hline & Усні & Письмові & 3мішані \\
\hline \multirow{2}{*}{ Продуктивні } & ГОВОРІННЯ & ПИСьМО & \\
\hline Рецептивні & Усний переклад на мову & Письмовий переклад на мову & \\
\hline Змішані & АУДІЮВАННЯ & ЧИТАННЯ про себе & \\
& Усний переклад з мови & Письмовий переклад з мови & ЧИТАННЯ вголос \\
& & & Запис мовлення \\
\hline
\end{tabular}

йом звукових повідомлень, а також усний переклад із вихідної мови на мову перекладу і навпаки. Письмовими видами іншомовної мовленнєвої діяльності є письмо - передача письмових повідомлень, і читання про себе - прийом письмових повідомлень, а також письмовий переклад з однієї мови на іншу і навпаки.

Два види - читання вголос і запис мови - відносяться до змішаних видів, що проявляється в їх проміжному характері: кожен із цих видів включає в себе, з одного боку, елементи усної та письмової комунікації, а 3 іншого - елементи передачі й прийому.

Ми бачимо, що процес іншомовної комунікації вимагає від майбутнього педагога володіння різними видами умінь та навичок, для забезпечення якісного користування іноземними мовами та обробки великих обсягів іншомовної інформації, які б вони могли застосовувати протягом своєї професійної діяльності.

Яким же чином можна поставити переваги та можливості використання інфрормаційних технологій на рейки покращення іншомовної компетентності, взагалі, та окремих її навичок й умінь? У процесі надбання таких навичок, важливу роль відіграє створення у вищому навчальному закладі іншомовного інорормаційного середовища.

Основна роль інфрормаційного середовища - це отримання інформації та її перетворення, орієнтація студента в інорормаційному просторі. Адже головна проблема не у здобутті інформації, а саме в її сприйнятті, перетворенні та використанні для конкретних завдань та вирішення окремих ситуацій.

В.А. Красильнікова визначає освітнє інорормаційне середовище як багатоаспектну, цілісну, соціально-психологічну реальність, що надає людині матеріальні і духовні умови для її освітньої діяльності, сукупність необхідних психолого-педагогічних умов для занурення людини в потік цілеспрямованої підготовленої інфрормації і способів її представлення до вивчення, усебічного розвитку особистості [4, с. 34]

О.Л. Шумський визначає структуру інорормаційного навчального середовища як комплекс інформаційних освітніх ресурсів; сукупність технологічних засобів інфрормаційних і комунікаційних технологій - комп'ютери та інше обладнання, комунікаційні канали; система новітніх педагогічних технологій, що є основою навчального про- цесу в рамках сучасного інфрормаційного навчального середовища [11, с. 380]

Сучасні викладачі також, у свою чергу, повинні вміти використовувати медійний інфрормаційний потік (радіо, телебачення, Інтернет) для створення сприятливого інформаційного середовище як інструмент підтримки для своїх програм навчання та професійного розвитку майбутніх педагогів. Адже в сучасному суспільстві індивіду доводиться приймати незмірно більший об'єм інорормації, ніж той, який він продукує та передає сам, причому особливо різко ця розбіжність проявляється для письмових видів мовленнєвої діяльності і особливо для перекладу, адже всі іншомовні інформаційні джерела повинні бути адекватно сприйняті та проаналізовані, що неможливо без достатньо сорормованої перекладацької компетентності студентів немовних спеціальностей.

Вже загальновідомим фактом $є$ те, що розвиток інформаційних технологій полегшує процес пошуку студентом інфрормації, та 3 іншого боку, ми можемо спостерігати труднощі в орієнтуванні та переробці цих обсягів інформації. Тому робота сучасного викладача повинна бути спрямована на орієнтування студента, пояснення особливостей розробки науково-методичних завдань та електронних курсів, внутрішніх платформ для співпраці з тими, хто навчається, та підкреслення важливості реалізації предметних завдань та проектів, які не порушують усталену освітню систему. Тому, створюючи інфрормаційне середовище на основі комп'ютерних технологій, зберігаємо основні етапи навчання:

- інформаційний (сховища, хмарні технології, інтернет посилання),

- тренувальний (комплекс вправ, тренувальних тестів, платорорм-тренажерів ) і

- контролюючий (завдання на розуміння письма, аудіо (рецептивної діяльності) та завдання на усне та письмове вираження (контролювання продуктивної діяльності).

Інтернет дає можливість підібрати автентичні та актуальні матеріали до кожного заняття 3 іноземної мови. За контентом ці інформаційні матеріали можемо розділити на довідкові та навчальні: словники (Larousse, Lingea, Glosbe); граматичні довідники (Grammaire prograissive та ін.); країнознавчі матеріали (France 2, Monde, Figaro); TV 5 monde, radio France, radio Canada ). 
Однак загалом для «профресійних педагогічних практик» процес застосування інноваційних елементів продовжує залишатися одиничним і $€$ виключно відповідальністю певного викладача, який на своєму занятті залишається єдиним, хто вміє (або повинен вміти) це робити. А отже, необхідно підготувати майбутнього фахівця до можливих викликів на педагогічній ниві.

Велике значення для успіху навчання має раціональна організація заняття, його педагогічний дизайн, про що говорять розробки вчених Тименко В.І., Мокрогуз О.П. [5; 9]. Досліджуване ними поняття означає чітке проектування та планування усіх складових майбутнього заняття, починаючи із цілей, які повинні бути досягнуті, змісту, що повинен бути опанований, засобів, які краще застосувати та аналізу ефективності отриманих результатів. Так, наприклад, у плані змісту кожне заняття з іноземної мови для студентів немовних спеціальностей повинно мати чітку комунікативну навчальну задачу у вигляді знаків і моделей, що підлягають обробці в певних видах мовленнєвої діяльності. Частина занять може бути повністю присвячена тренувальній роботі без введення будь-якого нового матеріалу, до речі, такі повторювальні, узагальнюючі заняття корисні в психологічному плані, так як знімають напругу, пов'язану з появою нового навчального матеріалу, і створюють у студентів почуття успіху.

Планування успішного навчального процесу повинне базуватися на основних дидактичних та методологічних принципах навчання іноземної мови. Такі дидактичні принципи, як наочність, посильність, міцність засвоєння знань, свідоме виконання завдань, що $є$ зрозумілими для студентів, науковість, активність, індивідуалізація, мають бути основою кожного заняття. Основними методологічними принципами при вивченні іноземної мови виступають комунікативність, домінуюча роль вправ, взаємопов'язаність видів мовленнєвої діяльності та врахування впливу рідної мови.

Основою успішного заняття $€$ комбінування різних моделей навчання іноземної мови (для тренування читання, письма, аудіювання та говоріння). Як частина проектування, модель дозволяє створювати образи об'єктів або явищ, імітувати реальні процеси майбутньої діяльності, програвати, порівнювати і оцінювати можливі результати проектування та робити обґрунтований вибір одного 3 альтернативних варіантів рішення проблем.

Відповідно до поставленої мети та цілей заняття викладач повинен постійно працювати над розробкою та збагаченням навчально-методичного комплексу (обов'язково використовуючи он-лайн матеріали та джерела), який би забезпечив зростання знань, умінь та навичок студентів на кожному занятті та на основі якого викладач моделює заняття, використовуючи інформаційні технології.
Розглядаючи застосування технологій педагогічного дизайну закордоном, вчений Уваров А.Ю. [10] зазначає, що проектування уроку іноземної мови в теоретичному плані має включати послідовну реалізацію таких етапів, як:

- визначення проблеми,

- постановка мети,

- відбір змісту навчання,

- вибір методів, прийомів і засобів навчання

- конкретизація завдань,

- обґрунтування фрорм організації навчального процесу та

- визначення способів контролю

- аналіз отриманих результатів та корекція, задля запобігання майбутніх помилок.

Вибір конкретних параметрів на кожному етапі моделювання уроку залежить від типу моделі, яку вибере для себе викладач, але у будь-якому випадку навчання повинно мати послідовний і системний характер.

Тому кожен викладач створює основу у вигляді технологічної карти наяку опираєтьсяпід часпроектування заняття. В основу якої входить назва етапу заняття, цілі, зміст, діяльність викладача, діяльність студентів, фрорми роботи, очікуваний результат.

Не можна рекомендувати якусь жорстку схему, оскільки організація заняття визначається безліччю фракторів: темою, комунікативним завданням, змістом попереднього заняття, рівнем підготовки студентів тощо. Тут відкривається широкий простір для творчості викладача, від якого вимагається попереднє продумування кожного заняття і його детальне планування і проектування. Кожне заняття має давати хоча б невелике, але відчутне збільшення знань студентів, що можна забезпечити педагогічним дизайном навчального процесу.

Переходячи до розгляду перекладацького аспекту у підготовці майбутніх педагогів, необхідно зауважити, що це дуже складний вид іншомовної мовленнєвої діяльності, адже він протікає у сорері двох мов, які корелюються в основному в плані змісту на рівні понять, хоча і тут відповідність $є$ неповною, тому що зміст багатьох понять у двох мовах не цілком збігаються, а деякі поняття взагалі відсутні. Слід зазначити, що у випадку збігу багатьох структур - частини мови, синтаксичні синтагми, типи речень і т.д. - спостерігається ряд суттєвих розбіжностей як в плані вираження, так і в плані змісту. Слід також відзначити розбіжності й у знакових системах двох мов, причому розбіжність прослідковується як в семантичній структурі власне слова так і в кореляції більш складного порядку: словосполучення, синтагми, речення тощо, що потрібно враховувати в підготовці завдань в цьому виді мовленнєвої діяльності.

Багато перекладознавців вважають, що суто перекладні вправи важкі і для їх виконання потрібна попередня підготовча робота. Слід роз- 


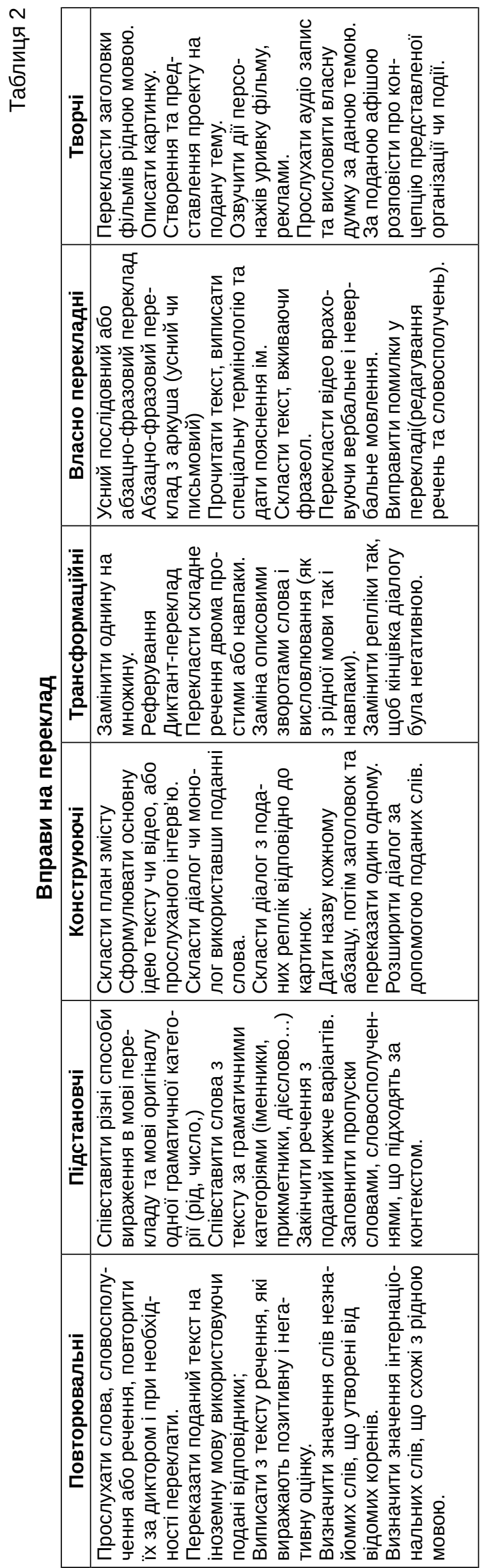

різняти тренувальні і власне перекладні вправи, причому другі можуть виконуватися тільки після належної тренувальної роботи. У тренувальних перекладних вправах обов'язковою $€$ наявність ряду однотипних елементів і тільки однієї проблеми (вживання знаку, що активізується), що має забезпечити їх безпомилкове виконання.

Слід по можливості уникати вправ зі перекладу окремих словоформ, оскільки вони суперечить принципу розгляду слова в контексті, і зробити упор на перекладі синтагм і речень.

Взагалі складання вправ повинно проводитися 3 особливою ретельністю з урахуванням відмінностей, які існують в двох мовах, а саме:

1) розбіжність семантичної структури слова, що збігається в одному значенні, але розходяться в іншому;

2) відсутність паралелізму в граматичних моделях, що вимагають вживання певних типів словоформ;

3) розбіжності в самих типах словоформ;

4) специфічність складу складних знаків, які зумовлюють неможливість дослівного перекладу;

5) непаралельність знакового складу ідіом і тощо.

Взагалі під час виконання перекладних вправ треба застерігати студентів від дослівного перекладуівимагатиточноїпередачізначення, ідеї, сенсу.

Існує багато класифрікацій вправ для тренування іншомовної перекладацької компетентності. Деякі вчені пропонують класифрікації вправ на формування навичок та умінь, які $€$ складовими елементами перекладацької компетентності. Так, Поршнева Е.Р. пропонує власну систему вправ, спрямованих на формування різних видів компетентностей. Вважаємо доцільним розглянути їі, оскільки такі вміння, на нашу думку, $€$ невід'ємною складовою фрормування перекладацької компетентності. Отже, лінгвіст пропонує таку класифікацію:

1. Вправи на активізацію семантичної компетентності.

2. Вправи на активізацію текстової компетентності.

3. Вправи на активізацію інтерпретативної компетентності [8, с. 233].

В.Н. Коміссаров виділяє такі перекладацькі вправи:

1) мовні, що розвивають уміння вирішувати перекладацькі завдання, пов'язані 3 особливостями семантики одиниць і структур мови оригіналу та мови перекладу;

2) операційні, що допомагають відпрацьовувати вміння використовувати різні способи та прийоми перекладу;

3) комунікативні, що формують уміння успішно виконувати необхідні дії на різних етапах перекладу [3, 391-397]. 
У своїй роботі ми хотіли б зупинитись на класифрікації, що стосується розвитку різних видів навичок під час фрормування перекладацької компетентності. Серед багатьох інших можна зазначити такі види вправ (таблиця 2).

Використання таких видів вправ, враховуючи той фракт, що кожний вид вправи є складнішим за попередній, поступово фрормує в майбутніх педагогів немовних спеціальностей уміння та навички якісного та адекватного перекладу .

Нижче ми надамо приклади різних видів вправ, які ми використовуємо у своїй практиці підготовки майбутніх педагогів немовних спеціальностей і які тренують ріні види навичок й умінь зі зразками:

Підставити замість пропусків дієслова схожі за перекладом та різні за смисловим значенням (підстановча)

1. .......-pour régner.(diviser)

2. Je ..... l'opinion de mon collègue, il faut agir vite. (partager)

3. Je n'ai plus faim, je ......ma part de gâteau avec qui le veut. (partager)

4. ........la feuille de papier en 3 colonnes identiques. (diviser)

5. L'état sert à ...........les richesses, les prélever chez les riches, les donner aux pauvres. (partager)

- Перекласти вираз «је t'en prie» (повторювальна):

1. Passe devant, je t'en prie. - Проходь, я тобі дозволяю.

2. Merci. - Je t'en prie. - Дякую. Немає за що, або із задоволенням.

3. Arrête de courir, je t'en prie. - Припини бігати, це вже занадто.

- Перекласти, враховуючи значення артикля (повторювальна).

Наприклад: Je veux l'argent. - Я хочу гроші. Je veux de l'argent. - Я хочу деяку суму грошей. Је voudrais l'eau. Je voudrais de l'eau.

Підставити замість пропусків прикметники звертаючи увагу на значення прикметника (прямий, переносний), відповідно до місця в реченні (підстановча):

1. Chaque fois que je vais à l'hôpital, je vois beaucoup de malades,........ !

(pauvres gens, gens pauvres ).

2. Ce centre médical associatif soigne surtout les malades qui n'ont pas de moyens, ............(des gens pauvres, des pauvres gens).

3. C'est ......, mais tu es capable de le faire. (un dur exercice, un exercice dur).

4. J'adore ........à base de lait de vache. (le fromage dur, le dur fromage).

5. Les parisiens adorent mettre ........, c'est la classe à la parisienne. (des vêtements gris, des gris vêtements).

Перефрразуйте речення зберігаючи суть висловлюваної думки (трансформаційна):
«Vos cadeaux me sont chers» іншими словами можна сказати -« Vos cadeaux sont très importants pour moi». Фразу «Vous êtes venus chez moi» можна передати «Vous vous êtes présentés chez moi», або «A propos de médicaments, où est mon aspirine ? - «Je me suis souvenu de mon aspirine ensuite nous parlerons de médicaments», «Je ne suis pas en mesure de vous répondre» - «Je n'ai pas la possibilité de vous répondre».

- Підібрати відповідники таким сталим виразам (повторювальна):

1. «Quand les poules auront des dents» - коли рак свисне.

2. «Faire la fine bouche» - бути вибагливим, крутити носом.

3. «Sauter aux yeux» - бути очевидним.

4. «Tenter le coup»- спробувати, ризикувати.

5. «Avoir du nez» - мати інтуїцію.

Можна також запропонувати скласти власні речення із цими вирази та знайти у словнику інші (конструюючі та трансформаційні вправи).

- Прослідкувати вживання виділеного словосполучення чи слова у контексті та перекласти (повторювальна та власне перекладна):

1. Depuis qu'il a gagné à la loterie, il mène grand traine et fait régulièrement le tour du monde.

2. Plus de 30 organisations algériennes appellent à battre le pavé à Paris.

3. Ce meuble est trop lourd pour moi, tu peux me filer un coup de main pour le déplaur?

4. Si on commence à tirer des plans sur la comète, on ne s'arrête plus.

5. Les enfants entendent tout et en prennent de la graine.

Прочитати статmю, здійснити поабзацовий переклад, скласти план та переказати від першої особи (конструююча, власне перекладна, трансорормаційна).

Jeune fumeur deviendra grand

Les 15-25 ans restent la cible privilégiée des cigarettes lorsqu'on gagne un très jeune fumeur adulte, sa consommation augmente avec l'âge, expliquant récemment une responsable d'une grande entreprise de cigarettes. Les méthodes actuelles vont du travail sur la présentation des paquets aux images glissées dans les salles obscures.

L'institut national de prévention et d'éducation pour la santé (INPES) note que «le nombre de films français laissant apparaitre une marque de tabac semble indiquer au mieux une méconnaissance de la loi, et au pire une action voulue de placement du produit».

La dernière stratégie en date, selon le magasine Heath Attairs, de l'université de Harvard, est d'attirer les plus jeunes en leur offrant des saveurs plaisantes. Ainsi, les cigarettes à la cerise, popularisées au Japon par le manga Nana, ou celles au chocolat ou à la vanille, font un malheur en France. 


\section{D'après l'Express}

Прослухати два коротких речення, а потім вказати чи речення, яке ви читаєте відповідає реченню, що ви почули (повторювальна).

Наприклад: ви почули «ll a bouché la bouteille», а прочитали «ll a bougé la bouteille », відповідно, можемо зробити висновок, що почуте не співпадає з прочитаним. Принцип цього завдання полягає в заміні складів, які дуже подібні, не втрачаючи сутті речення. В поданому прикладі це заміна ch на g, або можна замінити il на elle.

Вправи на заміну прийменника до одного $i$ того ж дієслова. Перекласти речення, звертаючи увагу на прийменник, що змінює значення дієслова (трансорормаційна).

Наприклад: penser à (qchlqn) - думати про когось, щось Vous avez pensé à ce projet», penser de (qchlqn) - думати про когось, щось в значенні власної думки «Que pensez-vous de ce projet?», penser +inf. - думати щось зробити «Que pensezvous faire?», penser à +inf. - не забути щось зробити «Ne pensez pas à envoyer la lettre», penser de +inf. запитувати думку перш ніж щось зробити «Que pensez-vous de commenser à réaliser ce projet?».

Вправи на переклад схожих речень, що мають різне стилістичне забарвлення (власне перекладна, творча).

Наприклад «Je ne pense pas qu'ils viennent»я не думаю, що вони прийдуть (я не впевнений), «Je ne pense pas qu'ils viendront» - я не думаю, що вони прийдуть (я впевнений).

- Подивитися відео без звуку, розставити картинки у послідовності розгортання подій. За картинками передати суть інфрормаційного повідомлення. Перевірити точність власного розуміння з відео, але вже зі звуком (підстановча, конструююча, творча).

- Перекладіть текст із географії українською мовою. Спробуйте передати точний інформаційний зміст тексту (власне перекладна).

La force d'attraction de la Lune

Même si la Lune est située à 378000 km de la Terre, elle exerce tout de même une forced'attraction suffisante pour déformer les océans.Lorsque le mouvement de rotation de la Terreplace une masse d'eau face au satellite, l'eau sesoulève en sa direction: ce renflement produitune marée haute . Au même moment, l'eauqui se trouve de l'autre côté de la Terre subitune attraction lunaire nettement plus faible.Elle obéit alors à la force centrifuge créée par la rotation du système Terre-Lune et tend às'échapper en formant un autre renflement,correspondant à une autre marée haute. Si laTerre n'était pas constituée de matières rigides,elle se déformerait elle aussi sous l'action de ces deux forces et aurait la forme d'un œuf.

- Встановіть логічну послідовність висловлювань у тексті (послідовність речень змінена) та перекладіть українською мовою (конструююча, власне перекладна).

La formation des geysers

Trois conditions sont nécessaires à la formationdes geysers : la présence d'un circuit souterrainoù l'eau qui s'infiltre dans le sol peut circuler puis remonter à la surface; un réservoir, où cetteeau peut s'accumuler; et la proximité d'une pochede magma (roche en fusion) qui réchauffe l'eau emprisonnée.

La durée du phénomène varie de quelques minutesà quelques heures. Le jet d'eau s'affaisse lorsquela cavité ne contient plus d'eau ni de vapeur. Ainsi chauffée, l'eau se transforme peuà peu en vapeur. La pression s'accroît et propulsevers la surface un puissant jet d'eau etde vapeur .L'eau s'infiltre d'abord dans le sol et s'accumuledans des cavités, à proximité d'une poche demagma .

Подивіться на афрішу, підберіть до виразу l'homme orchestre український еквівалент, потім спробуйте дати розгорнуте пояснення французькою мовою та придумати приклади його вживання в контексті (комплексна, творча).

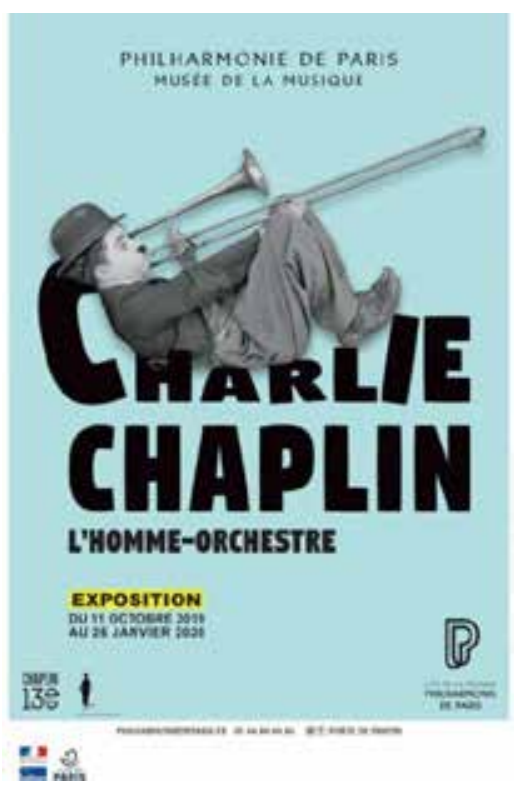

Рис. 1.

1. Спробувати зателеоронувати у фрілармонію і дізнатися повну інформацію щодо події, спробувати поставити близько десяти запитань. Завдання виконуємо у парах, де один студент виконує роль працівника, інший клієнта.

2. Організуйте виставку на певну тематику, пов'язану з перекладом, виділивши три етапи: підготовка, реалізація та представлення. На етапі підготовки, студенти, розбившись на групи, шукають матеріал в бібліотеці, Інтернеті чи за допомогою інших засобів. Під час реалізації студенти мають з'єднати всі матеріали, продумати спосіб представлення відповідно до обладнання (у вигляді газети чи презентації із застосуванням інтерактивної дошки), створити запрошення. 


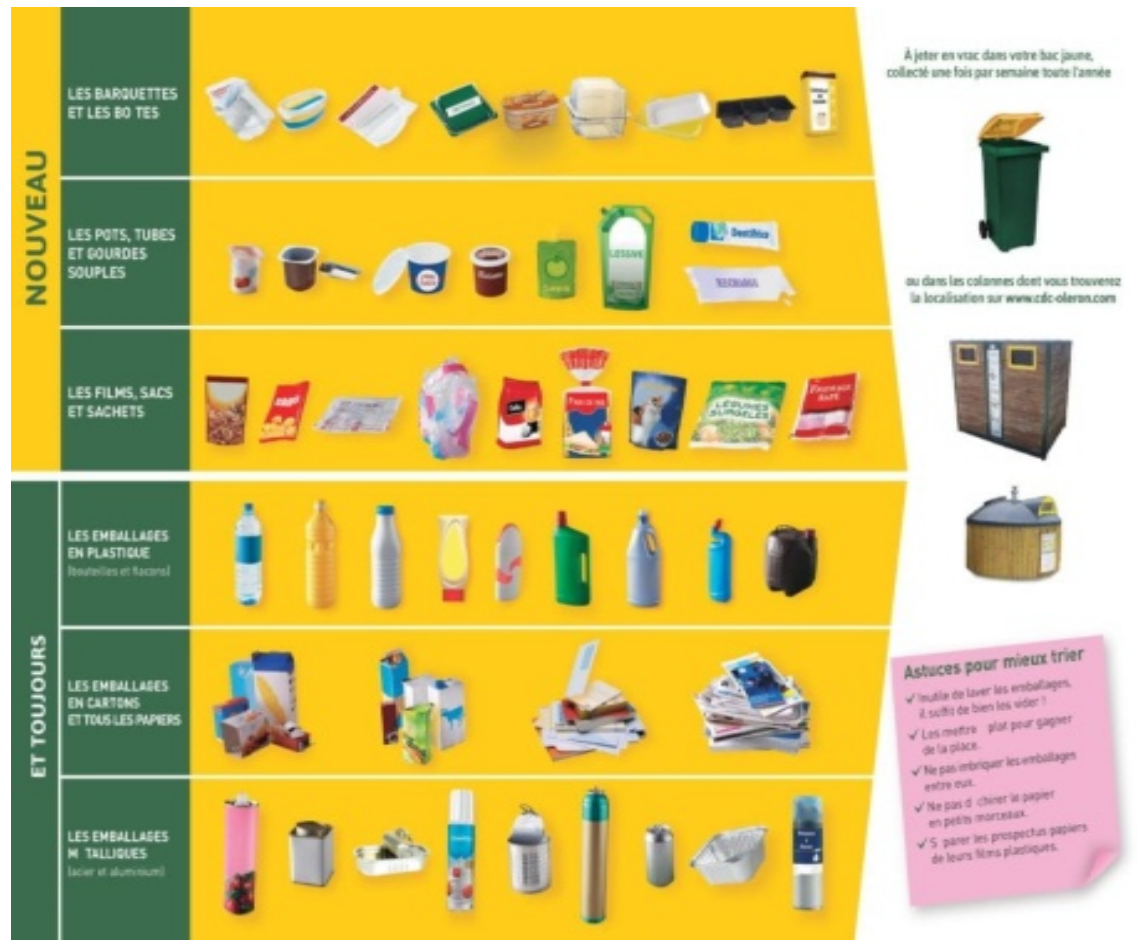

Рис. 2

1. Подивиться на фрото і визначте проблематику сюжету (комплексна, творча) (рис. 2).

2. За поданим малюнком опишіть систему сортування сміття у Франції.

3. Виділіть основні групи відходів. Створіть таблицю відходів, які відносяться до однієї групи.

4. Визначте основні правила сортування відходів.

5. Порівняйте систему сортування відходів у Франції з іншими країнами Європи чи світу, вкажіть основні спільні та відмінні дії.

6. Висловте свою власну думку цієї проблеми.

Слід зазначити, вправи на саме переклад та творчі вправи повинні бути ретельно підготовлені, з тим щоб при перекладі не знадобилося вживання слів і конструкцій, не відпрацьованих раніше в тренувальних вправах і щоб простимулювати вживання необхідних лексичних одиниць.

Висновки. Отже, поява радіо, телебачення, Інтернету посилила розрив між передачею та прийомом інсрормації, що вимагає від нас, викладачів, навчитись використовувати ці медійні засоби на свою користь. А трансформація системи освіти в бік все більшого використання сучасних інсоормаційно-комунікативних технологій та підходів, що формують у студента уміння та навички навчання впродовж життя, суттєво змінюють вимоги щодо майбутньої професії, особливо це стосується майбутніх педагогів.

Компонентами, які сприяють інтенсифрікації освітнього процесу, є використання дидактичних можливостей світової інфрормаційної мережі та інсоомаційних технологій, педагогічний дизайн освітнього середовища та ретельна розробка змісту навчання. Ці компоненти в контексті перекладацького аспекту іншомовної підготовки майбутніх педагогів немовних спеціальностей грають важливу роль, активізуючи процес засвоєння нової інфрормації, допомагаючи створити підґрунтя для ефективної імплементації теоретичних знань у практичні уміння та навички володіння іноземною мовою та формування іншомовної перекладацької компетентності.

Для подальших доробок ми могли б рекомендувати, враховуючи сучасну ситуацію з пандемією, розгляд перспектив запровадження дистанційної освіти в аспекті іншомовної підготовки студентів та технологізацію змісту такої підготовки, створення певного алгоритму навчання зокрема та освітнього процесу в цілому.

\section{БІБЛІОГРАФІЧНИЙ СПИСОК:}

1. Биков В.Ю., Жук Ю.О. Засоби навчання нового покоління в комп'ютерно орієнтованому навчальному середовищі. Комп'ютер в школі та сім'ї. № 5. 2005. C. 20-24.

2. Гавриленко О. Формування перекладацької компетентності студентів технічний спеціальностей. Наукові записки Кіровоградського державного педагогічного університету імені Володимира Винниченка. Серія : Педагогічні науки. 2014. Вип. 132. C. 73-77.

3. Комиссаров В.Н. Современное переводоведение : учеб. пособ. Москва : ЭТС, 2004.424 с.

4. Красильникова В.А. Инсорматизация образования: понятийный апарат. Инфрорматика и образование. 2003. № 4. С. 32-36.

5. Мокрогуз О.П. Педагогічний дизайн у контексті застосування мультимедійної презентації. Наукові 
записки НДУ ім. М. Гоголя. Психолого-педагогічні науки. 2012. № 2. С. 103-105.

6. Ніколаєва С.Ю. Загальноєвропейські Рекомендації з мовної освіти: вивчення, викладання, оцінювання. Київ :Ленвіт, 2003. 273 с.

7. Ніколаєва С.Ю. Методика викладання іноземних мов у середніх навчальних закладах : підручник. Вид. 2-е, випр.і перероб. Київ : Ленвіт, 2002. 328 с.

8. Поршнева Е.Р., Краснова М.А. Дидактический потенциал пропедевтических упражнений в процессе языковой подготовки переводчиков. Язык $и$ культура. 2017. № 37. С. 229-240.

9. Тименко В.П. Педагогічний дизайн у вищих професійних навчальних закладах технічного профрілю. Матеріали Всеукраїнської науково-практичної інтернет-конференції «Дизайн-освіта майбутніх фрахівців на сучасному етапі освітньої практики». Секція № 3. Інформаційні технології в дизайн-освіті. С. 133-147.

10. Уваров А.Ю. Педагогический дизайн. Инфрорматика. 2003. № 30. С. 2-31.

11. Шумський О.Л. Деякі аспекти організації навчального процесу 3 іноземної мови на основі інформаційного навчального середовища. Вісник
Дніпропетровського університету імені Альфреда Нобеля. Серія «Педагогіка і психологія». Педагогічні науки. 2016. № 1(11). С. 379-384.

12. Щетинкин В.Е. Пособие по переводу с французского языка на русский : учеб. Пособие для студентов пед. Ин-тов по спец. «Иностр.яз.». Москва : Просвещение, 1987. 160 с.

13. Isabelle Chollet, Jean-Michel Robert. Les verbes et leurs prépositions. CLE International, 2007. 226 c.

14. Serge D'Amico. La Terre: Comprendre notre planète. Québec Amérique, 2005. 128 c.

\section{ІНФОРМАЦЙНІ ДЖЕРЕЛА:}

1. URL : https://www.larousse.fr/.

2. URL : http://www.tv5monde.com/.

3. URL : https://canadadreamer.com/category/francais/ tef-canada/tef-comprehension-ecrite/.

4. URL : https://www.art-critique.com/en/event/ the-sound-of-charlie-chaplin/.

5. URL : https://www.cdc-oleron.com/agir-pourlenvironnement/gestion-des-dechets/collecte-et-tri/.

6. URL : https://go.mywebinar.com/fdrw-ndge-zgxkcrnz/record. 


\section{ФІЛОСОФСЬКІ ПОГЛЯДИ ЩОДО ВИХОВАННЯ ГРОМАДЯНИНА PHILOSOPHICAL VIEWS ON THE EDUCATION FOR CITIZENSHIP}

у статті досліджено виховання громадянина через аналіз фрілософських поглядів у різні періоди розвитку суспільства, що дає змогу виокремити такі проблеми, як ставлення особистості до суспільства, держави, нації, до себе як до громадянина, здатного до самореалізації та активної діяльності в соціальному середовищі.

Визначено, що дослідження фрілософських думок із питань громадянського виховання в історичному контексті розкриває діалектику взаємодії особистості та суспільства і глибоке розуміння людиною своєї соціальної ролі громадянина. Зазначено, що системне уявлення про соціум, гармонійний розвиток людини й суспільства складається завдяки поєднанню надбань, здобутих кожним із фрілософрських напрямів. Наголошено, що діалог між різними фрілософрськими школами, кожна 3 яких віднаходить особливий елемент істини, забезпечив різноманітність поглядів у фрілософії, що показує багатовимірність соціальної реальності та місця людини в ній.

Проаналізовано сучасні фрілософрські дослідження, що дає змогу розглядати виховання громадянина як комплексний процес, який ґрунтується на демократичних чінностях, фрундаментальних принципах прав і обов'язків людини, знаннях і навичках, необхідних для свідомої громадянської активності. Акцентовано, що фрілософрія XXI століття визнає необхідність виховання громадянина в сучасному суспільстві як активної, ініціативної, творчої особистості із власним світоглядом, переконаннями, позичією, здатної формувати цілі, приймати самостійні рішення, відстоювати свої права, усвідомлювати свої обов'язки, виявляти толерантність до поглядів інших людей, керуватися у вияві громадянської діяльності демократичними принципами На сучасному етапі фрілософський аспект в освіті відкриває інноваційні підходи до громадянського виховання, розглядаючи проблему соціалізації та громадянського становлення особистості як процес ії життєвого визначення в демократичному суспільстві.
Ключові слова: громадянин, суспільство, соціалізація, громадянське виховання, соціальне середовище, демократичні иінності.

The article examines the education for citizenship through the analysis of philosophical views in different periods of society, which allows identifying such issues as the attitude of the individual to the society, state, nation, to themselves as a citizen capable of self-realization and activity in the social environment.

It is determined that the study of philosophical thoughts on civic education in the historical context reveals the dialectic of interaction between the individual and society and a deep understanding of one's social role as a citizen. It is pointed out that the systematic idea of society, the harmonious development of man and society is formed due to the combination of achievements acquired by each of the philosophical directions. It is emphasized that the dialogue between different philosophical schools, each of which finds a special element of truth, has provided a diversity of views in philosophy, which shows the multidimensionality of social reality and man's place in it.

The modern philosophical research is analyzed, which allows considering the education for citizenship as a complex process based on democratic values, fundamental principles of human rights and responsibilities, knowledge and skills necessary for conscious civic activity. It is emphasized that philosophy of the $21^{\text {st }}$ century recognizes the need to educate citizens in modern society as an active, proactive, creative person with their own worldview, beliefs, position, able to form goals, make independent decisions, defend their rights, and realize their responsibilities, show tolerance to the views of others, follow democratic principles in the manifestation of civic activity. At the present stage, the philosophical aspect of education opens up innovative approaches to civic education, considering the problem of socialization and civic formation of the individual as a process of their vital identification in a democratic society.

Key words: citizen, society, socialization, civic education, socialenvironment, democratic values.
Постановка проблеми. У різні епохи розвитку суспільства виховання людини як громадянина розглядалося крізь призму фрілософрії. Філософрська антропологія вивчає людину в різних аспектах її суспільного життя, досліджуючи гармонійний взаємозв'язок особистості та суспільства. Демократизація суспільства, науково-технічний прогрес, водночас розв'язання екологічних проблем і боротьба за виживання людства потребують нового підходу до виховання сучасного громадянина.

Особливої актуальності набуває наукове обґрунтування і практичне забезпечення системи громадянського виховання, мета якого полягає у формуванні в особистості комплексу громадянських якостей, цінностей, компетентностей, соціальної активності та взаємодії, орормування громадянина як особистості 3 почуттям власної гідності, внутрішньої свободи, зі сорормованістю моральних ідеалів, здатної до самовизначення, самовдосконалення і самореалізації в соціальному середовищі [2].

Аналіз останніх досліджень і публікацій. Аналіз сучасних фрілософських досліджень дає змогу розглядати виховання громадянина як комплексний процес, який ґрунтується на демократичних цінностях, фрундаментальних принципах прав 
і обов'язків людини, знаннях і навичках, необхідних для свідомої громадянської активності. У своїх публікаціях науковці висвітлюють актуальні проблеми: виховання особистості в контексті соціалізації як активного суб'єкта діяльності (С. Гончаренко, В. Кушнір, В. Москаленко), творче осмислення людиною самої себе і процес трансформування людської діяльності у творчість (Б. Новіков), підхід до освіти як чинника гуманізації суспільства (В. Горбатенко), національна ідея як ціннісна детермінанта державотворчого процесу (М. Безотосний, О. Гринів, Ю. Калиновський, Н. Левченко, О. Луцків, В. Пасічник), національна самосвідомість як соціально-духовний френомен в реаліях політичного буття громадянського суспільства (С. Лавриченко, І. Надольний, В. Погребняк), громадянська відповідальність особистості як атрибутивний феномен правового суспільства (Є. Мануйлов, Ю. Калиновський), роль патріотизму і громадянськості у фрормуванні особистості (В. Кротюк) та ін.

Виділення невирішених раніше частин загальної проблеми. I надалі однією із провідних проблем фрілософрії залишається розвиток громадянського суспільства. Однак у сучасних фрілософських дослідженнях недостатньо розкрита проблема громадянського виховання особистості в різні історичні періоди.

Мета статті. Метою статті є дослідження фрілософських поглядів щодо виховання громадянина та його взаємодії із соціальним середовищем у різні періоди розвитку суспільства.

Виклад основного матеріалу. Дослідження фрілософської думки щодо громадянського виховання в історичному контексті розкриває діалектику взаємодії особистості та суспільства і глибоке розуміння людиною своєї соціальної ролі громадянина. Адже соціальна цінність фрілософії полягає в їі антропологічному призначенні - в осмисленні людини себе як особистості, розкритті її творчого потенціалу й самореалізації в соціальному середовищі. За таких умов відбувається активний процес формування в людини нових якостей як суб'єкта громадянського суспільства, моральних установок, ціннісних орієнтацій, світогляду, позиції, переконань, обов'язку та відповідальності. Виховання громадянськості, зокрема громадянської відповідальності, як зазначають Є. Мануйлов і Ю. Калиновський, зумовлено історичним контекстом, типом політико-правової системи, рівнем розвитку правосвідомості та моральної свідомості суспільства [12, с. 115].

За період кожної історичної епохи, як стверджує І. Надольний, формуються певні погляди, ідеї, переживання, спонукання, почуття, настрої, що адекватно відображають життєдіяльність індивідів і стосуються всіх різноманітних сторін суспільного буття: виробництва, розподілу, побуту, сім'ї, національно-етнічних відносин, освіти, культури $[14$, с. 178$]$.
Свого часу представники античної фрілософрії, Сократ, Демокрит, Платон, Аристотель, охарактеризували людину як самостійну цінність і визнали за нею право на ініціативу та активність. Визначивши центром своєї фрілософії людину, Сократ стверджував, що пізнати світ людина може тільки пізнавши себе, а найважливішим завданням вважав виховання людей. Взаємозв'язок розуму, моралі та поведінки людей він підніс до рівня провідного принципу організації соціальності, наголошуючи на сумлінному виконанні громадських обов'язків. Демокрит розглядав людину як атом суспільства, а демократичну державу вважав ідеалом державного устрою. На його думку, демократія повинна підтримуватися самими громадянами за допомогою створених ними законів для щасливого життя людей. Демокрит вважав, що демократично влаштована держава передбачає розв'язання проблеми доброустрою держави як співтовариства вільних громадян із правовим порядком, а єднання вільних громадян, взаємодопомога і братерство - ознака істинної демократії.

Пошук оптимальної фрорми співжиття людей «ідеальної держави» $є$ фрілософрською концепцією Платона, яка базується на принципі справедливості, згідно з яким кожному громадянинові відводиться особливе становище, можливість, займаючись своєю справою, отримувати належне. Як стверджував Платон, кожна людина повинна займатись чимось одним, що потрібно державі, i тим, до чого вона найбільше здатна за своїми природними здібностями [15, с. 223-224]. А головним завданням держави, як убачав Аристотель, є виховання громадян у дусі моральних чеснот та суспільної користі. Філософр обґрунтував статус людини в суспільстві як «політичної істоти» [1, с. 378-462].

Усупереч фрілософрській думці Античності, яка задавалася природою, середньовічні вчення про людину і суспільство розгорталися в теологічному напрямі, де суспільне буття тлумачилося як «Богом дане». Середньовічні мислителі намагались довести, що без віри та прозріння таїнство соціального залишається закритим, а розум неспроможний осягнути його в повному обсязі, обґрунтували ідею Бога як інтегративний принцип соціальності, що примирює людей, орієнтує на злагоду, працю та моральність.

В епоху Відродження постала нова парадигма соціальної фрілософії про людину і суспільство. У цей історичний період людину розглядають як творця власного світу і всього суспільства. Особисті чесноти, власна гідність і благородство стають пріоритетом духовних цінностей, а метою життя для людини є служіння суспільству. На думку М. Монтеня, той, хто відчуває власну людську гідність, зрозуміє свої обов'язки перед іншими людьми і суспільством, своє покликання сприяти суспільній користі, виконуючи обов'язок громадянина. Він наголошував, що немає нічого прекраснішого i 
більш гідного схвалення, як належним чином добре виконати своє людське призначення [13, с. 383].

У період Нового часу сорормувався погляд на людину як на суспільну істоту, соціальність якої закладена в ії природі. Надбанням соціальнофрілософської теорії цієї епохи стало заперечення теологічного бачення суспільства як продукту божественного творення і започатковане Р. Декартом розуміння механізмів творення соціального його реальними суб'єктами. Звідси бере свій початок концепція «суспільного договору». Згідно із цією концепцією, як зазначив Ж.-Ж. Руссо, кожен віддає себе і всі свої права громаді, верховну владу над якою здійснює загальна воля, і як член громади кожен стає невіддільною часткою цілого [20]. Предметом уваги фрілософрів стає державноправове будівництво, яке полягає в пошуку оптимальних законів, за допомогою яких можна було б забезпечити збалансованість економічних, політичних та соціально-побутових процесів. На думку Т. Гоббса, початком держави є право більшості, яке прийшло до згоди [5, с. 333]. За поглядами Ф.-М.-А. Вольтера, держава зобов'язана забезпечити «природні права» людей, найважливішими 3 яких є свобода, рівність перед законом і неподільна власність на продукти своєї праці [21].

Важливим надбанням соціальної фрілософрії цієї доби було вчення про людину як суб'єкта життєдіяльності суспільства, про «природні права людини», підґрунтя яких становить приватна власність та свобода. У цьому контексті Дж. Локк першим поставив перед державою вимогу не лише «мудрого піклування про підданих», а й глибокої поваги до дієздатності та громадянської самостійності індивіда. Мислитель зазначав: «Не держава над людиною, а людина над державою», підкреслюючи одночасно думку про те, що громадянин зобов'язаний підкорятись державі лише тією мірою, доки вона не починає загрожувати його головним інтересам [11, с. 406].

Важливе значення мислителі Нового часу надавали вихованню громадянина. На думку Дж. Локка, вихованець не тільки має набувати вміння ведення практичних справ, але й усвідомлювати свою громадянську відповідальність і цікавитись тим, чим він може бути корисним своїй країні [11]. Як зазначив Ш. Монтеск'є, закони виховання - це перші закони, які зустрічає людина у своєму житті. І оскільки ці закони готують людей до того, щоб стати громадянами, то кожна сім'я повинна керуватися зразком великої сім'ї [19, с. 38]. Виховання громадянина було одним із компонентів суспільноправового ідеалу Ж.-Ж. Руссо. Він вважав, що для підготовки громадян до життя в «державі розуму» потрібна розгалужена система виховання, побудована на засадах «наслідування природі», на продуктивній праці та виявленні самодіяльних можливостей, фрізичному, моральному та інте- лектуальному розвитку вихованців [20]. Як підкреслював К.-А. Гельвецій, людина фрормується через виховання і вплив суспільного середовища. Він вважав, що єдиним шляхом до справедливого і доброго суспільства $є$ узгодження особистих та суспільних інтересів, щоб суспільні інтереси стали для громадян особистими, а служіння суспільству стало вищим особистим інтересом. На його думку, все цілком можливо реалізувати шляхом втілення розумного законодавства, просвітництва та відповідного виховання [4, с. 475-476; 595-603]. Таким чином, у громадянському вихованні особистості просвітники вбачали можливість вдосконалювати саме суспільство.

Гуманістичне вчення про людину і сенс її життя, розвиток громадянської свідомості, ідеї патріотичного виховання розглядали у своїх працях українські мислителі XVII - XVIII ст. І. Вишенський, Г. Конинський, Г. Сковорода, М. Смотрицький, $€$. Славинецький, Ф. Прокопович, С. Яворський та ін. Вони розвивали ідеї природного права, суспільного договору, рівності всіх верств суспільства, вбачали джерело суспільного договору в прогресі науки і освіти, пропагували соціальну роль і національний характер виховання.

За поглядами Г. Сковороди, метою виховання є підготовка вільної, гармонійно розвиненої, корисної для суспільства людини, 3 почуттям власної гідності, здатної пізнати себе і навколишній світ. Найважливішою стороною теорії пізнання у Г. Сковороди було пізнання людиною своєї ролі в житті народу і держави в ім'я найкращого служіння «гражданского», «народного» i «государственного». Кожна людина, на думку фрілософра, повинна пізнати себе як частину свого народу. Свою теорію пізнання і самопізнання він вважав наукою, що веде до щастя: «Сіе-то есть быть щастливым узнать, найти самого себе» [17, с. 225].

Завдання виховання Г. Конинський убачав у тому, щоб навчити людину керувати своїми почуттями і діями на благо суспільного життя. Як зазначив мислитель, «всі громадські дії людей слід визначити, щоб ми були чесні, розумні, здорові, безпечні та щасливі» [9, с. 419]. Він наголошував на свободі та добровільності вибору діяльності людини, на добрій волі, що є умовою людського вчинку. На його думку, добровільним $€$ те, для чого властиве діяти з досконалим пізнанням мети [9, с. 434-435]. У фрілософській концепції Г. Конинського людина - це особистість, керована розумом, яка може усвідомлювати мету життя, прагне сама творити свою долю, здатна до цілеспрямованої діяльності.

Представники німецької класичної фрілософрії розглядали людину як вищу істоту, яка має право на приватну власність, свободу і щастя. Один із їі представників, І. Кант відтворив головну домінанту моральної регуляції суспільних відносин за умов 
повної індивідуальної свободи [8]. Таких поглядів дотримувався І. Фіхте, наголошуючи на незалежності та активності людської особистості. Сутність і призначення держави він вбачав у вихованні громадян у дусі свободи. Для нього виховання - це шлях до усвідомлення себе єдиною нацією [18]. У цьому контексті Ф. Гегель вважав, що завдяки вихованню особистість бере активну участь у культурному житті суспільства і формується у взаємозв'язку із соціальним середовищем [3].

Наприкінці XIX сторіччя почали формуватись і до середини XX сторіччя розвинулись розгалужені, оригінальні соціально-фрілософські течії, які досягли певних успіхів у поясненні суспільного життя людей, проте не відтворили його в гармонійній цілісності. Представники екзистенціалізму (К. Ясперс, Ж.-П. Сартр, А. Камю, М. Бердяєв та ін.) протиставляли людину суспільству як те, що руйнує індивідуальність та її свободу. Людська екзистенція ними розглядалась як абсолютна активність, що постійно перебуває у процесі творення. На думку Ж.-П. Сартра, людина спричиняє себе такою залежно від завдань, які поставлені на її шляху [16, с. 844]. Формування людини він пов'язував зі свідомим вільним вибором мети.

Найпоширенішою доктриною соціалізації $\epsilon$ фрілософсько-педагогічна теорія класика прагматизму Дж. Д'юї, який розглядав виховання як саморозвиток особистості та розгортання її внутрішньої потенції під впливом оточення. На його думку, людські потенції можуть виявляти себе лише в процесі соціалізації. Як стверджував Дж. Д'юї, залучення дітей до соціальних відносин є одночасно як засобом, так і результатом виховання [7, с. 54].

На сучасному етапі фрілософрський аспект в освіті відкриває інноваційні підходи до громадянського виховання, розглядаючи проблему соціалізації та громадянського становлення особистості як процес її життєвого визначення в демократичному суспільстві. Актуальною є думка С. Гончаренка і В. Кушніра, що в досягненні мети виховання інтегрованої особистості фрілософрія може бути теоретичною основою педагогіки толерантності й співробітництва, багатоваріантності підходів до розв'язання різних педагогічних ситуацій [6, с. 2]. Щоб підготувати людину до життя в громадянському суспільстві, як зазначає В. Кротюк, потрібно забезпечити їй належне виховання. Тому формування демократичних цінностей має стати основою виховання громадянина демократичного суспільства [10, с. 35]. Таким чином, фрілософрія XXI століття визнає необхідність виховання громадянина в сучасному суспільстві як активної, ініціативної, творчої особистості із власним світоглядом, переконаннями, позицією, здатною фрормувати цілі, приймати самостійні рішення, відстоювати свої права, усвідомлювати свої обов'язки, виявляти толерантність до поглядів інших людей, керуватися у вияві громадянської діяльності демократичними принципами.

Висновки. Аналіз фрілософрьких досліджень дає підставу зробити висновки, що системне уявлення про соціум, гармонійний розвиток людини і суспільства фрормується завдяки поєднанню надбань, здобутих кожним із фрілософрьких напрямів у різні періоди розвитку суспільства. Діалог між різними фрілософськими школами, кожна 3 яких віднаходить особливий елемент істини, забезпечив різноманітність поглядів у фрілософії, що відображає багатовимірність соціальної реальності і місця людини в ній.

Отже, фрілософські дослідження розкривають пошук шляхів налагодження гармонійних взаємозв'язків і взаємодії інтересів особистості, громадянина та суспільства. Філософрські погляди щодо громадянського виховання дають змогу виокремити такі проблеми, як ставлення особистості до суспільства, держави, нації, до себе як до громадянина та ії здатність до взаємодії із соціальним середовищем. Усвідомлення людиною своєї соціальної ролі сприяє процесу формування в неї якостей суб'єкта громадянського суспільства.

\section{БІБЛІОГРАФІЧНИЙ СПИСОК:}

1. Аристотель. Сочинения : в 4 т.; пер. с греческого : под ред. В. Ф. Асмуса и др. Москва : Мысль, 1976. Т. 4. С. 378-462.

2. Бабкіна М.І. Формування активної громадянської позиції підлітків у позакласній виховній роботі загальноосвітньої школи : дис. ... канд. пед. наук : 13.00.07. Київ, 2009. 231 с.

3. ГегельГ.В.Ф.Философияправа;пер.снем.:ред. и сост. Д.А. Керимов, В.С. Нерсесянц. Москва : Мысль, 1990. 524 с.

4. Гельвеций К.А. Сочинения : в 2-х т.; [пер. с фрр.]. Москва : Мысль, 1973. Т. 1. С. 595-647.

5. Гоббс Т. Основ фрилософии. Сочинения: в 2-х т.; [пер. с лат. и англ. : под ред. Д.А. Керимова]. Москва : Мысль, 1989. Т. 1. С. 221-379.

6. Гончаренко С.У., Кушнір В.А. Педагогічний процес $з$ погляду «Філософрії XXI ст.». Шлях освіти, 2005. № 1. С. 2-7.

7. Д'юї Дж. Досвід й освіта ; перекл. з англ. Марії Василечко. Львів : Кальварія, 2003. 84 с.

8. Кант И. Идея всеобщей истории во всемирногражданском плане. Сочинения : в 6-ти т. ; пер. с нем. ; ред. кол. : В.Ф. Асмус и др. Москва : Мысль, 1966. Т. 6. 743 c.

9. Конинський Г. Моральна фрілософрія, або етика. Філософські твори: у 2 т. Київ : Наукова думка, 1990. T. 1. C. $385-474$

10. Кротюк В.А. Патріотизм і громадянськість та їх роль у формуванні особистості-громадянина. Вісник Національного університету «Юридична академія України імені Ярослава Мудрого», 2011. Серія Філососрія. № 7. С. 29-37.

11. Локк Дж. Опыт о человеческом разумении. Сочинения : в 3-х т. ; пер. с англ. Савина А.Н. Москва : Мысль, 1985. Т. 1. 621 с. 
12. Мануйлов Є.М., Калиновський Ю.Ю. Громадянська відповідальність особистості як атрибутивний феномен правого суспільства. Вісник Національного університету «Юридична академія України імені Ярослава Мудрого», 2015. Серія Філософрія. № 2. C. 113-129.

13. Монтень М. Опыты. Сочинения : в 3-х т.; [пер. с фрранц.]. Москва : Голос, 1992. Т. 3. 394 с.

14. Надольний І. Національна самосвідомість як чинник державотворення. Філософрія освіти. 2006. № 3(5). С. 175-186.

15.Платон. Соч. : в 3 т.; [пер. с древнегрец.]. Москва : Мысль, 1971. Т. 3., Ч.1. С. 145-224.

16. Сартр Ж.-П. Буття і ніщо : нарис френоменології онтології ; пер. с фрранц. В. Лях, П. Таращук. Київ : Основи, 2001. 850 с
17. Сковорода Г.С. Твори : в 2-х т.; ред колегія : Д.Х. Острянин та ін. Київ : АН УРСР, 1961. Т. 1. 639 с.

18. Фихте И.Г. Назначение человека. Сочинения : в 2-х т. ; пер. с нем. Санкт-Петербург, 1993. T. 2. $395 \mathrm{c}$.

19. Montesquieu Ch. Del'espritdeslois. Paris:Éditions Gallimard, 1995. 560 p. URL : http://archives.ecolealsacienne.org/CDI/pdf/1400/14055_MONT.pdf.

20. Rousseau J.-J. Du Contrat social. URL : http://www.ac-grenoble.fr/PhiloSophie/logphil/oeuvres/ rousseau/contrat/contrat7.htm\#haut.

21. Voltaire F.-M.-A. Lettres philosophiques. Édition électronique (ePub) v.: 1,0 : Les Échos du Maquis, 2011.URL:https://philosophie.cegeptr.qc.ca/wp-content/ documents/Lettres-philosophiques-1734.pdf. 
ТЕОРЕТИЧНЕ ОБҐРУНТУВАННЯ ПЕДАГОГІЧНИХ УМОВ ФОРМУВАННЯ ГОТОВНОСТІ ДО УСВІДОМЛЕНОГО БАТЬКІВСТВА СТУДЕНТІВ ЗАКЛАДІВ ВИЩОЇ ОСВІТИ

\section{THEORETICAL FOUNDATION OF PEDAGOGICAL CONDITIONS OF THE FORMATION OF READYNESS FOR THE CONSCIOUS PATERNITY OF STUDENTS OF HIGHER EDUCATION INSTITUTIONS}

у статті доведено актуальність проблеми фоормування готовності до усвідомленого батьківства студентів закладів вищої освіти. Уточнено, в чому саме полягає усвідомленість батьківства. Визначено суть понять «усвідомлене батьківство» $i$ «готовність до усвідомленого батьківства», надано їх характерні ознаки, з'ясовано, що кожен із цих френоменів є системним утворенням, виокремлено їх структурні компоненті та складники.

Доведено, що для успішного вирішення вказаної проблеми важливим є створення певних педагогічних умов. Підкреслено. що під педагогічними умовами мається на увазі сукупність зовнішніх обставин, які забезпечують результативне формування готовності до усвідомленого батьківства. Теоретично обгрунтовано педагогічні умови формування готовності до усвідомленого батьківства студентів закладів вищої освіти.

З'ясовано, що першою умовою реалізації зазначеної проблеми є організація цілеспрямованої підготовки викладачів закладів вищої освіти до формування готовності до усвідомленого батьківства студентів. Зазначено ключові аспекти та зміст чієї підготовки в межах когнітивного, мотиваційного та поведінкового складників, розглянуто особливості кожного з цих компонентів. Розкрито сутність другої умови, яка полягає у створенні й реалізації на практиці науковометодичного забезпечення з фрормування готовності до усвідомленого батьківства студентів закладів вищої освіти. Встанов лено, що реалізація цієї умови є необхідним кроком для успішного здійснення діяльності з формування в студентів готовності до усвідомленого батьківства в межах когнітивного, емоційного, мотиваційного та поведінкового складників всіх його компонентів. Вказано, що третьою умовою успішного формування зазначеної готовності $є$ спонукання студентів до здійснення систематичного самовиховання. З'ясовано, що важливість цієї умови пов'язана з динамічною структурою готовності до усвідомленого батьківства та ії змінюваністю під впливам таких зовнішніх фоакторів, як соціальні норми, інфрормаційний простір, статеві відносини, вагітність тощо. Підкреслено, що ефективність формування готовності до усвідомленого батьківства підвищується за умови систематичної діяльності з боку студента в цьому напрямі.

Ключові слова: батьки, батьківство, усвідомлене батьківство, готовність до усвідомленого батьківства, дитячо-батьківські стосунки, педагогічні умови.
The article proves the urgency of the problem of forming readiness for conscious paternity of students of higher education institutions. It was clarified what exactly is the essence of paternity. The essence of the concepts "conscious paternity" and "readiness for the conscious paternity" has been determined and their characteristic features have been given. It was found that each of these phenomena is a systemic formation, their structural components and constituents were distinguished.

It was proved that for the successful solution of the mention problem the creation of certain pedagogical conditions is important. It was underlined that by the pedagogical conditions we mean a set of external circumstances that ensure the effective formation of readiness for conscious paternity. The pedagogical conditions for the formation of readiness for conscious paternity of students of higher education institutions have been theoretically substantiated in the article.

It was also found that the first condition for the implementation of this problem is the organization of targeted training of teachers of higher education institutions to form a readiness for conscious paternity of students. The key aspects and the content of this training within the cognitive, motivational and behavioral components are outlined and the features of each of these components are considered.

The essence of the second condition, that consists in the creation and implementation in the practice of scientific and methodological support for the formation of readiness for conscious paternity of students of higher education. It has been established that the implementation of this condition is a necessary step for the successful implementation of activities for the formation of students' readiness for conscious paternity within the cognitive, emotional, motivational and behavioral components of all its components. It was indicated that the third condition for the successful formation of this readiness is to encourage students to carry out systematic self-education.

It was also explained that the importance of this condition is related to the dynamic structure of readiness for conscious paternity and its variability under the influence of such external factors as social norms, information space, sexual relations, pregnancy, etc. It has been emphasized that the effectiveness of the formation of readiness for conscious paternity increases with the systematic activities of the student in this direction. Key words: parents, paternity, conscious paternity, readiness for the conscious paternity, childparent relations, pedagogical conditions. педагогічного університету імені Г.С. Сковороди

Постановка проблеми в загальному вигляді. Сучасний етап розвитку суспільства характеризується трансорормацією поглядів на батьківство. Зміна вимог до виховання дітей і здійснення батьківських фрункцій зумовлює необхідність розробки нових підходів до фрормування в молоді готовності до батьківства.

Актуальність зазначеної тематики посилюється наявністю суперечностей між потребою держави в підвищенні соціального стану сім'ї, її педагогіч- 
ного потенціалу та слабким використанням цього потенціалу в реальній практиці; між зростаючими вимогами суспільства в готовності молоді до батьківства та негативною динамікою в ії становленні; між нагальною потребою закладів вищої освіти в сучасному науково-методичному забезпеченні процесу формування готовності до усвідомленого батьківства студентів і недостатністю відповідних методичних доробок у педагогічній науці.

Одним із шляхів розв'язання перерахованих суперечностей $€$ забезпечення цілеспрямованого формування готовності до усвідомленого батьківства студентів закладів вищої освіти.

Аналіз останніх досліджень і публікацій. Як показав аналіз наукової літератури, сучасні науковці приділяють багато уваги питанню готовності до батьківства. Дослідження проводили С. Асрієва, Д. Бикова, А. Вагапова, О. Васильєва, О. Євдокимова, М. Єрміхіна, Ю. Іванова, А. Ролева тощо.

Серед українських науковців О. Лемещенко займалася вивченням соціально-психологічних умов фрормування у старшокласників готовності до усвідомленого батьківства [8], Л. Повалій досліджувала питання формування відповідального батьківства [12], О. Тіунова вивчала психологічні умови фрормування відповідального ставлення до материнства [13], Р. Хавула займався дослідженням психолого-педагогічних чинників формування психологічної готовності юнаків до батьківства [14]

Виділення не вирішених раніше частин загальної проблеми. Загалом наукові розвідки сучасних вчених висвітлюють різні аспекти досліджуваного френомену, але вивчення педагогічних умов фрормування готовності до усвідомленого батьківства студентів закладів вищої освіти не було окремим об'єктом наукових розробок, що і зумовило вибір теми дослідження.

Мета статті - визначення і теоретичне обґрунтування педагогічних умов фрормування готовності до усвідомленого батьківства студентів закладів вищої освіти.

Виклад основного матеріалу. На попередньому етапі дослідження було визначено, що усвідомленість батьківства полягає в здатності робити усвідомлений вибір бути батьками, сприймати дитину як особистість, як суб'єкта сімейних стосунків з урахуванням її індивідуальних особливостей вже з перших хвилин після її народження, усвідомлено оволодівати знаннями, вміннями та навичками здійснення батьківських функцій.

Характерними ознаками усвідомленого батьківства $€$ відповідальне ставлення до виховання дитини, здатність батька і матері до рефлексії та самоаналізу, вміння спостерігати власні батьківські реакції, сподівання, очікування, переживання. Усвідомлене батьківство є системним утворенням, у структурі якого виокремлюють такі компоненти: батьківське ставлення, батьківськи установки й очікування, батьківські позиції, батьківські почуття, батьківська відповідальність, ціннісні орієнтації та стилі сімейного виховання. Кожен компонент містить емоційний, мотиваційний, когнітивний, поведінковий складники [11, с. 23].

Готовність до усвідомленого батьківства $€$ цілісним, інтегративним, стійким особистісним утворенням, яке включає усвідомленість вибору бути відповідальними батьками та передбачає вдосконалення психічних процесів, станів і властивостей батьків, необхідних для ефективного виховання дитини. Це суб'єкт-суб'єктна позитивна орієнтація батьків на сприйняття і стосунки з майбутньою дитиною, сукупність знань стосовно себе як батьків і вміння використовувати педагогічні засоби і методи взаємодії так, щоб сприяти повноцінному психічному і фрізичному розвитку дитини.

У структурі готовності до усвідомленого батьківства виокремлюють мотиваційний, емоційний, когнітивний і поведінковий компоненти. Мотиваційний компонент поєднує мотиви народження та виховання дитини. Емоційний компонент включає емоційне сприйняття ситуації батьківства, емоційне й оцінювальне ставлення до дитини, фоновий настрій, який супроводжує взаємодію 3 дитиною, рівень задоволеності власною роллю батька чи матері. Когнітивний компонент відображає знання про себе, як особистість, про свій характер, здатність до взаємодії з дитиною на різних стадіях її розвитку. Поведінковий компонент поєднує суб'єкт-суб'єктне позитивне емоційне ставлення до дитини, що спостерігається в сприйнятті стану дитини та реагуванні на вияви цього стану, створенні стійких позитивних дитячо-батьківських стосунків [1, с. 10].

Успішності процесу фрормування готовності до усвідомленого батьківства студентів закладів вищої освіти сприяє створення необхідних педагогічних умов. Під умовами сучасна наука розуміє необхідні обставини, які роблять можливим здійснення чого-небудь [15, с. 632]; зовнішні обставини, від яких залежить щось інше [3, с. 707].

Під педагогічними умовами науковці розуміють зовнішні обставини, пов'язані 3 навчально-виховним процесом, які забезпечують його організацію, розвиток і фрункціювання [6, с. 97]; сукупність зовнішніх і внутрішніх характеристик та параметрів реалізації педагогічного процесу, що впливають на його високу результативність [10, с. 152]; сукупність організаційних форм і методів, матеріальних та змістових можливостей здійснення навчальновиховного процесу, який забезпечує успішність досягнення поставленої мети [2, с. 181].

Науковці виокремлюють два рівні педагогічних умов. Перший пов'язаний з особистісними характеристиками студентів, які зумовлюють успішність навчально-виховного процесу. До другого належать обставини реалізації процесу: зміст та реа- 
лізація діяльності студентів, міжособистісні стосунки, стосунки педагогів зі студентам, взаємодія навчального закладу з навколишнім середовищем тощо [4, с. 136].

У дослідженні під педагогічними умовами розуміється сукупність зовнішніх обставин, які забезпечують результативне фрормування готовності до усвідомленого батьківства студентів закладів вищої освіти. Першою умовою досягнення зазначеної мети є організація цілеспрямованої підготовки викладачів до формування готовності до усвідомленого батьківства студентів закладів вищої освіти.

Структура готовності викладача до професійної діяльності складається 3 когнітивного, мотиваційного і діяльнісного компонентів [7, с. 85]. Когнітивний компонент включає знання з питання усвідомленого батьківства, розуміння мети фрормування у студентів готовності до усвідомленого батьківства, врахування існуючих у навчальному закладі умов для цього, здатність аналізувати результати своєї діяльності.

Мотиваційний компонент складається зі ставлення до здійснення діяльності, прагнення до поглиблення власних знань, напрацювання навичок і здійснення діяльності 3 досягнення мети. Діяльнісний компонент виявляється у використанні отриманих знань та навичок для фрормування готовності до усвідомленого батьківства студентів закладів вищої освіти.

Другою умовою $є$ створення й реалізація на практиці науково-методичного забезпечення фрормування готовності до усвідомленого батьківства студентів закладів вищої освіти. Забезпечення може бути використано щодо навчального середовища, виховного середовища, інформаційного середовища, освітнього простору.

Науково-методичне забезпечення розуміється як сукупність нормативних, програмних, дидактичних і критеріально-оцінювальних матеріалів, спрямованих на підвищення ефективності діяльності. У структурі науково-методичного забезпечення поєднуються бесіди, семінари, зустрічі, лекції, навчальні заняття, тести, опитувальники, процес формування в студентів необхідних компетенцій, технологія навчання педагогічного колективу [9, с. 146]. В межах дослідження науково-методичне забезпечення спрямовано на підтримку процесу формування готовності до усвідомленого батьківства студентів закладів вищої освіти з урахуванням когнітивного, емоційного, мотиваційного та поведінкового складників усіх структурних компонентів усвідомленого батьківства.

Когнітивний складник поєднує знання щодо особливостей фрізичного і психічного розвитку дитини на різних вікових етапах, знання про способи, пріоритетні напрями і мету взаємодії 3 дитиною на кожному з них, уявлення про репродуктивні норми суспільства, відповідальну і без- відповідальну поведінку батьків, розподіл відповідальності між батьками в інших сім'ях [11, с. 403].

Мотиваційний складник включає усвідомлення власного бажання бути батьком чи матір'ю, усвідомлення потреб, спонукань і мотивів, які зумовлюють ступінь бажання студентів мати дітей. Серед основних мотивів зазначають чотири групи: 1) дитина заради дитини; 2) соціальні; 3) духовні; 4) матеріальні $[5$, с. 69].

Емоційний складник виражений в емоційному забарвлені й оціночному ставленні до батьківства, зумовлює ті чи інші переживання й почуття, виступаючи в якості маркеру пріоритетів у питаннях ставлення до себе як до майбутнього батька (матері); оцінки себе з точки зору відповідальності і розподілу ролей у сім'ї; домінуючого емоційного фону, що супроводжує думки про майбутнє батьківство; оцінки й судження щодо різних типів батьківського ставлення; оцінки й думки щодо образу майбутньої дитини та майбутніх дитячо-батьківських стосунків; сукупність поглядів, суджень і позицій особистості щодо кількості дітей у сім'ї.

Поведінковий складник характеризується здатністю до контролю власної поведінки, здійсненням діяльності (чи відмовою ії здійснювати) з оволодіння знаннями, вміннями на навичками взаємодії 3 майбутньою дитиною [11, с. 22].

Третьою умовою фрормування готовності до усвідомленого батьківства студентів закладів вищої освіти є спонукання студентів до здійснення систематичного самовиховання у вказаному напрямі. Важливість втілення цієї умови пояснюється тим, що готовність до усвідомленого батьківства $€$ динамічною структурою, яка постійно змінюється під впливом багатьох фракторів: соціальні норми суспільства, вплив інформаційного простору (телебачення, інтернет, соціальні мережі тощо), уклад життя батьківської сім'ї студента, спілкування 3 однолітками, статеві відносини, незапланована вагітність, пошук партнера для шлюбу, кохання тощо.

Готовність фрормується набагато ефективніше за умови систематичної самовиховної діяльності в зазначеному напрямі. Тому студенти мають здійснювати системну діяльність з формування в себе готовності до усвідомленого батьківства, що дасть можливість зробити ці напрацювання більш стійкими та якісними.

Висновки. Під час проведення дослідження визначено, що формування готовності до усвідомленого батьківства студентів закладів вищої освіти $€$ актуальною проблемою сьогодення. Успішність їі вирішення забезпечує створення таких педагогічних умов: організація цілеспрямованої підготовки викладачів закладів вищої освіти до формування готовності до усвідомленого батьківства студентів закладів вищої освіти; створення й реалізація на практиці науково-методичного забезпечення фрормування готовності до усвідомленого батьків- 
ства студентів закладів вищої освіти; спонукання студентів до здійснення систематичного самовиховання у вказаному напрямі. Наступним кроком буде проведення експериментальної перевірки ефективності цих умов.

\section{БІБЛІОГРАФІЧНИЙ СПИСОК:}

1. Антонович О.С. Формирование психологической готовности родителей к взаимоотношению с будущим ребенком : дис. ... канд. психол. наук: 19.00.07. Самара, 2009. 250 с.

2. Бражнич О.Г. Педагогічні умови диференційованого навчання учнів загальноосвітньої школи : дис. канд. пед. наук: 13.00.07. Кривий Ріг, 2001. 238 с.

3. Губский Е.Ф Философрский энциклопедический словарь. Губский Е.Ф., Кораблева Г.В., Лутченко В.А. М. : ИНФА. 1998. 576 c.

4. Дурманенко О.Л. Теоретичний аналіз поняття «педагогічні умови» в контексті моніторингу виховної роботи у вищому навчальному закладі. Молодь $і$ ринок. № 7 (90). 2012. С. 135-138.

5. Евдокимова Е.В. Формирование ценностного отношения к родительству у студентов вуза : дис. ... канд. психол. наук: 19.00.07. Пятигорск, 2015. 211 с.

6. Карпичев В.С. Организация и самоорганизация социальных систем: словарь. Российская академия гос. службы при Президенте РФ. М. : Издательство РАГС, 2001. 125 с.

7. Куликова Т.А. Формирование готовности будущего педагога к профрессиональной деятельности. Куликова Т.А., Пронина Н.А. Вестник ТГПУ (TSPU Bulletin). 2018. 3 (192). C. 84-90.

8. Лемещенко О.Р. Соціально-психологічні умови формування у старшокласників готовності до усві- домленого батьківства : дис. ... канд. психол. наук: 19.00.05. Сєвєродонецьк, 2016. 224 с.

9. Лиховцов С.Е. Система научно-методического обеспечения подготовки специалиста технического профриля в системе СПО. Теория и практика образования в современном мире : материалы IV Междунар. науч. конфр. СПб : Заневская площадь, 2014. C. 144-147.

10. Манько В.М. Дидактичні умови фрормування у студентів профресійно-пізнавального інтересу до спеціальних дисциплін. Соціалізація особистості : зб. наук. пр. Національного педагогічного університету імені М. Драгоманова. К., 2000. Вип. 2. С. 153-161.

11. Овчарова Р.В. Родительство как психологический феномен : учебное пособие. М. : Московский психолого-социальный институт. 2006. 496 с.

12. Повалій Л.В. Формування у старшокласників відповідального батьківства як сімейної цінності. 2015. Young Scientist, № 2 (17). C. 291-294.

13. Тіунова О.В. Психологічні умови фрормування відповідального ставлення до материнства у дівчат старшого шкільного віку : дис. ... канд. психол. наук: 19.00.07. Тернопільський національний педагогічний ун-т ім. Володимира Гнатюка. Т., 2008. 262 с.

14. Хавула Р.М. Психолого-педагогічні чинники формування психологічної готовності юнаків до батьківства. Проблеми сучасної психології : Збірник наукових праць Кам'янець Подільського національного університету імені Івана Огієнка, Інституту психології ім. Г.С. Костюка АПН України. 2010. Вип. 10. Кам'янець Подільський : Аксіома. С. 771-781.

15. Яременко В. Новий тлумачний словник української мови: у 4 т. Яременко В., Сліпушко О. К. : Аконіт, 1999. T. 2. 910 C. 


\section{ЗМІСТОВІ АСПЕКТИ ФОРМУВАННЯ ПРОФЕСІЙНО-ЦІННІСНИХ ОРІЄНТАЦІЙ УЧНІВ ДО ТРУДОВОЇ ДІЯЛЬНОСТІ}

\section{THE CONTENT ASPECTS OF FORMATION OF PROFESSIONAL AND VALUE ORIENTATIONS OF STUDENTS TO EMPLOYMENT}

\begin{abstract}
Стаття присвячена розкриттю змістовних аспектів формування профресійно-ціннісних орієнтацій учнів старшого підліткового і юнацького віку до трудової діяльності в умовах закладів загально середньої освіти. Доведено, що фоомування несуперечливої позиції у прочесі фрахової підготовки має активізуватися в підлітковому і старшому шкільному віці і втілюватися у вихованні професійно-ціннісних орієнтацій учнів. Відповідно до мети статті уточнено зміст поняття «профресійно-ціннісні орієнтації учнів до трудової діяльності» як складне інтегральне утворення особистості, що характеризується певними для старшого підліткового та юнацького віку професійно-технологічними знаннями та способами дій, що супроводжуються відповідними моральноціннісними надбаннями $і$ в результаті цього об'єктивуються в емоційні переживання особистої значущості трудової діяльності в межах певного профрілю навчання. Визначено, що розвивальний рух учнів здійснюється від уявлення про специфріку майбутньої трудової діяльності до усвідомлення себе як суб'єкта професійного становлення; від позитивного ставлення до майбутньої трудової діяльності до емоційно-ціннісного самоставлення; від здатності приймати на себе відповідальність за власну трудову діяльність до уміння організовувати власну професійно-ціннісну діяльність. Поєднує ці ланки самодіяльність учня, спрямована на самопізнання, позитивне самоставлення, самоефективність. Базуючись на компонентно-процесуальній моделі свідомого привласнення зростаючою особистістю духовних цінностей (I. Бех), у структурі профресійно-ціннісних орієнтацій учнів до трудової діяльності виокремлено: пізнавальний, емоційно-мотиваційний, довільного імпульсу, практично-дієвий та самоціннісний компоненти і відповідні до них показники. Схарактеризовано рівні (високий, середній, низький) сформованост профресійно-ціннісних орієнтацій в учнів до трудової діяльності.
\end{abstract}

Ключові слова: цінності, система цінностей, професійні цінності, профресійноціннісні орієнтації, профресійне самовизначення.

The article is devoted to the disclosure of substantive aspects of the formation of professional and value orientations of students of senior adolescence and adolescence to work in general secondary education. It is proved that the formation of a consistent position in the process of professional training should be intensified in adolescence and high school age, and embodied in the education of professional and value orientations of students. In accordance with the purpose of the article, the content of the concept of "professional and value orientations of students to work" is clarified - a complex integrated education of personality, characterized by certain for older adolescents and young people professional and technological knowledge and methods of action, accompanied by relevant moral values. this is objectified in the emotional experiences of personal significance of work within a certain profile of study. It is determined that the developmental movement of students is carried out from the idea of the specifics of future work to self-awareness as a subject of professional development; from a positive attitude to future work to emotional and value self-esteem; from the ability to take responsibility for their own work to the ability to organize their own professional and value activities. Combining these links amateur student is aimed at selfknowledge, positive self-esteem, self-efficacy. Based on the component-procedural model of conscious appropriation of spiritual values by a growing personality (I. Bekh), in the structure of professional and value orientations of students to work, the following are distinguished: cognitive, emotional-motivational, arbitrary impulse, practical-effective and self-valuable components and corresponding Indicators. Levels (high, average, low) of formation of professional and value orientations at pupils to labor activity are characterized.

Key words: value, value system, work values, professional and value orientations, professional self-determination.
Постановка проблеми. Ефрективна реалізація ключових напрямів розвитку нашого суспільства (в тому числі євроінтеграція) значною мірою залежать від трудового потенціалу країни загалом i, зокрема, від ресурсів фрахівців, професійне становлення яких починається 3 ефрективного профрільного та професійного самовизначення. Зазначимо, що профрільне і профресійне самовизначення зумовлюється особливостями ціннісних орієнтацій особистості, які надалі створюють ядро в професійній діяльності і у внутрішньому світі людини.

Однак, з одного боку, у старшому підлітковому і юнацькому віці ціннісні орієнтації характеризу- ються динамічністю та нестійкістю, а 3 іншого проблема цінностей загострюється у періоди, які пов'язані з втратою відчуття стабільності у суспільстві, що особливо гостро українці відчули в останні півроку.

На нашу думку, недостатня увага фрахівців до фрормування професійно-ціннісних орієнтацій у старшому підлітковому та юнацькому віці сприяє загостренню суперечностей між:

- запитом суспільства на виховання професійно-ціннісних орієнтацій та недостатньою теоретико-методологічною обґрунтованістю їх формування в учнів підліткового та юнацького віку; 
- зростаючими вимогами до людини як фрахівця, здатного до постійного професійного саморозвитку, та фррагментарною спрямованістю сучасної системи виховання;

- високим виховним потенціалом системи профресійної орієнтації та його неповною реалізацією, зокрема, стосовно створення виховних технологій фрормування професійно-ціннісних орієнтацій у підлітків та старшокласників;

- значущістю для зростаючої особисті фрормування професійно-ціннісних орієнтацій і фраховою непідготовленістю до реалізації такого виховного завдання з боку вчителів-предметників, психологів.

Зазначене вище актуалізує проблему вивчення особливостей виховання професійно-ціннісних орієнтацій в учнів основної і старшої школи до трудової діяльності в умовах 33СО.

Аналіз останніх досліджень і публікацій. Одним із завдань освітнього процесу тривалий час залишається допомога підростаючому поколінню у фрормуванні цінностей, які трансорормуються у стійку індивідуальну систему орієнтацій, здатну забезпечити саморегуляцію й мотивацію поведінки і діяльності. Відповідно, у психологопедагогічній науці накопичено великий доробок досліджень з проблем фрормування ціннісних орієнтацій. У контексті теми дослідження цікавість для нас мають праці, в яких розкриваються особливості: формування системи цінностей і ставлень в онтогенезі (І. Бех, І. Зязюн, Н. Кириченко, О. Коберник та інші); професійного становлення особистості (Є. Головаха, Е. Зеєр, Є. Клімов, І. Кон, М. Пряжников, П. Шавір, Б. Федоришин та ін.); формування ціннісних орієнтацій особистості в умовах освітніх закладів: І. Бех, І. Волощук, Г. Вороніна, І. Зязюн, О. Рудіна та інші.

Виділення не вирішених раніше частин загальної проблеми. Результати вказаних досліджень свідчать про те, що профресійні ціннісні орієнтації відіграють важливе значення у процесі професійного становлення особистості. Сучасні дослідники активно вивчають складники структури ціннісних орієнтацій, гендерні відмінності основних життєвих цінностей, ціннісні орієнтації різних вікових категорій, особливості ціннісної сорери студентів тощо. Проте питання формування професійно-ціннісних орієнтацій у рамках навчальновиховного середовища закладів системи загальної середньої освіти з погляду пошуку особистісного, ціннісного смислу в процесі трудової діяльності висвітлені недостатньо.

Мета статті. Відповідно до викладеного вище метою статті $€$ уточнення сутності поняття «професійно-ціннісні орієнтації учнів до трудової діяльності» та визначення його структурних компонентів і рівнів сформованості.

Виклад основного матеріалу дослідження. Аналіз наукових праць дозволяє стверджувати, що проблема цінностей та ціннісних орієнтацій достатньо повно розкрита в сучасній вітчизняній і зарубіжній науці. Так, сучасні дослідники, які вивчають фрормування профресійно-ціннісних орієнтацій, зосереджують увагу на таких дефініціях, як «цінності», «ціннісні орієнтації», «профресійноціннісні орієнтації». Відповідно, ціннісні орієнтації базуються на системі цінностей, які інтеріоризуються суб'єктом, а надалі екстеріоризуються і знаходять своє вираження в ціннісному ставленні особистості до навколишньої дійсності. Професійно-ціннісні орієнтації - це система професійної спрямованості й ставлення до професійної діяльності та їі різних сторін, що відображає змістову сторону, основу і сутність професійної діяльності.

Слід зазначити, що у науковому просторі багато психолого-педагогічних досліджень, у яких висвітлюється зміст поняття та структура профресійноціннісних орієнтацій до педагогічної діяльності у студентів (О. Лисенко, Є. Мамчур, Г. Печерська, Н. Шемигон та інші). Так, професійно-ціннісні орієнтації Г. Печерська розглядає як орієнтири, на основі яких людина обирає, опановує і виконує свою професійну діяльність. Відповідно, професійні цінності - це віддзеркалення вимоги профресії та суспільства до аксіосфери особистості фрахівця [5]. На думку Н. Шемигон, професійно-ціннісні орієнтації - система стійких відношень особистості до праці, що фрормуються на основі усвідомлених цінностей і втілюються в професійній діяльності, визначаючи її змістове наповнення і шляхи досягнення прооресійних цілей [8].

Отже, висвітлені нами визначення поняття «професійно-ціннісні орієнтації» не є суперечливими. Окрім цього, об'єднуючим моментом у всіх дослідженнях, що стосуються професійно-ціннісних орієнтацій, є акцентуація уваги на тому, що це індивідуальне (особистісне) утворення, яке забезпечує якість фахової діяльності, а також $є$ одним із найважливіших елементів успішної професійної діяльності, оскільки: стимулює професійно-особистісний розвиток людини, активізуючи внутрішні механізми особистості (потреби, інтереси, мотиви, установки, відношення); відіграє стратегічну роль у поведінці та діяльності, визначає напрями профресійної діяльності, забезпечуючи взаємозв'язок особистісного й предметного в діяльності на основі особистісної орієнтації. Натомість суперечливим положенням $€$ те, що становлення професійних ціннісних орієнтацій відбувається у взаємодії двох полярностей у єдиному полі - особистості і профресії, які зумовлюють розвиток одна одної [4; 5; 8].

На нашу думку, фрормування профресійно-ціннісних орієнтацій відбувається в онтогенезі набагато раніше. Адже проблема самостійного проєктування і творення свого професійного життя i, відповідно, потреба приймати рішення щодо вибору профресії, спеціальності тощо постає перед 
учнями, які здійснюють професійне та профрільне самовизначення. Зазначене підтверджується у дослідженнях М. Васьківського, І. Волощук, Г. Вороніної, О. Рудіної та інших. Так, дослідники підкреслюють, що розвиток самосвідомості, формування системи ціннісних орієнтацій, моделювання свого майбутнього, побудова еталонів ідеального спеціаліста - чинники утворення й розвитку певної системи переконань, які водночас формують світогляд. Якщо у цей період мають місце нечіткі світоглядні переконання, превалює змішаність цінностей, то визначитися 3 майбутньою професію майже неможливо [2; 7].

Профрільне та професійне самовизначення детермінує активізацію самосвідомості учнів, визначає іï змістовну характеристику та стає головною рушійною силою подальшого розвитку. Виступаючи системоутворюючим фрактором соціально активної позиції молодої людини, ціннісні орієнтації впливають на взаємозв'язок її потреб і мотивів та розвиток і формування особистості, на вибір життєвого шляху.

Отже, у самовизначенні присутні два компоненти: привласнення певних цінностей та їх усвідомлення як власних на основі самопізнання та самореалізації-як втілення цих цінностей в певних видах діяльності. Саме цінності створюють ядро в професійній діяльності внутрішньому світі людини. Таким чином, значним важелем ефективного професійного становлення особистості є їі здатність віднаходити особистісний смисл у майбутній профресійній діяльності. Профресійні ціннісні орієнтації, підкреслює І. Волощук, є різновидом ціннісних орієнтацій і являють собою систему особистих сенсів життя старшокласників, що регулює його поведінку на етапі вибору ним майбутньої професії [2]

На первинному етапі вибору професії починають формуватися професійні цінності, які особистістю детермінуються як найбільш значущі. Саме цінності створюють ядро в профресійній діяльності і внутрішньому світі людини. Своєю чергою сама особистість починає ідентифрікувати себе як представника певної конкретної профресії. Наступним кроком у процесі формування ціннісних орієнтацій майбутніх фрахівців є розвиток профресійно-ціннісного ставлення як активного аспекту репродукції ціннісних характеристик тієї професійної діяльності, в якій воно було сорормовано і виступає надбанням особистості [6].

Цікавим для нашого дослідження $€$ науковий доробок Г. Вороніної з порівняльного аналізу понять «профресійно-ціннісні орієнтації» у вітчизняному і зарубіжному науковому просторі. Так, дослідниця зазначає, що одним із важливих аспектів сучасного тлумачення поняття «професійні цінності» $є$ вивчення сутності дотичних понять, таких як «профресійне благополуччя» та «конструювання життя». Зазначені феномени є своєрідним ключем до успішної життєдіяльності та щасливого життя через активізацію таких процесів, як самопізнання та адаптування до нестабільного ринку праці, що сприяє побудові профресійного та особистого життя відповідно до власних цінностей, потреб та інтересів. На думку Г. Вороніної, професійно-ціннісні орієнтації є своєрідним компасом, який спрямовує людину у процесі вибору професії. Підкреслено, що система профресійних цінностей є надзвичайно важливою для конструювання життя, основи якого повинні закладатися у шкільні роки [3].

Зазначене вище доводить, що фрормування несуперечливої позиції в процесі фрахової підготовки має активізуватися в підлітковому і старшому шкільному віці і втілюватися у вихованні професійно-ціннісних орієнтацій учнів.

Відтак визначаємо, що профресійно-ціннісні орієнтації учнів до трудової діяльності можуть тлумачитися як складне інтегральне утворення особистості, що характеризується певними для старшого підліткового та юнацького віку профресійно-технологічними знаннями та способами дій, що супроводжуються відповідними морально-ціннісними надбаннями і в результаті цього об'єктивуються в емоційні переживання особистої значущості трудової діяльності в межах певного профрілю навчання. На нашу думку, таке визначення ключового поняття дозволяє не лише чітко виокремити його структурні компоненти, а й окреслити шляхи формування у старших підлітків та юнаків.

Базуючись на компонентно-процесуальній моделі свідомого привласнення зростаючою особистістю духовних цінностей (І. Бех [1]), у структурі професійно-ціннісних орієнтацій учнів до трудової діяльності ми виокремили пізнавальний компонент, який включає такі показники: рівень знань про зміст та специфіку майбутньої трудової діяльності та усвідомлення значущості професійно-ціннісних орієнтацій для майбутньої трудової діяльності; емоційно-мотиваційний компонент та його показники: характер емоційних переживань під час навчання і праці, первинна сорормованість мотивів до навчання і праці; критерій довільного імпульсу і такі показники: рівень прояву здатності приймати на себе відповідальність за власну трудову діяльність та сорормованість у трудовій діяльності вольових зусиль; практично-дієвий критерій 3 показниками: готовність до саморозвитку в трудовій діяльності, дієвість трудових умінь і навичок; самоціннісний критерій, який розкривають такі показники: рівень усвідомлення самоцінності та оцінка власної спроможності досягати поставлених цілей, певної мети (самоефективність).

Основна відмінність від традиційної структури професійно-ціннісних орієнтацій (в яких зазвичай визначають три показники: когнітивний, мотиваційний, поведінковий) полягає у тому, що процес фрормування ціннісної сфрери особистості - це 
завжди складний і довготривалий процес, тим більше в умовах панування Его-орієнтованого життя. Адже сходження особистості у виховному процесі до високих цінностей духовності вимагає від неї високого напруження всіх внутрішніх сил. Розгортання зазначеного процесу можливе лише через «самоцінність» як якісне в етико-психологічному вимірі ставлення особистості до самої себе (самоставлення), яке спричиняється реальними вчинками особистості [1].

Викладене вище дозволило зробити висновок, що зміст фрормування професійно-ціннісних орієнтацій учнів до трудової діяльності полягає в оволодінні учнями об'єктивними знаннями про специфріку майбутньої трудової діяльності, які складають підґрунтя його емоційних переживань (емоція бажання), що спонукають до емоційно-ціннісної діяльності учнів (Я-виклик) та виявляються в готовності втілювати привласнену духовну цінність у практичну сореру (вчинок), яка супроводжується переживанням особистісної самоцінності. Отже, розвивальний рух учнів здійснюється від уявлення про специфіку майбутньої трудової діяльності до усвідомлення себе як суб'єкта професійного становлення; від позитивного ставлення до майбутньої трудової діяльності до емоційно-ціннісного самоставлення; від здатності приймати на себе відповідальність за власну трудову діяльність до уміння організовувати власну профресійно-ціннісну діяльність. Поєднує ці ланки самодіяльність учня, спрямована на самопізнання, позитивне самоставлення, самоефективність.

Визначення компонентів, критеріїв та показників профресійно-ціннісної орієнтації учнів до трудової діяльності дозволило схарактеризувати її рівні (високий, середній, низький) ссрормованості.

Високий рівень. Учням цієї групи властива чітко сорормована система знань про майбутню трудову діяльність та усвідомлення значущості професійно-ціннісних орієнтацій у ній. Учні, позитивно налаштовані до навчання і праці, демонструють високий рівень мотивації, відповідально ставляться до власної трудової діяльності, виявляють вольові зусилля у ній. Їм притаманна готовність до саморозвитку в трудовій діяльності, дієвість трудових умінь і навичок, що супроводжується усвідомленням самоцінності і втілюється у спроможності досягати поставлених цілей, певної профрорієнтаційної мети.

Середній рівень. Учням цієї групи властива неповна система знань про майбутню трудову діяльність та часткове усвідомлення значущості професійно-ціннісних орієнтацій у ній. Такі учні загалом позитивно налаштовані на навчання і працю, однак не завжди демонструють високий рівень мотивації. Учні періодично виявляють відповідальність до власної трудової діяльності та не завжди докладають вольові зусилля у ній. Їм при- таманна готовність до саморозвитку в трудовій діяльності, але дієвість трудових умінь і навичок ситуативна, що періодично супроводжується усвідомленням самоцінності і не завжди втілюється у спроможності досягати поставлених цілей, певної профорієнтаційної мети.

Низький рівень. Для учнів характерні поверхові та несистематичні знання про майбутню трудову діяльність та значущість профресійно-ціннісних орієнтацій у ній. Учні, що негативно налаштовані на навчання і праці, мають низький рівень мотивації до них. Безвідповідально ставляться до власної трудової діяльності та слабко виявляють вольові зусилля у ній. Учні епізодично виявляють готовність до саморозвитку в трудовій діяльності та дієвість трудових умінь і навичок, що супроводжується непродуктивною самоцінностю і втілюється у неспроможності досягати поставлених цілей, певної профорієнтаційної мети.

Висновки. Аналіз стану досліджень процесу виховання професійно-ціннісних орієнтацій підростаючої молоді свідчить про постійну увагу дослідників різних галузей до визначеної проблеми на теоретико-методологічному та практичному рівнях. Попри різні концептуальні підходи до професійно-ціннісних орієнтацій, об'єднуючим моментом є те, що ціннісні орієнтації відіграють важливу роль як у професійному самовизначенні, так і у трудовій діяльності загалом. 3 урахуванням того, що старший підлітковий і юнацький вік є періодом інтенсивного становлення професійно-ціннісних орієнтацій, на нашу думку, важливим є формування зазначеного утворення в умовах 33СО, що забезпечить несуперечливу позицію у подальшому професійному становленні молоді.

Відповідно до мети було уточнено зміст поняття «професійно-ціннісні орієнтації учнів до трудової діяльності», який ми визначаємо як складне інтегральне утворення особистості, що характеризується певними для старшого підліткового та юнацького віку професійно-технологічними знаннями та способами дій, що супроводжуються відповідними морально-ціннісними надбаннями і в результаті цього об'єктивуються в емоційні переживання особистої значущості трудової діяльності в межах певного профрілю навчання. Базуючись на компонентно-процесуальній моделі свідомого привласнення зростаючою особистістю духовних цінностей (І. Бех), визначено компоненти: пізнавальний, емоційно-мотиваційний, довільного імпульсу, практично-дієвий та самоціннісний і відповідні їм показники та рівні (високий, середній, низький) сфрормованості професійно-ціннісних орієнтацій у учнів до трудової діяльності.

Подальшими перспективами в контексті теми дослідження ми вбачаємо підбір діагностувального інструментарію для проведення констату- 
вального етапу дослідження 3 метою емпіричного вивчення рівнів сорормованості професійно-ціннісних орієнтацій учнів до трудової діяльності.

\section{БІБЛІОГРАФІЧНИЙ СПИСОК:}

1. Бех І.Д. Компонентна технологія сходження зростаючої особистості до духовних цінностей. Початкова школа : науково методичний журнал. 2018. № 1, 5-10.

2. Волощук І.П. Формування професійних ціннісних орієнтацій старшокласників в умовах технічного ліцею : автореф. дис. ... канд. пед. наук : 13.00.07. Київ, 2013. 19 с.

3. Вороніна Г.Р. Поняття «профресійна перспектива старшокласників»: досвід Англії. Теоретико-методичні проблеми виховання дітей та учнівської молоді. 2017. Вип. 21(1). С. 134-144.

4. Лисенко О.М. Теоретичні і методичні засади формування профресійно-ціннісних орієнтацій май- бутніх педагогів дошкільних навчальних закладів у системі фрахової підготовки : автореф. дис. ... докт. пед. наук : 13.00.04. Хмельницький , 2019. 41 с.

5. Печерська Г.О. Профресійні ціннісні орієнтації вчителів. Психологічні науки: зб. наук. праць. 2013. Т. 2. Вип. 10. С. 252-257.

6. Повар І., Повар О. Ціннісний вимір професійної підготовки майбутнього фахівця. Науковий вісник Східноєвропейського національного університету ім. Л. Українки: науковий журнал. 2016. №2 (304). С. 94-100.

7. Рудіна О.М. Формування ціннісних орієнтацій старшокласників в умовах навчально-виховного процесу гімназії : автореф. дис.... канд. пед. наук : 13.00.07. Київ, 2002. 20 с.

8. Шемигон Н.Ю. Формування ціннісних орієнтацій майбутніх педагогів у процесі профресійної підготовки : автореф. дис... канд. пед. наук : 13.00.04. Харків, 2008. 21 с. 


\section{ПЕДАГОГІЧНІ УМОВИ ФОРМУВАННЯ ПСИХОЛОГІЧНОГО ПРОФІЛЮ ЖІНОК-ЄДИНОБОРЦІВ ВИСОКОЇ КВАЛІФІКАЦІЇ

\author{
PEDAGOGICAL CONDITIONS FOR THE FORMATION \\ OF THE PSYCHOLOGICAL PROFILE OF HIGHLY QUALIFIED \\ WOMEN ENGAGED IN MARTIAL ARTS
}

УДК 159.9:377.2; 796.071.2

DOI https://doi.org/10.32843/2663-

6085/2020/24-2.39

\section{Хуртенко О.В.,}

канд. психол. наук, доцент,

доцент кафедри теорії та методики фозичного виховання

Вінницького державного педагогічного університету

імені Михайла Коцюбинського

\section{Білошицький В.В.,}

начальник науково-дослідної лабораторії наукового супроводження розроблення нормативів і стандартів фрізичної підготовки і спорту

Науково-дослідного центру проблем фрізичного виховання, спеціальної фрізичної підготовки і спорту Навчально-наукового інституту фрізичної культури та спортивно-оздоровчих технологій

Національного університету оборони

України імені Івана Черняховського

\section{Власко С.В.}

викладач кафедри фрізичного виховання Харківського національного університету міського господарства імені О.М. Бекетова

\section{Партика С.C.,}

науковий співробітник

науково-дослідної лабораторії

наукового супроводження

розроблення нормативів і стандартів

фрізичної підготовки і спорту

Коновалов Д.О.

науковий співробітник

науково-дослідного відділу

розвитку фрізичного виховання,

спеціальної фрізичної підготовки і спорту

Науково-дослідного центру проблем фрізичного виховання, спеціальної

фрізичної підготовки і спорту

Навчально-наукового інституту

фрізичної культури та спортивно-

оздоровчих технологій

Національного університету оборони

України імені Івана Черняховського
Статтю присвячено актуальним проблемам удосконалення системи багаторічної підготовки жінок-єдиноборців високої квалісрікації. Головною метою роботи є визначення та теоретичне обгрунтування педагогічних умов фрормування психологічного просрілю жінок-єдиноборців високої квалісрікації як провідного чинника досягнення перемоги під час змагань різних рівнів. Під час дослідження нами використані такі методи: теоретичний аналіз та узагальнення науково-методичної (спеціальноі) літератури; аналіз інтернет-ресурсів; анкетування; педагогічні спостереження; метод експертних оцінок; методи математичної статистики; методи психофізичної діагностики; науковий інструментарій. $у$ результаті дослідження встановлено, що жінки-єдиноборці досліджуваної категорії, які мають високі спортивні результати та здобули спортивні звання найвищого ґатунку, володіють характерними особистісними відмінностями, а саме: вони не схильні до співпраці; володіють максимальними показниками домінування та лідерства; схильні до спілкування з неординарними особами (несоормальними людьми); нерідко демонструють прагнення індивіда до нових відчуттів через незагальноприйняті канони поведінки; епатажні та володіють незвичними способами реалізації особистісних здібностей. Членами науково-дослідної групи встановлено, що жінки, які займаються єдиноборствами, не схильні до ризику та розкутої поведінки в повсякденному житті, адже заняття єдиноборствами передбачає виникнення ризикованих ситуацій під час тренувальної (змагальноі) діяльності, тому в повсякденній діяльності спортсменки намагаються уникнути зазначених вище обставин. Володіючи необхідною інфрормацією про психологічні якості, які дозволяють жінкам-єдиноборцям досягати високих спортивних показників, тренерам можливо здійснювати ухил на їх розвиток, а також використовувати їх під час змагальної діяльності. Крім цього, зазначені вище якості можливо використовувати під час відбору кандидатів у збірні команди з повноконтактних єдиноборств. Перспективи подальших розробок у вибраному напрямі дослідження передбачають розроблення педагогічної моделі фоормування індивідуальної («коронної») техніки жінок-єдиноборців високої кваліфікації.
Ключові слова: єдиноборства, жінки-єдинобориі, система підготовки, педагогічні умови, психологічний профріль, тренувальний прочес, якості.

The article is devoted to topical issues of improving the system of long-term training of highly qualified single wrestlers. The main purpose of the work is to determine and theoretically substantiate the pedagogical conditions for the formation of the psychological profile of women wrestlers of high qualification, as a leading factor in achieving victory in competitions of different levels. During the research we used the following methods: theoretical analysis and generalization of scientific and methodical (special) literature; analysis of Internet resources; questionnaires; pedagogical observations; method of expert assessments; methods of mathematical statistics; methods of psychophysical diagnostics; scientific tools. As a result of the study, it was found that women wrestlers of the studied category, who have high sports results and received sports titles of the highest grade, have characteristic personal differences, namely: they are not willing to cooperate; have the maximum indicators of dominance and leadership; tend to communicate with extraordinary people (informal people); often demonstrate the individual's desire for new sensations through non-generally accepted canons of behavior; outrageous and have unusual ways of realizing personal abilities. The members of the research group found that women who engage in martial arts are not prone to risk and loose behavior in everyday life, because martial arts involves risky situations during training (competitive) activities, so in everyday activities athletes try to avoid the above circumstances. With the necessary information about the psychological qualities that allow women wrestlers to achieve high athletic performance, coaches may be inclined to their development, as well as use them during competitive activities. In addition, the above qualities can be used in the selection of candidates for national teams in full-contact martial arts. Prospects for further development in the chosen direction of research include the development of a pedagogical model of formation of individual ("crown") technique of highly qualified single wrestlers.

Key words: martial arts, women wrestlers, training system, pedagogical conditions, psychological profile, training process, qualities.
Постановка проблеми у загальному вигляді. У відповідності до результатів аналітичних звітів фрахівців спортивної статистики (М.С. Авербаха, В.В. Вербицького, Ш.І. Гамзатова, Є.П. Ільїна, В.М. Катихіна, В.К. Сіліна, В.А. Харькової, В.Г. Шилько та інших фрахівців) нині спостерігається сталий розвиток жіночих єдиноборств. Варто також зауважити, що жінки $з$ великим ентузіазмом опановують сугубо «чоловічі» види єдино- борств та беруть участь у змаганнях різних рівнів (чемпіонати світу, Європи, Олімпійські Ігри).

Крім цього, існує багато поглядів та припущень на мотивацію участі жінок в єдиноборствах. Цю мотивацію можливо розподілити на дві категорії: суттєво жіночі (у переважній більшості підсвідомі) та універсальні (які можливо застосувати як для жінок, так і для чоловіків). Однією із головних соціальних домінант поширення жіночих єдиноборств $€$ сумісна 
взаємодія таких відповідних фракторів, як: розвиток цивілізації; науково-технічний прогрес; емансипація жінок та фреміністський рух. У відповідності до зазначеного прослідковується наукова проблема постійного вдосконалення системи підготовки спортсменок високого рівня. Варто також зауважити, що формування всебічно розвинутої особистості єдиноборця здійснюється 3 використанням засобів технічної, тактичної фрізичної та психологічної підготовки. У свою чергу, для того щоб тренеру здійснювати ефективну психологічну підготовку, йому необхідно володіти інформацією про специфічні психологічні закономірності, які необхідні для досягнення високого спортивного результату, що підкреслює актуальність вибраного напряму дослідження.

Дослідження проведено у відповідності до Зведеного плану НДР і ДКР (РК) Українського інституту науково-технічної і економічної інфрормації (шифр «Модель-РБ», номер державної реєстрації 0108U007536).

Аналіз останніх досліджень і публікацій. У наукових працях Є.В. Боченкової, О.А. Надеждіна, А.В. Кондратьєвої, С.А. Літвінова, О.А. Овсянника, Ж.А. Позняка, С.Є. Табакової, Є.А. Тарасевича, І.Л. Тіхонової, В.А. Талача та інших учених розкриваються актуальні питання техніко-тактичної підготовленості жінок-єдиноборців до змагальної діяльності.

Питанням мотивації жінок до занять єдиноборствами присвячені роботи науковців: Ш.К. Шахова, А.С. Дамадаєва, М.М. Магдієва [1], К.І. Чемової [2], І.А. Греця, І.А. Живуцької, Т.М. Булкова [3] та інших провідних срахівців вибраного напряму дослідження.

Надалі, під час моніторингу науково-методичної та спеціальної літератури (інтернет-ресурсів), нашу увагу привернули роботи фрахівців А.С. Ганоля [4], Т.Ю. Маскаєва, Г.М. Германова [5], C.A. Умгаєва [6] та інших учених, в яких розкриваються гендерні характеристики єдиноборців. У свою чергу аналіз спеціальної науково-методичної літератури вибраного напряму дослідження дозволив виявити роботи провіднихучених: І.І. Рясної, А.І. Шевченко [7], В.В. Лісицина [8], Р.А. Султанова, Л.Г. Уляєва [9], К.А. Бугаевського [10] та інших фрахівців. У зазначених вище роботах розкриваються актуальні питання психологічної готовності жінок-єдиноборців до змагань різних рівнів.

Виділення невирішених раніше частин загальної проблеми. Аналіз науково-методичної та спеціальної літератури (інтернет-джерел) у напрямі психологічного супроводу системи багаторічної підготовки жінок-єдиноборців високої кваліфікації дозволив нам визначити такі суперечності між:

- потребою людства в жінках-єдинобрцях високої кваліфікації та відсутністю необхідних психологічних умов фрормування такого рівня спортсменок;
- потребою всебічного забезпечення підготовки спортсменок, які займаються на професійному рівні єдиноборствами та недостатніми педагогічними умовами фрормування їхнього психологічного профрілю.

Слід також зауважити, що, незважаючи на значну кількість напрацювань у вибраному нами напрямі, досліджень $з$ питань визначення та теоретичного обґрунтування педагогічних умов фрормування психологічного профрілю жінок-єдиноборців високої кваліфікації нами не виявлено, що потребує додаткового дослідження.

Мета статті - визначити й теоретично обґрунтувати педагогічні умови фрормування психологічного профрілю жінок-єдиноборців високої кваліфрікації (на прикладі спортсменок, членів збірних команд України 3 різних єдиноборств: боротьби самбо, військово-спортивних багатоборств, дзюдо, кікбоксингу, рукопашного бою).

Для досягнення мети дослідження планувалося вирішити такі завдання:

- здійснити аналіз науково-методичної та спеціальної літератури в напрямі психологічного забезпечення готовності жінок-єдиноборців до змагань різних рівнів;

- визначити психологічний профріль спортсменок, які займаються єдиноборствами.

Виклад основного матеріалу. Дослідження організовано на навчально-матеріальній базі Вінницького державного педагогічного університету імені М. Коцюбинського (2019-2020рр.). 3 метою якісного відпрацювання завдань та досягнення мети дослідження було створено науководослідну групу, до складу якої увійшли фрахівці вибраного напряму дослідження (О.В. Хуртенко, В.В. Білошицький, С.В. Власко, С.С. Партика, Д.О. Коновалов).

На першому етапі дослідження (вересень грудень 2019 р.), проведено моніторинг науковометодичних джерел (даних інтернет-ресурсів) у напрямі психологічного забезпечення готовності жінок-єдиноборців до змагань різних рівнів.

Упродовж другого етапу дослідження (січень квітень 2020 р.), членами науково-дослідної групи було здійснено визначення психологічного профрілю спортсменок, які займаються єдиноборствами. У відповідності до результатів моніторингу науково-методичної та спеціальної літератури в зазначеному напрямі нами встановлено, що в умовах жорсткої конкуренції на світовому рівні, коли всі спортсменки володіють приблизно однаковим рівнем фрізичної, тактичної та технічної підготовленості, на перший план виходить саме рівень психологічної підготовленості. Для того щоб здійснити ефективну психологічну підготовку, тренеру необхідно знати, які якості важливі та необхідні для досягнення високого спортивного результату. 
3 метою досягнення поставленого перед нами завдання було здійснено тестування 22-х спортсменок у віці від 18 до 28 років, членів збірних команд України $з$ різних єдиноборств (боротьба самбо, військово-спортивні багатоборства, дзюдо, кікбоксинг, рукопашний бій). Досліджувані спортсменки дали згоду на участь у тестуванні, яке було проведено з використанням мережі Інтернет, після чого ними були заповнені анкети, в яких відображалися їхні індивідуальні данні.

У подальшому було проведено ряд психологічних тестів, а саме: на вираженість рис особистості «NEO» [11]; на самооцінку агресивності [12]; на визначення домінантності, схильності до ризику [13]; на визначення статевих ролей [14]. Варто також зауважити, що для оцінки результатів були вибрані три критерії: місце в загальному заліку (середній показник зайнятих місць); частка виграних зустрічей у сумі всіх поєдинків; краща спортсменка (рангова оцінка за 6-бальною шкалою, 1 - краща, 6 - гірша). Крім цього, під час психологічного тестування враховувалися такі показники: стаж членства у збірній команді України; кількість виграних змагань вищих рівнів; спортивне звання. Статистична обробка результатів здійснювалася 3 використанням прикладних пакетів Windows 10 (дані тестування наведено в табл. 1).

Отримані дані (табл. 1) свідчать про те, що результати психологічного опитувальника по рисах особистості пов'язані $з$ показниками співробітництва, корелюють із місцем спортсменки в загальному заліку $(0,400)$. Кращі спортсменки у відповідності до оцінки тренерського штабу збірних команд отримали найвищі бали за шкалою домінування $(-0,342)$. Мінус зумовлений тим, що краща спортсменка вносилася в програму під кодом - 1. Слід також зауважити, що вони більш схильні до спілкування з незвичайними та неформальними особами. Схильність до розкутої поведінки виявилася негативно пов'язаною з часткою виграних поєдинків під час участі в змаганнях вищих рівнів із різних повноконтактних єдиноборств $(-0,546)$ та місцем у загальному заліку $(0,461)$. Слід зауважити, що в даному випадку спортсменка, яка посіла перше місце, позначалася цифрою - 1. Схильність до пошуку небезпеки та пригод також пов'язана з часткою переможних поєдинків $(-0,325)$.

Надалі, у відповідності до завдань дослідження, членами науково-дослідної групи визначено психологічний профріль спортсменок, які займаються єдиноборствами. Нами встановлено, що жінки-єдиноборці досліджуваної категорії, які мають високі спортивні результати та здобули спортивні звання найвищого ґатунку, володіють характерними особистісними відмінностями. Вони не схильні до співпраці. Співпраця відображає особливості міжособистісної взаємодії. Особа, яка схильна до співпраці, за своєю натурою $є$ альтруїстичною. Симпатизуючи іншим та намагаючись допомогти їм, така людина вірить у те, що інші у відповідь будуть взаємними. На відміну від такої людини, особа, яка конкурує, є ексцентричною та скептично налаштованою до намірів інших. Відповідним чином, в умовах жорсткої конкуренції на світовій спортивній арені особа, яка є конкурентоспроможною, має більше шансів на здобуття перемоги.

Крім цього, встановлено, що спортсменки, які займаються єдиноборствами, володіють максимальними показниками домінування та лідерства. Ці якості мало характерні для жінок загалом, але саме вони дозволяють їм досягати успіху. Жінки-єдиноборці, які проявляють ці якості під час змагальної сутички (захоплюючи ініціативу та домінуючи), мають більше шансів на перемогу. У свою чергу спортсменки, які надають перевагу спілкуванню з неординарними особами та неформальними людьми, демонструють прагнення індивіда до нових відчуттів через незагальноприйняті канони поведінки. Слід також зазначити, що жінки-єдиноборці в суспільстві сприймаються як певного роду екзотика. Тому в переважній більшості єдиноборствами займаються жінки, які схильні до епатажу та володіють незвичними способами реалізації особистісних здібностей. Варто відмітити, що жінки, які займаються єдиноборствами, не схильні до ризику та розкутої поведінки в повсякденному житті, адже заняття єдиноборствами передбачає виникнення ризикованих ситуацій під час тренувальної (змагальної) діяльності. Тому у звичайній діяльності

Порівняльний аналіз результатів успішності спортсменок, які займаються єдиноборствами, з їхніми біологічними та особистісними характеристиками

\begin{tabular}{|l|c|c|c|}
\hline \multicolumn{1}{|c|}{ Ознаки } & Краща спортсменка & Частка виграних поєдинків & Місце в загальному заліку \\
\hline NЕО співробітництво & - & - & $0,400(, 010)$ \\
\hline Домінування & $-0,342(, 030)$ & - & - \\
\hline Ризик trill & - & $-0,325(, 042)$ & - \\
\hline Eхреrience ризик & $0,370(, 025)$ & - & $0,461(, 007)$ \\
\hline Ризик disingib & - & $-0,546(, 002)$ & \\
\hline
\end{tabular}

Примітка: 1) у табл. 1 викладено лише значимі коефіцієнти кореляції між особистісними характеристиками спортсменок та оцінками результатів участі в змаганнях вищих рівнів; 2) у дужках наведена достовірність коефіцієнта; 3) NEO - визначення рис особистості (опитувальник NEO-PI-R); 4) ризик trill - пошук небезпеки, пригод та екстриму; 5) Ехреrience ризик - спілкування з несормальними особами; 6) ризик disingib - розкутість поведінки. 
спортсменки намагаються уникнути зазначених вище обставин. Важливим $є$ й те, що прагнення до розкутої поведінки суперечить такому поняттю, як «спортивний режим», через те що воно пов'язано 3 активністю індивіда в напрямі досягнення ним повної свободи та вседозволеності. Тому ті, хто суворо притримується «спортивного режиму», мають більше шансів на досягнення високих результатів на світовій арені.

Висновки. Таким чином, володіючи необхідною інформацією про психологічні якості, які дозволяють жінкам-єдиноборцям досягати високих спортивних показників, тренерам можливо здійснювати ухил на їх розвиток, а також використовувати їх під час змагальної діяльності. Крім цього, зазначені вище якості можливо використовувати під час відбору кандидатів у збірні команди з повноконтактних єдиноборств.

Під час дослідження нами визначено та теоретично обґрунтовано педагогічні умови фрормування психологічного профрілю жінок-єдиноборців високої кваліфрікації (на прикладі спортсменок, членів збірних команд України з різних єдиноборств: боротьби самбо, військово-спортивних багатоборств, дзюдо, кікбоксингу, рукопашного бою).

Результати дослідження впроваджені в систему багаторічної підготовки жінок-єдиноборців, здобувачів вищої освіти: Вінницького державного педагогічного університету імені Михайла Коцюбинського; навчально-наукового інституту фрізичної культури та спортивно-оздоровчих технологій Національного університету оборони України імені Івана Черняховського та Харківського національного університету міського господарства імені О.М. Бекетова.

Перспективи подальших розробок у вибраному напрямі дослідження передбачають розроблення педагогічної моделі формування індивідуальної («коронної») техніки жінок-єдиноборців високої кваліфрікації.

\section{БІБЛІОГРАФІЧНИЙ СПИСОК:}

1. Шахов Ш.К., Дамадаев А.С., Магдиев Н.Н. Проблемы спортивной мотивации в психологии спорта. URL: http://eir.pstu.edu.

2. Чемова К.И. Оценка мотивационной сферы женщин к занятиям единоборствами. Физическая культура, спорт, туризм: современные инновационные проекты. 2018. № 1 (15). С. 75-79.

3. Грец И.А., Живуцкая И.А., Булкова Т.М. Демограсрический портрет, предпочтения и мотивация женщин второго периода зрелого возраста к физкультурно-оздоровительным занятиям. Записки универcumema uм. П.Ф. Лесгафрта. 2018. № 1 (24). С. 37-42.

4. Ганоль А.С. Гендерные особенности структуры мотивации выбора экстремальных видов спорта. Записки университета им. П.Ф. Лесгафта. 2011. № 2 (12). С. 12-19.

5. Маскаева Т.Ю., Германов Г.Н. Гендерные психические и поведенческие особенности женщин и их проявление как результат занятий различными видами спорта. Записки университета им. П.Ф. Лесzaфpma. 2014. № 4 (7). C. 38-45.

6. Умгаев С.А. Гендерные психические и поведенческие особенности женщин и их проявление как результат занятий различными видами спорта. Гендерная характеристика единоборств в представлении участников Oriental Studies. 2015. № 2. C. 67-73.

7. Рясная И.И., Шевченко А.И. Значение морфоофункциональных особенностей организма спортсменок, занимающихся боксом. Науковий вісник Придніпров'я. 2014. № 25. С. 121-124.

8. Лисицын В.В. Некоторые аспекты психологической подготовки высококвалифиццированных женщин-боксеров. URL: http://cyberleninka.ru.

9. Султанова Р.А., Уляева Л.Г. Гендерный фрактор в психологической подготовке высококвалифицированных боксеров. Проблемы подготовки высококвалифицированных спортсменов. 2016. № 2 (5). С. 68-72.

10.Бугаевский К.А. Изучение уровня проявления агрессивности у спортсменок, занимающихся единоборствами и атлетическими видами спорта. Современные технологии в подготовке единоборцев. 2017. № 4. C. 124-127.

11. Costa P.T., Jr., Mc Crae R.R. The NEO-PI/NEOFFI manual supplement. Psychological Assessment Resource. 1989. № 1. P. 126-137.

12. Buss A.H. The aggression questionnaire. Journal of personality and Social Psychology. 1992. № 1. P. 452-459.

13. Zuckerman M.I. Behavioral Expressions and Biosocial Bases of Sensation Seeking. Cambridge University Press. 1994. № 2 (12). P. 357-421.

14.Bem S.L. The measurement of psychological androgyny. Journal of Consulting and Clinical Psychology. 1974. № 3. P. 155-162. 


\section{ІСТОРИЧНИЙ ОГЛЯД ПРОБЛЕМИ МОРАЛЬНО-ЕСТЕТИЧНОГО ВИХОВАННЯ ДІТЕЙ ДОШКІЛЬНОГО ВІКУ ЗАСОБАМИ МУЗИЧНО-РИТМІЧНОЇ ГІМНАСТИКИ

\author{
HISTORICAL OVERVIEW OF THE PROBLEM OF MORAL \\ AND AESTHETIC EDUCATION OF PRESCHOOL CHILDREN \\ BY MUSICAL AND RHYTHMIC GYMNASTICS
}

У статті проаналізовано попередні дослідження проблеми виховання моральноестетичних якостей dimeй старшого дошкільного віку засобами музично-ритмічної гімнастики й розглянуто процес становлення й розвитку теорії морального, естетичного та фрізичного виховання. Доведено актуальність дослідження проблеми морально-естетичного виховання дітей дошкільного віку. Визначено джерела наукових досліджень проблеми морально-естетичного виховання дітей дошкільного віку засобами музично-ритмічної гімнастики. у процесі дослідження виявлено взаємозв'язок морального, естетичного, музичного й фрізичного виховання з огляду на історію їх становлення й розвитку. Зокрема, розглядаються праці видатних мислителів i науковців різних періодів становлення й розвитку педагогічної науки, досвід i засоби народної педагогіки. Акцентується увага на проблемі пізнання й сприймання прекрасного людиною, а також на фрормуванні на цій основі ціннісних орієнтацій. здійснено аналіз наукової джерельної бази педагогічних і психологічних наук із метою визначення ретроспективи та перспективи досліджуваної проблеми. Визначено, що за різних культурно-історичних часів домінували різні тлумачення прекрасного, йому відводилася функціональна роль естетичного виховання людства. Також зауважено, що історично моральне й фрізичне виховання є однією з перших педагогічних проблем. Звертається увага на важливість аналізу генезису моральних суджень на різних етапах дошкільного періоду, зокрема старшого дошкільного віку. Зауважено, що необхідність фрізичних вправ для зміцнення здоров'я й загартування організму відзначали мислителі давніх цивілізацій, а в перших педагогічних системах було обгрунтовано роль орізичного розвитку як необхідної умови й результату правильного виховання. Таким чином, підтверджено значення музично-ритмічної гімнастики як засобу морально-естетичного виховання дітей старшого дошкільного віку. Прочес становлення й розвитку кожної з визначених виховних ліній представлено в хронологічній послідовності, що забезпечує унаочнення історичного огляду досліджуваноі проблеми.

Ключові слова: моральне виховання, естетичне виховання, фрізичне виховання, музичне виховання, музично-ритмічна гімнастика, старший дошкільний вік.

The article analyzes previous research on the problem of education of moral and aesthetic qualities of older preschool children by means of musical-rhythmic gymnastics and considers the process of formation and development of the theory of moral, aesthetic and physical education. The relevance of the study of the problem of moral and aesthetic education of preschool children is proved. The origins of scientific research on the problem of moral and aesthetic education of preschool children by means of musical-rhythmic gymnastics are determined. The study revealed the relationship between moral, aesthetic, musical and physical education, given the history of their formation and development. In particular, the works of outstanding thinkers and scientists of different periods of formation and development of pedagogical science, experience and means of folk pedagogy are considered. It is noted on the problem of cognition and perception of beauty by a person, and the formation, on this basis, of value orientations. The analysis of the scientific source base of pedagogical and psychological sciences is carried out, in order to determine the retrospective and perspective of the researched problem. It is determined that in different cultural and historical times different interpretations of beauty dominated, it was assigned the functional role of aesthetic education of mankind. It is also noted that historically moral and physical education is one of the first pedagogical problems. Attention is drawn to the importance of analyzing the genesis of moral judgments at different stages of the preschool period, in particular the older preschool age. It was noted that the need for exercise to strengthen health and harden the body was noted by thinkers of ancient civilizations, and in the first pedagogical systems, the role of physical development as a necessary condition and result of proper education was justified. Thus, the importance of musicalrhythmic gymnastics as a means of moral and aesthetic education of older preschool children is confirmed. The process of formation and development of each of the identified educational lines is presented in chronological order, which provides a clear historical overview of the problem under study.

Key words: moral education, aesthetic education, physical education, music education, musical-rhythmic gymnastics, senior preschool age. людей. Пріоритетним напрямом реформування дошкільної освіти є розвиток цілісної особистості дитини, зокрема ії̈ морально-естетичної ссрери. Дошкільний вік $€$ періодом засвоєння норм моралі, формування естетичного сприймання й фрізичної ніших, адже вони порушують пе нийсклад освітні питання, але й самосвідомість і почуття 
досконалості. До завершення цього періоду фрормуються основи моральності й естетики через засвоєння мови, її смислів і значень, звукової й музикальної тональності, людської діяльності тощо, отже, через освоєння історично виробленої людської культури. Морально-естетичне виховання особистості $€$ визначальним і пріоритетним у ставленні людини до себе, до інших, до природи й суспільства.

Аналіз останніх досліджень і публікацій. Виховання морально-естетичних якостей є однією 3 першооснов гармонійного розвитку особистості. Морально-естетичному вихованню дітей дошкільного віку присвячено чимало наукових праць таких учених, як П. Блонський, Н. Ветлугіна, Л. Виготський, О. Запорожець, О. Кононко, С. Кулачківська, М. Роганова, С. Русова, К. Ушинський, А. Шевчук та інші. Значну роль у процесі морально-естетичного виховання дітей старшого дошкільного віку відіграє музично-ритмічна гімнастика, головною складовою якої $€$ образні або наслідувальні фрізичні вправи, музика, елементи гри, що відкривають для цього величезні можливості. Відродженню та ефрективному впровадженню в освітньо-виховний процес закладу дошкільної освіти музично-ритмічної гімнастики присвячено чимало сучасних наукових досліджень, які здійснили А. Анохін, В. Бальсевич, В. Белутчик, Н. Веденський, Ю. Верхошанський, П. Віноградов, А. Душанін, М. Єорименко, В. Жолдак, К. Івлєв, Є. Крючок, Б. Лоу, Л. Назаренко, Т. Осокіна, Т. Ротерс, В. Смолевський, А. Шелемін та інші вчені.

Виділення не вирішених раніше частин загальної проблеми. Здійснивши аналіз останніх наукових досліджень з визначеної проблеми, доходимо висновку, що набуває актуальності розгляд історичного аспекту становлення й розвитку теорії морального, естетичного й фрізичного виховання дітей дошкільного віку, їх поєднання, що сприятиме гармонійному розвитку особистості.

Мета статті полягає у здійсненні аналізу наукової психолого-педагогічної літератури та визначенні ретроспективи й перспективи проблеми морально-естетичного виховання дітей старшого дошкільного віку засобами музично-ритмічної гімнастики.

Виклад основного матеріалу. Задля унаочнення процесу становлення й розвитку теорії морального, естетичного (музичного) й фрізичного виховання здійснено аналіз наукових праць 3 обраної проблеми. Становлення й розвиток теорії морального виховання дітей дошкільного віку висвітлено в провідних наукових дослідженнях вітчизняних і зарубіжних учених.

Я. А. Коменський наголошував на необхідності виховання таких «добрих якостей», як помірність, охайність, шанобливість до старших, люб'язність, справедливість, благодійність, терплячість, делі- катність, уміння триматися гідно, поводитися стримано й скромно [24, с. 218]. Видатний педагог К. Ушинський надавав моральному вихованню виняткової значущості. Особливу роль у моральному вихованні він відводив ідеї народності, народному ідеалу людини [24, с. 218]. Своєю чергою С. Русова наголошувала на необхідності виховання дітей з ранніх років на «рідному ґрунті», пробудження в них духовних сил, моральних почуттів до людей, світу, природи [24, с. 219].

Досліджуючи проблеми морального виховання, л. Виготський зауважував на появі внутрішніх моральних інстанцій (прагнення поводитися згідно 3 нормами не тому, що цього вимагають дорослі, а тому, що це приємно для себе та інших) [24, с. 214]. П. Блонський основою морального виховання вважав стосунки між дитиною та дорослим, моральні впливи на дитину, що ґрунтуються на довірливому ставленні та повазі до її особистості [24, с. 219].

Дослідник особливостей розвитку й виховання дітей дошкільного віку Е. Еріксон вважав, що саме в ранньому віці починає фрормуватися «базисна довіра до світу» - уявлення дитини про надійність дорослих, емоційну близькість із ними [24, с. 216].

Особливої уваги надавав вихованню єдності моральної свідомості й поведінки дітей А. Макаренко. Видатний педагог вважав, що дитина має пізнавати моральні норми в системі конкретних і реальних взаємин людей. На його думку, моральному вихованню в колективі сприяє атмосорера ділового співробітництва, добровільної взаємозалежності, доброзичливості [24, с. 219].

В. Сухомлинський наголошував на важливості активізації почуттів у дітей, оскільки кожна людина в дошкільному віці повинна пройти «емоційну школу», «школу виховання добрих почуттів». Практичний його досвід гармонійно поєднує переконливе слово, читання художніх творів, пояснення суті норм загальнолюдської моралі, етичні бесіди, створення моральних ситуацій [24, с. 220].

Дослідження проблеми морального виховання в різних видах діяльності висвітлено в наукових педагогічних працях Д. Менджерицької, Р. Жуковської, Ф. Левін-Щиріної (моральне виховання в ігровій діяльності); О. Булатової, Т. Маркової, В. Нечаєвої (моральне виховання засобами колективних взаємин дітей) [24, с. 220].

Психологічні аспекти проблеми розвитку моральної сфери дітей дошкільного віку визначено в психолого-педагогічних джерелах. О. Запорожець і Я. Неверович досліджували психологічні проблеми розвитку емоцій у дітей дошкільного віку [24]. Л. Артемова плідно працювала над проблемами морального виховання дітей дошкільного віку, керувала створенням програм виховання й навчання дітей у закладах дошкільної освіти [24]. В. Кортило розглядав проблему фрормування вольових якостей дітей дошкільного віку [24]. 
Науковці С. Кулачківська, С. Ладивір, Ю. Приходько досліджували проблему виховання гуманних почуттів і взаємин у дітей [24].

У своїх наукових працях, М. Роганова досліджує проблеми духовного виховання дітей дошкільного віку [27, с. 191-200]. Л. Лохвицька зазначає, що діяльність особистості у взаємодії з іншими спрямовується на досягнення поставленої мети на основі системи ціннісних орієнтацій, консолідованих у структурі моральної самосвідомості. Моральні цінності розглядаються як сплав інтегрального утворення моральної самосвідомості, що поєднує визнання моральних принципів й ідеалів, безапеляційне дотримання особистістю моральних норм на основі моральних уявлень і понять [16, с. 128-138]. Для дітей дошкільного віку (особливо молодшого) характерно, що вони не визнають наявність у себе проявів порушення моралі, а помічають це виключно в конкретних випадках і вказують на провину ровесників. Описуючи когось із дітей, вони зазначають, що добрий це, як правило, гарний, розумний, слухняний, але не зазначають таких рис, як чесність, справедливість, відповідальність, чуйність, товариськість тощо. Моральний портрет частково залишається поза увагою, бо дорослі концентруються на «знаннєвоцентричному», а не на «дитиноцентричному» підході до виховання [15, с. 6-7].

А. Лазарець зазначає, що виховне значення гри багато в чому залежить від професійної майстерності педагога, від знання ним психології дитини, урахування її вікових й індивідуальних особливостей, від правильного методичного керівництва взаємовідносинами дітей, від чіткої організації різноманітної ігрової діяльності [14, с. 47-52].

Своєю чергою Ю. Никоненко звертає увагу на противагу існуванню багатьох методів психолого-педагогічного впливу на поведінковий і когнітивний аспект морального становлення дітей. Зауважує, що недостатня увага приділяється розвитку емоційного складника виховання дошкільників. Вважає, що недоліком сучасних технологій морального виховання дошкільнят $€$ недостатнє змістове заповнення програм виховання, зокрема, переважання пасивних методів, їх низька ціннісна спрямованість [19, с. 132-136].

Т. Круцевич розглядає заняття фрізичними вправами, іграми, спортом і туризмом як засіб фрормування й виховання моральних якостей особистості дитини. Адже ці заняття сприяють задоволенню широкого спектра потреб особистості в освіті, вихованні, оздоровленні. Їх спрямованість не обмежується розвитком і вдосконаленням рухових здібностей дитини, а виконує рекреативну, гігієнічну, реабілітаційну, пізнавальну, ціннісно-орієнтовну, позитивно регулятивну, естетичну та інші функції, включно з соціалізацією. Дитина намагається підтримувати гармонію й рівновагу з навко- лишнім світом, її поведінка визначається бажанням зняти напругу, уникнути конорліктних ситуацій і здобути визнання в будь-яких фрормах діяльності й за будь-яких обставин. Заняття фрізичними вправами чинять виховний вплив на особистість дошкільника й можуть визначати характер його поведінки [11, с. 28-30].

О. Сурмило вважає, що моральне виховання фрормує моральні поняття, погляди й переконання. Воно покликане також сприяти розвитку моральних почуттів, що виражають запити, оцінки, спрямованість духовного розвитку особистості. Не менше значення має й вироблення навичок i звичок моральної поведінки. На всіх етапах розвитку суспільства мораль є важливим регулятором людської поведінки, людських відносин, а моральність - одним із критеріїв оцінки чеснот людини [29, c. $120-124]$.

3 метою визначення сутності поняття «морально-етична сорера» А. Курчатова здійснила аналіз його дефініцій у відповідних словниках. Методологічною основою формування моральноетичної сфери, відповідно до її досліджень, $€$ етика - наука про мораль, її природу, структуру й особливості походження [13, с. 85-89]. Л. Котлова визначає, що моральна поведінка передбачає вчинок, який відповідає моральним нормам і одночасно суперечить миттєвим інтересам особистості [9, с. 113-115]. Л. Московчук у загальному значенні морально-естетичне виховання розглядає як створення сприятливих умов для розкриття морального й естетичного потенціалу особистості на засадах істини, добра, краси та інших загальнолюдських цінностей. Цю категорію характеризує розвиненість почуттів, навичок і поведінки. Саме ці компоненти утворюють структуру особистості й діагностуються [18, с. 190-195].

Становлення й розвиток теорії естетичного (музичного) виховання розкрито фрілософами й педагогами різних часів. Аналізуючи праці видатних фрілософрів із досліджуваної проблеми, варто взяти до уваги думку Сократа, який розкрив співвідношення між етичним й естетичним, послуговувався поняттям «калокагатія» на позначення єдності прекрасного й доброго, гармонії внутрішнього й зовнішнього. Саме 3 того часу фрігурує вічна тема мистецтва й виховання, яка полягає в з'ясуванні співвідношення красивого й корисного [24, с. 282].

Своєю чергою Аристотель обстоював ідею єдності краси й добра, тобто гармонії. Вважаючи естетичне пізнання, мистецтво відображенням світової (космічної) гармонії, обґрунтував таку категорію естетики, як «мімезис» - наслідування, яке приносить людині особливе задоволення, доводячи, що ця здатність властива їй з дитинства. Філософр був переконаний у необхідності узагальнення й передавання художнього досвіду в процесі виховання [24, с. 282]. 
Платон досліджував проблеми естетичного виховання, природу сприйняття прекрасного, джерела талановитості. Доводив, що саме від впливу мистецтва залежить моральний світ дитини. Йому належать твердження про відносність краси, абсолютне прекрасне [24, с. 282].

Конфруцій переконував, що виховання має починатися з поезії, а закінчуватися вивченням правил етики, музики, яка втілює в собі найвищі естетичні цінності [24, с. 282]. Сюнь-цзи стверджував, що саме музика відкриває шлях до досконалості [24, с. 282].

У працях видатних педагогів висвітлено різні аспекти, взаємозв'язки та співвідношення естетичного (музичного) виховання й інших виховних ліній. Так, Я. А. Коменський пропонував розвивати в дітей музичні вміння, застосовувати в розвитку мовлення вивчення напам'ять віршів або рим, рекомендував розвивати почуття краси [24, с. 283].

С. Русова пов'язувала теорію й практику естетичного виховання дітей з ідеями народності виховання й навчання, вважаючи ігри, усну народну творчість, свята, природу невичерпним джерелом для пробудження в дитині духовних сил. Естетичне виховання вона розглядала в єдності 3 моральним, які, за ії̈ твердженням, мають спільну основу - розвиток вищих почуттів [24, с. 283].

$€$. Фльоріна запропонувала у своїх дослідженнях системний погляд на проблему естетичного виховання. Значну роль відводила художньому вихованню дітей на зразках мистецтва, розкрила своєрідністьестетичногорозвитку[24, с. 284].Н.Ветлугіна вбачала діяльність з естетичного виховання дітей у дитячому садку в щоденній життєвій практиці з залученням засобів мистецтва [24, с. 284].

Проблему естетичного виховання засобами різних видів діяльності висвітлено в ряді наукових праць, як-от Г. Григор'євої (естетичне виховання дітей в образотворчій діяльності за допомогою ігрових методів), Р. Чумічевої (естетичне виховання дітей за допомогою ознайомлення 3 творами живопису), А. Шевчук (вплив українських музично-хореографрічних традицій на музично-руховий розвиток старших дошкільників) [24, с. 285], М. Роганова (виховання естетичного ставлення до природи в дітей старшого дошкільного віку як основа їхньої духовності) [24, с. 184-194].

На думку С. Штремель, слухаючи музику, діти вчаться розрізняти характер музичних творів, відчувати єдність поетичного й музичного вираження. Для кращого сприйняття музики вихователь використовує словесні пояснення, у яких наголошується зв'язок музичної композиції 3 життєвими явищами. Важливо, користуючись небагатьма словами, точно й правильно передати поетичні характеристики образів, вкладених автором твору за допомогою виразних засобів. Навчання музично-ритмічним рухам застосовується для набуття рухових навичок, які дають більше можливостей індивідуально проявити себе, творчо діяти [24, с. 210-214].

Л. Сбітнєва, К. Полянська зазначали, що серед видів музичної діяльності відомі вчені наголошують на важливості розвитку в дітей музичного сприйняття. Повноцінне сприйняття $€$ необхідною передумовою виховання в дітей любові й інтересу до музики, формування музичного смаку [28, с. 23-53].

У своїх працях Н. Кривошея зазначала, що в чуттєвій природі людини естетичному чуттю належить особливе місце, адже це найскладніше чуття, спираючись на яке, людина орієнтується у світі прекрасного й потворного. Естетичне чуття це складний синтез зовнішніх і внутрішніх чуттів. Зовнішні чуття - зір, слух, дотик, смак, нюх - мають неоднакове значення в житті людини. У процесі історичного розвитку «олюднюються» передусім чуття зору, слуху, дотику, а в чутті смаку й нюху переважає фрізіологічний рівень [10, с. 217-222].

В. Кузьменко досліджувала критерії естетичної обдарованості: потреба у сприйнятті естетичного; позитивні емоційні переживання під час сприйняття й створення естетичного (явищ природи, творів мистецтва, навколишнього); здатність адекватно оцінити естетичне (естетичний смак); здатність до створення естетичного [12, с. 28-30].

Н. Пахальчук зазначає, що для формування естетичного досвіду дітей у процесі фрізичного виховання необхідно послуговуватися певними принципами, що зумовлюють його теоретико-практичні аспекти. Окрім загальної системи вихідних положень, $€$ низка специфрічних, які $€$ основними для побудови ефективного процесу естетичного виховання. Так, учені виокремлюють принцип загальності естетичного виховання й художньої освіти; принцип єдності всіх сторін виховного процесу (розумового, трудового, морального, естетичного й фрізичного), принцип комплексного впливу мистецтва та його взаємодія 3 основами наук, принцип творчої самореалізації учнів, принцип естетики дитячого життя, естетичної організації дитячої діяльності [23, с. 8-11].

С. Матвієнко вважає, що, виконуючи фрункцію соціалізації, музика сприяє фрормуванню особистості, розвитку її самопізнання та самовираження. Музика впливає на фрормування світогляду людини та $є$ своєрідним засобом міжособистісного спілкування. Відображаючи життя, музичне мистецтво утверджує моральну красу людини, розкриває багатство духовного світу, наголошує на вічних людських ідеалах, таких як відданість, дружба тощо. Діти особливо гостро відчувають прекрасне й тягнуться до нього. Музика - це унікальний, універсальний засіб людського спілкування, який долає кордони й час. За допомогою музики людина не просто має можливість розповісти про себе, 
свій внутрішній світ, свої почуття й переживання, але й може стати зрозумілою іншим людям [17].

Н. Овсяннікова зауважує, що виховна роль української народної пісні полягає у вдалому поєднанні слова з музичним матеріалом. Вона водночас залучає до цінностей української культури, виховує моральні й патріотичні почуття, розширює світогляд і формує свідомість. Естетична свідомість має емоційне походження. Спочатку виникає емоційне сприйняття, відчуття, яке потім усвідомлюється в результаті естетично-творчої діяльності. Емоційність відіграє важливу роль у діяльності артиста-вокаліста, вона надає впевненості у вираженні почуттів, дає змогу позбутися скутості й тим самим чинить інтенсивний вплив на глядача [21, с. 251-258].

Г. Дідич розглядає усну народну творчість як цінність, важливу для виховання й усебічного розвитку особистості. Досліджує проблему моральноестетичного виховання школярів засобами народної музики [6, с. 67-70].

Т. Вільховченко зазначає, що краса нерозривно пов'язана з душею людини, її працею, поведінкою, мовою, зовнішністю. Творча душа людства, в тому числі й українського народу, витворила справжні шедеври виховання в дитини почуття прекрасного: від маминої колискової пісні до складних видів мистецтва, які може опановувати людина впродовж життя, якщо їхня основа закладена в дошкільному дитинстві [2, с. 256-259].

Становлення й розвиток теорії фрізичного виховання дітей дошкільного віку розглядалися як одна $з$ найперших педагогічних проблем. Платон зазначав: «Гімнастика є цілюща сила медицини» $[24$, c. 165$]$.

Я. А. Коменський вважав турботу про здоров'я дитини найпершим обов'язком матері, яка поруч із повноцінним харчуванням має забезпечувати умови для рухової активності дитини. Для зміцнення здоров'я й фрізичного розвитку дітей рекомендував правильно підібрані й дозовані фрізичні вправи [24, с. 165].

Дж. Локк вважав, що догляд за тілом, турбота про зміцнення здоров'я необхідні для виховання гідної людини. Він започаткував введення обов'язкового фрізичного виховання в англійських закладах освіти у фрормі рухливих ігор і спортивних вправ [24, с. 165].

Ж. Ж. Руссо особливу увагу приділяв дитячим рухливим іграм і фрізичним вправам на свіжому повітрі. Для того щоб розвивати дитину мудрою й розсудливою, потрібно зміцнювати ії тіло, робити ії здоровою [24, с. 165].

Й. Г. Песталоцці охарактеризував типи вправ залежно від рухливості суглобів, за анатомічною класифрікацією. Ці вправи він розглядав як «підготовчий засіб» до більш складних видів рухової діяльності [24, с. 166].
Видатний педагог і фрілософ Г. Сковорода вважав, що фрізичне виховання має зміцнити дітей «таким чином, що допоможе краще пізнати їй науки» $[24$, с. 166$]$.

Більшість видатних педагогів і провідних науковців приділяли увагу проблемі фрізичного виховання засобами ігрової діяльності: К. Ушинський надавав виняткового значення народним рухливим іграм як засобу фрізичного виховання і схвалював дослідження цього засобу зміцнення здоров'я дітей; $\epsilon$. Покровський обґрунтував культурологічні засади фрізичного виховання, у своїх роботах зібрав і проаналізував ігри різних народів; В. Гориневський розробив систему засобів фрізичного виховання, яка включала фрізичні вправи, загартовування, рухливі ігри, наголошував на значенні дошкільного віку як часу найбільшої пластичності тіла дитини; С. Русова приділяла значну увагу питанням здоров'я, повноцінної життєдіяльності дитини та рухливим народним іграм [24, с. 166].

Процес розвитку системи фрізичного виховання дітей дошкільного віку висвітлено в провідних працях П. Лесгастта (наукова концепція фізичного виховання, заснована на зв'язку фрізичних і духовних сил людини); В. Сухомлинського (гармонізація фрізичного розвитку й духовного життя дитини); $\epsilon$. Леві-Гориневської, Г. Бикової (методика навчання дітей рухам і проведення занять з фізичної культури); М. Кистяковської (розвиток рухів у ранньому дитинстві); Т. Осокіної (система занять 3 фрізичної культури) [24]; Е. Вільчковського (розробив цілісну систему фрізичного виховання дітей дошкільного віку) [4]; Т. Дмитренко (забезпечення рухового режиму в закладі дошкільної освіти) [7; 8]; Г. Шалигіної (удосконалення основних рухів під час різних фрорм організації фрізичного виховання) [24, с. 167]; Л. Глазиріної (основні напрями, завдання, засоби, принципи, що регламентують діяльність педагога у фрізичному вихованні дітей дошкільного віку) [5]; В. Шишкіної (діагностика рівня фрізичної підготовленості дітей дошкільного й молодшого шкільного віку) [31]; Т. Бабюк (визначає здоров'я як повне фрізичне, духовне, психічне, морально-духовне й соціальне благополуччя, гармонійний розвиток фрізичних і духовних сил) [1]; Н. Пангелової (зауважує, що фрізичне здоров'я $€$ фрундаментом здорової особистості, а від психічного залежить моральне, інтелектуальне, духовне і соціальне) [22]; А. Вільчковської (досліджуючи проблеми музично-ритмічного виховання дітей дошкільного віку за системою Далькроза, визначає, що основою його системи ритмічного виховання $€$ тісний зв'язок музики й рухів, де музика $€$ стимулом до активної рухової діяльності дітей) [3, с. 173-186]; Г. Ніколаї, В. Ключко (наголошують, що завдяки ритміці ефективно розвивається музикальний слух, пам'ять, відчуття ритму й метру, часу й простору, незалежність і синхронність рухів, 
швидкість реакції, рухово-просторова уява, аналітико-синтетична вправність, уміння концентрувати увагу й розподіляти їі, а також емоційна вразливість) [20, с. 202-218]; Г. Пономарьової, А. Чаговець, О. Молчанюк (історичний аспект проблеми формування здорового способу життя в дітей дошкільного віку) [25]; А. Шарапанюк (педагогічні засади музично-ритмічного виховання в закладах дошкільної освіти) [30, с. 210-214].

Висновки. Отже, здійснивши історичний огляд проблеми морально-естетичного виховання дітей дошкільного віку засобами музично-ритмічної гімнастики, доходимо висновку, що, незважаючи на те що досліджувана проблема має практичну значущість, нині залишається недостатньо дослідженою як у теоретичному, так і в експериментальному плані й потребує детального наукового обґрунтування, яке може бути перспективою подальших наукових досліджень.

\section{БІБЛІОГРАФІЧНИЙ СПИСОК:}

1. БабюкТ.Й.Наступністьувихованніздорового способу життя старших дошкільників та молодших школярів : монографрія. Кам'янець-Подільський, 2014. 234 c. URL: http://elar.kpnu.edu.ua:8081/ xmlui/bitstream/handle/123456789/1921/BabiukT.I.-Nastupnist-u-vykhovanni-zdorovoho-sposobuzhyttia-starshykh-doshkilnykiv-ta-molodshykhshkoliariv.pdf?sequence=1\&isAllowed=y (дата звернення: 19.11.2019).

2. Вільховченко Т. Сучасні естетичні технології виховання дітей дошкільного віку засобами ритміки. Дидаскал. 2017. № 17. С. 256-259. URL: h t t p : //d s pace.pn pu.edu.ua/handle / 123456789/8788 (дата звернення: 20.11.2019).

3. Вільчковська А. Музично-ритмічне виховання Еміля Далькроза. Edukacja muzyczna jako edukacja estetyczna. 2019. № 1 (57). C. 173-186. URL: https://www.ignatianum.edu.pl/storage/files/ January2019/YNG7Wbd2hhkqsDyuBfLs.pdf\#page= 173 (дата звернення: 20.11.2019).

4. Вільчковський Е.С., Курок О.І. Теорія і методика фрізичного виховання дітей дошкільного віку. Суми : Університетська книга, 2005. 458 с.

5. Глазырина Л. Физическая культура дошкольникам : программа и программные требования. Москва : ВЛАДОС, 2004. 143 с.

6. Дідич Г. Вплив народної музики в моральноестетичному вихованні школярів. Наукові записки Кіровоградського державного педагогічного університету імені Володимира Винниченка. Серія «Педагогічні науки». 2014. Вип. 125. С. 67-70. URL: http://nbuv.gov.ua/UJRN/Nz_p 2014 12519 (дата звернення: 20.11.2019).

7. Дмитренко Т.І. Руховий режим у дитячому садку. Київ : Радянська школа, 1980. 96 с.

8. Дмитренко Т.І. Спортивні вправи і розваги для дітей дошкільного віку. Київ : Радянська школа, 1976. 118 с.

9. Котлова Л.О. Виховання чесності у дітей: історичнийаспект. ВісникПольсько-українськоїнауково-дослідницької лабораторії психодидактики імені Яна Амоса Коменського. 2019. С. 113-115. URL: http://eprints.zu.edu.ua/29966/1/Kotlova.pdf (дата звернення: 20.11.2019).

10. Кривошея Н. Розвиток музично-естетичної культури старших дошкільників засобами музичної казки. Психолого-педагогічні проблеми сільської школи. 2014. Вип. 48. С. 217-222. URL: http://nbuv.gov.ua/UJRN/Ppps_2014_48_36 (дата звернення: 19.11.2019).

11. Круцевич Т. Розвиток моральної складової особистості старших дошкільників у процесі організованої рухової активності. Спортивний вісник Придніпров'я. 2015. № 2. C. 93-97. URL: http://nbuv.gov.ua/UJRN/svp_2015_2_18 (дата звернення: 20.11.2019).

12. КузьменкоВ.У.Теоретичнізасадидіагностики естетичної обдарованості дітей дошкільного віку. Освіта та розвиток обдарованої особистості. 2013. № 7 (14). C. 28-30. URL: http://lib.iitta.gov.ua/ 10301/1/Кузьменко.pdf (дата звернення: 19.11.2019).

13. Курчатова А. Формування морально-етичної сорери дітей дошкільного віку на засадах ідей В.О. Сухомлинського. Науковий вісник Миколаївського національного університету імені В.О. Сухомлинського. Серія «Педагогічні науки». 2018. № 3. T. 2. C. 85-89. URL: https://www.google. com.ua/url? sa $=\mathrm{t} \& \mathrm{rct}=\mathrm{j} \& \mathrm{q}=\& \mathrm{esrc}=\mathrm{s} \&$ source $=$ web $\&$ $\mathrm{cd}=1 \&$ ved=2ahUKEwi647a3i nIAhWLuIsKHZK C2oQFjAAegQIARAC\&url=http\%3A\%2F\%2Fir bis-nbuv.gov.ua\%2Fcgi-bin\%2Fopac\%2Fsearch. exe\%3FC21COM\%3D2\%26I21DBN\%3DUJR N\%26P21DBN\%3DUJRN\%26IMAGE_FILE DOWNLOAD\%3D1\%26Image file name\%3DPDF\% 2FNvmdup\%255F2018\%255F $\overline{3} \% 25281 \% 2529 \% 255$ F\%255F18\%252Epdf\&usg=AOvVaw3jIKDSFRbSm6 ZDoygK7UxP (дата звернення: 20.11.2019).

14. Лазарець А. Теоретичні основи виховання моральних якостей у дітей дошкільного віку під час організації ігрової діяльності. DSpace at IUEH named by academician Stepan Demianchuk бірка студентських наукових праць. 2016. № 1 (5). Рівне : РВЦ Міжнародного економіко-гуманітарного університету імені академіка Степана Дем'янчука. C. 47-52. URL: http://dspace.regi.rovno.ua:8080/jspui/ handle/123456789/490 (дата звернення: 20.11.2019).

15. Лохвицька Л.В. Аргументація принципу ціннісно-регуляційної інтеракції у концептуальній моделі морального виховання дошкільників. Психологія і особистість. 2018. № 1 (13). С. 128-138. URL: http://doi.org/10.5281/zenodo.1169793 (дата звернення: 19.11.2019).

16. Лохвицька Л.В. Програма 3 морального виховання дітей дошкільного віку «Скарбниця моралі». Тернопіль : Мандрівець, 2014. С. 6-7. URL: http://ephsheir.phdpu.edu.ua/xmlui/bitstream/ handle/8989898989/1038/Програма_СКАРБНИЦЯ \%20МОРАЛ_Лохвицька.pdf? sequence $=1$ \& isAllowed=y (дата звернення: 20.11.2019).

17. Матвієнко С. І. Теорія та методика музичного виховання дітей дошкільного віку : навчальний посібник. Ніжин : Ніжинський державний університет імені Миколи Гоголя, 2017. 297 с. URL: http://lib.ndu.edu.ua/dspace/handle/123456789/75 (дата звернення: 19.11.2019). 
18. Московчук Л.М. Методика діагностики морально-естетичної вихованості учнів загальноосвітніх шкіл у процесі вивчення духовної музики українських композиторів. Науковий часопис Національного педагогічного університету імені М.П. Драгоманова. Серія 14 «Теорія і методика мистецької освіти». 2014. Вип. 16 (2). С. 190-195. URL: http://www.irbis-nbuv.gov.ua/cgi-bin/irbis_nbuv/ cgiirbis 64.exe?C21COM=2\&I21DBN=UJRN\&P21D $\mathrm{BN}=U \mathrm{JRN} \& I M A G E$ FILE_DOWNLOAD=1\&Image file_name=PDF/Nchnpu_014_2014_16(2)_50.pdf (дата звернення: 20.11. 2019 )

19. Никоненко Ю.П. Особливості морального розвитку та виховання дітей дошкільного віку. Психологія: реальність і перспективи : збірник наукових праць Рівненського державного гуманітарного університету. 2013. Вип. 2. С. 132-136. URL: http://nbuv.gov.ua/UJRN/prp_2013_2_39 (дата звернення: 20.11.2019).

20. Ніколаї Г.Ю., Ключко В.В. Розповсюдження ритміки Еміля Жак-Далькроза в міжнародному просторі вищої мистецької освіти. Проблеми інноваційного розвитку вищої освіти у глобальному, регіональному та національному контекстах : монографрія / Міністерство освіти і науки України, Сумський державний педагогічний університет імені А.С. Макаренка ; за заг. ред. А.А. Сбруєвої та Г.Ю. Ніколаї. Суми : Вид-во СумДПУ імені А.С. Макаренка, 2017. Розд. II : Регіональний контекст інноваційного розвитку вищої освіти. С. 202-218. URL: http://repository.sspu. edu.ua/handle/123456789/3173 (дата звернення: 20.11.2019).

21. Овсяннікова Н. Формування моральноестетичних цінностей засобами музичного вокального мистецтва. Проблеми підготовки сучасного вчителя. 2018. № 18. С. 251-258. URL: h t t p : / / p s v.ud p u. ed u . u a / a r t i c le / view/162397/161367 (дата звернення: 20.11.2019).

22. Пангелова Н.Є. Теоретико-методичні засади фрормування гармонійно розвиненої особистості дитини дошкільного віку в процесі фрізичного виховання : авторефр. дис. ... д-ра наук 3 фрізичного виховання і спорту : 24.00.02. Київ, 2014. 42 с. URL: http://repository.ldufk.edu. ua/bitstream/34606048/20944/1/Пангелова_автоpedp_5.2014.pdf (дата звернення: 20.11.2019).

23. Пахальчук Н. Формування естетичного досвіду дітей дошкільного віку в процесі фрізичного виховання. Реалізація ідей В.О. Сухомлинського в практиці роботи сучасної початкової школи : збірник матеріалів педагогічних читань. Вінниця :
Ландо ЛТД, 2015. Вип. 10. С. 8-11. URL: http://library. vspu.net/jspui/bitstream/123456789/682/1/007.pdf (дата звернення: 19.11.2019).

24. Поніманська Т.І. Дошкільна педагогіка : навчальний посібник. Київ : Академвидав, 2006. 456 c.

25. Пономарьова Г.Ф., Чаговець А.І., Молчанюк О.В. Проблема фрормування здорового способу життя дітей дошкільного віку у вітчизняній педагогіці (історичний аспект) : монографрія. Харків : Ранок, 2014. 217 с.

26. Роганова М.В. Виховання естетичного ставлення до природи у дітей старшого дошкільного віку як основа їх духовності. Духовність особистості: методологія, теорія і практика. 2017. Вип. 1. С. 184-194. URL: http://nbuv.gov.ua/UJRN/ domtp_2017_1_22 (дата звернення: 09.05.2020).

27. Роганова М.В. Виховання духовно-моральних цінностей в учнів основної школи в позакласній виховній роботі. Професійна освіта: методологія, теорія та технології. 2016. Вип. 4. С. 191-200. URL: http://nbuv.gov.ua/UJRN/ profe_2016_4_16 (дата звернення: 09.05.2020).

28. Сбітнєва Л.М., Полянська К.В. Зміст і особливості музично-естетичного виховання дітей і молоді в Україні в післявоєнні роки. Вісник Луганського національного університету імені Тараса Шевченка. 2013. № 18 (277). 4.II.C.43-53.URL:http://nbuv.gov.ua/UJRN/vlup_2013_ 18\%282\%29 9 (дата звернення: 19.11.2019).

29. Сурмило О.А. Вивчення педагогічних умов використання казки як засобу морального вихованнястаршихдошкільників. НауковізапискиНіжинського державного університету імені Миколи Гоголя. Серія «Психолого-педагогічні науки». 2014. № 5. C. 120-124. URL: http://nbuv.gov.ua/ UJRN/Nzspp_2014_5_24 (дата звернення: 20.11.2019).

30. Шарапанюк А. Педагогічні засади музичноритмічної діяльності у сучасних вітчизняних дошкільних навчальних закладах. Психологопедагогічні проблеми сільської школи. 2012. Вип. 40. С. 210-214. URL: http://nbuv.gov.ua/UJRN/ Ppps_2012_40_33 (дата звернення: 20.11.2019).

31. Шишкина В.А. Физическое воспитание дошкольников. Минск, 2007.

32. Штремель С. Естетичне виховання дошкільників засобами музичного мистецтва. Психолого-педагогічні проблеми сільської школи. 2015. Вип. 52. С. 210-214. URL: https://library.udpu. edu.ua/library_files/psuh_pedagog_probl_silsk_ shkolu/52/35.pdf (дата звернення: 19.11.2019). 


\section{НЕОБХІДНІСТЬ РОЗРОБЛЕННЯ СИМУЛЯТОРА УПРАВЛІННЯ ПЕРСОНАЛЬНИМИ ФІНАНСАМИ \\ NECESSITY OF THE PERSONAL FINANCE MANAGEMENT SIMULATION DEVELOPMENT}

УдК 004.4+336

DOI https://doi.org/10.32843/2663-

6085/2020/24-2.41

\section{Антонюк Д.С.,}

канд. пед. наук,

доцент кафредри інженерії програмного

забезпечення

Державного університету

«Житомирська політехніка»

\section{Вакалюк Т.А.,}

докт. пед. наук, доцент,

професор кафедри інженерії

програмного забезпечення

Державного університету

«Житомирська політехніка»

\section{Дідківський В.В.,}

магістр факультету інсормаційно-

компютерних технологій

Державного університету

«Житомирська політехніка»

Візгалов О.ю.,

магістр факультету інформаційно-

компютерних технологій

Державного університету

«Житомирська політехніка» y статті проаналізована необхідність розроблення симулятора в галузі персональних фрінансів, що буде зорієнтований на вивчення та напрацівання умінь використання базових фрінансових інструментів та засобів. Проаналізовано поняття «персональні фрінанси» та його особливості. Проаналізовано праці світвоих науковців щодо дослідження даної проблеми. У результаті вставновлено, що частина науковців персональні фрінанси розглядають як елемент ринку, інша частина вважає, що головну роль у плануванні персональних фінансів відіграють лише стійкі соціальні звязки, окрім того, що $\epsilon$ частина науковців, які ствреджують, що все таки власними фрінанасами не лише доцільно, але й потрібно управляти. Виокремлено види витрат та доходів. З'ясовано, що управління персональними фрінансами включає в себе уміння ними керувати. Встановлено, що правильно обгрунтоване керування такими фрінансами потребує окремого навчання. Для з'ясування окремих аспектів фрінансово грамотності студентів-першокурсників, як осіб, які мають власні ффінансові ресурси, було проведено опитування, в результаті якого було зроблено висновок, що школярів, студентів варто зацікавлювати вивченням персональних фрінансів, навіть у межах інших дисциплін, у вигляді окремих розділів. Проаналізовано наявні програмні продукти, що можна використовувати для управління персональними фрінансами. У результаті зроблено висновок, що такких додатків існує багато, але всі вони розраховані скоріш на ведення та управління персональними фрінансами, а не навчання ними керувати. Тут у нагоді i стають симулятори, які імітують фрінансову діяльність упродовж певного проміжку часу. Саме тому розроблення симулятора планування власних фрінасів дозволить у майбутньому використовувати його для навчання елементам управління персональними фрінансами навіть у шкільному віці.

Ключові слова: бізнес-симулятор, персональні фрінанси, розробка, економічний симулятор, персональна фрінансовіа компетентність, програмне забезпечення.

The authors of the article analyze the necessity of the personal finance management simulation development. The simulation will be oriented to learning and developing skills in basic personal finance instruments and tools. The "personal finance" term and its specifics have been analyzed. The works of the international scientists have been analyzed on the topics discussed. As the result it is possible to see that some scientists define personal finance as the market element. The others conclude that the main role in the personal finance management is being played by the sustainable social connections. In the same time, some part of the researchers prove that personal finance not only may be but shall be managed by individuals themselves. The main types of income and expences are defined. The need and skills to manage personal finance are proved to be essential. The dedicated learning needs to be organized formally or informaly to succeed in the area. To find some aspects of the personal finance literacy, the dedicated survey was conducted among university students of the first year. It was found that to properly teach personal finance concept some interest need to be ignited. It might be dome by injecting personal finance modules into other educational courses with practical application. The software-based tools to manage personal finance were studied. Substantila quantity of such tools are present and are regularly appearing on the market worldwide. The conclusion that these tools are oriented to the personal finance skills application rather that learning and formation was made. The personal finance simulations are needed to fulfill the gap and help to form personal finance competence, including knowledge, skills and personal attitude to it. Thi why personal finance simulation development is needed. These tools will let form and develop personal finance competency starting from school and following in life-long learning regime.

Key words: business simulation, personal finance, development, economic simulator, personal finance competency, software.
Постановка проблеми. Персональні фрінансице власний капітал особистості або сім'ї, яким вона розпоряджається самостійно. Цей капітал включає в себе всі доходи та заощадження особистості або всіх членів сім'ї, у тому числі й депозити, цінні папери тощо. щодня кожна людина витрачає власні кошти на комунальні платежі, покупки, оплату певних послуг, кредитів тощо. Управління персональними фінансами включає в себе уміння ними керувати.

До найбільш поширених видів доходів можна віднести такі, як: стипендія, офріційна заробітна плата, премія, пенсія, депозитні виплати, подарунки тощо. 
До найбільш поширених витрат можна віднести: покупки продуктів харчування, комунальні платежі, кредити, оренду житла, витрати на поточний ремонт, покупки товарів першої необхідності, покупки одягу, витрати на траспорт тощо.

Правильно обгрунтоване керування такими фрінансами потребує окремого навчання.

Аналіз останніх досліджень і публікацій. Існує безліч підходів до планування власних фрінансів у сучасній науковій літературі. Зокрема, частина науковців персональні фрінанси розглядають як елемент ринку (Г. Беккер, Дж.К. Гелбрейт, В.М. Жеребін, Дж.М. Кейнс, А.Н. Романов та ін.), інша частина вважає, що головну роль у плануванні персональних фрінансів відіграють лише стійкі соціальні звязки (С.Ю. Барсукова, Т.В. Богомолова, Й. Бен-Порат, В.В. Радаєв, В.Д. Симоненко, В.С. Тапіліна та ін.), окрім того, що $є$ частина науковців, які ствреджують, що все таки власними фрінанасами не лише доцільно, але й потрібно управляти (В.А. Бобров, Б.А. Жнякін, В.А. Кашин та ін). Окрім того, різні аспекти розвитку персональних фінансів розглядали: В.А. Васильєв, В.В. Глухов, Т.О. Кізима, П.Р. Кругман та ін.

Формулювання цілей статті. Власне тому метою даної статті $€$ визначення необхідності розроблення симулятора управління власних фрінансів.

Виклад основного матеріалу. Деякі автори вважають, що персональні фрінанси - це «сукупність розподільних і перерозподільних відносин, у які вступає громадянин із приводу розподілу і перерозподілу валового внутрішнього продукту, формування і використання централізованих та децентралізованих грошових фрондів суспільства 3 метою збереження чи підвищення свого соці- ального статусу, а також вирішення основних завдань поточного і перспективних етапів життєвого циклу» [6].

Зокрема, Т.Г. Гончар досліджує сутність поняття «персональні фінанси» [1] та наводить узагальнену схему використання даного поняття серед відчизняних науковців (див. рис. 1) [1, с. 126]. Досліниця, узагальнюючи наукові праці в галузі персональних фрінансів, окреслює напрями їх досліджень серед вітчизняних науковців: управління заощадженнями; індивідуальне інвестування; новітні форми фінансування; розвиток індивідуального бізнесу тощо [1, с. 126]. Науковець стверджує, що поняття «персональні фрінанси» і «особисті фрінанси» «відображають сенс фрінансових відносин на індивідуальному рівні [1, с. 126].

В. Куцяк обґрунтувує економічну сутність «особистих фінансів в умовах ринку та визначення їх впливу на розвиток фрінансових процесів у державі» [2]. Автор стверджує, що «особисті фрінанси $€$ невід'ємною складовою частиною будь-якої економічної системи, оскільки саме з появою товарногрошових відносин відбулася персоналізація цих відносин та власності, на фрункціонування яких суттєвий вплив здійснюють не лише загальні економічні закони, а й людський фрактор» [2].

Автор робить висновок, що упродовж життя в кожної особистості фрормується своє індивідуальне ставлення до «особистих фрінансів та виробляються навички управління ними з корисністю для себе та інших людей» [2].

Метою управління особистими фрінансами $€$ отримання усіх даних щодо власних срінансів для їх ефрективного використання [3].

В.О. Мельник стверджує, що фрінансова освіта в сучасних реаліях вже розглядається

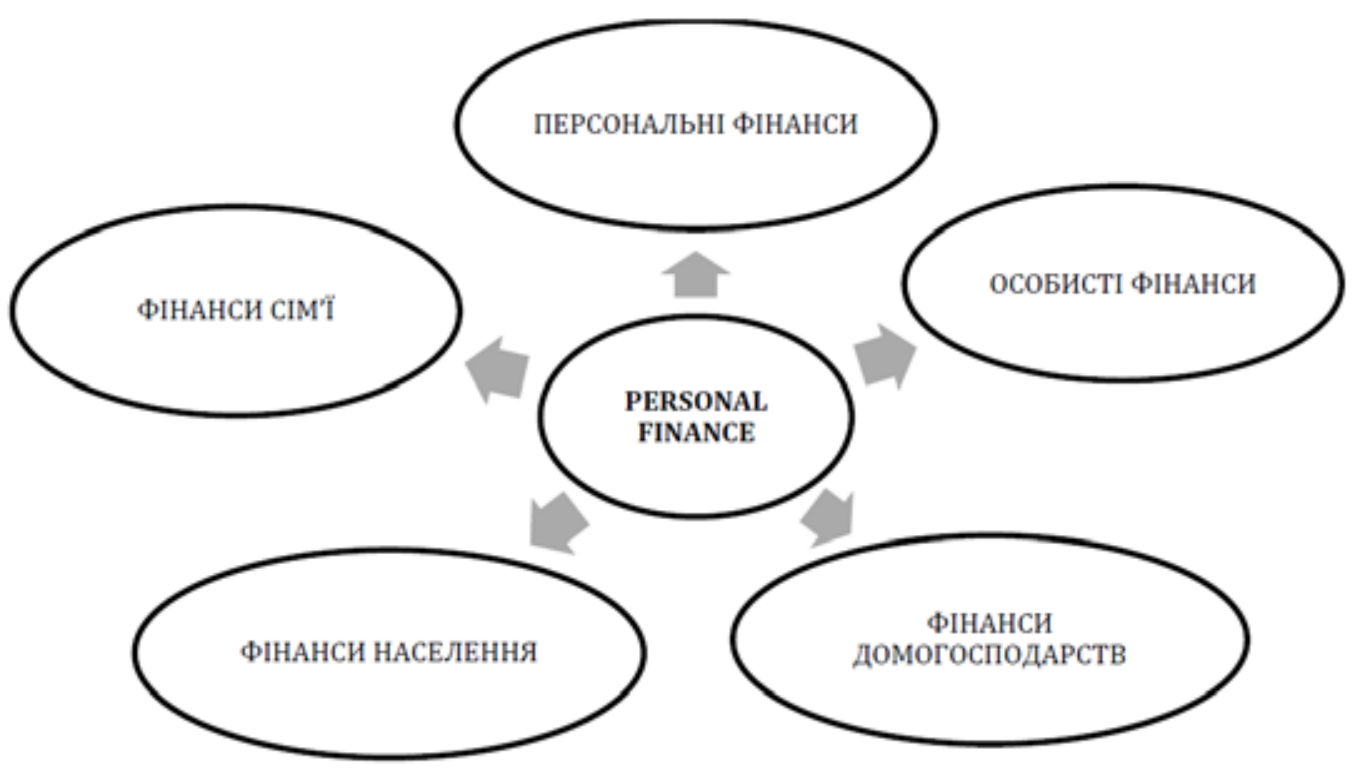

Рис. 1. Використання категорії «personal finance» серед вітчизняних науковців (узагальнення Гончар Т.Г.) 


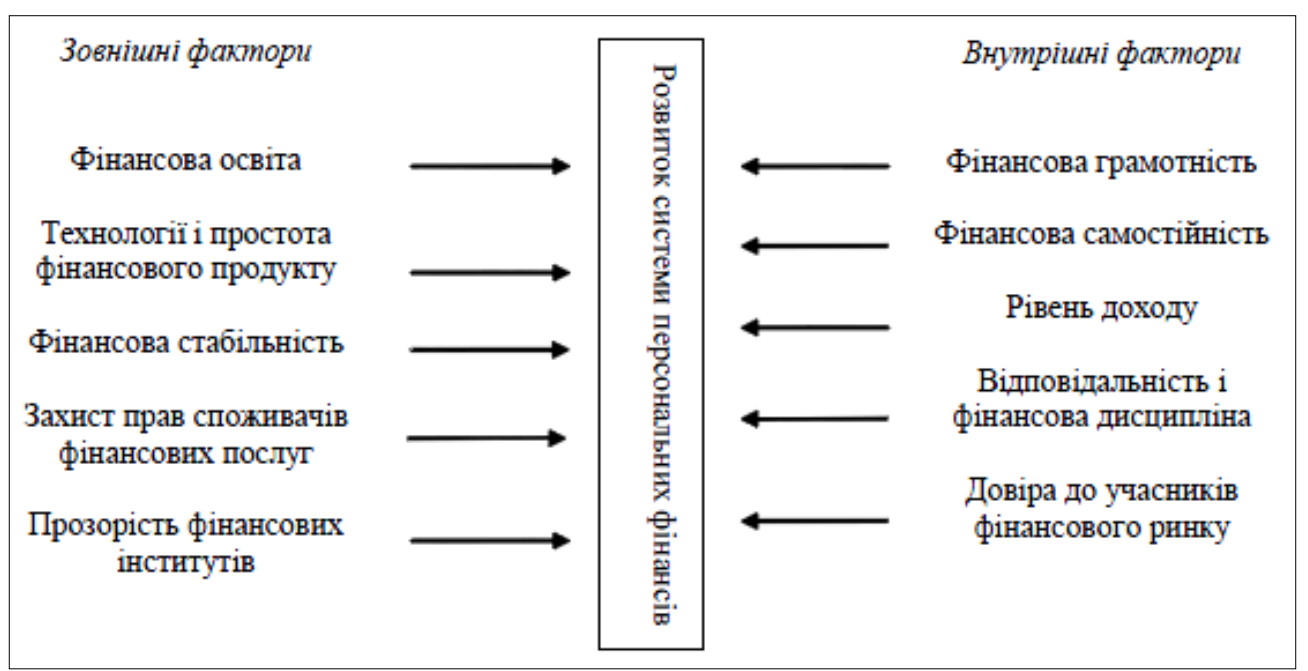

Рис. 2. Фактори впливу на розвиток системи персональних фінансів

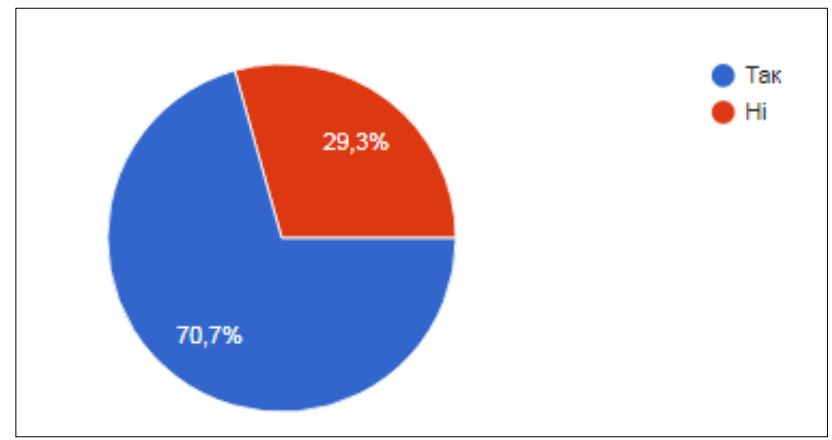

Рис. 3. Результати опитування

як життєво необхідна навичка, яка зумовлена деякими особливостями сучасності, що першочергово мають безпосереднє відношення до фрінансів: протягом останніх років різновиди фрінансових продуктів, а також послуг, кредитних історій стрімко зростає; при цьому індивіди мають постійно приймати персональні фрінансові рішення щоденно, розуміючи власну відповідальність за наслідки цих рішень тощо [4, с. 116].

Як стверджує група фрахівців, на розвиток системи персональних фрінансів впливають зовнішні та внутрішні фрактори. До зовнішніх авори від- носять: фрінансову освіту, технології та простоту фінансового продукту, фрінансову стабільність, захист прав споживачів фрінансових послуг, прозорість фрінансовх інститутів; до внутрішніх: фрінансову гармотність та самостійність, рівень власного доходу, відповідальність та фрінансову дисципліну, а також довіру до учасників фрінансовго ринку (див. рис. 2) [5, с. 84].

Власне тому будь-яка особистість, навіть не фрінансист, повинна бути обізнаною у сорері управління персональних фрінансів. Саме тому для з'ясування окремих аспектів фрінансової грамотності студентів-першокурсників, як осіб, які мають власні фрінансові ресурси, було проведено опитування. В опитуванні взяли участь 167 респондентів (студент першого курсу Державного університету «Житомирська політехніка»). У результаті було встановлено, що 70,7\% з опитаних вважають себе фрінансово грамотною людиною, яка готова до свідомого та ефрективного управління власними та родинними фрінансовими ресурсами. Водночас $29,3 \%$ опитаних не вважають себе в цьому плані достатньо обізнаними (див. рис. 3).

Також у відповідності до результатів опитування було встановлено, що 14,4\% респондентів на най-

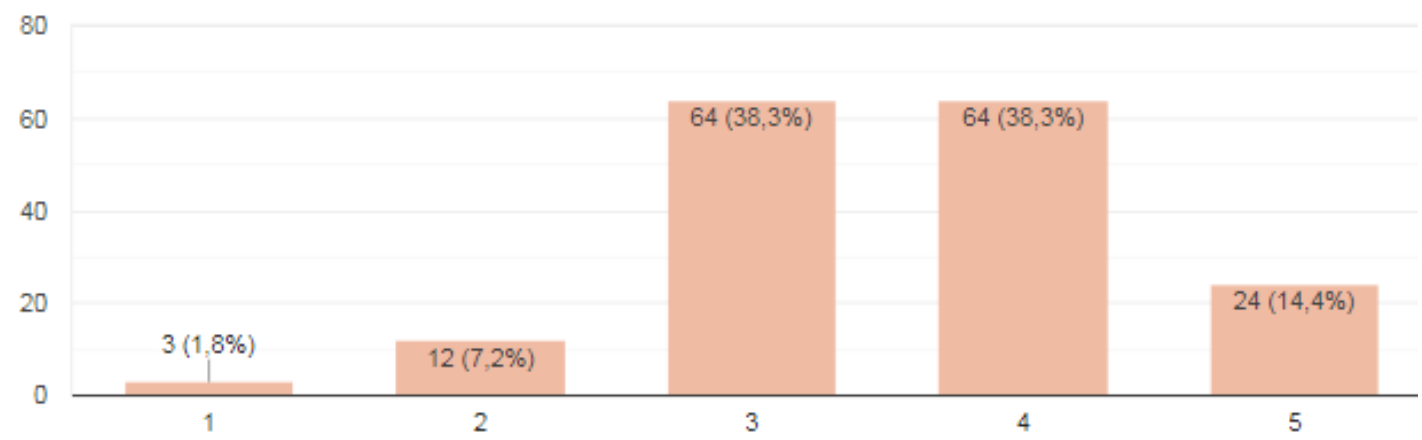

Рис. 4. Гістограма рівня готовності до свідомого та ефективного управління власними та родинними фрінансовими ресурсами 


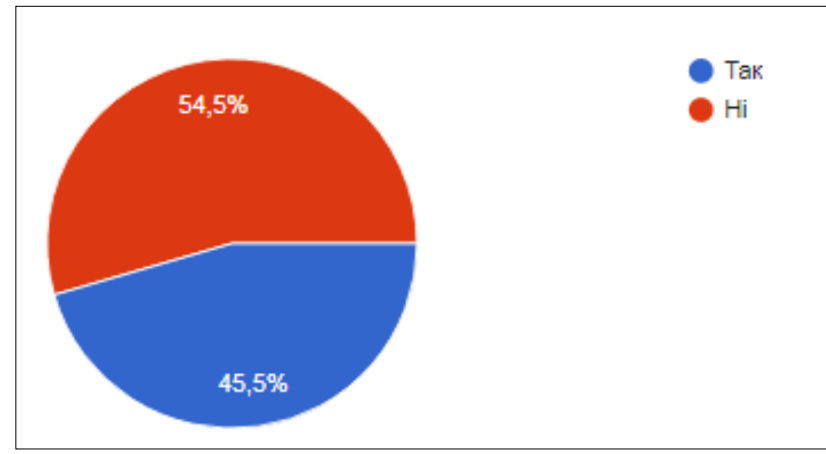

Рис. 5. Результати опитування

вищому рівні оцінюють свій рівень готовності до свідомого та ефективного управління власними та родинними срінансовими ресурсами, до $38,3 \%$ опитуваних вказали рівень готовності «добре» та «задовільно». Усі інші або оцінили готовність на найнижчому рівні або на рівні «незадовільно» (див. рис. 4).

Також було прийнято рішення встановити, чи студенти вивчали основи фрінансової грамотності в межах одного із предметів у попередньому закладі освіти (чи то школа, чи то коледж тощо). У результаті було встановлено, що 54,5\% опитуваних вивчали основи фрінансової грамотності хоча 6 в одінй із форм, 45,5\% не вивчали ні в якому вигляді (див. рис. 5).

У результаті проведеного опитування було зроблено висновок, що школярів, студентів варто зацікавлювати вивченням персональних фрінансів, навіть у межах інших дисциплін, у вигляді окремих розділів.

Успішний власний досвід та знання викладача в галузі персональних фрінанстів $\epsilon$ важливою складовою частиною ефрективності фрормування компетентності учнів, студентів та дорослих у галузі персональнихфінансів. Аленезавждимолодепокоління можна зацікавити лише теорією. Тут у нагоді стають інсрормаційно-комунікаційні технології, що останнім часом стрімко розвиваються. Одним із різновидів IКТ є симулятори, які імітують певну діяльність. Не виключенням $€$ і персональні фрінанси.

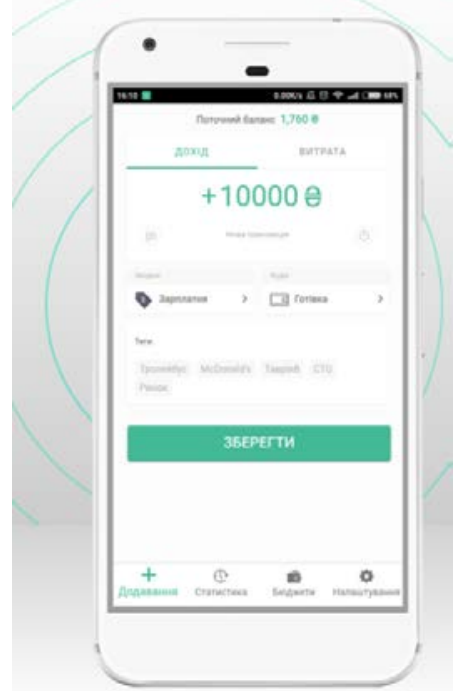

Рис. 7. Finkee

Проаналізуємо наявні програмні продукти, що можна використовувати для управління персональними фрінансами.

MoneyWiz [9] - це програмний продукт, що призначений для обліку власних фрінансів (див. рис. 6).

Даний програмний продукт реалізований підбільшість операційних систем: Mac, iPad, iPhone, Windows, Android. Можливості MoneyWiz досить широкі: ведення рахунків та контроль за ними в різних валютах; розрахунок бюджету; побудова звітів; можливість інвестицій, а таож синхронізація з деякими банками (хоча дана послуга не $€$ безкоштовною).

Finkee [10] - вітчизняний додаток, що призначений для планування, управління та обліку персональних фрінансів (див. рис. 7). Можливості даного програмного продукту також досить широкі: внесення та редагування доходів, а також витрат, групування і тих, і тих за різними категоріями, відмітка дати /часу обох категорій, розрахунок балансу, аналіз доходів, рекомендації щодо покращення планування. Знову ж таки, якщо вибрати не безкоштовний тарифрний план, то зявляються й інші можливості, наприклад синхронізація з картками Приватбанку.

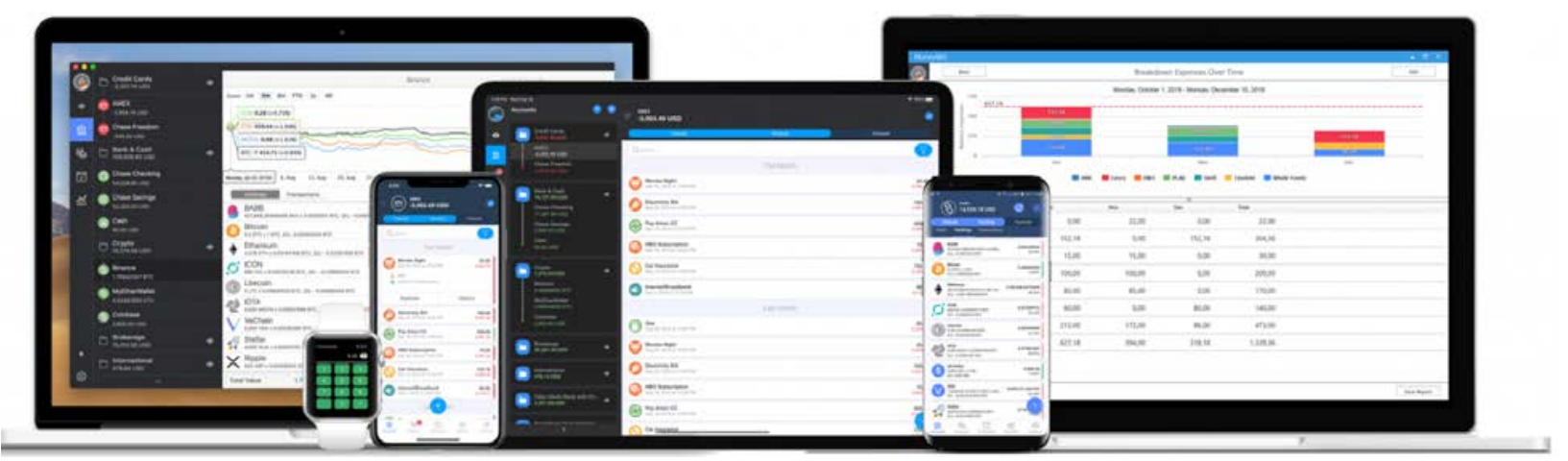

Pис. 6. MoneyWiz 
Таких додатків є достатньо багато, але всі вони розраховані скоріше на ведення та управління персональними фрінансами, а не навчання ними керувати. Тут у нагоді і стають симулятори, які імітують фрінансову діяльність упродовж певного проміжку часу. Саме тому розроблення симулятора планування власних фріннасів дозволить у майбутньому використовувати його для навчання елементам управління персональними фрінансами навіть у шкільному віці.

Майбутній симулятор надасть змогу користувачу ознайомитись та використати такі фрінансові поняття, інструменти та засоби, як:

- поточні грошові кошти та заощадження;

- валютна диверсифрікація заощаджень;

- депозитні вклади та їхні типи;

- касовий розрив та засоби його подолання;

- вплив випадкових подій на стан персональних орінансів та ін.

Також необхідним $€$ розроблення засобів спонукання до конструктивної поведінки в галузі персональних фрінансів та методів її оцінки.

Висновки. У даній роботі проаналізована необхідність розроблення симулятора в галузі персональних фрінансів, що буде зорієнтований на вивчення та напрацівання умінь використання базових фрінансових інструментів та засобів.

У подальшому передбачається розроблення та вдосконалення програмного засобу з додаванням більш складних фрінансових інструментів і засобів та розроблення механізмів оцінки поведінки користувача та вироблення рекомендацій щодо використання фрінансових інструментів на основі персональних особистісних характеристик.

\section{БІБЛІОГРАФІЧНИЙ СПИСОК:}

1. Гончар Т.Г. Сутність поняття «personal finance» та його використання у вітчизняних дослідженнях. Економічний аналіз. 2016 рік. Том 23. № 1. C. 123-129.

2. Куцяк Вадим. Особисті фрінанси як первинний елемент фрінансової системи держави. Світ фрінансів. № 3. 2012. С. 97-100.

3. Фінансова грамотність. Фінанси. Що? Чому? Як? : навчальний посібник / авт. кол. Київ, 2019. 272 с.
4. Мельник В.О. Напрями активізації інвестиційного потенціалу персональних фрінансів в Україні. Інвестиції: практика та досвід. № 24/2019. С. 114-119.

5. Фінанси : підручник / І.О. Лютий, С.Я. Боринець, 3.С. Варналій та ін.; за ред. д. е. н., профр. І.О. Лютого. Київ : Видавництво Ліра_Київ, 2017. 728 c.

6. Особисті фрінанси, їх розвиток в умовах ринку. URL:https://pidruchniki.com/14940807/finansi/osobisti_ finansi rozvitok umovah rinku.

7. Кізима Т.О. Особисті (персональні) фрінанси: необхідність виокремлення та перспективи розвитку в умовах ринку. Актуальні проблеми економіки. 2008. № 11. С. 194-203.

8. Кізима Тетяна. Фінансова грамотність населення: зарубіжний досвід і вітчизняні реалії. Вісник Тернопільського національного економічного універсuтemy. 2012. Вип. 2. С. 64-71.

9. MoneyWiz - Особисті фрінанси. URL : https://wiz.money/uk/.

10. Finkee. URL : https://finkee.org/ua/.

11. Financesimulator.URL:https://financesimulator. azurewebsites. net/?fbclid=IWAROSLjcfvMkA7 2TnGBqBfB2aCA7ulpHmADTz5BuNIvyFONXI4Fnlb6Udw.

12. Антонюк Д.С., Вакалюк Т.А., Якобчук А.С., Янчук В.М. Проектування програмно-імітаційного комплексу візуалізації та управління персональними фрінансами. Вчені записки Таврійського національного університету імені B.І. Вернадського. Серія: Технічні науки. Том 30(69), № 5. 2019. Частина 1. С. 45-55.

13. Антонюк Д., Вакалюк Т., Янчук В., Якобчук А. Огляд програмних засобів планування персональних фрінансів. Збірник матеріалів VII Всеукраїнської науково-практичної конференції молодих учених «Наукова молодь-2019» (Київ, 4 жовтня 2019 р.). Київ : ЦП Компринт, 2019. C. 105-107.

14. Tetiana A. Vakaliuk, Valerii V. Kontsedailo, Dmytro S. Antoniuk, Olha V. Korotun, Iryna S. Mintii and Andrey V. Pikilnyak. Using game simulator Software Inc in the Software Engineering education. Proceedings of the 2nd International Workshop on Augmented Reality in Education, Kryvyi Rih, Ukraine, March 22, 2019. Pp. 66-80. CEUR-WS.org, URL : http://www.ceur-ws.org/Vol-2547/paper05.pdf. 


\section{ОПТИМІЗАЦІЯ КОГНІЦІї У СТУДЕНТІВ ЧЕРЕЗ ВІЗУАЛЬНИЙ СКЛАДНИК ЛЕКЦІЙНОГО ЗАНЯТТЯ

\author{
OPTIMIZATION OF THE STUDENT'S COGNITION THROUGH \\ THE VISUAL COMPONENT OF THE LECTURE
}

\begin{abstract}
Стаття інформує про те, що сучасний освітній процес в Україні вимагає інтенсивного використання інформаційно-комунікаційних технологій, які слугуватимуть основним засобом інноваційного розвитку. Саме вони повинні виконувати роль інструмента, що забезпечуватиме гнучкість навчального процесу, відкриватиме можливість доступу студентів до глобальних ресурсів, здійснюватиме збір, аналіз, обробку та передачу великого масиву інформації.

Висвітлено нові принципи наповнення та оформлення лекційного матеріалу, серед яких є принцип науковості (вирізняється глибиною, науковою вірогідністю матеріалу, використанням останніх досліджень), системності (передбачає фрормування знань та вмінь у певну систему, що допомагатиме під час їх практичного застосування), наочності (передбачає застосування мультимедійних засобів), проблемності (зумовлюється сутністю та характером навчально-пізнавальної діяльності) та принцип доступності (означає необхідність визначення ступеня теоретичної складності навчального матеріалу) тощо.
\end{abstract}

Проаналізовано технологічну привабливість програми Power Point під час створення візуальної частини лекційного заняття (презентаціі). Розкрито можливості інсрормаційного збагачення лекційного матеріалу за допомогою зазначеної програми через додавання графічних об'єктів, текстів, діаграм. Доведено, що Power Point $\epsilon$ чудовим інструментом як для створювача, так і для користувача.

Висвітлено вплив структури, різновиду шрифттів та кольорів, використаних у презентації, на рівень сприйняття та засвоєння лекційного матеріалу студентами. Відображено в таблиці 1 результати опитування користувачів щодо найбільш читабельних шрифотів. Рекомендовано врахувати дану інфрормацію під час подальшого фрормування текстів у презентаціях

здійснено дисреренціацію кольорів, розкрито їхній зміст та значення у презентачії. Висвітлено досвід рекламної діяльності у використанні кращих поєднань кольорів під час рекламування продукції, що також $є$ необхідним в оформленні презентащій лекцій і сприятиме кращому сприйняттю та засвоєнню матеріалу студентами.

Розкрито проблемні аспекти створення візуальної частини лекції задля попередження ряду помилок, що негативно впливатимуть на когніцію студента.
Ключові слова: інформаційно-комунікаційні технології, оптимізація, навчальний прочес, лекція, презентація, програмне забезпечення, колір, шрифрт, когніція.

The article informs that the modern educational process in Ukraine requires intensive use of information and communication technologies, which will serve as the main means of innovative development. They should act as a tool that will provide flexibility in the learning process, open access to global resources, collect, analyze, process and transmit a large array of information.

New principles of filling and design of lecture material were shown. Among them the principle of scientific (characterized by depth, scientific credibility of the material, the use of recent research), systematic (involves the formation of knowledge and skills in a system that will help in their practical application), clarity (involves the use of multimedia means), problems (determined by nature of educational and cognitive activities) and the principle of accessibility (means the need to determine the degree of theoretical complexity of educational material) etc.

The technological attractiveness of the Power Point program at the time of creation of the visual part of the lecture (presentation) is analyzed. Possibilities of information enrichment of lecture material with the help of the specified program through addition of graphic objects, texts, diagrams are opened. Power Point has been proven to be a great tool for both the creator and the user.

The influence of the structure, variety of fonts and colors used in the presentation on the level of perception and assimilation of lecture material by students is highlighted. Table 1 shows the results of a user survey on the most readable fonts. It is recommended to take this information into account when further forming texts in presentations. The colors are differentiated, their content and meaning in the presentation are revealed. The experience of advertising in the use of the best combinations of colors in advertising products is highlighted, which is also necessary in the design of lecture presentations and will promote better perception and assimilation of material by students.

The problematic aspects of creating the visual part of the lecture are revealed in order to prevent a number of mistakes that will make negative affect to the student's cognition.

Key words: information and communication technologies, optimization, educational process, lecture, presentation, software, color, font, cognition.
Постановка проблеми у загальному вигляді. Сучасний навчально-виховний процес у закладах вищої освіти України передбачає інтенсивне використання індормаційно-комп'ютерних технологій. Такі обставини зумовлюють активізацію процесів збору, аналізу та передачі інформації студентам через посередництво сучасних засобів. Нами зосереджено увагу на одній зі складових частин інформаційної технології візуалізації лекційного матеріалу через демонстрацію презентації. Дане дослідження розглядає важливі аспекти стилістичного оформлення матеріалу, коректного використання кольорової палітри, правильного вибору шрифтів із метою покращення когнітивного процесу у студентів, якісного засвоєння теоретичного матеріалу. 
Аналіз останніх досліджень і публікацій. Різні аспекти впровадження інформаційно-комунікаційних технологій у своїх наукових працях висвітлювали В. Безпалько, В. Мономахов, О. Спірін, Л. Романишин, В. П. Зінченко тощо [10].

Один із найбільш популярних психологічних тестів - кольоровий тест, розроблений М. Люшером [9], що використовується для діагностики внутрішнього стану людини та сприйняття того чи іншого кольору. Характеристику чуттєво-емоційного впливу окремих кольорів та їхніх сполучень здійснив Г. Гете [1].

Виділення невирішених раніше частин загальної проблеми. У статті наголошується на тому, що під час створення презентацій викладачі повинні зважати на психологічні особливості структури презентації, іï поліграфрічне офрормлення як передумову сприйняття інформації. Врахування даних особливостей побудови візуальної частини лекційного заняття сприятиме оптимізації когнітивного процесу у студентів.

Мета статті. Головне завдання дослідження полягає у висвітленні впливу структури, кольорової гами, різновиду шрифту презентації лекційного матеріалу на рівень сприйняття та засвоєння інфрормації особою студента.

Виклад основного матеріалу. 3 давніхдавен людство накопичувало певні знання, що стосувались розвитку та становлення різних соціально-економічних сорер, правил та норм взаємодії окремих соціальних груп. Суспільно корисна інорормація потребувала обробки, аналізу та передачі, що й створювало передумови до пошуку новітніх методів з її есрективної адресації та роботи 3 науковими джерелами. Проте світова цивілізація відкриває все більше можливостей та перспектив розвитку, з'являються нові відомості, що стрімко збільшуються. Дана тенденція вимагає використання інструментарію, спрямованого на обробку інформації та ефективну її передачу. Цю місію покладено на інорормаційно-комунікаційні технології, що забезпечуватимуть гнучкість освітнього процесу, відкриватимуть шлях до глобальних ресурсів для навчання, здійснюватимуть передачу великого масиву інфрормації. Використання новітніх інформаційних технологій передбачає якісну переробку інорормації та її повну передачу користувачеві.

У роботі зі студентами викладач традиційно використовує лекційне заняття для передачі інформації. Ми здійснюємо наголос на інноваційному підході щодо передачі знань, нових принципах наповнення та оформлення лекційного матеріалу.

Отже, лекція має вирізнятись своєю глибиною та науковою вірогідністю навчального матеріалу, використанням останніх наукових досягнень у досліджуваній сорері. Лекційний матеріал не повинен характеризуватись складністю, перена- вантаженням навчального матеріалу. У роботі 3 новим інфрормаційним масивом студент, намагаючись його зрозуміти та засвоїти, активізує свої когнітивні можливості. Тому гарно оформлена та інформативно насичена презентація лекційного матеріалу стане в нагоді для студента. Принцип системності передбачає послідовність засвоєння користувачем певної системи знань у досліджуваній предметній галузі. Формування знань та умінь у певну систему допомагатимуть особі під час їх практичного застосування. Необхідно також враховувати чуттєве сприйняття досліджуваних об'єктів, їхніх моделей, спостереження за ними студентом. Принцип наочності передбачає нову фрорму передачі інформації із застосування мультимедійних засобів [2; 3].

Сорормулювавши новітні принципи лекційного заняття та подачі матеріалу, висвітлимо програмне забезпечення нашої презентації. Серед сервісів та програм для створення презентацій вирізняються Apple Keytone, Prezi, LibreOffice, Impress, Microsoft Power Point. Остання є найбільш популярною програмою підготовки презентацій та їх перегляду, яка $€$ частиною Microsoft Office, доступна для операційних систем Microsoft Windows та macOS, мобільних платорорм Android та IOS.

Звернемо увагу на технологічну привабливість програми Power Point щодо створення презентацій, яке відбувається поступово, стартуючи з вибору загального оформлення, створення нових слайдів, їх інфрормаційного наповнення, створення ефектів анімації під час демонстрації слайдів. Power Point надає можливість перегляду презентації у звичайному режимі сортування слайдів та їх показу.

Область структури містить текст презентації без графічних об'єктів, її призначення полягає у швидкому введенні та впорядкуванні тексту. Режим області слайда дає змогу переглядати кожен слайд, додавати графрічні об'єкти, тексти, діаграми, що збагачує інформаційне наповнення лекційного матеріалу.

Майстер автозмісту надає можливість вибору макету слайдів та їх офрормлення. Допускається доступ до готового сценарію презентації, де викладач матиме змогу розвинути два напрями роботи у створенні презентаційного проекту: підігнати свій матеріал під заготівку або переробити шаблон під свою презентацію. Користуючись шаблонами, викладач зможе реалізувати довільний проект, не прив'язуючись до наявної презентації або її заготовки. Під час створення презентації на основі шаблону можна додавати нові слайди, вибирати відповідний макет для нього, зміст, підбирати відповідний шаблон оформлення, кольорової палітри, відповідних шаблонів ефектів анімації. Після зазначених дій створювач проекту матиме нагоду візуально оцінити вибраний ефект, поліграфічне офрормлення та інформаційне наповнення [6; 11]. 
Power Point $€$ чудовим інструментом як для створювача презентації, так і для адресатів, адже матеріал доповнюється різними мультимедійними есректами до слайдів у формі різноманітних звуків, промов доповідача, відео-кліпів, мелодій, які знаходяться в середовищі Internet або на комп'ютері.

Нагадаємо, що пріоритетним завданням нашого дослідження $є$ висвітлення впливу структури, різновиду шрифтів та кольорів, використаних у презентації, на рівень сприйняття та засвоєння лекційного матеріалу студентами. Отже, необхідно зауважити, що сприйняття тексту залежить від зручності його читання. Гарнітура шрифту фрормує попередню оцінку змісту презентації та зароджує бажання у студента знайомитись із текстом повністю чи залишити його поза увагою. Ми класифрікуємо шрифрти за їх кеглем, щільністю, нахилом літер, пробілами між рядками та літерами тощо.

Нерідко перше сприйняття тексту або ж презентації загалом відбувається на підсвідомому рівні, завдяки чому в образній пам'яті людини при зоровому сприйнятті невідомого інсрормаційного матеріалу, набраного певною гарнітурою, з'являються образи вже бачених текстів. Таким чином, людина асоціює інфрормацію і ототожнює зміст відомого тексту із тим, який вона вже опанувала [5;7].

У таблиці 1 [5] відображено результати опитування користувачів щодо найбільш читабельних шрифтів.Вказаніданівартоврахуватиуподальшому фрормуванні текстів у презентаційних матеріалах.

Нагадаємо, що колір відіграє важливу роль у формуванні візуальної частини лекційного заняття.
Перш за все, потрібно враховувати фрізичне сприйняття кольору людиною, що являлось об'єктом багаторічної експериментальної роботи фрізіологів та психологів. Інший різновид впливу кольорової гами на людину - психологічний: колір може заспокоювати або подразнювати, відштовхувати або приваблювати. Наприклад, сірий колір асоціюється із силою та твердістю, підсилює почуття респектабельності. Його сприйняття може супроводжуватись тугою, меланхолією.

Чорний - траур, біда, стрункість. Цей колір має здатність поглинати обсяг, приховувати недоліки. Інший його зміст - гідність, влада, але він може стати на заваді людських взаємовідносин. Саме тому чорний колір не використовується в поліграфрічній рекламі.

Фіолетовий вважається кольором творчих особистостей, адже він надихає. Розкриваючи психологічний вплив фріолетового кольору на людину, необхідно зауважити на тому, що він заспокоює душу. Рекламна діяльність стверджує, що за його допомогою можна підкреслити креативність товару, в нашому випадку - інформаційного масиву та елементів, які він вміщує.

Білий колір - відкритість. У повідомленнях цей колір несе нейтральний зміст, не здійснює жодних наголошень на певній частині повідомлення.

Синій допомагає зосередити увагу на головній інформації, не відволікаючись на дрібниці. Синій колір у презентації одразу активізує увагу студентів і не викликатиме негативних емоцій.

Блакитний пояснюється як колір поміркова-

Таблиця 1

\begin{tabular}{|c|c|c|}
\hline Характеристика гарнітури шрифрту & $\begin{array}{c}\text { Ступінь зручності } \\
\text { читання }\end{array}$ & $\begin{array}{l}\text { Попередня характеристика } \\
\text { змісту тексту }\end{array}$ \\
\hline Рублені & $\begin{array}{l}\text { Загалом дуже } \\
\text { добра }\end{array}$ & Серйозний \\
\hline $\begin{array}{l}\text { Літери під невеличким нахилом, курсивом невеликого роз- } \\
\text { міру (Helios Cond, Fiesta). }\end{array}$ & Добра & Діловий, публіцистичний \\
\hline $\begin{array}{l}\text { Літери менші, жирніші, з маленькими пробілами, без } \\
\text { нахилу, пддібність до конденсованого (Helios Cond, Fiesta). }\end{array}$ & Середня & Науковий, історичний \\
\hline $\begin{array}{l}\text { Літери без нахилу, жирність середня, різниця у розмірі } \\
\text { (Heivetica Light Norm Europe, Futura Light). }\end{array}$ & Дуже добра & Публіцистичний \\
\hline Великі літери, жирні, без нахилу. & Низька & Несерйозний \\
\hline Літери квадратичної фрорми (Aksent). & Низька & Несерйозний \\
\hline $\begin{array}{l}\text { Співвідношення між основними елементами нормальне } \\
\text { (Everest Ultra). Найкраще використовувати як видільний } \\
\text { шрифт або для заголовків. }\end{array}$ & Низька & Несерйозний або дитячий \\
\hline $\begin{array}{l}\text { Шрифтт із засічками у вигляді трикутника, жирність і вели- } \\
\text { чина середні (Times New Roman Cеу). Найкраще викорис- } \\
\text { товувати для звичайних текстів без особливого змісту. }\end{array}$ & Найвища & $\begin{array}{l}\text { Серйозний, художній, публіцис- } \\
\text { тичний, науковий, діловий }\end{array}$ \\
\hline $\begin{array}{l}\text { Рукописний, без нахилу (Betina Script). Цілком можливо } \\
\text { використовувати в публіцистиці або ж художній літературі } \\
\text { як засіб для образного відтворення людського почерку. }\end{array}$ & Дуже низька & $\begin{array}{l}\text { несерйозний або художній, } \\
\text { історичний, про сучасне }\end{array}$ \\
\hline $\begin{array}{l}\text { Гарнітура має маленькі засічки, основні елементи з кон- } \\
\text { турами, але пусті всередині (Асаdemу Но). Використову- } \\
\text { ється виключно для виділень і заголовків. }\end{array}$ & Найнижча & Несерйозний \\
\hline $\begin{array}{l}\text { Гарнітура кирилиці XI ст. - устав (група додаткових шриф- } \\
\text { тів) (Izhitsa). Найкраще сприймаються відповідні історичні } \\
\text { тексти на замовлення. }\end{array}$ & Середня & $\begin{array}{c}4 / 5 \text { опитаних назвали як істо- } \\
\text { ричний або художній }\end{array}$ \\
\hline
\end{tabular}


ності, втішання, розуму, меланхолійності, франтазії, творчості. У візуальній частині лекційного матеріалу він відіграє важливу роль: придасть матеріалу цілісного вигляду, глобальності та успішності.

Жовтий колір у презентації приваблює увагу студента, стимулює мозок, має здатність зберігатись у пам'яті людей довше, ніж інші кольори. Але його яскравість може порушувати психологічну рівновагу.

Червоний - теплий, подразнюючий, символізує заборону та небезпеку. Цей колір сприяє стимуляції мозкової діяльності.

Коричневий символізує твердість міркувань, поглядів на перебіг соціальних процесів. Використання цього кольору в роботі посилюватиме почуття стабільності.

Зелений колір зменшує кров'яний тиск і розширює капіляри, на тривалий час посилює рухову працездатність. Цей колір заспокоює, знімає втому. У змісті повідомлення зелений уособлює спокій та стабільність $[1 ; 4 ; 8 ; 9]$.

Зауважимо, що швейцарський психолог Макс Люшер приділяв велику увагу кольорам та колірній гамі, які сильно впливають на свідомість людини. Правильне поєднання кольорів викликає в людини позитивні емоції і покращує сприйняття поданої інфрормації.

Багаторічний рекламний досвід пропонує найбільш вдалі поєднання кольорів (червоний на білому, жовтий на чорному, зелений на жовтому, білий на синьому, чорний на жовтому, синій на білому) [8], використання яких у презентаціях оптимізує сприйняття та запам'ятовування матеріалу студентами.

Висновки. У дослідженні проаналізовано презентацію лекційного матеріалу як складову частину інформаційної технології, що передбачає збір, передачу, обробку, зберігання та доведення інформації до студентів. Висвітлено програмне забезпечення візуальної частини лекції. Продемонстровано переваги Power Point як інструмента під час створення презентацій.

Розкрито проблемні аспекти правильного підбору кольорів та шрифтів у візуальній частині лекції як попередження таких поширених помилок, як невідповідність фрорми повідомлення сприйняттю студента, відсутність узгодженості мети та фрорми викладу, нечитабельний шрифт, велика кількість тесту на слайді, некоректне використання великих літер та підкреслень, відсутність графрічної узгодженості, занадто контрастні кольори, неадекватне використання фотографій та зображень, низька читабельність діаграм та графріків, велика кількість анімованих елементів.

\section{БІБЛІОГРАФІЧНИЙ СПИСОК:}

1. Андрущенко Л.М., Ясінський В.П. Вплив червоного кольору на психосоматику людини. URL : http://www.Ivduvs.edu.ua/documents_pdf/visnyky/ nvsp/01_2014/14almnpl.pdf.

2. Андрущенко О.. Англомовне профресійне спілкування 3 використанням IT. Журнал «Відкритий урок: розробки, технології, досвід». 2012. № 1(205). C. 56-60.

3. Афранасьєв М., Ромашова Я. Інформаційні технології в навчальному процесі. Журнал «Вища школа». 2010. № 10. С. 49-62.

4. Бебик В., Левашова К. Національні характеристики в кольоровому інтер'єрі: глобальний і національний вимір. Актуальні проблеми міжнародних відносин: збірник наукових праць. 2006. Випуск 59. Частина II (у двох томах). С. 11-17.

5. Гарнітура шрифту та ії вплив на сприйняття тексту. URL : http://ru.osvita.ua/vnz/reports/ journalism/25035/.

6. Данілова І. Мультимедійні ресурси. Журнал «Відкритий урок: розробки, технології, досвід». 2011. № 2(194). С. 19-21.

7. Ковальчук М.М. Шрифт як інструмент впливу на свідомість.URL:https://nau.edu.ua/site/variables/news/ 2018/5/\%D0\%A2\%D0\%B5\%D0\%B7\%D0\%B8\% 202018/16.

8. Сінельниченко Ю.В., Дубрівна А.П. Кольорові особливості візуальних повідомлень в рамках комерційної реклами. Вісник Київського національного університету технології і дизайну. 2015. № 3(86). C. 277-281.

9. Трач Н.О. Психологічні аспекти використання кольорів у відеороликах кандидатів на пост Президента України під час виборчої кампанії 2004 року. Актуальні проблеми міжнародних відносин: Збірник наукових праць. Випуск 59. Частина II (у двох томах). 2006. C. 113-117.

10. Шарова Т.М. Використання інорормаційних технологій у навчальному процесі вищої школи. URL : eprints.mdpu.org.ua/id/eprint/2728/1/sharova_ soloviy_2018.pdf.

11. Шило С.Г. Інформаційні системи та технології : навчальний посібник. Харків : Вид. ХНЕУ, 2013. 220 с. (Укр. мова). 


\section{ПЕРСОНАЛІЗАЦІЯ НАВЧАННЯ СТУДЕНТІВ У ЦИФРОВОМУ ОСВІТНЬОМУ СЕРЕДОВИЩІ УНІВЕРСИТЕТІВ КИТАЮ}

\section{PERSONALIZED LEARNING FOR COLLEGE STUDENTS IN THE DIGITAL ENVIRONMENT OF THE PEOPLE'S REPUBLIC OF CHINA}

Бурхливий розвиток інсрорматизації освіти поступово змінює традиційні методи викладання та навчання. Інформаційні технології в освіті створили безпрецедентне цифрове середовище навчання для університетів, що дало змогу поліпшити розширення викладання і навчання. Цисррове середовище навчання забезпечує більше зручностей для навчання. Персоналізоване навчання - че продукт цисрового навчального середовища, яке $\epsilon$ однією з основних характеристик навчання XXI століття, а також новою тенденцією у навчанні, що сприяє індивідуальному розвитку студентів в епоху «lнтернет +». Персоналізоване навчання порушує традиційні концепції викладання $i$ навчання. Персоналізоване навчання дає змогу особистості кожного учня повністю розвиватися, поважати індивідуальні відмінності і задовольняти індивідуальні потреби навчання, такі як зміст, методи, стратегії і цілі навчання. Персоналізоване навчання надає студентам університету вільне $і$ невимушене середовище навчання і персоналізовані навчальні ресурси, отже, студенти можуть вибирати власні навчальні матеріали та ресурси відповідно до своїх характеристик і потреб у відповідності до своїх здібностей і прогресу. Цей метод навчання може максимально розкрити індивідуальний потенціал студентів, щоб вони отримали індивідуальний навчальний досвід, що відповідає поточним потребам у навчанні талановитих срахівців у коледжах і університетах. На основі огляду літератури в Китаї та інших країнах автором підготовлено звіт за результатами анкетування студентів про стан персоналізованого навчання. В опитуванні взяли участь 2077 студентів із 35 державних університетів на південному заході Китаю. Проведено аналіз індивідуалізованої навчальної ситуації студентів університету, які методи навчання їм подобаються в класі, і поточний стан цифрового середовища. Зроблено висновок про те, що нинішне просування персоналізованого навчання недостатне, метод оцінки навчання занадто загальний, механізм персоналізованого зворотного зв'язку не досконалий. Недоліком є низьке використання розумного середовища. у роботі надаються відповідні контрзаходи і рекомендації.
Ключові слова: чисррове освітнє середовище, студенти університетів, персоналізоване навчання, контрзаходи.

The rapid development of education Informatization is gradually changing the traditional methods of teaching and learning. Information technology in education has created an unprecedented digital learning environment for universities, which helped to improve the expansion of teaching and learning. Digital learning environment provides more facilities for training. Personalized learning is a product of the digital learning environment, which is one of the main characteristics of teaching of the 21st century, a new trend in learning that promotes personal development of students in the era of "Internet +". Personalized training violates traditional concepts of teaching and learning. Personalized training allows the personality of each student to fully develop, to respect individual differences and to meet individual needs of learning, such as content, methods, strategies and learning objectives. Personalized learning provides University students with a free and relaxed learning environment and personalized learning resources so that students can choose their own materials and resources according to their characteristics and needs, in accordance with their abilities and progress. This method of training may be to maximize the individual potential of the students so they received an individual learning experience that meets current training needs of talented professionals in colleges and universities. Based on the review of literature in China and other countries the author has prepared a report on the results of questioning students about the state of personalized learning. In the survey participated 2077 students from 35 public universities in South-West China. The analysis of individualized learning situation of University students, the teaching methods they like in the class, and the current status of the digital environment. It is concluded that the current promotion of personalized learning is not enough, the method of assessment of learning is too General, the mechanism of the personalized feedback is not perfect. Shortcomings such as low utilization of the smart environment. The article gives the corresponding countermeasures and recommendations.

Key words: digital environment, college students, personalized learning, current situation and countermeasures.

Харківського національного економічного університету імені Семена Кузнеця

мати велику кількість якісних освітніх ресурсів через мережеві термінали та розширити канали для навчання протягом усього життя. Університет має зробити навчання студентів більш різноманітним та персоналізованим. Концепція Національного плану середньої та довгострокової реформи та розвитку освіти КНP (2010-2020рр.) [2] та десятирічного плану розвитку освіти щодо інфрорматизації освіти (2011-2020рр.) [4] пропонують Концепцію талантів 3 орієнтацію на людей великих даних, глибокого навчання та інтернеттехнологій студенти університету можуть отри- 
та різноманітність, повагою до індивідуального вибору, заохочують розвиток особистості та забезпечують індивідуальну освіту для кожного учня. У цифрову епоху стрімкий розвиток інформаційних технологій повністю змінив традиційну модель навчання та викладацької роботи, сприяв реформі класового навчання та реформі методів навчання, забезпечив хороший матеріальний фрундамент для дослідження й практики персоналізованого навчання [17; 18]. 3 огляду на це актуальним є проведення теоретичних та практичних досліджень щодо вивчення стану персоналізованого навчання студентів та впливу цифрового освітнього середовища на якість навчання.

Аналіз актуальних досліджень. Натепер як вітчизняні, так і закордонні уряди та освітянське співтовариство усвідомили цінність персоналізованого навчання і зробили багато спроб практичного дослідження персоналізованого навчання, особливо на технічному рівні. До таких робіт належать персональне планування навчального шляху та динамічна навігація, що досліджували Хван та ін.[6], Чень та ін. [14], Хван та ін [7], та розумне освітнє середовище (Smart Learning Environment, SLE). SLE - це своєрідний інтерактивний інструмент, який може сприймати навчальні ситуації, визначати особливості навчального закладу, забезпечувати відповідні навчальні ресурси та зручну взаємодію. Він може автоматично записувати навчальний процес та оцінювати результати навчання 3 метою розширення місця навчання чи простору діяльності для персоналізованого навчання учнів [9; 10]. Що стосується SLE, то мало випадків, коли зарубіжні країни в основному досліджують свої ключові технології та розробляють відповідні програми. Серед них порівняно помітними є арабські дослідження розумного навчання, які почали використовувати технологію Internet of Things для створення всюдисущих розумних навчальних середовищ для викладання у коледжах [2; 8]. Типові китайські дослідження частіше ґрунтуються на прикладних і теоретичних дослідженнях на основі суміжних технологій, побудові системи та розвитку персоналізованих фрункцій платформи навчання та побудові персоналізованих моделей навчання [1]. Серед них - команда Хуанга Ронгвайя, яка проводила піонерські роботи [8; 15; 16]; Лі Йіпін та інші проаналізували зміст статей міжнародних журналів за останні десять років, детально обговорили стан досліджень та тенденції сприятливого навчального середовища [3]. Ученими обговорені характеристики, склад, інтелектуальне втілення та технологія впровадження навчального середовища [14]; Фен Сян та інші запропонували дизайн інтелектуального досвіду навчання студентів [5].

3 огляду наукових робіт видно, що революція в цифрових технологіях створила сприятливе середовище для персоналізованого навчання студентів. Китайські та зарубіжні ученні також провели багато досліджень, але робіт з персоналізованого навчання студентів у цифровому освітньому середовищі університетів все ще не досить. У цьому контексті актуальним є дослідження персоналізованого навчання студентів університетів.

Мета статті - з'ясувати проблеми персоналізованого навчання в сучасному цисровому освітньому середовищі та дати відповідні протизаходи знайденим проблемам.

\section{Виклад основного матеріалу.}

1. Дослідження стану персоналізації навчання студентів університетів ПівденноЗахідного Китаю в цифровому середовищі

Об'єкт обстеження - персоналізація навчання студентів у цифровому освітньому середовищі університету. Респондентами опитування $€$ студенти університетів 3 Південно-Західного Китаю: Технологічного університету Ченду, Кунмінського університету науки і техніки, Педагогічного коледжу Лешана, Ібінськомого коледжу, педагогічного коледжу Квіцзіна, Нормандського університету Гуйчжоу, Педагогічного коледжу Нейдзян, Педагогічного коледжу Міньян, Чанкінського нормального університету, Нормандського університету Янцзи. У 35 університетах та інших коледжах для опитування студентів були використані анкети, зібрано 2077 справжніх анкет. Серед них розподіл за статтю та оцінкою студентів представлений у таблиці 1. 3 погляду студентських дисциплін вони включають більшість дисциплін першого рівня, таких як управління, економіка, медицина, наука, література, освіта, сільське господарство, інженерія, право та фрілософрія. Загалом, показники обстежуваних в основному перебувають у збалансованому стані, певною мірою забезпечуючи всебічність та репрезентативність джерел даних цього опитування.

Таблиця 1

Розподіл респондентів за статтю та курсами

\begin{tabular}{|l|c|c|c|}
\hline \multicolumn{1}{|c|}{ клас } & чоловіки & жінки & $\begin{array}{c}\text { Проміжні } \\
\text { підсумки }\end{array}$ \\
\hline Перший курс & 279 & 312 & $591(28,45 \%)$ \\
\hline Другий курс & 352 & 372 & $724(34,86 \%)$ \\
\hline Третій курс & 201 & 247 & $448(21,57 \%)$ \\
\hline $\begin{array}{l}\text { Четвертий } \\
\text { курс }\end{array}$ & 200 & 114 & $314(15,12 \%)$ \\
\hline Всього & $\begin{array}{c}1032 \\
(49,69 \%)\end{array}$ & $\begin{array}{c}1045 \\
(50,31 \%)\end{array}$ & $\begin{array}{c}2077 \\
(100 \%)\end{array}$ \\
\hline
\end{tabular}

\section{2. Зміст та методи опитування}

Це дослідження фрокусується на ситуації студентів коледжу, які використовують наявні інорормаційні технології для розвитку персоналізованого навчання в сучасних цифрових умовах. Розроблена нами анкета опитування ґрунтується на аналізі китайської та зарубіжної літератури. 
Опитування фрормулюється шляхом аналізу характеристик персоналізованого навчання та навчальних характеристик студентів університету в поточному середовищі цифрового навчання та поточному статусі розумних аудиторій, розумних лабораторій та розумних кампусів. Зміст анкети в основному включає запитання: Чи любите ви використовувати сучасні інформаційні технології на занятті? Чи мають розумні аудиторії кращий навчальний ефект, ніж традиційні аудиторії? Чи можуть розумні аудиторії покращити вивчення та розуміння предметних знань? Студентам було запропоновано поміркувати самостійно про сучасний стан персоналізованого навчання: Чи підходить ваша школа для персоналізованого навчання? Яку роль відіграє персоналізоване навчання в оптимізації міжособистісних стосунків в університеті (між викладачами, студентами та одногрупниками)?

\section{3. Результати опитування}

3.1. Індивідуальний статус навчання cmyдентів у цифровому середовищі

Опитування показало, що близько 85\% студентів коледжу заявляють, що користуються мобільними телефонами, планшетами, комп'ютерами та Інтернетом для особистого навчання в середньому щодня. Перед навчанням 87\% студентів склали особисті плани навчання, але лише 15,56\% можуть їх виконати дуже добре (відмінно), як показано на рисунку 1. Судячи з оцінки загального статусу персоналізованого навчання, 73,08\% учнів вважають виконання індивідуального навчального плану добрим, але $25,69 \%$ учнів вважають його виконання середнім. Основна причина полягає в тому, що студенти не досить активні в навчанні, мають недостатню свідомість та навички навчання. Відповідно, перші становили 13,8\%, останні - 24,67\%, що також відповідає низькому загальному ефректу.
Що стосується онлайн-платформ навчання, то студенти коледжів в основному використовують такі мережі, як широкомасштабні відкриті онлайнкурси, тобто МООС (масові відкриті онлайн-курси), різні актуальні вебсайти для навчання, власна онлайн-платорорма для навчання кожної школи, цисрова бібліотека та вебсайти для навчання за навчальними курсами, платформи для навчання. Однак на багатьох платсрормах передбачено лише завантаження навчального програмного забезпечення, подання завдань тощо. Багато інших корисних ресурсів не були інтегровані інтелектуально, і студенти не можуть використовувати платформу для персоналізованого навчання.

що стосується мотивації навчання, то 18,94\% студентів вважають, що персоналізоване навчання відбувається під тиском викладачів чи батьків, 36,05\% є нейтральними, а 45,01\% студентів активно беруть на себе ініціативу щодо персоналізації навчання.

Щодо засвоєння знань та підсумків навчання, то лише $6,77 \%$ студентів активно сортуватимуть знання, які вони засвоїли, у фрормі паперів або конспектів, щоб полегшити розуміння та засвоєння знань, 34,58\% студентів пасивно організують знання, а 58,64\% студентів не систематизують і не узагальнюють знання.

Що стосується рефлексії навчання, то 83,73\% учнів задумаються про свої недоліки після закінчення навчання, щоб скорегувати методи та зміст навчання.

3.2. Підтримка навчального середовища для персоналізованого навчання студентів університету

За результатами опитування 87,92\% студентів вважають, що їх навчальний заклад може задовольнити потреби персоналізованого навчання із розумними кампусами, розумними аудиторіями, розумними лабораторіями та відповідними

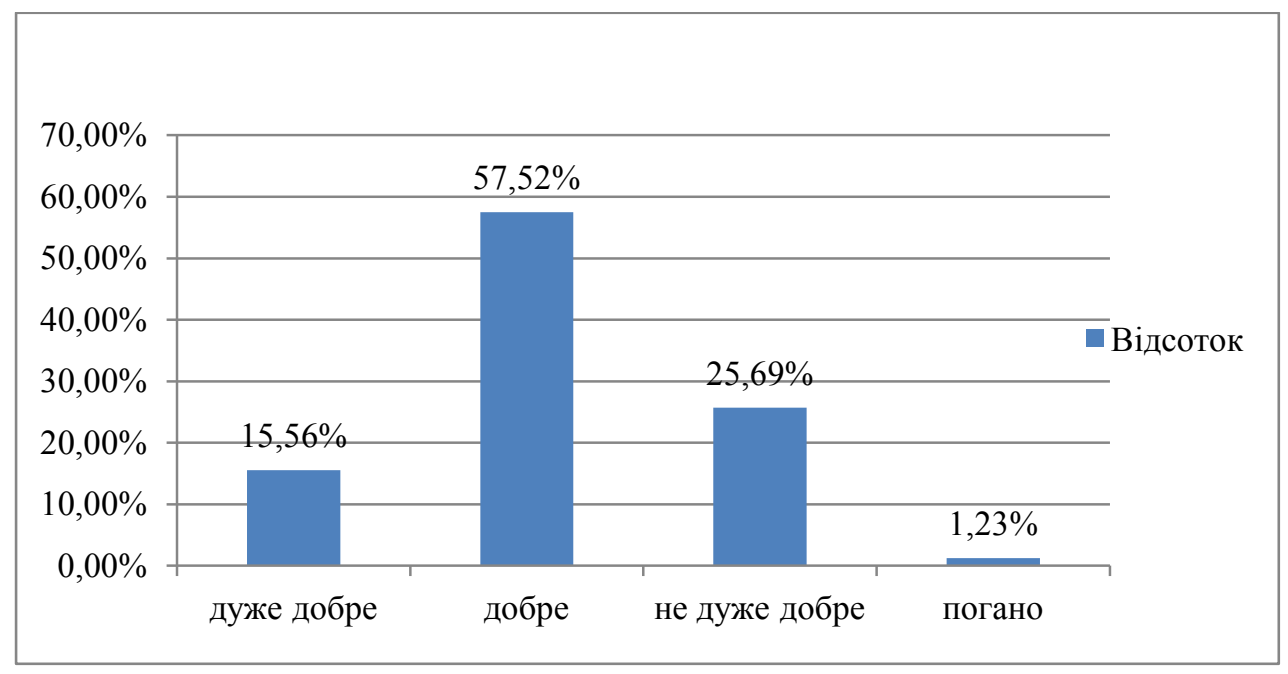

Рис. 1. Якість виконання індивідуального плану навчання студентами (відмінно, добре, середньо, погано) 
платформами оцінювання навчальних процесів та онлайн-системами оцінювання курсу.

3.3. Підтримка персоналізованого навчання студентів університету через онлайн-платформи навчання

Щодо наявних ресурсів онлайн-платорорми навчання 82,29\% студентів вважають, що вони можуть задовольнити свої потреби в знаннях, але також $€ 12,71 \%$ студентів, які вважають, що важко знайти потрібні ресурси для навчання. Більше 85\% студентів заявили, що вони можуть пропустити, і близько 60\% з них необхідно консолідувати за допомогою тестів або вправ. Це свідчить про те, що під час навчального процесу студенти мають певну самостійність у визначенні власного змісту навчання. Для того щоб учні могли по-справжньому зрозуміти знання відповідних розділів, навчальна платорорма також встановить невеликий тест після завершення кожної точки знань, щоб виявити отримані знання, і той, хто впорався, може перейти до наступної точки знань, щоб перешкодити деяким студентам пропустити вивчення відповідних знань, просто щоб завершити процес навчання.

Що стосується рекомендацій стосовно ресурсів, якщо студенти стикалися 3 труднощами у навчанні, 20,14\% студентів вважали, що система не рекомендує їм активніших чи складніших навчальних ресурсів. I коли студенти не повністю зрозуміли або не здали тест з певної галузі знань, то 33,32\% студентів сказали, що онлайн-платформа навчання може надати допомогу, наприклад, навчальні ресурси, але не надала додаткових тестів.

\section{4. Персоналізований ефект навчання}

3 точки зору ролі персоналізованої онлайнплатформи навчання в оволодінні основними знання 3 курсу 74,72\% студентів вважають, що це може допомогти засвоїти та зрозуміти предметні знання, а 19,55\% студентів не були впевнені, чи це корисно. Завдяки персоналізованому навчанню 84,52\% студентів вважають, що очікуваний ефект від навчання досягнутий.

\section{4. Проблеми щодо персоналізованого} навчання

Аналізуючи вибіркові дані опитування, ми можемо виявити, що до основних проблем сучасного персоналізованого навчання належать:

1. Сучасна пропаганда персоналізованого навчання недостатня. Основними причинами $€$ недостатня увага керівників та глибоко вкорінений вплив традиційної освіти. Водночас викладачі не бажають сприймати нові речі.

2. Циорровому освітньому середовищу не вистачає підтримки та послуг для персоналізованого навчання студентів університету, вкрай необхідні якісні ресурси та навчальні платформи. Натепер більшість досліджень зосереджені на тому, як побудувати циорове освітнє серед- овище за допомогою технології, персоналізовану навчальну платформу на основі великих даних та динамічно розподіляти студентів на основі результатів модуля прогнозування, що підштовхує різноманітні навчальні ресурси та різні рівні навчання для студентів на різних рівнях. $€$ дуже мало персоналізованих навчальних платфрорм, які реально можуть бути використані для побудови навчальних шляхів та надання персоналізованого зворотного зв'язку студентам у режимі реального часу.

3. Метод оцінювання навчання занадто простий. Через вплив традиційних концепцій освіти здається, що визначати якість навчальних результатів студентів не можна незмінним фактом, приймаючи екзаменаційно орієнтовану освіту. Хоча педагогічна реформа коледжів та університетів неодноразово підкреслювала, що викладачі мають використовувати кілька методів оцінювання для визначення всебічної якості учнів, вона не була реалізована. Єдиний метод оцінювання якості викладання також став важкою проблемою для персоналізованого навчання в цифровому освітньому середовищі.

4. Неповний персоналізований механізм зворотного зв'язку. У цій анкеті багато студентів згадували питання створення механізму зворотного зв'язку для персоналізованого навчання. Особливо для тих студентів, які часто використовують цифрове середовище для персоналізованого та автономного навчання, існує вдосконалений механізм зворотного зв'язку для викладачів та студентів. Важливий міст спілкування - це також ефективний спосіб для викладачів аналізувати навчальні інтереси та характеристики учнів.

5. Пропозиції щодо персоналізованого навчання. 3 огляду на результати аналізу опитувальника у цьому дослідженні пропонуються такі пропозиції щодо проблем персоналізованого навчання студентів університету в сучасному цифровому освітньому середовищі для відповідних керівників чи дослідників:

а) університет має розробити відповідну політику для заохочення викладачів до повноцінної щодо суб'єктивної ініціативи та ентузіазму студентів за допомогою різних засобів інформаційних технологій у навчанні курсу та стимулювання жаги студентів до знань;

б) збільшити інвестиції у будівництво розумних містечок, розумних аудиторій, розумних лабораторій та розвиток персоналізованих навчальних платсрорм;

в) підвищити підготовку викладачів з розвитку навичок інорормаційних технологій, вдосконалення вміння застосовувати та дати можливість викладачам проєктувати, оцінювати та розробляти інфрормаційні ресурси, оптимізувати аудиторне навчання та удосконалювати методи та методики навчання; 
г) удосконалити систему оцінювання якості викладання та оцінити ефективність результатів навчання студентів у кількох вимірах.

Висновки. На основі вивчення літератури розроблено анкету та проведено дослідження, в якому взяли участь 2077 студентів із 35 коледжів тауніверситетів Південно-Західного Китаю, та використано анкети для дослідження індивідуалізованої ситуації навчання студентів у цифровому освітньому середовищі, сприятливого навчального середовища для персоналізованого навчання студентів коледжу та онлайн-платорорми для навчання.

Підтримка персоналізованого навчання студентів коледжу, персоналізовані ефекти навчання тощо дали змогу зрозуміти реальну ситуацію щодо персоналізованого навчання студентів університету в цифровому освітньому середовищі, проаналізувати проблеми персоналізованого навчання в поточному цифровому середовищі та узагальнити результати. Запропоновані відповідні пропозиції до використання.

На основі цього дослідження у подальших роботах ми зосередимо увагу на чинниках, що впливають на індивідуалізований ефект навчання студентів, та будемо розробляти відповідну персоналізовану модель навчання.

\section{БІБЛІОГРАФІЧНИЙ СПИСОК:}

1. Гу ТІ Ангел, Ван Хард. Аналіз стану вітчизняних досліджень персоналізованого навчання на основі CNKI. Цифррова освіта. 2017. № 3 (06). С. 10-15.

2. Захрані М.С. Переваги і потенціал інноваційного повсюдно мінливого середовища для поліпшення інорраструктури вищої освіти і підвищення кваліфікації студентів у Саудівській Аравії. Журнал прикладних наук. 2010. № 10 (20). С. 2358-2368.

3. Лі Пінпінг, Цзян Шаосян, Цзян Фенгуанг та ін. Стан досліджень і тенденція розумного навчального середовища. Аналіз змісту доповідей міжнародних журналів за минуле десятиліття. Відкриті освітні дослідження. 2014. № 20 (5). С. 111-119.

4. Министерство образования Китайской Народной Республики. Десятилетний план развития образовательной информации (2011-2020) (EB/OL). URL: http://www.moe.gov.cn/publicfiles/business/htmlfiles/ moe/s3342/201203/xxgk-133322.html.

5. Фен Сян, Ву Йонге, Чжу Чжитінг. Дизайн досвіду розумного навчання. Китай. Освітні технології. 2013. № 12. С. 14-19.

6. Хван Дж. Дж. Куо, Ф.Р. Інь, П.Й. і Чуанг, К.Х. Евристичний алгоритм. Плановані персоналізовані шляхи навчання для усвідомленого контекстом повсюдного навчання. Комп'ютери та освіта. 2010. № 54. С. 404-415.

7. Хван Г.Ж., Ву П.Х., Чен С.С. \& Ту Н.Т. Вплив мобільного конкурентного підходу до ігор на навчальні установки і досвід студентів у бойових поїздках. Праці Міжнародної конференції освітніх інновацій через технології. 2014. С. 62-67.

8. Хуан Ронгвай. Поняття та характеристики розумних аудиторій. Дослідження відкритої освіти. 2012. № 18 (2). С. 22-27.

9. Хуан Ронгвай, Чжан Цзіньбао, Ху Йонбін, Ян Юнфенг. Розумний кампус: неминуча тенденція розвитку цифрових кампусів. Дослідження відкритої освіти. 2012. № 18 (4). С. 12-17.

10. Хуан Ронгвай, Ян Юнфенг, Ху Йонбін. Від цифрового середовища навчання до розумного навчального середовища: зміни та тенденції в навчальному середовищі. Відкрите дослідження в галузі освіти. 2012. № 2. С. 1-3.

11. Центральний народний уряд Китайської Народної Республіки. План національного середньострокового і довгострокового плану реформи та розвитку освіти (2010-2020 роки). (EB/OL). URL: http:// old.moe.gov.cn//publicfiles/business/htmlfiles/moe/ s7496/201308/155119.html.

12.Центральний народний уряд Китайської Народної Республіки. План національного середньострокового і довгострокового плану реформи та розвитку освіти (2010-2020 роки) (EB/OL).

13. Чен Дж. Динамічна навігація для персоналізованої навчальної діяльності на основі моделі рекомендації поступової адаптації. Праці ICWL. Конспект лекцій в галузі комп'ютерних наук (LNCS). 2010. № 6483. С. 31-40.

14. Чень Вейдун, Е. Сіньдун, Сюй Яфен. Майбутні класні кімнати: інтелектуальне навчальне середовище. Журнал дистанційної освіти. 2012. № 5. C. 42-49.

15. Чжан Йонге, Сяо Гуанде, Ху Йонбін, Хуан Ронгхуай. Визначення контекстів навчання в розумних навчальних середовищах. Нехай навчальне середовище ефективно служить учням. Open Education Research. 2012. № 18 (1). C. 85-89.

16. Чжан Цзіньбао, Хуан Ронхуай, Чжан Лянанг. Хмарні сервіси інтелектуальної освіти: нова модель інсрормаційної освітньої послуги. Open Education Research. 2012. № 18 (3). С. 20-26.

17. Чжен Юньсян. Дослідження персоналізованого навчання студентів коледжу в середовищі інфрормаційних технологій. Китай. Освітні техноло2iї. 2014. № 7. С. 126-132.

18. Чжен Юньсян. Дослідження стану квот персоналізованого навчання студентів коледжу в контексті інформаційних технологій. Дистанційна освіта в Kumaï. 2015. № 7. С. 19-25. 


\section{ІНФОРМАЦІЙНІ ТЕХНОЛОГІЇ У ВИВЧЕННІ ІНОЗЕМНОЇ МОВИ INFORMATION TECHNOLOGIES IN FOREIGN LANGUAGE EDUCATION}

у статті розкриваються деякі аспекти використання інсрормаційних технологій у змісті професійного навчання, які дають змогу зробити навчальний процес ефективним та індивідуалізованим. Актуальність дослідження зумовлена швидкими та радикальними змінами, які відбуваються в сучасному українському суспільстві під впливом інформатизації та вимагають від сучасної системи освіти інноваційного підходу до підготовки майбутніх фрахівців і швидкого й ефективного оволодіння іноземними мовами. Ці вимоги призвели до повторного перегляду традиційних способів викладання іноземних мов у вищих навчальних закладах. Адже іноземна мова є обов'язковим елементом профресійної підготовки. Експерти різних галузей зацікавлені у високому рівні володіння мовою. Від цього залежить можливість успішної співпраці з іноземними представниками та особистісне професійне зростання.

Також окреслено основні фуункції та переваги використання інфрормаційних можливостей комп'ютерних технологій та мережі Інтернет для досягнення освітніх цілей у процесі вивчення іноземної мови та розглянуто складники самостійної роботи курсантів із застосуванням інформаційних технологій. Наголошується на тому, що сучасні інфрормаційні технології $є$ результативним інструментом, який сприяє засвоєнню знань, розвиває інтерактивне, комунікативно спрямоване навчання. Саме інтерактивний метод роботи за допомогою мультимедійних засобів дає змогу найкраще налаштувати темп та складність завдань, сприяє покращенню засвоєння граматичного матеріалу та збільшенню лексичного багажу, що уможливлює створення індивідуально освітньої траєкторії. Завдяки мультимедійним технологіям викладач може подати інформацію в абсолютно новій фрормі та наближеною до тематики спілкування, що вивчається.

Обгрунтовано доцільність використання методу проєкту як багаторівневого підходу до вивчення англійської мови, що охоплюе читання, аудіювання, говоріння і граматику. Акцентується на тому, що метод проєктів сприяє розвитку активного самостійного мислення студентів, орієнтує їх на спільну дослідницьку роботу.

Ключові слова: інсоормачійні технології, інтернет-технології, інтернет-ресурси, іноземна мова, комп'ютерно орієнтоване навчання, інтерактивне навчання, мультимедійні засоби.

In the article the peculiarities of the usage of information technologies in the system of preparation of future specialists are considered, which allow to make an educational process effective and individualized. The topicality of research is conditioned on social-economic processes which take place in modern society under the influence of informatization and require of the educational system the innovative approach in preparation of future specialists.

The article describes the functionality of internet technologies in teaching English for Specific Purposes. There are different ways in which teaching and learning can be made more efficient especially in program delivery through the use of the technology. Examples of computer technology, including the internet resources in the educational process in higher educational establishments. Online education is widely extending and is trying to get the place of conventional methods of teaching and learning. Specific features of the use of information technologies in the content of vocational training in the forms of the educational process and in practice are analyzed. Attention is focused on the relevance of information technology training for Ukrainian educational system. It is spoken in detail about technological applications and resources used in classrooms today. Particular attention is paid to learning English through the news, with options for reading articles online, listening to news podcasts or watching news videos on an app - all on your own time and wherever you like is the great benefit.

As can be seen Internet access gives great opportunities for education authoritative to improve the quality of education for individual learners and contribute to national economic and social welfare. The internet is full of sites specifically for practicing and learning English.

Key words: internet technology, internet resources, foreign language, computer-based learning, interactive learning, multimedia tools.
Постановка проблеми в загальному вигляді. На сучасному етапі розвитку освітньої системи, що характеризується розробкою нових методів та засобів навчання, надзвичайно актуальним $є$ використання інсоормаційних технологій у вивченні іноземної мови. Важливою складовою частиною профресійної підготовки курсантів $€$ вивчення іноземної мови, яке потребує значних зусиль, але $\epsilon$ запорукою вдалої майбутньої кар'єри майбутніх правоохоронців. Раціональне та вмотивоване використання інформаційних технологій на заняттях з іноземної мови вимагає креативного підходу з боку викладача та курсанта.
Використання інфрормаційних технологій на заняттях іноземної мови - розвиток мовленнєвої культури, творчих здібностей, критичного мислення, формування стійкої мотивації до вивчення іноземної мови, формування практичних умінь та навичок в усіх видах мовленнєвої діяльності, фрормування мовленнєвої компетенції для підготовки майбутніх правоохоронців.

Підготувати фрахівця, який добре володіє іноземною мовою, можна через формування в курсанта необхідної комунікативної спроможності у ссрерах профресійного спілкування в усній i писемній формі, тобто розвитку комунікативних 
умінь і навичок. Комунікативні мовні компетенції забезпечують людині змогу діяти, застосовуючи специфічні лінгвістичні засоби.

Аналіз останніх досліджень і публікацій. Нині в Україні спостерігається зростаюча тенденція кількості досліджень, які тісно пов'язані з використанням інформаційно-комунікативних технологій у навчальному процесі вищих шкіл. Цій темі в Україні присвячені дослідження таких науковців, як В. Биков, Я. Булахова, О. Бондаренко, В. Заболотний, О. Міщенко, О. Пінчук та ін. Розробкою і впровадженням у навчальний процес нових інфрормаційних технологій активно займаються такі дослідники як, Г. Баранова, Н. Гез, В. Гузеев, Е. Дмітреєва, О. Кузнєцова, О. Кулькіна, В. Кумарін, Б. Лапідус, С. Логачевська, М. Ляховицький, Ж-П. Мартан, Н. Мойсеюк, С. Новіков, І. Підласий, Л. Подимова, Е. Полат, Т. Полілов, О. Савченко, Г. Селевко, В. Сластьонін, О. Тарнопільський, Л. Цвєткова та багато ін. [2-4].

Виділення невирішених раніше частин загальної проблеми. Вивчення іноземної мови передбачає накопичення мовного матеріалу, тобто опанування всіма аспектами мови - фонетикою, лексикою, граматикою. Необхідно також фрормувати та використовувати ці аспекти мови в різних видах мовленнєвої діяльності, а саме: аудіюванні, говорінні, читанні та письмі. Значну допомогу в поглибленні знань аспектів мови та розвитку вмінь мовленнєвої діяльності можуть надати інорормаційні технології, починаючи від вивчення лексики, відпрацювання вимови, навчання діалогічного мовлення, навчання письму до тестування набутих знань.

Саме тому нині назріла одна 3 найголовніших потреб в системі освіти -інтеграція інформаційних технологій у навчальний процес. Запровадження інфрормаційних технологій - одна з умов успішного вивчення іноземної мови. Тому викладач іноземної мови має, окрім ґрунтовної фрахової підготовки, володіння сучасною комунікативною методикою, використовувати інсрормаційні технології на усіх етапах навчання - це вимога часу.

Мета статті - огляд та використання різноманітних сучасних інорормаційних технологій у процесі навчання іноземної мови.

Виклад основного матеріалу. У зв'язку зі швидкими та радикальними змінами, які відбуваються в сучасному українському суспільстві, перед системою вищої освіти в Україні постає вимога осучаснити зміст та методи застосування інорормаційних технологій у викладанні іноземної мови. Адже саме вони відповідають потребам майбутніх поколінь, а будь-які підходи та стиль подання інорормації піддаються впливу модернізації $з$ появою нових можливостей.

Поява України у світовому та європейському просторі зумовлює кардинальні зрушення у галузі освіти, особливо, що стосується викладання іноземних мов у вищій школі.
Сучасні інорормаційні технології мають бути еорективним інструментом, який полегшить засвоєння знань, зробить навчання інтерактивним, комунікативно спрямованим, цікавим, наочним, індивідуальним. Впровадження інфрормаційних технологій підготує майбутніх правоохоронців до самостійної праці, стимулюватиме до самоосвіти протягом усього життя. Внаслідок науково-технічної революції виникла потреба в неперервній освіті: знання старіють так швидко, що доводиться постійно перенавчатися. Відповідно, вміння вчитися стає однією з найголовніших навичок. I саме ця навичка набувається в процесі вивчення іноземної мови за допомогою інформаційних технологій [4, с. 77$]$.

Сучасні технології в освіті - це профресійно орієнтоване навчання іноземної мови, проектна робота в навчанні, застосування інорормаційних та телекомунікаційних технологій, робота 3 навчальними комп'ютерними програмами 3 іноземних мов (система мультимедіа), дистанційні технології в навчанні іноземних мов, створення презентацій у програмі PowerPoint, використання інтернет-ресурсів, навчання іноземної мови в комп'ютерному середовищі (форуми, блоги, електронна пошта), новітні тестові технології (створення діагностичних матеріалів із курсу навчального предмета «Іноземна мова» для проведення комп'ютерного тестування) [1].

Інформаційні технології стають дедалі важливішими засобами в процесі вивчення іноземної мови. Цифрові платформи допомагають викладачам та курсантам урізноманітнювати та покращувати навчальний процес, удосконалювати знання.

Л.І. Стрельчук вважає, що основа масової комп'ютеризації освіти, безсумнівно, пов'язана з тим, що сучасний комп'ютер є ефективним засобом оптимізації умов розумової праці взагалі, в будь-якому її прояві [7].

До технічних переваг цього методу можна зарахувати використання інтерактивних аудіо- та відеороликів у процесі навчання усного мовлення. У разі використання фрото, схем та малюнків за тематикою мовного спілкування втілюється принцип наочності. Впровадження різних мультимедійних новинок розширює межі інтерактивного спілкування, що нині відіграє провідну роль навчального процесу.

Запровадження мультимедійних технологій у навчальний процес створює умови для інтерактивного спілкування. Використовуючи мультимедійні технології, викладач може подати інорормацію в абсолютно новій та ефективній фрормі, зробити її більш повною, цікавою та наближеною до тематики спілкування, що вивчається.

Мультимедійні засоби - це використання електронних лекторів, тренажерів, підручників, енциклопедій, розробка ситуаційно-рольових та інтелектуальних ігор, моделювання процесів і явищ, забезпечення дистанційної форми навчання, побу- 
дова систем контролю й перевірки знань і умінь курсантів (використання контролюючих програм тестів), створення і підтримка сайтів навчальних закладів, створення презентацій навчального матеріалу, здійснення проективної і дослідницької діяльності курсантів [6].

Шляхом використання таких мультимедійних засобів комунікації, як Chinswing (http://www. chinswing.com), Gabmail (http://www.freegabmail. com) i Vaestro (http://www.vaestro.com), можна організовувати фроруми англійською мовою для студентів як нашої країни, так і інших країн із студентами англомовних країн.

Розвиток мобільних технологій уможливив отримати доступ до всесвітньої мережі, яка дає змогу відправлятися у віртуальну подорож навколо світу, брати учать у міжнародних конкурсах та олімпіадах, організовувати та проводити спільні телекомунікаційні проекти, тематичні презентації, спілкуватися в текстових і голосових чатах, які можна використовувати для вивчення іноземної мови в будь-який вільний час.

Інтеграція ресурсів мережі Інтернет у навчальний процес надає змогу більш ефективно вирішувати цілу низку дидактичних завдань:

- знайомитися 3 культурою, що включає в себе мовний етикет, особливості мовної поведінки різних народів в умовах спілкування, культуру та традиції країни;

- вдосконалювати вміння діалогічного і монологічного мовлення на основі проблемного обговорення представлених матеріалів викладачем або кимось із курсантів;

- вдосконалювати вміння аудіювання на основі автентичних звукових текстів;

- формувати навички та вміння читання, безпосередньо використовуючи матеріали мережі різного ступеня складності;

- поповнювати свій словниковий запас, як пасивний, так і активний, лексикою сучасної іноземної мови, що відбиває певний етап розвитку культури народу, політичного і соціального устрою суспільства.

Завдяки цим технологіям викладач має змогу подати інформацію в суттєво новому образі. Мультимедійні засоби дозволяють створювати цікаві та різноманітні завдання в ігровій фрормі. Це дає змогу залучити до роботи навіть лінивих, бо ці технології $€$ новими та цікавими для студентів. Також інноваційні методи підштовхують до самостійної роботи над проектами та їх презентації для ширшої аудиторії. Тернопільський дослідник Г.А. Чередніченко стверджує, що застосування мультимедійних матеріалів та комп'ютерних мереж скорочує час навчання майже втричі, а рівень запам'ятовування через одночасне використання зображень, тексту, звуку, зростає на 30-40\% [8].

Основою Всесвітньої мережі є спілкування, яке забезпечує безпосередній зв'язок із носіями мови через листування, створення і проведення спільних телекомунікаційних проектів, участь у текстових і голосових чатах, читання гіпертекстової інфрормації за фрахом, використання онлайн-словників. Прикладами є такі сайти:

$$
\text { - Easy Language Exchange }
$$

(https://www.easylanguageexchange.com)

- Conversation

(https://www.conversationexchange.com/index);

- InterPals (https://www.interpals.net);

- My Language Exchange (https://www.mylanguageexchange.com).

Можливості та переваги сайтів:

- співрозмовників добирають за рівнем англійської мови;

- спілкування за інтересами, блог із корисними порадами від викладачів та курсантів, а також форору;

- листування англійською мовою у Skype чи Windows Messenger;

- користування онлайн-бібліотеками, словниковими іграми та онлайн-листування;

- змога влаштовувати розмовний онлайнклуб (групи до 4 осіб) і вчити один одного, наприклад, половина заняття англійською, половина українською, російською або іншою мовою, якою володієте.

Однією з технологій, що забезпечує особисто орієнтоване навчання, $€$ метод проєктів як спосіб розвитку творчості, пізнавальної діяльності, самостійності. Проєкти можуть підрозділятися на монопроєкти, колективні, усно-мовні, видові, письмові й інтернет-проєкти. Робота над проєктом це багаторівневий підхід до вивчення англійської мови, що охоплює читання, аудіювання, говоріння і граматику. Метод проєктів сприяє розвитку активного самостійного мислення учнів і орієнтує їх на спільну дослідницьку роботу [5].

Також треба пам'ятати, що в процесі вивчення іноземної мови в курсантів виникає низка проблем, пріоритетною 3 яких $є$ низька мотивація до вивчення мови. Саме в таких випадках сучасні інтерактивні технології $€$ найбільш доречними для застосування, тому що вони створюють такі умови, коли курсант розуміє власні інтелектуальні можливості. Ефективна співпраця та комунікація $€$ основою такого навчання, яке має на меті спільне розв'язання проблем, здобуття навичок монологічного мовлення, відповідальність, критичного мислення та досягнення переконливих результатів.

Висновки. Отже, впровадження нових інорормаційних технологій і мобільних додатків в освітній процес вносить абсолютно нові компоненти до змісту освіти, необхідні для підготовки конкурентоспроможних фрахівців. Вибір інфрормаційних технологій для самостійної та аудиторної роботи з іноземної мови визначається рівнем володіння 
мовою, інтересами і профрілем підготовки курсантів. Перспективою подальших досліджень $є$ проведення експериментальних спроб практичного застосування різних технологій у процесі навчання іноземної мови з метою вибору найефективніших.

\section{БІБЛІОГРАФІЧНИЙ СПИСОК:}

1. Альошина О.М. Сучасні методи та технології викладання іноземних мов у ВН3. 2012. С. 242-247.

2. Дрофра Т.П. Використання сучасних інорормаційно-комунікативних технологій під час викладання іноземної мови. URL: http://www.psyh.kiev.ua/3бірник_наук._праць (дата звернення: 19.05.2020).

3. Жигжитова Л.М. Нові тенденції у викладанні іноземних мов в немовних вузах. URL: http://confesp. fl .kpi.ua/ru/node/1165 (дата звернення: 21.05.2020).
4. Коновалов О.Ю. Internet і його вплив на розвиток закладів середньої, професійної та вищої освіти Америки і Європи. Київ : НМЦ ВО, 2002. С. 77-88.

5. Науменко У.В Інноваційні методи навчання англійської мови у вищій школі в умовах модернізації. Молодий вчений. 2018. № 3.1.

6. Ставицька І.В. Інформаційно-комунікаційні технології в освіті. URL: http://confesp.fl.kpi.ua/ node/1103 (дата звернення: 19.03.2014).

7. Стрельчук Л.І. Сучасні технології у викладанні англійської. Передовий педагогічний досвід. URL: http://www.ukrreferat.com/index.php?referat=81356 (дата звернення: 19.05.2020).

8. Чередніченко Г.А. Мультимедійні технології у процесі викладання дисципліни «іноземна мова» у вищих технічних навчальних закладах. Тернопіль, 2011. 


\section{УПРОВАДЖЕННЯ ДИСТАНЦІЙНОЇ ФОРМИ ПІДВИЩЕННЯ КВАЛІФІКАЦІЇ НАУКОВО-ПЕДАГОГІЧНИХ ПРАЦІВНИКІВ 3 ІННОВАЦІЙНИХ ТЕХНОЛОГІЙ ВИКЛАДАННЯ

\author{
INTRODUCTION OF A DISTANCE FORM OF TEACHER TRAINING \\ ON INNOVATIVE TEACHING TECHNOLOGIES
}

у статті розглянуто теоретичні аспекти
та практичну реалізацію упровадження дис-
танційного навчання в освітній процес підви-
щення кваліфрікації педагогічних та науково-
педагогічних працівників фармацевтичних
та медичних закладів освіти відповідно до
реалій сьогодення та викликів часу. Від-
значено переваги дистанційного навчання
педагогічних та науково-педагогічних пра-
цівників, до яких належать його гнучкість,
можливість індивідуально навчатися, виби-
раючи час, місце й темп навчання. Наведено
приклад досвіду впровадження дистанцій-
ного навчання для слухачів циклу «Іннова-
ційні технології викладання» в системі під-
вищення кваліфрікації викладачів медичної
та фрармачевтичної галузі у закладах вищої
освіти.

Представлено результати анкетного опитування слухачів, наведено одержані результати та досліджено психолого-педагогічні особливості дистанційної форми навчання у сучасних умовах організації освітнього процесу в закладах вищої освіти. Визначено особливості навчання слухачів на такому курсі, ступінь їх задоволеності щодо інфрормаційного забезпечення та змістової наповненості курсу, ступінь збагачення знаннями з інноваційних технологій та проблемами в оволодінні інноваційними технологіями викладання. Також з'ясовано думки респондентів щодо вчасності та об'єктивності оцінювання успішності виконання практичних завдань (тестів, опитувальників та ін.) і подальшого використання сучасних інноваційних технологій у викладанні навчальних дисциплін.

Визначено, що дистанційне навчання в системі підвищення квалісрікації дає змогу: професійного вдосконалення викладачів без відриву від основної діяльності; індивідуалізаціі навчання з орієнтацією на можливості та рівень профресіоналізму викладача, забезпечення умов його педагогічної діяльності; зробити процес підвищення кваліфрікації більш відкритим, неперервним і гнучким. Дистанційне навчання в післядипломній освіті має відповідати сучасним формам і методам навчання, доповнюватись інноваційними підходами, з можливістю для професійного зростання та навчання на відстані.

Ключові слова: дистаниійна срорма навчання, підвищення кваліфікації педагогічних та науково-педагогічних працівників, формацевтичні та медичні заклади вищої освіти, інноваційні технології викладання, підготовка викладачів у системі Moodle.

The article considers the theoretical aspects and practical implementation of distance learning in the educational process of professional development of pedagogical and scientific-pedagogical workers of pharmaceutical and medical educational institutions in accordance with the realities of today and the challenges of the time. The advantages of distance learning of pedagogical and scientific-pedagogical workers are noted, which include its flexibility, ability to study individually, choosing the time and place of study. An example of the experience of introducing distance learning for students of the course "Innovative teaching technologies" in the system of advanced training of teachers of medicine and pharmaceuticals in higher education.

The results of the questionnaire survey of students are presented, the obtained results are presented and the psychological and pedagogical features of distance learning in modern conditions of the educational process in higher education institutions are studied. Peculiarities of students' training in this course, the degree of their satisfaction with the information support and content of the course, the degree of enrichment with knowledge of innovative technologies and problems in mastering innovative teaching technologies are determined. Respondents' opinions on the timeliness and objectivity of assessing the success of practical tasks (tests, questionnaires, etc.) and the further use of modern innovative technologies in the teaching of academic disciplines were also clarified.

It is determined that distance learning in the system of advanced training allows: professional development of teachers without separation from the main activity; individualization of education with a focus on the capabilities and level of professionalism of the teacher, providing conditions for his teaching activities; make the training process more open, continuous and flexible. Distance learning in postgraduate education should correspond to modern forms and methods of learning, complemented by innovative approaches, with the opportunity for professional growth and distance learning.

Key words: distance learning, advanced training of pedagogical and scientific-pedagogical workers, pharmaceutical and medical institutions of higher education, innovative teaching technologies, teacher training in the Moodle system.
Постановка проблеми у загальному вигляді та їі зв'язок з важливими науковими чи практичними завданнями. Питання підготовки та підвищення кваліфікації педагогічних і науковопедагогічних працівників визначаються як пріоритетні. Метою підвищення кваліфікації педагогічних та науково-педагогічних працівників фрармацевтичних та медичних закладів вищої освіти (3ВО) на циклах підвищення кваліфрікації $€$ підготовка викладача сучасної генерації, озброєного не тільки професійними знаннями, вміннями та компетентностями, а й педагогічною, психологічною, комунікативною компетентностями, розвиненими професійно значущими та особистісними якостями.

Актуальна нині неперервна освіта або «навчання протягомжиття» маєвиключне значення 
як для самої особистості, так і для держави загалом. Підвищення кваліфрікації забезпечує фрахове зростання шляхом реалізації сучасних освітніх інновацій, упровадження технологій навчання на засадах андрагогіки, оволодіння працівниками освіти інформаційно-комунікаційними технологіями, мережевими та медіа-технологіями тощо.

Вітчизняні 3ВО, у т.ч. і післядипломної, у короткі терміни змушені були стрімко адаптуватися до новітніх змін у фрормах і засобах навчання, підвищення кваліфрікації і перепідготовки. Виникла потреба в оволодінні досвідом дистанційного навчання, постійному підвищенні кваліфікації викладачів, які мають оволодіти необхідними компетентностями інноваційного викладання.

Аналіз останніх досліджень і публікацій. Стосовно тематики статті актуальними є праці вітчизняних і зарубіжних науковців, присвячені питанням неперервності освіти (С. Зінченко, Т. Ткач, В. Шелудько та ін.), навчання дорослих та підвищення кваліфікації педагогічних кадрів (О. Андрєєв, Л. Даниленко, В. Олійник та ін.); технологіям дистанційного навчання у післядипломній педагогічній освіті (В. Биков, Л. Ляхоцька та ін.) [5; 6; 7; 8].

Теоретичний пошук виявив недостатню кількість наукових праць, присвячених підвищенню кваліфрікації науково-педагогічних та педагогічних праць за дистанційною формою викладачів закладів фрармацевтичної та медичної освіти (Л. Галій, Л. Кайдалова, Т. Серопян, В. Фесенко та ін.), що й спонукало до більш ретельного дослідження цієї тематики [1; 2].

Метою статті $є$ висвітлення досвіду дистанційної форми підвищення кваліфрікації педагогічних та науково-педагогічних працівників фармацевтичних та медичних 3ВО на циклі «Інноваційні технології викладання».

Виклад основного матеріалу. Планом циклів підвищення кваліфрікації викладачів фрармацевтичних та медичних 3ВО колективом кафедри педагогіки та психології Інституту підвищення кваліфікації спеціалістів фрармації (далі - ІПКСФ) Національного фрармацевтичного університету було розроблено навчально-методичні матеріали для очного навчання слухачів, але у зв'язку із непередбачуваними обставинами викладачі кафедри в короткий термін адаптували курс у дистанційний фрормат та розмістили відповідні навчальні матеріали на платформі Moodle.

Курс підвищення кваліфікації «Інноваційні технології викладання» обсягом 75 годин (2,5 кредити) передбачав опанування слухачами знань з сучасних педагогічних технологій, умінь та навичок їх використання в освітньому процесі 3ВО. Змістом передбачено такі теми: сучасні педагогічні технології, веб-квест технологія, технологія групового навчання, кейс-технологія, технології інтерактивного навчання, інфрормаційно-комуніка- ційні технології навчання, розробка мультимедійної презентації, проблемна технологія навчання, здоров'язберігаючі технології в освіті.

Освітній процес та оцінювання реалізовувався через систему управління навчанням LMS MOODLE, електронну пошту, конференції в ZOOM та ін. Певні функції системи управління навчанням використовувались як засоби комунікації для проведення занять, а також як навчальні завдання зокрема використовувались форуми, чати. Для забезпечення цього процесу для слухачів були підготовлені та розміщені різні матеріали, такі як: відеолекції, презентації та конспекти лекцій, інтерактивні завдання 3 питань певної теми, що були представлені; опитування та інші ресурси в мережі Інтернет.

Під час розробки та впровадження дистанційного курсу «Інноваційні технології викладання» було враховано вимоги нормативно-законодавчих документів 3 дистанційного навчання та «Положення про експертизу дистанційного курсу», за яким курс містить ресурси трьох типів (інфрормаційні, діяльнісні, комунікативні) та має типову структуру, що розміщує такі складники:

- загальні відомості про курс (презентація курсу, графрік навчального процесу, алгоритм навчання, критерії оцінювання знань, список друкованих та інтернет-джерел, глосарій);

- супроводження дистанційного курсу тьютором (форум «Знайомство», новини курсу, фрорум «Допомоги (консультацій) тьютора та взаємодопомоги»);

- навчально-методичні матеріали з кожної теми (основний інформаційний матеріал: структуровані та візуалізовані електронні навчальні матеріали; додатковий інформаційний матеріал: аудіо-, відео-, анімаційні навчальні ресурси, посилання тощо; практичні або семінарські заняття: зміст, методичні рекомендації щодо їх виконання, фрорми подання результатів та приклади виконання; тести або запитання для самоконтролю та контролюючі тести).

Слухачі мали опановувати теоретичний матеріал, вивчати представлений інформаційний матеріал у терміни, зазначені графріком навчального процесу відповідно до тем, брати участь у обговореннях на фрорумах, виконувати індивідуальні завдання, а також ознайомлюватися 3 іншими додатковими джерелами. Протягом вивчення курсу всі види діяльності слухачів підлягали поточному контролю, що здійснювався протягом вивчення теми. Після закінчення курсу його учасники взяли участь в анкетному опитуванні (онлайн-опитування за google-фрормою, анонімно) 3 метою з'ясування організації, форм навчання, інфрормаційного забезпечення цього циклу підвищення кваліфікації.

В опитуванні взяли участь доценти, викладачі та асистенти медичних і фрармацевтичних ЗВО. Кількість учасників становила 40 осіб, серед 
яких -більшість жіночої статі $(84,4 \%)$ та 15,6\% чоловічої. В опитуванні здебільшого взяли участь респонденти молодого та середнього віку (від 30 до 50 років) - 58\%, решта опитаних (51-60 років) становила $25,8 \%$, а $12,9 \%$ респондентів була віком старші за 60 років. Щодо педагогічного стажу серед учасників курсу, то майже 50\% опитаних викладачів на педагогічній ниві працюють від 11 до 25 років.

Більшість питань анкети стосувалась особливостей організації навчання, інформаційного забезпечення дистанційного курсу підвищення кваліфікації «Інноваційні технології викладання» 3 метою його подальшого удосконалення. Так, на запитання «Наскільки курс збагатив ваші знання щодо інноваційних технологій викладання» 54,4\% респондентів відповіли, що збагатили максимально, варіант відповіді «більшою мірою» обрали майже 43\% опитаних педагогічних працівників.

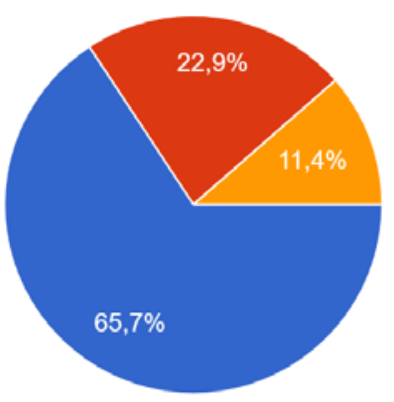

Повністю задоволена(ий)

Задоволена(ий)

Частково задоволена(ий)

Не задоволена(ий)

Категорично не задоволена(ий)

Рис. 1. Ступінь задоволеності проведенням курсу у дистанційній формі
На запитання щодо задоволеності проведення курсу саме у дистанційній фрормі, здебільшого було отримано позитивні відповіді, а саме майже $67 \%$ респондентів виявились повністю задоволеними або задоволеними (майже 23\%) такою формою. Зрозумілим є і відсоток частково задоволених, адже не всі педагогічні працівники були «технічно» підготовлені до такого навчання, дещо не вистачало комп'ютерної грамотності або відповідного обладнання (рис. 1).

У зв'язку із цим були поставлені питання щодо зрозумілості і зручності роботи 3 певними структурними складниками курсу. Так, на запитання: «Чи досить роз'яснений алгоритм, програма та графрік навчання за дистанційним курсом?» респонденти обирали варіанти відповідей «повною мірою» або «більшою мірою» - 88,6\% і 11,4\% опитаних відповідно.

Також нас цікавила думка слухачів щодо тематичної наповненості курсу, наскільки навчальнометодичні матеріали 3 наведених тем були цікавими і корисними для подальшого впровадження у педагогічній діяльності. Як бачимо 3 гістограми, найбільший відсоток респондентів зацікавила представлена тематика і здебільшого була корисною (рис. 2).

Слухачам було запропоновано відзначити, які ресурси та матеріали задовольнили їх найбільше. Загалом, більшість респондентів
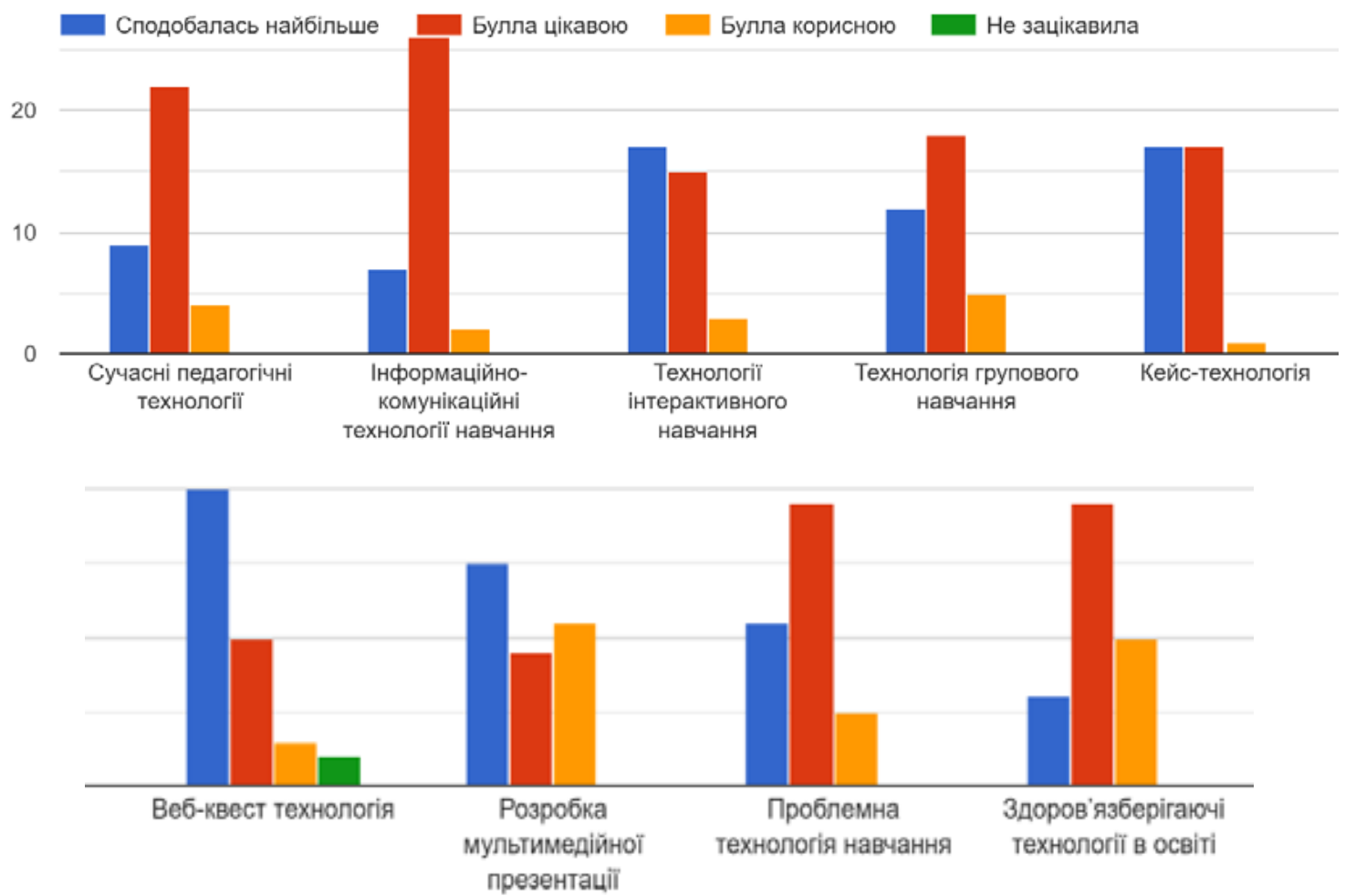

Рис. 2. Відповіді на запитання: «Які із зазначених тем курсу були цікавими та корисними?» 
були повністю задоволеними презентаціями до лекцій, відеолекціями та теоретичним матеріалом до тем; більшою мірою залишились задоволеними участю у форумах, практичними завданнями та інорормаційними джерелами, хоча деякий відсоток відзначав, що доопрацювання потребують форуми та конспекти лекцій, і така думка нас буде мотивувати на подальше вдосконалення.

Слід також зазначити, що на запитання стосовно того, яких навчальних матеріалів не вистачало на цьому курсі, попри більшість тих, кому «всього вистачало», 30\% респондентів вказали на те, що їм не досить саме відеолекцій. Це може бути пов'язане або зумовлене браком спілкування, обговорення та взаємодії за такою фрормою навчання.

Розглянемо також питання стосовно оцінювання результатів навчання на цьому дистанційному курсі. Наводилась шкала та критерії оцінювання, поточна сума балів за кожну тему та максимальна кількість балів за курс. Для цього перш за все визначимо показники того, наскільки слухачі погоджувались із наведеними критеріями оцінювання практичних завдань. Наведені показники свідчать про те, що більшість респондентів погоджувалась та повністю погоджувалась $\quad(36,3 \%$ і майже $62 \%$ відповідно) із тим, що критерії оцінювання практичних завдань дають змогу їм чітко зрозуміти межі якісного виконання завдання для отримання позитивної оцінки (рис. 3).

Наступний показник якість оцінювання виконання практичних завдань, яке здійснювалось у балах. Ми звертали увагу слухачів на те, що наприкінці кожної теми є практична частина, яка містить: завдання, що складається 3 одного або кількох складників, вирішення яких спрямоване на досягнення різних рівнів навчальних цілей: розуміння, розпізнавання (вибір), застосування, аналіз, оцінювання, створювання. За результатами опитування 91,2\% респондентів висловили позитивне ставлення щодо вчасності та об'єктивності оцінювання успішності виконання практичних завдань (тестів, опитувальників та ін.).
Також нас цікавила думка слухачів щодо можливих труднощів у роботі з дистанційним курсом. Відповіді більшості опитаних розподілилися за групами тих, у кого бракує досвіду дистанційного навчання (майже 42\%) і тих, у кого виникли проблеми технічного характеру (35,5\%), у решти (інші поодинокі відповіді) відзначались інші труднощі, що представлені в гістограмі (рис. 4).

До результатів роботи слухачів вважаємо доцільним додати інформацію щодо досвіду дистанційного навчання та наявності власних дистанційних курсів у слухачів, таких слухачів виявилось 29,4\%. Кількість респондентів, що мають досвід дистанційного навчання, але поки що не мають власних дистанційних курсів, становила 32,4\% опитаних. Більшість слухачів курсу $(38,2 \%)$ відзначали, що дистанційне навчання почали освоювати нещодавно.

Дещо розділилась думка слухачів щодо переваг дистанційного та очного навчання. Так, з питанням: «Чи згодні ви з тим, що дистанційні

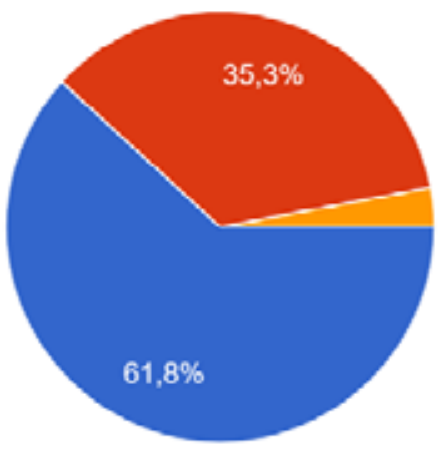

Повністю погоджуюсь

Погоджуюсь

Частково погоджуюсь

He погоджуюсь

Категорично не погоджуюсь

Рис. 3. Ступінь погоджуваності із критеріями оцінювання завдань
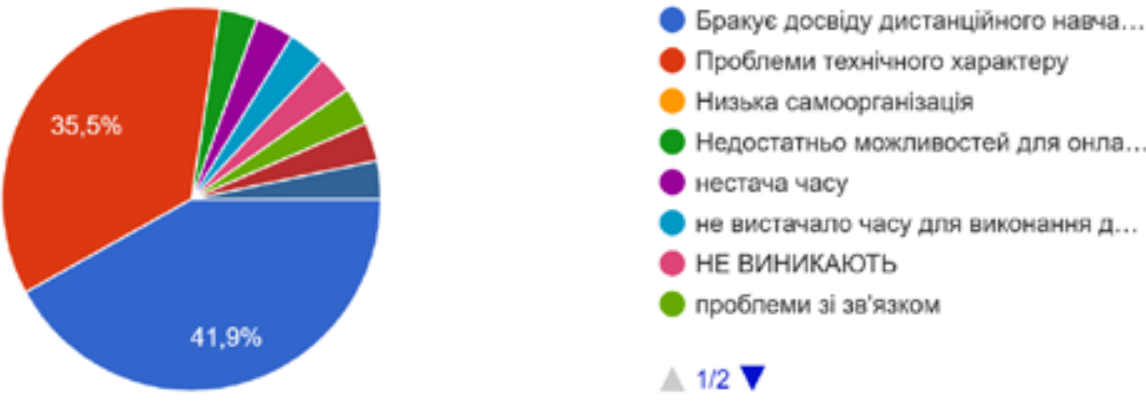

Рис. 4. Труднощі в роботі з дистанційним курсом, що виникають у слухачів

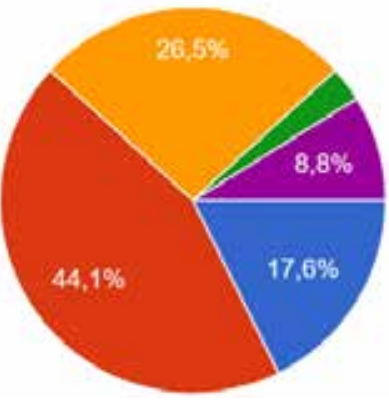

Повністю згодна(ий)

Скоріше згодна(ий), нік не агодна(ий) Скоріше не згодна(ий), нік згодна(ий)

Повністю не зодна(ий)

Важко відповісти

Рис. 5. Відповіді на запитання: «Чи згодні ви з тим, що дистанційні курси есрективніші за очні курси?» 
курси ефрективніші за очні курси?» повністю погодились лише 17,6\% респондентів, більшість опитаних (44,1\%) вибрала варіант відповіді «скоріше згодний, ніж не згодний». Тих, хто майже не погоджувався із перевагами дистанційного навчання, виявилось 26,5\% (рис. 5).

Разом із тим слід зазначити, що в анкеті слухачам було запропоновано відповісти і на декілька питань, де вони могли висловити власну думку щодо того, які інноваційні технології використовуються під час викладання власних навчальних дисциплін. Отримані результати свідчать, що майже всі респонденти використовують у викладанні навчальних дисциплін інформаційнокомунікаційні технології, проєктну, інтерактивну, проблемну, особистісно орієнтовану, тренінгову технологію, технологію групового навчання, мультимедійні технології, кейс-технологію, інтерактивні навчання та ін. Поряд із цим учасники відзначали, що не досить обізнані у створенні веб-квестів, систем управління навчанням та контентом, навчальними методами для онлайн-середовища, ресурсами та інтерактивними елементами LMS Moodle, програмами для монтажу та редагування відео.

Також ми звернулись до слухачів із питанням: «Які фрорми (ресурси) можете запропонувати Ви, як користувач, для додаткового опрацювання тем дистанційного курсу?» і отримали інорормацію про те, що деякі слухачі прагнули більш «живого» спілкування у вигляді онлайн-семінарів, вебінарів, конфреренцій у платформі ZOOM.

Загалом, відгуки та пропозиції від слухачів, що проходили навчання на дистанційному курсі, були позитивними. На запитання: «Чи порекомендували б Ви своїм колегам пройти курс підвищення кваліфрікації «Інноваційні технології викладання?» 91,2\% відзначили, що із задоволенням порекомендують і 8,8\% порекомендують деяким.

Отже, результати впровадження дистанційного навчання підвищення кваліфрікації педагогічних та науково-педагогічних працівників фрармацевтичних та медичних 3ВО, з одного боку, свідчать про необхідність якісної розробки інформаційних матеріалів та відеолекцій, а також високої внутрішньої мотивації слухачів циклів, самоорганізації, самодисципліни та самоконтролю у дотриманні поставлених цілей, завершенні розпочатої справи, яка була наявна не у всіх учасників циклу, елементарної комп'ютерної грамотності. 3 іншого - серед слухачів курсу були більш досвідчені в плані ІКТкомпетентності слухачі (навички спілкування засобами мережі Інтернет, уміння працювати з необхідними додатками і програмними засобами тощо), відсутність якої породжує психологічний дискомфрорт і бар'єри для подальшої роботи.
Висновки. Упровадження дистанційного навчання в підвищенні кваліфрікації педагогічних та науково-педагогічних працівників фрармацевтичних та медичних ЗВО є нагальною потребою і на перше місце виходить проблема постійного вдосконалення профресійного рівня кожного, що $€$ гарантом успішності кар'єри, утвердження статусу особистості в суспільстві та самореалізації. У зв'язку з цим дослідно-експериментальний пошук дає змогу визначити, що дистанційне навчання в системі підвищення кваліфікації, зокрема на циклі «Інноваційні технології викладання», дає змогу: професійного вдосконалення викладачів без відриву від основної діяльності; індивідуалізації навчання з орієнтацією на можливості та рівень професіоналізму викладача, забезпечення умов його педагогічної діяльності; зробити процес підвищення кваліфрікації більш відкритим, неперервним і гнучким. Дистанційне навчання в післядипломній освіті має відповідати сучасним формам і методам навчання, доповнюватись інноваційними підходами з можливістю для профресійного зростання та навчання на відстані.

\section{БІБЛІОГРАФІЧНИЙ СПИСОК:}

1. Галій Л.В., Серопян Т.М. Впровадження дистанційної форми навчання у фармацевтичну освіту (на прикладі Національного фармацевтичного університету). Фармацевтичний часопис. 2017. № 3. C. 112-117. URL: http://nbuv.gov.ua/UJRN/Phch 2017_3_17.

2. Галій Л.В., Кайдалова Л.Г., Фесенко В.Ю. Дистанційне навчання в системі підвищення квалісрікації науково-педагогічних працівників фрармацевтичних і медичних закладів освіти. Освіта для XXI столітmя: виклики, проблеми, перспективи : матеріали міжнародної наук.-практ. конф. (29-30 жовтня 2019, Суми). Суми, 2019. С. 3-5.

3. Про Концепцію Національної програми інфрорматизації : Закон України від 4 лютого 1998 року № 75/98-BP. URL: https://zakon.rada.gov.ua/laws/ show/75/98-\%D0\%B2\%D1\%80\#Text.

4. Биков В. Ю. Теоретико-методологічні засади моделювання навчального середовища сучасних педагогічних систем. Інфрормаційні технології $i$ засоби навчання. URL: https://lib.iitta.gov.ua/3583/1/1. pdf.

5. Зінченко С., Котирло Т. Особливості навчання дорослих у системі неперервної освіти. Педагогічні інновації: ідеї, реалії, перспективи. 2018. Вип. 2. С. 40-45. URL: http://nbuv.gov.ua/UJRN/ ped in 201828.

6. Ляхоцька Л.Л. Особливості науково-методичного забезпечення щодо використання цифрового контенту в закладах післядипломної педагогічної освіти. Нова педагогічна думка. 2018. № 4. С. 60-62.

7. Олійник В.В. Система післядипломної педагогічної освіти України: стратегія розвитку. Освіта на Луганщині. 2009. № (31). С. 14-20. 


\title{
ОСОБЛИВОСТІ ВИКОРИСТАННЯ СУЧАСНИХ ТЕХНІЧНИХ ЗАСОБІВ НАВЧАННЯ СПОРТСМЕНАМИ ВИСОКОЇ КВАЛІФІКАЦІЇ В УМОВАХ САМОІЗОЛЯЦІї
}

\author{
FEATURES OF USE OF MODERN TECHNICAL MEANS \\ OF TRAINING SPORTSMEN OF HIGH QUALIFICATION \\ IN CONDITIONS OF ISOLATION
}

УДК 378.147; 796.011.3-796.8 DOI https://doi.org/10.32843/2663$6085 / 2020 / 24-2.46$

\section{Климович В.Б.,} канд. наук з фіз. виховання і спорту, викладач кафедри фізичного виховання, спеціальної фізичної підготовки і спорту Національної академії сухопутних військ імені гетьмана

Петра Сагайдачного

\section{Паламарчук Ю.Г.,} канд. наук з фріз. виховання і спорту, завідувач каседри теорії і методики фрізичного виховання та спорту КЗВО «Вінницький гуманітарнопедагогічний коледж»

\section{Пилипчак I.B.,}

викладач кафедри фрізичного виховання, спеціальної фрізичної підготовки і спорту Національної академії сухопутних військ імені гетьмана Петра Сагайдачного

\section{Пилипчак B.B.,}

начальник навчально-тренувального комплексу кафедри фрізичного виховання, спеціальної фрізичної підготовки і спорту Національної академії сухопутних військ імені гетьмана Петра Сагайдачного

\section{Василенко М.М.,} викладач кафедри службово-бойового застосування підрозділів Національної гвардії України

Київського фракультету

Національної академії

Національної гвардії України
Статтю присвячено актуальним питанням використання сучасних технічних засобів навчання, спрямованих на підтримання необхідного рівня технічної підготовленості єдиноборців високої кваліфікації в умовах самоізоляції. Головною метою роботи $\epsilon$ визначення впливу використання сучасних технічних засобів навчання, спрямованих на підтримання оптимальної спортивно форми спортсменами-самбістами високої кваліфрікації в умовах самоізоляції. Під час дослідження членами науково-дослідної групи використано такі методи: теоретичний аналіз та узагальнення науково-методичної (спеціальноі) літератури; моніторинг інтернет-ресурсів; педагогічні спостереження; контрольне тестування рівня технічної підготовленості, методи математичної сmатистики; технічні засоби. 3 метою визначення ефрективності запропонованого нами технічного засобу навчання, спрямованого на підтримання оптимальної спортивної форми спортсменами-самбістами високої кваліфікації в умовах самоізоляиії, було проведено педагогічний експеримент (березень - травень 2020 р.). У педагогічному експерименті взяли участь спортсмени високої кваліфікації, члени збірних команд областей України з боротьби самбо $(n=22$ ос.). Для визначення ефективності запропонованої нами технології було визначено експериментальну Ег (n=11 ос.) та контрольну групи Кг ( $n=11$ ос.). Представники Кг під час індивідуальних тренувань із боротьби самбо в умовах самоізоляції з метою підтримання належного технічного рівня зазначеного єдиноборства використовували розроблені нами плани індивідуального рухового вдосконалення, які передбачали використання інтернет-ресурсів спеціального спрямування, а також методично-аналітичний підхід для його оцінювання (К.В. Ананченко, О.В Хацаюк [12]). У свою чергу, досліджувані Ег під час тренувань в умовах самоізоляції додатково використовували ВКС «Katsumoto» [11] Запропонована нами експериментальна модель використовувалася представниками Ег 5 разів на тиждень упродовж зазначеного вище періоду самоізоляції (час відпрацювання тренувального завдання - 50-60 хв.), що, у свою чергу, призвело до створення кумулятивного ефректу, наслідком чого у представників Ег було помічено більш сталі показники збереження «еталонного рівня» технічної підготовленості в обраному виді єдиноборства, на відміну від самбістів КГ, і иі відмінності переважно достовірні (Ег $P<0,05)$.
Ключові слова: боротьба самбо, єдино борства, самоізолячія, індивідуальне тренування, спортсмени високої квалісрікації, технічні засоби навчання, техніка, оптимальна форма.

The article is devoted to topical issues of using modern technical means of training aimed at maintaining the required level of technical training of highly qualified martial arts in self-isolation. The main purpose of the work is to determine the impact of the use of modern technical means of training aimed at maintaining optimal sports form by highly qualified Sambo wrestlers in selfisolation. During the research the members of the research group used the following methods: theoretical analysis and generalization of scientific-methodical (special) literature; monitoring of Internet resources; pedagogical observations; control testing of the level of technical readiness, methods of mathematical statistics; technical means. In order to determine the effectiveness of our proposed technical means of training aimed at maintaining optimal sports form, highly qualified Sambo athletes in self-isolation conducted a pedagogical experiment (March - May 2020). The pedagogical experiment was attended by highly qualified athletes, members of the national teams of the regions of Ukraine in Sambo $(n=22$ people). To determine the effectiveness of our proposed technology, we determined the experimental group Eg ( $n=11$ people) and the control group $\mathrm{Kg}$ ( $n=11$ people). Representatives of $\mathrm{Kg}$ during individual training in Sambo in selfisolation in order to maintain the proper technical level of this martial arts used our individual plans for individual motor development, which included the use of Internet resources for special purposes, as well as methodological and analytical approach to its evaluation (K.V. Ananchenko, O.V. Khatsaiuk [12]). In turn, the studied Eg during training in self-isolation additionally used VKS "Katsumoto" [11]. Our proposed experimental model was used by representatives of $\mathrm{Eg} 5$ times a week during the above period of self-isolation (training time 50-60 minutes), which in turn led to a cumulative effect, resulting in representatives of Eg were observed more stable rates of preservation "reference level" of technical training in the chosen type of martial arts in contrast to Sambo wrestlers KG and these differences are mostly significant $(\mathrm{Eg} P<0,05)$.

Key words: Sambo wrestling, martial arts, selfisolation, individual training, highly qualified athletes, technical means of training, technique, optimal form.
Постановка проблеми в загальному вигляді. Глобальним викликом для системи фрізичної культури та спорту України стала короновірусна пандемія (COVID-19). Хвороба вийшла за межі однієї країни та набула світових масштабів, захопивши всі країни. Ситуація, у якій опинилися міжнародні спортивні організації та федерації з олімпійських і не олімпійських видів спорту, а також безпосередньо висококваліфіковані атлети, поставила перед тренерськими «штабами» завдання в найкоротші терміни перевести всіх спортсменів на дистанційну систему тренування. 
Самоізоляція не привід згортати активну освітню діяльність і спортивну кар'єру. Варто зауважити, що повноцінно займатися самоосвітою та тренуваннями в обраному виді спорту в зазначених обставинах не досить просто, але з урахуванням сучасних наукових розробок у напрямі використання технічних засобів навчання та тренування - цілком можливо, що сьогодні $€$ актуальним напрямом наукових розробок.

Дистанційних тренувальних технологій, які пов'язанні 3 навчанням і вдосконаленням рухових дій спортсменів в обраному виді спорту, з проведенням ними практичних тренувань, контролем за їхнім рівнем рухової підготовленості та ступенем сорормованості у них необхідних профресійних (прикладних) компетенцій, нині розроблено в недостатній кількості, що потребує відповідних подальших наукових розвідок.

Зв'язок роботи 3 науковими програмами, планами і темами. Дослідження виконано відповідно до планів науково-дослідної роботи та дослідно-конструкторських робіт: кафедри фрізичного виховання, спеціальної фрізичної підготовки та спорту Національної академії сухопутних військ імені гетьмана Петра Сагайдачного та кафедри теорії і методики фрізичного виховання та спорту комунального закладу вищої освіти «Вінницький гуманітарно-педагогічний коледж» (2020р.).

Аналіз останніх досліджень і публікацій. У результаті моніторингу науково-методичної та спеціальної літератури (інтернет-ресурсів) нами встановлено, що питанням використання технічних засобів навчання в освітньому процесі здобувачів вищої освіти, а також висококваліфрікованих спортсменів під час самоізоляції присвячено наукові праці таких учених: В.М. Головачьова, А.М. Карєва, А.Д. Мурзіна, М.А. Правдова, М.Б. Саркесова, І.А. Сергєєва, А.М. Шутова, О.В. Щербакова, А.М. Яблонського та інших провідних учених і практиків зазначеного напряму дослідження.

Подальший аналіз науково-методичної та спеціальної літератури в обраному напрямі дослідження дав нам змогу виявити низку робіт провідних учених, а саме: К.В. Козерук [1], О.А. Никифрорової [2], Т.В. Носової, О.Г. Авруніна [3], С.В. Петренка [4], М.А. Правдова, А.М. Шутова, Д.М. Правдова [5], О.А. Чиханцева, [6], І.С. Щадилової [7], А.М. Яблонських [8], у яких розкрито питання розв'язання проблеми самоосвіти та індивідуальних фрізичних тренувань в обраному виді спорту в умовах самоізоляції. У свою чергу, систему організації онлайн-змагань серед військовослужбовців Національної гвардії України та членів їхніх сімей в умовах самоізоляції розкрито в роботах С.В. Лещені, С.С. Забродського, А.О. Мелешка, О.В. Хацаюка [9; 10].

Слід зауважити, що відповідно до результатів аналізу науково-методичної та спеціальної літера- тури (інтернет-ресурсів) в обраному нами напрямі дослідження прослідковується готовність силових структур до викликів сьогодення (умов самоізоляції), що підкреслюється збалансованим фрункціонуванням системи професійної (службової) підготовки військовослужбовців та працівників силових структур і спеціальних служб України.

Виділення не вирішених раніше частин загальної проблеми. Формування професійних компетентностей у спортсменів високої квалісрікації в умовах самоізоляції потребує врахування змісту їхньої індивідуальної та групової програми багаторічної підготовки в обраному виді спорту. Тому до атлетів високої кваліфрікації висуваються особливі вимоги, які пов'язані 3 необхідністю демонструвати ними високий рівень базових умінь і спеціальних навичок, необхідних для досягнення високих спортивних показників під час участі в змаганнях різних рівнів.

Аналіз науково-методичної та спеціальної літератури (інтернет-джерел) в обраному нами напрямі дослідження дав змогу визначити такі суперечності між:

- потребою розвитку та вдосконалення технічної майстерності атлетів високої кваліфрікації в обраному виді спорту та відсутністю умов повноцінного тренування з урахуванням превентивних карантинних заходів, спрямованих на боротьбу з пандемією COVID-19 у всьому світі;

- наявним фрізичним, технічним, тактичним i теоретичним рівнем підготовленості атлетів високої квалісрікації та необхідністю розроблення програм індивідуального тренування, спрямованих на підтримання наявної спортивної фрорми в умовах самоізоляції;

- потребою використання в повному обсязі спеціалізованих відеопрограм, прикладних комп'ютерних програм, пов'язаних із теоретичним і практичним розвитком технічної майстерності атлетів високої кваліфрікації в обраному виді спорту, та відсутністю таких доступних і ефективних технічних засобів навчання.

Незважаючи на значну кількість робіт із цього напряму наукових розвідок, питанням використання сучасних технічних засобів навчання спортсменами високої кваліфрікації для підтримання на належному рівні технічної майстерності в обраному виді спорту в умовах самоізоляції увага не приділялася, що підкреслює актуальність дослідження.

Мета статті - визначити вплив використання сучасних технічних засобів навчання на підтримання оптимальної спортивної фрорми спортсменами високої кваліфікації в обраному виді спорту в умовах самоізоляції (на прикладі спортсменів, які займаються боротьбою самбо).

Для досягнення мети дослідження планувалося розв'язати такі завдання: 
- провести аналіз науково-методичної та спеціальної літератури у напрямі підтримання належного рівня профресійної компетентності спортсменів високої кваліфікації в різних видах спорту в умовах самоізоляції;

- здійснити огляд наявних технічних засобів навчання, які можливо використовувати у напрямі індивідуального технічного вдосконалення атлетами в обраному виді спорту в умовах самоізоляції;

- розробити й апробувати експериментальну модель із технічними засобами навчання, яка спрямована на підтримання й удосконалення належного рівня технічної підготовленості самбістів високої кваліфрікації в умовах самоізоляції.

Виклад основного матеріалу. Як один зі шляхів розв'язання окресленої проблематики в системі дистанційної освіти та підготовки висококваліфікованих атлетів в умовах самоізоляції може використовуватися відеокомп'ютерна програма експресаналізу техніки єдиноборств «Katsumoto» [11] (далі - BKC «Katsumoto»).

BKC «Katsumoto» дає змогу ефективно проводити порівняльний аналіз технічних дій боротьби самбо на основі бази даних зразкової техніки. Крім того, зазначена прикладна програма визначає швидкість виконання технічних дій єдиноборства, прискорення, рух загального центру маси, окремих біоланок людини, радіус виконання технічних дій, і на основі отриманих даних будуються порівняльні грасріки. Крім того, завдяки програмному функціоналу ВКС «Katsumoto» можливим $€$ для спортсмена-єдиноборця в умовах самоізоляції на наступній серії виконання імітаційних прийомів

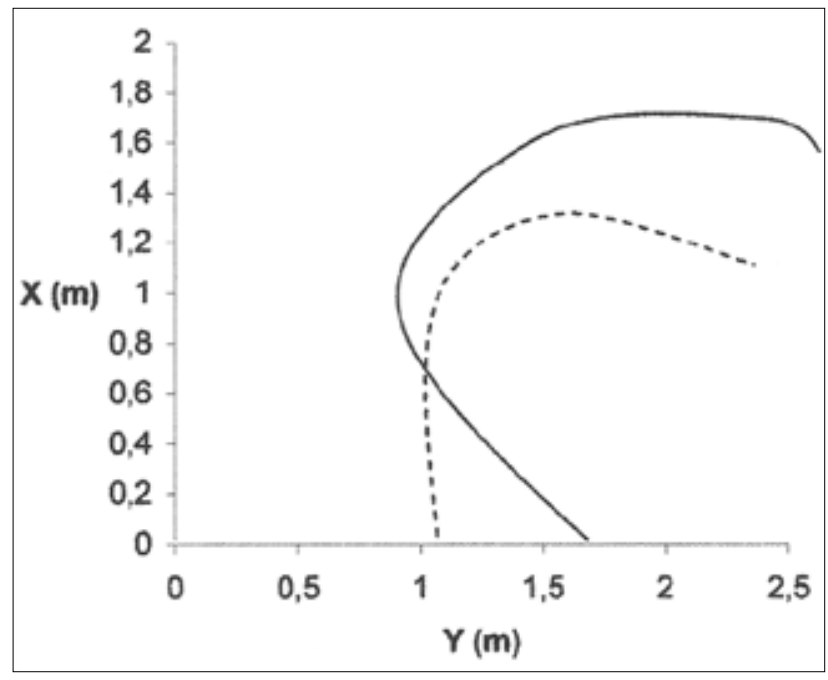

Рис. 1. Графік руху окремої біоланки (кисті) самбістів Ег ( ) та Кг (--) під час відпрацювання імітаційних технічних дій боротьби самбо (на прикладі кидка через спину)

і технічних дій боротьби самбо проводити якісну корекцію (в онлайн-режимі), що є актуальним для практичного застосування в умовах самоізоляції.

3 метою визначення ефективності запропонованого нами технічного засобу навчання, спрямованого на підтримання оптимальної спортивної форми спортсменами-самбістами високої кваліфікації в умовах самоізоляції, було проведено педагогічний експеримент (березень - травень 2020 р.). У педагогічному експерименті взяли участь спортсмени високої кваліфікації, члени збірних команд областей України 3 боротьби самбо (n=22 ос.). Для визначення ефективності

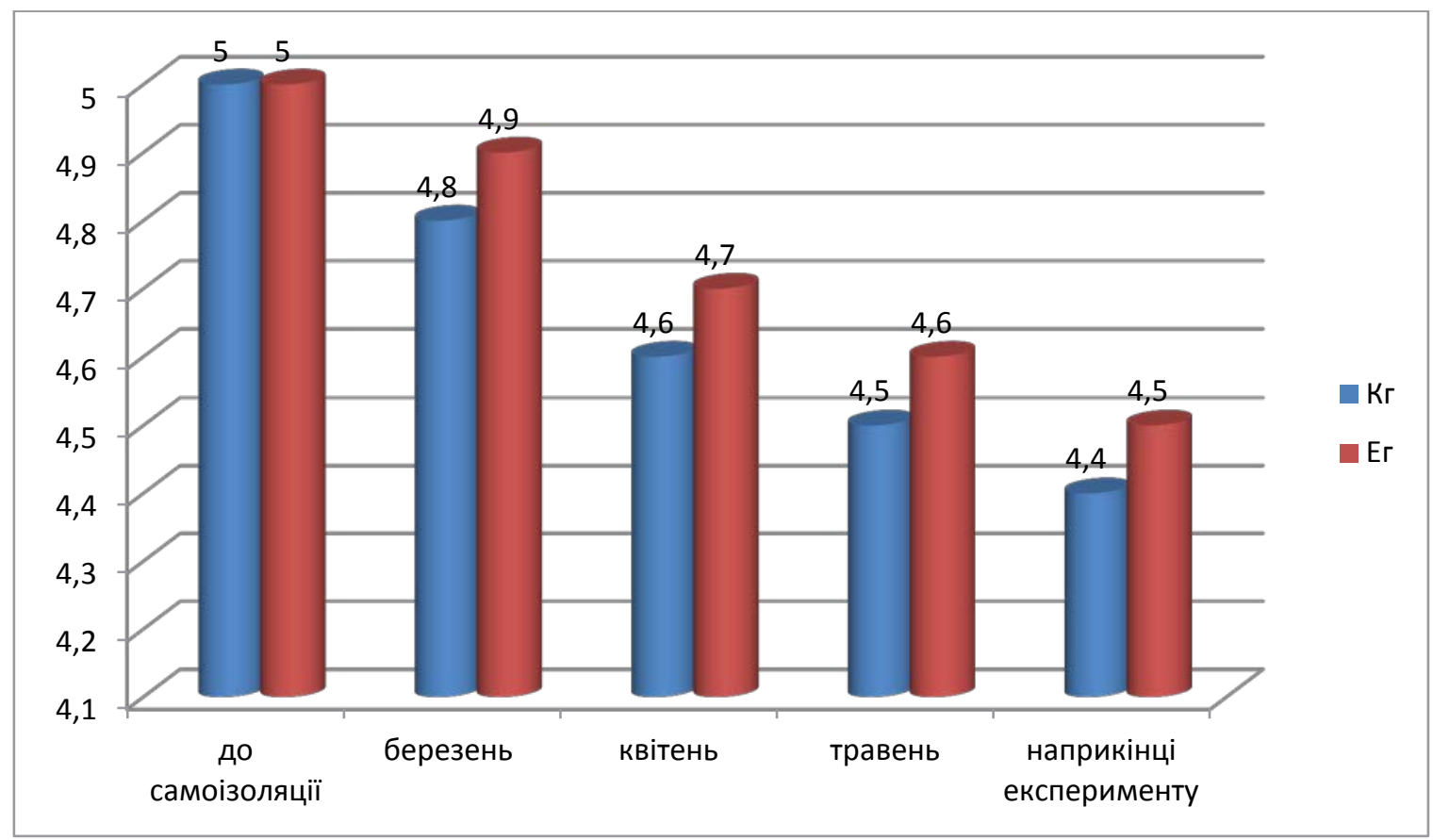

Рис. 2. Результати аналізу рівня технічної підготовленості досліджуваних самбістів високої кваліфікації упродовж педагогічного експерименту (березень-травень 2020 р.) 
запропонованої нами технології було визначено експериментальну групу Ег (n=11 ос., спортсменисамбісти Національної академії сухопутних військ імені гетьмана Петра Сагайдачного) та контрольну групу Кг (n=11 ос., спортсмени-самбісти комунального закладу вищої освіти «Вінницький гуманітарно-педагогічний коледж»).

Представники Кг під час індивідуальних тренувань із боротьби самбо в умовах самоізоляції 3 метою підтримання належного технічного рівня зазначеного єдиноборства використовували розроблені нами плани індивідуального рухового вдосконалення, які передбачали використання інтернет-ресурсів спеціального спрямування, а також методично-аналітичний підхід для його оцінювання (К.В. Ананченко, О.В. Хацаюк [12]).

У свою чергу, досліджувані Ег під час тренувань в умовах самоізоляції додатково використовували ВКС «Katsumoto». Особливість застосування цієї технології під час індивідуальних тренувань у зазначених умовах полягала в тому, що під час відпрацювання біомеханічних рухів спеціальної спрямованості проводилася відеозйомка 3 використанням відеокамери. Отримана інфрормація оброблялася ВКС «Katsumoto». Надалі в режимі реального часу видавалися графріки (рис. 1) та розкадрування технічних дій, які відпрацьовуються.

Надалі відповідно до графічного та візуального аналізу отриманих даних проводилася мобільна корекція біомеханічних рухів, що, у свою чергу, дало змогу тренерам у режимі онлайн із використанням мережі Інтернет уже на наступній серії відпрацювання рухових завдань вносити індивідуальні корективи у програму рухового вдосконалення тих спортсменів-самбістів, що тренуються. Варто також зауважити, що кінцева фраза відпрацювання технічний дій боротьби самбо передбачала виконання імітаційних дії у положенні лежачи (імітація больових прийомів на руки, ноги, утримання) та комбіноване силове тренування 3 використанням засобів кросфріту. Крім того, відпрацювання імітаційних дій проводилося у різні сторони, у такий спосіб було ліквідовано асиметрію досліджуваних самбістів Ег.

Запропонована нами експериментальна модель використовувалася 5 разів на тиждень упродовж зазначеного вище періоду самоізоляції (час відпрацювання тренувального завдання 50-60 хв), що, у свою чергу, привело до створення кумулятивного ефекту, наслідком чого у представників Ег було помічено більш сталі показники збереження «еталонного рівня» технічної підготовленості в обраному виді єдиноборства, на відміну від самбістів КГ, і ці відмінності переважно достовірні (Ег $\mathrm{P}<0,05$; результати аналізу рівня технічної підготовленості досліджуваних самбістів високої кваліфікації наведено на рис. 2).
Визначення рівня технічної підготовленості самбістів високої кваліфрікації Ег та Кг здійснено за допомогою методу експертної оцінки. До складу експертної групи було включено фрахівців боротьби самбо. Оцінювання рівня технічної майстерності досліджуваних атлетів здійснювалося за 5-ти бальною системою оцінювання (де 5 - максимальний бал, а 1 - мінімальний).

Висновки. Відповідно до завдань дослідження нами проведено аналіз науково-методичної та спеціальної літератури у напрямі підтримання належного рівня професійної компетентності спортсменів високої кваліфікації у різних видах спорту в умовах самоізоляції. Крім того, здійснено огляд наявних технічних засобів навчання, які можливо використовувати у напрямі індивідуального технічного вдосконалення атлетів-єдиноборців (самбістів) в обраному виді спорту в умовах самоізоляції.

У результаті дослідження нами помічено позитивний вплив використання сучасних технічних засобів навчання, спрямованих на підтримання оптимальноїспортивноїформиспортсменами-самбістами високої кваліфрікації в умовах самоізоляції.

Отже, мети роботи досягнуто, а поставлені перед нами завдання - виконано. Результати дослідження впроваджено у тренувальний процес самбістів високої кваліфікації Київського фракультету Національної академії Національної гвардії України. Перспективи подальших досліджень передбачають розроблення змістово-функціональної моделі підтримання необхідного рівня фрізичного розвитку самбістів високої кваліфрікації в умовах самоізоляції.

\section{БІБЛІОГРАФІЧНИЙ СПИСОК:}

1. Козерук К.В. Пліометричні вправи в процесі неформального навчання в умовах сьогодення. Інноваційний розвиток вищої освіти: глобальний, європейський та національний виміри змін. 2020. T. 1. C. $113-115$.

2. Никисророва О.А. Реалізація дистанційного навчання в закладах освіти системи MBC. Cmpameгічні напрями розвитку науки: фрактори впливу та взаємодіï. 2020. № 1. С. 83-84.

3. Носова Т.В., Аврунін О.Г. Сучасний погляд на можливості технології панорамного відео для інклюзивної освіти. Стан, досягнення і перспективи інфрормаційних систем і технологій. 2020. № 20. C. 4-146.

4. Петренко С.В. Сутність та особливості українських платформ масових відкритих онлайн-курсів (МBOK). 2020. URL: https://ojs.itup.com.ua/index.php/ iiu/article/view/260.

5. Правдов М.А., Шутов А.Н., Правдов Д.М. Готовность педагогов фракультетов фризической культуры к обучению студентов в условиях коронавирусной пандемии. Физическое воспитание в условиях современного образовательного процесса. 2020. № 1. С. $132-138$.

6. Чиханцева О.А. Самоізоляція та якість життя особистості. Розвиток обдарованої особистості 
в освітньому просторі: ціннісний вимір. 2020. № 10. C. 89-90.

7. Щадилова И.С. Организация коммуникативных связей в ВУЗЕ по дисциплине «Физическая культура» в условиях режима социальной самоизоляции. Ученые записки университета имени П.Ф. Лесгафтma. 2020. № 4 (182). С. 522-527.

8. Яблонских А.М. Анализ средств и методов контроля и дистанционной подготовки спортсменовориентировщиков в период самоизоляции. Ученые записки университета имени П.Ф. Лесгафтта. 2020. № 4 (182). C. 535-541.

9. Лещеня С.В., Забродський С.С., Хацаюк О.В. Нові форми спортивно-масової роботи військовослужбовців НГУ та членів їхніх сімей в умовах пандемії. Шляхи збереження працездатності військо- вослужбовців та працівників МВС України в умовах всесвітньої пандемії». 2020. № 1. С. 47-51.

10.Лещеня С.В., Мелешко А.О., Забродський С.С. Положення про проведення змагань (онлайн) Національної гвардії України «Гвардійський комплекс». ГУНГУ (Відділ фрізичної підготовки і спорту). 2020. $10 \mathrm{c}$.

11.Бизин В.П., Миргород Д.А., Хацаюк А.В. Технические средства обучения двигательным действиям : научное пособие. Берлин (Германия) : Lambert Academic Publishing, 2014. C. 36-42.

12. Ананченко К.В., Хацаюк О.В. Новий методичний підхід для оцінки відеоматеріалу, що використовується при підготовці дзюдоїстів. Слобожанський науково-спортивний вісник. 2016. №4 (54). C. 11-16. 


\title{
ПІДГОТОВКА МАЙБУТНІХ ВИХОВАТЕЛІВ ДО ПРОЦЕСУ ФІЗИЧНОГО ВИХОВАННЯ ДОШКІЛЬНИКІВ ЗАСОБАМИ ІНФОРМАЦІЙНО-КОМУНІКАЦІЙНИХ ТЕХНОЛОГІЙ
}

\author{
PREPARATION OF FUTURE EDUCATORS FOR THE PROCESS \\ OF PHYSICAL EDUCATION OF PRESCHOOL CHILDREN BY MEANS \\ OF INFORMATION AND COMMUNICATION TECHNOLOGIES
}

у статmі розглянуто питання підготовки майбутніх вихователів закладів дошкільноі освіти до застосування інорормаційно-комунікаційних технологій із фрізичного виховання дошкільників. Визначено компоненти системи підготовки майбутніх вихователів у навчальному процесі. Значні перетворення в сучасній освіті акцентують увагу на забезпеченні збереження здоров'я як необхідного компонента реалізації особистого, профресійного плану майбутніх педагогів. Застосування комунікаційних технологій у навчанні дітей дошкільного віку - одна 3 порівняно нових і найбільш активно обговорюваних тем у педагогічному співтоваристві. Стаття присвячена особливо слабо вивченій проблемі використання інфоормаційно-комунікаційних технологій у фрізичному вихованні дітей дошкільного віку. Зазначено, що вирішальне значення для вдосконалення якості освіти дошкільників у галузі фрізичної культури має професійна готовність фрахівців, які організовують їхню рухову діяльність. Ці обов'язки покладаються на інструктора з фрізичної культури дошкільного навчального закладу, діяльність якого вимагає індивідуального підходу до кожної дитини з ураху ванням віку, стану здоров'я, особливостей психофрізичного розвитку, а також рівня фрізичної підготовленості.

Зроблено висновок, що пошук ефективних шляхів зміцнення здоров'я дітей дошкільного віку засобами фрізичної культури гальмується існуючою в Україні системою професійної підготовки фрахівців до фрізичного виховання дітей дошкільного віку, яка має значні недоліки, що ускладнюють вирішення проблем освіти дошкільників у галузі фрізичної культури. Аналіз базових понять засвідчить, що в науковій літературі поняття «просресійна підготовка майбутніх фрахівців фрізичного виховання та спорту» визначається як: процес, який характеризує засади діяльності вищих навчальних закладів країни щодо надання особистості такого рівня профресіоналізму, завдяки якому вона стане конкурентоспроможною на ринку праці, буде самостійно організовувати орізичне виховання різних верств населення регіону й успішно працювати в усіх ланках спортивного руху. Мета - доведення обгрунтованості і продуктивності впровадження комунікаційних технологій навчальних здоро'язберігаючих $і$ оздоровчих програм в освітній процес дошкільних закладів. До уваги пропонуються теоретичні матеріали про інформаційно-комунікаційні технологі в дошкільній освіті. Дані технології мають очевидні педагогічні, методичні й економічні переваги порівняно із традииійними срормами виховно-освітньої роботи. Однак їх освоєння вимагає реорганізації як сорормованої системи занять, так і режиму закладу дошкільної освіти загалом. Описано фрормування в дітей навичок збереження здоров'я i уявлень про здоровий спосіб життя.
Стаття орієнтована на вихователів і студентів педагогічних вишів та інститутів фрізичної культури, методистів і фрахівців. Ключові слова: дошкільники, фрізичне виховання, інсрормаційно-комунікаційні технології, мультимедійні засоби, якість вищої освіти, здоровий спосіб життя, спорт, якість дошкільної освіти.

The article considers the issue of preparation of future educators of preschool institutions for the use of information and communication technologies in physical education of preschoolers. The components of the system of training future educators in the educational process are determined. Leading significant changes in modern education, they require the need to ensure health as a necessary component of the implementation of personal, professional plan of future teachers. The use of communication technologies in the education of preschool children is one of the relatively new and most actively discussed topics in the pedagogical community. The article is devoted to a particularly poorly studied problem of using information and communication technologies in physical education of preschool children. It is noted that the professional readiness of specialists who organize their physical activity is crucial for improving the quality of education of preschoolers in the field of physical culture. These responsibilities are assigned to the instructor of physical culture of the preschool educational institution, whose activity requires an individual approach to each child, taking into account age, health status, features of psychophysical development, as well as the level of physical fitness.

It is concluded that the search for effective ways to improve the health of preschool children by means of physical culture is hampered by the existing system of vocational training in Ukraine for physical education of preschool children, which has significant shortcomings that complicate the solution of preschool education in physical education. The analysis of basic concepts will show that in the scientific literature the concept of "training of future specialists in physical education and sports" is defined as: a process that characterizes the principles of higher education institutions to provide a person with a level of professionalism that will make him competitive in the labor market. Independently organize physical education of various segments of the population of the region and successfully work in all parts of the sports movement. The purpose of proving the validity and productivity of the introduction of communication technologies of educational health and health programs in the educational process of preschool institutions. Theoretical materials on information and communication technologies in the preschoo education are offered for attention. These technologies have obvious pedagogical, methodological and economic advantages over tradi- 
tional forms of educational work. However, their development requires the reorganization of both the existing system of classes and the whole regime of the preschool institutions as a whole. The formation of children's health skills and ideas about a healthy lifestyle is described. The article is aimed at educators and students of pedagogical universities and institutes of physical culture, methodologists and specialists. Key words: preschoolers, Physical Education, information and communication technologies, multimedia means, quality of higher education, healthy lifestyle, sports, quality of preschool education.
Постановка проблеми в загальному вигляді зумовлена потребою сучасного суспільства та національної системи освіти України в підготовці педагогів, здатних виховувати здорових, витривалих, вправних, життєздатних людей. 3 огляду на те, що здоров'я громадян $€$ складовою частиною соціально-економічного зростання, безпеки та розвитку держави, дослідження спрямоване на вивчення педагогічних умов підготовки майбутніх вихователів до орізичного виховання засобами інорормаційно-комунікаційних технологій (далі IKT). На обґрунтуванні педагогічних умов підготовки майбутніх вихователів наголошується в Конституції України та законах «Про вищу освіту», «Про освіту», «Про дошкільну освіту», у Базовому компоненті дошкільної освіти України. Зазначені нормативні документи підкреслюють важливість забезпечення створення педагогічних умов підготовки майбутніх вихователів до фрізичного виховання засобами інфрормаційно-комунікаційних технологій.

Сучасний педагог повинен володіти знаннями методик роботи з дітьми, знати психологічні особливості вихованців, мати сорормовані педагогічні вміння та здібності для забезпечення гармонійного розвитку дитини дошкільного віку

Багато хто 3 вихователів творчо підходять до організації занять із фрізичної культури, вигадують цікаві фрорми їхпроведення, зміст, методи іприйоми, цим самим забезпечують фрормування міцного, стійкого інтересу до фрізкультури в дітей, потреби займатися нею. Обґрунтування й упровадження у практику доцільних методів і прийомів фрормування рухів, розвиток фрізичних якостей у дітей - найважливіше завдання фрізичного виховання. Необхідно розвивати фрізичну культуру дошкільника, передбачати насамперед фрормування ставлення до рухово-активної діяльності, інтересу та потреби у фрізичному самовдосконаленні, отримання задоволення від ігор, вправ, занять.

Аналіз останніх досліджень і публікацій. Дослідники О. Ільїн, Н. Денисенко й інші зазначали, що на процес фрізичного виховання дітей впливають емоційні переживання дитини. О. Ільїн обґрунтував ефективні шляхи фрормування емоційної сфери дошкільника у процесі фрізичного виховання, виявив роль деяких складних моральних почуттів і вольових рис характеру та визначив раціональні методи їх виховання в дитини у процесі занять фрізкультурно-оздоровчою діяльністю. На думку автора, повнота і глибина фрормування позитивних емоцій, почуттів і морально-вольо- вих якостей дітей молодшого дошкільного віку перебувають у прямій залежності від конкретних умов організації навчально-виховного процесу та створення відповідного оздоровчого середовища в сім’ї. Він відзначив, що за умов умілої, методично правильної організації виховання в дітей створюються оптимальні емоційні стани, що сприяють засвоєнню ними відповідних знань, позитивно впливають на процес формування рухових навичок. I навпаки, астенічні емоції демобілізують вольові зусилля дітей, знижують їхню рухову активність, гальмують процес фрормування правильних рухових навичок. Учений стверджує, що найефективнішим засобом фрормування емоційної сорери дошкільників у процесі фрізичного виховання $€$ змагальний метод проведення занять, який сприятливо впливає на швидкість рухових реакцій, зростання м'язової сили, покращення координації рухів, підвищення здатності до сприйняття і відтворення рухів та фрормування рухових навичок. Автор звернув увагу й на те, що головна роль у створенні оптимальних емоційних станів дітей засобами фрізичної культури належить батькам, їхнім особистісним якостям, педагогічній майстерності та досвіду.

Н. Денисенко показала значущість задоволеності від занять фрізичною культурою як одного із чинників педагогічного управління діяльністю дитини та підвищення еорективності процесу фрізичного виховання. Вона розглядає задоволення від занять фрізичною культурою як складне багатокомпонентне емоційне утворення, що включає окремі види задоволеності основними сторонами фрізкультурно-оздоровчої діяльності (умови, зміст занять, спортивні результати, взаємини 3 батьками). Н. Денисенко зазначала, що фрормування такого задоволення істотно впливає на процес фрізичного виховання дітей у сім'ї [2, с. 23-27].

Науковець Е. Вільчковський, який досліджував проблему розвитку фрізичних якостей (швидкість, спритність, сила й ін.), уважає, що формування рухових дій - важлива сторона педагогічного процесу на заняттях із фрізичної культури, де в єднанні формуються рухові навички та розвиваються фрізичні якості дітей різних вікових груп [1, с. 52].

М. Маконєва, Н. Хоменко й інші під час дослідження мотивів занять фрізичною культурою дітей молодшого шкільного віку вивчали умови становлення мотивів як самостійних чинників, здатних впливати на діяльність дітей та їхнє ставлення до занять фрізичною культурою. М. Маконєва визна- 
чила головні та другорядні чинники, що викликають мотиви, які безпосередньо спонукають дітей займатися фрізичною культурою (прямі мотиви), і ті, що впливають опосередковано (непрямі мотиви). Прямими мотивами є: зміцнення здоров'я, розвиток фрізичних якостей, прагнення стати чемпіоном, сорормувати певні рухові навички, бути схожим на батьків, старших товаришів, на відомих спортсменів. Серед чинників, що впливають на становлення непрямих мотивів, він виділив такі: поради й особистий приклад батьків, друзів, звичка виконувати фрізичні вправи, вплив навчального закладу, вихователя, інструктора з фрізичного виховання, різних форм пропаганди. Автор також зазанчила, що в сім'ї найбільший вплив на прояв прагнення дітей до фрізичної активності спричиняє приклад батьків, їхня увага до успіхів дітей, створення умов для домашніх занять фрізичними вправами. Осмислення накопиченого досвіду фрізкультурнооздоровчої роботи з дітьми дає підстави стверджувати, що немалу роль у розв'язанні цих завдань відіграє характер ставлення батьків до занять фрізичною культурою. Адже місце фрізичної культури і спорту в бюджеті вільного часу сім'ї визначається передусім ставленням до цього людей [4, с. 188]. Це ставлення регулюється ціннісними орієнтаціями, має двоякий характер.

Вербальне ставлення, щопритаманне більшості людей, не відповідає реальному, тобто такому, яке виражалося б в активній фрізкультурно-оздоровчий діяльності. Звідси необхідність фрормування такого рівня ставлення, яке виражалося б в активних заняттях фрізичною культурою. Знання сутності фрізичного виховання дітей - одна 3 необхідних педагогічних умов наукового вирішення проблеми фрізичного виховання дітей молодшого дошкільного віку в сім'ї, як стверджує Е. Вільчковський.

Виділення не вирішених раніше частин загальної проблеми. Завдання фрізичного виховання дітей у сім'ї надзвичайно важливі і вимагають конкретного їх вирішення з боку батьків та близьких людей, які оточують дітей. Батьки повинні чітко уявляти собі завдання фрізичного виховання дітей, щоб здійснювати цей процес цілеспрямовано. Чітко визначені завдання можуть служити критеріями перевірки ефективності виховної системи, яка застосовується в сім'ї. Фізичне виховання дітей у сім'ї повинно вирішувати такі завдання:

- збереження і зміцнення здоров'я дітей. Це завдання $€$ найважливішим у фрізичному вихованні дітей. Виростити дітей здоровими, життєздатними - це людський і громадський обов'язок батьків. Це завдання вирішується всією системою фрізичного виховання, яка використовується в сім'ї, усім укладом життя сім'ї;

- підвищення працездатності дитячого організму. Це завдання може бути вирішене за умови, якщо дитина здорова. Але здоров'я - не єдина умова високої працездатності. Навіть у здорових дітей інколи спостерігається низька працездатність певних м'язів і систем організму, якщо вони недостатньо треновані. Отже, важливою умовою високої працездатності організму є його тренованість;

- загартування організму. Це завдання включає в себе чотири елементи: формування адаптивних механізмів до холоду (до низьких температур), до різких змін температури навколишнього середовища, до спеки (до високої температури), протистояння організму різноманітним вірусним інфекціям. Загартування організму здійснюється не тільки спеціальними засобами, але і всіє системою фрізичного виховання і сімейного побуту;

- усебічний фрізичний розвиток дітей. Це загальне завдання вирішується всім комплексом фрізичного виховання, це його результат, критерій якості й ефективності всієї системи фрізичного виховання дітей;

- якісне опанування дітьми основних рухів. Це завдання вирішується в навчальному закладі й у сім'ї шляхом застосування різних фрізичних вправ, які забезпечують набуття життєво необхідних прикладних навичок із ходьби, бігу, стрибків, метання, кидання, ловіння, повзання, лазіння, вправ із рівноваги, плавання тощо. Ці завдання вирішуються шляхом цілеспрямованого фрормування й удосконалення рухових навичок у процесі фрізичного виховання;

- розвиток у дітей стійких і життєво необхідних рухових якостей: сили, швидкості, гнучкості, спритності, витривалості, координації рухів. Ці завдання вирішуються шляхом виконання спеціальних фрізичних вправ, дій у побуті та суспільній праці, їхньої систематичності, поступового збільшення навантажень і темпу виконання. Виховання рухових якостей поєднується з вихованням маральних якостей. Обидва ці аспекти повинні об'єднуватись у єдиний виховний процес, оскільки рухові і моральні якості тісно пов'язані, хоча не тотожні одне одному. Рухові якості легше сорормувати, ніж моральні;

- озброєння дітей теоретичними відомостями 3 питань фрізичної культури (гігієна, сон, харчування, загартування, валеологічні знання). Це завдання вирішується шляхом поєднання теоретичних і практичних фрорм виховання;

- виховання в дітей стійкого інтересу до постійних занять фрізичними вправами. Це завдання вирішується правильно побудованим систематичним фрізичним вихованням;

- формування навичок до самостійних занять;

- формування в батьків навичок і умінь з організації і проведення занять із дітьми: проведення бесіди, постановка завдань, показ і пояснення вправ, проведення ігор тощо;

- усунення і реабілітація вроджених і набутих недоліків фрізичного розвитку і каліцтв: плоскостопості, порушення постави, ДЦП тощо. 
Вирішення завдань фрізичного виховання в комплексі та кожного з них зокрема треба розглядати як внесок у фрормування особистості, яка поєднує в собі моральну чистоту, духовне багатство і фрізичне вдосконалення, у майбутній добробут як окремо взятої особистості, так і всієї держави.

Мета статті - теоретично обґрунтувати процес створення й організації педагогічних умов підготовки майбутніх вихователів до фрізичного виховання засобами інформаційно-комунікаційних технологій.

Безумовно, стан здоров'я дитини є основою іiі успіху в будь-якій діяльності, оскільки повноцінний фізичний розвиток забезпечує загальну високу працездатність організму. Рухова діяльність сприяє розвитку системи аналізаторів, активізує роботу органів чуття, прискорює розвиток мовлення, допомагає формуванню розумових дій. Дитина пізнає навколишній світ, у неї розвиваються просторові уявлення, збагачується кругозір. Крім цього, заняття фрізичною культурою і спортом розвивають її волю, активізують емоційну сореру.

Раціональна організація фрізичного виховання дітей сприяє фрормуванню в них інтересу до рухової активності, а також до певних видів фрізичних вправ. Виховання інтересу до рухів здійснюється на основі життєвої потреби дитини бути сміливою, сильною, спритною. Засвоюючи правила гігієни, дитина набуває навичок культури поведінки, а організація фрізкультурних занять 3 яскравою наочністю, іграшками, у належному одязі сприяє розвитку естетичних почуттів.

Належна рухова діяльність у процесі фрізичного виховання забезпечує підготовку дитини до трудової діяльності. У процесі проведення фрізкультурних заняттях, під час ранкової гімнастики відбувається виховання дисциплінованості, фрормується прагнення досягти успіху, розвивається наполегливість. Успішна рухова діяльність у колективі однолітків, позитивна оцінка зусиль дитини дорослими, самоаналіз якості виконання вправ, радість співучасті в рухливих іграх - усе це сприяє розвитку емоційно-почуттєвої сорери.

Здорова, фрізично розвинена дитина зазвичай вірить у свої сили, бадьора, життєрадісна, більш повноцінноопановуєпринципишляхетноїповедінки у взаємодії з однолітками і дорослими, дбає про гармонійність свого буття, уважна до інших людей [3] .

Отже, вивчення й узагальнення історико-педагогічних аспектів проблеми фрізичного виховання дітей доводить, щодошкільнийвік-найбільш відповідальний етап розвитку організму та найважливіший у становленні особистості. У цей період закладаються основи здоров'я, повноцінного фрізичного розвитку, фрізичної підготовленості, відбувається стабілізація біологічних передумов особистісного розвитку, фрормування психічних процесів.
Підготовка студентів педагогічних вишів до реалізації дошкільної комп'ютеризації була висвітлена в дослідженні російської вченої М. Гандери. Автор зазначає, що сучасний вихователь закладу дошкільної освіти (далі - ЗДО) повинен знати основи дошкільної комп'ютеризації як бази для психологічної готовності дітей до наступної діяльності 3 комп'ютерною технікою у ЗДО, повинен використовувати комп'ютер як засіб виховання і розвитку творчих здібностей дитини, формування ії̈ особистості. Учена дослідила підготовку студентів 3ВО до реалізації дошкільної комп'ютеризації; обґрунтувала модель професійно-педагогічної діяльності педагога природно-математичних предметів щодо реалізації дошкільної комп'ютеризації; визначила організаційні фрорми, методи і засоби фрормування у студентів професійно-педагогічних видів діяльності в підготовці до дошкільної комп'ютеризації [5].

Навчання студентів педагогічного фракультету використанню нових інфрормаційних технологій буде успішнішим, якщо: навчання буде прийнято студентами як мета і критерій ефрективності майбутньої професійної діяльності; процес підготовки планомірно переходитиме від низького до більш високого рівнів відповідно до логіки становлення професійної готовності; у процесі профресійної підготовки буде створена система педагогічних умов, що сприяють ефективному фрормуванню готовності: структура і зміст курсу спеціалізації, технологія і методи навчання адекватно відбиватимуть специоріку майбутньої педагогічної діяльності, зумовлену використанням нових інформаційних технологій. Комп'ютер можна застосувати в педагогічному процесі: у системі управління педагогічним процесом; системі безпосереднього навчання за допомогою комп'ютера; для індивідуальної самостійної роботи; під час організації технічної творчості, для моделювання створюваних об'єктів; для обслуговування пошуку додаткової інформації; для діагностики розвитку тих, хто навчається.

Узагальнення досліджень вітчизняних і закордонних учених щодо використання комп'ютерних технологій у навчальному процесі дозволили сорормулювати кілька вимог, яких потрібно дотримуватись, як-от: системність у застосуванні комп'ютера; об'єктивність оцінювання результатів; оперативність у застосуванні; диореренціація навчальних траєкторій. Наявні на ринку сучасні комп'ютерні програми підтримки навчально-виховного процесу в закладі дошкільної освіти дозволяють вирішувати кілька проблем: використовувати комп'ютерні технології в роботі з дітьми та в управлінні закладом дошкільної освіти.

Підсумовуючи досвід упровадження комп'ютерних технологій у закладах дошкільної освіти, зазначимо, що комп'ютерні засоби можна вважати ефективним способом передання знань, який відповідає якісно новому змісту навчання і розвитку дитини. 
Інтереси дітей бувають різними. Це й прагнення зміцнити здоров'я, сорормувати поставу, ще й бажання розвинути рухові та вольові якості. 3 урахуванням конкретних причин прояву дошкільнятами інтересу до фрізичної культури керівник фрізичного виховання повинен будувати свою роботу 3 агітації та пропаганди фрізичної культури, з формування інтересу до фрізкультури, незалежно від прохідного матеріалу. Однак додатково виявляють і диференційований інтерес до різного програмного матеріалу (хлопчики віддають перевагу спортивним іграм, а дівчатка - руховим). Від правильної постановки цілей залежить підтримування, а часом і фрормування інтересу та цілеспрямованості дошкільнят у сорері фрізичної культури. Підтримування інтересу та цілеспрямованості дошкільнят багато в чому залежить від того, чи відчувають вони задоволення від занять фрізичною культурою .

Дошкільний вік - це час активного фрормування організму дитини. Постійне використання тільки класичної структури часто веде до зниження інтересу дітей до зайнять і, як наслідок, до зниження їхньої результативності. Тому необхідно використовувати інформаційно-комунікаційні технології до побудови та змісту занять, що дозволяють постійно підтримувати інтерес дітей, індивідуалізувати підхід до кожної дитини, розумно розподіляти навантаження, ураховуючи рівень рухової активності й напіврольовий принцип підбору рухів.

Тому в дошкільних навчальних закладах 3'явилася необхідність використовувати інформаційно-комунікаційні технології під час занять із фрізичного виховання. Оздоровчий ефект, який досягається за допомогою використання IKT, тісно пов'язаний із позитивними емоціями дітей, благотворно впливає на психіку дитини.

Під час вибору таких методів педагогу необхідно враховувати завдання, зміст, місце й умови проведення заняття, фрізичну підготовленість дітей, ступінь володіння певними видами рухів, індивідуальні особливості й інтерес дітей.

Висновки. Отже, можна стверджувати, що соціальне замовлення суспільства на педагога дошкільного навчального закладу потребує нових підходів до підготовки висококваліфікованих педагогічних кадрів, у зв'язку із цим проблема підготовки таких фрахівців для роботи з дітьми дошкільного віку, які володіють уміннями використовувати інорормаційно-комунікаційні технології під час занять із фрізичного виховання, нині особливо актуальна. Можна зробити висновок, що використання інтерактивно-комунікаційних технологій під час фрізкультурних зайнять допомагає педагогу розвинути в дітей інтерес до фрізкультури, підвищити рухову активність дітей і моторну щільність занять. Так само фрізкультурні заняття виконують пізнавальну функцію, діти дізнаються про різні техніки та цікаві види спортивних занять, що надалі веде до залучення дітей до спорту й здоров'я.

\section{БІБЛІОГРАФІЧНИЙ СПИСОК:}

1. Вільчковський Е., Денисенко Н. Організація рухового режиму дітей у дошкільних навчальних закладах. Тернопіль, 2008. 126 с.

2. Денисенко Н. Структурно-фрункціональне управління процесом фрізичного виховання дітей у дитячих садках. Палітра педагога. 2011. № 3. C. 23-27.

3. Калуська Л. Спосіб життя - здоровий у родині й у дитсадку: напрями роботи з батьками 3 валеологічного виховання. Дошкільне виховання. 2006. № 1. $198 \mathrm{C}$.

4. Маханева М. Здоровый ребенок: рекомендации по работе в детском саду и начальной школе. Москва : АРКТИ, 2004. 263 с.

5. Гандера М. Создание и использование мультимедийных презентаций на занятиях по ознакомлению с окружающим с детьми старшей группы детского сада. URL: https://openedu.kubg.edu.ua/ journal/index.php/openedu/article/view/297 (дата звернення: 06.06.2020). 
ДИСТАНЦІЙНЕ НАВЧАННЯ ПЕДАГОГІЧНИХ ПРАЦІВНИКІВ ЗАКЛАДІВ ДОШКІЛЬНОЇ ОСВІТИ

\section{DISTANCE TRAINING OF PEDAGOGICAL EMPLOYEES OF PRESCHOOL EDUCATION INSTITUTIONS}

\begin{abstract}
У cmammi зазначено, що період пандемії $\epsilon$ новим етапом змін та можливостей у системі післядипломної освіти дошкільних фахівців, який потребує надання освітніх послуг дистанційно, шляхом застосування сучасних інформаційно-комунікаційних технологій. Зазначено, що необхідною умовою ефективної діяльності педагогічних працівників закладів дошкільної освіти постає розвиток його ІК-компетентності. Констатовано, що за важливості сучасних досліджень проблема розвитку ІК-компетентності кваліфрікованих педагогів закладів дошкільної освіти засобами Інтернет-простору потребує нових підходів до ії системати зації та теоретичного узагальнення. Особливої уваги потребує дослідження розвитку ІК-компетентності педагогів закладу дошкільної освіти з використанням сучасних платформ дистанційного навчання в системі післядипломної освіти.
\end{abstract}

Проведено аналітичний огляд функціональних можливостей сучасних систем дистанчійного навчання, а саме: Blackboard Inc.; Dokeos; ATutor; Cisco WebEx; Zoom; Microsoft Teams; Equity maps; EdEra;Prometheus; Moodle. Розглянуто їхні переваги й недоліки, надані рекомендації для їх вибору. Встановлено, що натепер кожна з розглянутих систем дистанційного навчання має свої переваги та недоліки, реалізує важливі для електронного навчання фрункції, але не всі забезпечують прочес дистанційного навчання в комплексі. Найголовнішими критеріями під час вибору інструментів для організації дистанційного навчання в системі післядипломної освіти мають бути відповідність поставленим методичним цілям, універсальність, зрозумілість інтерфейсу, доступність програмних засобів для різних пристроїв (персональні комп'ютери, планшети, мобільні пристрої Apple, Android тощо). Описано можливості використання систем дистанційного навчання як засобу організації навчання орахівців дошкільної освіти в післядипломній освіті. Обгрунтовано роль Навчально-наукового lнституту неперервної освіти Національного педагогічного університету імені М. П. Драгоманова в удосконаленні змісту й спроектуванні дистанційної системи Moodle з урахуванням досягнень сучасної педагогіки, з акцентом на взаємодію між педагогічними працівни ками (http://www.do.ippk.npu.edu.ua.).
Ключові слова: системи дистанційного навчання, ІК-компетентність, педагогічні працівники закладів дошкільної освіти.

The article states that the pandemic period is a new stage of changing and opportunities in the system of postgraduate education of preschool professionals, which requires the provision of educational services remotely, through the use of modern information and communication technologies. It is noted that a necessary condition for the effective operation of pedagogical employees of preschool education is the formation and development of its IR competence. It is stated that due to the importance of the modern research, the problem of development of IC competence of qualified teachers of preschool education by means of the Internet, requires new approaches of systematization and theoretical generalization. Particular attention needs to be paid to the study of the development of IC competence of preschool teachers using modern distance learning platforms in the system of postgraduate education. An analytical review of the functionality of modern distance learning systems, namely: Blackboard Inc .; Dokeos; ATutor; Cisco WebEx; Zoom; Microsoft Teams; Equity maps; EdEra, Prometheus; Moodle. It is established that today each of the considered distance learning systems has its advantages and disadvantages, realizing important functions for e-learning, but not all functions provides the process of the distance learning in the complex. The most important criteria of choosing tools for distance learning in the system of postgraduate education should be compliance with the set methodological objectives, versatility, clarity of the interface, availability of software for different devices (PCs, tablets, Apple mobile devices, Android, etc.). Their advantages and disadvantages are considered, recommendations for their choice are given. Possibilities of using distance learning systems as a means of organizing training of preschool education specialists in postgraduate education are described. The role of the Educational and Scientific Institute of Continuing Education of the National Pedagogical University M.P. Drahomanov in improving the content and design of the remote Moodle system, taking into account the achievements of modern pedagogy with emphasis on interaction between teachers. Key words: distance learning systems, IC competence, pedagogical employees of preschool education institutions.
Національного педагогічного університету імені М.П. Драгоманова
Постановка проблеми у загальному вигляді. У зв'язку з пандемією COVID-19, під час кризи, особлива увага спрямована на задоволення освітніх потреб педагогічних працівників закладів дошкільної освіти. Через це в умовах карантинних обмежень запропоновано багато рішень щодо розвитку ІК-компетенцій кваліфрікованих педагогічних працівників закладів дошкільної освіти в системі неперервної освіти. Це одночасно виклик і новий етап змін та можливостей, який потребує надання освітніх послуг дистанційно, шляхом застосування сучасних інсрормаційно-комунікаційних технологій за певними освітніми рівнями згідно з Державними стандартами освіти.

Відповідно до ситуації, в якій сьогодні опинилася Україна, до педагогів закладів дошкільної освіти пред'являються нові вимоги. До нововведень відноситься: застосування новітніх ІКТ в освітньому процесі (розвиток мобільних технологій, поява освітніх віртуальних ігрових технологій, використання 
соціальних мереж, створення відкритого електронного контенту та ін.); своєчасне оновлення змісту освіти; створення, підтримка та удосконалення інорормаційно-освітнього середовища закладу дошкільної освіти або його окремих елементів.

У дійсності існують основні протиріччя, що полягають у невідповідності рівня професійнопедагогічної підготовленості сучасного педагога дошкільної освіти, його готовності до організації дистанційної освіти і застосування інфрормаційнокомунікаційних технологій в педагогічному процесі закладу дошкільної освіти та розвитку особистісного профресійного потенціалу і вимог, які пред'являються до нього в професійній діяльності відповідно до викликів сучасності.

Нині з упевненістю можна сказати, що необхідною умовою ефективної діяльності дошкільних педагогів постає орормування та розвиток їхньої ІК-компетентності. Водночас це інтенсифрікує та стимулює неперервну освіту фрахівців дошкільної освіти.

Аналіз останніх досліджень і публікацій 3 питань теорії і практики інформатизації освіти в сучасному науковому дискурсі свідчить про актуалізацію зазначеної проблеми. Загальні аспекти використання Інтернет-технологій у педагогічній освіті висвітлено в роботах А. Андрєєва, І. Зимньої, Г. Козлакової, С. Мушер, Е. Полат, А. Себрант, А. Семенова, Ю. Татур, В. Філіппова та інших. Важливе значення для нашого наукового пошуку мають результати досліджень 3 використання інорормаційних та комп'ютерних технологій у педагогічному процесі (Р. Вільямс, Б. Гершунський, В. Глушков, А. Єршов, К. Маклін, Ю. Машбиця, C. Пейперта, Є. Полат тощо); формування і розвитку особистості педагога в інформаційному суспільстві (В. Бондар, І. Зязюн, Н. Кузьміна, Н. Мойсеюк, Н. Ничкало, С. Сисоєва та ін).; з розвитку професійної компетентності у неперервній педагогічній освіті (С. Вершловський, Л. Даниленко, Г. Єльникова, Ю. Кулюткін, В. Маслов, Н. Ничкало, В. Олійник, В. Онушкін, В. Пікельна, Н. Протасова, Л. Пуховська, М. Романенко, В. Семиченко, Т. Сущенко, П. Худоминський, Т. Шамова та ін.).

Виділення невирішених раніше частин загальної проблеми. За важливості сучасних досліджень проблема розвитку ІК-компетентності кваліфрікованих педагогів закладів дошкільної освіти засобами Інтернет-простору потребує нових підходів до ії систематизації та теоретичного узагальнення. Особливої уваги потребує дослідження розвитку ІК-компетентності педагогів закладу дошкільної освіти з використанням зробленого аналізу сучасних платфрорм дистанційного навчання в системі післядипломної освіти.

Звідси метою статті стало вивчення та узагальнення платформ дистанційного навчання як інноваційних засобів, які сприяють розвитку
ІК-компетентності педагога закладу дошкільної освіти в системі післядипломної освіти.

Виклад основного матеріалу. Нові вимоги до фрахівців спонукають сучасного педагогічного працівника закладу дошкільної освіти адаптуватися до загальносвітових тенденцій розвитку IКT в освітній системі, які надають можливості в пошуку, відборі, обробці та зберіганні інфрормації, брати участь у створенні та впровадженні нового змісту освіти, нести відповідальність за результати своєї професійної діяльності.

Так, у Законі «Про основні засади розвитку інформаційного суспільства в Україні на 2007-2015 роки» виокремлено стратегічні цілі, a саме: «забезпечення комп'ютерної та інорормаційної грамотності населення, насамперед шляхом створення системи освіти, орієнтованої на використання новітніх IКТ у формуванні всебічно розвиненої особистості; створення загальнодержавних інформаційних систем». Стратегічним напрямом визначено: «надання кожній людині можливості для здобуття знань, умінь і навичок 3 використанням IKT під час навчання, виховання та професійної підготовки; створення умов для забезпечення комп'ютерної та інформаційної грамотності всіх верств населення, створення системи мотивацій щодо впровадження і використання IKT для фрормування широкого попиту на такі технології в усіх сорерах життя суспільства» [1].

Принагідно зазначимо, що особливу роль у вирішенні зазначених цілей відіграє дистанційне навчання як індивідуалізований процес набуття знань, умінь, навичок і способів пізнавальної діяльності людини, який відбувається в основному за опосередкованої взаємодії віддалених один від одного учасників навчального процесу в спеціалізованому середовищі, яке фрунціонує на базі сучасних психолого-педагогічних та інорормаційно-комунікаційних технологій [2].

Дистанційне навчання педагогічних працівників закладів дошкільної освіти має ряд переваг: звільняє від необхідності відвідувати освітній заклад у визначений розкладом час; дає можливість отримати освіту всім тим, хто велику частину дня зайнятий на роботі, 3 дітьми або із сім'єю; здобувати освіту паралельно з побудовою кар'єри; перебувати у відпустці по догляду за дитиною; отримувати знання, не виїжджаючи за межі своєї країни, області, міста; можливість отримати освіту особам, які мають медичні обмеження для отримання освіти за традиційними формами, особам з особливими потребами. Найбільш перспективним і цілеспрямовано організованим середовищем для розвитку ІК-компетентності педагогів закладів дошкільної освіти є система післядипломної педагогічної освіти.

Нам імпонує думка С. Семчук, згідно з якою інорорматизація освітнього процесу в закладі вищої освіти підвищує якість підготовки спеціа- 
ліста, підвищує їхній рівень самоорганізації і відповідальності, вдосконалює рівень комп'ютерної грамотності, надає можливість більш вільно орієнтуватися в сучасному житті загалом та у сорері професійної діяльності зокрема [3, с. 34].

Зауважимо, що в системі післядипломної освіти завжди була можливість використовувати дистанційне навчання, апробовувати освітні онлайн-ресурси, але завжди ці можливості використовувались лише частково. У нинішній ситуації відбуваєтьсязміщенняакцентівізтрадиційнихорорм навчання на дистанційні. Особлива роль при цьому належить платформам дистанційного навчання.

Поняття «платорорма дистанційного навчання» $€$ відносно новим терміном, метоюякогоєстворення та управління педагогічним змістом, індивідуалізоване навчання та телетьюторат. Воно включає засоби, необхідні для трьох основних користувачів - викладача, студента, адміністратора [4].

У розрізі нашого дослідження зацікавленість становлять платорорми для організації дистанційного навчання педагогічних працівників закладів дошкільної освіти, зокрема [5]:

- платформа Blackboard Inc. (www.blackboard. com), що забезпечує єдине інтерактивне середовище для навчання, взаємодії, обміну інорормацією між слухачами і викладачами закладів післядипломної освіти. Система Blackboard дозволяє здійснювати облік і контроль персональних критеріїв освітнього процесу, вводити нормативнодовідкову інформацію, накопичувати, структурувати, керувати доступом, поповнювати освітню базу, а також надавати засоби комунікації та інорормування учасників;

- Dokeos - платфрорма побудови сайтів дистанційного навчання, заснована на гілці (fork) Claroline (версії 1.4.2.). Система Dokeos має великий набір можливостей, а саме: вбудовані мультимедійні додатки для ілюстрації змісту зображеннями, анімацією, звуком і відео. Система має широкий спектр обліку і контролю успішності слухачів, можливість постійного оновлення і доповнення змісту курсів підвищення кваліфрікації. Важливою особливістю $є$ модульність - кожен модуль освітньої програми окремо можна редагувати, робити відкритим або прихованим, а також експортувати у вигляді SCORM. При цьому викладач має можливість поділу слухачів на малі групи. Використання різноманітних засобів (пошта, чат, форум, обмін фрайлами, відеоконференції) дозволяє комунікувати з викладачем та іншими слухачами;

- ATutor $€$ веб-орієнтованою системою керування навчанням слухачів курсів підвищення кваліфрікації (Learning Management System, LMS) у різноманітних форматах (Microsoft Word, PDF, DJVU). Цей проект дозволяє здійснювати тестування, проводити електронні конференції; управляти базами знань, у тому числі інтегруватися із зовнішніми інформаційними джерелами та оцінкою слухачів. У системи є ряд недоліків: відсутня підтримка української мови; система закрита для змін; для створення курсів необхідні навички програмування;

- Платформа для вебінарів Cisco WebEx - це хмарний сервіс для проведення будь-яких webконференцій, що дозволяє учасникам обмінюватися інфрормацією в будь-який момент часу 3 глобального хмарного середовища, в будь-якому місці, використовуючи комп'ютер або мобільні пристрої. Ця платорорма не дуже цікава для організації освітнього процесу в післядипломній освіті, але ми не змогли її не згадати.

- У цей складний період за лічені години система Zoom стала самою популярною платформою для проведення конфреренцій, зустрічей і вебінарів. На наш погляд, Zoom має ряд переваг. Так, слухачі можуть використовувати додаток як на комп'ютері, так і на планшеті чи смартфоні. До відеоконференції може підключитися за посиланням або ідентифікатором конореренції. Заняття можна запланувати заздалегідь, а також зробити посилання для постійних зустрічей у певний час. У платорорму вбудована інтерактивна дошка, яку можна демонструвати слухачам. Крім того, є можливість легко й швидко перемикатися 3 демонстрації екрана на інтерактивну дошку. Але під час карантину на сервіс Zoom були нарікання через низький рівень безпеки й захищеності, випадки підключення до конференцій сторонніх осіб;

- Microsoft Teams - платформа спільної роботи в Office 365 Education, що включає Word, Excel, PowerPoint, OneNote, який інтегрує слухачів, вміст і засоби. Microsoft Teams доступний 39-ма мовами. Об'єднує все в спільному робочому середовищі, яке містить чат для проведення вебінарів, семінарів, фрайлообмінник. Microsoft Teams можна використовувати на комп'ютері 3 операційною системою Windows 10 S, Windows 7+ або Mac OS X 10.10+ чи в Інтернеті, на пристрої iOS, Android, планшеті чи ноутбуці;

- Equity maps $€$ інструментом, завдяки якому можливо розкласти свої думки «по поличках», структурувати всі дані у вигляді схем, графіків та діаграм, перетворити їх на статистику. Завдяки Equity maps можливо проводити заняття у форматі лекцій, дискусійного клубу, залучати слухачів до активних обговорень;

- EdEra - соціально-публічний проект широкого спектра, з використанням IT, де розроблено різні освітні проекти, які поділено на онлайн-курси, інтерактивні підручники та спецпроекти. Так, 3 метою ознайомлення педагогів із сучасними сервісами дистанційної освіти, фрормування навичок для вибору онлайн-інструментів, Міністерство цифрової трансформації запустило безкоштовний онлайн-курс про організацію дистанційного 
навчання (освітній серіал «Карантин: онлайн-сервіси для вчителів» на сайті Дія (osvita.diia.gov.ua);

- Система Prometheus є суб'єктом надання освітніх послуг з підвищення кваліфрікації педагогічних працівників згідно з КВЕД 85.59 в Національному класифрікаторі України. Це проект масових відкритих онлайн-курсів. За допомогою системи дистанційного навчання «Prometheus», можна створити віртуальний університет та організувати дистанційне навчання з великою кількістю слухачів, автоматизуючи при цьому весь навчальний процес від початку курсів підвищення кваліфікації до видачі електронного сертифікату, який підтверджуватиме здобуті знання.

На наш погляд, лідером серед популярних платформ дистанційного навчання $€$ платорорма Moodle (модульне об'єктно-орієнтоване динамічне навчальне середовище).

Відповідно до вимог, методів та змісту навчання освітні послуги Навчально-наукового інституту неперервної освіти НПУ імені М.П. Драгоманова спроектовані в системі Moodle 3 урахуванням досягнень сучасної педагогіки, з акцентом на взаємодію між педагогічними працівниками (http:// www.do.ippk.npu.edu.ua.).

Система Moodle має ряд переваг. Так, платформа має багатий набір модулів-складників для курсів підвищення кваліфрікації педагогічних працівників закладів дошкільної освіти - Чат, Опитування, Форум, Глосарій, Робочий зошит, Тест, Анкета, Scorm, Survey, Wiki, Семінар, Ресурс (у вигляді текстової або веб-сторінки або у вигляді каталогу).

Крім того, система надає можливість здійснити аналіз участі та активності слухачів курсу; аналіз часу, відведеного на роботу з матеріалами; оцінку труднощів, які виникли у групі (або даного слухача) під час опанування того чи іншого модуля; швидко надати допомогу під час навчальної роботи слухачів у мережі Інтернет чи локальній мережі закладу післядипломної освіти шляхом завантаження додаткових матеріалів.

Можливості платформи забезпечують і комунікаційну взаємодію слухачів курсів як у синхронному режимі за допомогою чату (учасникам навчального процесу необхідно мати доступ до мережі в один і той самий час), так і в асинхронному режимі за допомогою фроруму, e-mail, робочого зошиту тощо (одночасний доступ до мережі не потрібен). Чат використовується викладачами Інституту згідно з графріком навчального процесу, на дистанційному етапі, з метою «живого» спілкування. Форум проводиться у формі семінару, який розтягнутий у часі, та консультацій, як на дистанційному етапі курсового навчання, так і в міжкурсовий період для обговорення актуальних питань.

Натепер кожна з розглянутих систем дистанційного навчання має свої переваги та недоліки, реалізує важливі для електронного навчання фрункції, але не всі забезпечують процес дистанційного навчання в комплексі. На наш погляд, найголовнішими критеріями під час вибору інструментів для організації дистанційного навчання в системі післядипломної освіти мають бути відповідність методичним цілям, універсальність, зрозумілість інтерорейсу, доступність програмних засобів для різних пристроїв (персональні комп'ютери, планшети, мобільні пристрої Apple, Android тощо).

Висновки. Сучасні мережні технології спонукають педагогічного працівника закладу дошкільної освіти адаптуватися до загальносвітових тенденцій розвитку освітньої системи, бути здатним брати участь у створенні та впровадженні нового змісту освіти, нести відповідальність за результати своєї діяльності. Найбільш перспективним і цілеспрямовано організованим середовищем для розвитку IK компетентності педагогів закладів дошкільної освіти є система післядипломної педагогічної освіти.

Перспективами подальших досліджень є створення авторського сайту як платформи для розвитку ІК-компетентності педагогічних працівників закладів дошкільної освіти.

\section{БІБЛІОГРАФІЧНИЙ СПИСОК:}

1. Про Основні засади розвитку інорормаційного суспільства в Україні на 2007-2015 роки № 537-V від 09.01.2007 р. URL: http://zakon4.rada.gov.ua/laws/ show/537-16

2. Положення про дистанційне навчання від 25.04.2013 р. № 466, зареєстрованого в Міністерстві юстиції України 30 квітня 2013 р. за № 703/23235.

3. Семчук C.I. Психолого-педагогічні аспекти ефективного застосування комп'ютерних технологій у процесі навчання майбутніх фрахівців в галузі дошкільної освіти. Психолого-педагогічні проблеми сільської школи. 2012. № 42. С. 31-38.

4. Що таке платформа дистанційного навчання. URL: http://www.webostudio.com/ua/stats/whatissite

5. Сисоєва С.О., Осадча К.П. Системи дистанційного навчання: порівняльний аналіз навчальних можливостей. URL: http://www.academia.edu/931578. 


\section{НОВИЙ ВИД НАУКОВИХ ПОСЛУГ}

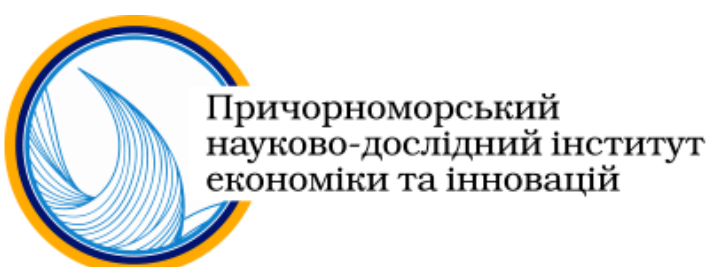

Шановні колеги! Питання академічної доброчесності $€$ надзвичайно актуальними у наш час. Враховуючи великі масиви інформації, що з'являються у всесвітній мережі, жоден вчений не може бути впевненим, що його авторське право захищене. Крім того, поширеною є ситуація, коли декілька вчених в одній галузі науки користуються однаковими джерелами інформації, а в результаті безкоштовні програми пошуку плагіату засвідчують стовідсоткові збіги тексту, що може призвести до безпідставних звинувачень у плагіаті, особливо після перевірки за базою даних авторефератів та дисертацій. Це викликано тим, що порівняння з іншими дисертаціями не вказує на використання спільних першоджерел (статей, монографій, статистичних щорічників, словників тощо), а однозначно визначає тільки збіг тексту, ігноруючи навіть цитати. Важливим є також те, що чинне законодавство однозначно визначає, що перевірку може здійснювати виключно установа за профрілем дослідження, а не поширені в мережі безкоштовні програми. Для уникнення подібних ситуацій ми пропонуємо Вам скористатися науковою послугою оцінки технічної унікальності наукового тексту за допомогою ліцензованого програмного забезпечення, яке гарантує похибку перевірки до 3\%. Переваги такої перевірки порівняно з іншими методами:

- Ви укладаєте угоду про надання послуг;

- Ваш фрайл не розмішується у мережі, тобто інфрормація і авторство залишаються анонімними;

- Ви отримуєте звіт, підготовлений за допомогою ліцензованого програмного забезпечення; порівняльну таблицю однакових фррагментів тексту із зазначенням джерела; офріційний звіт про надану послугу із зазначенням результатів;

- Ви отримуєте вичерпну інформацію про текстові збіги у Вашому дослідженні та дослідженнях інших авторів не тільки українською, але і російською та англійською мовами;

- Ви користуєтесь програмним забезпеченням, яке використовується тільки спеціалізованими науковими та освітніми установами і розроблене виключно для пошуку текстових збігів саме у наукових дослідженнях, а не у публіцистиці, рекламних веб-сайтах тощо;

- Виключна робота з авторами - ніхто, крім автора тексту, не зможе замовити у нас перевірку цього тексту, що убезпечить Вас від перевірок третіми особами;

- Ви отримуєте можливість коректно осрормити посилання на першоджерела;

- Існує можливість перевірки будь-яких наукових досліджень: статей, рефератів, авторефрератів, дисертацій, доповідей, тез, звітів тощо.

\begin{tabular}{|c|c|c|}
\hline \multicolumn{3}{|c|}{ Терміни і вартість перевірки і надання звіту: } \\
\hline Характер наукової роботи & Терміни (робочих днів) & Вартість \\
\hline Докторська дисертація & $5-10$ & 5500 грн \\
\hline Кандидатська дисертація & $3-7$ & 3500 грн \\
\hline Автореферат & $1-2$ & 500 грн \\
\hline Стаття & $1-2$ & 500 грн \\
\hline (обсягом до 12 сторінок) & За домовленістю & За домовленістю \\
\hline Інші види робіт &
\end{tabular}

Для того, щоб замовити послугу, Вам необхідно звернутись електронною поштою до Причорноморського науково-дослідного інститут економіки та інновацій, вказавши у темі листа «Оцінка унікальності тексту». У листі вкажіть адресу для листування, додайте файл у форматі MS Word з текстом наукового дослідження. Фахівець відповідного відділу надасть Вам відповідь щодо процедури здійснення експертизи.

Контактна особа:

Партенюха Дар'я - молодший науковий співробітник

Причорноморського науково-дослідного інституту економіки та інновацій.

+38 (048) 709-38-69

+38 (093) 253-57-15

info@iei.od.ua

3 повагою, дирекція Причорноморського науково-дослідного інституту економіки та інновацій. 


\title{
ІННОВАЦІЙНА ПЕДАГОГІКА
}

\author{
Науковий журнал
}

Випуск 24

\section{ToM 2}

Коректура • Н. Ігнатова

Комп'ютерна верстка • С. Калабухова

Формат 60х84/8. Гарнітура Arimo.

Папір офрсетний. Цифрровий друк. Обл.-вид. арк. 29,12. Ум.-друк. арк. 28,59.

Підписано до друку 30.06.2020. Наклад 100 прим.

Видавництво і друкарня - Видавничий дім «Гельветика»

65101, м. Одеса, вул. Інглезі, 6/1

Телесрон +38 (048) 70938 69, +38 (095) 93448 28, +38 (097) 7230608

E-mail: mailbox@helvetica.com.ua

Свідоцтво суб'єкта видавничої справи

ДК № 6424 від 04.10.2018 р. 